UNIVERSIDADE DE BRASÍLIA

FACULDADE DE DIREITO

MARIANA BORGES FRIZZERA PAIVA LYRIO

LIMITES DA DOUTRINA JURÍDICA CONSTITUCIONAL BRASILEIRA PARA ANALISAR A DISTRIBUIÇÃO DOS ROYALTIES DO PETRÓLEO

BRASÍLIA 2015 
Dissertação apresentada ao Curso de Pós-Graduação em Direito da Universidade de Brasília como requisito parcial para a obtenção do grau de Mestre em Direito. Área de Concentração: Direito, Estado e Constituição. Linha de Pesquisa: Transformações na Ordem Social e Econômica e Regulação.

\section{Orientador:}

Prof. Dr. Marcus Faro de Castro 


\title{
LIMITES DA DOUTRINA JURÍDICA CONSTITUCIONAL BRASILEIRA PARA ANALISAR A DISTRIBUIÇÃO DOS ROYALTIES DO PETRÓLEO
}

\begin{abstract}
Dissertação apresentada ao Curso de PósGraduação em Direito da Universidade de Brasília como requisito parcial para a obtenção do grau de Mestre em Direito. Área de Concentração: Direito, Estado e Constituição. Linha de Pesquisa: Transformações na Ordem Social e Econômica e Regulação.
\end{abstract}

BANCA EXAMINADORA:

Prof. Dr. Marcus Faro de Castro

Universidade de Brasília - UnB

Prof. Dr. Márcio Cammarosano

Pontifícia Universidade Católica de São Paulo - PUC/SP

Prof. Dr. Valcir Gassen

Universidade de Brasília - UnB 


\section{AGRADECIMENTOS}

Aos meus pais, Penha e Jader, pelo exemplo, por me ensinarem desde cedo o valor da educação e da determinação, e pelo apoio incondicional.

À minha avó, Jeny, pelo carinho e por suas orações, para que tudo desse certo em minha vida.

Ao meu irmão, Mateus, pelo incentivo, admiração e amizade.

Ao meu orientador, Prof. Marcus Faro de Castro, pela confiança e pelo apoio que tornaram possível a realização desse objetivo. 


\section{RESUMO}

A presente dissertação tem por objetivos: a) demonstrar as limitações das categorias jurídicas propostas pelas visões dominantes no direito constitucional brasileiro para considerar claramente fatos econômicos e políticos e, ao mesmo tempo, referenciais normativos que reflitam preocupações com a fruição de direitos capazes de conduzir à realização de aspirações de justiça da sociedade; b) propor novas categorias jurídicas para o tratamento jurídico da problemática de distribuição dos royaties e participações especiais (PE) do petróleo entre os entes federativos no Brasil; e c) apresentar, com base nas categorias jurídicas propostas, os fundamentos relevantes para a decisão sobre a controvérsia delineada. Para tanto, são apresentadas: a sistemática legal de partilha dos royalties e PE do petróleo mais recente (Leis $\mathrm{n}^{0}$ 9.478/97 e 12.351/10), as mudanças propostas pelo Legislativo para redistribuir essas receitas e as ações judiciais intentadas com o objetivo de impedir as modificações aprovadas pelo legislador. Posteriormente, são caracterizadas as visões dominantes no direito constitucional brasileiro - neoconstitucionalismo e dogmática jurídica e apresentadas, de modo sintético, algumas perspectivas de pensamento dessas visões. Com base em caracterizações críticas de tais visões dominantes, o trabalho argumenta que as categorias jurídicas por elas propostas são limitadas em sua capacidade de refletir fatos e escolhas políticos e econômicos relevantes. Como parte do esforço de caraterização das limitações do discurso do direito constitucional brasileiro, são também estudados e classificados, com base em análise de conteúdo, os fundamentos usados por atores envolvidos no debate sobre a partilha do pré-sal: os poderes Legislativo, Executivo e Judiciário, os demais atores processuais, os juristas e economistas. A partir desse exame é analisado: qual dos três poderes e qual dos dois lados (contrário ou favorável à redistribuição) utiliza fundamentos mais aptos a refletir fatos e escolhas políticos e econômicos relevantes e ideais de justiça reconhecíveis pela sociedade. Por fim, são sugeridas novas características para a análise jurídica acerca da problemática de partilha do pré-sal e apresentados os fundamentos relevantes para que a controvérsia passe a se apoiar em fundamentos aptos a adequar as soluções políticas à realidade e aos objetivos que devem ser buscados pelo direito: proporcionar a fruição mais efetiva de direitos fundamentais e humanos pelos indivíduos e grupos, contribuindo para diminuir a desigualdade social, econômica e regional.

Palavras-chave: Distribuição de royalties e PE do petróleo. Neoconstitucionalismo. Dogmática. Fatos políticos e econômicos. Realidade. Interdisciplinaridade. Consequências das decisões. Fruição de direitos humanos e fundamentais. 


\begin{abstract}
The present essay aims to: a) demonstrate the limitations of the dominant views about Brazilian constitutional law to clearly consider economic and political facts and, at the same time, bring to the fore normative references that reflect concerns about the enjoyment of rights as means to realize justice aspirations of society; b) propose alternative categories for the legal treatment of the distribution of oil royalties between the federal entities of the Brazilian state; c) submit, based on the legal categories proposed, the relevant grounds for deliberation regarding the outlined controversy. Therefore, the work presents the legal system of distribution of oil royalties existing in Brazil, the changes proposed by the Legislature to redistribute these revenues and the lawsuits brought by stakeholders in order to prevent the changes approved by the legislature. The essay then characterizes the views about constitutional law that are prevalent among Brazilian lawyers, namely: neoconstitutionalism and legal dogmatics. The essay also presents, in summary form, some perspectives of thought of these visions. Subsequently, the essay argues that the legal categories put forward by the dominant vies on Brazilian constitutional law are limited in their ability to reflect economic facts and political choices. Moreover, the work employs the method of "Content Analysis" to study the arguments used by the actors involved in the debate on the distribution of oil royalties: the Legislative, Executive and Judiciary, other stakeholders that are parties to legal actions. Based on this analysis, the essay presents some conclusions and examines: which of the three branches of the Brazilian state and which group of stakeholders (those in favor or against the redistribution of oil royalties) rely more on language that is able to reflect economic facts and political choices and recognizable ideals of justice. Finally, the work proposes new legal and interdisciplinary categories to be employed in deliberations about the distribution of proceeds resulting from the pre-salt exploration and presents the relevant grounds that may be useful in tailoring policy solutions attuned to factual reality while helping to achieve goals such as the reduction of social, economic and regional inequalities.
\end{abstract}

Key-words: Distribution of oil royalties. Neoconstitucionalism. Dogmatic. Economic facts. Political choices. Reality. Interdisciplinarity. Consequences of decisions. Enjoyment of rights. 


\section{SUMÁRIO}

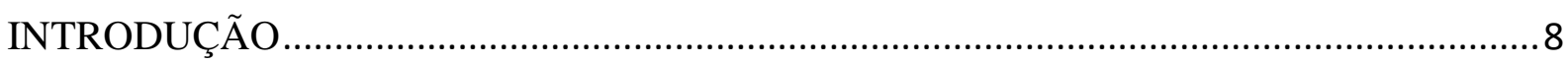

1. A DISTRIBUIÇÃO DOS FRUTOS DA EXPLORAÇÃO DO PETRÓLEO:

EVOLUÇÃO RECENTE.

1.1. SISTEMÁTICA LEGAL DE DISTRIBUIÇÃO DOS ROYALTIES E

PARTICIPAÇÕES ESPECIAIS (PE) DO PETRÓLEO

1.1.1. Regime de concessão. 12

1.1.2. Regime de partilha de produção 16

1.1.3. A hiperconcentração de recursos e seus efeitos 17

1.2. HISTÓRIA LEGISLATIVA RECENTE (PÓS CONSTITUIÇÃO DE 1988) ACERCA DA DISTRIBUIÇÃO DOS ROYALTIES E PARTICIPAÇÕES ESPECIAIS DO PETRÓLEO

1.3. AÇÕES JUDICIAIS INICIADAS CONTRA A NOVA SISTEMÁTICA DE DISTRIBUIÇÃO DOS ROYALTIES E PARTICIPAÇÕES ESPECIAIS 28

2. UMA CARACTERIZAÇÃO DAS VISÕES DOMINANTES NO DIREITO CONSTITUCIONAL 30

2.1. INTERPRETAÇÃO DOGMÁTICA DO DIREITO 32

2.2. O NEOCONSTITUCIONALISMO 39

2.3. PONTOS DE CONVERGÊNCIA ENTRE O NEOCONSTITUCIONALISMO E A DOGMÁTICA JURÍDICA. 48

2.4. LIMITAÇÕES DAS VISÕES DOMINANTES NO DIREITO CONSTITUCIONAL

PARA O ENFRENTAMENTO DA PARTILHA DO PRÉ-SAL .55

3. FUNDAMENTOS UTILIZADOS NO DEBATE ACERCA DA DISTRIBUIÇÃO DOS ROYALTIES E PE DO PETRÓLEO

4. PARA ALÉM DOS LIMITES DAS CATEGORIAS JURÍDICAS

CONVENCIONAIS

4.1. NOVAS CARACTERÍSTICAS DA ANÁLISE JURÍDICA: ALGUMAS SUGESTÕES

4.1.1. Análise de dados empíricos, a fim de compatibilizar a decisão com a realidade 73

4.1.2. Necessidade de diálogo com outras disciplinas (interdisciplinaridade) 74

4.1.3. Análise das consequências da decisão judicial. 77

4.1.4. Buscar objetivos como: maior fruição de direitos fundamentais e humanos e menor desigualdade social, econômica e regional 
4.2. FUNDAMENTOS RELEVANTES PARA UMA DECISÃO ADEQUADA ACERCA DA DISTRIBUIÇÃO DOS ROYALTIES E PARTICIPAÇÕES ESPECIAIS DO PETRÓLEO

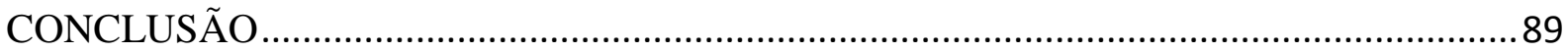

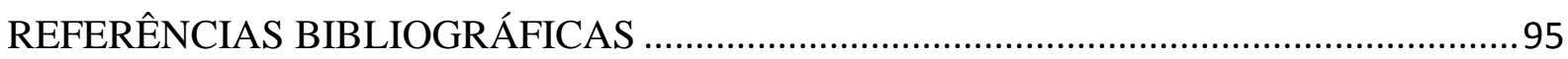

TABELA 1 - ATOS LEGISLATIVOS RELEVANTES ................................................. 105

TABELA 2 - PROCESSOS JUDICIAIS RELEVANTES …............................................. 128

TABELA 3 - FUNDAMENTOS UTILIZADOS PELO LEGISLATIVO: FAVORÁVEIS À REDISTRIBUIÇÃO DOS ROYALTIES E PE ................................................................ 141

TABELA 4 - FUNDAMENTOS DO LEGISLATIVO CONTRÁRIOS À

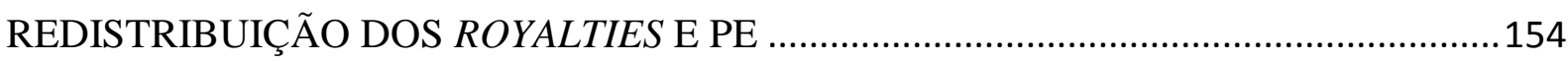

TABELA 5 - FUNDAMENTOS UTILIZADOS PELO EXECUTIVO ................................ 163

TABELA 6: FUNDAMENTOS UTILIZADOS PELO JUDICIÁRIO .................................165

TABELA 7 - FUNDAMENTOS UTILIZADOS PELOS DEMAIS ATORES

PROCESSUAIS FAVORÁVEIS À REDISTRIBUIÇÃO DOS ROYALTIES E PE..............168

TABELA 8 - FUNDAMENTOS UTILIZADOS PELOS DEMAIS ATORES

PROCESSUAIS CONTRÁRIOS À REDISTRIBUIÇÃO DOS ROYALTIES E PE 184

TABELA 9 - POSICIONAMENTOS DE JURISTAS E ECONOMISTAS: CONTRA E A FAVOR DA REDISTRIBUIÇÃO DOS ROYALTIES E PE

TABELA 10 - FUNDAMENTOS UTILIZADOS POR JURISTAS E ECONOMISTAS FAVORÁVEIS À REDISTRIBUIÇÃO DOS ROYALTIES E PE 199

TABELA 11 - FUNDAMENTOS UTILIZADOS POR JURISTAS E ECONOMISTAS CONTRÁRIOS À REDISTRIBUIÇÃO DOS ROYALTIES E PE 


\section{INTRODUÇÃO}

Desde a descoberta de petróleo abaixo da camada de sal (pré-sal ${ }^{1}$ ), no ano de 2006, na Bacia de Campos $^{2}$ muito se tem debatido a respeito de como se dará a distribuição dos recursos advindos da sua exploração.

Atualmente, como consequência de negociações políticas e tentativas de construção institucional, formaram-se consensos políticos, embora frágeis, sobre as possibilidades de adoção de regramentos em torno de dois regimes utilizados para a pesquisa e exploração de petróleo: (i) o de concessão e (ii) o de partilha de produção. Em ambos os regimes estabelecidos, há leis especiais que adotam regras específicas sobre diversos aspectos e consequências desta atividade econômica.

Os principais diplomas legais que estruturam cada um dos regimes são:

a) para o regime de concessão: a Lei $n^{\circ}$ 9.478/1997; e

b) para o regime de partilha de produção: a Lei $\mathrm{n}^{\circ} 12.351 / 2010$.

As regras relativas a ambos os regimes, contudo, foram submetidas a revisões em anos recentes, em decorrência de múltiplas iniciativas, encaminhadas por diversos canais institucionais, refletindo o interesse de políticos de vários estados da federação em obter para suas regiões parcelas maiores dos frutos da exploração do petróleo e gás do pré-sal, conforme se descreve nos parágrafos a seguir.

De acordo com a Lei $\mathrm{n}^{0}$ 9.478/97, os critérios de distribuição de royalties e PE, sob o regime de concessão privilegiam os estados e municípios produtores, confrontantes e aqueles

\footnotetext{
1 "O termo pré-sal refere-se a um conjunto de rochas localizadas nas porções marinhas de grande parte do litoral brasileiro, com potencial para a geração e acúmulo de petróleo. Convencionou-se chamar de pré-sal porque forma um intervalo de rochas que se estende por baixo de uma extensa camada de sal, que em certas áreas da costa atinge espessuras de até $2.000 \mathrm{~m}$. O termo pré é utilizado porque, ao longo do tempo, essas rochas foram sendo depositadas antes da camada de sal. A profundidade total dessas rochas, que é a distância entre a superfície do mar e os reservatórios de petróleo abaixo da camada de sal, pode chegar a mais de 7 mil metros." (Perguntas e respostas sobre o pré-sal. Disponível em: <http://sites.petrobras.com.br/minisite/presal/perguntasrespostas/index.asp>. Acesso em: 2 mar. 2015).

2 "Em 2004 foram perfurados alguns poços em busca de óleo na Bacia de Santos. É que ali haviam sido identificadas, acima da camada de sal, rochas arenosas depositadas em águas profundas, que já eram conhecidas. Se fosse encontrado óleo, a ideia era aprofundar a perfuração até chegar ao pré-sal, onde os técnicos acreditavam que seriam encontrados grandes reservatórios de petróleo.

Em 2006, quando a perfuração já havia alcançado $7.600 \mathrm{~m}$ de profundidade a partir do nível do mar, foi encontrada uma acumulação gigante de gás e reservatórios de condensado de petróleo, um componente leve do petróleo. No mesmo ano, em outra perfuração feita na Bacia de Santos, a Companhia e seus parceiros fizeram nova descoberta, que mudaria definitivamente os rumos da exploração no Brasil. A pouco mais de 5 mil metros de profundidade, a partir da superfície do mar, veio a grande notícia: o poço, hoje batizado de Tupi, apresentava indícios de óleo abaixo da camada de sal. O sucesso levou à perfuração de mais sete poços e em todos encontrou-se petróleo. O investimento valeu a pena." (Perguntas e respostas sobre o pré-sal. Disponível em: $<$ http://sites.petrobras.com.br/minisite/presal/perguntas-respostas/index.asp >. Acesso em: 2 mar. 2015).
} 
que são afetados de alguma maneira por operações relacionadas com essa atividade ${ }^{3}$. A título de exemplo, vale observar que, no ano de 2007, o Estado do Rio de Janeiro concentrou 84,5\% dos royalties transferidos aos estados. No que tange aos municípios, apenas 907 dos 5.562 municípios brasileiros foram contemplados, sendo que os dez maiores beneficiados entre os municípios concentraram $61,34 \%$ de todos os recursos, índice que sobe para $99 \%$ se considerados os 230 municípios mais favorecidos. O Município de Campos dos Goytacazes, por exemplo, recebeu $24,25 \%$ do total dos royalties destinados aos municípios de todo o país ${ }^{4}$.

No ano de 2009, o Município de Campos também foi o maior beneficiário em valores brutos, obtendo R $\$ 775.875 .811,13$ a título de royalties e PE. Se considerado o valor per capita, o Município aparece em $8^{\circ}$ lugar no ranking, tendo recebido $\mathrm{R} \$ 1.787,85$ de royalties e PE por cada habitante. O Município de Presidente Kennedy, no Espírito Santo, foi o que ocupou o $1^{\circ}$ lugar, se considerado o valor per capita, sendo beneficiado com $\mathrm{R} \$ 6.196,72$ por habitante ${ }^{5}$.

Apesar da grande quantidade de recursos recebidos, $21,76 \%$ da população do Município de Presidente Kennedy encontrava-se na pobreza em 2010 e 6,8\% na indigência 6 .

Por conta da hiperconcentração de recursos em poucos estados e municípios, gerada pelos critérios de distribuição definidos na Lei $\mathrm{n}^{0}$ 9.478/97 e após diversas tentativas de mudança das regras de partilha pelo Congresso Nacional, foi proposto e aprovado o Projeto de Lei ${ }^{\circ} 448 / 11^{7}$, de autoria do Senador Wellington Dias (PT/PI), no Senado Federal ${ }^{8}$, o qual foi confirmado pela Câmara dos Deputados (PL no 2565/11, na Câmara). O projeto, apresentado por um representante de estado não produtor de petróleo, estabelecia novas regras de distribuição de royalties e PE que tornavam a distribuição desses recursos mais equânime.

\footnotetext{
${ }^{3}$ Vale a pena explicar que os estados e municípios são considerados produtores quando a exploração do petróleo se dá em seu território, portanto, extração em terra (onshore). São confrontantes aqueles estados e municípios localizados em área limítrofe com as bacias em que se ocorre a atividade petrolífera (extração offshore). Os entes afetados são aqueles impactados de outras maneiras pela atividade, como os que possuem instalações de embarque e desembarque de petróleo e gás natural.

${ }^{4}$ AFONSO, José Roberto Rodrigues; GOBETTI, Sérgio Wulff. Renda do petróleo no Brasil: alguns aspectos fiscais e federativos. Revista do BNDES, Rio de Janeiro, v. 15, n. 30, p. 242, dez. 2008.

${ }^{5}$ Cf. Tabelas 1 e 2 (POSTALI, Fernando Antonio Slaibe; NISHIJIMA, Marislei. Distribuição das rendas do petróleo e indicadores de desenvolvimento municipal no Brasil nos anos 2000. Estudos econômicos, São Paulo, v. 41 , n. 2 , p. 472 , abr./jun. 2011).

${ }^{6}$ Cf. ANEXO V. \% da população na pobreza e na indigência em 2010 (MACROPLAN. Royalties do Petróleo e Desenvolvimento Municipal: avaliação e propostas de melhoria. Relatório Final. Jun. 2012. Disponível em: <http://macroplan.com.br/Documentos/EstudoMacroplan 201282717367.pdf>. Acesso em 22 fev. 2015).

${ }^{7}$ Redação final do PL/SF no 448/2011. Disponível em: <http://www.senado.gov.br/atividade/materia/detalhes. asp?p_cod_mate $=101405>$. Acesso em: 5 fev. 2015.

${ }^{8}$ O Projeto foi aprovado, no Senado, na forma de Substitutivo apresentado pelo Senador Vital do Rêgo.
} 
Em 30/11/12, a Presidente Dilma Rousseff sancionou parcialmente o referido projeto (Lei $\mathrm{n}^{\mathrm{o}}$ 12.734/12). O veto recaiu sobre os dispositivos que redistribuíam royalties e PE. Contudo, o Congresso Nacional derrubou o veto em 6/3/13, mantendo na Lei $n^{0} 12.734 / 12$ a redação aprovada pelo Legislativo, que beneficia os estados e municípios não produtores.

A Lei $\mathrm{n}^{\mathrm{o}}$ 12.734/12 modificou sobremaneira a distribuição dos royalties e participações especiais. Exemplificando, de acordo com os novos critérios de rateio previstos pela Lei $n^{0}$ 12/734/12 para o regime de concessão, os municípios produtores deixam de receber os 26,25\% de royalties na exploração em mar, percentual assim fixado pela Lei $n^{\circ}$ 9.478/97, para deter apenas 4\%, após o período de transição estabelecido na nova lei (até 2020). Ademais, as novas regras destinam 54\% desses ganhos ao Fundo de Participação Especial dos Estados e Municípios, ao invés dos 8,75\% destinados pela Lei $n^{\circ}$ 9.478/979 . $^{9}$

Após a derrubada do veto pelo Congresso Nacional foram propostas quatro Ações Diretas de Inconstitucionalidade (ADI) no Supremo Tribunal Federal, postulando o reconhecimento da inconstitucionalidade dos dispositivos da Lei $\mathrm{n}^{0} 12.734 / 12$ que alteram as regras de partilha de royalties e PE ou, subsidiariamente, o reconhecimento da impossibilidade de sua aplicação às rendas geradas pelos campos de petróleo já licitados. As ações foram propostas pelos Governadores dos Estados do Rio de Janeiro, do Espírito Santo e de São Paulo, e pela Mesa da Assembleia Legislativa do Estado do Rio de Janeiro.

A Relatora das ações, Ministra Cármen Lúcia, deferiu medida cautelar nos autos da ADI $n^{\circ}$ 4.917, de autoria do Governador do Estado do Rio de Janeiro, determinando a suspensão dos artigos da Lei $\mathrm{n}^{\mathrm{o}}$ 12.734/12 que alteravam as regras de distribuição dos royalties e PE.

Diante da existência de diversas tentativas de mudança das regras de distribuição das receitas do petróleo pelo Parlamento, que serão melhor apresentadas no decorrer do trabalho, bem como considerando o grande volume dos recursos, que podem ser aplicados em prol do desenvolvimento econômico e social do país, é fundamental que a decisão sobre a partilha do pré-sal seja tomada com base em fundamentos jurídicos que reflitam claramente fatos e escolhas políticos e econômicos e contemplem, ao mesmo tempo, ideais de justiça reconhecíveis pela sociedade como um todo.

Objetivando contribuir para explicitar quais seriam tais fundamentos jurídicos que serão denominados fundamentos relevantes -, no que se refere à exploração do petróleo e à destinação de seus frutos financeiros no Brasil, o presente trabalho,

\footnotetext{
${ }^{9}$ Relatório parcial da Comissão do Pacto Federativo. Disponível em: <http://www12.senado.gov.br/noticias/ arquivos/2012/10/veja-o-relatorio-da-comissao-de-especialistas-1>. Acesso em: 20 de fev. 2015.
} 
apresentará, no Capítulo 1, a evolução recente acerca da distribuição dos royalties e PE, no âmbito dos Poderes Legislativo (tentativas de alteração das regras de distribuição) e Judiciário (ações judiciais propostas contra as tentativas de mudança). Em seguida, nos Capítulos 2 e 3, a) analisará se as ideias e modos de análise dominantes no direito constitucional brasileiro (dogmática e neoconstitucionalismo) são capazes de fornecer fundamentos jurídicos que reflitam fatos e escolhas políticos e econômicos e contemplem os ideais de justiça reconhecíveis pela sociedade; e b) investigará se as teses dominantes no âmbito do direito constitucional brasileiro foram utilizadas pelos diversos atores que participam do debate sobre a partilha do pré-sal (a saber: Poderes Legislativo, Executivo e Judiciário, demais atores processuais e posicionamentos de juristas e economistas). O trabalho indicará também que as doutrinas jurídicas dominantes, bem como os fundamentos utilizados pelo Poder Judiciário (responsável pela decisão que atualmente prevalece) são limitados em sua capacidade de considerar claramente fatos econômicos e políticos e ao mesmo tempo referenciais normativos, que reflitam preocupações com a fruição de direitos e realizem aspirações de justiça da sociedade. No Capítulo 4, o trabalho proporá novas categorias jurídicas para que o tratamento jurídico da controvérsia já delineada passe a se apoiar em fundamentos aptos a adequar as soluções políticas à realidade e aos objetivos que devem ser buscados pelo direito: proporcionar a fruição mais efetiva de direitos fundamentais e humanos pelos indivíduos e grupos contribuindo para diminuir a desigualdade social, econômica e regional. 


\title{
1. A DISTRIBUIÇÃO DOS FRUTOS DA EXPLORAÇÃO DO PETRÓLEO: EVOLUÇÃo RECENTE
}

O presente capítulo tem por objetivo expor o debate existente acerca da distribuição dos royalties e participações especiais (PE) do petróleo, o que inclui: a) explicar a sistemática legal de distribuição desses recursos, composta por dois regimes de exploração e produção do petróleo - concessão e partilha de produção -; b) descrever a história legislativa recente (pós Constituição de 1988) acerca da distribuição dos royalties e participações especiais do petróleo, isto é, as tentativas de mudança das regras de distribuição e os debates ocorridos no Parlamento em torno do tema; c) descrever as ações judiciais ajuizadas em face das tentativas de alteração dos critérios de distribuição dos royalties e PE.

\subsection{SISTEMÁTICA LEGAL DE DISTRIBUIÇÃO DOS ROYALTIES E PARTICIPAÇÕES ESPECIAIS (PE) DO PETRÓLEO}

Desde a descoberta de petróleo abaixo da camada de sal nas Bacias de Campos, de Santos e do Espírito Santo (pré-sal), no ano de 2006, muito se tem debatido a respeito de como se dará a distribuição dos recursos advindos da sua exploração.

Atualmente, existem dois regimes utilizados para a pesquisa e exploração de petróleo: o de concessão e o de partilha de produção.

\subsubsection{Regime de concessão}

De acordo com o regime de concessão, disciplinado pela Lei $n^{\circ}$ 9.478/97, a propriedade do petróleo extraído na área objeto da concessão é exclusiva do concessionário, que deve pagar retribuições financeiras ao ente público pela exploração: as participações governamentais, conforme explica Artur Watt Neto:

\begin{abstract}
Por esse regime, o Estado outorga a um particular o direito de explorar petróleo em uma determinada área sob sua própria conta e risco, normalmente mediante o pagamento antecipado de uma soma em dinheiro (bônus de assinatura). Em caso de descoberta, o particular será recompensado pelo direito de produzir os recursos descobertos, que passarão a ser de sua propriedade. Durante a produção, normalmente são devidos pagamentos regulares ao Estado, denominados royalties, que costumavam ser estabelecidos em valores fixos ou em um percentual do valor da produção ${ }^{10}$.
\end{abstract}

\footnotetext{
${ }^{10}$ WATT NETO, Artur. Petróleo, gás natural e biocombustiveis: doutrina, jurisprudência e legislação. São Paulo: Saraiva, 2014. p. 38-39.
} 
Há quatro espécies de participações governamentais no regime de concessão, a saber: pagamento pela ocupação ou retenção de área, royalties, participações especiais (PE) e bônus de assinatura, sendo que apenas os dois primeiros são de cobrança obrigatória ${ }^{11}$. O trabalho tem por objeto os royalties e PE, pela sua importância em termos numéricos ${ }^{12}{ }^{13}$ e por serem as espécies contempladas na lei que alterou a sistemática de distribuição entre os entes federativos (Lei $\left.n^{\circ} 12.734 / 12^{14}\right)$.

Os royalties são pagos mensalmente a partir da data de início da produção comercial de cada campo. O montante é, em regra, de $10 \%$ da produção de petróleo, mas pode ser reduzido a um mínimo de $5 \%$, a depender dos riscos geológicos, das expectativas de produção e de outros fatores pertinentes ${ }^{15}$.

A alíquota mínima de 5\% é distribuída de acordo com os critérios da Lei $n^{0} 7.990 / 89$ e do Decreto $n^{\circ}$ 01/91 (art. 48 da Lei ${ }^{\circ}$ 9.784/97), da seguinte forma:

a) Exploração em terra, lagos, rios, ilhas fluviais e lacustres (onshore): $70 \%$ aos estados produtores; $20 \%$ aos municípios produtores ${ }^{16} ; 10 \%$ aos municípios com instalações marítimas ou terrestres de embarque e desembarque de óleo bruto ou gás natural.

b) Exploração na plataforma continental, no mar territorial ou na zona econômica exclusiva (offshore): $30 \%$ aos estados confrontantes com poços; 30\% aos municípios confrontantes e suas respectivas áreas geoeconômicas; $10 \%$ aos municípios com instalações marítimas ou terrestres de embarque e desembarque de óleo bruto ou gás natural; $20 \%$ ao Comando da Marinha e 10\% ao Fundo Especial, cujos recursos são distribuídos a todos os estados ( $20 \%$ do fundo) e a todos os municípios ( $80 \%$ do fundo).

\footnotetext{
${ }^{11}$ Art. 45, caput e $\S 1^{\circ}$ da Lei $\mathrm{n}^{\circ} 9.478 / 97$.

${ }^{12} \mathrm{Em} 2005$, foram arrecadados $\mathrm{R} \$ 13,2$ bilhões a título de participações governamentais, sendo $\mathrm{R}$ \$ 6,21 bilhões o valor dos royalties e $\mathrm{R} \$ 6,96$ bilhões das participações especiais. (PIQUET, Rosélia; SERRA, Rodrigo. Petróleo e região no Brasil: o desafio da abundância. Rio de Janeiro: Garamond, 2007, p. 77).

${ }^{13} \mathrm{O}$ bônus de assinatura e a retenção de área correspondem a menos de $10 \%$ do montante arrecadado com royalties e participação especial, relativamente a um bloco licitado. (VIEGAS, Paulo Roberto Alonso. Aspectos da MP $n^{\circ} 592$, de 2012, sobre a distribuição de royalties e outras participações governamentais na exploração de petróleo e gás natural. Disponível em: <http://www12.senado.gov.br/publicacoes/estudos-legislativos/tiposde-estudos/textos-para-discussao/ td-119-aspectos-da-mp-no-592-de-2012-sobre-a-distribuicao-de-royalties-eoutras-participacoes-governamentais-na-exploracao-de-petroleo-e-gas-natural >. Acesso em: 29 jan. 2015).

${ }^{14}$ A Lei no 12.734 "modifica as Leis no 9.478, de 6 de agosto de 1997, e no 12.351, de 22 de dezembro de 2010, para determinar novas regras de distribuição entre os entes da Federação dos royalties e da participação especial devidos em função da exploração de petróleo, gás natural e outros hidrocarbonetos fluidos, e para aprimorar o marco regulatório sobre a exploração desses recursos no regime de partilha." (Ementa da Lei).

${ }^{15}$ Art. 47, caput e $\$ 1^{\circ}$ da Lei ${ }^{\circ}$ 9.784/97.

${ }^{16}$ A referência a estados e municípios "produtores" se dará para o caso de exploração onshore, já que nesse caso a produção se dá no território desses entes. Já no caso de exploração marítima (offshore), os entes mais beneficiados serão denominados confrontantes, uma vez que nesse caso a exploração se dá em território da União e os critérios de distribuição são estabelecidos de acordo com a relação geográfica do estado ou município com os poços de petróleo.
} 
Já o percentual que ultrapassa o mínimo de 5\% da produção tem os seus critérios de distribuição fixados na Lei $n^{\circ}$ 9.784/97 e no Decreto $n^{\circ}$ 2.705/98 da seguinte maneira:

a) Exploração onshore: $52,5 \%$ aos estados onde se der a produção; $15 \%$ aos municípios onde ocorrer a produção; 7,5\% aos municípios afetados pelas operações de embarque e desembarque de petróleo e gás natural e $25 \%$ ao Ministério da Ciência e Tecnologia (MCT).

b) Exploração offshore: $22,5 \%$ aos estados confrontantes; $22,5 \%$ aos municípios confrontantes; $15 \%$ ao Comando da Marinha; 7,5\% aos municípios afetados pelas operações de embarque e desembarque de petróleo e gás natural; 7,5\% para o Fundo Especial e 25\% ao Ministério da Ciência e Tecnologia.

As participações especiais constituem um pagamento adicional aos royalties e são devidas apenas nos casos de grande volume de produção, ou de grande rentabilidade, sendo aplicadas sobre a receita bruta da produção, deduzidos os royalties, os investimentos na exploração, os custos operacionais, a depreciação e os tributos previstos na legislação em vigor ${ }^{17} \cdot{ }^{18}$ A distribuição dessas receitas não varia de acordo com o local da produção - se em terra ou em mar - e ocorre da seguinte forma: $40 \%$ ao Ministério de Minas e Energia (MME); 10\% ao Ministério do Meio Ambiente (MMA); 40\% ao estado produtor ou confrontante e $10 \%$ ao município produtor ou confrontante, conforme art. 50, $\S 2^{\circ}$ da Lei $n^{\circ}$ 9.478/97.

Vale a pena destacar que o valor arrecadado com os royalties e participações especiais é aproximadamente o mesmo (ambas geraram cerca de R\$ 12 bilhões, cada, em 2011) ${ }^{19}$.

Observa-se que o regime de distribuição é complexo e considera diversos fatores, tais como a localização da lavra (se em terra ou em mar), a parcela incidente sobre o valor da produção (que varia entre 5 e 10\%), a relação geográfica de estados e municípios com poços de petróleo e as consequências do transporte do minério. Ademais, há diversos diplomas normativos que regulamentam a matéria, o que dificulta a sistematização. A fim de facilitar a

\footnotetext{
${ }^{17}$ Art. 50, caput e $\$ 1^{\circ}$ da Lei $n^{\circ} 9.784 / 97$.

${ }^{18}$ Artur Watt Neto explica que as participações especiais foram introduzidas em vários países para refletir a maior ou menor lucratividade de cada projeto, já que os royalties, cobrados sobre o percentual da produção, têm um grave inconveniente: por incidirem sobre a renda bruta, não levam em consideração os pesados investimentos realizados na extração do petróleo nem as acentuadas economias de escala decorrentes da produção de petróleo em larga escala. (WATT NETO, Artur. Petróleo, gás natural e biocombustíveis: doutrina, jurisprudência e legislação. São Paulo: Saraiva, 2014, p. 61).

${ }^{19}$ VIEGAS, Paulo Roberto Alonso. Aspectos da MP $n^{\circ}$ 592, de 2012, sobre a distribuição de royalties e outras participações governamentais na exploração de petróleo e gás natural, p.6. Disponível em: < http://www12.senado.gov.br/publicacoes/estudos-legislativos/tipos-de-estudos/textos-para-discussao/td-119aspectos-da-mp-no-592-de-2012-sobre-a-distribuicao-de-royalties-e-outras-participacoes-governamentais-naexploracao-de-petroleo-e-gas-natural >. Acesso em: 29 jan. 2015.
} 
visualização de como se dá a partilha de royalties e PE no regime de concessão, confiram-se as seguintes tabelas:

\begin{tabular}{|c|c|c|c|}
\hline \multicolumn{4}{|c|}{ Regime de Concessão - Exploração onshore } \\
\hline & \multicolumn{2}{|c|}{ Royalties } & \multirow{2}{*}{$\begin{array}{l}\text { Participações } \\
\text { especiais }\end{array}$} \\
\hline & Alíquota mínima $=5 \%$ & Alíquota > 5\% (até 10\%) & \\
\hline Estados & Produtores: $70 \%$ & Produtores: $52,5 \%$ & $\begin{array}{l}\text { Produtores ou } \\
\text { Confrontantes: } \\
40 \%\end{array}$ \\
\hline Municípios & $\begin{array}{l}\text { Produtores: } 20 \% \\
\text { Afetados: } 10 \%\end{array}$ & $\begin{array}{l}\text { Produtores: } 15 \% \\
\text { Afetados: } 7,5 \%\end{array}$ & $\begin{array}{l}\text { Produtores ou } \\
\text { Confrontantes: } \\
10 \%\end{array}$ \\
\hline União & - & MCT: $25 \%$ & $\begin{array}{l}\mathrm{MME}=40 \% \\
\mathrm{MMA}=10 \%\end{array}$ \\
\hline Fundo Especial & - & - & - \\
\hline
\end{tabular}

\begin{tabular}{|c|c|c|c|}
\hline \multicolumn{4}{|c|}{ Regime de Concessão - Exploração offshore } \\
\hline & \multicolumn{2}{|c|}{ Royalties } & \multirow{2}{*}{$\begin{array}{l}\text { Participações } \\
\text { especiais }\end{array}$} \\
\hline & Alíquota mínima $=5 \%$ & $\begin{array}{l}\text { Alíquota > 5\% (até } \\
10 \% \text { ) }\end{array}$ & \\
\hline Estados & Confrontantes: $30 \%$ & Confrontantes: $22,5 \%$ & $\begin{array}{l}\text { Produtores ou } \\
\text { Confrontantes: } 40 \%\end{array}$ \\
\hline Municípios & $\begin{array}{l}\text { Confrontantes: } 30 \% \\
\text { Afetados: } 10 \%\end{array}$ & Confrontantes: $30 \%$ & $\begin{array}{l}\text { Produtores ou } \\
\text { Confrontantes: } 10 \%\end{array}$ \\
\hline União & Marinha: $20 \%$ & $\begin{array}{l}\text { MCT: } 25 \% \\
\text { Marinha: } 15 \%\end{array}$ & $\begin{array}{l}\text { MME }=40 \% \\
\text { MMA }=10 \%\end{array}$ \\
\hline Fundo Especial & $\begin{array}{l}\text { 10\% (FPE: } 20 \% \text {; } \\
\text { FPM: } 80 \% \text { ) }\end{array}$ & $\begin{array}{l}\text { 7,5\% (FPE: } 20 \% \text {; } \\
\text { FPM: } 80 \% \text { ) }\end{array}$ & - \\
\hline
\end{tabular}

No que concerne à partilha entre os entes subnacionais, há duas percepções importantes para o trabalho, facilmente constatadas através da tabela: a) os royalties e PE provenientes da extração do petróleo em terra são destinados exclusivamente para os estados e municípios produtores ou afetados; b) somente os royalties decorrentes da extração em mar são destinados aos demais estados e municípios, em proporção que corresponde a exatamente $1 / 3$ (um terço) daquele que é destinado aos confrontantes.

A Lei $n^{0} 12.734 / 12$ mantém os percentuais de distribuição acima para a exploração onshore, alterando os critérios apenas para o caso de extração do petróleo offshore. No entanto, como tais dispositivos foram suspensos pelo Poder Judiciário, continuam sendo aplicadas as alíquotas da tabela. 


\subsubsection{Regime de partilha de produção}

O regime de partilha de produção é regulamentado pela Lei ${ }^{\circ}$ 12.351/2010 e destinase às áreas do pré-sal e a áreas declaradas estratégicas pelo Chefe do Executivo. Nesse sistema, a propriedade do petróleo extraído continua sendo exclusiva da União. Cabe ao contratado exercer, por sua conta e risco, as atividades de exploração, avaliação, desenvolvimento e produção e, em caso descoberta comercial, adquire o direito à apropriação do custo em óleo (cost oil), do volume da produção correspondente aos royalties devidos, bem como de parcela do excedente em óleo (profit oil), na proporção, condições e prazos estabelecidos em contrato ${ }^{20}$.

O custo em óleo diz respeito aos investimentos realizados pelo contratado na execução das atividades de exploração, avaliação, desenvolvimento, produção e desativação das instalações. Já o excedente em óleo corresponde à parcela da produção a ser repartida entre a União e o contratado, segundo critérios definidos em contrato ${ }^{21}$.

Nesse novo modelo, as únicas receitas governamentais cabíveis são os royalties e o bônus de assinatura ${ }^{22}$. Os royalties foram estabelecidos em $15 \%$ e houve a substituição da participação especial pela participação direta da União na partilha do óleo, parcela não passível de divisão entre os entes subnacionais ${ }^{23}$. A distribuição desses royalties ocorre nos termos do art. 42-B da Lei $\mathrm{n}^{\circ}$ 12.351/10, conforme se segue:

a) Produção onshore: $20 \%$ aos estados produtores; $10 \%$ aos municípios produtores; $5 \%$ aos municípios afetados pelas operações de embarque e desembarque de petróleo e gás natural; $25 \%$ para todos os Estados; $25 \%$ para todos os municípios e $15 \%$ para a União.

b) Produção offshore: $22 \%$ aos estados produtores; $5 \%$ aos municípios produtores; $2 \%$ aos municípios afetados pelas operações de embarque e desembarque de petróleo e gás natural; 24,5\% para todos os Estados; 24,5\% para todos os municípios e $22 \%$ para a União.

\footnotetext{
${ }^{20}$ Art. $2^{\circ}$, I da Lei $\mathrm{n}^{\mathrm{o}} 12.351 / 10$.

${ }^{21}$ Art. $2^{\circ}$, II e III da Lei $\mathrm{n}^{\circ} 12.351 / 10$.

${ }^{22}$ Art. 42 da Lei ${ }^{\circ}$ 12.351/10.

${ }^{23}$ WATT NETO, Artur. Petróleo, gás natural e biocombustíveis: doutrina, jurisprudência e legislação. São Paulo: Saraiva, 2014, p. 71.
} 


\subsubsection{A hiperconcentração de recursos e seus efeitos}

É fácil constatar que o sistema de distribuição previsto na Lei $\mathrm{n}^{\circ}$ 9.478/97 privilegia os estados e municípios produtores, confrontantes e aqueles que são afetados por operações relacionadas com a atividade petrolífera. A título de exemplo, no ano de 2005, o Estado do Rio de Janeiro foi responsável por aproximadamente 83,4\% da produção nacional, recebendo $46,7 \%$ das rendas nacionais (o equivalente a $81,1 \%$ do total destinado aos estados, ao DF e aos municípios) ${ }^{24}$. Em 2006, os estados e municípios beneficiados receberam 56,89\% do total de royalties e PE, enquanto que para o Fundo Especial (rateado entre todos os entes federativos) foram destinados $3,55 \%$ dos recursos ${ }^{25}$.

Em 2007, o Estado do Rio de Janeiro concentrou 84,5\% do total das rendas petrolíferas transferidas aos estado, enquanto o Estado do Ceará recebeu apenas 0,25\% desse $\operatorname{total}^{26}$. No que tange aos municípios, apenas 907 dos 5.562 municípios brasileiros foram contemplados, sendo que os dez maiores beneficiados entre os municípios concentraram $61,34 \%$ de todos os recursos, índice que sobe para $99 \%$ se considerados os 230 municípios mais favorecidos (desconsiderando o que é rateado por meio do Fundo Especial). O Município de Campos dos Goytacazes, por exemplo, recebeu 24,25\% do total dos royalties municipais ${ }^{27}$.

Se calculada a participação média, no período de 2000 a 2007, constata-se que o Estado do Rio de Janeiro foi beneficiado com $84 \%$ do total de royalties e PE destinados aos estados brasileiros, enquanto os municípios desse mesmo estado receberam $75 \%$ do total de rendas destinadas a todos os municípios. No âmbito estadual, três estados concentraram $91 \%$ da totalidade de recursos petrolíferos nesse período - RJ, RN e BA. Já na esfera municipal, esse percentual foi alcançado pelos municípios pertencentes a cinco estados - RJ, RN, SP, BA e $\mathrm{ES}^{28}$.

Especificamente quanto à exploração offshore, em 2008, o royalty incidente sobre a alíquota mínima (5\%) beneficiou 829 municípios, sendo que a alíquota superior a 5\% somente

\footnotetext{
${ }^{24}$ PIQUET, Rosélia; SERRA, Rodrigo. Petróleo e região no Brasil: o desafio da abundância. Rio de Janeiro: Garamond, 2007, p. 84.

${ }^{25}$ Cf. Tabela 5.1 - Distribuição das participações governamentais (royalties + PE) em 2006 (SZKLO, Alexandre Salem; MAGRINI, Alessandra (org.). Textos de discussão em geopolítica e gestão ambiental de petróleo. Rio de Janeiro: Interciência: Faperj, 2008. p. 73).

${ }^{26}$ Cf. tabela - Distribuição da renda petrolífera entre estados (AFONSO, José Roberto Rodrigues; GOBETTI, Sérgio Wulff. Renda do petróleo no Brasil: alguns aspectos fiscais e federativos. Revista do BNDES, Rio de Janeiro, v. 15, n. 30, p. 242, dez. 2008).

${ }^{27}$ Id. Ibid., p. 242.

${ }^{28}$ FREITAS, Paulo Springer de. Rendas do petróleo, questão federativa e instituição de fundo soberano. Releitura: compilação de textos para discussão, v. 1, n. 1, p. 91, jan./jun. 2010.
} 
foi destinada a 114 localidades. A participação especial - que representa cerca de metade das rendas petrolíferas - contemplou, no primeiro trimestre de 2008, apenas dois estados e 13 municípios brasileiros ${ }^{29}$.

No ano de 2009, o Município de Campos também foi o maior beneficiário em valores brutos, obtendo R $\$ 775.875 .811,13$ a título de royalties e PE. Se considerado o valor per capita, o Município aparece em $8^{\circ}$ lugar no ranking, tendo recebido $\mathrm{R} \$ 1.787,85$ de royalties e PE por cada habitante. O Município de Presidente Kennedy, no Espírito Santo, foi o que ocupou o $1^{\circ}$ lugar, se considerado o valor per capita, sendo beneficiado com $\mathrm{R} \$ 6.196,72$ por habitante. Se considerado o valor bruto, esse mesmo município aparece em $7^{\circ}$ lugar, com R $\$$ 66.193.393,48 de royalties e $\mathrm{PE}^{30} .31$

Em 2012, a produção nacional de petróleo, associada à produção de condensado e de gás natural, gerou uma receita de $\mathrm{R}$ \$ 31,5 bilhões, sendo $\mathrm{R}$ \$ 15,6 bilhões de royalties e $\mathrm{R} \$$ 15,9 bilhões de participação especial. Desse total, foram destinados R $\$ 12,7$ bilhões para o Estado do Rio de Janeiro e seus Municípios. As receitas de royalties e PE do Município de Campos dos Goytacazes totalizaram R \$ 1,4 bilhão, sendo que os municípios brasileiros, em conjunto, receberam, através do Fundo Especial, cerca de R \$ 1,3 bilhão, ou seja, valor inferior ao destinado a um único município fluminense ${ }^{32}$.

A hiperconcentração dos royalties em poucos entes e a abundância de recursos a ele destinados despertou o interesse acerca da destinação do dinheiro, sobretudo nos Municípios. Assim, há diversos estudos na literatura econômica dedicados à análise do desempenho dos entes denominados "petro-retistas". O objetivo é saber se os royalties favoreceram o desenvolvimento socioeconômico das municipalidades ou se pode ser verificada a "doença holandesa" ou "maldição dos recursos naturais", designações atreladas à ausência de diversificação na economia e ao desperdício da renda obtida com a exploração dos minerais (má aplicação dos recursos, corrupção, etc).

Como será exposto a seguir, a maioria desses estudos chegou à conclusão de que os recursos são mal aplicados e não beneficiam as populações das localidades beneficiadas.

\footnotetext{
${ }^{29}$ AFONSO, José Roberto Rodrigues; GOBETTI, Sérgio Wulff. Renda do petróleo no Brasil: alguns aspectos fiscais e federativos. Revista do BNDES, Rio de Janeiro, v. 15, n. 30, p. 241, dez. 2008.

${ }^{30}$ Cf. Tabelas 1 e 2 (POSTALI, Fernando Antonio Slaibe; NISHIJIMA, Marislei. Distribuição das rendas do petróleo e indicadores de desenvolvimento municipal no Brasil nos anos 2000. Estudos econômicos, São Paulo, v. 41, n. 2, p. 472, abr./jun. 2011).

${ }^{31}$ Para maiores informações sobre a distribuição de royalties per capita por município cf. Anexo 3: quadro histórico: royalties per capita, que abrange o período de 1999 a 2010. MACROPLAN. Royalties do Petróleo e Desenvolvimento Municipal: avaliação e propostas de melhoria. Relatório Final. Jun. 2012, p. 62. Disponível em: <http://macroplan.com.br/Documentos/EstudoMacroplan201282717367 .pdf>. Acesso em 22 fev. 2015.

${ }^{32}$ LIMA, Paulo César Ribeiro. Os "royalties do petróleo", a Lei no 12.734/2012 e Ação a ser julgada pelo STF. Disponível em: <http://www.aslegis.org/2013/04/os-royalties-do-petroleo-lei-n.html>. Acesso em 15 fev. 2015.
} 
Afonso e Gobetti observam que o grau de dependência de alguns municípios das receitas do petróleo é tamanha, que já se pode considerar que eles sofrem da "maldição dos recursos naturais". Dados do FMI apontam que os países ricos em hidrocarbonetos e minerais têm mais da metade de suas receitas advindas desses recursos, o que se constata em 40 entre 79 municípios examinados no Rio de Janeiro, conforme a Secretaria do Tesouro Nacional e o Tribunal de Contas do Estado do Rio de Janeiro ${ }^{33}$.

Os autores demonstram que, a partir de um certo ponto, o aumento da renda per capita provoca redução da eficiência tributária, ou seja, os governos locais tendem a relaxar na arrecadação de tributos próprios, pois eles não são necessários para o custeio das despesas municipais ${ }^{34}$.

Ademais, verificam que quanto maior a renda per capita com royalties, maior o gasto per capita com o legislativo municipal (vereadores e funcionários) e com o funcionalismo público de modo geral. Os gastos com pessoal "são mais elevados no grupo dos cem principais beneficiários dos royalties, ultrapassando em $33 \%$ a média per capital dos demais municípios recebedores desse tipo de compensação financeira." Entre 2002 e 2006, as despesas desse caráter nos vinte municípios que mais receberam royalties aumentou 70,7\% em valores nominais, o dobro da inflação verificada no período. Em Campos, por exemplo, o aumento chegou a $306,9 \%$.

O pior é que o aumento das despesas correntes não é convertido em benefício da população, ou seja, não há expansão dos serviços públicos e dos investimentos em obras e equipamentos, conforme se segue:

\begin{abstract}
Os gastos com o ensino fundamental são praticamente uniformes em todos os grupos, as despesas com atenção básica em saúde são inferiores entre os recebedores de rendas do petróleo e os investimentos em gestão ambiental - um dos pilares da argumentação em favor da concentração dos royalties em um grupo restrito de localidades sob impacto das atividades petrolíferas - são irrisórios em todas as classes de municípios.

As evidências reunidas indicam, portanto, que há sobrefinanciamento de alguns nichos da esfera municipal e que isso não está gerando nem retorno social à população das localidades impactadas pelas atividades petrolíferas nem ações preventivas para preparar economicamente essas regiões para um futuro sem petróleo. Mais do que isso, pode-se dizer que, em alguns casos específicos, há fortes indícios de desperdício de recursos públicos ${ }^{36}$.
\end{abstract}

\footnotetext{
${ }^{33}$ AFONSO, José Roberto Rodrigues; GOBETTI, Sérgio Wulff. Renda do petróleo no Brasil: alguns aspectos fiscais e federativos. Revista do BNDES, Rio de Janeiro, v. 15, n. 30, p. 243, dez. 2008. Para maiores detalhes, cf. tabela (p. 244) que expõe a receita tributária per capita dos Municípios, segundo dependência ou não dos royalties do petróleo.

${ }^{34}$ Id. Ibid., p. 245-246.

${ }^{35}$ Id. Ibid., p. 246-247.

${ }^{36}$ Id. Ibid., p. 248.
} 
Na mesma linha, Carnicelli e Postali, em pesquisa que avalia o gasto dos royalties e PE com pessoal, concluem que "as localidades beneficiadas estão direcionando os royalties a fins que não condizem com os preceitos econômicos e legais de bom uso destas riquezas ${ }^{37}$.".

Freitas avalia os indicadores socioeconômicos dos municípios por grau de dependência dos royalties e participações especiais advindos do petróleo e conclui que "não houve diferenças estatisticamente significantes entre os municípios que dependem fortemente das receitas do petróleo e os demais. Em relação ao PIB per capita, (...) o desempenho dos municípios dependentes de petróleo foi inferior à média nacional ${ }^{38}$."

Postali e Nishijima, ao investigar empiricamente se os royalties contribuem para a melhoria dos indicadores educação, saúde e emprego, e renda dos municípios beneficiados (medidos pelo IFDM - Índice Firjan de Desenvolvimento Municipal), em relação à média nacional, concluem que apenas nos anos de 2005 e 2006 o indicador relativo a emprego e renda foi superior nos municípios beneficiários. Para os demais indicadores, as médias dos municípios petrorentistas ficaram abaixo das médias dos municípios não beneficiados com royalties. Quando analisado o indicador como um todo, verificou-se que embora a abundância de recursos (medida por royalties per capita) não tenha interferência, "quanto mais dependente de rendas do petróleo, menor o IFDM do Município em relação à média nacional." O mesmo ocorre com os indicadores relacionados ao mercado de trabalho formal: quanto mais dependente de royalties, maior a informalidade das relações de trabalho.

Decat cita como exemplos de má gestão dos royalties as cidades de Campos dos Goytacazes e Quissamã. A primeira, apesar de líder em volume de repasses, está na posição $445^{\circ}$ no ranking nacional de desenvolvimento municipal realizado pela Federação de Indústrias do Estado do Rio de Janeiro, enquanto Quissamã, também grande beneficiária, está em $1.290^{\circ}$ da lista ${ }^{39}$.

Barros e Ikeda denunciam a má aplicação dos royalties e PE nos municípios de Campos (RJ) e Guamaré (RN). Em Campos, faltam escolas para as crianças e jovens e as existentes estão em péssima condição. Tanto que o Índice de Desenvolvimento da Educação Básica em 2010 foi o mais baixo do estado para os primeiros anos do ensino fundamental. Guamaré é hoje o $20^{\circ}$ município brasileiro em renda per capita. No entanto, há bairros sem

\footnotetext{
${ }^{37}$ CARNICELLI, Laur; POSTALI, Fernando Antonio Slaibe. Royalties do petróleo e emprego público nos municípios brasileiros. Estudos econômicos, São Paulo, v. 44, n. 3, p. 491-492, jul./set. 2014.

${ }^{38}$ FREITAS, Paulo Springer de. Rendas do petróleo, questão federativa e instituição de fundo soberano. Releitura: compilação de textos para discussão, v. 1, n. 1, p. 97, jan./jun. 2010.

${ }^{39}$ DECAT, Erich. A maldição do petróleo. Desafios do desenvolvimento, v. 6, n. 48, p. 59, mar. 2009.
} 
água, energia e esgoto. Um quarto da cidade trabalha para a prefeitura e os analfabetos representam mais de $1 / 5$ (um quinto) da população ${ }^{40}$.

Estudo realizado pela consultoria Macroplan que analisou os indicadores econômicos, sociais e de finanças públicas das 25 (vinte e cinco) cidades que mais receberam royalties entre 2000 e 2010 ${ }^{41}$, nos Estados do Rio de Janeiro, São Paulo e Espírito Santo, concluiu que os recursos não beneficiaram a maioria da população.

O estudo contemplou diversos aspectos relacionados ao desenvolvimento e chegou às seguintes conclusões: a) o crescimento do número de empregos formais nas cidades analisadas, entre 2003 e 2010, foi de 65\%, superior à média nacional (49,2\%). Entretanto, considerando o conjunto dos 25 municípios, houve um incremento de $74 \%$ no emprego na administração pública, mais do dobro da média brasileira; b) os royalties financiam em grande parte as despesas permanentes, implicando riscos futuros para a manutenção da gestão municipal. Verificou-se que, excluídos os royalties e PE da renda dos municípios analisados, apenas 7 dos 25 teriam recursos, no biênio 2009-2010, para cobrir as despesas de pessoal e custeio em geral entre 2003 e 2010; c) as despesas de pessoal e as demais despesas de custeio do conjunto dos municípios analisados dobraram, em termos reais, enquanto os investimentos cresceram apenas $24 \%$; d) o forte crescimento demográfico gera demanda por serviços públicos, o que se refletiu na deterioração do acesso adequado a serviços de saneamento; e) quanto à frequência e desempenho educacional, 50\% das "cidades petróleo" (CP) fluminenses estão abaixo da média do estado do Rio de Janeiro; f) os indicadores de mortalidade infantil mostraram avanços significativos, mas a situação ainda é preocupante em algumas cidades; g) a situação da segurança ainda é crítica na maioria das CP: 13 (treze) cidades possuem taxas de homicídios acima das respectivas médias estaduais, sendo que quatro delas figuram entre as 100 (cem) cidades mais violentas do Brasil; h) os royalties não se traduziram em melhorias compatíveis nos índices de desenvolvimento socioeconômico. Tendo por base o Índice Firjan de Desenvolvimento (IFDM), constatou-se que 16 (dezesseis) das 25 (vinte e cinco) cidades consideradas no estudo apresentaram IFDM abaixo da média nacional; i) há um número significativo de pessoas vivendo com renda insuficiente para o seu sustento nessas cidades: 41 mil pessoas vivem com renda inferior a $\mathrm{R} \$ 70$ e 191,5 mil pessoas com renda inferior a $\mathrm{R} \$ 127,5$ (1/4 do salário mínimo); j) em 2010, 14 (quatorze) dos 25 (vinte e cinco) municípios

\footnotetext{
${ }^{40}$ BARROS, Daniel; IKEDA, Patrícia. A festa dos royalties. Exame, v. 46, n. 16, p. 186-188, ago. 2012.

${ }^{41} \mathrm{O}$ PIB per capita é maior nessas cidades se comparados ao Brasil e aos seus Estados. Em alguns casos, seu valor chega a ser de cinco a mais de dez vezes o nacional (MACROPLAN. Royalties do Petróleo e Desenvolvimento Municipal: avaliação e propostas de melhoria. Relatório Final. Jun. 2012. Disponível em: <http://macroplan.com.br/Documentos/EstudoMacroplan 201282717367.pdf>. Acesso em 22 fev. 2015).
} 
analisados, possuíam percentual de pessoas na condição de pobreza extrema mais alto do que a média dos respectivos estados; k) dentre as 25 CP, 14 apresentaram, em 2010, um percentual de domicílios com acesso à internet menor do que a média brasileira; 1) os investimentos em cultura e lazer e preservação do meio ambiente não ocupam um espaço importante na destinação dos recursos na maioria das "cidades petróleo"; m) Nos municípios pesquisados não foram percebidos avanços significativos no modelo de gestão, para uma melhor aplicação dos recursos dos royalties ${ }^{42}$.

Ribeiro, Teixeira e Gutierrez, em pesquisa que investiga o impacto dos royalties do petróleo no PIB per capita dos municípios do Estado do Espírito Santo, também concluem que o recebimento de royalties não favoreceu o crescimento econômico daqueles municípios, conforme se segue:

\footnotetext{
Historicamente observou-se que a receita de royalties vem crescendo, fortalecendo o papel arrecadador do Estado. Apesar disso, os resultados não apresentaram evidências de que essa transferência de recursos do setor privado para o setor público e forma de royalties do petróleo e gás natural tenha proporcionado um efeito positivo no crescimento econômico dos municípios do Estado do Espírito Santo, aqui medido pelo PIB per capita municipal. (...)

Os resultados empíricos sugerem a necessidade de uma reavaliação de política pública de royalties no Brasil, buscando fundamentação econômica na sua condução, com o propósito de gerar sustentação financeira entre os entes federativos quando os recursos naturais se exaurirem ${ }^{43}$.
}

Vale acrescentar que os critérios de partilha, responsáveis pela hiperconcentração de recursos, nem sempre privilegiam os estados e municípios mais impactados pela exploração do petróleo.

Nesse sentido, Lima observa que eles privilegiam critérios de confrontação, ao invés de considerar critérios de real impacto ou "afetação". Para exemplificar, o autor cita o caso do campo de Lula, considerado o mais importante do pré-sal. Embora seja confrontante com o Estado do Rio de Janeiro (que recebe royalties), a atividade nessa área gera pouco impacto naquele estado, sendo o Estado de São Paulo o mais afetado, pois o gás natural produzido em

\footnotetext{
${ }^{42}$ MACROPLAN. Royalties do Petróleo e Desenvolvimento Municipal: avaliação e propostas de melhoria. Relatório Final. Jun. 2012. Disponível em: <http://macroplan.com.br/Documentos/EstudoMacroplan 201282717367.pdf>. Acesso em 22 fev. 2015.

${ }^{43}$ RIBEIRO, Edivan Guidote; TEIXEIRA, Arilton; GUTIERREZ, Carlos Enrique Carrasco. Impacto dos royalties do petróleo no PIB per capita dos municípios do Estado do Espírito Santo, Brasil. Revista Brasileira de Gestão de Negócios. Disponível em: <www.spell.org.br/documentos/download/6586>. Acesso em: 20 fev. 15.
} 
Lula é processado em Caraguatatuba. O município de Caraguatatuba recebe royalties por ser considerado "afetado", mas São Paulo não recebe recursos, por não ser confrontante ${ }^{44}$.

Na mesma linha, Serra aduz que os critérios de distribuição dos royalties decorrentes da exploração offshore entre os municípios "encerram um notável determinismo físico", pois contemplam aqueles que estão mais próximos dos campos de produção, sem considerar a efetiva presença das empresas petrolíferas no continente, que é o fator que efetivamente gera impacto. Por isso, o autor entende que os municípios mais agraciados pelos royalties são, na verdade, "sortudos" 45 .

Mercadante salienta que o critério utilizado pelo IBGE cria situações esdrúxulas. Cita o exemplo dos Municípios de Quissamã e Belford Roxo. O primeiro recebe ao ano quase R\$ 7 mil per capita de royalties, enquanto o segundo, um município com graves problemas sociais decorrentes da exploração do petróleo, recebe apenas $\mathrm{R} \$ 13,00 .{ }^{46}$

Freitas cita o exemplo das cidades de Campos e Macaé. Esta é a maior impactada pela atividade petrolífera, pois possui a maior estrutura de apoio à produção, no entanto Campos é a cidade mais beneficiada pelos royalties ${ }^{47}{ }^{48}$

A concentração de recursos aliada a sua má aplicação, bem como a expansão do volume da produção, com a descoberta do pré-sal ${ }^{49}$, suscitaram intensos debates no Congresso Nacional que tentou, por diversas vezes, alterar o modelo de partilha existente, conforme será detalhado a seguir.

\footnotetext{
${ }^{44}$ LIMA, Paulo César Ribeiro. Os "royalties do petróleo", a Lei no 12.734/2012 e Ação a ser julgada pelo STF, p. 21. Disponível em: <http://www.aslegis.org/2013/04/os-royalties-do-petroleo-lei-n.html>. Acesso em 15 fev. 2015.

${ }^{45}$ SERRA, Rodrigo Valente. O sequestro das rendas petrolíferas pelo poder local: a gênese das quase sortudas regiões produtoras. Revista brasileira de estudos urbanos e regionais, v. 9, n. 1, p. 102-103, maio 2007.

${ }^{46}$ MERCADANTE, Aloizio. Os campos do possível: a oportunidade histórica do pré-sal. Interesse nacional, v. 1, n. 4, p. 36, jan./mar. 2009.

${ }^{47}$ FREITAS, Paulo Springer de. Rendas do petróleo, questão federativa e instituição de fundo soberano. Releitura: compilação de textos para discussão, v. 1, n. 1, p. 87, jan./jun. 2010.

${ }^{48}$ No mesmo sentido cf. LIMA, op. cit., p. 11-12.

49 "Não há estimativa concreta do potencial do pré-sal. Os mais pessimistas falam em algo entre 30 bilhões e 50 bilhões de barris, o que elevaria em cerca de quatro vezes as reservas do País. Mas há quem diga que esse valor pode ser seis vezes maior. Segundo o ex-diretor da Agencia Nacional do Petróleo (ANP) Newton Monteiro, o pré-sal pode guardar 338 bilhões de barris. Caso esse número se confirme, o Brasil poderá ser o maior detentor de reservas provadas do mundo. (...) o pré-sal poderá render mais de $\mathrm{R} \$ 47$ bilhões em arrecadação de royalties, participação especial e impostos, nos próximos 50 anos. (...) A necessidade de mudança se torna cada vez mais urgente, visto que as regras atuais incentivam a concentração das compensações financeiras." (DECAT, Erich. A maldição do petróleo. Desafios do desenvolvimento, v. 6, n. 48, p. 58, mar. 2009).
} 


\subsection{HISTÓRIA LEGISLATIVA RECENTE (PÓS CONSTITUIÇÃO DE 1988)}

\section{ACERCA DA DISTRIBUIÇÃO DOS ROYALTIES E PARTICIPAÇÕES ESPECIAIS DO PETRÓLEO}

Nesse tópico, serão analisadas algumas tentativas do legislador infraconstitucional de alterar as regras de partilha dos royalties e PE decorrentes da exploração do petróleo, que culminaram com a aprovação da Lei $n^{\circ} 12.734 / 12$.

A seleção dos projetos de lei que serão tratados nesse tópico se deu em virtude de sua temática - proposta de alteração das regras de partilha - e de sua relevância política, isto é, serão analisados aqueles que despertaram maiores discussões no Parlamento.

Vale dizer que ao final do presente trabalho consta tabela ${ }^{50}$ detalhada dos atos legislativos que objetivaram alterar o marco regulatório do petróleo, tanto os que sugerem nova sistemática de distribuição, bem como os que propõem a vinculação das receitas geradas pela exploração do recurso. É que, embora o foco do trabalho seja discutir a partilha dos royalties e PE, a sua destinação é de grande relevância para o debate, sendo inclusive um dos fundamentos utilizados para que haja uma distribuição mais equânime. A tabela permite a consulta da tramitação dos atos legislativos até 30/9/2014, a data de sua apresentação, a sua autoria, o Relator designado em cada Comissão e no Plenário, os pareceres aprovados e se houve algum tipo de veto ao projeto.

O debate acerca do marco regulatório do petróleo teve início em 2009, com o encaminhamento de quatro projetos de lei pelo Presidente da República ao Congresso Nacional: PLs n ${ }^{\circ}$ 5.938/09, 5.939/09, 5.940/09 e 5.941/09. Esses atos tratavam da criação do regime de partilha de produção e de outros temas correlatos, mas silenciavam quanto à redistribuição de royalties e $\mathrm{PE}^{51}$.

A primeira tentativa de mudança na sistemática de distribuição desses recursos ficou conhecida como "Emenda Ibsen". Trata-se de emenda apresentada pelo Deputado Ibsen

\footnotetext{
${ }^{50}$ Cf. Tabela 1 - Atos legislativos relevantes.

${ }^{51}$ Para melhor visualização das propostas encaminhadas pelo Chefe do Executivo e respectivas temáticas, cf. quadro resumo: Esquema da tramitação das matérias sobre a mudanças do marco regulatório do petróleo, promovidas desde 2009 (VIEGAS, Paulo Roberto Alonso. Aspectos da MP no 592, de 2012, sobre a distribuição de royalties e outras participações governamentais na exploração de petróleo e gás natural, p. 10. Disponível em: <http://www12.senado.gov.br/publicacoes/estudos-legislativos/tipos-de-estudos/textos-para-discussao/td119-aspectos-da-mp-no-592-de-2012-sobre-a-distribuicao-de-royalties-e-outras-participacoes-governamentaisna-exploracao-de-petroleo-e-gas-natural >. Acesso em: 29 jan. 2015.
} 
Pinheiro que foi apresentada em Plenário e incorporada à redação final do Projeto de Lei $\mathrm{n}^{\circ}$ 5.938/09. ${ }^{52}$ Eis o teor da referida emenda:

\begin{abstract}
Art. 45. Ressalvada a participação da União, a parcela restante dos royalties e participações especiais oriundos dos contratos de partilha de produção e de concessão de que trata a Lei $\mathrm{n}^{\mathbf{0}}$ 9.478, de 6 de agosto de 1997, quando a lavra ocorrer na plataforma continental, mar territorial ou zona econômica exclusiva, será dividida entre Estados, Distrito Federal e Municípios da seguinte forma:

I - 50\% (cinquenta por cento) para constituição de Fundo Especial a ser distribuído entre todos os Estados e o Distrito Federal, de acordo com os critérios de repartição do fundo de Participação dos Estados - FPE;

II $-50 \%$ (cinquenta por cento) para constituição de Fundo Especial a ser distribuído entre todos os Municípios, de acordo com os critérios de repartição do Fundo de Participação dos Municípios - FPM ${ }^{53}$.
\end{abstract}

Após a sua aprovação na Câmara dos Deputados, a "Emenda Ibsen" seguiu para o Senado Federal, onde passou a tramitar como PLC no 16/10. O Senador Romero Jucá foi designado relator da matéria em Plenário, mas nem chegou a apresentar Relatório. O projeto foi arquivado no Senado, em virtude da aprovação de Substitutivo ao PLS n ${ }^{\circ}$ 448/11, que será abordado adiante.

Também objetivando a mudança das regras de partilha dos royalties e PE, o Senador Pedro Simon apresentou uma emenda ao PLC $n^{\circ} 7 / 10$, que ficou conhecida como "Emenda Simon”. Ela sugere divisão semelhante à proposta pelo Deputado Ibsen Pinheiro, com duas diferenças: a) ressalva, além da participação da União, a dos municípios afetados pelas operações de embarque e desembarque de petróleo e gás natural; b) prevê que a União compensará os estados e municípios que sofrerem redução de suas receitas em virtude da Lei, até que estas se recomponham mediante o aumento da produção. Confira-se o teor da emenda:

Art. 64. Ressalvada a participação da União, bem como a destinação prevista na alínea $d$ do inciso II do art. 49 da Lei no 9.478, de 6 de agosto de 1997, a parcela restante dos royalties e participações especiais oriunda dos contratos de partilha de produção ou de concessão de que trata a mesma Lei, quando a lavra ocorrer na plataforma continental, mar territorial ou zona econômica exclusiva, será dividida entre Estados, Distrito Federal e Municípios da seguinte forma:

I - 50\% (cinquenta por cento) para constituição de fundo especial a ser distribuído entre todos os Estados e Distrito Federal, de acordo com os critérios de repartição do Fundo de Participação dos Estados - FPE; e

II - 50\% (cinquenta por cento) para constituição de fundo especial a ser distribuído entre todos os Municípios, de acordo com os critérios de repartição do Fundo de Participação dos Municípios - FPM.

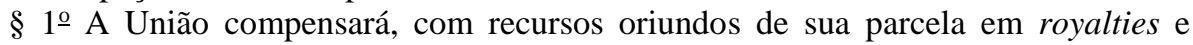
participações especiais, bem como do que lhe couber em lucro em óleo, tanto no

52 Tramitação do PL $\mathrm{n}^{\mathrm{o}}$ 5.938/09. Disponível em: <http://www.camara.gov.br/proposicoesWeb/ fichadetramitacao?idProposicao=447934>. Acesso em: 27 fev. 2015.

53 Disponível em: <http://www.camara.gov.br/proposicoesWeb/prop_mostrarintegra?codteor=744347 \&filename=RDF+1+\%3D\%3E+PL+5938/2009>. Acesso em: 27 fev. 2015. 
regime de concessão quanto no regime de partilha de produção, os Estados e Municípios que sofrerem redução de suas receitas em virtude desta Lei, até que estas se recomponham mediante o aumento de produção de petróleo no mar.

$\S 2^{\circ}$ Os recursos da União destinados à compensação de que trata o $\S 1$ o deverão ser repassados aos Estados e Municípios que sofrerem redução de suas receitas em virtude desta Lei, simultaneamente ao repasse efetuado pela União aos demais Estados e Municípios.

$\S 3^{\circ}$ Os royalties correspondem à participação no resultado da exploração de petróleo, de gás natural e de outros hidrocarbonetos fluidos de que trata o $\S 1$ o do art. 20 da Constituição Federal, vedada a sua inclusão no cálculo do custo em óleo, bem como qualquer outra forma de restituição ou compensação aos contratados, ressalvado o disposto no $\S 11^{\circ}$ do art. 50 da Lei no 9.478 , de 6 de agosto de $1997^{54}$.

A "Emenda Simon" restou aprovada no Senado Federal como uma das "disposições finais e transitórias" do PLC $\mathrm{n}^{\mathrm{o}} 7 / 2010$, o qual, após sancionado, se transformou na Lei $\mathrm{n}^{\mathrm{o}}$ 12.351/2010. No entanto, a referida emenda foi vetada pelo Presidente Lula (Veto Parcial $n^{\circ}$ 39/2010). Esse veto não foi deliberado pelo Congresso Nacional, embora muitos parlamentares defendessem a sua derrubada.

Como se vê, ambas as tentativas trataram de redistribuir os royalties e PE do petróleo, tanto no regime de concessão quanto no de partilha, apenas no caso de exploração offshore. $\mathrm{O}$ fundamento defendido era o de que a exploração em mar é distinta da realizada em terra, pois, no primeiro caso, ela não se dá em solo de um determinado estado ou município, mas sim em solo da União.

As principais discussões que essas emendas despertaram no Congresso giraram em torno: a) da sua aplicação aos contratos de concessão já celebrados; b) da ausência de qualquer parcela diferenciada para os estados e municípios confrontantes em relação aos demais entes da federação; c) do fato de toda a receita ser partilhada de acordo com os Fundos de Participação dos Estados e Municípios, cujos critérios de rateio foram considerados inconstitucionais pelo Supremo Tribunal Federal, por não mais refletirem a realidade socioeconômica dos entes da federação ${ }^{55}$; e d) ausência de critérios legais para a compensação de receitas aos estados e municípios confrontantes pela União (no caso da Emenda Simon).

Por conta dos vetos presidenciais que impediram a redistribuição dos frutos do petróleo, foram apresentados diversos projetos de lei no Senado Federal ${ }^{56}$ com o objetivo de modificar a sistemática de partilha, dentre eles o Projeto de Lei $\mathrm{n}^{\circ} 448 / 11$, de autoria do Senador Wellington Dias, o qual foi aprovado na forma de Substitutivo apresentado pelo

\footnotetext{
54 Redação final do PLC no 7/10. Disponível em: <http://www.senado.gov.br/atividade/materia/getPDF. asp?t=79699\&tp=1>. Acesso em: 25 fev. 2015.

${ }^{55}$ Cf. ADI no 875/DF, Relator: Min. Gilmar Mendes, Tribunal Pleno, julgado em 24/02/2010, DJe de 30/4/2010 EMENT VOL-02399-02 PP-00219 RTJ VOL-00217- PP-00020 RSJADV jul., 2010, p. 28-47). Disponível em: <www.stf.jus.br>. Acesso em 20 abril de 2015.

${ }^{56}$ Vide tabela de atos legislativos ao final do trabalho.
} 
Senador Vital do Rêgo (Relator) e confirmado pela Câmara dos Deputados (PL nº 2565/11, na Câmara).

Em 30/11/12, a Presidente Dilma Rousseff sancionou o referido projeto (Lei $\mathrm{n}^{\mathrm{o}}$ 12.734/12). Quase todos os dispositivos do projeto que estabeleciam novos critérios de distribuição de royalties e PE, no entanto, foram vetados (Veto $\mathrm{n}^{\circ}$ 38/12).

Para compensar o veto, a Presidente da República Dilma Rousseff publicou, em 31/12/12, a Medida Provisória (MP) no 592, que determinou novas regras de distribuição de royalties e PE decorrentes da exploração do petróleo em mar, sob o regime de concessão, bem como disciplinou a destinação dos recursos do Fundo Social. A referida MP continha regras de transição e determinava que as novas regras - que reduzem percentuais dos estados e municípios confrontantes em benefício dos demais - compreenderiam apenas os contratos de concessão firmados a partir de 3 de dezembro de $2012^{57}$. No entanto, foi arquivada sem ter havido parecer aprovado pelo Legislativo.

Em 6/3/13, o Congresso Nacional derrubou o veto parcial da Presidente ao Projeto de Lei $n^{\circ} 2565 / 11$, restabelecendo-se a sua redação original. A Lei $n^{0} 12.734 / 12$, originada do referido projeto, redistribui royalties e participações especiais devidos em função da exploração de petróleo, tanto no regime de partilha como no de concessão, sendo que neste último regime, a lei estabelece regras de transição que culminam em redução anual das alíquotas devidas aos estados e municípios produtores e confrontantes até 2020. Em síntese, a divisão aprovada é a seguinte:

Proposta do Substitutivo para repartição dos royalties de 2012 a $2020^{58}$ :

\begin{tabular}{|l|l|l|l|l|l|l|l|l|l|l|l|}
\hline ROYALTIES & $\mathbf{2 0 1 0}$ & $\mathbf{2 0 1 1}$ & $\mathbf{2 0 1 2}$ & $\mathbf{2 0 1 3}$ & $\mathbf{2 0 1 4}$ & $\mathbf{2 0 1 5}$ & $\mathbf{2 0 1 6}$ & $\mathbf{2 0 1 7}$ & $\mathbf{2 0 1 8}$ & $\mathbf{2 0 1 9}$ & $\mathbf{2 0 2 0}$ \\
\hline Total & $100 \%$ & $100 \%$ & $100 \%$ & $100 \%$ & $100 \%$ & $100 \%$ & $100 \%$ & $100 \%$ & $100 \%$ & $100 \%$ & $100 \%$ \\
\hline União & $30 \%$ & $30 \%$ & $20 \%$ & $20 \%$ & $20 \%$ & $20 \%$ & $20 \%$ & $20 \%$ & $20 \%$ & $20 \%$ & $20 \%$ \\
\hline $\begin{array}{l}\text { Total dos } \\
\text { Confrontantes }\end{array}$ & $61,25 \%$ & $61,25 \%$ & $40 \%$ & $38 \%$ & $36 \%$ & $34 \%$ & $32 \%$ & $29 \%$ & $27 \%$ & $26 \%$ & $26 \%$ \\
\hline $\begin{array}{l}\text { Estados } \\
\text { confrontantes }\end{array}$ & $26,25 \%$ & $26,25 \%$ & $20 \%$ & $20 \%$ & $20 \%$ & $20 \%$ & $20 \%$ & $20 \%$ & $20 \%$ & $20 \%$ & $20 \%$ \\
\hline $\begin{array}{l}\text { Municípios } \\
\text { confrontantes }\end{array}$ & $26,25 \%$ & $26,25 \%$ & $17 \%$ & $15 \%$ & $13 \%$ & $11 \%$ & $9 \%$ & $7 \%$ & $5 \%$ & $4 \%$ & $4 \%$ \\
\hline $\begin{array}{l}\text { Municípios } \\
\text { afetados }\end{array}$ & $8,75 \%$ & $8,75 \%$ & $3 \%$ & $3 \%$ & $3 \%$ & $3 \%$ & $3 \%$ & $2 \%$ & $2 \%$ & $2 \%$ & $2 \%$ \\
\hline
\end{tabular}

\footnotetext{
${ }^{57}$ Cf. artigo $2^{\circ}$ da MP n ${ }^{\circ} 592 / 12$.

58 Tabelas constantes do Parecer do Senador Vital do Rêgo ao PLS n ${ }^{\circ}$ 448/11, p. 17-18. Disponível em: <http://www.senado.gov.br/noticias/agencia/pdfs/parecer_\%20royalties.pdf>. Acesso em 26 fev. 2015.
} 


\begin{tabular}{|l|c|c|c|c|c|c|c|c|c|c|c|}
\hline ROYALTIES & $\mathbf{2 0 1 0}$ & $\mathbf{2 0 1 1}$ & $\mathbf{2 0 1 2}$ & $\mathbf{2 0 1 3}$ & $\mathbf{2 0 1 4}$ & $\mathbf{2 0 1 5}$ & $\mathbf{2 0 1 6}$ & $\mathbf{2 0 1 7}$ & $\mathbf{2 0 1 8}$ & $\mathbf{2 0 1 9}$ & $\mathbf{2 0 2 0}$ \\
\hline Fundo especial & $8,75 \%$ & $8,75 \%$ & $40 \%$ & $42 \%$ & $44 \%$ & $46 \%$ & $48 \%$ & $51 \%$ & $53 \%$ & $54 \%$ & $54 \%$ \\
\hline FPE & $7 \%$ & $7 \%$ & $20 \%$ & $21 \%$ & $22 \%$ & $23 \%$ & $24 \%$ & $25 \%$ & $\begin{array}{c}26,5 \\
\%\end{array}$ & $27 \%$ & $27 \%$ \\
\hline FPM & $1,75 \%$ & $1,75 \%$ & $20 \%$ & $21 \%$ & $22 \%$ & $23 \%$ & $24 \%$ & $\begin{array}{c}25,5 \\
\%\end{array}$ & $\begin{array}{c}26,5 \\
\%\end{array}$ & $27 \%$ & $27 \%$ \\
\hline
\end{tabular}

Proposta do Substitutivo para repartição da participação especial de 2012 a 2020:

\begin{tabular}{|c|c|c|c|c|c|c|c|c|c|c|c|}
\hline ROYALTIES & 2010 & 2011 & 2012 & 2013 & 2014 & 2015 & 2016 & 2017 & 2018 & 2019 & 2020 \\
\hline Total & $100 \%$ & $100 \%$ & $100 \%$ & $100 \%$ & $100 \%$ & $100 \%$ & $100 \%$ & $100 \%$ & $100 \%$ & $100 \%$ & $100 \%$ \\
\hline União & $50 \%$ & $50 \%$ & $42 \%$ & $43 \%$ & $44 \%$ & $45 \%$ & $46 \%$ & $46 \%$ & $46 \%$ & $46 \%$ & $46 \%$ \\
\hline $\begin{array}{l}\text { Total dos } \\
\text { confrontantes }\end{array}$ & $50 \%$ & $50 \%$ & $39 \%$ & $37 \%$ & $34 \%$ & $31 \%$ & $29 \%$ & $27 \%$ & $25 \%$ & $24 \%$ & $24 \%$ \\
\hline $\begin{array}{l}\text { Estados } \\
\text { confrontantes }\end{array}$ & $40 \%$ & $40 \%$ & $34 \%$ & $32 \%$ & $29 \%$ & $26 \%$ & $24 \%$ & $22 \%$ & $20 \%$ & $20 \%$ & $20 \%$ \\
\hline $\begin{array}{l}\text { Municípios } \\
\text { confrontantes }\end{array}$ & $10 \%$ & $10 \%$ & $5 \%$ & $5 \%$ & $5 \%$ & $5 \%$ & $5 \%$ & $5 \%$ & $5 \%$ & $4 \%$ & $4 \%$ \\
\hline $\begin{array}{l}\text { Municípios } \\
\text { afetados }\end{array}$ & $0 \%$ & $0 \%$ & $0 \%$ & $0 \%$ & $0 \%$ & $0 \%$ & $0 \%$ & $0 \%$ & $0 \%$ & $0 \%$ & $0 \%$ \\
\hline $\begin{array}{l}\text { Fundo } \\
\text { especial }\end{array}$ & $0 \%$ & $0 \%$ & $19 \%$ & $20 \%$ & $22 \%$ & $24 \%$ & $25 \%$ & $27 \%$ & $29 \%$ & $30 \%$ & $30 \%$ \\
\hline FPE & $0 \%$ & $0 \%$ & $9,50 \%$ & $10 \%$ & $11 \%$ & $12 \%$ & $12,50 \%$ & $13,50 \%$ & $14,50 \%$ & $15 \%$ & $15 \%$ \\
\hline FPM & $0 \%$ & $0 \%$ & $9,50 \%$ & $10 \%$ & $11 \%$ & $12 \%$ & $12,50 \%$ & $13,50 \%$ & $14,50 \%$ & $15 \%$ & $15 \%$ \\
\hline
\end{tabular}

A lei estabelece, ainda, um teto para os municípios, que seria o valor recebido em 2011 ou o dobro do que foi distribuído pelo FPM, mensurado em termos per capita.

No entanto, poucos dias após a derrubada do veto, foi concedida medida cautelar pela Ministra Carmen Lúcia, na ADI $n^{\circ} 4917$, para suspender os efeitos dos dispositivos da Lei $\mathrm{n}^{\circ}$ 12.734/12 que redistribuem royalties e PE.

\subsection{AÇÕES JUDICIAIS INICIADAS CONTRA A NOVA SISTEMÁTICA DE} DISTRIBUIÇÃO DOS ROYALTIES E PARTICIPAÇÕES ESPECIAIS

Já durante a análise do Projeto de Lei n ${ }^{0}$ 2565/11 foram ajuizados diversos Mandados de Segurança por Parlamentares, sobretudo do Rio de Janeiro e do Espírito Santo, com o objetivo de impedir a sua tramitação. O principal fundamento utilizado era o de que o projeto tendia a abolir cláusula pétrea consubstanciada na forma federativa de Estado (art. 60, § $4^{\circ}$, I da Constituição). 
Os mandados de segurança com esse fundamento não foram apreciados. No entanto, foi deferida medida cautelar no MS no 31816/DF que, impetrado em fase posterior, questionava a possibilidade de derrubada do veto parcial aposto ao projeto de lei (Veto $\mathrm{n}^{\mathrm{o}}$ 38/2012), sob o principal argumento de que a Constituição exige, nos $\S \S 4^{\circ}$ e $6^{\circ}$ do art. 66 , que os vetos sejam apreciados em ordem que obedeça a algum critério objetivo razoável. O Relator, Ministro Luiz Fux, deferiu a liminar em 18/12/12 para determinar à Mesa Diretora do Congresso que se abstivesse de deliberar acerca desse veto antes que se procedesse à análise de todos os vetos pendentes com prazo de análise expirado. A decisão, no entanto, foi reformada pelo STF, em sede de agravo regimental, o que possibilitou a apreciação e derrubada do veto pelo Parlamento.

Após a derrubada do Veto $\mathrm{n}^{0} 38 / 12$ pelo Congresso Nacional, foram ajuizadas quatro ações diretas de inconstitucionalidade questionando a Lei $\mathrm{n}^{\mathrm{o}}$ 12.734/12, de autoria dos governadores do Estado do Rio de Janeiro (ADI 4917), do Espírito Santo (ADI 4916) e de São Paulo (ADI 4920), e da Mesa da Assembleia Legislativa do Estado do Rio de Janeiro (ADI 4918). A Relatora, Ministra Carmen Lúcia, concedeu medida cautelar na primeira delas, para determinar a suspensão dos efeitos dos dispositivos da Lei $\mathrm{n}^{\circ}$ 12.734/12 que redistribuem royalties e PE decorrentes da exploração do petróleo.

Por fim, vale dizer que ao final do trabalho consta tabela ${ }^{59}$ detalhando os processos judiciais relacionados à problemática de partilha dos royalties e PE, com informações sobre data de ajuizamento, atores processuais, peças processuais, decisões judiciais proferidas e o último andamento (até 30/9/2014).

${ }^{59} \mathrm{Cf}$. Tabela 2 - processos judiciais relevantes. 


\section{UMA CARACTERIZAÇÃO DAS VISÕES DOMINANTES NO DIREITO CONSTITUCIONAL}

O objetivo deste capítulo é oferecer uma descrição genérica e esquemática das doutrinas dominantes no âmbito do direito constitucional brasileiro (dogmática e neoconstitucionalismo), com o escopo principal de assinalar, em relação a ambas as abordagens, a carência de meios para tratar em detalhe suficiente de fatos econômicos e políticos relevantes - no particular, de aspectos econômicos e políticos abrangidos nas discussões acerca da partilha do pré-sal.

Nessa linha, o presente trabalho não tem o propósito de esgotar as origens conceituais e a evolução teórica do neoconstitucionalismo e da dogmática jurídica, mas apenas caracterizar perspectivas de pensamentos quanto ao modo de interpretar e aplicar a Constituição, presentes na cultura jurídica brasileira de forma mais perceptível.

A identificação dessas duas doutrinas como dominantes no direito constitucional brasileiro é realizada por Marcus Faro de Castro, conforme se segue:

\footnotetext{
Com origem nas tradições alemã e estadunidense de discurso jurídico sobre a constituição, acima referidas, o direito constitucional brasileiro conta hoje com duas principais visões de fundo sobre o que a constituição é e como deve ser realizada na prática. Estas duas visões de fundo correspondem, respectivamente:

- a um projeto germanizante (que procura reproduzir e adaptar, na medida do possível, no Brasil, construções dogmáticas do direito constitucional alemão positivado e seus apoios doutrinários); e

- a um projeto mais eclético, aderente ao chamado neoconstitucionalismo, com inspiração forte em juristas que - sob a liderança de Ronald Dworkin e seu foco na produção jurisprudencial da Suprema Corte dos Estados Unidos, mas com influência também em Robert Alexy - atribuem à noção de "direitos", referidos a "princípios" abstratos, e à ponderação entre eles, um papel chave na determinação do significado das normas constitucionais ${ }^{60}$,
}

Tercio Ferraz Jr., estudioso e crítico da dogmática, também reconhece que essa visão é dominante, ao explicar que o foco no modelo se dá pelo fato de ser "o ângulo privilegiado com que o direito é conhecido e ensinado nas Faculdades de Direito. Não que isso signifique um desprezo pela perspectiva zetética. Trata-se, apenas, de escolher uma tônica dominante ${ }^{61} . "$

${ }^{60}$ CASTRO, Marcus Faro de. Globalização, Democracia e Direito Constitucional: Legados Recebidos e Possibilidades de Mudança. In: CLĖVE, Clèmerson Merlin; FREIRE, Alexandre (coords.). Direitos Fundamentais e Jurisdição Constitucional: Análise, Crítica e Contribuições. São Paulo: Editora Revista dos Tribunais, 2014, p. 712.

${ }^{61}$ FERRAZ JUNIOR, Tercio Sampaio. Introdução ao estudo do direito: técnica, decisão, dominação. São Paulo: Atlas, 2007, p. 51. 
Depois de identificadas as doutrinas dominantes, serão caracterizadas as visões dogmática e neoconstitucionalista, bem como apresentados os pontos de convergência entre ambas (ponderação de valores e primazia do Poder Judiciário).

A exposição das teses encampadas pelas visões dominantes no direito constitucional brasileiro permitirá a conclusão de que as categorias jurídicas que propõem para interpretar e aplicar a Constituição são insuficientes para tratar de fatos e escolhas políticos e econômicos relevantes, pois quanto ao modelo dogmático: a) defende que as decisões devem ser baseadas exclusivamente em normas jurídicas; b) apresenta as normas jurídicas como se fossem dogmas, que possuem uma única interpretação correta, e cuja legitimidade ou validade não se questiona; c) interpreta de modo excessivamente formalista as normas jurídicas; d) com isso, impossibilita a flexibilização do direito para atender as demandas sociais; f) atua como instrumento de perpetuação das ideologias dominantes, favorecendo a desigualdade; g) também favorece a manutenção da ordem estabelecida, que nem sempre é adequada para se obter uma decisão justa e; g) afasta a possibilidade crítica e reflexiva acerca das normas jurídicas e de sua interpretação.

Quanto ao neoconstitucionalismo: a) foca exageradamente na distinção entre regras e princípios, propondo formas de aplicação distintas para tais categorias, o que gera uma divisão imprópria do texto constitucional, esvaindo-se a noção do todo e do conjunto de objetivos constitucionais; b) enxerga a Constituição como uma carta de princípios abstratos, cujo conteúdo deve ser preenchido pelo intérprete, sem oferecer critérios objetivos para tanto; c) supervaloriza tais princípios, como se fossem suficientes para resolver os casos em que não há uma solução evidente no texto constitucional; d) com isso, é demasiadamente abstrato.

Quanto a ambas: a) as categorias propostas não focam em uma abordagem interdisciplinar do Direito, que considere as disciplinas envolvidas no estudo das problemáticas reais envolvidas no litígio; com isso, b) distanciam o direito da realidade; c) supervalorizam a ponderação de valores como método de solução de conflitos e; d) deixam a cargo do Poder Judiciário a última decisão, inclusive sobre demandas de natureza política, negligenciando por vezes a importância do papel dos demais poderes, sobretudo do Legislativo. 


\subsection{INTERPRETAÇÃO DOGMÁTICA DO DIREITO}

A dogmática apresenta-se como ciência, cujo objeto são as normas jurídicas. Elas são vistas como dogmas, como verdades incontestes, inflexíveis, nas quais devem apoiar-se as decisões jurídicas. O sistema jurídico é visto, assim como as demais ciências, livre de contradições internas. Trata-se de modelo formalista de aplicação do direito, que é transposto para o direito constitucional.

Max Weber ensina que:

O ponto de vista jurídico ou mais precisamente aquele dos dogmas legais objetiva o significado correto das proposições, o conteúdo das quais constitui uma ordem supostamente determinante para a conduta de um grupo definido de pessoas. Em outras palavras, o ponto de vista dogmático tenta definir os fatos para os quais esta ordem se aplica e a forma com que ela incide sobre eles. Nesse sentido, o jurista, negligenciando a validade empírica da proposição legal, examina cada uma delas e tenta determinar o seu significado lógico correto de tal forma que todas elas podem ser combinadas em um sistema que é logicamente coerente, ou seja, livre de contradições internas. Esse sistema é o "sistema legal", no sentido jurídico, ou seja, dogmático da palavra ${ }^{62}$.

Luis Alberto Warat expõe o conceito tradicional da dogmática com clareza, destacando a sua autodenominação enquanto ciência que se limita ao estudo e aplicação das normas legais, sem questionar a sua procedência ideológica ou a sua validade, bem como abstraindo eventual caráter sociológico, antropológico ou econômico da norma. Confira-se:

A dogmática jurídica se apresenta como a tentativa de construir uma teoria sistemática do direito positivo. Sem formular sobre ele nenhum juízo de valor, convertendo-se em uma mera ciência formal.

Conforme o pensamento de Bielsa, a dogmática jurídica partiria do pressuposto de que é possível descrever a ordem legal, sem nenhum tipo de referência de caráter sociológico, antropológico, político e econômico. Portanto, se apresenta como uma construção teórico-objetiva e rigorosa, uma elaboração conceitual do direito vigente sem indagação alguma acerca de sua instância ideológica e política; uma mera ciência lógico-formal dedicada ao estudo exclusivo das normas legais (...).

As proposições da dogmática jurídica, deste modo, se integram dentro de um sistema axiomático. A demonstração de sua estrutura lógico-formal está dirigida ao pensamento jurídico. É elaborado um sistema de conceitos, noções, princípios, aforismos e instituições com os quais se pretende completá-lo e, ao mesmo tempo, fechá-lo.

A dogmática jurídica requer um trabalho de lógica e de técnica jurídica, por meio do qual se realizariam operações de análise e de síntese, de dedução e de indução, que resultariam em uma série de conceitos e princípios, mediante os quais se obteria uma clara interpretação das regras legais integrantes do direito positivo. Esta tarefa

${ }^{62}$ WEBER, Max. Economy and Society: an outline of interpretive sociology. California: University of California Press, 1978. Tradução livre. 
construtiva é chamada método técnico-jurídico ou lógico-abstrato, considerado pela dogmática jurídica, como o único método possível no estudo da ciência jurídica. ${ }^{63}$

Warat anota, ainda, que a dogmática confia nas palavras da lei, como se fosse "um algo semântico que está fora de toda transmutação interpretativa, para poder servir à organização da relação com o outro no laço social e na estruturação dos argumentos interpretativos nos que se definem o sentimento da lei”, ou seja, não há qualquer questionamento acerca das interpretações possíveis para a norma ${ }^{64}$.

Na mesma linha, João Maurício Adeodato explica que a interpretação jurídica dogmática "é presa a regras relativamente rígidas, como pontos de partida, e a procedimentos formais específicos, os quais não admitem que qualquer um significado venha a ser escolhido ${ }^{65} . "$ Em outras palavras, o modelo tem como dogma prefixado a norma jurídica, cuja interpretação não deve ser contestada. É justamente o fato de as normas serem incontestáveis que possibilita o enquadramento da dogmática como "ciência do direito". Não é papel do jurista questionar as normas, mas sim do filósofo ${ }^{66}$. Caso contrário, ele estaria negando a qualidade de ciência do modelo.

Rodolfo Vigo também salienta que a dogmática apresenta-se como ciência, cujo objeto de estudo é a lei - única fonte reconhecida do direito:

\begin{abstract}
O modelo dogmático estimulou um saber jurídico que se assemelha aos saberes matemáticos. Desse modo, tinha a pretensão de que fosse meramente cognitivo ou especulativo, desligado do campo do obrar humano e sem compromisso ético ou axiológico; por outro lado, deveria subministrar saberes de certeza absoluta ou sem exceções, cuja obtenção não transitasse por um caminho controverso, mas pacífico e linear ${ }^{67}$.
\end{abstract}

Quanto às etapas de aplicação do método dogmático, Warat destaca que são três: a primeira etapa compreende a interpretação exegética das normas, cuja legitimação e justificação não se questiona; na segunda etapa, são fixados os dogmas jurídicos, a partir da elaboração de proposições, categorias e princípios obtidos a partir das normas legais; a terceira e última etapa caracteriza-se pela sistematização, que leva o jurista à meta perseguida:

\footnotetext{
${ }^{63}$ WARAT, Luis Alberto (1941). Epistemologia e ensino do direito: o sonho acabou. Vol. II. Florianópolis: Boiteux, 2004, p. 153-154. Tradução livre.

${ }^{64}$ Id. (1941). Introdução geral ao direito. Porto Alegre: S.A. Fabris, 1994-1997. v. 3, p. 145.

${ }^{65}$ ADEODATO, João Mauricio Leitão. Uma teoria retórica da norma jurídica e do direito subjetivo. São Paulo: Noeses, 2011, p. 256.

${ }^{66}$ Id. Ética e retórica: para uma teoria da dogmática jurídica. São Paulo: Saraiva, 2012, p. 145.

${ }^{67}$ VIGO, Rodolfo Luis. Interpretação jurídica: do modelo juspositivista-legalista do século XIX às novas perspectivas. São Paulo: Editora Revista dos Tribunais, 2005, p. 47-48.
} 
a construção de uma disciplina específica, que possui conceitos e princípios universais e invariáveis. Essa disciplina é a teoria geral do Direito ${ }^{68}$.

Tercio Ferraz Jr. sustenta, com base no pensamento de Niklas Luhmann, que a visão dogmática do direito apresenta dois postulados, a saber: a) o "princípio da proibição da negação", que está consubstanciado na inegabilidade dos pontos de partida dos fundamentos utilizados, que correspondem às normas jurídicas ou "dogmas" do sistema; b) "proibição do non liquet", ou seja, a obrigação de decidir todo e qualquer conflito. ${ }^{69}$

Sobre a ciência dogmática na atualidade, o autor sustenta que o modelo

(...) costuma encarar seu objeto, o direito posto e dado previamente, como um conjunto compacto de normas, instituições e decisões que lhe compete sistematizar, interpretar e direcionar, tendo em vista uma tarefa prática de solução de possíveis conflitos que ocorrem socialmente. O jurista contemporâneo preocupa-se, assim, com o direito que ele postula ser um todo coerente, relativamente preciso em suas determinações, orientado para uma ordem finalista, que protege a todos indistintamente ${ }^{70}$.

Ainda sobre a visão atual do modelo, Ferraz Jr. salienta que ela tende a priorizar questões formais. Preocupa-se com a busca da natureza jurídica, do regime jurídico de cada instituto do direito, o que pressupõe uma atividade teórica na qual os fenômenos são divididos como de direito público ou privado, real ou pessoal, civil ou comercial ${ }^{71}$.

Vale salientar a existência de outra perspectiva da dogmática jurídica: a abordagem historicista presente na obra da Escola Histórica alemã, liderada por Friedrich Carl von Savigny, tendo desdobramentos na formação da chamada "jurisprudência dos conceitos". Tal abordagem (historicista) é considerada dogmática, na medida em que apresenta o direito como ciência, com rigorosa sistematicidade. É historicista porque vê o direito positivo como sendo predeterminado pelos fatos revelados na pesquisa histórica.

Nesse sentido, Marcus Faro de Castro observa que:

(...) o que Savigny fez, obtendo incontestável sucesso inicial, foi elaborar uma combinação discursiva entre o que considerava ser a historicidade do direito (a ideia de que o direito como realidade ou fato concreto é dada pela história) e a sua rigorosa sistematicidade. Essa ligação entre a "ciência das leis" (direito) e a "ciência filosófica" (sistema) correspondeu a um programa já definido por Savigny desde o seu Curso de Inverno de 1802-1803, ministrado na Faculdade de Direito de Marburgo.

\footnotetext{
${ }^{68}$ WARAT, Luis Alberto. (1941). Epistemologia e ensino do direito: o sonho acabou. MEZZAROBA, Orides. et al. (Coord.). Florianópolis: Boiteux, 2004, p. 154-156.

${ }^{69}$ FERRAZ JUNIOR, Tercio. (1941). Introdução ao estudo do direito: técnica, decisão, dominação. 5. ed. São Paulo: Atlas, 2007, p. 48-49.

${ }^{70}$ Id. Ibid., p. 82.

${ }^{71}$ Id. Ibid., p. 81-82.
} 
(...)

A jurisprudentia desenvolvida por Savigny era, portanto, a um só tempo filosófica (ou seja, "sistemática" no sentido que se acaba de explicitar) e histórica. Isso significa dizer que a jurisprudentia de Savigny ambicionava ser, por excelência, Rechtswissenschaft (um direito filosófico ou científico, ou ainda, uma ciência do direito) e, mais ainda, uma ciência histórica do direito: geschichtliche Rechtswissenschaft ${ }^{72}$.

Ainda de acordo com Castro há duas características presentes nas formulações de Savigny que serviram de base para construções dogmáticas, a saber: "(i) a ideia de que o direito evolui espontânea e organicamente no espírito do povo; e (ii) a sua noção de 'instituto' jurídico"73.

A primeira característica evidencia o direito como sendo uma produção espontânea do povo, que está presente de forma imanente em sua consciência. No entanto, conforme Savigny, apenas os juristas seriam capazes de revelá-lo. Por sua vez, a noção de "instituto" jurídico assinala um conjunto de relações supostamente espontâneas e boas existentes na sociedade e identificáveis pelos juristas. Nas palavras de Castro "o instituto jurídico pressupõe a presença espontânea, 'intuitiva' de normas, não como um produto da razão, mas como um ‘sentimento' ou 'convicção' - enfim, como um modo de consciência não disponível para ser criticado". Essa noção evidencia uma característica que reforça o fato de a abordagem historicista integrar a visão dogmática do direito: a incontestabilidade dos dogmas jurídicos.

Vale acrescentar que a Escola Histórica de Savigny também inspirou o Direito Constitucional alemão em sua origem, com Carl Friedrich Von Gerber e Paul La Band. Com efeito, até o século XVIII, a constituição política e as diversas formas de Estado eram tratadas, sobretudo, pela filosofia política. A partir do século XIX, os juristas passam a tratálas no âmbito do "Direito Constitucional", porém utilizando-se de conceitos formais para embasar o discurso sobre a constituição, conforme explica Castro. ${ }^{74}$

A obra de Gerber denominada "Características de um sistema de direito do Estado alemão" pode ser considerada um marco para a sistematização de formas da jurisprudentia dedicadas a tratar da ordem do Estado. Para Gerber, o direito do Estado deveria respaldar-se nos mesmos princípios de interpretação exata e lógica do direito privado. Foi a partir desse marco que Laband desenvolveu as doutrinas de "Direito Constitucional" com maior influência na Alemanha daquele período.

\footnotetext{
${ }^{72}$ CASTRO, Marcus Faro de. Formas Jurídicas e Mudança Social: interações entre o Direito, a Filosofia, a Política e a Economia. São Paulo: Saraiva, 2012, p. 147-148.

${ }^{73}$ Id. Ibid., p. 150.

${ }^{74}$ Id. Ibid., p. 183-184.
} 
Assim, de acordo com Castro (2012), a abordagem de ambos pode ser considerada positivista, na medida em que os autores "excluíam considerações políticas e filosóficas de sua dogmática e atinham-se, sem maiores reflexões, ao material dado pelo direito positivo, ou seja, pelas leis aprovadas pelo Estado", isto é, consideravam inquestionável a validade das leis positivadas $^{75}$. Essa ideia de que as normas são incontestáveis evidencia que a abordagem historicista, influente na formação do direito constitucional alemão, traduz uma visão dogmática.

Entende-se que essa visão em nada contribui para a adequada decisão dos problemas jurídicos, sobretudo em razão das críticas a seguir apresentadas.

Verifica-se que o uso de dogmas, de abstrações e de formalismos pela dogmática: a) dificulta a compreensão do direito pela sociedade; b) o distancia da realidade; c) bloqueia a capacidade de crítica e de reflexão do intérprete e do aplicador da lei, bem como de seus destinatários; d) pode conduzir ao arbítrio; e e) servir de instrumento de manipulação da sociedade e manutenção das classes dominantes no poder, na medida em que permite a perpetuação das ideologias dessas classes. As críticas aqui formuladas ao modelo encontram respaldo, mesmo que indiretamente, no pensamento de diversos autores, conforme se segue.

O formalismo e a ideia de que as normas - interpretadas de forma dogmática - são capazes de solucionar qualquer conflito afastam o direito da realidade. E para que a realidade "caiba" nas normas, a dogmática utiliza o seguinte artifício: "a generalização abstrata para absorção da contingência. ${ }^{76 "}$. Todavia, é evidente que o mundo real não "cabe" nas normas jurídicas. Ao contrário, elas devem ser adequadas e flexibilizadas, por meio da interpretação, para que observem fatos econômicos e políticos relevantes, na solução dos conflitos.

Para Lenio Streck, a dogmática está em crise e é incapaz de solucionar de modo adequado os complexos conflitos sociais, sobretudo em uma sociedade desigual como a brasileira, justamente porque o modelo afasta o direito da realidade. Confira-se:

(...) a consequente crise de paradigma de dupla face (...) retrata a incapacidade histórica da dogmática jurídica em lidar com os problemas decorrentes de uma sociedade díspar/excludente como a brasileira. Na verdade, tais problemas são deslocados no e pelo discurso dogmático. Cria-se uma espécie de transparência discursiva. (...) A este fenômeno podemos denominar de "fetichização do discurso jurídico”, é dizer, através do discurso dogmático, a lei passa a ser vista como sendo uma-lei-em-si, abstraída das condições (de produção) que a engendraram, como se a

\footnotetext{
${ }^{75}$ CASTRO, Marcus Faro de. Formas Jurídicas e Mudança Social: interações entre o Direito, a Filosofia, a Política e a Economia. São Paulo: Saraiva, 2012, p. 184 e 191.

${ }^{76}$ ADEODATO, João Mauricio Leitão. Ética e retórica: para uma teoria da dogmática jurídica. São Paulo: Saraiva, 2012, p. 147.
} 
sua condição-de-lei fosse uma propriedade "natural". Consequentemente, (...) o discurso dogmático transforma-se em uma imagem, na tentativa (ilusória) de expressar a realidade-social-de-forma-imediata ${ }^{77}$.

Na mesma linha, Tercio Ferraz Jr. sustenta que a dupla abstração da dogmática - o modo de ver as normas, como dogmas, e as regras de interpretação construídas pelo modelo implicam distanciamento da realidade social. Confira-se:

(...) não podemos esquecer que o estudo dogmático do direito está ligado a uma dupla abstração. Ou seja, como não existe sociedade sem dogmas, pois, sem pontos fixos de referência, a comunicação social (interação humana) é impossível (...), toda a comunidade elabora suas normas. Todavia, as normas só não bastam. Sua ambiguidade e vagueza (afinal elas se expressam por palavras) exigem também regras de interpretação. É preciso saber dizer não só qual é a norma, mas também o que ela significa. Ora, as normas (ou dogmas de ação) são, elas próprias, um produto abstrato, e as regras sociais de interpretação (dogmas que dizem como devem ser entendidas as normas) são também um produto abstrato. Temos, pois, um produto abstrato, as regras, que tem por objeto outro produto abstrato, as normas. daí a dupla abstração (...). Pois bem, o objeto do conhecimento jurídico-dogmático é essa dupla abstração, que o jurista elabora num grau de abstração ainda maior (regras sobre as regras de interpretação das normas). Com isso, seu estudo paga um preço: o risco de distanciamento progressivo da própria realidade social ${ }^{78}$.

Além de afastar o direito da realidade, a dogmática pode ser utilizada como forma de manipulação e manutenção das ideologias dominantes e da ordem estabelecida, tornando-se um instrumento perigoso, até porque essa manipulação não é perceptível pela maioria das pessoas, conforme destaca Adeodato:

2. A independência do pensamento dogmático em relação à realidade não é facilmente perceptível para o senso comum; as pessoas acreditam que as decisões jurídico-dogmáticas realmente eliminam - ou deveriam eliminar - o conflito, e que a partir dessa "solução", é mantida a estabilidade social, quando, na verdade é o fato de as pessoas se manterem nesse distanciamento, em relação aos terceiros envolvidos, que traz presunção de legitimidade àquelas decisões e propicia sua aceitação. Estimular a crença no seu sistema decisório é uma das tarefas precípuas da dogmática jurídica: para isso camufla eficientemente seu aspecto necessariamente arbitrário mediante princípios prefixados - pela própria dogmática escolhidos e manipulados - dos quais a decisão parece fluir racionalmente, sem ser opressiva. Um exemplo disso é o papel exercido pela dogmática no encobrimento da violência social: por meio de abstrações conceituais, como as de "violência legítima" (em defesa própria, por exemplo), "violência abusiva" e outras, a dogmática afasta os elementos irracionais e contingentes dos atos violentos e transporta a noção de violência, devidamente enfraquecida e controlada, para dentro de seu universo conceitual. Limita e controla um dado real, ontologicamente ilimitado e incontrolável.

\footnotetext{
77 STRECK, Lenio Luiz. Hermenêutica jurídica $e(m)$ crise: uma exploração hermenêutica da construção do direito. 11. ed. Porto Alegre: Livraria do Advogado, 2014, p. 116-117.

${ }^{78}$ FERRAZ JUNIOR, Tercio Sampaio. (1941). Introdução ao estudo do direito: técnica, decisão, dominação. São Paulo: Atlas, 2007, p. 49.
} 
3. Difundir determinada ideologia, evidentemente aquela adotada pelos grupos detentores do poder, é outra das funções da dogmática. Isso significa que toda dogmática jurídica é necessariamente ideológica. ${ }^{79}$

O autor salienta, ainda, que buscando passar a impressão de que está livre de pressupostos ideológicos, o modelo dogmático manipula o conceito da noção filosófica de valor, cujo conteúdo é eleito segundo os interesses do momento ${ }^{80}$. Os valores são transmitidos como se fossem neutros, estáveis e incondicionados, e a dogmática se utiliza deles com o objetivo de provocar determinadas reações nas condutas dos indivíduos, como uma espécie de manipulação do seu comportamento ${ }^{81}$.

Adeodato sintetiza o controle social exercido pelo modelo dogmático da seguinte forma: ela prescreve que as decisões devem ser sempre tomadas de acordo com dogmas prefixados, travestindo os conflitos de caráter abstrato, por meio de generalizações. Com isso: define o que é juridicamente relevante; estimula a coerência social; propaga a ideologia dominante; neutraliza os conteúdos axiológicos, a exemplo dos valores.

Tercio Ferraz Jr. lembra que a dogmática empresta sentido aos seus próprios dogmas, e isso lhe propicia certa manipulação ${ }^{82}$.

Castro também corrobora a crítica, ao apresentar a abordagem historicista do direito, liderada por Savigny. Afirma que: "ao deixar de assumir um compromisso individualista no plano sociopolítico, o classicismo alemão de fim de século constituiu uma estratégia cultural e política de reafirmação de hierarquias tradicionais. ${ }^{83}$ ".

Ademais, ao apresentar as normas jurídicas como se fossem dogmas incontestáveis, e os valores como se fossem neutros, estáveis e incondicionados, a dogmática desestimula a capacidade de reflexão e de crítica não só do intérprete e do aplicador da lei, mas da própria sociedade. Do aplicador da lei, porque ele não questiona a validade ou utilidade da norma ou, ainda, se ela produz consequências desejáveis. Da sociedade porque, ao utilizar uma linguagem excessivamente formalista, a dogmática dificulta a compreensão do direito pelas pessoas, que acreditam que o modelo será capaz de solucionar os conflitos sociais, e não o contesta.

\footnotetext{
${ }^{79}$ ADEODATO, João Mauricio Leitão. Ética e retórica: para uma teoria da dogmática jurídica. São Paulo: Saraiva, 2012, p. 148.

${ }^{80}$ Id. Ibid., p. 149-150.

${ }^{81}$ Id. Ibid., p. 150.

${ }^{82}$ FERRAZ JUNIOR, Tercio Sampaio. (1941). Introdução ao estudo do direito: técnica, decisão, dominação. São Paulo: Atlas, 2007, p. 49.

${ }^{83}$ CASTRO, Marcus Faro de. Formas Jurídicas e Mudança Social: interações entre o Direito, a Filosofia, a Política e a Economia. São Paulo: Saraiva, 2012, p. 149-150.
} 
Adeodato sustenta que a utilização de dogmas e fórmulas ideológicas (como "bem comum", "princípios" e "boa-fé), cujo conteúdo é preenchido pela dogmática e, acrescenta-se, aceito por juristas e pela sociedade de modo irrefletido e acrítico propicia o arbítrio e a violência. Da mesma forma, a seleção de determinada alternativa, dentro de um universo amplo, como se fosse a única possível é uma escolha arbitrária ${ }^{84}$. Para impedir que isso ocorra, o autor propõe:

(...) ampliar o alcance da linguagem jurídica, no sentido de torná-la mais precisa e acessível a um maior número de pessoas, minimizando sua utilização como instrumento de dominação política; e (...) modificar a atitude pedagógica que a dogmática impõe ao ensino jurídico, auxiliando a adaptação dos profissionais do direito às novas exigências sociais ${ }^{85}$.

Püschel e Machado relacionam a pretensão da dogmática de abarcar todos os fenômenos sociais com a atividade jurisdicional, por meio da qual é possível manipular as normas jurídicas, a partir de sua interpretação. Nas palavras dos autores: "São os juízes que têm o poder de dizer o sentido das normas e, portanto, detém todo o poder de qualificar juridicamente os fatos. Vivemos na ditadura dos juízes ${ }^{86} . "$.

\subsection{O NEOCONSTITUCIONALISMO}

O surgimento das constituições do segundo pós-guerra, sobretudo na Alemanha, Itália, Espanha e Portugal, preocupadas com a garantia de direitos humanos e direitos sociais, após as atrocidades cometidas pelos nazistas e fascistas e os próprios efeitos destrutivos da guerra, marcam o surgimento das ideias posteriormente identificadas como neoconstitucionalistas ${ }^{87}$.

O marco filosófico do neoconstitucionalismo é o pós-positivismo, que procura fazer uma releitura moral do direito, mas sem recorrer a categorias metafísicas - como o

\footnotetext{
${ }^{84}$ ADEODATO João Mauricio Leitão. Ética e retórica: para uma teoria da dogmática jurídica. São Paulo: Saraiva, 2012, p. 151 e 160.

${ }^{85}$ Id. Ibid., p. 152.

${ }^{86}$ RODRIGUEZ, José Rodrigo; PÜSCHEL, Flavia Portella; MACHADO, Marta Rodriguez de Assis. (Org.). Dogmática é conflito: uma visão crítica da racionalidade jurídica. São Paulo: Saraiva, 2012, p. 35 e 42.

${ }^{87}$ BARROSO, Luís Roberto. Neoconstitucionalismo e constitucionalização do Direito (o triunfo tardio do direito constitucional no Brasil). In: QUARESMA, Regina; OLIVEIRA, Maria Lúcia de Paula; OLIVEIRA, Farlei Martins Riccio (Coord.). Neoconstitucionalismo. Rio de Janeiro: Forense, 2009, p. 52-53; KAMINSKI, Marcos Massiero; ROANI, Alcione Roberto. Neoconstitucionalismo: paradigma de nova aplicabilidade do direito, a ruptura do modelo positivista legalista. Revista perspectiva, Erechim, v. 36, n. 134, p. 58-61, junho/2012; SARMENTO, Daniel. O Neoconstitucionalismo no Brasil: riscos e possibilidades. In: SARMENTO, Daniel (Coord.). Filosofia e Teoria Constitucional Contemporânea. Rio de Janeiro: Lumen Juris, 2009, p. 117.
} 
jusnaturalismo - e tem como símbolos: o reconhecimento da normatividade dos princípios e sua distinção qualitativa em relação às regras ${ }^{88}$.

Como marcos teóricos do neoconstitucionalismo são registrados: a) o reconhecimento da força normativa da constituição; b) a expansão da jurisdição constitucional (constitucionalização do direito) e; c) o desenvolvimento de nova dogmática de interpretação constitucional, isto é, de princípios próprios de interpretação constitucional ${ }^{89}$.

Marcos Kaminski e Alcione Roberto Roani apontam como principais protagonistas desse pensamento Ronald Dworkin, Robert Alexy, Gustavo Zagrebelsky e Luigi Ferrajoli ${ }^{90}$. Daniel Sarmento acrescenta a esses Peter Haberle e Carlos Santiago Nino, embora reconheça que não há um único neoconstitucionalismo, mas diversas visões sobre o fenômeno ${ }^{91}$.

Alfonso García Figueroa distingue entre o neoconstitucionalismo fraco, ao qual estariam alinhados Ferrajoli e Luis Prieto e o neoconstitucionalismo forte - antipositivista de Dworkin, Alexy e Nino que, para ele, é a única versão apta a explicar o discurso jurídico de aplicação de princípios jusfundamentais. Para Antonio Cavalcanti Maia existem duas abordagens conflitantes visando superar a insuficiência dos modelos tradicionais: o neoconstitucionalismo não positivista, defendido por Alexy, Zagrebelsky, Alfonso Garcia Figueroa e Santiago Sastre Ariza e o neoconstitucionalismo alinhado com o positivismo inclusivo, observado nas obras de Luis Prieto Sanchís, José Juan Moreso, Paulo Comanducci e Susana Pozzolo 92.

Há, ainda, quem diferencie o neoconstitucionalismo do garantismo, apontando como principal diferença entre ambos o fato de o garantismo insistir na separação entre direito e moral, sendo portanto alinhado ao positivismo, enquanto o neoconstitucionalismo estaria mais próximo do jusnaturalismo, por defender o oposto. Ferrajoli é apontado como principal defensor do garantismo ${ }^{93}$, enquanto Dworkin, Zagrebelsky, Nino e Alexy são citados como neoconstitucionalistas ${ }^{94}$.

\footnotetext{
${ }^{88}$ BARROSO, Luís Roberto. Neoconstitucionalismo e constitucionalização do Direito (o triunfo tardio do direito constitucional no Brasil). In: QUARESMA, Regina; OLIVEIRA, Maria Lúcia de Paula; OLIVEIRA, Farlei Martins Riccio (Coord.). Neoconstitucionalismo. Rio de Janeiro: Forense, 2009, p. 54 e 59.

${ }^{89}$ Id. Ibid., p. 55-56.

${ }^{90}$ KAMINSKI; ROANI, op. cit., p. 58 e 61. No mesmo sentido, cf. MELLO, Sebastian Borges de Albuquerque. Ensaio sobre o Neoconstitucionalismo. Revista Jurídica da Presidência, Brasília, v. 13, n. 101, p. 491, out. 2011/jan. 2012.

${ }^{91}$ SARMENTO, Daniel. O Neoconstitucionalismo no Brasil: riscos e possibilidades. In: SARMENTO, Daniel (Coord.). Filosofia e Teoria Constitucional Contemporânea. Rio de Janeiro: Lumen Juris, 2009, p. 115.

${ }_{92}$ MAIA, Antonio Cavalcanti. Neoconstitucionalismo, Positivismo Jurídico e a Nova Filosofia Constitucional. In: QUARESMA, Regina; OLIVEIRA, Maria Lúcia de Paula; OLIVEIRA, Farlei Martins Riccio (Coord.). Neoconstitucionalismo. Rio de Janeiro: Forense, 2009, p. 12.

93 "Recentemente, o mestre fiorentino [Ferrajoli] alterou sua posição: não considera mais sua perspectiva teórica como sendo parte desse fenômeno neoconstitucional. Entende que as posturas teóricas neoconstitucionalistas
} 
No Brasil, são identificados como neoconstitucionalistas: Paulo Bonavides ${ }^{95}$, Luís Roberto Barroso ${ }^{96}$, Écio Oto Ramos Duarte ${ }^{97}$ e Daniel Sarmento ${ }^{98}$, dentre outros. Tais autores inspiram-se, sobretudo, no pensamento de Ronald Dworkin. ${ }^{99}$

No que tange às perspectivas de pensamento defendidas pelo neoconstitucionalismo, foram elas sintetizadas da seguinte forma, com o objetivo de facilitar a sua compreensão: a) conexão necessária entre o direito e a moral; b) divisão das normas constitucionais entre regras e princípios; c) visão de que os princípios estão no cerne do ordenamento jurídico e que por isso devem orientar toda a aplicação do direito: jurisprudência dos valores; d) uso da ponderação de princípios como principal método de aplicação da Constituição e de solução de conflitos; e) natureza principiológica dos direitos fundamentais; f) protagonismo do Poder Judiciário na proteção dos direitos fundamentais e na solução das complexas demandas da sociedade; e g) constitucionalização do direito.

Vale lembrar, mais uma vez, que o propósito do presente trabalho não é esgotar as origens conceituais e evolutivas do neoconstitucionalismo, mas apenas apresentar as suas principais perspectivas de pensamento.

O exame das teses dessa visão dominante no âmbito do direito constitucional brasileiro permitirá a conclusão de que, embora os seus defensores não afirmem

acabam simplesmente por repristinar teses jusnaturalistas que reivindicam uma espécie perniciosa de conexão entre o direito e a moral. (...) As posturas derivadas do neoconstitucionalismo representam um tipo principialista de constitucionalismo; ao passo que, no que tange à proposta teórica de Ferrajoli, ficaria melhor colocado o termo constitucionalismo garantista, cuja principal característica reside no fato de se operar um aperfeiçoamento do positivismo jurídico a partir da função normativa atribuída aos direitos fundamentais." (STRECK, Lenio Luiz. Entre neoconstitucionalismo e (pós)-positivismo: das insuficiências da teoria neoconstitucional para as particularidades do caso brasileiro. Revista do Tribunal Regional do Trabalho da Oitava Região. Belém, v. 46, n. 90, p. 125, jan.-jul. 2013).

94 SANCHÍS, Luis Prieto. Constitucionalismo e Garantismo. In: QUARESMA, Regina; OLIVEIRA, Maria Lúcia de Paula; OLIVEIRA, Farlei Martins Riccio (Coord.). Neoconstitucionalismo. Rio de Janeiro: Forense, 2009, 165-167. No mesmo sentido: UGARTE, Pedro Salazar. Garantismo e Neoconstitucionalismo frente a frente: algunas claves para su distinción. Disponível em: <http://rua.ua.es/dspace/handle/10045/32777>. Acesso em: 22/11/2014.

${ }^{95}$ Cf. BONAVIDES, Paulo. Curso de Direito Constitucional. 25. ed. São Paulo: Malheiros, 2009.

${ }^{96}$ Cf. BARROSO, Luís Roberto. Interpretação e Aplicação da Constituição: fundamentos de uma dogmática constitucional transformadora. 7. ed. São Paulo: Saraiva, 2009, 432 p. e BARROSO, Luís Roberto. Curso de Direito Constitucional Contemporâneo: os conceitos fundamentais e a construção do novo modelo. 3. ed. São Paulo: Saraiva, 2011.

${ }^{97}$ Cf. DUARTE, Écio Oto Ramos; POZZOLO, Susanna. Neoconstitucionalismo e Positivismo Jurídico: as faces da Teoria do Direito em tempos de interpretação e moral da Constituição. 2. ed. São Paulo: Landy Editora, 2010.

${ }^{98}$ Daniel Sarmento assume o rótulo com ressalvas (Cf. SARMENTO, Daniel. O Neoconstitucionalismo no Brasil: riscos e possibilidades. In: SARMENTO, Daniel (Coord.). Filosofia e Teoria Constitucional Contemporânea. Rio de Janeiro: Lumen Juris, 2009, p. 146).

${ }^{99}$ De acordo com Lenio Luiz Streck, Dworkin e Alexy representam “a grande viragem teórica operada pelo neoconstitucionalismo". (STRECK, Lenio Luiz. Entre neoconstitucionalismo e (pós)-positivismo: das insuficiências da teoria neoconstitucional para as particularidades do caso brasileiro. Revista do Tribunal Regional do Trabalho da Oitava Região. Belém, v. 46, n. 90, p. 119, jan.-jul. 2013). 
explicitamente que exista uma hierarquia entre elas, enfatizam determinados paradigmas, dos quais decorrem diretamente a defesa dos demais, nessa ordem: $1^{\circ}$ ) conexão necessária entre direito e moral; $2^{\circ}$ ) visão de que os princípios estão no cerne do ordenamento jurídico e que por isso devem orientar toda a aplicação do direito; $3^{\circ}$ ) uso da ponderação de princípios como principal método de aplicação da Constituição e de solução de conflitos.

Com efeito, a ausência de abertura do direito para a moral esvaziaria o conteúdo dos princípios, que são preenchidos, de acordo com os neoconstitucionalistas, pela utilização de preceitos éticos e morais.

Por outro lado, a visão de que os princípios devem orientar a tomada de decisões aliada ao uso da ponderação como principal meio de aplicação do texto constitucional - que é decorrência lógica da tese anterior - servem de base ou fundamento para as demais perspectivas de pensamento, conforme se segue.

A divisão das normas constitucionais entre regras e princípios é feita com o escopo de permitir a identificação dos últimos, já que eles devem orientar a tomada de decisões; a natureza principiológica dos direitos fundamentais decorre do próprio conceito de princípio defendido pelos neoconstitucionalistas: norma de caráter aberto e que se submete à ponderação, bem como do fato de que os princípios são postos no topo do ordenamento jurídico, assim como devem ser vistos os direitos fundamentais; o protagonismo do Poder Judiciário é defendido sob o argumento de que os juízes e tribunais são os responsáveis por aplicar os princípios mediante a técnica da ponderação de valores; e a constitucionalização do direito é permitida por meio da aplicação dos princípios constitucionais aos demais ramos do direito.

Assim, considerando que as três teses enumeradas acima respaldam os demais pensamentos defendidos pelos neoconstitucionalistas, pode-se dizer que são hierarquicamente superiores às demais, na ordem apresentada.

A análise das teses neoconstitucionalistas também leva à conclusão de que são coesas entre si, com exceção da defesa do protagonismo do Poder Judiciário. É que elas decorrem do raciocínio de que os princípios - normas de conteúdo moral - constituem o cerne do ordenamento jurídico. No entanto, não é decorrência lógica desse raciocínio a afirmação de que o Judiciário é o Poder responsável por aplicar a Constituição em última instância ou o mais preparado para proteger direitos fundamentais.

Ora, os Poderes Executivo e Legislativo também aplicam a Constituição e também podem fazê-lo por meio de princípios e da técnica de ponderação de valores, se assim preferirem. Todavia, o que se constata na realidade é que os juízes e tribunais são os que mais 
se utilizam desses meios para decidir. Talvez daí se origine a defesa neoconstitucionalista de que o protagonismo do Judiciário é decorrência dos paradigmas anteriores, quando na verdade o ponto central para estabelecer o protagonismo não é a forma de decidir ou a motivação das decisões - que em tese pode ser a mesma em todos os poderes -, mas sim a avaliação da competência constitucionalmente estabelecida para a tomada da decisão, o que raras vezes é discutido.

Também não é coesa a tese de que o Poder Judiciário é o que possui maiores condições de proteger os direitos fundamentais, já que não há qualquer evidência que comprove tal afirmação, muito menos outros paradigmas neoconstitucionalistas que a respalde. Com efeito, o fato de decidir com base em princípios e ponderação não significa maior proteção a esses direitos.

Enunciadas, de modo sintético, algumas perspectivas de pensamento neoconstitucionalistas e discutidos alguns aspectos relevantes acerca delas, passa-se à análise individualizada de cada uma e à comprovação de sua existência por meio das obras dos autores dessa literatura, já identificados no tópico anterior.

No que tange à conexão necessária entre o direito e a moral, os neoconstitucionalistas afirmam que as normas que não se enquadram nos padrões definidos pela moral não constituem direito, por isso a sua aplicação deve ser afastada pelo Poder Judiciário $^{100}$.

A exposição anterior do marco filosófico dessa doutrina possibilita maior compreensão nesse ponto, já que o pós-positivismo tem como principal defesa, em contraponto ao positivismo, a junção entre direito e moral.

Ronald Dworkin é um dos principais defensores da conexão entre direito e moral, sendo por isso considerado antipositivista. Para ele, o direito poderia ser tratado como segmento da moral e a teoria jurídica como parte da moral política ${ }^{101}$.

A postura antipositivista de Dworkin é bastante destacada por Brian Leitter, em artigo intitulado "Beyond the Hart/Dworkin Debate: the methodology problem in jurisprudence",

\footnotetext{
${ }^{100}$ Cf. FIGUEROA, Alfonso García. Neoconstitucionalismo, derrotabilidade e razão prática. Trad. Eduardo Ribeiro Moreira. Revista de Direito Constitucional e Internacional, São Paulo, Ano 20, vol. 79, p. 12, abr./jun 2012. No mesmo sentido Antonio Maia, para quem o neoconstitucionalismo surgiu como contraponto ao positivismo jurídico, opondo a ele o argumento da injustiça - de acordo com o qual uma norma injusta não é Direito - e o argumento dos princípios - segundo o qual se existem princípios no Direito, então há uma conexão necessária entre direito e moral, isto é, os princípios seriam a ponte que os liga (MAIA, Antonio Cavalcanti. Neoconstitucionalismo, Positivismo Jurídico e a Nova Filosofia Constitucional. In: QUARESMA, Regina; OLIVEIRA, Maria Lúcia de Paula; OLIVEIRA, Farlei Martins Riccio (Coord.). Neoconstitucionalismo. Rio de Janeiro: Forense, 2009, p. 6).

${ }^{101}$ DWORKIN, Ronald. A Justiça de Toga. Trad. Jefferson Luiz Camargo. São Paulo: Editora WMF Martins Fontes, 2010, p. 46 e 51.
} 
que evidencia o embate entre Dworkin e Hart (positivista), sobretudo no que diz respeito à separação entre direito e moral ${ }^{102}$. Vale dizer que na obra "A Justiça de Toga", Dworkin dedica um capítulo para expor e contestar o pensamento de Hart ${ }^{103}$.

De acordo com Dworkin, o magistrado, ao julgar, acaba fazendo uma escolha discricionária e subjetiva entre valores, os quais devem ser explicitados na decisão, até por que "o argumento jurídico é um argumento típica e completamente moral"104. Nesse sentindo, a afirmação de Brian Leitter de que, para Dworkin, uma lei só integra o conceito de direito se puder ser moralmente justificada ${ }^{105}$.

Dworkin é tão enfático em sua postura, ao ponto de afirmar que se os juízes norteamericanos fossem positivistas "seriam obrigados a declarar que não existe absolutamente direito algum nos Estados Unidos, a não ser as palavras simples e não interpretadas da Constituição.” E se assim procedessem, acabariam subvertendo o positivismo, ao admitir “ou que o direito nada diz sobre a questão em litígio, ou que o direito é por demais injusto, insensato ou ineficaz para ser aplicado" ${ }^{106}$.

O autor sustenta, ainda, que a validade da atuação do Poder Legislativo deve ser analisada sob a ótica da moral, já que as razões que legitimam a sua atuação são de moralidade política, ou seja, se a lei é inquestionável do ponto de vista moral, logo está legitimada a ação do legislador ${ }^{107}$.

Dworkin também destaca o papel da moral na atividade de julgar. Para ele, quando o produto da atividade legislativa é injusto ou insensato, o juiz tem o dever de ignorar a lei. Também deve se guiar pela moral nos casos em que não há lei a ser seguida (omissão). ${ }^{108}$

No Brasil, a tese neoconstitucionalista de ligação entre direito e moral é corroborada por Daniel Sarmento, ao destacar que

No paradigma neoconstitucionalista, a argumentação jurídica, apesar de não se
fundir com a Moral, abre um significativo espaço para ela. Por isso, se atenua a
distinção da teoria jurídica clássica entre a descrição do Direito como ele é, e a
prescrição sobre como ele deveria ser. Os juízos descritivo e prescritivo de alguma
maneira se sobrepõem, pela influência dos princípios e valores constitucionais
impregnados de forte conteúdo moral, que conferem poder ao intérprete para buscar,
em cada caso difícil, a solução mais justa, no próprio marco da ordem jurídica. Em

${ }^{102}$ LEITTER, Brian. Beyond the Hart/Dworkin Debate: the methodology problem in jurisprudence. Disponível em: < http://papers.ssrn.com/sol3/papers.cfm?abstract_id=312781>. Acesso em 20/11/2014.

${ }^{103}$ DWORKIN, Ronald. A Justiça de Toga. Trad. Jefferson Luiz Camargo. São Paulo: Editora WMF Martins Fontes, 2010, p. 199-264.

${ }^{104}$ Id. Ibid., p. 39 e 205.

${ }^{105}$ LEITTER, op. cit., p. 23-24.

${ }^{106}$ DWORKIN, op. cit., p. 255.

${ }^{107}$ DWORKIN, op. cit., p. 12, 23, 25-26.

${ }^{108}$ DWORKIN, op. cit., p. 28 e 31. 
outras palavras, as fronteiras entre Direito e Moral não são abolidas, e a diferenciação entre eles permanece em vigor, mas as fronteiras entre os dois domínios torna-se muito mais porosa, na medida em que o próprio ordenamento incorpora, no seu patamar mais elevado, princípios de justiça, e a cultura jurídica começa a "levá-los a sério"109.

Écio Oto Duarte defende a tese utilizando-se dos termos interpretativismo moralconstitucional e judicialismo ético-jurídico. O primeiro determina que o aplicador da Constituição considere os valores morais da pessoa humana e os efetive, enquanto o segundo seria constatado na medida em que a concretização da justiça depende da utilização, pelo magistrado, de fundamentos éticos, e não apenas jurídicos ${ }^{110}$.

Coerente a defesa neoconstitucionalista sobre a conexão entre direito e moral, uma vez que os princípios, cerne da teoria, são normas cujo conteúdo abstrato requer a análise da ética e da moral para serem aplicados.

No que concerne à divisão das normas constitucionais entre regras e princípios, é ela inspirada na obra de Robert Alexy, para quem as regras são mandamentos definitivos normas que sempre são totalmente satisfeitas ou não são - e os princípios são mandamentos de otimização -caracterizados por poderem ser satisfeitos em graus variados e pelo fato de que somente adquirem conteúdo exato quando relacionados com as possibilidades dos mundos fático e jurídico ${ }^{111}$.

Paulo Bonavides destaca que o critério mais marcante de diferenciação entre as duas espécies de normas seria o grau de generalidade. Enquanto os princípios são dotados de elevado grau de generalidade, as regras têm grau baixo. Ademais, existe uma diferença qualitativa: os princípios são mandamentos de otimização, cuja principal característica consiste em poderem ser efetivados em distintos graus, ao passo que as regras podem sempre ser cumpridas ou não, ou seja, quando uma regra vale deve-se realizar exatamente o que ela prescreve, nem mais, nem menos ${ }^{112}$.

Uma perspectiva teórica marcante no neoconstitucionalismo é a visão de que os princípios estão no cerne do ordenamento jurídico e que por isso devem orientar toda a aplicação do direito.

\footnotetext{
${ }^{109}$ SARMENTO, Daniel. O Neoconstitucionalismo no Brasil: riscos e possibilidades. In: SARMENTO, Daniel (Coord.). Filosofia e Teoria Constitucional Contemporânea. Rio de Janeiro: Lumen Juris, 2009, p. 121-122.

${ }^{110}$ DUARTE, Écio Oto Ramos; POZZOLO, Susanna. Neoconstitucionalismo e Positivismo Jurídico: as faces da Teoria do Direito em tempos de interpretação e moral da Constituição. 2. ed. São Paulo: Landy Editora, 2010, p. 67-68.

${ }^{111}$ ALEXY, Robert. Teoria dos Direitos Fundamentais. Trad. Virgílio Afonso da Silva. São Paulo: Malheiros, 2008, p. 90, 94-95, 104 e 108.

112 BONAVIDES, Paulo. Curso de Direito Constitucional. 25. ed. São Paulo: Malheiros, 2009, p. 277-279.
} 
Ronald Dworkin destaca, com ênfase, o papel de relevância dos princípios. Para ele, a solução de um caso difícil - aquele para o qual não há uma regra que traga uma solução específica - depende da identificação dos princípios gerais que fundamentam e justificam o direito aplicável ao caso concreto. Após identificá-los, o julgador deve decidir que conjunto de princípios oferece a melhor justificação para aquela área do direito, em termos morais ${ }^{113}$.

Em sua obra "Uma Questão de Princípio", defende que uma decisão acerca de questões políticas deve ser específica e calcada em princípios, isto é, o Tribunal deve tomar decisões de princípio, e não de política. Nesse sentido, a revisão judicial é “invejada e cada vez mais copiada, (...) porque obriga o debate político a incluir o argumento acerca do princípio, não apenas quando um caso vai ao Tribunal, mas muito antes e muito depois"114.

No Brasil, os neoconstitucionalistas também defendem a ideia de que os princípios são os elementos centrais do direito ${ }^{115}$, sendo acentuado o seu status de norma jurídica e a sua superioridade no sistema. Por isso, a aplicação da Constituição passa a ser feita muito menos por regras e mais por princípios ${ }^{116}$, prática que é denominada "jurisprudência dos princípios" ou "jurisprudência dos valores".

Luís Roberto Barroso afirma que os princípios constitucionais constituem o cerne do sistema, os seus postulados básicos, a ideologia da sociedade. Aponta para eles três funções: materializar valores, dar unidade ao sistema e condicionar a atividade do intérprete ${ }^{117}$. Confira-se:

\begin{abstract}
A Constituição passa a ser encarada como um sistema aberto de princípios e regras, permeável a valores jurídicos suprapositivos, no qual as ideias de justiça e de realização dos direitos fundamentais desempenham um papel central. A mudança de paradigma nessa matéria deve especial atributo às concepções de Ronald Dworkin e aos desenvolvimentos a ela dados por Robert Alexy ${ }^{118}$.
\end{abstract}

Na visão do autor, o ponto de partida do intérprete deve ser os princípios constitucionais, por sintetizarem os valores mais importantes do ordenamento. O juiz, ao

\footnotetext{
${ }^{113}$ DWORKIN, Ronald. A Justiça de Toga. Trad. Jefferson Luiz Camargo. São Paulo: Editora WMF Martins Fontes, 2010, p. 204 e DWORKIN, Ronald. Levando os Direitos a Sério. Trad. Nelson Boeira. 3. ed. São Paulo: Editora WMF Martins Fontes, 2010, p. 132 e 151.

${ }^{114}$ Id. Uma questão de princípio. Trad. Luís Carlos Borges. São Paulo: Martins Fontes, 2000, pp. VIII, 101-103.

${ }^{115}$ MAIA, Antonio Cavalcanti. Neoconstitucionalismo, Positivismo Jurídico e a Nova Filosofia Constitucional. In: QUARESMA, Regina; OLIVEIRA, Maria Lúcia de Paula; OLIVEIRA, Farlei Martins Riccio (Coord.). Neoconstitucionalismo. Rio de Janeiro: Forense, 2009, p. 9.

${ }^{116}$ Cf. MELLO, Sebastian Borges de Albuquerque. Ensaio sobre o Neoconstitucionalismo. Revista Jurídica da Presidência, Brasília, v. 13, n. 101, p. 503, 504 e 508, out. 2011/jan. 2012.

${ }^{117}$ BARROSO, Luís Roberto. Interpretação e Aplicação da Constituição: fundamentos de uma dogmática constitucional transformadora. 7. ed. São Paulo: Saraiva, 2009, p. 326-329.

${ }^{118}$ Id. Ibid., p.353.
} 
decidir o caso concreto, deve primeiro identificar os princípios aplicáveis à demanda, do mais genérico para o mais específico, até chegar à formulação da regra concreta ${ }^{119}$.

No mesmo sentido, Bonavides destaca que os princípios são "as normas-chave de todo o sistema jurídico", as "normas supremas do ordenamento jurídico", as "normas das normas", “fonte das fontes", “expressão da vontade geral”, "sede de toda a legitimidade do poder”, “o oxigênio das Constituições na época do pós-positivismo", de tal maneira que se pode falar em um "Estado principial" 120.

Da ideia de centralidade dos princípios no sistema, decorre a de sua superioridade em relação às regras. Tal posição fica evidente no seguinte trecho da obra de Bonavides:

Daqui já se caminha para o passo final da incursão teórica: a demonstração do
reconhecimento da superioridade e hegemonia dos princípios na pirâmide
normativa; supremacia que não é unicamente formal, mas sobretudo material, e
apenas possível na medida em que os princípios são compreendidos e equiparados e
até mesmo confundidos com os valores, sendo, na ordem constitucional dos
ordenamentos jurídicos, a expressão mais alta da normatividade que fundamenta a
organização do poder ${ }^{121}$.

Écio Oto Duarte denomina essa tese neoconstitucionalista de principialismo. Para ele, trata-se de paradigma decorrente do reconhecimento da existência de princípios jusfundamentais, que se encontram no topo do sistema e possibilitam a conexão entre direito e moral, já que têm valores como conteúdo ${ }^{122}$.

A constitucionalização do direito é também uma perspectiva de pensamento defendida pelos neoconstitucionalistas. Trata-se da interpretação de todos os ramos do direito à luz dos princípios constitucionais. O termo "Direito Civil Constitucional ${ }^{123}$ ", bastante utilizado pelos autores que se dedicam ao estudo do direito privado exemplifica bem o sentido do termo.

Luís Roberto Barroso defende a constitucionalização do direito como consequência do "efeito expansivo das normas constitucionais, cujo conteúdo material e axiológico se irradia, com força normativa, por todo o sistema jurídico.” Assim, afirma, as normas constitucionais passam a condicionar a validade e o sentido das normas infraconstitucionais; o legislador fica

\footnotetext{
${ }^{119}$ BARROSO, Luís Roberto. Interpretação e Aplicação da Constituição: fundamentos de uma dogmática constitucional transformadora. 7. ed. São Paulo: Saraiva, 2009, p. 155.

${ }^{120}$ BONAVIDES, Paulo. Curso de Direito Constitucional. 25. ed. São Paulo: Malheiros, 2009, p. $284-293$.

${ }^{121}$ Id. Ibid., p. 288.

122 DUARTE, Écio Oto Ramos; POZZOLO, Susanna. Neoconstitucionalismo e Positivismo Jurídico: as faces da Teoria do Direito em tempos de interpretação e moral da Constituição. 2. ed. São Paulo: Landy Editora, 2010 , p. 66.

${ }^{123}$ Cf. TEPEDINO, Gustavo (Coord). A nova parte do novo código civil: estudos na perspectiva civilconstitucional. Rio de Janeiro: Renovar, 2007; SILVA, Virgílio Afonso. A Constitucionalização do Direito: os direitos fundamentais nas relações entre particulares. 1. ed. 2. tiragem. São Paulo: Malheiros, 2008, pp. 171-172.
} 
limitado à observância de seu conteúdo, assim como a Administração Pública; e o Poder Judiciário deve considerá-las para a interpretação e aplicação de todas as normas infraconstitucionais, utilizando-as como parâmetro para o controle de constitucionalidade, se for o caso ${ }^{124}$.

Sebastian Mello também defende a constitucionalização do direito, que estaria respaldada na supremacia da Constituição frente às leis e na sua força normativa, que se irradia por todo o ordenamento jurídico ${ }^{125}$.

No mesmo sentido, Daniel Sarmento, para quem a Constituição de 1988 favoreceu esse processo, pois dispõe sobre os mais diversos temas, deixando pouco espaço para a atuação do legislador infraconstitucional, bem como contém inúmeros princípios dotados de forte carga axiológica, que se irradiam pelos diversos campos do Direito, fazendo com que haja uma "releitura de toda a ordem jurídica a partir de uma ótica pautada pelos valores constitucionais - a chamada filtragem constitucional do Direito" ${ }^{126}$.

\subsection{PONTOS DE CONVERGÊNCIA ENTRE O NEOCONSTITUCIONALISMO} E A DOGMÁTICA JURÍDICA

A ponderação de valores como técnica de solução de conflitos e o protagonismo do Poder Judiciário são perspectivas teóricas comuns a ambas as visões dominantes no direito constitucional brasileiro.

Com efeito, tanto os defensores do neoconstitucionalismo, como Dworkin, Barroso, Daniel Sarmento e Écio Oto Duarte, como os adeptos da dogmática jurídica, sobretudo de influência alemã, como Gilmar Ferreira Mendes, Virgílio Afonso da Silva, Inocência Coelho e Paulo Gonet Branco defendem essas perspectivas teóricas, conforme será demonstrado a seguir.

A ponderação de valores é o método utilizado para a aplicação dos princípios constitucionais. Essa técnica consiste na identificação dos princípios aplicáveis ao caso concreto, atribuição de peso a cada um deles e, a partir daí, seleção daqueles que devem prevalecer.

\footnotetext{
${ }^{124}$ BARROSO, Luís Roberto. Curso de Direito Constitucional Contemporâneo: os conceitos fundamentais e a construção do novo modelo. 3. ed. São Paulo: Saraiva, 2011, p. 376-377.

${ }^{125}$ MELLO, Sebastian Borges de Albuquerque. Ensaio sobre o Neoconstitucionalismo. Revista Jurídica da Presidência, Brasília, v. 13, n. 101, p. 499, 508 e 510, out. 2011/jan. 2012.

${ }^{126}$ SARMENTO, Daniel. O Neoconstitucionalismo no Brasil: riscos e possibilidades. In: SARMENTO, Daniel (Coord.). Filosofia e Teoria Constitucional Contemporânea. Rio de Janeiro: Lumen Juris, 2009, p. 125.
} 
A ponderação é vista como necessária, diante do confronto entre normas constitucionais, que o método da subsunção é incapaz de solucionar, conforme aponta Barroso:

\begin{abstract}
A existência de colisões de normas constitucionais leva à necessidade de ponderação. A subsunção, por óbvio, não é capaz de resolver o problema, por não ser possível enquadrar o mesmo fato em normas antagônicas. Tampouco podem ser úteis os critérios tradicionais de solução de conflitos normativos - hierárquico, cronológico e da especialização - quando a colisão se dá entre disposições da Constituição originária. Nesse cenário, a ponderação de normas, bens ou valores é a técnica a ser utilizada pelo intérprete por via da qual ele: (i) fará concessões recíprocas, procurando preservar o máximo possível cada um dos interesses em disputa ou, no limite, (ii) procederá à escolha do direito que irá prevalecer, em concreto, por realizar mais adequadamente a vontade constitucional. Conceito-chave da matéria é o princípio instrumental da razoabilidade ${ }^{127}$.
\end{abstract}

Écio Oto Duarte também aponta como paradigmas do neoconstitucionalismo, corrente à qual se filia, o juízo de ponderação e a especificidade interpretativa. O primeiro seria utilizado para resolver os casos difíceis, ou seja, aqueles para os quais não há regra que determine uma solução ou quando a regra existente contraria a Constituição. A especificidade interpretativa do direito constitucional em relação aos demais ramos do Direito seria decorrência do próprio uso da ponderação, bem como do fato de a Constituição ser permeada por valores morais ${ }^{128}$.

A técnica decisória da ponderação é norteada pelos princípios da proporcionalidade e da razoabilidade e deve ser aplicada em etapas, conforme descrito por Barroso. Na primeira etapa, o intérprete detecta no sistema as normas que regulam o caso e identifica eventuais conflitos entre elas. Na segunda etapa, devem ser analisados os fatos, as circunstâncias específicas do caso e a sua interação com as normas aplicáveis. Na terceira etapa, são apurados os pesos dos princípios, a depender das circunstâncias jurídicas e fáticas, podendo ser eles aplicados com maior ou menor grau de intensidade. Chega-se aí ao grupo de normas que deve prevalecer no caso. Em seguida, deve-se decidir quão intensamente esse grupo de normas deve preponderar. É nessa última etapa que a ponderação se evidencia, em contraste à subsunção ${ }^{129}$.

\footnotetext{
${ }^{127}$ BARROSO, Luís Roberto. Neoconstitucionalismo e constitucionalização do Direito (o triunfo tardio do direito constitucional no Brasil). In: QUARESMA, Regina; OLIVEIRA, Maria Lúcia de Paula; OLIVEIRA, Farlei Martins Riccio (Coord.). Neoconstitucionalismo. Rio de Janeiro: Forense, 2009, p. 60-61.

${ }^{128}$ DUARTE, Écio Oto Ramos; POZZOLO, Susanna. Neoconstitucionalismo e Positivismo Jurídico: as faces da Teoria do Direito em tempos de interpretação e moral da Constituição. 2. ed. São Paulo: Landy Editora, 2010, p. 69-71.

${ }^{129}$ BARROSO, Luís Roberto. Interpretação e Aplicação da Constituição: fundamentos de uma dogmática constitucional transformadora. 7. ed. São Paulo: Saraiva, 2009, p. 361-362.
} 
A ponderação de valores, para as doutrinas dominantes do direito constitucional, tem por objetivo produzir uma solução justa para o caso concreto, mesmo que para isso seja necessário afastar uma regra que é compatível com a Constituição. É que o efeito da regra, no particular, pode mostrar-se inconstitucional. Por isso, a solução adequada depende da análise dos elementos do caso concreto. Ou seja, valoriza-se a justiça do caso concreto, em detrimento da geral ${ }^{130}$.

Barroso reconhece que

(...) a ponderação ingressou no universo da interpretação constitucional como uma necessidade antes que como uma opção filosófica ou ideológica. É certo, no entanto, que cada uma das três etapas descritas acima - identificação das normas pertinentes, seleção dos fatos relevantes e atribuição geral de pesos, com a produção de uma conclusão - envolve avaliações de caráter subjetivo, que poderão variar em função das circunstâncias pessoais do intérprete e de outras tantas influências ${ }^{131}$.

Entretanto, o autor defende que "o risco de tal disfunção (...) não a desmerece como técnica de decisão nem priva a doutrina da possibilidade de buscar parâmetros mais bem definidos para sua aplicação" 132 .

A defesa da ponderação no Brasil foi inspirada, sobretudo, na Teoria dos Direitos Fundamentais de Robert Alexy, em que é desenvolvida uma fórmula para atribuir peso aos princípios que constituem esses direitos e selecionar aquele(s) que deve(m) prevalecer ${ }^{133}$. Tal seleção é sempre realizada no caso concreto, já que abstratamente os princípios estão no mesmo nível, ou seja, a situação é resolvida por meio do "estabelecimento de uma relação de precedência condicionada entre os princípios, com base nas circunstâncias do caso concreto." $" 134$

Para o autor, a própria natureza dos princípios implica a proporcionalidade. Isso significa que

\footnotetext{
A proporcionalidade, com suas três máximas parciais da adequação, da necessidade (mandamento do meio menos gravoso) e da proporcionalidade em sentido estrito (mandamento do sopesamento propriamente dito), decorre logicamente da natureza dos princípios, ou seja, que a proporcionalidade é deduzível dessa natureza. (...)
}

\footnotetext{
${ }^{130}$ BARROSO, Luís Roberto. Interpretação e Aplicação da Constituição: fundamentos de uma dogmática constitucional transformadora. 7. ed. São Paulo: Saraiva, 2009, p. 332, 339-340 e 349.

${ }^{131}$ Id. Ibid., p. 362.

132 Id. Ibid., p. 363.

${ }^{133}$ Para ver a fórmula apresentada por Alexy, cf. Teoria dos Direitos Fundamentais. Trad. Virgílio Afonso da Silva. São Paulo: Malheiros, 2008, p. 95-102 e 119-120.

${ }^{134}$ ALEXY, Robert. Teoria dos Direitos Fundamentais. Trad. Virgílio Afonso da Silva. São Paulo: Malheiros, 2008, p. 95-96.
} 
Princípios são mandamentos de otimização em face das possibilidades jurídicas $e$ fáticas. A máxima da proporcionalidade em sentido estrito, ou seja, exigência de sopesamento, decorre da relativização em face das possibilidades jurídicas. (...)

Já as máximas da necessidade e da adequação decorrem da natureza dos princípios como mandamentos de otimização em face das possibilidades fáticas. ${ }^{135}$

Critica-se o sopesamento, reconhece Alexy, com a afirmação de que não é um modelo sujeito a controle racional, ficando "sujeito ao arbítrio daquele que sopesa (...). Ele abriria espaço para o subjetivismo e o decisionismo dos juízes" ${ }^{136}$.

A solução apresentada pelo autor alemão para superar essa crítica é a necessidade de fundamentação racional das escolhas feitas pelos juízes. A fundamentação deve levar em conta a "lei do sopesamento", de acordo com a qual "a medida permitida de não-satisfação ou de afetação de um princípio depende do grau de importância da satisfação do outro"137. O trecho a seguir expõe de forma clara o modelo sugerido:

O modelo fundamentado apresentado aqui evita uma série de dificuldades que estão frequentemente associadas ao conceito de sopesamento. Ele faz com que fique claro que o sopesamento não é um procedimento por meio do qual um interesse é realizado às custas de outro de "forma precipitada". De acordo com esse modelo, o sopesamento é tudo, menos um procedimento abstrato ou generalizante. (...) Do próprio conceito de princípio decorre a constatação de que os sopesamentos não são uma questão de tudo-ou-nada, mas uma tarefa de otimização. Nesse sentido, o modelo de sopesamento aqui defendido é equivalente ao assim chamado princípio da concordância prática. (...) Ainda que o sopesamento em si não estabeleça um parâmetro com o auxílio do qual os casos possam ser decididos de forma definitiva, o modelo de sopesamento como um todo oferece um critério, ao associar a lei de colisão à teoria da argumentação jurídica racional ${ }^{138}$.

A inspiração em Alexy é evidenciada na obra de Virgílio Afonso da Silva, para quem é da distinção existente entre a estrutura das regras e dos princípios que decorre as diferentes forma de aplicação dessas normas, quais sejam a subsunção e o sopesamento. O conflito entre regras é solucionado pela premissa do "tudo ou nada". Já que elas contêm mandamentos definitivos, devem ser aplicadas de maneira integral, afastando a aplicação das demais. A solução se dá no âmbito da validade. No que tange aos princípios, não se pode falar em invalidade de um deles. O confronto é resolvido pela fixação de "relações condicionadas de precedência", ou seja, é impossível formular, em abstrato, uma relação de precedência entre

\footnotetext{
${ }^{135}$ ALEXY, Robert. Teoria dos Direitos Fundamentais. Trad. Virgílio Afonso da Silva. São Paulo: Malheiros, 2008, p. 116-118.

${ }^{136}$ Id. Ibid., p. 164.

${ }^{137}$ Id. Ibid., p. 165-169.

${ }^{138}$ Id. Ibid., p. 173.
} 
princípios, pois essa relação sempre dependerá das condições e circunstâncias do caso concreto $^{139}$.

Vale acrescentar que os direitos fundamentais são vistos como princípios pelas doutrinas dominantes do direito constitucional brasileiro. Por isso, a colisão entre eles é solucionada por meio da ponderação de valores.

Virgílio Afonso da Silva defende a natureza principiológica dos direitos fundamentais em sua obra "A Constitucionalização do Direito", ao afirmar que a resposta para a irradiação dos efeitos dos direitos fundamentais previstos na Constituição nas relações privadas está no "conceito de direitos fundamentais como princípios" 140.

No mesmo sentido, Bonavides afirma que o reconhecimento da natureza principial dos direitos fundamentais foi essencial para respaldar a Nova Hermenêutica, de acordo com a qual a interpretação constitucional deve ser guiada pelos princípios ${ }^{141}$.

Gilmar Ferreira Mendes, Inocêncio Coelho e Paulo Branco também indicam esse pensamento, ao afirmarem que o peso dos direitos fundamentais é definido de acordo com as circunstâncias do caso concreto, ou seja, mesmo raciocínio aplicado aos princípios ${ }^{142}$.

No que concerne à defesa do protagonismo do Poder Judiciário em detrimento dos demais poderes, decorre das crenças de que o juiz seria o responsável por preservar os direitos fundamentais - desrespeitados com frequência pelo processo legislativo majoritário - e por decidir em última instância as complexas demandas da sociedade, inclusive aquelas de natureza política, por meio da utilização dos princípios e da ponderação de valores ${ }^{143}$.

O pensamento acima é facilmente extraído da obra de Gilmar Mendes, Inocêncio Coelho e Paulo Branco, quando defendem que o Judiciário é o poder com maiores condições de preservar os direitos fundamentais, pois além de sofrer menor influência de interesses externos, é mais acessível do que o Legislativo. Confira-se:

Se tivermos presente, igualmente, que a defesa das constituições democráticas é, também, a defesa dos valores que elas reconhecem e proclamam; que é muito mais fácil aos grupos minoritários, com uma singela petição, acionar a jurisdição

\footnotetext{
${ }^{139}$ SILVA, Virgílio Afonso da. Direitos Fundamentais: conteúdo essencial, restrições e eficácia. São Paulo: Malheiros, 2009, p. 46-52 e 168.

${ }^{140}$ Id. A Constitucionalização do Direito: os direitos fundamentais nas relações entre particulares. 1. ed. 2. tiragem. São Paulo: Malheiros, 2008, p. 146.

${ }^{141}$ BONAVIDES, Paulo. Curso de Direito Constitucional. 25. ed. São Paulo: Malheiros, 2009, p. 648.

142 MENDES, Gilmar; COELHO, Inocêncio Mártires; BRANCO, Paulo Gonet. Hermenêutica Constitucional e Direitos Fundamentais. Brasília: Brasília Jurídico, 2000, p. 283.

${ }^{143}$ Cabe ao Tribunal Constitucional o papel de "dizer a última palavra em nome do Poder Constituinte" (KAMINSKI, Marcos Massiero; ROANI, Alcione Roberto. Neoconstitucionalismo: paradigma de nova aplicabilidade do direito, a ruptura do modelo positivista legalista. Revista perspectiva, Erechim, v. 36, n. 134, p. 61, junho/2012).
} 
constitucional contra as leis que os discriminem do que fazer abaixo-assinados ou gritar palavras de ordem, de resto incapazes de inibir esses e outros abusos legislativos; se atentarmos para tudo isso, enfim, acabaremos admitindo que longe de ser politicamente ilegítima, como dizem os seus detratores históricos, essa superlegislatura acabará se mostrando uma instituição das mais democráticas ${ }^{144}$.

No âmbito da jurisdição constitucional, os autores entendem que a criatividade é ilimitada, "não só porque as cortes constitucionais estão situadas fora e acima da tradicional tripartição de poderes estatais, mas também porque a sua atividade interpretativa se desenvolve, essencialmente, em torno de enunciados abertos, indeterminados" ${ }^{\text {"145 }}$. O trecho a seguir evidencia o poder conferido aos tribunais constitucionais, em detrimento dos legisladores:

Intérpretes finais da Constituição e juízes últimos de sua própria autoridade, as modernas cortes constitucionais - de resto com ampla aceitação nas sociedades democráticas, acabaram se transformando em quarto poder, gabinete na sombra, variante do poder legislativo, legislador complementar, parlamento de notáveis, legislador positivo, juiz soberano, contracapitão, instância suprema de revisão ou, ainda, em verdadeira constituinte de plantão, confirmando assim, as célebres palavras de Charles Hughes - então Governador do Estado de Nova York e, depois, membro da Suprema Corte dos Estados Unidos - quando afirmou que os americanos viviam sob uma Constituição, mas que essa Carta Política era aquilo que os juízes diziam que ela era ${ }^{146}$.

No mesmo sentido, Luís Roberto Barroso afirma que os Tribunais Constitucionais são responsáveis por preservar os direitos fundamentais contra eventuais investidas do legislador, que podem suprimi-los ou alterá-los por meio do processo legislativo, majoritário ${ }^{147}$.

Nesse contexto, defende-se o ativismo judicial ou judicialização da política ${ }^{148}$, fenômeno que consiste na decisão de demandas de natureza política, em última instância, pelo Poder Judiciário e que representa, por isso, uma quebra da visão tradicional da separação de poderes. Defendem os neoconstitucionalistas que a Constituição de 1988 propiciou este fenômeno, na medida em que confere legitimidade ativa a qualquer partido político ou entidade da sociedade civil organizada para propor ações perante o Supremo Tribunal Federal. Por isso, afirmam, é quase impossível que as demandas de caráter político, sobre as quais há grande controvérsia na sociedade não sejam levadas ao STF por meio dos perdedores no

\footnotetext{
${ }^{144}$ MENDES, Gilmar Ferreira; COELHO, Inocêncio Mártires; BRANCO, Paulo Gustavo Gonet. Curso de Direito Constitucional. 2. ed., São Paulo: Saraiva, 2008, p. 143.

${ }^{145}$ Id. Ibid., p. 58.

146 Id. Ibid., p. 59.

${ }^{147}$ BARROSO, Luís Roberto. Curso de Direito Constitucional Contemporâneo: os conceitos fundamentais e a construção do novo modelo. 3. ed. São Paulo: Saraiva, 2011, p. 285.

${ }^{148}$ SARMENTO, Daniel. O Neoconstitucionalismo no Brasil: riscos e possibilidades. In: SARMENTO, Daniel (Coord.). Filosofia e Teoria Constitucional Contemporânea. Rio de Janeiro: Lumen Juris, 2009, p. 119.
} 
processo legislativo $^{149}$ ou daqueles que buscam a efetivação de um direito não regulamentado pelo legislador.

Ronald Dworkin é um dos autores que mais enaltece o papel do juiz, ao colocá-lo como o responsável por dizer o direito e por preservar a sua integridade, que é alcançada por meio da existência de princípios coerentes no sistema, que motivam as decisões judiciais ${ }^{150}$. Em suas obras "O Império do Direito ${ }^{151 " ~ e ~ " L e v a n d o ~ o s ~ D i r e i t o s ~ a ~ S e ́ r i o ", ~ D w o r k i n ~ u t i l i z a ~ a ~}$ figura metafórica do juiz Hércules, para afirmar a sua responsabilidade por manter a integridade e a coerência do sistema.

Para Hércules, o direito real contemporâneo consiste nos princípios que proporcionam a melhor justificativa disponível para as doutrinas e dispositivos do direito como um todo. Seu deus é o princípio da integridade na prestação jurisdicional, que o força a ver, na medida do possível, o direito como um todo coerente e estruturado ${ }^{152}$.

Hércules entende que a força de um precedente judicial advém da argumentação principiológica que o sustenta. Assim, cabe a ele construir um esquema de princípios abstratos e concretos que forneça uma justificação coerente a todos os precedentes do direito e às disposições legislativas. ${ }^{153}$

Conforme exposto no capítulo anterior, as principais teses de Dworkin são a existência de conexão necessária entre direito e moral e a necessidade de as decisões judiciais serem respaldadas por princípios. Nesse sentido, o juiz é visto como protagonista do processo decisório, já que não só pode, como deve ignorar uma lei que esteja em descompasso com a moral, como é ele quem identifica, seleciona e aplica os princípios disponíveis ao caso concreto.

\footnotetext{
${ }^{149}$ SARMENTO, Daniel. O Neoconstitucionalismo no Brasil: riscos e possibilidades. In: SARMENTO, Daniel (Coord.). Filosofia e Teoria Constitucional Contemporânea. Rio de Janeiro: Lumen Juris, 2009, p. 124-123.

${ }^{150}$ DWORKIN, Ronald. O Império do Direito. Trad. Jefferson Luiz Camargo. São Paulo: Martins Fontes, 2007, p. 274 e 488.

${ }^{151}$ Lutiana Lorentz, em artigo que resume a obra "O Império do Direito", apresenta a seguinte ideia de Dworkin: a lei governa a vida dos cidadãos que seriam, portanto, súditos do império do direito. Mas questiona como a lei pode governar a vida das pessoas se, muitas vezes, é dúbia, ambígua e abstrata. Nesses casos - denominados casos difíceis -, a solução correta pode estar ou não no comando legal, mas sempre se relaciona à moral e aos valores da comunidade. Para encontrá-la, o juiz deve percorrer três etapas: na primeira, identifica as questões fáticas, na segunda as questões jurídicas e, por fim, verifica os fundamentos ligados à moralidade e à fidelidade, na busca por um direito justo. O núcleo da construção da decisão judicial seria a integridade, ou seja, a manutenção da coerência do sistema, como um todo, através de um princípio aplicável ao caso. (LORENTZ, Lutiana Nacur. O Império do Direito de Ronald Dworkin. Revista do Tribunal Regional do Trabalho $3^{a}$ Região. Belo Horizonte, n. 33, p. 101-103 e 107-109, jan./jun. 2001).

${ }^{152}$ DWORKIN, op. cit., p. 477.

${ }^{153}$ DWORKIN, Ronald. Levando os Direitos a sério. Trad. Nelson Boeira. 3. ed. São Paulo: Editora WMF Martins Fontes, 2010, p. 180-182.
} 


\subsection{LIMITAÇÕES DAS VISÕES DOMINANTES NO DIREITO CONSTITUCIONAL PARA O ENFRENTAMENTO DA PARTILHA DO PRÉ-SAL}

A análise das perspectivas de pensamento dominantes no direito constitucional brasileiro permite concluir que refletem de maneira insuficiente fatos e escolhas políticos e econômicos relevantes para o enfrentamento da partilha das rendas do petróleo no Brasil, sobretudo porque priorizam o formalismo e a abstração em detrimento da realidade e não incentivam a abordagem interdisciplinar na solução das demandas. Com efeito, o modelo dogmático defende que as decisões devem ser baseadas exclusivamente em normas jurídicas, que possuem uma única interpretação possível, e cuja legitimidade ou validade não se questiona. O neoconstitucionalismo, por sua vez, sustenta que as decisões devem ser fundamentadas, preponderantemente, em princípios abstratos.

O trabalho "Globalização, Democracia e Direito Constitucional: Legados Recebidos e Possibilidades de Mudança", de autoria de Marcus Faro de Castro, realça a distância existente entre a Constituição Política - o que ocorre na vida da sociedade e o que ela deseja, ou seja, a realidade - e a Constituição Jurídica - o texto normativo e o discurso dos juristas -, que é marcada sobretudo por um fechamento conceitual que torna fixos os direitos subjetivos e inalcançável pela democracia o discurso jurídico sobre a Constituição ${ }^{154}$, sendo tais características presentes nas visões dominantes do direito constitucional aqui abordadas.

Trata-se de legados incorporados ao discurso constitucional que já não são mais adequados à interpretação e aplicação do Direito das constituições no século XXI, segundo o autor. Na visão de Castro, os direitos subjetivos são vistos pelas doutrinas dominantes como "prontos, completos e inalteráveis", o que impossibilita a sua flexibilização para atender às demandas sociais em constante movimento. A ideia de que as decisões dos tribunais que aplicam a Constituição gozam de superioridade em virtude da supremacia do direito constitucional - bastante difundida pelos neoconstitucionalistas - também contribui para distanciar a realidade e o discurso jurídico. Ademais, o autor destaca que esses legados serviram para institucionalizar os interesses da classe burguesa, acirrando as desigualdades sociais $^{155}$.

\footnotetext{
${ }^{154}$ CASTRO, Marcus Faro de. Globalização, Democracia e Direito Constitucional: Legados Recebidos e Possibilidades de Mudança. In: CLÈVE, Clèmerson Merlin; FREIRE, Alexandre (coords.). Direitos Fundamentais e Jurisdição Constitucional: Análise, Crítica e Contribuições. São Paulo: Editora Revista dos Tribunais, 2014, p. 700-701.

155 Id. Ibid., p. 701-706.
} 
A ponderação de valores como modo de aplicação de princípios, utilizada para solucionar conflitos entre direitos fundamentais, por se mostrar extremamente abstrata, é vista por Castro como técnica que distancia ainda mais as constituições política e jurídica. Da mesma forma, a interpretação dogmática do direito, pelo seu excessivo formalismo.

Assim, Castro apresenta inovações possíveis para democratizar o direito constitucional e aproximar as constituições política e jurídica. Sugere que os juristas troquem o discurso sobre formas abstratas pelo discurso acerca da "constituição política, tal como percebida em sua realidade empírica"; que descartem o apego à doutrina clássica de separação de poderes e; que não tratem os direitos subjetivos como entidades metafísicas, com conteúdo fixo e inalterável, mas sim como flexíveis.

Propõe que

(...) ao contrário de procurar apoio em noções formalistas de direitos fundamentais incluindo as que se traduzem em declamações especulativas e idealistas sobre tais direitos, ou em principiologias abstratas bem organizadas, ou ainda em teorias prontas também abstratas e dogmáticas sobre tais direitos - o jurista que se dedique a desenvolver o direito constitucional de orientação democrática deve aceitar que seu papel não é o de declarar, com base em concepções normativas "prontas", a constitucionalidade ou inconstitucionalidade de uma norma ou comportamento, mas sim o de ser coadjuvante em um processo complexo de descobertas e de construção contínua desses referenciais normativos que são os direitos fundamentais ${ }^{156}$.

Em trabalho que propõe uma abordagem nova para o direito no trato de políticas econômicas (Análise Jurídica da Política Econômica - AJPE), Castro defende que a utilização de conceitos formais e dogmáticos, bem como de abstrações (princípios e ponderação de valores) não são capazes de gerar uma decisão justa do ponto de vista econômico, ou seja, que garanta a equânime proteção dos direitos fundamentais (objetivo que deve ser buscado) que abriguem interesses econômicos. A primeira se prende a formas jurídicas e construções dogmáticas, ignorando situações empíricas dramáticas e injustas, como a fome e a miséria. A ponderação de valores, por ser genérica e abstrata, "acaba se apoiando em especulações imprecisas sobre o que são os 'valores' em questão, e sobre qual a maneira de ajuste mútuo entre eles que seria mais adequada para atender aos interesses concretos dos membros da sociedade." Por isso, o autor rejeita noções metafísicas de direitos e a caracterização de direitos subjetivos como formas inalteráveis ou abstratas ${ }^{157}$.

156 CASTRO, Marcus Faro de. Globalização, Democracia e Direito Constitucional: Legados Recebidos e Possibilidades de Mudança. In: CLÈVE, Clèmerson Merlin; FREIRE, Alexandre (coords.). Direitos Fundamentais e Jurisdição Constitucional: Análise, Crítica e Contribuições. São Paulo: Editora Revista dos Tribunais, 2014, p. 717-718.

${ }^{157}$ CASTRO, Marcus Faro de. Análise jurídica da política econômica. Revista da Procuradoria-Geral do Banco Central, v. 3, n. 1, p. 17-22 e 47, jun. 2009. 
João Maurício Adeodato reforça a ideia do uso da linguagem dogmática jurídica como instrumento de dominação política e manutenção da desigualdade. O cerne do domínio, segundo o autor, está na desconexão dessa linguagem com a realidade, na abstração que utiliza para absorver a contingência. $\mathrm{O}$ autor salienta, ainda, que não faz sentido, do ponto do vista científico, decidir um problema jurídico a partir de um dogma prévio, não raras vezes desconectado do conflito concreto ${ }^{158}$.

Lenio Streck fala da necessidade de superar o "sentido comum teórico dos juristas", que seria

o conjunto de crenças, valores, e justificativas (...) legitimadas mediante discursos produzidos pelos órgãos institucionais, tais como os parlamentos, os tribunais, as escolas de direito, as associações profissionais e a administração pública. Tal conceito traduz um complexo de saberes acumulados, apresentados pelas práticas jurídicas institucionais, expressando, destarte, um conjunto de representações funcionais provenientes de conhecimentos morais, teológicos, metafísicos, estéticos, políticos, tecnológicos, científicos, epistemológicos, profissionais e familiares, que os juristas aceitam em suas atividades por intermédio da dogmática jurídica ${ }^{159}$.

De acordo com o autor, esse senso comum teórico relaciona-se com o processo de aprendizado nas faculdades de Direito - por meio de manuais - e com os cursos de preparação para concursos - que simplificam o ensino jurídico, a partir de standards e lugares comuns -. O positivismo jurídico ainda é a regra e, quando se quer superá-lo, são construídos novos princípios a todo o momento, fenômeno que Streck denomina de "pamprincipiologismo". Ademais, na visão do autor, a doutrina limita-se a comentar a jurisprudência, sem sequer contextualizá-la. Ela "não mais doutrina; é doutrinada pelos tribunais. 160

Essa distância do direito com a realidade, segundo o autor, é reforçada por exemplos utilizados em sala de aula e cobrados nos concursos públicos ${ }^{161}$ totalmente desconectados do

\footnotetext{
${ }^{158}$ ADEODATO, João Mauricio Leitão. Ética e retórica: para uma teoria da dogmática jurídica. São Paulo: Saraiva, 2012, p. 154-155 e 161.

${ }^{159}$ STRECK, Lenio Luiz. De como a dogmática jurídica traiu a filosofia. Constituição e processo: uma análise hermenêutica da (re)construção dos códigos. Belo Horizonte: Fórum, 2012, p. 199.

${ }^{160}$ Id. Hermenêutica jurídica e $(m)$ crise: uma exploração hermenêutica da construção do direito. 11. ed. Porto Alegre: Livraria do Advogado, 2014, p. 98-100.

${ }^{161}$ Para ilustrar o raciocínio o autor cita exemplo da seguinte questão cobrada em importante concurso no Rio Grande do Sul: "Caio quer matar Tício, com veneno; ao mesmo tempo Mévio também deseja matar Tício (igualmente com veneno!). Um não sabe da intenção assassina do outro. Ambos ministram apenas a metade da dose letal (na pergunta não há qualquer esclarecimento acerca de como o personagem Tício - com certeza um idiota, bebe as duas porções de veneno). Em consequência da ingestão das meias doses, Tício vem a perecer...Encerrando, a questão do seguinte concurso indagava: Caio e Mévio respondem por qual tipo penal???? (STRECK, Lenio Luiz. Hermenêutica jurídica $e(m)$ crise: uma exploração hermenêutica da construção do direito. 11. ed. Porto Alegre: Livraria do Advogado, 2014, p. 101-102).
} 
que se verifica no cotidiano das pessoas. "Isso decorre de uma cultura estandardizada, no interior da qual a dogmática jurídica trabalha com prêt-à porters significativos ${ }^{162}$ ".

Por fim, o sentido comum reproduz valores sem explicá-los, o que culmina com uma espécie de "conformismo dos operadores jurídicos" 163 , que trava as possibilidades de mudança.

Apesar disso, o "discurso dogmático consegue (ainda) aparecer, aos olhos do usuário/operador do Direito, como, ao mesmo tempo, seguro, justo, abrangente, sem fissuras, e, acima de tudo, técnico e funcional", afirma Streck. As consequências são drásticas, pois essa ideia culmina "num universo do silêncio: um universo do texto, do texto que sabe tudo, que diz tudo, que faz as perguntas e dá as respostas". Diante desse panorama, o autor conclui "ou se acaba com a estandardização do direito, ou ela acaba com o que resta da ciência

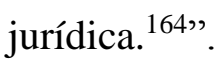

Cesar Pasold, Sandra Gonçalves e Pablo Dietrich também defendem que é preciso "abandonar o sufocamento interpretativo que deriva do senso comum teórico e ampliar as possibilidades críticas, sobretudo de modo a compatibilizar efetivamente as decisões judiciais com a Constituição vigente ${ }^{165}$ ".

Samyra Sanches e Samantha Meyer, ao pesquisar o ensino jurídico, concluem que ele reproduz o paradigma dogmático de Ciência Jurídica e o senso comum teórico. É necessário renová-lo através de novas concepções metodológicas ${ }^{166}$, pois

(...) não se mostra mais capaz para formar bacharéis em Direito aptos a lidarem com êxito aos desafios que lhe impõe a vida acadêmica e a vida profissional.

A própria evolução da sociedade e as inovações tecnológicas impõem uma concepção mais dinâmica do Direito, exige-se do bacharel em direito, cada vez mais, a capacidade de criar soluções para esse mundo globalizado e em constante mutação. No entanto, a grade curricular dos cursos de Direito baseadas num dogmatismo jurídico, que se limita ao estudo apenas das normas jurídicas, do direito positivo, não se apresenta capaz de formar um bacharel em direito apto a enfrentar os desafios de um mundo globalizado ${ }^{167}$.

\footnotetext{
${ }^{162}$ STRECK, Lenio Luiz. Hermenêutica jurídica $e(m)$ crise: uma exploração hermenêutica da construção do direito. 11. ed. Porto Alegre: Livraria do Advogado, 2014, p. 101.

${ }^{163}$ Id. De como a dogmática jurídica traiu a filosofia. Constituição e processo: uma análise hermenêutica da (re)construção dos códigos. Belo Horizonte: Fórum, 2012, p. 200.

${ }^{164}$ Id. Hermenêutica jurídica $e(m)$ crise: uma exploração hermenêutica da construção do direito. 11. ed. Porto Alegre: Livraria do Advogado, 2014, p. 109-110.

165 PASOLD, Cesar Luiz; GONÇALVES, Sandre Krieger; DIETRICH, Pablo. A fundamentação das decisões judiciais amparadas em princípios constitucionais: necessidade de superação do senso comum teórico no Brasil. Revista Eletrônica Direito e Política, Programa de Pós-Graduação Stricto Sensu em Ciência Jurídica da UNIVALI, Itajaí, v.9, n.3, p. 1946-1948, $3^{\circ}$ quadrimestre de 2014. Disponível em: <www.univali.br/direitoepolitica>. Acesso em 5 fev. 2015.

166 SANCHES, Samyra Naspolini. O paradigma da Ciência jurídica nos manuais de ensino de Direito. Universitas Jus, v. 24, n. 2, p. 8, 2013.

${ }^{167}$ Id. Ibid, p. 2.
} 
Claudia Servilha Monteiro salienta que a procura por princípios universais de justiça e por uma teoria moral capazes de legitimar e fundamentar os raciocínios jurídicos e decisões "acabou recaindo ao longo dos séculos em uma armadilha circular porque os resultados decorrentes desses esforços de investigação proporcionaram os únicos critérios de racionalidade que se dispõem a aceitar. ${ }^{168 "}$. Ademais, alerta que o uso de conceitos abstratos e inespecíficos, bem como o emprego da subjetividade em larga escala conduz ao arbítrio ${ }^{169}$.

Ana Isabel Mendes e Marcio Renan Hamel, em artigo que analisa a falta de compreensão das decisões judiciais por parte da sociedade, sustentam que esse problema decorre principalmente da aplicação dogmática do direito, excessivamente formalista, que o distancia da realidade social e da vivência das pessoas ${ }^{170}$.

No caso da partilha dos royalties do pré-sal, os fundamentos baseados em princípios abstratos, tais como os princípios da isonomia, da segurança jurídica e da proporcionalidade, e em interpretações dogmáticas do direito negligenciam os aspectos mais importantes que envolvem a problemática - os econômicos e políticos - e não enfrentam o cerne do debate. Por isso, são incapazes de promover uma solução apropriada para o caso. Daí a necessidade de desconsiderá-los.

A distribuição do pré-sal é tema que envolve sobremaneira questões econômicas, federativas e ambientais, cuja análise é imprescindível para que se chegue a uma adequada decisão sobre a partilha, conforme será comprovado nos capítulos seguintes.

A atividade petrolífera implica grandes transformações sociais, a exemplo da geração de empregos, do aumento populacional e do custo de vida. Por outro lado, os recursos gerados por esta exploração são enormes e interferem diretamente na economia das localidades beneficiadas e na vida das pessoas, em razão dos investimentos que podem ser feitos a partir dessa renda.

Atualmente, alguns estados e municípios são completamente dependentes de royalties, enquanto outros são alijados quase que totalmente da distribuição das receitas geradas pelo petróleo. Portanto, qualquer decisão acerca da partilha dos recursos advindos da exploração do petróleo trará consequências econômicas e sociais notáveis.

\footnotetext{
${ }^{168}$ MONTEIRO, Cláudia Servilha. Fundamentos para uma teoria da decisão judicial, p. 6106-6107. Disponível em: <www.conpedi.org.br/manaus/arquivos/anais/bh/claudia_servilha_monteiro.pdf>. Acesso em: 7 fev. 2015. ${ }^{169}$ Id. Ibid., p. 6109-6110.

${ }^{170}$ HAMEL, Marcio Renan; MENDES, Ana Isabel. A dogmática e o discurso jurídico entre a ciência e a realidade. Direito e Práxis, vol. 04, n. 01, p. 129-132, 2012.
} 
Por tal motivo, a decisão sobre a partilha do pré-sal deve contemplar fatos políticos e econômicos relevantes, bem como valores de justiça reconhecíveis pela sociedade. Como a investigação desses fatores não é provocada pelas visões dominantes do direito constitucional, fica evidente que devem ser superadas. 


\section{FUNDAMENTOS UTILIZADOS NO DEBATE ACERCA DA DISTRIBUIÇÃO DOS ROYALTIES E PE DO PETRÓLEO}

Os objetivos desse capítulo são: a) apresentar o material utilizado na pesquisa; b) detalhar os resultados obtidos com a exposição e classificação dos fundamentos utilizados pelos atores que participam do debate acerca da distribuição dos royalties e PE do petróleo, bem como retirar algumas conclusões a partir dessa análise; c) avaliar qual o tipo de fundamento é capaz de ensejar uma decisão que reflita fatos e escolhas políticos e econômicos e que contemple ideais de justiça reconhecíveis pela sociedade e por quê; d) investigar se é possível inferir, a partir da análise dos fundamentos, qual dos atores envolvidos e qual o posicionamento (favorável ou contrário à redistribuição) apresenta fundamentos mais aptos a solucionar a problemática.

Os resultados - que serão apresentados a seguir - foram obtidos por meio da identificação e classificação dos fundamentos, realizada de modo detalhado nas tabelas ${ }^{171}$ anexas ao presente trabalho.

A identificação e classificação dos fundamentos utiliza como método a "Análise de Conteúdo" ${ }^{172}$, técnica que possui como fases a pré-análise; a exploração do material; o tratamento dos resultados; a inferência; e a interpretação. Na pré-análise são escolhidos os documentos a serem examinados e formuladas hipóteses. A exploração do material consiste em codificar os documentos, a fim de escolher categorias para classificar os dados brutos dos textos analisados. Por fim, são apresentadas as conclusões obtidas por meio da Análise de Conteúdo. ${ }^{173}$

Dentre as fases acima expostas, a exploração do material merece ser desenvolvida, a fim de explicar ao leitor a motivação da escolha das categorias utilizadas para classificar o texto, bem como os indicadores escolhidos para a classificação de cada fundamento.

\footnotetext{
171 cf. Tabela 3 - fundamentos utilizados pelo legislativo: favoráveis à redistribuição dos royalties e PE; Tabela 4 - fundamentos do legislativo contrários à redistribuição dos royalties e PE; Tabela 5 - fundamentos utilizados pelo Executivo; Tabela 6 - fundamentos utilizados pelo judiciário; Tabela 7 - fundamentos utilizados pelos demais atores processuais favoráveis à redistribuição dos royalties e PE e Tabela 8 - fundamentos utilizados pelos demais atores processuais contrários à redistribuição dos royalties e PE; Tabela 10 - fundamentos utilizados pelos juristas e economistas favoráveis à redistribuição dos royalties e PE; e Tabela 11 - fundamentos utilizados pelos juristas e economistas contrários à redistribuição dos royalties e PE.

${ }^{172}$ A análise de conteúdo pode ser definida como um "conjunto de instrumentos metodológicos (...) que se aplicam a 'discursos' (conteúdos e continentes) extremamente diversificados. O fator comum dessas técnicas múltiplas (...) é uma hermenêutica controlada, baseada na dedução: a inferência.”. (BARDIN, Lawrence. Análise de Conteúdo. Trad. Luís Antero Reto e Augusto Pinheiro. São Paulo: Edições 70, 2011, Prefácio).

${ }^{173}$ Id. Ibid., p. 125-132.
} 
Antes de expor as categorias e indicadores utilizados, é importante destacar que a unidade de contexto escolhida foi o parágrafo. Em alguns casos, utiliza-se mais de um parágrafo, a fim de possibilitar melhor compreensão das unidades de registro. ${ }^{174}$

Para a classificação dos fundamentos utilizados pelos atores envolvidos no debate acerca da distribuição dos royalties e PE do petróleo foram escolhidas duas grandes categorias: 1) aquelas derivadas das "visões dominantes" do direito constitucional brasileiro (VD) e 2) os "outros fundamentos" (O).

Na primeira categoria, inserem-se os fundamentos neoconstitucionalistas, os jurídicos dogmáticos e jurídicos historicistas ${ }^{175}$. Os "outros fundamentos" englobam os econômicos, ambientais, jurídicos (não dogmáticos) e federativos.

A escolha dessas categorias tem por objetivo observar se as visões dominantes do direito constitucional são capazes de refletir fatos políticos e econômicos relevantes e ideais de justiça reconhecidos pela sociedade.

No que tange aos indicadores utilizados para a classificação, o fundamento será considerado neoconstitucionalista se fizer referência às perspectivas de pensamento defendidas por essa visão, a saber: conexão entre direito e moral, divisão entre regras e princípios, fundamentação em princípios abstratos, visão dos direitos fundamentais como princípios, e constitucionalização do direito.

Será jurídico dogmático se apresentar interpretações fechadas e incontestáveis da norma analisada (visão da norma como dogma).

Um fundamento da primeira categoria (VD) pode ser, ainda, considerado neoconstitucionalista e jurídico dogmático, quando utilizar a ponderação de valores ou apresentar uma visão de protagonismo do Poder Judiciário (pontos de convergência entre as duas doutrinas).

Em relação aos fundamentos jurídicos historicistas, encontram-se na primeira categoria por expressarem uma visão dogmática do direito, na medida em que consideram que as normas jurídicas são predeterminadas pelos fatos, tal como revelados pela pesquisa histórica, como se o seu conteúdo e a sua interpretação fossem imutáveis.

\footnotetext{
${ }^{174}$ A unidade de contexto é a unidade de compreensão utilizada para codificar o texto. Deve ser escolhida de modo que possibilite a compreensão exata da unidade de registro, que pode ser a palavra, o tema, o referente, o personagem ou o documento. (BARDIN, Lawrence. Análise de Conteúdo. Trad. Luís Antero Reto e Augusto Pinheiro. São Paulo: Edições 70, 2011, p. 134-137).

${ }^{175}$ Conforme já discutido no tópico 2.1, a visão jurídica historicista, inspirada na Escola Histórica alemã, sob a liderança de Savigny (e com desdobramentos na "jurisprudência dos conceitos"), é considerada dogmática, na medida em que apresenta o direito positivo como ciência dotada de rigorosa sistematicidade, cujo conteúdo é predeterminado pelos fatos revelados pela pesquisa histórica e cuja validade é indiscutível.
} 
No que concerne à categoria dos "outros fundamentos" $(\mathrm{O})$, os indicadores utilizados para a classificação de um fundamento em econômico são os seguintes: indicação da realidade econômica, uso de referenciais da ciência econômica (que não se restringe à visão neoclássica), bem como menção aos impactos econômicos, à destinação de recursos e ao desenvolvimento social e humano.

Para a classificação do fundamento em ambiental o indicador usado é a referência a impactos ao meio ambiente.

O fundamento jurídico não dogmático é reconhecido pela citação ou interpretação de artigos da lei ou da Constituição, valendo lembrar que o critério utilizado aqui é o residual, ou seja, o que não for considerado fundamento jurídico dogmático, historicista ou neoconstitucionalista será classificado como fundamento jurídico não dogmático.

Por fim, o fundamento será classificado como federativo quando fizer menção ao pacto federativo, ao equilíbrio federativo, às desigualdades regionais (incluindo o Fundo de Participação dos Estados e dos Municípios, que têm por objetivo reduzi-las), à distribuição e à redistribuição de recursos entre os entes federativos.

As categorias escolhidas são boas porque observam as seguintes qualidades expostas por Bardin: exclusão mútua (cada elemento não pode existir em mais de uma divisão); homogeneidade (um único princípio de classificação deve governar a organização das categorias); pertinência (categoria adaptada ao material de análise escolhido e capaz de refletir as intenções da investigação); objetividade (definição clara das variáveis e dos indicadores que determinam a entrada de um elemento numa categoria); e produtividade (um conjunto de categorias é produtivo se fornece resultados férteis).

No que tange à primeira qualidade, está presente em relação às duas categorias utilizadas: um fundamento não se enquadra nas "visões dominantes" do direto constitucional e em "outros fundamentos", simultaneamente. Porém, dentro da mesma categoria, é possível combinar elementos, isto é, um fundamento pode ser de econômico e ambiental ou dogmático e neoconstitucionalista, ao mesmo tempo.

Quanto à homogeneidade, o princípio de classificação utilizado é: presença ou ausência das teses dominantes no direito constitucional brasileiro. As categorias escolhidas são pertinentes e produtivas, porque possibilitam o teste da principal hipótese: as doutrinas dominantes do direito constitucional não refletem fatos políticos e econômicos relevantes e ideais de justiça social. A objetividade encontra-se presente pela exposição dos indicadores utilizados para categorizar os fundamentos. 
Os fundamentos estão divididos de acordo com os atores envolvidos e conforme o posicionamento de cada um - se contra ou a favor da redistribuição -, quando pertinente, a fim de iluminar a resposta a dois questionamentos: a) qual dos atores e qual dos dois lados (contrário ou favorável à redistribuição) utiliza fundamentos que mais refletem fatos e escolhas políticos e econômicos relevantes em relação à partilha do pré-sal; b) a análise dos fundamentos permite concluir se deve ou não haver a redistribuição dos royalties e PE?

No que tange aos fundamentos utilizados pelo Poder Legislativo, foram ele extraídos de Projetos de Lei e de Pareceres aprovados nas duas Casas do Congresso. Analisou-se todos os atos expostos no tópico 1.2 e outros escolhidos de modo aleatório, a saber: PL n ${ }^{0}$ 323/07 na Câmara (PLC no 41/13 no Senado); PLS no 2/10; PLS no 594/11 e PLS no 227/11 (os três últimos são de autoria de Senadores e não chegaram a ser analisados pela Câmara dos Deputados). Também foram analisados os argumentos utilizados pelos parlamentares nas sessões do Senado e da Câmara que debateram o PLS no 448/11 (PL nº 2565 na Câmara) e na sessão conjunta que culminou com a derrubada do Veto Parcial no ${ }^{\circ} 8 / 12$.

Foram identificados vinte fundamentos do Poder Legislativo favoráveis à redistribuição e doze contrários, no material selecionado. Tais argumentos encontram-se detalhados e classificados nas Tabelas 3 e 4 - fundamentos do legislativo favoráveis e contrários à redistribuição dos royalties e $\mathrm{PE}$ do petróleo, respectivamente.

Os fundamentos utilizados pelos parlamentares favoráveis à distribuição dos royalties são todos de outra natureza, sendo que $80 \%$ deles envolve algum aspecto econômico e $45 \%$ algum aspecto federativo.

Vale repisar que os fundamentos são classificados como decorrentes das visões dominantes no direito constitucional (VD) e outros fundamentos (O), mas dentro dessas classificações há diversos fundamentos que combinam elementos, isto é, são ao mesmo tempo dogmáticos e neoconstitucionalistas (aqueles que encampam as perspectivas de pensamento comuns a ambas as visões) e econômicos e federativos, dentre outras combinações. É exatamente por conta dessas combinações que a soma dos percentuais ultrapassa $100 \%$.

Por sua vez, os parlamentares contrários à redistribuição dos royalties se valeram de dois fundamentos jurídicos dogmáticos $(16,6 \%)$, mas a maioria deles também se valeu de aspectos econômicos $(58,3 \%)$ e federativos $(41,6 \%)$. Os demais fundamentos utilizados pelo legislador foram jurídicos não dogmáticos e ambientais.

Os fundamentos utilizados pelo Executivo encontram-se detalhados na Tabela 5 e foram extraídos dos dois vetos parciais à alteração na sistemática de partilha dos frutos do petróleo: o veto à "Emenda Simon", constante do PLC n ${ }^{\circ} 7 / 2010$, que originou a Lei $n^{\circ}$ 
12.351/10 (Veto $\mathrm{n}^{\mathrm{o}}$ 39/10, do Presidente Lula) e o Veto $\mathrm{n}^{\circ}$ 38/12, da Presidente Dilma Roussef, que atingiu as normas de redistribuição constantes da Lei $n^{0} 12.734 / 12$. Foram também analisados os fundamentos utilizados para a edição da Medida Provisória ${ }^{0}$ 592/12, que determinou novas regras de partilha de royalties e PE entre os entes federados, mas somente aplicáveis aos campos de petróleo ainda não licitados. Vale ressaltar que o conteúdo das informações prestadas pela Advocacia-Geral da União na ADI que questiona a constitucionalidade dessa lei será tratado como manifestação de outros atores processuais.

Quanto ao primeiro veto (Veto $\mathrm{n}^{0} 39 / 10$ ), nota-se que o Presidente silenciou acerca da possibilidade jurídica de redistribuição dos royalties, tema gerador de enorme conflito federativo, preferindo valer-se de razões que não atacam o cerne do problema, tais como: ausência de critérios legais para o cálculo exato do montante de royalties devidos aos entes federados; deficiência de critérios para o cálculo da indenização devida pela União aos estados e municípios impactados pela mudança das regras; falta de clareza quanto à aplicação da lei aos contratos já celebrados.

De outro lado, os fundamentos do Veto $\mathrm{n}^{0}$ 38/12 relacionam-se diretamente à possibilidade de alteração dos critérios de partilha, analisando o suposto direito dos estados e municípios produtores e confrontantes ao recebimento desses recursos, bem como a possibilidade de as novas regras atingirem os contratos de concessão já celebrados.

A partir do material analisado foram extraídos onze fundamentos. A maioria deles (45,45\%) combina elementos jurídicos (não dogmáticos) e econômicos. Apenas 18,18\% dos fundamentos do Executivo enquadram-se na visão dominante do direito - são todos jurídicos dogmáticos.

Os fundamentos utilizados pelo Judiciário constam da Tabela 6 e foram retirados da decisão proferida na ADI $n^{\circ} 4917$, que suspendeu os dispositivos da Lei $n^{0} 12.734 / 12$ que redistribuem royalties e PE. Em síntese, a decisão amparou-se nos seguintes argumentos: urgência em manter as regras de distribuição; violação ao art. 20, §1 $1^{\circ}$ da Constituição; ao pacto federativo; e ao art. $5^{\circ}$, XXXVI da Constituição (direito adquirido, ato jurídico perfeito e princípio da segurança jurídica), conforme detalhado na tabela.

Ao todo, foram identificados dez fundamentos. Chama a atenção o fato de que o Judiciário é o único dos Poderes que se vale de argumento classificado como neoconstitucionalista. Ademais, é o que mais utiliza fundamentos respaldados na visão dominante do direito (40\%), se comparado com o Legislativo $(6,25 \%)$ e com o Executivo $(18,18 \%)$. 
Ademais, $30 \%$ dos fundamentos utilizados pelo Judiciário apresenta aspectos econômicos. Todavia, todos eles estão relacionados às consequências financeiras e sociais da aplicação imediata das regras de partilha de royalties previstas na Lei ${ }^{\circ} 12.734 / 12$ para os entes produtores e confrontantes, ou seja, não são avaliadas as consequências da aplicação das novas regras para os entes não produtores.

Os argumentos utilizados pelos demais atores processuais encontram-se detalhados nas Tabelas 7 e 8 (favoráveis e contrários à redistribuição dos royalties e PE, respectivamente). Foram analisados os fundamentos utilizados: a) pelos três Governadores de Estado (RJ, ES e SP) para pleitear o reconhecimento da inconstitucionalidade dos dispositivos da Lei $n^{\circ} 12.734 / 12$, que alteram a distribuição dos royalties e PE ou, subsidiariamente, a sua não aplicação aos contratos já firmados para a exploração do petróleo; b) pela ProcuradoriaGeral da República que, em seu parecer, opina "pela procedência parcial do pedido, apenas para afastar a aplicabilidade imediata dos dispositivos impugnados (...) a fim de que as alterações questionadas vigorem somente a partir do exercício financeiro de 2016"; c) pela Advocacia-Geral da União que, nas informações prestadas, sustenta as razões do veto da Presidente da República; d) pelo Advogado-Geral da União que, em virtude da função atribuída pelo art. $103, \S 3^{\circ}$ da $\mathrm{CF}$, defende a constitucionalidade da lei; e) pela Mesa do Congresso Nacional, nas informações prestadas na ADI e em agravo regimental interposto contra a decisão cautelar que determinou a suspensão das novas regras de distribuição dos royalties e PE; por alguns atores que se manifestaram na qualidade de amici curiae, a favor da redistribuição: Confederação Nacional dos Municípios, Estado da Bahia, OAB de Minas Gerais e do Mato Grosso do Sul e contra a redistribuição: Organização dos Municípios Produtores de Petróleo e Gás e Limítrofes da Zona de Produção Principal da Bacia de Campos (OMPETRO) e Associação Brasileira dos Municípios com Terminais Marítimos, Fluviais e Terrestres de Embarque e Desembarque de Petróleo e Gás Natural (ABRAMT).

Vale dizer que todas as manifestações analisadas, com exceção das ações propostas pelos Governadores do Estado do Espírito Santo e de São Paulo constam dos autos da ADI n ${ }^{\circ}$ $4917^{176}$, por ser aquela em que houve a decisão que suspendeu os efeitos da lei.

Foram identificados vinte e dois argumentos favoráveis à redistribuição dos royalties e PE e dezoito contrários, no material analisado. Percebe-se que os atores processuais também se valem de fundamentos neoconstitucionalistas $(13,63 \%$ dos fundamentos utilizados pelos

\footnotetext{
${ }^{176}$ É possível consultar todas as peças constantes da ADI n ${ }^{\circ}$ 4917-DF, por se tratar de processo eletrônico. Disponível em: <http://redir.stf.jus.br/estfvisualizadorpub/jsp/consultarprocessoeletronico/ConsultarProcesso Eletronico.jsf?seqobjetoincidente=4379376>. Acesso em: $1^{\circ}$ mar. 2015.
} 
que defendem a redistribuição e 22,2\% dos argumentos dos atores contrários à redistribuição), o que demonstra que essa visão é utilizada preponderantemente no meio jurídico, ou seja, no âmbito da doutrina jurídica e do processo judicial, seja pelos atores do processo ou pelo próprio magistrado.

Chama também a atenção o fato de que quase $50 \%$ dos fundamentos utilizados pelos demais atores processuais que defendem a inconstitucionalidade da Lei $n^{0}$ 12.734/12 são decorrentes da visão dominante do direito (neoconstitucionalistas, jurídicos dogmáticos e jurídicos historicistas). Já quando se observa os fundamentos dos atores favoráveis à Lei, esse percentual cai para $18,18 \%$.

No que tange aos debates realizados por juristas e economistas acerca da distribuição de royalties e PE, foram analisados 24 (vinte e quatro) trabalhos, sendo 11 (onze) escritos por juristas, 12 (doze) por economistas e 1 (um) escrito, em coautoria, por um jurista e um economista. Muitos deles, sobretudo os escritos por economistas, não se posiciona especificamente sobre a constitucionalidade da Lei $\mathrm{n}^{\mathrm{o}} 12.734 / 12$ - até por não ser este o objeto de estudo da disciplina -, mas apenas sobre a necessidade ou não de os recursos do petróleo serem redistribuídos. Interessante notar que, na literatura econômica, todos os 12 (doze) trabalhos pesquisados defendem a necessidade de redistribuição dos royalties e PE. No universo jurídico, constatou-se um equilíbrio: 6 (seis) defendem a inconstitucionalidade da mudança dos critérios de partilha e 5 (cinco) se posicionam favoravelmente à redefinição dos critérios. Por fim, o artigo interdisciplinar defende a necessidade de redistribuição. Ao final do trabalho consta tabela que especifica os trabalhos analisados, conforme o posicionamento adotado e o foco da abordagem, se Direito ou Economia. ${ }^{177}$

Foram extraídos 14 (quatorze) fundamentos favoráveis à redistribuição e 12 (doze) contrários, a partir do material analisado. Eles estão detalhados nas Tabelas 10 e 11 (fundamentos de juristas e economistas favoráveis e contrários à redistribuição, respectivamente).

Intrigantes também os resultados obtidos com a identificação dos fundamentos utilizados pelos juristas e economistas, pois enquanto não foi identificado nenhum argumento decorrente da visão dominante entre os favoráveis à redistribuição, quase $60 \%$ dos fundamentos contrários à redistribuição das rendas do petróleo foram assim classificados.

Ademais, observa-se que a maioria dos fundamentos utilizados por juristas e economistas favoráveis à redistribuição das rendas do petróleo se vale de algum aspecto

${ }^{177}$ Cf. Tabela 9 - Posicionamentos de juristas e economistas: contra e a favor da redistribuição dos royalties e PE. 
econômico $(64,28 \%)$ ou jurídico não dogmático $(42,85 \%)$. Tal resultado reflete bem o fato de que a maioria dos artigos analisados que concluem pela necessidade de modificação dos critérios de rateio dos frutos do petróleo foram escritos por economistas.

Também vale observar que $25 \%$ dos argumentos utilizados por juristas e economistas contrários à redistribuição dos royalties se vale de elementos da Economia. Considerando que nenhum dos artigos escritos por economistas defende a manutenção dos critérios atuais, temse que os juristas contrários à mudança dos critérios de partilha utilizam poucos fundamentos de ordem econômica para defender o seu ponto de vista, se comparados com aqueles que defendem a redistribuição dos royalties.

No que concerne ao terceiro objetivo desse tópico - avaliação do tipo de fundamento que é capaz de ensejar uma decisão que reflita fatos e escolhas políticos e econômicos e que contemple ideais de justiça reconhecíveis pela sociedade - observou-se que os argumentos decorrentes das visões dominantes do direito não exprimem esses fatos ou ideais.

Os fundamentos neoconstitucionalistas são abstratos quando utilizam princípios. $\mathrm{O}$ preenchimento do conteúdo de tais princípios é feito pelo intérprete sem que haja preocupação em comprovar por que o princípio deve ser empregado de um modo ou de outro. Tal afirmação fica evidente quando se observa que um mesmo princípio é utilizado para defender a constitucionalidade e a inconstitucionalidade da Lei $\mathrm{n}^{\mathrm{o}} 12.734 / 12$, a exemplo do que foi verificado com o princípio da isonomia: o Governador do Estado do Espírito Santo (ator processual contrário à redistribuição) afirmou que a Lei $\mathrm{n}^{0} 12.734 / 12$ ofende o princípio da isonomia, que estabelece a igualdade de todos perante a lei, sem distinção de qualquer natureza ${ }^{178}$, enquanto que a Confederação Nacional dos Municípios (ator processual favorável à alteração das regras de partilha) defendeu que a distribuição do petróleo deve ser igualitária, pois entendimento diverso ofenderia o princípio da igualdade ${ }^{179} \cdot 180$

A inconsistência das defesas possibilitadas pela aplicação de princípios abstratos, que podem ser utilizados para defender qualquer posição que o intérprete queira assumir leva à conclusão de que a fundamentação com base nesses princípios não é a melhor opção para solucionar conflitos, sobretudo aqueles que envolvem aspectos econômicos e políticos, insuficientemente abordados pelas visões dominantes no direito constitucional.

178 ADI 4916 (ES). Petição inicial, p. 80. Disponível em: <http://redir.stf.jus.br/paginadorpub/ paginador.jsp?docTP=TP\&docID=3511895\&ad=s\#1\%20-\%20Peti\%E7\%E3o\%20inicial\%20-\%20 Peticao\%20 inicial\%201>. Acesso em 3 mar. 2015.

${ }_{179}$ Razões de mérito apresentadas pela Confederação Nacional dos Municípios, p. 31. Disponível em: <http://redir.stf.jus.br/paginadorpub/paginador.jsp?docTP=TP\&docID=3582768\&ad=s\#48\%20-\%20Pedido\%20 de $\% 20$ ingresso $\% 20$ como $\% 20$ amicus $\% 20$ curiae $\% 20-\% 20$ Pedido $\% 20$ de $\% 20$ ingresso $\% 20$ como $\% 20$ amicus $\% 20$ curiae\%201>. Acesso em: 3 mar. 2015.

${ }^{180}$ Cf. Tabela 7 (A16) e Tabela 8 (B15). 
Outras perspectivas de pensamento dominantes, como por exemplo, a de que o Judiciário é a instância adequada para solucionar o problema, porque protege a Constituição, os direitos fundamentais das minorias e analisa fundamentos jurídicos negligenciados pelo legislador; ou de que a Constituição é suprema e possui uma "força normativa" que "irradia" por todo o sistema e que limita o legislador infraconstitucional, também não são relevantes para solucionar a problemática de rateio dos recursos do pré-sal. Isso porque ignoram o cerne do debate, que é saber se a redistribuição é possível ou não, tendo em vista os preceitos constitucionais e, sobretudo, a realidade.

Os fundamentos jurídicos dogmáticos também não se mostram aptos a possibilitar uma decisão adequada do problema, porque carregam em si uma interpretação formalista e fachada da norma, como se fosse a única possível dentre tantas que o Direito, em verdade, permite. Nesse caso, assim como ocorre com a aplicação de princípios, verifica-se que o mesmo artigo da Constituição é utilizado para se chegar a conclusões diametralmente opostas.

Exemplo claro disso ocorre quando se debate a natureza jurídica dos royalties: os que são a favor da redistribuição defendem que predomina ou é exclusiva a natureza de participação no resultado, enquanto os contrários aduzem que prepondera ou é exclusivo, o seu caráter indenizatório. E ambas as afirmações são extraídas do art. $20, \S^{\circ}$ da Constituição ${ }^{181}$.

Verifica-se que, embora os fundamentos jurídicos dogmáticos muitas vezes enfrentem o cerne da problemática, como se dá no exemplo dado acima, são incapazes de apresentar uma resposta convincente, porque partem de premissas que necessitariam ser comprovadas ou debatidas, mas não o são.

O mesmo raciocínio se aplica aos fundamentos jurídicos historicistas, que se enquadram como dogmáticos, na medida em que apresentam o sentido originário da norma como imutável.

Assim, restam os "outros fundamentos", classificados como econômicos, ambientais, jurídicos (não dogmáticos) e federativos. Todos eles são relevantes, na medida em que a solução de conflitos deve aliar o direito à realidade.

As normas constitucionais e legais atinentes ao tema são lembradas nos fundamentos jurídicos, sendo a realidade e as escolhas políticas - retratadas nos fundamentos econômicos, federativos e ambientais - imprescindíveis para a correta interpretação dessas normas.

${ }^{181}$ Cf. Tabela 7 (A1) e Tabela 8 (B1). 
Ora, o problema de distribuição das rendas do petróleo envolve a divisão de receitas entre os entes federados e as possibilidades de aplicação dessas rendas - sobretudo em prol do desenvolvimento - que consistem em temas ligados diretamente ao Federalismo e que são estudados pela Economia (vale ressaltar que a afirmação não se limita à Economia neoclássica). Trata-se de atingir o cerne do debate, de olhar para a realidade, essencial para a correta solução das complexas demandas sociais.

Os aspectos ambientais também são relevantes para a decisão acerca da partilha do pré-sal seja adequada, pois avaliam, juntamente com os econômicos, os reais impactos e danos relacionados à atividade petrolífera e a sua magnitude, os quais justificam maior alocação de royalties e PE em um ou outro ente político.

Com efeito, o aplicador do direito não pode negligenciar os dados empíricos que evidenciam o acerto ou não do legislador, bem como as consequências que a sua decisão provocará na vida das pessoas.

E quando se fala em acerto do legislador, quer-se passar a seguinte ideia: se a lei vigente traz consequências positivas para a sociedade, se ela permite menor desigualdade e maior fruição de direitos por parte das pessoas, ela deve ser mantida. Caso contrário, a sua alteração é bem-vinda.

Em termos gerais, pode-se dizer então que para se interpretar adequadamente uma norma jurídica, é necessário recorrer às disciplinas que enfrentam o cerne do debate, empiricamente considerado.

Por fim, as conclusões obtidas com a exposição e a classificação dos fundamentos em "visão dominante do direito" e "outra natureza", bem como a partir da análise de adequação dos argumentos, podem ser assim sintetizadas:

1) A maior parte dos fundamentos utilizados - inclusive pelo Poder Judiciário está na categoria "outra natureza", em especial os que trazem aspectos econômicos, o que demonstra que os fundamentos decorrentes da visão dominante do direito não são suficientes para solucionar a partilha do pré-sal.

2) Os fundamentos apresentados por juristas e economistas, sobretudo pelos últimos são os mais adequados, porque investigam os dados empíricos relevantes para a decisão (tais como volume da produção, estimativa de produção e de receitas futuras, impactos da atividade petrolífera, valor distribuído a cada ente federado, destinação dos royalties e PE); as consequências da hiperconcentração de recursos resultante da partilha atual e as possíveis consequências da redistribuição; comprovam as teses levantadas por meio de estudos empíricos e não fazem uso de conceitos abstratos ou dogmas. 
3) Considerando os três poderes, o Legislativo é o que mais utiliza, proporcionalmente, fundamentos de "outra natureza". Ademais, se verificado o seu conteúdo nas Tabelas 3 e 4, os fundamentos debatidos no Parlamento são os que mais se aproximam daqueles apresentados pelos economistas, porque não consideram somente os aspectos jurídicos, mas, sobretudo, fatos econômicos e aspectos do federalismo.

4) Os fundamentos apresentados pelos demais atores processuais consideram fatos econômicos e políticos relevantes. No entanto, a decisão judicial não considerou a maioria dos fundamentos expostos pelos demais atores processuais, sobretudo por aqueles favoráveis à redistribuição, basicamente só levou em conta os apresentados pelo autor ${ }^{182}$.

5) Os fundamentos econômicos utilizados pela decisão relacionam-se aos impactos e consequências da aplicação das novas regras de partilha aos estados produtores e confrontantes, tais como desequilíbrio orçamentário, prejuízo para o custeio de serviços públicos e pagamento de pessoal; ou seja, não se avaliam as consequências da aplicação da nova sistemática para os estados não produtores.

6) Todas as abordagens econômicas analisadas concluem pela necessidade de redistribuição dos royalties e PE.

7) Os favoráveis à redistribuição dos royalties e PE utilizam, proporcionalmente, mais fundamentos de outra natureza do que aqueles que são contrários à redistribuição.

8) Os atores que defendem a redistribuição dos royalties utilizam fundamentos que melhor refletem os fatos econômicos e escolhas políticas relevantes, bem como os ideais de justiça reconhecíveis pela sociedade (nesse sentido, o fundamento de que a redistribuição privilegia a redução das desigualdades regionais $)^{183}$.

\footnotetext{
${ }^{182}$ Sabe-se que se trata de decisão liminar e que, pela urgência considerada, não observou o contraditório, ou seja, a decisão foi tomada antes de os atores processuais favoráveis à redistribuição se manifestarem. No entanto, entende-se que a relevância do tema e a quantidade de recursos envolvidos merecia uma análise mais acurada do problema, com a consideração de fundamentos de outros atores processuais, ou ao menos dos estudiosos do tema, o que não foi feito.

${ }^{183} \mathrm{~A}$ exposição dos fundamentos favoráveis e contrários à redistribuição dos royalties realizada em monografia intitulada A Justa Distribuição dos Royalties do Petróleo no Brasil também corrobora a afirmação. Foram citados como argumentos contrários à alteração dos critérios legais de partilha: interpretação adequada ao dispositivo constitucional, violação ao princípio da isonomia, violação ao princípio da segurança jurídica e violação ao princípio federativo - ou seja, quase toda a fundamentação se dá com base em princípios, cuja insuficiência para refletir fatos e escolhas políticos e econômicos já se demonstrou -. Por outro lado, como argumentos favoráveis à alteração dos critérios são enumerados: o petróleo pertence a todos os cidadãos, a hiperconcentração da distribuição dos royalties em poucas regiões, a pobreza e a riqueza nas cidades do petróleo, a exploração distante da costa dos municípios, elevação do nível da atividade como compensação, royalty como mecanismo de promoção de justiça intergeracional, e como recurso para período do pós-esgotamento da reserva - como se vê, todos os fundamentos expostos como favoráveis à redistribuição dos royalties envolvem aspectos socioeconômicos, e nenhuma abstração (GONÇALVES, Reginaldo Brasão. A Justa Distribuição dos Royalties do Petróleo no Brasil. 2010. 60 fl. Dissertação (Mestrado em Direito). Faculdade de Direito, Universidade Federal do Amazonas, Manaus, 2010, p. 44-57).
} 
9) Os fundamentos de natureza econômica e ambiental são comprovados com dados empíricos.

10) Há casos em que o mesmo fundamento principiológico é utilizado pelos dois lados (atores favoráveis e contrários à redistribuição), conforme exemplificado anteriormente com o princípio da isonomia.

11) Há casos em que o mesmo fundamento jurídico dogmático é utilizado pelos dois lados.

12) O Judiciário é o único dos três Poderes que utiliza fundamentos classificados como neoconstitucionalistas.

Por fim, a análise dos fundamentos indica que o Legislativo, dentre os poderes, é o que está mais apto a apresentar uma decisão que melhor reflita fatos econômicos e escolhas políticas relevantes (cf. conclusões 2 e 3). Isso sem considerar que a ele é constitucionalmente destinada a função de tomar decisões políticas e, mais especificamente, de regulamentar a partilha de royalties e PE, conforme art. $20, \S 1^{\circ}$ da Constituição. Por sua vez, as conclusões 6 , 7 e 8 indicam que a redistribuição dos royalties e PE entre estados e municípios é a decisão mais consentânea com a realidade e com os ideais de justiça reconhecíveis pela sociedade. 


\section{PARA ALÉM DOS LIMITES DAS CATEGORIAS JURÍDICAS CONVENCIONAIS}

Caracterizadas as visões dominantes no direito constitucional brasileiro e comprovado que são limitadas em sua capacidade de considerar claramente fatos econômicos e políticos e ao mesmo tempo referenciais normativos, que reflitam preocupações com a fruição de direitos e realizem aspirações de justiça da sociedade, o presente capítulo terá por objetivo propor novas categorias jurídicas para respaldar a decisão sobre a partilha do pré-sal.

Após a apresentação das novas categorias jurídicas e, com base nelas, serão indicados os fundamentos relevantes para decidir a distribuição dos royalties e PE do petróleo, bem como analisado se eles permitem a conclusão acerca da necessidade ou não de redistribuição dessas receitas.

\subsection{NOVAS CARACTERÍSTICAS DA ANÁLISE JURÍDICA: ALGUMAS} SUGESTÕES

\subsubsection{Análise de dados empíricos, a fim de compatibilizar a decisão com a realidade}

No lugar de princípios genéricos e dogmas, propõe-se a análise de dados empíricos fornecidos, sobretudo pela Economia, a fim de que a decisão se aproxime da realidade. Não se pode negligenciar que as decisões judiciais têm impacto na vida das pessoas e, no caso dos royalties, inclusive na situação de estados e municípios.

Ana Isabel Mendes e Marcio Renan Hamel ${ }^{184}$ sustentam que o ensino do Direito deve buscar a interação social; que não deve limitar-se a normas, doutrinas, precedentes, mas buscar a compreensão, pelo jurista, da realidade social.

Cláudia Monteiro sustenta que as decisões devem ser racionais. A racionalidade está relacionada diretamente à análise da realidade. Uma decisão racional, de acordo com a autora, é aquela que se conecta com o mundo fático. Confira-se:

O debate sobre a racionalidade das decisões evidencia que os comportamentos reais dos indivíduos em Sociedade devem ser considerados para a formulação do que venha a ser um comportamento racional. Isso porque, se a maioria das prescrições é

\footnotetext{
${ }^{184}$ HAMEL, Marcio Renan; MENDES, Ana Isabel. A dogmática e o discurso jurídico entre a ciência e a
} realidade. Direito e Práxis, vol. 04, n. 01, 2012. 
calcada na ideia de um agente de decisão idealmente racional, elas perdem a conexão com a realidade do comportamento de agentes de decisão do mundo fático $^{185}$.

No caso da distribuição das rendas advindas da atividade petrolífera, devem ser observados dados empíricos como: o volume da produção de petróleo; a estimativa de produção e de receitas futuras; os impactos da atividade petrolífera e quais são as localidades impactadas; se os critérios de rateio atuais contemplam as localidades de fato impactadas; se o valor dos royalties e PE corresponde ao valor dos riscos e danos decorrentes da atividade; o valor distribuído a cada ente federado; a destinação dos royalties e PE - se contribui para o desenvolvimento nacional e para a justiça intergeracional -; quais as razões que levaram o Congresso Nacional a estabelecer novas regras de distribuição de royalties e PE; se as regras atuais são justas do ponto de vista econômico; as consequências econômicas e sociais da hiperconcentração de recursos resultante da partilha atual; as consequências da mudança das regras para os estados e municípios produtores; e para os estados e municípios não produtores.

Vale ressaltar que os fundamentos detalhados nas Tabelas 3 a 11, sobretudo aqueles apresentados pelo Legislativo, pelos demais atores processuais e por juristas e economistas, abordam os fatores enumerados acima.

Entende-se que tais dados correspondem a fatos econômicos e políticos relevantes para a tomada de decisão acerca da partilha do pré-sal. Daí a necessidade de serem avaliados.

\subsubsection{Necessidade de diálogo com outras disciplinas (interdisciplinaridade)}

A abertura do Direito a outras disciplinas - que estudam os aspectos empíricos do problema - é fundamental para que as decisões jurídicas reflitam fatos e escolhas políticos e econômicos relevantes, pois favorece a aproximação do Direito com a realidade. A enumeração dos dados relevantes para a decisão constante do tópico anterior evidencia a necessidade de buscar auxílio em outras disciplinas, já que o direito não os tem por objeto de estudo.

A partilha do pré-sal é questão de cunho eminentemente econômico, daí porque buscar apoio em pesquisas e artigos de economistas sobre o tema é fundamental. Além disso, são mais seguros, porque comprovados por meio de dados empíricos.

\footnotetext{
${ }^{185}$ MONTEIRO, Cláudia Servilha. Fundamentos para uma teoria da decisão judicial, p. 6110. Disponível em: <www.conpedi.org.br/manaus/arquivos/anais/bh/claudia_servilha_monteiro.pdf>. Acesso em: 7 fev. 2015.
} 
Reconhecendo a necessidade da análise dos problemas jurídicos com apoio em outras disciplinas e constatando a inadequação do ensino jurídico no Brasil, Ana Mendes e Marcio Hemel propõem que "a formação dos magistrados, advogados, promotores, servidores e demais juristas seja pautada na interdisciplinaridade, a fim de que esta atue como suporte ao direito nos âmbitos filosófico, psicológico e sociológico ${ }^{186}$.".

A interdisciplinaridade é defendida também por Claudia Servilha que, ao apresentar os "Fundamentos da Teoria da Decisão no Direito", afirma que as decisões judiciais devem apoiar-se nos conhecimentos da Matemática, da Economia, da Filosofia, da Psicologia, da Ética e das Ciências Sociais ${ }^{187}$.

A fundamentação, nesse contexto, não é vista somente como uma exigência técnica da dogmática das decisões judiciais, mas como forma de legitimação da atividade jurisdicional. Assim, uma decisão legítima seria aquela que se apoia em razões aceitas pela sociedade, as quais estão relacionadas não apenas com o ordenamento jurídico vigente, mas também com questões de ordem social, econômica e ambiental, dentre outras ${ }^{188}$.

Alexandre Morais da Rosa, ao explorar a temática dos fundamentos da decisão judicial no crime, defende a interdisciplinaridade, ao concluir que um diálogo com a psicanálise contribuiria para uma sentença penal mais adequada ${ }^{189}$.

No que se refere ao trato de questões econômicas, a "Análise Econômica do Direito" AED (inspirada na Law and Economics americana) defende a ideia de que as normas e decisões judiciais devem ser elaboradas objetivando a maior eficiência possível, a qual será desvendada através do emprego de ferramentas teóricas e empíricas da Economia e das ciências afins. Assim, ao decidir, o juiz deve considerar a relação custo-benefício entre as opções possíveis, optando pela solução que seja mais eficiente ${ }^{190}$.

A AED é importante porque abre o caminho do Direito para a Economia. No entanto, é incapaz de contemplar ideais de justiça - que podem ter significados não econômicos -reconhecíveis pela sociedade, na medida em que se limita às ferramentas da Economia neoclássica. Nesse sentido, considera que o homem toma decisões sempre visando à

\footnotetext{
${ }^{186}$ HAMEL, Marcio Renan; MENDES, Ana Isabel. A dogmática e o discurso jurídico entre a ciência e a realidade. Direito e Práxis, vol. 04, n. 01, p. 136, 2012.

${ }^{187}$ MONTEIRO, Cláudia Servilha. Fundamentos para uma teoria da decisão judicial, p. 6106-6109. Disponível em: <www.conpedi.org.br/manaus/arquivos/anais/bh/claudia_servilha_monteiro.pdf>. Acesso em 7 fev. 2015.

${ }^{188}$ Id. Ibid., p. 6110-6112.

${ }^{189}$ ROSA, Alexandre Morais da. Fundamentos da decisão judicial: crime e psicanálise. Revista Eletrônica Direito e Política, Programa de Pós-Graduação Stricto Sensu em Ciência Jurídica da UNIVALI, Itajaí, v.8, n.3, $3^{\circ}$ quadrimestre de 2013. Disponível em: www.univali.br/direitoepolitica. Acesso em: 5 fev. 15.

${ }^{190}$ RIBEIRO, Marcia Carla Pereira; KLEIN, Vinicius (Coord.). O que é análise econômica do direito: uma introdução. Belo Horizonte: Fórum, 2011. p. 18 e 29.
} 
maximização dos resultados (ou seja, desconsidera que há inúmeros outros fatores que influenciam a tomada de decisões, como os valores e ideais humanos), e considera que as decisões devem buscar a máxima eficiência econômica (sem se preocupar com a justiça do que será decidido).

Contrapondo-se à AED, Marcus Faro de Castro propõe a “Análise Jurídica da Política Econômica" (AJPE), abordagem que também tem por objetivo "encorajar a abertura interdisciplinar do estudo do Direito no trato de questões economicamente relevantes", mas que não se restringe à Economia neoclássica, interagindo com estudos econômicos de orientação institucionalista, como também a Antropologia Econômica, a Sociologia Econômica, a Ciência Política e a Sociologia Política. Ademais, a AJPE defende que as decisões sobre políticas econômicas devem buscar a justiça econômica, ou seja, a máxima fruição de direitos humanos fundamentais pelos indivíduos, e não a mera eficiência almejada pela AED que, não raras vezes, gera injustiça ${ }^{191}$.

Nesse sentido, a AJPE é ferramenta mais adequada para orientar a decisão acerca do rateio dos royalties e PE do petróleo entre os entes federados, pois além de ser necessário levar em conta os aspectos econômicos envolvidos para decidir, é preciso verificar se a mudança na distribuição dos frutos do petróleo tem condições de garantir maior fruição de direitos por parte das populações envolvidas, sobretudo porque parte dessa riqueza está vinculada a gastos em educação e saúde, nos termos do art. $2^{\circ}$ da Lei ${ }^{\circ} 12.858 / 13^{192}$.

A abordagem interdisciplinar é facilmente identificada no artigo "Custos e rendas na distribuição federativa dos recursos do pré-sal", de autoria de Brosio - economista - e Loureiro - jurista -. Após defenderem a impossibilidade de se decidir a questão por meio do

${ }^{191}$ CASTRO, Marcus Faro de. Análise jurídica da política econômica. Revista da Procuradoria-Geral do Banco Central, v. 3, n. 1, p. 23 e 40, jun. 2009.

${ }^{192}$ Art. $2^{\circ}$ Para fins de cumprimento da meta prevista no inciso VI do caput do art. 214 e no art. 196 da Constituição Federal, serão destinados exclusivamente para a educação pública, com prioridade para a educação básica, e para a saúde, na forma do regulamento, os seguintes recursos:

I - as receitas dos órgãos da administração direta da União provenientes dos royalties e da participação especial decorrentes de áreas cuja declaração de comercialidade tenha ocorrido a partir de 3 de dezembro de 2012, relativas a contratos celebrados sob os regimes de concessão, de cessão onerosa e de partilha de produção, de que tratam respectivamente as Leis $\mathrm{n}^{\circ} \mathrm{s}$ 9.478, de 6 de agosto de 1997, 12.276, de 30 de junho de 2010, e 12.351, de 22 de dezembro de 2010, quando a lavra ocorrer na plataforma continental, no mar territorial ou na zona econômica exclusiva;

II - as receitas dos Estados, do Distrito Federal e dos Municípios provenientes dos royalties e da participação especial, relativas a contratos celebrados a partir de 3 de dezembro de 2012, sob os regimes de concessão, de cessão onerosa e de partilha de produção, de que tratam respectivamente as Leis ${ }^{\circ}$ s 9.478 , de 6 de agosto de 1997, 12.276, de 30 de junho de 2010, e 12.351, de 22 de dezembro de 2010, quando a lavra ocorrer na plataforma continental, no mar territorial ou na zona econômica exclusiva;

III - 50\% (cinquenta por cento) dos recursos recebidos pelo Fundo Social de que trata o art. 47 da Lei no 12.351 , de 22 de dezembro de 2010, até que sejam cumpridas as metas estabelecidas no Plano Nacional de Educação; e IV - as receitas da União decorrentes de acordos de individualização da produção de que trata o art. 36 da Lei no 12.351, de 22 de dezembro de 2010. 
uso de elementos de compreensão tradicionais, como a "natureza jurídica" e a defesa de “direitos adquiridos", propõem uma interpretação interdisciplinar do art. $20, \S 1^{\circ}$ da Constituição. A interpretação sugerida trata a distinção entre "participação no resultado" e "compensação financeira" como uma diferença de caráter econômico que se apoia nos conceitos de renda e custo. Os autores defendem que essa "estratégia interpretativa", além de tornar a norma mais compreensível, auxilia na resposta à questão por eles lançada: se é possível estabelecer critérios de rateio de royalties e PE diferenciados, conforme a exploração do petróleo se dê onshore ou offshore ${ }^{193}$.

Sem dúvida, a interpretação do art. $20, \S 1^{\circ}$ da Constituição proposta pelos autores é a mais apropriada para tratar da problemática de distribuição das receitas do petróleo, pois ao mesmo tempo que atenta para os aspectos jurídicos que envolvem o tema, não descura dos aspectos econômicos relevantes.

\subsubsection{Análise das consequências da decisão judicial}

Propõe-se, ainda, como categoria jurídica alternativa àquelas das visões dominantes do direito, que o juiz dimensione os impactos de suas decisões no mundo dos fatos por ocasião do julgamento das demandas que lhe são submetidas.

Para dimensionar as consequências de sua decisão, sugere-se que o juiz observe alguns parâmetros: a) preserve ao máximo a vontade do legislador, bem como as consequências que ele levou em consideração ao elaborar a lei; b) não limite a abordagem às consequências jurídicas; c) considere as consequências da decisão para os dois lados envolvidos na demanda; e d) privilegie as necessidades humanas e sociais.

Os parâmetros propostos acima têm inspiração no consequencialismo de Neil MacCormick, cuja exposição sintética se faz necessária.

O pensamento desenvolvido por Neil MacCormick acerca do consequencialismo encontra-se inserido no âmbito da teoria da argumentação jurídica. Em sua obra “Argumentação Jurídica e Teoria do Direito", o autor repensa os elementos da argumentação que não são dedutivos ${ }^{194}$ - e aí se inserem os argumentos consequencialistas. A questão que

\footnotetext{
193 BROSIO, Giorgio; LOUREIRO, Gustavo Kaercher. Custos e rendas na distribuição federativa dos recursos do pré-sal. Revista de direito público da economia, v. 12, n. 46, p. 82 e 89, abr./jun. 2014.

${ }^{194} \mathrm{O}$ argumento dedutivo é aquele auferido através do enquadramento exato do fato na norma - a verdade das premissas, fato e norma, assegura a verdade da conclusão (consequência legal do fato).
} 
busca enfrentar é a seguinte: como pode a argumentação jurídica avançar quando tivermos "esgotado as normas"? 195

O modo consequencialista de argumentar pondera os impactos de adotar uma deliberação para as duas partes envolvidas no litígio, "pelo menos até o ponto de examinar os tipos de decisão que teriam de ser tomados em outros casos hipotéticos que poderiam ocorrer e que se enquadrariam nos termos da deliberação" 196.

E como seria realizada a escolha dentre os argumentos consequencialistas? MacCormick afirma que:

A argumentação consequencialista de fato trata de estabelecer que uma deliberação preferida é a melhor em vista de todas as considerações. Contudo, essa conclusão quanto à "melhor" não é determinada por referência a uma única escala de avaliação (por exemplo, a escala do prazer - dor como no utilitarismo hedonista de Bentham). Ela é uma sentença definitiva expressa como soma dos resultados cumulativos ou concorrentes da avaliação por meio de referência a uma série de critérios de valor, aí incluídos a "justiça" e "senso comum" bem como o "proveito público" e a "conveniência" 197 .

Os juízes teriam acesso a tais argumentos por meio dos advogados das partes que, em suas defesas, demonstrariam todos os impactos possíveis de uma decisão favorável ou desfavorável aos seus clientes. ${ }^{198}$

Importante frisar que as consequências que importam para MacCormick são as de caráter jurídico - as que reforçam as normas e princípios que alicerçam o sistema jurídico -, bem como aquelas com potencial universalizador. O juiz deve ter em mente que a sua decisão, e os fundamentos dela poderão ser aplicados para casos semelhantes futuros. Por isso, a decisão deve prestigiar os valores que o ordenamento jurídico visa proteger. Ademais, para que as decisões judiciais orientem decisões futuras, é necessário que a sua justificação tenha potencial para ser universalizada, de modo que a decisão possa se tornar "norma" aplicável aos casos similares ${ }^{199}$.

MacCormick defende, ainda, que o uso de argumentos consequencialistas encontra limites nas normas jurídicas, ou seja, eles não devem ser utilizados quando forem contrários

\footnotetext{
${ }^{195}$ MACCORMICK, Neil. Argumentação Jurídica e Teoria do Direito. Trad. Waldéa Barcellos. São Paulo: Martins Fontes, 2006, preâmbulo, p. IX.

${ }^{196}$ Id. Ibid., p. 133.

${ }^{197}$ Id. Ibid., p. 147.

198 Id. Ibid., p. 152-157.

${ }^{199}$ Id. Retórica e Estado de Direito: uma teoria da argumentação jurídica. Trad. Conrado Hübner Mendes. Rio de Janeiro: Elsevier, 2008, p. 120 e 133.
} 
às leis ${ }^{200}$. Entretanto, o próprio autor sustenta que tal preceito acaba sendo flexibilizado a partir das possibilidades de interpretação da norma.

O consequencialismo de MacCormick é bastante relevante, pelo seu alcance mundial e porque indica que o aplicador do direito deve atentar às consequências de sua decisão, diante da insuficiência das normas jurídicas e do método dedutivo na resolução de todas as demandas sociais. Todavia, não há concordância com a sua teoria no que tange à limitação da análise às consequências jurídicas.

No que concerne à distribuição dos royalties e PE, é imprescindível que, ao julgá-la, o Supremo Tribunal Federal considere: a) as escolhas e motivações políticas do legislador para alterar os critérios legais de distribuição dos frutos do petróleo (primeiro parâmetro); b) as consequências - sobretudo de cunho socioeconômico - tanto da manutenção dos critérios atuais de rateio, como da aplicação das novas regras de distribuição, considerando os dois lados envolvidos - estados e municípios produtores e não produtores - (segundo e terceiro parâmetros); e c) priorize as consequências capazes de melhor atender as necessidades humanas e sociais (quarto parâmetro) ${ }^{201}$.

\subsubsection{Buscar objetivos como: maior fruição de direitos fundamentais e humanos} e menor desigualdade social, econômica e regional

Na linha do que foi defendido como parâmetro do consequencialismo, ou seja, que ele privilegie as necessidades humanas e sociais, entende-se que a decisão judicial deve buscar a interpretação da norma que assegure a maior fruição de direitos pelos indivíduos e, consequentemente, menor desigualdade social, econômica e regional.

A AJPE, ao verificar que as políticas econômicas são, muitas vezes, injustas, por excluírem grande parte da população da fruição de direitos delas decorrentes, busca exigir que tais políticas sejam sempre estruturadas de modo a assegurar a concretização de direitos fundamentais e humanos a todos os indivíduos ${ }^{202}$.

De acordo com Marcus Faro de Castro:

\footnotetext{
${ }^{200}$ MACCORMICK, Neil. Argumentação Jurídica e Teoria do Direito. Trad. Waldéa Barcellos. São Paulo: Martins Fontes, 2006, p. 136, 192-193, 215, 220 e 222.

${ }^{201}$ Os parâmetros sugeridos para a abordagem consequencialista foram apresentados no início do tópico. Vale a pena relembrá-los: a) preservar ao máximo a vontade do legislador, bem como as consequências que ele levou em consideração ao elaborar a lei; b) não limitar a abordagem às consequências jurídicas; c) considerar as consequências da decisão para os dois lados envolvidos na demanda; e d) privilegiar as necessidades humanas e sociais.

${ }^{202}$ CASTRO, Marcus Faro de. Análise jurídica da política econômica. Revista da Procuradoria-Geral do Banco Central, v. 3, n. 1, p. 26, jun. 2009.
} 
(...) a abordagem aponta caminhos novos para se identificar, descrever, avaliar e agir diante de - obstáculos que tornam as sociedades injustas, e o dinamismo transformativo da economia de mercado sob muitos aspectos, paradoxalmente nefasto para uma grande parcela da humanidade ${ }^{203}$.

Com base nessa ideia, propõe-se que as decisões judiciais, sobretudo aquelas que cuidam de demandas que envolvem aspectos socioeconômicos - como é o caso da distribuição das rendas do petróleo -, devem buscar a efetividade de direitos para todos os seres humanos, bem como a redução das desigualdades sociais, econômicas e regionais.

No caso específico dos recursos minerais, como é o petróleo, defende-se que as rendas por eles geradas devem promover a justiça intergeracional, em razão de sua escassez e do fato de não serem renováveis. Assim, a geração presente deve compensar as futuras pela extração de um bem exaurível.

Os economistas citam amplamente a "Regra de Hartwick", de acordo com a qual as receitas geradas por bens esgotáveis devem ser poupadas e investidas em ativos físicos, como a diversificação da economia, a fim de manter o estoque de capital constante diante do decréscimo do recurso. A "Regra de Hartwick" considera que o gasto dessas receitas implica queda do bem-estar da sociedade, pela impossibilidade de manter o consumo per capita ao longo do tempo, propondo fontes alternativas de renda para compensar o esgotamento do recurso mineral ${ }^{204}$.

O exemplo da Noruega é trazido por diversos autores como modelo de aplicação dos royalties do petróleo na promoção da justiça intergeracional. Naquele país, todos os recursos do petróleo são destinados a um Fundo Soberano, que já possui mais de US\$ 400 bilhões e tem por objetivo investir no capital humano - educação e qualificação dos noruegueses, pesquisa, tecnologia - e na diversificação da economia. Interessante que o governo só pode movimentar $4 \%$ do fundo (valor aproximado de sua rentabilidade anual) para cobrir o déficit

\footnotetext{
${ }^{203}$ CASTRO, Marcus Faro de. Análise jurídica da política econômica. Revista da Procuradoria-Geral do Banco Central, v. 3, n. 1, p. 61, jun. 2009.

${ }^{204}$ POSTALI, Fernando Antonio Slaibe; NISHIJIMA, Marislei. Distribuição das rendas do petróleo e indicadores de desenvolvimento municipal no Brasil nos anos 2000. Estudos econômicos, São Paulo, v. 41, n. 2, p. 469, abr./jun. 2011; COSTA, Hirdan Katarina de Medeiros; SANTOS, Edmilson Moutinho. Justiça e sustentabilidade: a destinação dos royalties de petróleo. Estudos Avançados, v. 27, n. 77, p. 144, jan./abr. 2013; ARAGÃO, Alexandre Santos de (Coord.). Direito do petróleo e de outras fontes de energia. Rio de Janeiro: Lumen Juris, 2011, p. 47; SZKLO, Alexandre Salem; MAGRINI, Alessandra (org.). Textos de discussão em geopolítica e gestão ambiental de petróleo. Rio de Janeiro: Interciência: Faperj, 2008, p. 80; CARNICELLI, Laur; POSTALI, Fernando Antonio Slaibe. Royalties do petróleo e emprego público nos municípios brasileiros. Estudos econômicos, São Paulo, v. 44, n. 3, p. 491, jul./set. 2014.
} 
do orçamento. O objetivo, então, além de capacitar e melhorar a qualidade de vida da geração presente, é poupar o dinheiro para que possa ser utilizado pelas gerações futuras ${ }^{205}$.

No que tange à distribuição dos royalties e PE do petróleo, os fundamentos analisados indicam que a hiperconcentração de recursos não favorece o desenvolvimento socioeconômico dos estados e municípios mais beneficiados ${ }^{206}$. Indicam também que a redistribuição dessas receitas minimizaria as desigualdades existentes no país, pois poderiam ser utilizadas no incremento de serviços públicos, no investimento em infraestrutura local, em lazer, enfim, permitiriam, em tese, uma maior fruição de direitos fundamentais. Em tese, porque tudo dependerá da forma com que o dinheiro será aplicado, se serão priorizados investimentos que contribuem para o desenvolvimento local, se não haverá desvio ou corrupção. Embora o trabalho não tenha como foco a aplicação de royalties e PE, é temática de fundamental importância quando se trata de recurso público.

Felizmente, verifica-se que há uma preocupação maior dos atores envolvidos no debate sobre a distribuição dos royalties em garantir a adequada destinação dos recursos e a justiça intergeracional. Prova disso foram as discussões travadas no Parlamento, os diversos projetos de lei que propuseram vinculação dos royalties e PE e, por fim, a aprovação da Lei n $^{0}$ 12.858/13, que destina parte significativa dos recursos à educação e à saúde.

${ }^{205}$ Cf. AFONSO, José Roberto Rodrigues; GOBETTI, Sérgio Wulff. Renda do petróleo no Brasil: alguns aspectos fiscais e federativos. Revista do BNDES, Rio de Janeiro, v. 15, n. 30, p. 251-254, dez. 2008; BARROS, Daniel; IKEDA, Patrícia. A festa dos royalties. Exame, v. 46, n. 16, p. 192-193, ago. 2012; MERCADANTE, Aloizio. Os campos do possível: a oportunidade histórica do pré-sal. Interesse nacional, v. 1, n. 4, p. 37, jan./mar. 2009.

${ }^{206}$ Para fundamentos detalhados, conferir Tabelas 3 a 11, constantes do final do trabalho. Ademais, o tópico 1.1.3 examina as consequências da concentração de recursos. 


\subsection{FUNDAMENTOS RELEVANTES PARA UMA DECISÃO ADEQUADA} ACERCA DA DISTRIBUIÇÃO DOS ROYALTIES E PARTICIPAÇÕES ESPECIAIS DO PETRÓLEO

Nesse tópico serão apresentados os fundamentos considerados relevantes para uma decisão acerca da partilha do pré-sal, ou seja, fundamentos que sejam capazes de refletir fatos e escolhas políticos e econômicos e contemplem, ao mesmo tempo, ideais de justiça reconhecíveis pela sociedade como um todo. Também será investigado se esses fundamentos relevantes possibilitam concluir se deve ou não haver a redistribuição dos royalties e PE do petróleo. A exposição e análise será feita com base nas novas características da análise jurídica propostas no tópico anterior.

No que tange à avaliação da realidade por meio de dados empíricos, devem ser construídos fundamentos com base nos seguintes fatores: o volume da produção de petróleo; a estimativa de produção e de receitas futuras, tendo em vista a descoberta do pré-sal; estimativa de preços do petróleo em nível mundial, considerando a demanda do produto; os impactos da atividade petrolífera e quais são as localidades impactadas; se os critérios de rateio atuais contemplam as localidades de fato impactadas; se o valor dos royalties e PE corresponde ao valor dos riscos e danos decorrentes da atividade; o valor distribuído a cada ente federado de acordo com as regras atuais; o montante de royalties e PE que seria destinado aos estados e municípios brasileiros caso fossem aplicadas as novas regras de distribuição; a destinação dos royalties e PE - se a hiperconcentração de recursos contribui para o desenvolvimento nacional e para a justiça intergeracional -; se as regras atuais são justas do ponto de vista socioeconômico.

No que tange às receitas geradas pelo pré-sal e expectativas futuras, Aloisio Mercadante lembra que a descoberta do pré-sal é extraordinária. Os testes feitos em uma área de $14.000 \mathrm{~km}^{2}$ permitem inferir que as jazidas podem ter entre 50 e 80 bilhões de barris, sendo que a formação do pré-sal possui uma extensão de mais de $160.000 \mathrm{~km}$. "Levando em conta as estimativas mais otimistas o Brasil passaria a ter cerca de 6,5\% das reservas mundiais". Ademais, o autor salienta que o crescimento da produção do petróleo não tem acompanhado a demanda, o que leva a crer que haverá valorização do preço em nível mundial $^{207}$.

\footnotetext{
${ }^{207}$ MERCADANTE, Aloizio. Os campos do possível: a oportunidade histórica do pré-sal. Interesse nacional, v. 1, n. 4, p. 32-34, jan./mar. 2009.
} 
Quanto aos impactos da atividade petrolífera - danos ambientais, inchaço populacional, aumento do custo de vida e dos gastos com infraestrutura -, a pesquisa demonstrou que estão mais associados à extração do petróleo onshore. No caso da exploração offshore, as localidades mais impactadas são aquelas escolhidas para a instalação das empresas do ramo, nem sempre confrontantes com os poços de petróleo.

No que se refere à concentração de recursos em poucos entes, as diversas pesquisas feitas sobre a aplicação dos royalties nos municípios petro-rentistas concluíram que ela não favorece e, em alguns casos, até mesmo prejudica o desenvolvimento socioeconômico da localidade beneficiada.

A segunda categoria proposta - interdisciplinaridade -, além de contribuir no estudo dos dados empíricos enumerados acima, deve ser empregada para: a) verificar se as normas de distribuição atuais são adequadas - vale repisar que todos os trabalhos pesquisados na área da Economia indicam que elas são inadequadas e que há necessidade de redistribuição dos royalties e PE -; b) redefinir os critérios dos beneficiados, já que os artigos econômicos demonstraram que não há correspondência entre os impactos causados pela atividade petrolífera e as localidades contempladas com maior volume de royalties e PE; c) garantir uma destinação de recursos que permita o desenvolvimento econômico nacional, a melhoria da qualidade de vida da geração presente e o benefício das gerações futuras, pois os trabalhos também comprovam que os recursos estão sendo mal aplicados; d) calcular o valor dos riscos e danos (externalidades negativas) da exploração do petróleo, bem como os benefícios gerados pela atividade, para que haja correspondência entre esses fatores e o montante de royalties e PE. Esse cálculo estimativo é necessário diante da existência de pesquisas que demonstram que não há essa correspondência ${ }^{208}$.

No mais, as consequências da decisão, sobretudo aquelas no mundo fático, são fundamentos relevantes para a decisão judicial. Devem ser analisadas não só as consequências da aplicação da Lei $n^{\circ}$ 12.734/12 para os estados e municípios atualmente beneficiados (como perda de recursos com os quais contavam, desequilíbrio orçamentário e impossibilidade de arcar com compromissos assumidos), como fez a decisão judicial que suspendeu a aplicação dos novos critérios de partilha, mas também as implicações da hiperconcentração de recursos resultante da partilha atual e aquelas que poderiam advir de uma melhor distribuição de

\footnotetext{
${ }^{208}$ Brosio e Loureiro destacam que um fato óbvio, muitas vezes desconsiderado pelos juristas é o de que os danos causados pela exploração do petróleo e as afetações negativas de provável ou certa ocorrência são "empiricamente cientificáveis e passíveis - com maior ou menor exatidão - de mensuração" (BROSIO, Giorgio; LOUREIRO, Gustavo Kaercher. Custos e rendas na distribuição federativa dos recursos do pré-sal. Revista de direito público da economia, v. 12, n. 46, p. 92, abr./jun. 2014).
} 
recursos entre os entes da federação. Até porque devem ser priorizadas as consequências que melhor atendam às necessidades humanas e sociais, bem como aquelas que elevem a fruição de direitos e que reduzam as desigualdades econômicas, sociais e regionais.

Como se sabe, existe enorme desigualdade regional no país, sendo a renda per capita, a educação, o consumo e o índice de desenvolvimento humano das regiões sudeste e sul muito superiores às do norte e nordeste, conforme se segue:

(...) "o que parece ser a grande diferença no Nordeste é o baixo nível educacional de seus habitantes". (...)

A renda per capita do Nordeste permanece apenas um terço da observada no Sudeste, e a taxa de analfabetismo é o triplo. A mortalidade infantil no Maranhão é quase três vezes superior à de São Paulo. Cerca de $40 \%$ da população do Nordeste ainda vive na pobreza, contra $11 \%$ no Sudeste ${ }^{209}$.

Fazendo uma classificação, baseada no IDH das regiões brasileiras, teremos a seguinte hierarquia:

Primeiro lugar: Rio Grande do Sul, Santa Catarina, São Paulo, Paraná, Rio de Janeiro, Espírito Santo e Mato Grosso do Sul;

Segundo lugar: Minas Gerais, Goiás, Mato Grosso, Rondônia, Amazonas, Roraima e Amapá;

Terceiro lugar: Acre, Pará e Sergipe.

Por último, estão os estados do Nordeste, com exceção de Sergipe.

Lembrando que o IDH (Índice de Desenvolvimento Humano) significa como a população de um determinado lugar está vivendo, segundo a qualidade de vida, renda per capita, mortalidade infantil, taxa de analfabetismo, expectativa de vida, qualidade dos serviços públicos (saúde, educação e infraestrutura em geral) ${ }^{210}$.

Nossa Constituição manda que se levem em conta as desigualdades regionais ao desenvolver políticas públicas. No entanto, o que o Estado brasileiro diz (na Constituição) não é necessariamente o que faz na hora de empregar recursos públicos. Nesse sentido, observa-se que a despesa per capita é tradicionalmente menor nas Regiões Norte e Nordeste, que compreendem os municípios e Estados que abrigam as parcelas da população mais desassistidas ou carentes em termos da provisão de direitos ${ }^{211}$.

Uma pesquisa divulgada neste sábado $\left(1^{\circ}\right)$ mostrou os melhores e os piores lugares para se viver no Brasil.

Entre as campeãs de qualidade de vida, cidades do interior do Sudeste se destacaram.

A pesquisa revela os novos números de um velho problema: a desigualdade. Dos 500 municípios do Brasil com melhores condições de vida, 90,8\% estão nas regiões

209 Instituto Humanitas Unisinos. As desigualdades regionais. Disponível em: <http://www.ihu.unisinos. br/noticias/505860-asdesigualdadesregionais>. Acesso em: 4 mar. 2015.

${ }^{210}$ Brasil Escola. Desigualdades regionais. Disponível em: <http://www.brasilescola.com/brasil/ desigualdadesregionais.htm>. Acesso em: 4 mar. 2015.

211 Estadão. Federalismo e desigualdade regional. Disponível em: <http://opiniao.estadao.com.br/ noticias/geral,federalismo-e-desigualdade-regional-imp-,1095382>. Acesso em: 4 mar. 2015. 
Sul e Sudeste. Dos 500 piores, 96,4\% estão nas regiões Norte e Nordeste. E a região Nordeste foi a que mais cresceu em dez anos ${ }^{212}$.

O Tribunal de Contas da União (TCU) divulgou em abril deste ano o Fisc Saúde, primeiro relatório sistêmico de fiscalização da saúde no Brasil, produzido durante o ano de 2013 (...). Os técnicos do órgão avaliaram os serviços de saúde brasileiros por meio de diversos indicadores e constataram: o maior problema do sistema de saúde no Brasil é a desigualdade entre as regiões do país. Segundo o relatório, enquanto alguns estados apresentam indicadores semelhantes aos dos países desenvolvidos, a performance de outros está mais próxima do desempenho de países africanos $^{213}$. (grifou-se).

Embora as desigualdades regionais ainda persistam, um maior investimento público nas regiões norte e nordeste, ou seja, transferência de renda às regiões menos favorecidas, é capaz de trazer avanços consideráveis, reduzindo a desigualdade entre os entes federativos e suas respectivas populações. Foi o que comprovaram os seguintes estudos:

A geografia do consumo brasileiro vai mudar neste ano. Pela primeira vez, a fatia da Região Sudeste no potencial de consumo do País ficará abaixo de $50 \%$. Um estudo feito pela consultoria IPC Marketing mostra que São Paulo, Rio de Janeiro, Minas Gerais e Espírito Santo responderão por $49,21 \%$ de tudo o que será consumido no País este ano.

A perda de participação do Sudeste tem sido lenta, mas contínua ao longo dos anos. Em 2013, o peso da região foi de 50,53\%. Há dez anos, ela representava 55,79\%. A estimativa da IPC Marketing é de que o consumo atinja R\$ 3,262 trilhões neste ano, acima do verificado em 2012 ( $\mathrm{R} \$ 3,011$ trilhões).

A menor participação do Sudeste pode ser explicada pela melhora econômica das demais regiões brasileiras. A fatia do Nordeste no consumo será recorde em 2014 e vai chegar a $19,48 \%$. Haverá ainda um forte crescimento do Norte, cuja participação também será a maior da história $(6,04 \%)$.

"Em 2008, o Nordeste atingiu o segundo lugar no ranking do potencial de consumo e a diferença para a Região Sul vem aumentando nos últimos anos", afirma Marcos Pazzini, diretor da IPC Marketing.

As economias do Norte e principalmente as do Nordeste foram impulsionadas nos dois últimos anos por dois grandes fatores: programas de transferência de renda e política de reajuste real do salário mínimo.

No caso da economia nordestina, quase $20 \%$ da origem da renda familiar vem do Instituto Nacional do Seguro Social (INSS) - boa parte do pagamento é atrelada ao salário mínimo. O Bolsa Família representa 3\%. O restante é dividido entre trabalho $(71,9 \%)$ e outras fontes $(5,4 \%)$, como aluguel ${ }^{214}$ (grifou-se).

Uma das principais especialistas em política regional, a pernambucana Tânia Bacellar foi a primeira economista a identificar a revitalização da economia nordestina, a partir do Bolsa Família e do aumento do salário mínimo. Mas não apenas isso.

\footnotetext{
212 Jornal Nacional. Pesquisa mostra os melhores e os piores lugares para se viver no Brasil. Disponível em: <http://g1.globo.com/jornal-nacional/noticia/2012/12/pesquisa-mostra-os-melhores-e-os-piores-lugares-para-seviver-no-brasil.html>. Acesso em: 4 mar. 2015.

213 Portal Fiocruz. A desigualdade regional pesa no SUS. Disponível em: <http://portal.fiocruz.br/ptbr/content/desigualdade-regional-pesa-no-sus>. Acesso em: 4 mar. 2015.

214 Estadão. Sudeste deixa de responder por mais da metade do consumo brasileiro. Disponível em: $<$ http://economia.estadao.com.br/noticias/geral,sudeste-deixa-de-responder-por-mais-da-metade-do-consumobrasileiro-imp-,1159183>. Acesso em: 4 mar. 2015.
} 
Houve avanços setoriais relevantes em algumas políticas públicas de sucesso. Dentre elas:

1. O PRONAF (Programa de Apoio à Agricultura Familiar) (...)

2. O aumento do SM beneficiou especialmente o nordeste - onde $45 \%$ dos ocupados recebem um SM contra a média brasileira de $26 \%$. A melhoria do consumo está promovendo uma reindustrialização da região.

3. O REUNI (Programa de Recuperação das Universidades Federais), que elevou de 43 para 230 os campi universitários, valorizando a interiorização e a desconcentração regional. ${ }^{215}$

A perda de participação do Sudeste tem sido lenta, mas contínua ao longo dos anos. Em 2013, o peso da região foi de 50,53\%. Há dez anos, ela representava 55,79\%. A estimativa da IPC Marketing é de que o consumo atinja R\$ 3,262 trilhões neste ano, acima do verificado em 2012 (3,011 trilhões).

FATORES

A menor participação do Sudeste pode ser explicada pela melhora econômica das demais regiões brasileiras. A fatia do Nordeste no consumo será recorde em 2014 e vai chegar a 19,48\%. Haverá ainda um forte crescimento do Norte, cuja participação também será a maior da história $(6,04 \%)$. (...)

As economias do Norte e principalmente as do Nordeste foram impulsionadas nos dois últimos anos por dois grandes fatores: programas de transferência de renda e políticas de reajuste real do salário mínimo ${ }^{216}$.

Na mesma linha, pesquisa acerca do "Crescimento Pró-Pobre no Nordeste do Brasil", realizada por Raul da Mota Silveira Neto, comprovou que no período de 2000 a 2010 todos os estados nordestinos apresentaram crescimento do tipo pró-pobre. Esse crescimento foi medido pelo economista a partir de dois índices: Taxas de Crescimento da Pobreza Equivalente (PEGR) e Crescimento Efetivamente Verificado (EGR). O crescimento do tipo empobrecedor é aquele em que há crescimento da renda, mas valor negativo da PEGR. Ao contrário, no crescimento pró-pobre, constatam-se valores positivos da PEGR e maiores do que a taxa de crescimento da renda média da economia (EGR) ${ }^{217}$.

De acordo com a pesquisa, o crescimento pró-pobre deve-se à inserção produtiva dos indivíduos mais pobres, que "é mais fortemente vinculada à capacidade de geração de oportunidades da economia local, bem como às políticas públicas vinculadas ao mercado de trabalho, como o aumento do salário mínimo"218.

Especificamente sobre as rendas do petróleo, Mesquita sustenta que "a riqueza representada pelo pré-sal constitui oportunidade ímpar para reduzir disparidades.” Focando no desenvolvimento do Nordeste, o autor entende que “com o reforço do fundo especial do pré-

\footnotetext{
215 Jornal GGN. Agenda 2015: o planejamento territorial do país. Disponível em: <http://horia.com.br/noticia/agenda-2015-o-planejamento-territorial-do-pais>. Acesso em 15/8/2014.

216 Jornal de Brasília. 28 de abril de 2014. A força do Nordeste. Disponível em: <http://www.jornaldebrasilia.com.br/edicaodigital/pages/20140428-jornal/pdf/16.pdf>. Acesso em: 4 mar. 2015.

217 SILVEIRA NETO, Raul da Mota. Crescimento pró-pobre no nordeste do Brasil. Estudos econômicos, São Paulo, v. 44, n. 3, p. 518-523, jul./set. 2014.

${ }^{218}$ Id. Ibid., p. 519 e 523.
} 
sal seria possível à região executar ações estratégicas para reforçar seu potencial como mercado consumidor de bens e serviços". Cita como exemplos a ferrovia Transnordestina, que integraria a economia nordestina à das demais regiões, a produção de fertilizantes fosfatados, a partir da exploração da mina de urânio de Itatiaia (CE), a revitalização do São Francisco e o investimento em programas para revitalizar a pesquisa e a tecnologia na região 219 .

No mesmo sentido, Mercadante sustenta que os royalties poderiam fazer grande diferença no desenvolvimento socioeconômico e redução das desigualdades, se bem distribuídos e aplicados:

\begin{abstract}
Ainda temos três grandes entraves que nos impedem de alçar voos maiores no desenvolvimento sustentado: $O$ entrave da educação de baixa qualidade, que repercute na ausência de inovação e pesquisa mais robustas, o entrave da infraestrutura e logística precárias, que inibe investimentos e eleva custos, e o entrave da desigualdade social que, apesar dos avanços recentes, limita o dinamismo do mercado interno e gera tensões sociais e políticas.

É aí que o petróleo recém-descoberto pode fazer diferença. Grande diferença. Se os recursos do pré-sal forem bem investidos e distribuídos com objetivo estratégico de superar esses obstáculos, o Brasil poderá acelerar o tempo histórico do seu crescimento e dar grande salto de qualidade no desenvolvimento econômico e social $^{220}$.
\end{abstract}

Enfim, há diversos estudos que demonstram que a transferência de renda à região nordeste e aos mais pobres - o que pode ser feito por meio de royalties e PE -, bem como o aumento da infraestrutura local e de oportunidades para a inserção produtiva desses indivíduos possibilita menor desigualdade social e econômica.

A maior distribuição de recursos poderia, ainda, ampliar o acesso e melhorar a qualidade da saúde e da educação - necessidades de todos os estados e municípios - na medida em que tornou-se obrigatória a destinação de percentual significativo dos royalties e PE do petróleo para gastos nesses serviços essenciais, inclusive em âmbito estadual e municipal. ${ }^{221}$

Vale lembrar que a Constituição de 1988 adotou o "federalismo cooperativo 222 ", que objetiva o equilíbrio do desenvolvimento e do bem-estar em âmbito nacional (cf. art. 23,

\footnotetext{
${ }^{219}$ MESQUITA, Ribamar. Pré-sal: um novo projeto para o Nordeste. Rumos: economia \& desenvolvimento para os novos tempos, v. 34, n. 248, p. 40-41, nov./dez. 2009.

${ }^{220}$ MERCADANTE, Aloizio. Os campos do possível: a oportunidade histórica do pré-sal. Interesse nacional, v. 1, n. 4, p. 38, jan./mar. 2009.

${ }^{221}$ Cf. Lei $\mathrm{n}^{\mathrm{o}} 12.858 / 2013$, especialmente o art. $2^{\mathrm{o}}$.

222 "Tradicionalmente no Brasil, os recursos e a capacidade de execução distribuem-se desigualmente entre as unidades federativas, por essa razão o sistema de cooperação deve procurar dotar cada uma delas com as condições mínimas necessárias para desempenhar seu papel dentro da estrutura federativa". (TAVARES,
} 
parágrafo único da Constituição), bem como fixou como fundamento da República Federativa do Brasil a redução das desigualdades regionais (cf. arts. $1^{\circ}$, III e 170, VII da Constituição).

No mais, é importante repisar que os estados do sudeste, que são os mais beneficiados por royalties e PE, já são os que apresentam maior desenvolvimento econômico e social.

Nesse sentido, sugere-se que a distribuição e a destinação dos royalties e PE leve em conta a renda per capita dos estados e municípios e os indicadores sociais, a saber: expectativa de vida, taxa de mortalidade, taxa de mortalidade infantil, taxa de analfabetismo, saúde, acesso à alimentação adequada, qualidade de vida e acesso ao consumo. ${ }^{223}$

Vale ressaltar que os aspectos jurídicos (não dogmáticos), sociais e ambientais que circundam o tema também são relevantes para decidir se devem ou não ser mantidos os critérios de rateio de royalties e PE atuais. As normas existentes, sobretudo as constitucionais, como a constante do art. $20, \S 1^{\circ}$, são de análise obrigatória, pois não se negligencia a necessidade de observância da Constituição, mas apenas se debate a forma de interpretá-la. Os aspectos ambientais também são de grande valia para a decisão acerca da partilha do pré-sal, porque avaliam, juntamente com os econômicos, os reais impactos relacionados à atividade petrolífera e a sua magnitude, os quais justificam maior alocação de royalties e PE em um ou outro ente político.

Por fim, é possível concluir a partir da utilização das categorias jurídicas propostas que os critérios de distribuição de royalties e PE são inadequados, sendo necessária a redistribuição desses recursos entre os entes federativos. Isso não significa que os critérios definidos pela Lei $n^{0} 12.734 / 12$ sejam adequados - essa análise não é objeto do presente trabalho -, mas apenas que as regras atuais devem ser alteradas com urgência.

Alessandra Schettino. O federalismo cooperativo no Brasil: o perfil do Estado Brasileiro segundo a Constituição Federal de 1988. p. 41. Disponível em: <http://bd.camara.gov.br/bd/handle/ bdcamara/341>. Acesso em 5 mar. 2015).

${ }^{223}$ Disponível em: <http://www.brasilescola.com/geografia/os-indicadores-sociais.htm>. Acesso em 10 jul. de 2015. 


\section{CONCLUSÃO}

O objetivo principal do presente trabalho era apresentar os fundamentos relevantes para informar uma deliberação acerca da partilha dos royalties e PE do petróleo, que seja capaz de refletir escolhas e aspectos políticos e econômicos mais valorizados pela comunidade política. Para tanto: investigou-se se as doutrinas dominantes no direito constitucional brasileiro (dogmática e neoconstitucionalismo) eram capazes de fornecê-los; foram analisados e classificados os fundamentos dos atores que participam do debate sobre a partilha do pré-sal (Poderes Legislativo, Executivo e Judiciário, demais atores processuais, juristas e economistas); demonstrou-se que as categorias jurídicas propostas pelas visões dominantes do direito constitucional brasileiro não são capazes de fornecer uma decisão que considere a realidade socioeconômica; foram propostas novas características da análise jurídica para embasar a deliberação acerca da partilha dos pré-sal; foram finalmente apresentados os fundamentos relevantes para eventual tratamento judicial da distribuição dos frutos do petróleo que reflita fatos e decisões políticos e econômicos e ideais de justiça reconhecíveis pela sociedade.

Após sintetizado o caminho percorrido pelo trabalho para alcançar o seu objetivo, devem ser recordadas as principais conclusões obtidas com a pesquisa.

No Capítulo 1, a apresentação da evolução recente acerca da distribuição dos royalties e PE - sistemática legal de distribuição; tentativas de alteração das regras pelo Legislativo e ações judiciais propostas contra essas tentativas de mudança - permitiu concluir que o sistema legal de distribuição é extremamente concentrador de recursos, ou seja, destina quase que a totalidade dos royalties e PE aos estados e municípios produtores, confrontantes e afetados, e quase nada aos demais estados e municípios.

No Capítulo 2, a exposição e análise crítica das teses encampadas pelas visões dominantes no direito constitucional brasileiro implicou a conclusão de que as categorias jurídicas que propõem para interpretar e aplicar a Constituição não são adequadas ao enfrentamento da temática da partilha das rendas do petróleo no Brasil, sobretudo porque priorizam o formalismo e a abstração em detrimento da realidade e não incentivam a abordagem interdisciplinar na solução das demandas. Com efeito, o modelo dogmático defende que as decisões devem ser baseadas exclusivamente em normas jurídicas concebidas à luz de uma postura formalista. O neoconstitucionalismo, por sua vez, sustenta que as 
decisões devem ser fundamentadas, preponderantemente em princípios excessivamente abstratos.

A distribuição do pré-sal, conforme comprovado, é tema que envolve sobremaneira questões econômicas e políticas, cuja análise é imprescindível para a deliberação acerca da constitucionalidade da Lei $\mathrm{n}^{\circ} 12.734 / 12$, que altera a distribuição de royalties e PE do petróleo.

No Capítulo 3, a análise dos fundamentos dos atores envolvidos no debate constitucional sobre a distribuição dos royalties e PE, utilizando como método a "Análise de Conteúdo" evidenciou que os argumentos decorrentes das visões dominantes do direito (neoconstitucionalistas, jurídicos dogmáticos e historicistas) não consideram de modo suficiente fatos e escolhas políticos e econômicos relevantes.

Os fundamentos neoconstitucionalistas são excessivamente abstratos, sobretudo porque utilizam princípios com esse caráter. O preenchimento do conteúdo de tais princípios é feito pelo intérprete sem que haja preocupação em comprovar por que o princípio deve ser empregado de um modo ou de outro. Tal afirmação foi evidenciada quando se observou que um mesmo princípio é utilizado para defender a constitucionalidade e a inconstitucionalidade da redistribuição dos royalties e PE, como ocorreu com o princípio da isonomia.

Da mesma forma, os fundamentos jurídicos dogmáticos carregam em si afirmações formalistas, que decorrem de mera interpretação da norma, como se aquela fosse a única possível dentre tantas que o Direito, em verdade, permite. Nesse caso, assim como constatado com a aplicação de princípios, o mesmo artigo da Constituição foi utilizado para se chegar a conclusões diametralmente opostas. É o que se verificou quando do debate acerca da natureza jurídica dos royalties: os que são a favor da redistribuição defendem que predomina a natureza de participação no resultado, enquanto os contrários aduzem que prepondera o seu caráter compensatório. E ambas as afirmações são extraídas do art. $20, \S 1^{\circ}$ da Constituição.

Demais fundamentos respaldados nas visões dominantes do direito constitucional como, por exemplo, o de que o Judiciário é a instância adequada para solucionar a questão, porque protege a Constituição, os direitos fundamentais das minorias e analisa fundamentos jurídicos negligenciados pelo legislador, ou de que a Constituição é suprema e possui uma "força normativa" que "irradia" por todo o sistema e que limita o legislador infraconstitucional - também não se prestaram a solucionar a problemática de rateio dos recursos do pré-sal. Isso porque ignoram o cerne do debate, que é saber se a redistribuição é possível ou não, tendo em vista os preceitos constitucionais e, sobretudo, a realidade. 
Assim, restam os "outros fundamentos", classificados como econômicos, ambientais, jurídicos (porém, não dogmáticos, não historicistas e não neoconstitucionalistas) e federativos. Todos eles são relevantes, na medida em que a solução de conflitos deve transitar pela análise da realidade dos fatos.

As normas constitucionais e legais atinentes ao tema são lembradas nos fundamentos jurídicos, sendo a realidade - representada nos fundamentos econômicos, federativos e ambientais - imprescindível para a correta interpretação dessas normas.

A exposição e classificação dos fundamentos em derivados das "visões dominantes" no direito constitucional e "outros”, bem como a análise acerca de sua adequação também permitiram conclusões, assim sintetizadas:

1) A maior parte dos fundamentos utilizados - inclusive pelo Poder Judiciário está na categoria "outra natureza”, em especial os que trazem aspectos econômicos, o que demonstra que os fundamentos decorrentes da visão dominante do direito são insuficientes para a solução do problema.

2) Os fundamentos apresentados por análises, sobretudo econômicas, são os mais adequados, por refletirem investigação de dados empíricos relevantes para a deliberação (tais como volume da produção, estimativa de produção e de receitas futuras, impactos da atividade petrolífera, valor distribuído a cada ente federado, destinação dos royalties e PE); as consequências da hiperconcentração de recursos resultante da partilha atual e as possíveis consequências da redistribuição. Além disso, as investigações econômicas comprovam teses levantadas por meio de estudos empíricos ${ }^{224}$.

3) Considerando os três poderes, o Legislativo é o que mais utiliza, proporcionalmente, fundamentos de "outra natureza". Ademais, se verificado o seu conteúdo nas Tabelas 3 e 4, os fundamentos debatidos no Parlamento são os que mais se aproximam daqueles decorrentes de análises econômicas, porque não consideram somente os aspectos jurídicos, mas, sobretudo, a realidade socioeconômica.

4) Os fundamentos apresentados pelos demais atores processuais consideram fatos econômicos e políticos relevantes. No entanto, a decisão judicial liminar, proferida no âmbito da ADI nº 4.917-DF, não considerou a maioria dos fundamentos expostos pelos demais atores processuais, basicamente só levou em conta os apresentados pelo autor (o que não se considera adequado diante de problemática tão relevante e complexa).

\footnotetext{
${ }^{224}$ Embora boa parte dos economistas de orientação ortodoxa busque apoio em formalismos e modelos matemáticos, há muitos economistas de orientação estruturalista e desenvolvimentista que se afastam desses formalismos e fazem uma análise histórica e empírica das estruturas e instituições econômicas. Na presente pesquisa buscou-se priorizar a análise de trabalhos que se apoiam menos em modelos e mais na realidade.
} 
5) Os fundamentos econômicos utilizados pela decisão judicial acima citada relacionam-se aos impactos e consequências da aplicação das novas regras de partilha aos estados produtores e confrontantes, ou seja, não se avaliam as consequências da aplicação da nova sistemática para os estados não produtores.

6) Todas as abordagens econômicas analisadas concluem pela necessidade de redistribuição dos royalties e PE.

7) Os favoráveis à redistribuição dos royalties e PE utilizam, proporcionalmente, mais fundamentos de "outra natureza" (i.e., não formulados em termos das visões dominantes do direito constitucional brasileiro) do que aqueles que são contrários à redistribuição.

8) Os atores que defendem a redistribuição dos royalties utilizam fundamentos que melhor refletem os fatos econômicos e escolhas políticas relevantes, bem como os ideais de justiça reconhecíveis pela sociedade (nesse sentido, o fundamento de que a redistribuição privilegia a redução das desigualdades regionais) ${ }^{225}$.

9) Os fundamentos de natureza econômica são comprovados com dados empíricos, enquanto os decorrentes da visão dominante do direito não são comprovados.

10) Há casos em que o mesmo fundamento principiológico é utilizado pelos dois lados (atores favoráveis e contrários à redistribuição), conforme exemplificado anteriormente com o princípio da isonomia.

11) Há casos em que o mesmo fundamento jurídico dogmático é utilizado pelos dois lados (atores favoráveis e contrários à redistribuição), o que indica que se trata de interpretar a lei da forma que for mais conveniente.

No Capítulo 4, foram propostas as seguintes categorias alternativas: a) análise de dados empíricos, a fim de relacionar a decisão com a realidade; b) necessidade de recorrer a outras disciplinas (interdisciplinaridade); c) análise das consequências da decisão para ambos os lados e; d) buscar objetivos como: maior fruição de direitos, menor desigualdade social e

\footnotetext{
${ }^{225}$ A exposição dos fundamentos favoráveis e contrários à redistribuição dos royalties realizada em monografia intitulada A Justa Distribuição dos Royalties do Petróleo no Brasil também corrobora a afirmação. Foram citados como argumentos contrários à alteração nos critérios legais de partilha: interpretação adequada ao dispositivo constitucional, violação ao princípio da isonomia, violação ao princípio da segurança jurídica e violação ao princípio federativo - ou seja, quase toda a fundamentação se dá com base em princípios, cuja inadequação já se demonstrou -. Por outro lado, como argumentos favoráveis à alteração dos critérios são enumerados: o petróleo pertence a todos os cidadãos, a hiperconcentração da distribuição dos royalties em poucas regiões, a pobreza e a riqueza nas cidades do petróleo, a exploração distante da costa dos municípios, elevação do nível da atividade como compensação, royalty como mecanismo do promoção de justiça intergeracional, e como recurso para período do pós-esgotamento da reserva - como se vê, todos os fundamentos expostos como favoráveis à redistribuição dos royalties envolvem aspectos socioeconômicos, e nenhuma abstração (GONÇALVES, Reginaldo Brasão. A Justa Distribuição dos Royalties do Petróleo no Brasil. 2010. 60 fl. Dissertação (Mestrado em Direito). Faculdade de Direito, Universidade Federal do Amazonas, Manaus, 2010, p. 44-57).
} 
econômica. A partir das categorias sugeridas, foram apresentados os fundamentos relevantes para a solução da problemática.

Concluiu-se que devem ser construídos fundamentos com base nos seguintes fatores, os quais são estudados pela Economia (interdisciplinaridade): o volume da produção de petróleo; a estimativa de produção e de receitas futuras, tendo em vista a descoberta do présal; estimativa de preços do petróleo em nível mundial, considerando a demanda do produto; os impactos da atividade petrolífera e quais são as localidades impactadas; se os critérios de rateio atuais contemplam as localidades de fato impactadas; se o valor dos royalties e PE corresponde ao valor dos riscos e danos decorrentes da atividade; o valor distribuído a cada ente federado de acordo com as regras atuais; o montante de royalties e PE que seria destinado aos estados e municípios brasileiros caso fossem aplicadas as novas regras de distribuição; se as regras de distribuição previstas nas Leis $n^{\circ}$ 9.478/97 e 12.351/10, as quais acarretam concentração de recursos, contribuem para o desenvolvimento nacional e para a justiça intergeracional; o juízo sobre se as regras atuais são justas do ponto de vista socioeconômico; a consideração das consequências da aplicação das novas regras (previstas na Lei $n^{\circ} 12.734 / 12$ ) para os estados e municípios atualmente beneficiados; a consideração das consequências socioeconômicas da concentração/hiperconcentração de recursos resultante da partilha atual; consideração das consequências que poderiam advir de uma melhor distribuição de recursos entre os entes da federação.

$\mathrm{Na}$ análise consequencialista, demonstrou-se que os fundamentos relevantes são aqueles que priorizam as consequências que melhor atendem as necessidades humanas e sociais, bem como aquelas que elevam a fruição de direitos humanos e fundamentais pelos indivíduos e que reduzem as desigualdades econômicas, sociais e regionais.

Ressaltou-se que os aspectos jurídicos (não dogmáticos) e ambientais que circundam o tema também são relevantes para decidir se devem ou não ser mantidos os critérios de rateio de royalties e PE atuais. As normas existentes, sobretudo as constitucionais, como a constante do art. $20, \S 1^{\circ}$, são de análise obrigatória, pois não se negligencia a necessidade de observância da Constituição, mas apenas se debate a forma de interpretá-la. Os aspectos ambientais também são de grande valia e imprescindíveis para que a decisão acerca da partilha do pré-sal seja adequada. Primeiro porque avaliam, juntamente com os econômicos, os reais impactos relacionados à atividade petrolífera e a sua magnitude, os quais justificam maior alocação de royalties e PE em um ou outro ente político. Depois porque as consequências da distribuição de recursos à sociedade também envolvem aspectos ambientais. 
Por fim, concluiu-se, a partir da utilização das categorias jurídicas propostas, que os critérios de distribuição de royalties e PE (percentuais de distribuição previstos nas Leis $\mathrm{n}^{\circ}$ 9.478/97 e 12.351/10) são inadequados, sendo necessária a redistribuição desses recursos entre os entes federativos. Isso não significa que os critérios definidos pela Lei ${ }^{\circ} 12.734 / 12$ sejam corretos - essa análise não foi objeto do presente trabalho -, mas apenas que as regras atuais devem ser alteradas. 


\section{REFERÊNCIAS BIBLIOGRÁFICAS}

ADEODATO, João Mauricio Leitão. Ética e retórica: para uma teoria da dogmática jurídica. São Paulo: Saraiva, 2012. 496 p.

. Retórica analítica como metódica jurídica. Argumenta: revista do curso de mestrado em ciência jurídica da Fundinopi, n. 18, p. 11-29, jan./jul. 2013.

. Uma teoria retórica da norma jurídica e do direito subjetivo. São Paulo: Noeses, 2011. 403 p.

ADI 4916. Petição inicial, p. 83-97. Disponível em: <http://redir.stf.jus.br/paginadorpub/ paginador.jsp?docTP=TP\&docID=3511895\&ad=s\#1\%20-\%20Peti\%E7\%E3o\%20inicial\%20$\% 20$ Peticao\%20 inicial\%201>. Acesso em 3 mar. 2015;

ADI 4917. Peças eletrônicas. Disponíveis em: <http://redir.stf.jus.br/estfvisualizadorpub/jsp/ consultarprocessoeletronico/ConsultarProcessoEletronico.jsf? seqobjetoincidente $=4379376>$. Acesso em: $1^{\circ}$ mar. 2015.

ADI 4920. Petição inicial. Disponível em: <http://redir.stf.jus.br/paginadorpub/ paginador.jsp?docTP=TP\&docID=3513371\&ad=s\#1\%20-\%20Peti\%E7\%E3o\%20inicial\%20\%20Peticao\%20inicial\%201>. Acesso em 3 mar. 2015.

AFONSO, José Roberto; ALMEIDA, Vivian. Tributação do petróleo e federalismo brasileiro: a histórica oscilação na divisão da receita. Direito público, v. 8, n. 42, p. 206-219, nov./dez. 2011.

AFONSO, José Roberto Rodrigues; GOBETTI, Sérgio Wulff. Renda do petróleo no Brasil: alguns aspectos fiscais e federativos. Revista do BNDES, Rio de Janeiro, v. 15, n. 30, p. 231269, dez. 2008.

ALEXY, Robert. Teoria dos Direitos Fundamentais. Trad. Virgílio Afonso da Silva. São Paulo: Malheiros, 2008, 669 p.

ALMEIDA FILHO, Jorge Celso Fleming de. Os royalties do petróleo e a impossibilidade de sua partilha igualitária entre os entes federativos. Disponível em: <http://www.epublicacoes.uerj.br/index.php/rfptd/article/view/5127>. Acesso em 15 fev. 2015.

Anuário Estatístico Brasileiro do Petróleo, Gás Natural e Biocombustíveis. Disponível em: <www.anp.gov.br/?dw=57887> . Acesso em 18 jan. 2015.

ARAGÃO, Alexandre Santos de (Coord.). Direito do petróleo e de outras fontes de energia. Rio de Janeiro: Lumen Juris, 2011. 497 p. 
ARRUDA, Thais Nunes. Como os Juízes decidem os casos difíceis: a guinada pragmática de Richard Posner e a crítica de Ronald Dworkin. 2011. 287 fl. Dissertação (Mestrado) Faculdade de Direito da Universidade de São Paulo. 2011. Disponível em: <http://www.teses.usp.br/>. Acesso em 3 mar. 2015.

ASSUNÇÃO, Lorena Carneiro de. A (in) segurança jurídica na contemporaneidade. Direito público. Belo Horizonte: PUC Minas, Instituto de Educação Continuada, 2012, p. 31-42.

ÁVILA, Humberto. "Neoconstitucionalismo": entre a "Ciência do Direito" e o "Direito da Ciência". In: Revista Brasileira de Direito Público RBDP, ano 6, n. 23, out.-dez. 2008. Belo Horizonte: Editora Fórum, p. 9-30.

BARCELLOS, Ana Paula de. Neoconstitucionalismo, Direito Fundamentais e Controle das Políticas Públicas. In: QUARESMA, Regina; OLIVEIRA, Maria Lúcia de Paula; OLIVEIRA, Farlei Martins Riccio (Coord.). Neoconstitucionalismo. Rio de Janeiro: Forense, 2009, p. $797-$ 816.

BARROS, Daniel; IKEDA, Patrícia. A festa dos royalties. Exame, v. 46, n. 16, p. 186-193, ago. 2012.

BARROSO, Luís Roberto. Curso de Direito Constitucional Contemporâneo: os conceitos fundamentais e a construção do novo modelo. 3. ed. São Paulo: Saraiva, 2011, 505 p.

. Federalismo, isonomia e segurança jurídica: inconstitucionalidade das alterações na distribuição de royalties do petróleo. Disponível em: <http://www.luisrobertobarroso.com.br/wp-content/themes/LRB/pdf/royalties_do_petroleo. pdf >. Acesso em 15 fev. 2015.

Interpretação e Aplicação da Constituição: fundamentos de uma dogmática constitucional transformadora. 7. ed. São Paulo: Saraiva, 2009, 432 p.

Neoconstitucionalismo e constitucionalização do Direito (o triunfo tardio do direito constitucional no Brasil). In: QUARESMA, Regina; OLIVEIRA, Maria Lúcia de Paula; OLIVEIRA, Farlei Martins Riccio (Coord.). Neoconstitucionalismo. Rio de Janeiro: Forense, 2009, p. 51-92.

BONAVIDES, Paulo. Curso de Direito Constitucional. 25. ed. São Paulo: Malheiros, 2009, $835 \mathrm{p}$.

BORNHOLDT, Rodrigo Meyer. O art. $20, \S 1^{\circ}$ da constituição e a distribuição dos royalties relativos à exploração de petróleo na plataforma continental. Boletim de administração pública e gestão municipal, v. 3, n. 21, p. 814-833, jun. 2013.

BROSIO, Giorgio; LOUREIRO, Gustavo Kaercher. Custos e rendas na distribuição federativa dos recursos do pré-sal. Revista de direito público da economia, v. 12, n. 46, p. 79103, abr./jun. 2014. 
BUSTAMANTE, Thomas da Rosa de. O direito e a incerteza de suas fontes: um problema em aberto para a dogmática jurídica contemporânea. Revista da Faculdade de Direito da Universidade Federal de Minas Gerais, n. especial [2], p. 299-325, 2013.

Camada Pré-Sal: o que é a camada pré-sal, petróleo, poços, gás natural, produção, formação, localização da camada, importância. Disponível em: <http://www.suapesquisa.com/geografia/ petroleo/camada_pre_sal.htm>. Acesso em 2 março 2015.

CARNICELLI, Laur; POSTALI, Fernando Antonio Slaibe. Royalties do petróleo e emprego público nos municípios brasileiros. Estudos econômicos, São Paulo, v. 44, n. 3, p. 469-495, jul./set. 2014.

CASTRO, Antonio O. (Coord.). Impactos Sociais do Desenvolvimento da Atividade de Exploração e Produção de Petróleo nas Regiões das Baixadas Litorâneas e do Norte Fluminense. Projeto CTPETRO: Tendências Tecnológicas. Disponível em: <www.cgee.org.br/atividades/redirKori/461 >. Acesso em $1^{\circ}$ mar. 2015.

CASTRO, Marcus Faro de. Análise jurídica da política econômica. Revista da ProcuradoriaGeral do Banco Central, v. 3, n. 1, p. 17-70, jun. 2009.

- Globalização, Democracia e Direito Constitucional: Legados Recebidos e Possibilidades de Mudança. In: CLÈVE, Clèmerson Merlin; FREIRE, Alexandre (coords.). Direitos Fundamentais e Jurisdição Constitucional: Análise, Crítica e Contribuições. São Paulo: Editora Revista dos Tribunais, 2014, p. 697-719.

- Formas Jurídicas e Mudança Social: interações entre o Direito, a Filosofia, a Política e a Economia. São Paulo: Saraiva, 2012, 246 p.

CAVALCANTI, Caio César Torres. Responsabilidade civil por dano ambiental causado pela atividade petrolífera : uma análise a partir do Caso Chevron e da sua repercussão no projeto de distribuição dos royalties do petróleo. Revista Fórum de direito civil, v. 1, n. 1, p. 55-72, set./dez. 2012.

CLAUDINO, João Vicente. Royalties do petróleo: região nordeste. Brasília: Senado Federal, Gabinete do Senador João Vicente Claudino, 2007. 78 p.

COÊLHO, Sacha Calmon Navarro. Royalties do petróleo: a lei nova $n^{\circ}$ 12.734/2012: constitucionalidade. Revista brasileira de direito tributário e finanças públicas, v. 7, n. 38, p. 65-82, maio/jun. 2013.

COSTA, Hirdan Katarina de Medeiros; SANTOS, Edmilson Moutinho. Justiça e sustentabilidade: a destinação dos royalties de petróleo. Estudos Avançados, v. 27, n. 77, p. 143-160, jan./abr. 2013.

DANTAS, André Ribeiro. O dever de fundamentação das decisões judiciais. Revista forense, v. 108, n. 416, p. 69-88, jul./dez. 2012. 
DECAT, Erich. A maldição do petróleo. Desafios do desenvolvimento, v. 6, n. 48, p. 56-61, mar. 2009.

Diário do Congresso Nacional de 7/3/12. Disponível em: $<$ http://legis.senado.leg.br/diarios/BuscaDiario?tipDiario=2\&datDiario=07/03/2013\&paginaD ireta $=00969>$. Acesso em 27 fev. 2015.

Diário do Senado Federal de 19/10/11. Disponível em: <http://legis.senado.leg.br/ diarios/BuscaDiario?tipDiario=1\&datDiario=19/10/2011\&paginaDireta $=42544>$. Acesso em: 27 fev. 2015.

Diário do Senado Federal de 20/10/11. Disponível em: $<$ http://legis.senado.leg.br/diarios/BuscaDiario?tipDiario=1\&datDiario=20/10/2011\&pagina Direta=42763\#>. Acesso em: 27 fev. 2015.

DUARTE, Écio Oto Ramos; POZZOLO, Susanna. Neoconstitucionalismo e Positivismo Jurídico: as faces da Teoria do Direito em tempos de interpretação e moral da Constituição. 2. ed. São Paulo: Landy Editora, 2010, 244 p.

DWORKIN, Ronald. A Justiça de Toga. Trad. Jefferson Luiz Camargo. São Paulo: Editora WMF Martins Fontes, 2010, 421 p.

Levando os Direitos a Sério. Trad. Nelson Boeira. 3. ed. São Paulo: Editora WMF Martins Fontes, 2010, 568 p.

$2007,513 \mathrm{p}$.

O Império do Direito. Trad. Jefferson Luiz Camargo. São Paulo: Martins Fontes, 2000,593 p.

Uma questão de princípio. Trad. Luís Carlos Borges. São Paulo: Martins Fontes,

EMERIQUE, Lilian Balmant. Neoconstitucionalismo e Alguns Elementos das Percepções Contemporâneas da Hermenêutica Constitucional. In: QUARESMA, Regina; OLIVEIRA, Maria Lúcia de Paula e OLIVEIRA, Farlei Martins Riccio (Coord.). Neoconstitucionalismo. Rio de Janeiro: Forense, 2009, p. 631-666.

FARO, Julio Pinheiro. O petróleo é nosso, mas o dinheiro é meu. Consulex: revista jurídica, v. 17, n. 390, p. 55 , abr. 2013.

FERNANDES, Andressa Guimarães Torquato. Do tratamento constitucional à partilha de royalties: o que nos diz o par. 1 do art. 20 da CF? Revista tributária e de finanças públicas, v. 21, n. 109, p. 281-297, mar./abr. 2013.

FERRAZ JUNIOR, Tercio Sampaio. (1941). Introdução ao estudo do direito: técnica, decisão, dominação. São Paulo: Atlas, 2007. 385 p. 
FIGUEROA, Alfonso García. Neoconstitucionalismo, derrotabilidade e razão prática. Trad. Eduardo Ribeiro Moreira. Revista de Direito Constitucional e Internacional, São Paulo, Ano 20, vol. 79, p. 11-31, abr./jun 2012.

FREITAS, Paulo Springer de. Rendas do petróleo, questão federativa e instituição de fundo soberano. Releitura: compilação de textos para discussão, v. 1, n. 1, p. 79-126, jan./jun. 2010.

GONÇALVES, Reginaldo Brasão. A Justa Distribuição dos Royalties do Petróleo no Brasil. 2010. 60 fl. Dissertação (Mestrado em Direito). Faculdade de Direito, Universidade Federal do Amazonas, Manaus, 2010.

HAMEL, Marcio Renan; MENDES, Ana Isabel. A dogmática e o discurso jurídico entre a ciência e a realidade. Direito e Práxis, vol. 04, n. 01, p. 129-143, 2012.

KAMINSKI, Marcos Massiero; ROANI, Alcione Roberto. Neoconstitucionalismo: paradigma de nova aplicabilidade do direito, a ruptura do modelo positivista legalista. Revista Perspectiva, Erechim, v. 36, n. 134, p. 53-63, junho/2012.

LEAL, Mônia Clarissa Henning. Jurisdição Constitucional Aberta: Reflexões sobre a Legitimidade e os Limites da Jurisdição Constitucional na Ordem Democrática - uma Abordagem a partir das Terias Constitucionais Alemã e Norte-Americana. Rio de Janeiro: Lumen Juris, 2007. 244 p.

LEITTER, Brian. Beyond the Hart/Dworkin Debate: the methodology problem in jurisprudence. Disponível em: <http://papers.ssrn.com/sol3/papers.cfm?abstract_id= 312781>. Acesso em 20/11/2014.

Lei $\mathrm{n}^{\mathrm{o}}$ 12.734/12. Disponível em: <http://www.planalto.gov.br/ccivil_03/_ato2011-2014/ 2012/ lei/ 112734.htm>. Acesso em: 19 fev. 2015.

LIMA, Paulo César Ribeiro. Os “royalties do petróleo", a Lei n ${ }^{\circ} 12.734 / 2012$ e Ação a ser julgada pelo STF. Disponível em: <http://www.aslegis.org/2013/04/os-royalties-do-petroleolei-n.html>. Acesso em 15 fev. 2015.

LORENTZ, Lutiana Nacur. O Império do Direito de Ronald Dworkin. Revista do Tribunal Regional do Trabalho $3^{a}$ Região. Belo Horizonte, n. 33, p. 101-113, jan./jun. 2001.

LOUREIRO, Gustavo Kaercher. Participações governamentais na indústria do petróleo: evolução normativa. Porto Alegre : S.A. Fabris, 2012. 174 p.

MACCORMICK, Neil. Argumentação Jurídica e Teoria do Direito. Trad. Waldéa Barcellos. São Paulo: Martins Fontes, 2006, 391 p.

Retórica e Estado de Direito: uma teoria da argumentação jurídica. Trad. Conrado Hübner Mendes. Rio de Janeiro: Elsevier, 2008, 389 p. 
MACROPLAN. Royalties do Petróleo e Desenvolvimento Municipal: avaliação e propostas de melhoria. Relatório Final. Jun. 2012. Disponível em: <http://macroplan.com.br/Documentos/EstudoMacroplan 201282717367.pdf〉. Acesso em 22 fev. 2015.

MADUREIRA, Cláudio Penedo. Royalties de petróleo e federação. Belo Horizonte: Fórum, 2012. 157 p.

. Licitações sustentáveis e royalties de petróleo. Interesse público, v. 16, n. 83, p. 153-193, jan./fev. 2014.

MAIA, Antonio Cavalcanti. Neoconstitucionalismo, Positivismo Jurídico e a Nova Filosofia Constitucional. In: QUARESMA, Regina; OLIVEIRA, Maria Lúcia de Paula; OLIVEIRA, Farlei Martins Riccio (Coord.). Neoconstitucionalismo. Rio de Janeiro: Forense, 2009, p. 328.

MARTINS, Ives Gandra da Silva. Uma Teoria sobre a Teoria da Constituição. In: QUARESMA, Regina; OLIVEIRA, Maria Lúcia de Paula; OLIVEIRA, Farlei Martins Riccio (Coord.). Neoconstitucionalismo. Rio de Janeiro: Forense, 2009, p. 303-332.

MAUS, Ingeborg. Judiciário como superego da sociedade: o papel da atividade jurisprudencial na "sociedade órfã". Disponível em: <http://www.direitocontemporaneo.com/wp-content/uploads/2014/02/JUDICI\%C3\%81RIOCOMO-SUPEREGO-DA-SOCIEDADE.pdf>. Acesso em: 25 mar. 2015.

Medida cautelar na ADI $n^{0}$ 4917-DF. Decisão. Disponível em: $<$ http://redir.stf.jus.br/paginadorpub/paginador.jsp?docTP=TP\&docID=3518637\&ad=s\#28\%2 0-\%20Decis\%E3o\%20monocr\%E1tica>. Acesso em: $1^{\circ}$ mar. 2015.

MELLO, Sebastian Borges de Albuquerque. Ensaio sobre o Neoconstitucionalismo. Revista Jurídica da Presidência, Brasília, v. 13, n. 101, p. 489-517, out. 2011/jan. 2012.

MENDES, Gilmar Ferreira; COELHO, Inocêncio Mártires; BRANCO, Paulo Gustavo Gonet. Curso de Direito Constitucional. 2. ed., São Paulo: Saraiva, 2008, 1432 p. 2000, p. 283.

Hermenêutica Constitucional e Direitos Fundamentais. Brasília: Brasília Jurídico,

MERCADANTE, Aloizio. Os campos do possível: a oportunidade histórica do pré-sal. Interesse nacional, v. 1, n. 4, p. 30-38, jan./mar. 2009.

MESQUITA, Ribamar. Pré-sal: um novo projeto para o Nordeste. Rumos: economia \& desenvolvimento para os novos tempos, v. 34, n. 248, p. 40-41, nov./dez. 2009.

MONTEIRO, Cláudia Servilha. Fundamentos para uma teoria da decisão judicial. Disponível em: <www.conpedi.org.br/manaus/arquivos/anais/bh/claudia_servilha_ monteiro.pdf>. Acesso em: 7 fev. 2015. 
NEVES, Marcelo. A constitucionalização simbólica. São Paulo: WMF Martins Fontes, 2007, $263 \mathrm{p}$.

OLIVEIRA, Farlei Martins Riccio (Coord.). Neoconstitucionalismo. Rio de Janeiro: Forense, 2009, p. 313-333.

OLIVEIRA, Samuel Cunha de. A distribuição dos royalties do petróleo entre os entes federados: Uma análise da Lei $\mathrm{n}^{\mathrm{o}}$ 12.734/2012. Disponível em: $<$ http://jus.com.br/artigos/27646/a-distribuicao-dos-royalties-do-petroleo-entre-os-entesfederados/2>. Acesso em: 15 fev. 2015.

PAIXÃO JUNIOR, Sebastião Ventura Pereira da. Os royalties, a constituição e o supremo. Consulex: revista jurídica, v. 17, n. 394, p. 20-21, jun. 2013.

Parecer apresentado no Plenário da Câmara dos Deputados ao PL nº 2565/11. Disponível em: http://www.camara.gov.br/proposicoesWeb/prop_mostrarintegra?codteor=1036648\&filename $=\mathrm{PPP}+1+\% 3 \mathrm{D} \% 3 \mathrm{E}+\mathrm{PL}+2565 / 2011$. Acesso em: 25 fev. 2015.

Parecer aprovado no Senado Federal ao PLS 448/12. Disponível em: $<$ http://www.senado.gov.br/atividade/materia/getPDF.asp?t $=98057 \& t p=1>$. Acesso em 27 fev. 2015.

PASOLD, Cesar Luiz; GONÇALVES, Sandre Krieger; DIETRICH, Pablo. A fundamentação das decisões judiciais amparadas em princípios constitucionais: necessidade de superação do senso comum teórico no Brasil. Revista Eletrônica Direito e Política, Programa de PósGraduação Stricto Sensu em Ciência Jurídica da UNIVALI, Itajaí, v.9, n.3, $3^{\circ}$ quadrimestre de 2014. Disponível em: <www.univali.br/direitoepolitica〉. Acesso em 5 fev. 2015.

PATRUS, Rafael Dilly. Nem tanto ao mar nem tanto a terra: a saia-justa das novas regras de distribuição dos royalties e participações especiais devidos pela exploração do petróleo. Fórum administrativo, v. 13, n. 148, p. 62-74, jun. 2013.

PEIXINHO, Manoel Messias; MERÇON, Gustavo. Fundamentos teóricos do positivismo e do neoconstitucionalismo. In: QUARESMA, Regina; OLIVEIRA, Maria Lúcia de Paula; OLIVEIRA, Farlei Martins Riccio (Coord.). Neoconstitucionalismo. Rio de Janeiro: Forense, 2009, p. 313-333.

Perguntas e respostas sobre o pré-sal. Disponível em: <http://sites.petrobras.com.br/minisite/presal/perguntas-respostas/index.asp>. Acesso em: 2 mar. 2015.

PINHEIRO, Guilherme César. A ponderação de valores como supressora do contraditório. Revista de processo, v. 36, n. 193, p. 403-420, mar. 2011.

PINTO, Nelson Guilherme Machado; CORONEL, Daniel Arruda. Se o petróleo é nosso, porque os royalties petrolíferos beneficiam apenas alguns municípios? Observatorio de la Economía Latinoamericana, Número 179, 2013. Disponível em: 
$<$ http://www.eumed.net/cursecon/ecolat/br/13/ royalties-petroleo-brasil.html>. Acesso em 19 fev. 15 .

PIQUET, Rosélia; SERRA, Rodrigo. Petróleo e região no Brasil: o desafio da abundância. Rio de Janeiro: Garamond, 2007. 351 p.

POGREBINSCHI, Thamy. $O$ que é o pragmatismo jurídico?, p. 3. Disponível em: <http://www.cis.puc-rio.br/cedes/PDF/paginateoria/ pragmatismo.pdf $>$. Acesso em: 3 mar. 2015).

POSTALI, Fernando Antonio Slaibe; NISHIJIMA, Marislei. Distribuição das rendas do petróleo e indicadores de desenvolvimento municipal no Brasil nos anos 2000. Estudos econômicos, São Paulo, v. 41, n. 2, p. 463-485, abr./jun. 2011.

Redação final do PLC $\mathrm{n}^{\mathrm{O}}$ 7/10. Disponível em: $<$ http://www.senado.gov.br/atividade/materia/getPDF.asp?t=79699\&tp=1>. Acesso em: 25 fev. 2015.

Redação final do PL/SF $\mathrm{n}^{\circ}$ 448/2011. Disponível em: $<$ http://www.senado.gov.br/atividade/materia/detalhes. asp?p_cod_mate=101405>. Acesso em: 5 fev. 2015.

Relatório parcial da Comissão do Pacto Federativo. Disponível em: <http://www12.senado.gov.br/noticias/arquivos/2012/10/veja-o-relatorio-da-comissao-deespecialistas-1>. Acesso em: 20 de fev. 2015.

RIBEIRO, Edivan Guidote; TEIXEIRA, Arilton; GUTIERREZ, Carlos Enrique Carrasco. Impacto dos royalties do petróleo no PIB per capita dos municípios do Estado do Espírito Santo, Brasil. Revista Brasileira de Gestão de Negócios. Disponível em: <www.spell.org.br/documentos/download/6586>. Acesso em: 20 fev. 15.

ROCHA, Fernando Luiz Ximenes; MORAES, Filomeno (Coord.). Direito Constitucional Contemporâneo: Estudos em homenagem ao Professor Paulo Bonavides. Belo Horizonte: Del Rey, 2005, 734 p.

RODRIGUEZ, José Rodrigo; PÜSCHEL, Flavia Portella; MACHADO, Marta Rodriguez de Assis. (Org.). Dogmática é conflito: uma visão crítica da racionalidade jurídica. São Paulo: Saraiva, 2012. 252 p.

ROSA, Alexandre Morais da. Fundamentos da decisão judicial: crime e psicanálise. Revista Eletrônica Direito e Política, Programa de Pós-Graduação Stricto Sensu em Ciência Jurídica da UNIVALI, Itajaí, v.8, n.3, $3^{\circ}$ quadrimestre de 2013. Disponível em: www.univali.br/direitoepolitica. Acesso em: 5 fev. 15.

SANCHES, Samyra Naspolini. O paradigma da Ciência jurídica nos manuais de ensino de Direito. Universitas Jus, v. 24, n. 2, p. 1-10, 2013. 
SANCHÍS, Luis Prieto. Constitucionalismo e Garantismo. In: QUARESMA, Regina; OLIVEIRA, Maria Lúcia de Paula; OLIVEIRA, Farlei Martins Riccio (Coord.). Neoconstitucionalismo. Rio de Janeiro: Forense, 2009, p. 165-206.

SARMENTO, Daniel. O Neoconstitucionalismo no Brasil: riscos e possibilidades. In: SARMENTO, Daniel (Coord.). Filosofia e Teoria Constitucional Contemporânea. Rio de Janeiro: Lumen Juris, 2009, p. 113-146.

SERRA, Rodrigo Valente. O seqüestro das rendas petrolíferas pelo poder local: a gênese das quase sortudas regiões produtoras. Revista brasileira de estudos urbanos e regionais, v. 9, n. 1, p. 101-114, maio 2007.

Sessão da Câmara dos Deputados de 6/11/12 às 10hs, p. 94. Disponível em: <http://www.camara.leg.br/internet/plenario/notas/extraord/em0611121000.pdf>. Acesso em: 27 fev. 2015.

Sessão da Câmara dos Deputados de 6/11/12 às 16hs, p. 13. Disponível em: <http://www.camara.leg.br/internet/plenario/notas/extraord/EV0611121620.pdf>. Acesso em 27 fev. 2015.

SILVA, Virgílio Afonso da. Direitos Fundamentais: conteúdo essencial, restrições e eficácia. São Paulo: Malheiros, 2009, 279 p.

A Constitucionalização do Direito: os direitos fundamentais nas relações entre particulares. 1. ed. 2. tiragem. São Paulo: Malheiros, 2008, 191 p.

SILVEIRA NETO, Raul da Mota. Crescimento pró-pobre no nordeste do Brasil. Estudos econômicos, São Paulo, v. 44, n. 3, p. 497-526, jul./set. 2014.

SOUZA NETO, Cláudio Pereira; SARMENTO, Daniel; BINENBOJM, Gustavo. (Coord.). Vinte anos da Constituição federal de 1988. Rio de Janeiro: Lumen Juris, 2009. XIII, 868 p.

STRECK, Lenio Luiz. De como a dogmática jurídica traiu a filosofia. Constituição $e$ processo: uma análise hermenêutica da (re)construção dos códigos. Belo Horizonte: Fórum, 2012, p. 197-229.

Entre neoconstitucionalismo e (pós)-positivismo: das insuficiências da teoria neoconstitucional para as particularidades do caso brasileiro. Revista do Tribunal Regional do Trabalho da Oitava Região. Belém, v. 46, n. 90, p. 119-130, jan.-jul. 2013.

Hermenêutica jurídica e $(m)$ crise: uma exploração hermenêutica da construção do direito. 11. ed. Porto Alegre: Livraria do Advogado, 2014. 455 p.

SZKLO, Alexandre Salem; MAGRINI, Alessandra (Org.). Textos de discussão em geopolítica e gestão ambiental de petróleo. Rio de Janeiro: Interciência: Faperj, 2008. 424 p. 
UGARTE, Pedro Salazar. Garantismo e Neoconstitucionalismo frente a frente: algunas claves para su distinción. Disponível em: <http://rua.ua.es/dspace/handle/10045/32777>. Acesso em: 22/11/2014.

Veto Parcial $\mathrm{n}^{\mathrm{o}}$ 38/12. Disponível em: <http://www.senado.gov.br/atividade/ materia/detalhes.asp?p_cod_mate=109332>. Acesso em 27 fev. 2015.

Veto Parcial no 39/10. Disponível em: <http://www.senado.gov.br/atividade/materia/detalhes. asp?p_cod_mate=98783>. Acesso em: 27 fev. 2015.

VIEGAS, Paulo Roberto Alonso. Aspectos da MP $n^{\circ}$ 592, de 2012, sobre a distribuição de royalties e outras participações governamentais na exploração de petróleo e gás natural. Disponível em: < http://www12.senado.gov.br/publicacoes/estudos-legislativos/tipos-deestudos/textos-para-discussao/td-119-aspectos-da-mp-no-592-de-2012-sobre-a-distribuicaode-royalties-e-outras-participacoes-governamentais-na-exploracao-de-petroleo-e-gas-natural >. Acesso em: 29 jan. 2015.

WARAT, Luis Alberto. (1941). Epistemologia e ensino do direito: o sonho acabou. MEZZAROBA, Orides. et al. (Coord.). Florianópolis: Boiteux, 2004. 493 p.

. (1941). Introdução geral ao direito. Porto Alegre: S.A. Fabris, 1994-1997. v. 3. (1941). O direito e sua linguagem: $2^{\mathrm{a}}$ versão. Porto Alegre: S. A. Fabris, 1995. 120

p.

WATT NETO, Artur. Petróleo, gás natural e biocombustíveis: doutrina, jurisprudência e legislação. São Paulo: Saraiva, 2014. 460 p.

WEBER, Max. Economy and Society: an outline of interpretive sociology. California: University of California Press, 1978. 
TABELA 1 - ATOS LEGISLATIVOS RELEVANTES

\begin{tabular}{|c|c|c|c|c|c|c|c|c|}
\hline $\begin{array}{l}\text { Tipo de } \\
\text { Ato }\end{array}$ & Ementa & $\begin{array}{l}\text { Data de } \\
\text { apresenta } \\
\text { ção }\end{array}$ & Autor & Tramitação & Relator/ Parecer/ Relatório ${ }^{226}$ & Pareceres & Vetos & $\begin{array}{l}\text { Andamento } \\
\text { em 30-Set- } \\
2014\end{array}$ \\
\hline $\begin{array}{l}\text { Medida } \\
\text { Provisóri } \\
\text { a n }^{\circ} 592 \\
\text { de } 2012\end{array}$ & $\begin{array}{l}\text { Modifica as Leis } \mathrm{n}^{\circ} \\
9.478, \text { de } 6 \text { de agosto } \\
\text { de } 1997, \text { e } \mathrm{n}^{\circ} 12.351 \text {, } \\
\text { de } 22 \text { de dezembro de } \\
2010 \text {, para determinar } \\
\text { novas regras de } \\
\text { distribuição entre os } \\
\text { entes da Federação dos } \\
\text { royalties e da } \\
\text { participação especial } \\
\text { decorrentes da } \\
\text { exploração de petróleo, } \\
\text { gás natural e outros } \\
\text { hidrocarbonetos fluidos } \\
\text { sob o regime de } \\
\text { concessão, e para } \\
\text { disciplinar a destinação } \\
\text { dos recursos do Fundo } \\
\text { Social. }\end{array}$ & $3 / 12 / 2012$ & $\begin{array}{l}\text { Presidente } \\
\text { da } \\
\text { República }\end{array}$ & $\begin{array}{l}\text { CMMPV } \\
\text { 592/2012 - } \\
\text { Comissão } \\
\text { Mista da } \\
\text { Medida } \\
\text { Provisória no } \\
\text { 592, de } 2012 .\end{array}$ & $\begin{array}{l}\text { Relator: Deputado Carlos } \\
\text { Zarattini. Voto pelo } \\
\text { atendimento aos pressupostos } \\
\text { constitucionais de relevância e } \\
\text { urgência da Medida Provisória } \\
\text { no }^{\circ} 592 / 2012 ; \text { pela } \\
\text { constitucionalidade, } \\
\text { juridicidade e boa técnica } \\
\text { legislativa da Medida } \\
\text { Provisória e das emendas } \\
\text { apresentadas, com exceção das } \\
\text { de n }{ }^{\circ} \text { s } 1,26,31,43,45 \text { e } 54, \\
\text { que tratam de matéria estranha; } \\
\text { pela adequação e } \\
\text { compatibilidade financeira e } \\
\text { orçamentária da Medida } \\
\text { Provisória e das emendas } \\
\text { apresentadas; e no mérito, pela } \\
\text { aprovação da Medida } \\
\text { Provisória e pela aprovação, } \\
\text { total ou parcial, das Emendas } \\
\text { de n }{ }^{\circ} 2,4,11,12,14,15,16, \\
18,21,22,24,27,28,29,35, \\
36,37,41,42,44,46,47,48, \\
49,52,53,56,57,58,60,61 \\
\text { na forma do Projeto de Lei de } \\
\text { Conversão apresentado, e pela } \\
\text { rejeição das demais Emendas. } \\
\text { Relator Revisor: }\end{array}$ & $\begin{array}{l}\text { Não houve parecer } \\
\text { aprovado. Colocada a } \\
\text { matéria em discussão, } \\
\text { decide o Plenário da } \\
\text { Comissão sobrestar a } \\
\text { apreciação da matéria } \\
\text { até que seja julgado } \\
\text { pelo Supremo Tribunal } \\
\text { Federal o mérito da } \\
\text { Ação Direta de } \\
\text { Inconstitucionalidade } \\
\text { questionando a Lei no } \\
\text { 12.734 de } 30 \text { de } \\
\text { novembro de } 2012 .\end{array}$ & - & Arquivada. \\
\hline
\end{tabular}

${ }^{226} \mathrm{Na}$ Câmara dos Deputados, a manifestação produzida pelo Relator do Projeto de Lei chama-se Parecer, assim como é o denominado o Parecer aprovado por uma das Comissões ou pelo Plenário. Já no Senado Federal essa manifestação é denominada Relatório, somente recebendo o nome de Parecer após a sua aprovação por uma das Comissões do Senado ou pelo Plenário (CF. art. 52, §1 ${ }^{\circ}$ do Regimento Interno da Câmara dos Deputados e arts. 130 a 132 do Regimento Interno do Senado Federal). 


\begin{tabular}{|c|c|c|c|c|c|c|c|c|}
\hline $\begin{array}{l}\text { Tipo de } \\
\text { Ato }\end{array}$ & Ementa & $\begin{array}{l}\text { Data de } \\
\text { apresenta } \\
\text { ção }\end{array}$ & Autor & Tramitação & Relator/ Parecer/ Relatório ${ }^{227}$ & Pareceres & Vetos & $\begin{array}{l}\text { Andamento } \\
\text { em 30-Set- } \\
2014\end{array}$ \\
\hline & & & & & Wellington Dias & & & \\
\hline $\begin{array}{l}\text { Na } \\
\text { Câmara: } \\
\text { Projeto } \\
\text { de Lei no } \\
323 \text { de } \\
2007 \\
\\
\text { No } \\
\text { Senado: } \\
\text { Projeto } \\
\text { de Lei da } \\
\text { Câmara } \\
n^{\circ} 41 \text { de } \\
13\end{array}$ & $\begin{array}{l}\text { Dispõe sobre a } \\
\text { destinação para as } \\
\text { áreas de educação e } \\
\text { saúde de parcela da } \\
\text { participação no } \\
\text { resultado ou da } \\
\text { compensação } \\
\text { financeira pela } \\
\text { exploração de petróleo } \\
\text { e gás natural, com a } \\
\text { finalidade de } \\
\text { cumprimento da meta } \\
\text { prevista no inciso VI } \\
\text { do caput do art. } 214 \text { e } \\
\text { no art. } 196 \text { da } \\
\text { Constituição Federal; } \\
\text { altera as Leis nº } \\
7.990, \text { de } 28 \text { de } \\
\text { dezembro de 1989, e } \\
\text { 12.351, de 22 de } \\
\text { dezembro de 2010; e } \\
\text { dá outras providências. }\end{array}$ & 26/06/2013 & $\begin{array}{l}\text { Deputado } \\
\text { Brizola } \\
\text { Neto }\end{array}$ & $\begin{array}{l}\text { Câmara: } \\
\text { Comissão de } \\
\text { Desenvolvim } \\
\text { ento } \\
\text { Econômico, } \\
\text { Indústria e } \\
\text { Comércio } \\
\text { (CDEIC); } \\
\text { Comissão de } \\
\text { Minas e } \\
\text { Energia } \\
\text { (CME); } \\
\text { Comissão de } \\
\text { Finanças e } \\
\text { Tributação } \\
\text { (CFT); } \\
\text { Comissão de } \\
\text { Constituição } \\
\text { e Justiça e de } \\
\text { Cidadania } \\
\text { (CCJC); } \\
\text { Comissão } \\
\text { Especial } \\
\text { destinada a } \\
\text { proferir } \\
\text { parecer ao } \\
\text { PL 323, de }\end{array}$ & $\begin{array}{l}\text { Câmara: Relator CDEIC: Dep. } \\
\text { Albano Franco. Parecer: pela } \\
\text { aprovação deste, do PL } \\
\text { 381/2007, do PL 413/2007, e } \\
\text { do PL 445/2007, apensados, } \\
\text { com substitutivo. } \\
\text { Relator CME: Dep. Andre } \\
\text { Vargas. Parecer: pela rejeição } \\
\text { do PL, do PL 381/2007, do PL } \\
\text { 413/2007, e do PL 445/2007. } \\
\text { Relator CFT: Dep. Pedro } \\
\text { Eugênio. } \\
\text { Relator CCJC: Dep. Luiz } \\
\text { Couto. } \\
\text { Relator Comissão Especial: } \\
\text { Dep. André Figueiredo. } \\
\text { Parecer: conclui pela } \\
\text { apresentação da Subemenda } \\
\text { Substitutiva Global } \\
\text { Relator Senado: Senador } \\
\text { Eduardo Braga. Relatório: Pela } \\
\text { aprovação do Projeto de Lei da } \\
\text { Câmara no 41, de 2013, na }\end{array}$ & $\begin{array}{l}\text { Parecer CDEIC: } \\
\text { aprovado por } \\
\text { unanimidade o } \\
\text { Relatório. } \\
\text { Parecer CME: } \\
\text { Aprovado por } \\
\text { Unanimidade o Parecer. } \\
\text { Parecer Plenário } \\
\text { Câmara: conclui pela } \\
\text { apresentação da } \\
\text { Subemenda Substitutiva } \\
\text { Global } \\
\text { Parecer Senado: } \\
\text { Aprovado o } \\
\text { Substitutivo, em turno } \\
\text { suplementar, } \\
\text { ressalvadas as emendas. } \\
\text { Rejeitadas, em globo, as } \\
\text { Emendas n's } 1 \text { a } 8- \\
\text { PLEN. } \\
\\
\text { Parecer da Câmara ao } \\
\text { Substitutivo: Aprovado } \\
\text { o inciso II do art. } 2^{\circ} \text { do } \\
\text { Substitutivo do Senado }\end{array}$ & - & $\begin{array}{l}\text { Arquivado o } \\
\text { Projeto, em } \\
\text { razão de ter } \\
\text { se } \\
\text { Transformado } \\
\text { em norma } \\
\text { jurídica. } \\
\text { Sancionada a } \\
\text { lei } 12.858 \text { de } \\
2013 \text { pela } \\
\text { Presidente da } \\
\text { República. } \\
\text { DOU de } \\
10 / 09 / 2013\end{array}$ \\
\hline
\end{tabular}

${ }^{227}$ Na Câmara dos Deputados, a manifestação produzida pelo Relator do Projeto de Lei chama-se Parecer, assim como é o denominado o Parecer aprovado por uma das Comissões ou pelo Plenário. Já no Senado Federal essa manifestação é denominada Relatório, somente recebendo o nome de Parecer após a sua aprovação por uma das Comissões do Senado ou pelo Plenário (CF. art. 52, $\S 1^{\circ}$ do Regimento Interno da Câmara dos Deputados e arts. 130 a 132 do Regimento Interno do Senado Federal). 


\begin{tabular}{|c|c|c|c|c|c|c|c|c|}
\hline $\begin{array}{l}\text { Tipo de } \\
\text { Ato }\end{array}$ & Ementa & $\begin{array}{l}\text { Data de } \\
\text { apresenta } \\
\text { ção }\end{array}$ & Autor & Tramitação & Relator/ Parecer/ Relatório ${ }^{227}$ & Pareceres & Vetos & $\begin{array}{l}\text { Andamento } \\
\text { em 30-Set- } \\
2014\end{array}$ \\
\hline & & & & $\begin{array}{l}2007 \\
\text { Senado: } \\
\text { Plenário } \\
\text { Câmara } \\
\text { (Análise do } \\
\text { Substitutivo } \\
\text { do Senado): } \\
\text { Comissão } \\
\text { Especial e } \\
\text { Plenário. }\end{array}$ & $\begin{array}{l}\text { forma do Substitutivo que } \\
\text { apresenta. } \\
\text { Relator do Substitutivo do } \\
\text { Senado na Câmara: } \\
\text { Dep. André Figueiredo. } \\
\text { Parecer proferido em Plenário } \\
\text { que conclui pela } \\
\text { constitucionalidade, } \\
\text { juridicidade e técnica } \\
\text { legislativa; pela adequação } \\
\text { financeira e orçamentáia; e, no } \\
\text { mérito, pela rejeição de todo o } \\
\text { Substitutivo do Senado } \\
\text { Federal, com exceção do inciso } \\
\text { II do artigo } 2^{\circ} \text {, reestabelecendo } \\
\text { o texto da Câmara dos } \\
\text { Deputados. }\end{array}$ & $\begin{array}{l}\text { Federal, para substituir } \\
\text { o inciso II do art. } 2^{\circ} \text { do } \\
\text { texto aprovado na } \\
\text { Câmara dos Deputados, } \\
\text { com parecer pela } \\
\text { aprovação, ressalvados } \\
\text { os destaques. } \\
\text { Rejeitados os demais } \\
\text { dispositivos do } \\
\text { Substitutivo do Senado } \\
\text { Federal, com parecer } \\
\text { pela rejeição, exceto o } \\
\text { inciso II do art. } 2^{\circ}, \text { para } \\
\text { fins de manutenção de } \\
\text { todo o restante do texto } \\
\text { aprovado na Câmara } \\
\text { dos Deputados, } \\
\text { ressalvados os } \\
\text { destaques. } \\
\text { Aprovada a } \\
\text { Subemenda Substitutiva } \\
\text { Global apresentada pelo } \\
\text { Relator da Comissão } \\
\text { Especial, ressalvados os } \\
\text { destaques. } \\
\text { Ficam prejudicados a } \\
\text { proposição inicial; as } \\
\text { Emendas de Plenário; o } \\
\text { Substitutivo } \\
\text { apresentado pelo } \\
\text { Relator da Comissão } \\
\text { Especial; e os Projetos } \\
\text { de Lei nos } 381 / 07, \\
413 / 07,445 / 07, \\
6.668 / 09,4.671 / 12, \\
\end{array}$ & & \\
\hline
\end{tabular}




\begin{tabular}{|c|c|c|c|c|c|c|c|c|}
\hline $\begin{array}{l}\text { Tipo de } \\
\text { Ato }\end{array}$ & Ementa & $\begin{array}{l}\text { Data de } \\
\text { apresenta } \\
\text { ção }\end{array}$ & Autor & Tramitação & Relator/Parecer/ Relatório ${ }^{227}$ & Pareceres & Vetos & $\begin{array}{l}\text { Andamento } \\
\text { em 30-Set- } \\
2014\end{array}$ \\
\hline & & & & & & $\begin{array}{l}\text { 4.681/12, 4.711/12, } \\
\text { 4.718/12, 4.808/12, } \\
\text { 4.867/12, 4.902/12, } \\
5.397 / 13,5.453 / 13 \mathrm{e} \\
5.500 / 13, \text { apensados. }\end{array}$ & & \\
\hline 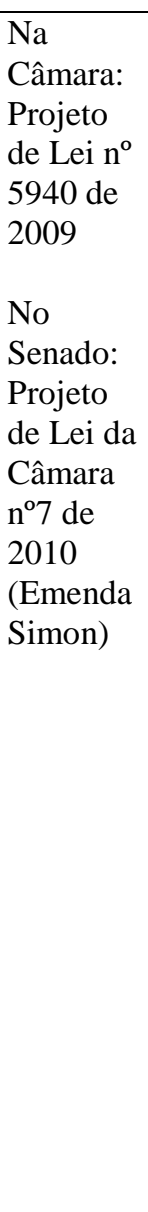 & $\begin{array}{l}\text { Dispõe sobre a } \\
\text { exploração e a } \\
\text { produção de petróleo, } \\
\text { de gás natural, e de } \\
\text { outros hidrocarbonetos } \\
\text { fluidos, sob o regime } \\
\text { de partilha de } \\
\text { produção, em áreas do } \\
\text { pré-sal e em áreas } \\
\text { estratégicas; altera } \\
\text { dispositivos da Lei no } \\
9.478 \text {, de } 6 \text { de agosto } \\
\text { de } 1997 ; \text { cria o Fundo } \\
\text { Social - FS, dispõe } \\
\text { sobre sua estrutura e } \\
\text { fontes de recursos; e dá } \\
\text { outras providências. }\end{array}$ & $\begin{array}{l}\text { Na } \\
\text { Câmara: } \\
\text { 01/9/2009 } \\
\text { No } \\
\text { Senado: } \\
\text { 8/03/2010 }\end{array}$ & $\begin{array}{l}\text { Presidente } \\
\text { da } \\
\text { República }\end{array}$ & $\begin{array}{l}\text { Câmara: } \\
\text { Comissão } \\
\text { Especial e } \\
\text { Plenário. } \\
\text { Senado: } \\
\text { Comissão de } \\
\text { Constituição, } \\
\text { Justiça e } \\
\text { Cidadania } \\
\text { (CCJ), } \\
\text { Plenário. } \\
\text { Câmara para } \\
\text { votação do } \\
\text { Substitutivo } \\
\text { do Senado: } \\
\text { Comissão } \\
\text { Especial e } \\
\text { Plenário. }\end{array}$ & $\begin{array}{l}\text { Relator Câmara: Dep. Antonio } \\
\text { Palocci. Foram apresentadas as } \\
\text { Emendas de Plenário de nº } \\
302 \text { a } 333 \text {. } \\
\text { Parecer proferido em Plenário, } \\
\text { que conclui pela aprovação } \\
\text { parcial da Emenda de Plenário } \\
\text { no }^{\circ} 333 \text {, com Subemenda } \\
\text { Substitutiva, e pela rejeição das } \\
\text { demais Emendas. } \\
\text { Relator Plenário Senado: } \\
\text { Senador Romero Jucá. } \\
\text { Relatório: Pela aprovação do } \\
\text { Projeto, na forma do } \\
\text { Substitutivo que apresenta. } \\
\\
\text { Relator na Câmara do } \\
\text { Substitutivo do Senado: Dep. } \\
\text { Antonio Palocci. Parecer: } \\
\text { conclui pela } \\
\text { constitucionalidade, } \\
\text { juridicidade e técnica } \\
\text { legislativa; pela adequação } \\
\text { financeira e orçamentária; e, no } \\
\text { mérito, pela aprovação do } \\
\text { Substitutivo do Senado Federal } \\
\text { ao Projeto de Lei no } 5940 / 09, \\
\text { com subemendas de redação e } \\
\text { supressão do inciso V do artigo }\end{array}$ & $\begin{array}{l}\text { Parecer Plenário } \\
\text { Câmara: Aprovado o } \\
\text { Substitutivo adotado } \\
\text { pela Comissão Especial } \\
\text { ao Projeto de Lei n } \\
\text { 5.940/09, apensado, } \\
\text { ressalvados os } \\
\text { destaques. Rejeitadas as } \\
\text { Emendas de Plenário } \\
\mathrm{n}^{\circ} \mathrm{s} 302 \text { a 332, com } \\
\text { parecer contrário, } \\
\text { ressalvados os } \\
\text { destaques. } \\
\text { Aprovada a Subemenda } \\
\text { Substitutiva oferecida } \\
\text { pelo relator da } \\
\text { Comissão Especial à } \\
\text { Emenda de Plenário } \mathrm{n}^{\circ} \\
333 \text {. Rejeitadas as } \\
\text { Emenda de Plenário } \mathrm{n}^{\circ} \\
310,5,269,332,64 . \\
\text { Aprovadas as Emendas } \\
\text { de Plenário } \mathrm{n}^{\circ} 116 . \\
\text { Rejeitada a Emenda } \\
\text { Aglutinativa } \mathrm{n}^{\circ} 3 \text {. } \\
\text { Aprovada a Emenda } \\
\text { Aglutinativa } \mathrm{n}^{\circ} 2 \text {, } \\
\text { resultante da fusão entre } \\
\text { a Emenda de Plenário } \mathrm{n}^{\circ} \\
169 \text { e } \S 1^{\circ} \text { do artigo } 12\end{array}$ & $\begin{array}{l}\text { Veto parcial } \\
\text { (vet 39, de } \\
2010) . \\
\text { Vetado, } \\
\text { parcialmente } \\
\text {. Vide MSG } \\
00707 \text { de } \\
\text { 2010). DOU } \\
\text { - 23/12/20 }\end{array}$ & $\begin{array}{l}\text { Arquivado o } \\
\text { Projeto, em } \\
\text { razão de ter } \\
\text { se } \\
\text { transformado } \\
\text { em norma } \\
\text { jurídica - lei } \\
12.351 / 10 \text {. } \\
\text { Sancionada } \\
\text { em } \\
22 / 12 / 2010 .\end{array}$ \\
\hline
\end{tabular}




\begin{tabular}{|c|c|c|c|c|c|c|c|c|}
\hline $\begin{array}{l}\text { Tipo de } \\
\text { Ato }\end{array}$ & Ementa & $\begin{array}{l}\text { Data de } \\
\text { apresenta } \\
\text { ção }\end{array}$ & Autor & Tramitação & Relator/Parecer/ Relatório ${ }^{227}$ & Pareceres & Vetos & $\begin{array}{l}\text { Andamento } \\
\text { em 30-Set- } \\
2014\end{array}$ \\
\hline & & & & & 47, do artigo 65 e do artigo 64. & $\begin{array}{l}\text { do Substitutivo. } \\
\text { Aprovada a Emenda } \\
\text { Aglutinativa no } 1 \text {, } \\
\text { resultante da fusão entre } \\
\text { a Emenda de Plenário n } \\
302 \text { e o artigo } 12 \text { do } \\
\text { Substitutivo. Prejudicas } \\
\text { as Emenda de Plenário } \\
169 \text { e } 302 \text {. } \\
\\
\text { Parecer Plenário } \\
\text { Senado: Aprovado o } \\
\text { Substitutivo, em turno } \\
\text { suplementar, } \\
\text { ressalvadas as emendas. } \\
\\
\text { Parecer Câmara ao } \\
\text { Substitutivo do Senado: } \\
\text { Rejeitados o inciso V } \\
\text { do artigo } 47 \text { e os artigos } \\
64 \text { e } 65 \text { do Substitutivo } \\
\text { do Senado Federal, com } \\
\text { parecer contrário, } \\
\text { ressalvado o destaque. } \\
\text { Aprovados os artigos de } \\
1 \text { a } 46,47 \text { exceto o } \\
\text { inciso V e } 48 \text { a } 64 \text { do } \\
\text { Substitutivo do Senado } \\
\text { Federal. }\end{array}$ & & \\
\hline $\begin{array}{l}\mathrm{Na} \\
\text { Câmara: } \\
\text { Projeto } \\
\text { de Lei } \mathrm{n}^{\circ} \\
5.938 \text { de } \\
2009\end{array}$ & $\begin{array}{l}\text { Dispõe sobre a } \\
\text { exploração e a } \\
\text { produção de petróleo, } \\
\text { de gás natural e de } \\
\text { outros hidrocarbonetos } \\
\text { fluidos sob o regime de }\end{array}$ & $\begin{array}{l}\text { Na } \\
\text { Câmara: } \\
01 / 09 / 2009 \\
\text { No } \\
\text { Senado: }\end{array}$ & $\begin{array}{l}\text { Presidente } \\
\text { da } \\
\text { República }\end{array}$ & $\begin{array}{l}\text { Câmara: } \\
\text { CCJC, } \\
\text { Comissão } \\
\text { Especial e } \\
\text { Plenário. }\end{array}$ & $\begin{array}{l}\text { Relator Câmara: Dep. } \\
\text { Henrique Eduardo Alves. } \\
\text { Parecer: conclui pela } \\
\text { aprovação da Emenda de } \\
\text { Plenário no } 385 \text {, na forma da } \\
\text { Subemenda Substitutiva Global }\end{array}$ & $\begin{array}{l}\text { Parecer Câmara: } \\
\text { Aprovada a Subemenda } \\
\text { Substitutiva Global de } \\
\text { Plenário oferecida pelo } \\
\text { Relator da Comissão } \\
\text { Especial, ressalvados os }\end{array}$ & - & $\begin{array}{l}\text { Câmara: } \\
\text { Recebimento } \\
\text { do Ofício } \mathrm{n}^{\circ} \\
1981 / 11(\mathrm{SF}) \\
\text { comunicando } \\
\text { o }\end{array}$ \\
\hline
\end{tabular}




\begin{tabular}{|c|c|c|c|c|c|c|c|c|}
\hline $\begin{array}{l}\text { Tipo de } \\
\text { Ato }\end{array}$ & Ementa & $\begin{array}{l}\text { Data de } \\
\text { apresenta } \\
\text { ção }\end{array}$ & Autor & Tramitação & Relator/ Parecer/ Relatório ${ }^{227}$ & Pareceres & Vetos & $\begin{array}{l}\text { Andamento } \\
\text { em 30-Set- } \\
2014\end{array}$ \\
\hline $\begin{array}{l}\text { (Emenda } \\
\text { Ibsen) } \\
\text { No } \\
\text { Senado: } \\
\text { Projeto } \\
\text { de Lei da } \\
\text { Câmara } \\
\text { no }^{\circ} 16 \text { de } \\
2010\end{array}$ & $\begin{array}{l}\text { partilha de produção, } \\
\text { em áreas do pré-sal e } \\
\text { em áreas estratégicas, } \\
\text { altera dispositivos da } \\
\text { Lei no } \text { n }^{\circ} .478, \text { de } 6 \text { de } \\
\text { agosto de } 1997, \text { e dá } \\
\text { outras providências. }\end{array}$ & $22 / 3 / 2010$ & & $\begin{array}{l}\text { Senado: CCJ, } \\
\text { Comissão de } \\
\text { Ciência, } \\
\text { Tecnologia, } \\
\text { Inovação, } \\
\text { Comunicaçã } \\
\text { o e } \\
\text { Informática } \\
\text { (CCT), } \\
\text { Plenário. }\end{array}$ & $\begin{array}{l}\text { de Plenário, e pela rejeição das } \\
\text { de nºs } 363 \text { a 384, e } 386 \text { a } 393 . \\
\text { Relator Plenário Senado: } \\
\text { Senador Romero Jucá. }\end{array}$ & 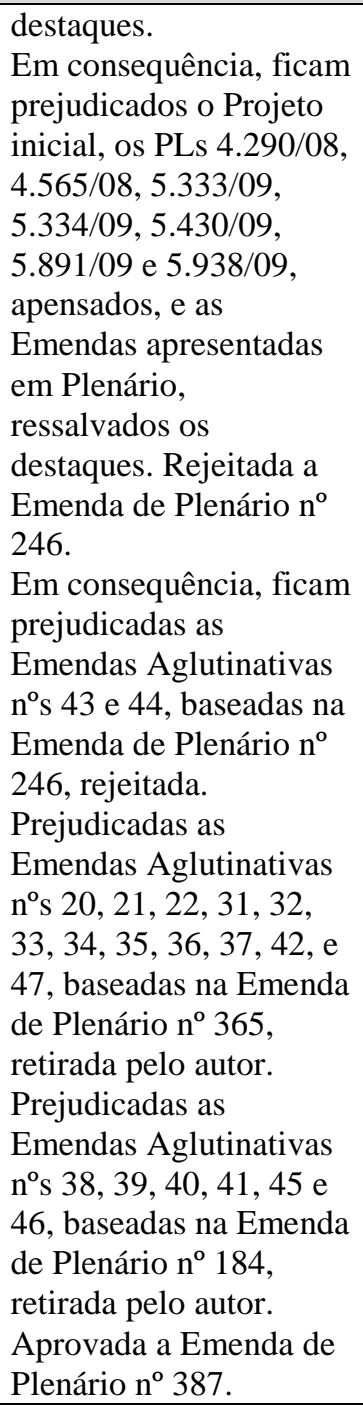 & & $\begin{array}{l}\text { arquivamento } \\
\text { da matéria. } \\
\text { Senado: } \\
\text { Processo } \\
\text { Arquivado. A } \\
\text { presente } \\
\text { matéria é } \\
\text { prejudicada } \\
\text { em virtude da } \\
\text { aprovação de } \\
\text { Substitutivo } \\
\text { ao PLS } \\
\text { 448/2011. }\end{array}$ \\
\hline
\end{tabular}




\begin{tabular}{|c|c|c|c|c|c|c|c|c|}
\hline $\begin{array}{l}\text { Tipo de } \\
\text { Ato }\end{array}$ & Ementa & $\begin{array}{l}\text { Data de } \\
\text { apresenta } \\
\text { ção }\end{array}$ & Autor & Tramitação & Relator/ Parecer/ Relatório $^{227}$ & Pareceres & Vetos & $\begin{array}{l}\text { Andamento } \\
\text { em 30-Set- } \\
2014\end{array}$ \\
\hline $\begin{array}{l}\text { Projeto } \\
\text { de Lei do } \\
\text { Senado } \\
\mathrm{n}^{\circ} 280 \text { de } \\
2013\end{array}$ & $\begin{array}{l}\text { Dispõe sobre a } \\
\text { destinação para as } \\
\text { áreas de educação e } \\
\text { saúde da totalidade dos } \\
\text { recursos oriundos do } \\
\text { pagamento referente } \\
\text { aos bônus de assinatura } \\
\text { dos contratos de } \\
\text { partilha de produção de } \\
\text { blocos exploratórios de } \\
\text { petróleo e gás natural } \\
\text { na área do pré-sal. }\end{array}$ & $8 / 07 / 2013$ & $\begin{array}{l}\text { Senadores } \\
\text { Ricardo } \\
\text { Ferraço e } \\
\text { Cristovam } \\
\text { Buarque }\end{array}$ & $\begin{array}{l}\text { Senado: } \\
\text { Comissão de } \\
\text { Serviços de } \\
\text { Infraestrutura } \\
\text { (CI); } \\
\text { Comissão de } \\
\text { Educação, } \\
\text { Cultura e } \\
\text { Esporte } \\
\text { (CE), } \\
\text { Comissão de } \\
\text { Assuntos } \\
\text { Sociais } \\
\text { (CAS) e } \\
\text { Comissão de } \\
\text { Assuntos } \\
\text { Econômicos } \\
\text { (CAE). }\end{array}$ & $\begin{array}{l}\text { Relator CI: Sen. } \\
\text { Inácio Arruda. Relatório: pela } \\
\text { aprovação do projeto com uma } \\
\text { emenda que apresenta. } \\
\text { Relator CE: Sen. } \\
\text { Cyro Miranda. Relatório: } \\
\text { Relatório favorável ao projeto, } \\
\text { acatando a Emenda no 1-CI, na } \\
\text { forma da subemenda oferecida. } \\
\text { Relator CAS: } \\
\text { Sen. Rodrigo Rollemberg. } \\
\text { Relatório: pela aprovação do } \\
\text { Projeto de Lei do Senado no } \\
\text { 280, de } 2013 \text {; da Emenda que } \\
\text { apresenta; e da Emenda no } 1 \text {-CI } \\
\text { nos termos da Subemenda no } 1- \\
\text { CE e das } 3 \text { (três) Subemendas } \\
\text { que apresenta. } \\
\text { Relator na CAE: Sen. Gleisi } \\
\text { Hoffmann. }\end{array}$ & $\begin{array}{l}\text { Parecer CI: aprovado o } \\
\text { Relatório favorável do } \\
\text { Senador Inácio Arruda, } \\
\text { com a Emenda no 01/CI, } \\
\text { que passa a constituir } \\
\text { Parecer da Comissão. } \\
\text { Parecer CE: aprova } \\
\text { parecer favorável, de } \\
\text { autoria do Senador Cyro } \\
\text { Miranda, acatando a } \\
\text { emenda no } 1 \text {-CI/CE, na } \\
\text { forma da subemenda n } \\
\text { 1-CE. } \\
\text { Parecer CAS: aprova o } \\
\text { Relatório do Senador } \\
\text { Rodrigo Rollemberg, } \\
\text { que passa a constituir o } \\
\text { Parecer da CAS, } \\
\text { favorável ao Projeto de } \\
\text { Lei, à Emenda no } 1 \text {-CI- } \\
\text { CE-CAS nos termos das } \\
\text { Subemendas no } 1 \text {-CE- } \\
\text { CAS e nos } 2,3 \text { e } 4 \text { - } \\
\text { CAS; e à Emenda no } 2 \text { - } \\
\text { CAS. }\end{array}$ & - & $\begin{array}{l}\text { Matéria com } \\
\text { a relatoria na } \\
\text { Comissão de } \\
\text { Assuntos } \\
\text { Econômicos. }\end{array}$ \\
\hline $\begin{array}{l}\text { Projeto } \\
\text { de Lei do } \\
\text { Senado } \\
\mathrm{n}^{\circ} 227 \text { de } \\
2011\end{array}$ & $\begin{array}{l}\text { Altera as Leis } \mathrm{n}^{\circ} 9.478, \\
\text { de } 6 \text { de agosto de } 1997, \\
\text { e } \mathrm{n}^{\circ} 12.351, \text { de } 22 \text { de } \\
\text { dezembro de } 2010, \\
\text { para garantir que parte } \\
\text { dos recursos dos } \\
\text { royalties e do Fundo } \\
\text { Social sejam }\end{array}$ & $05 / 05 / 2011$ & $\begin{array}{l}\text { Senador } \\
\text { Walter } \\
\text { Pinheiro }\end{array}$ & $\begin{array}{l}\text { Senado: CI, } \\
\text { CAE e CE }\end{array}$ & $\begin{array}{l}\text { Relator CI: Senador Acir } \\
\text { Gurgacz. Relator ad "ad hoc": } \\
\text { Senador Waldemir Moka. } \\
\text { Relatório: pela aprovação do } \\
\text { PLS no 227, de 2011, com duas } \\
\text { emendas que apresenta. } \\
\text { Relatores CAE: }\end{array}$ & $\begin{array}{l}\text { Parecer CI: aprovado o } \\
\text { Relatório, que passa a } \\
\text { constituir Parecer da } \\
\text { Comissão, pela } \\
\text { aprovação do projeto } \\
\text { com as Emendas no }{ }^{\circ} 01 \\
\text { e } 02 \text { - CI. }\end{array}$ & - & $\begin{array}{l}\text { Aguardando } \\
\text { inclusão em } \\
\text { Ordem do } \\
\text { Dia r o } \\
\text { Requerimento } \\
\mathrm{n}^{\circ} 937, \text { de } \\
2013, \quad \text { de } \\
\text { desapensame }\end{array}$ \\
\hline
\end{tabular}




\begin{tabular}{|c|c|c|c|c|c|c|c|c|}
\hline $\begin{array}{l}\text { Tipo de } \\
\text { Ato }\end{array}$ & Ementa & $\begin{array}{l}\text { Data de } \\
\text { apresenta } \\
\text { ção }\end{array}$ & Autor & Tramitação & Relator/ Parecer/ Relatório ${ }^{227}$ & Pareceres & Vetos & $\begin{array}{l}\text { Andamento } \\
\text { em } 30 \text {-Set- } \\
2014\end{array}$ \\
\hline & $\begin{array}{l}\text { destinados para } \\
\text { prevenção de desastres } \\
\text { naturais ou provocados } \\
\text { por vazamento } \\
\text { radioativo, bem como } \\
\text { para o atendimento das } \\
\text { populações e áreas } \\
\text { atingidas por esses } \\
\text { desastres, e dá outras } \\
\text { providências. OBS: } \\
\text { Trata apenas da } \\
\text { vinculação das receitas } \\
\text { geradas pela } \\
\text { exploração do petróleo. }\end{array}$ & & & & $\begin{array}{l}\text { Lídice da Mata. Relatório: } \\
\text { pela aprovação do Projeto e } \\
\text { pela rejeição das Emendas } \mathrm{n}^{\circ} \mathrm{s} \\
1 \text { e 2-CI, apresentando, ainda, a } \\
\text { Emenda n } \mathrm{n}^{\circ} \quad 3 \text { Alfredo } \\
\text { Nascimento e } \\
\text { Buarque. } \\
\text { Reristovam } \\
\text { Relatora CE: Kátia Abreu. }\end{array}$ & & & $\begin{array}{l}\text { nto do PLS no } \\
138 \text {, de } 2011 \text {, } \\
\text { que tramita } \\
\text { em conjunto } \\
\text { com o PLS n } \\
227 \text {, de } 2011 .\end{array}$ \\
\hline $\begin{array}{l}\text { Projeto } \\
\text { de Lei do } \\
\text { Senado } \\
n^{\circ} 338 \text { de } \\
2011\end{array}$ & $\begin{array}{l}\text { Dispõe sobre royalties } \\
\text { e participação especial } \\
\text { devidos em função da } \\
\text { produção de petróleo, } \\
\text { de gás natural e de } \\
\text { outros hidrocarbonetos } \\
\text { fluidos no mar } \\
\text { territorial, na zona } \\
\text { econômica exclusiva e } \\
\text { na plataforma } \\
\text { continental e sob o } \\
\text { regime de partilha de } \\
\text { produção, instituído } \\
\text { pela Lei no } 12.351 \text {, de } \\
22 \text { de dezembro de } \\
2010 \text {. }\end{array}$ & $15 / 06 / 2011$ & $\begin{array}{l}\text { Senador } \\
\text { Wellington } \\
\text { Dias }\end{array}$ & Senado: CCJ. & - & - & - & 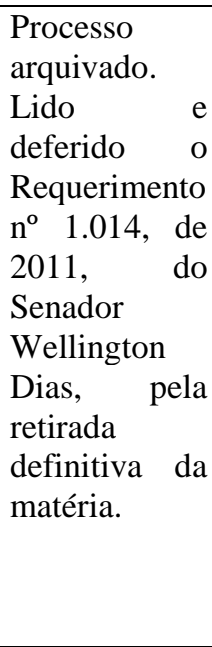 \\
\hline $\begin{array}{l}\text { Projeto } \\
\text { de Lei do } \\
\text { Senado } \\
n^{\circ} 345 \text { de } \\
2011\end{array}$ & $\begin{array}{l}\text { Altera a Lei } n^{\circ} 12.351, \\
\text { de } 22 \text { de dezembro de } \\
2010 \text {, para dispor sobre } \\
\text { os royalties e a receita } \\
\text { da comercialização }\end{array}$ & $16 / 06 / 2011$ & $\begin{array}{l}\text { Senador } \\
\text { Francisco } \\
\text { Dornelles }\end{array}$ & Senado: CCJ & - & - & - & $\begin{array}{lr}\text { Processo } \\
\text { arquivado. } \\
\text { Lido } \quad \mathrm{e} \\
\text { deferido } \quad \text { o } \\
\text { Requerimento }\end{array}$ \\
\hline
\end{tabular}




\begin{tabular}{|c|c|c|c|c|c|c|c|c|}
\hline $\begin{array}{l}\text { Tipo de } \\
\text { Ato }\end{array}$ & Ementa & $\begin{array}{l}\text { Data de } \\
\text { apresenta } \\
\text { cão }\end{array}$ & Autor & Tramitação & Relator/ Parecer/ Relatório $^{227}$ & Pareceres & Vetos & $\begin{array}{l}\text { Andamento } \\
\text { em 30-Set- } \\
2014\end{array}$ \\
\hline & $\begin{array}{l}\text { relativos ao regime de } \\
\text { partilha de produção. }\end{array}$ & & & & & & & $\begin{array}{l}\mathrm{n}^{\circ} 1.151 \text {, de } \\
2011 \text {, pela } \\
\text { retirada } \\
\text { definitiva da } \\
\text { matéria. }\end{array}$ \\
\hline 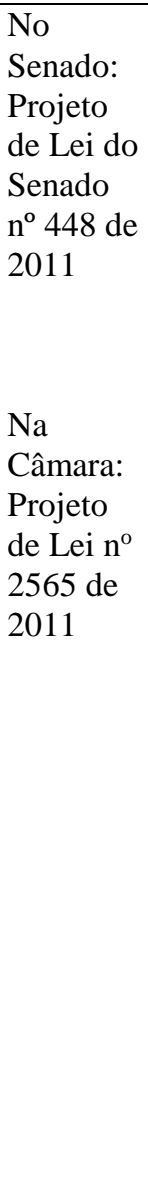 & $\begin{array}{l}\text { Dispõe sobre royalties } \\
\text { e participação especial } \\
\text { devidos em função da } \\
\text { produção de petróleo, } \\
\text { gás natural e outros } \\
\text { hidrocarbonetos fluidos } \\
\text { sob o regime de } \\
\text { concessão no mar } \\
\text { territorial, na zona } \\
\text { econômica exclusiva e } \\
\text { na plataforma } \\
\text { continental, e sobre } \\
\text { royalties devidos sob o } \\
\text { regime de partilha de } \\
\text { produção, instituído } \\
\text { pela Lei no } 12.351, \text { de } \\
22 \text { de dezembro de } \\
2010 .\end{array}$ & 04/08/2011 & $\begin{array}{l}\text { Senador } \\
\text { Wellington } \\
\text { Dias }\end{array}$ & $\begin{array}{l}\text { Senado: CCJ, } \\
\text { CCT e } \\
\text { Plenário. } \\
\\
\text { Câmara: } \\
\text { Plenário. }\end{array}$ & 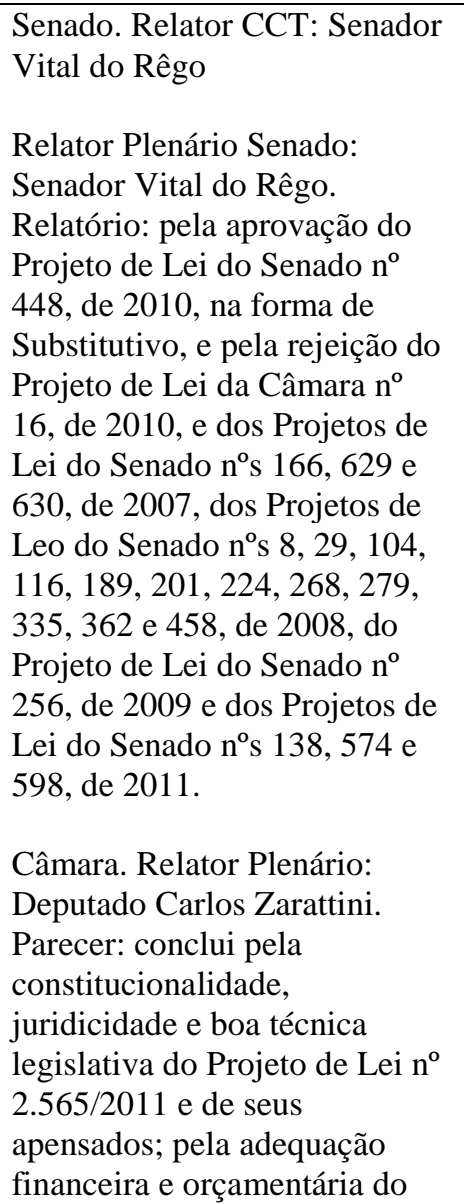 & $\begin{array}{l}\text { Parecer Plenário } \\
\text { Senado: Aprovado o } \\
\text { substitutivo. Rejeitada, } \\
\text { no turno suplementar, a } \\
\text { Emenda no } 19-\text { PLEN. } \\
\text { Rejeitadas, em globo, } \\
\text { no turno suplementar, } \\
\text { as demais emendas, de } \\
\text { parecer contrário. } \\
\\
\text { Parecer Plenário } \\
\text { Câmara: Aprovado o } \\
\text { Projeto de Lei no } \\
\text { 2.565/2011, ressalvados } \\
\text { os destaques. Sim: } 286 ; \\
\text { não: } 124 ; \text { total: } 410 . \text { Em } \\
\text { consequência, fica } \\
\text { prejudicado o } \\
\text { Substitutivo } \\
\text { apresentado pelo } \\
\text { Relator designado em } \\
\text { Plenário, pela Comissão } \\
\text { Especial; e os PLs n }{ }^{\circ} \mathrm{s} \\
\text { 1.618/03, 1.636/03, } \\
\text { 4.887/05, 299/07, } \\
\text { 341/07, 543/07, } \\
1.900 / 07,2.137 / 07, \\
\text { 2.177/07, 3.174/08, } \\
3.589 / 08,4.018 / 08, \\
\text { 4.206/08, 4.476/08, }\end{array}$ & $\begin{array}{l}\text { Veto } \\
\text { parcial. Ve } \\
\text { to } 38 / 2012: \\
\text { vide } \quad \text { MSG } \\
00522 \quad \text { de } \\
2012\end{array}$ & $\begin{array}{l}\text { Processo } \\
\text { arquivado. } \\
\text { Projeto } \\
\text { transformado } \\
\text { em norma } \\
\text { jurídica com } \\
\text { veto parcial: } \\
\text { Lei } 12.734 \text { de } \\
2012 \text {. } \\
\text { Sancionada } \\
\text { em } \\
\text { 30/11/2012. }\end{array}$ \\
\hline
\end{tabular}




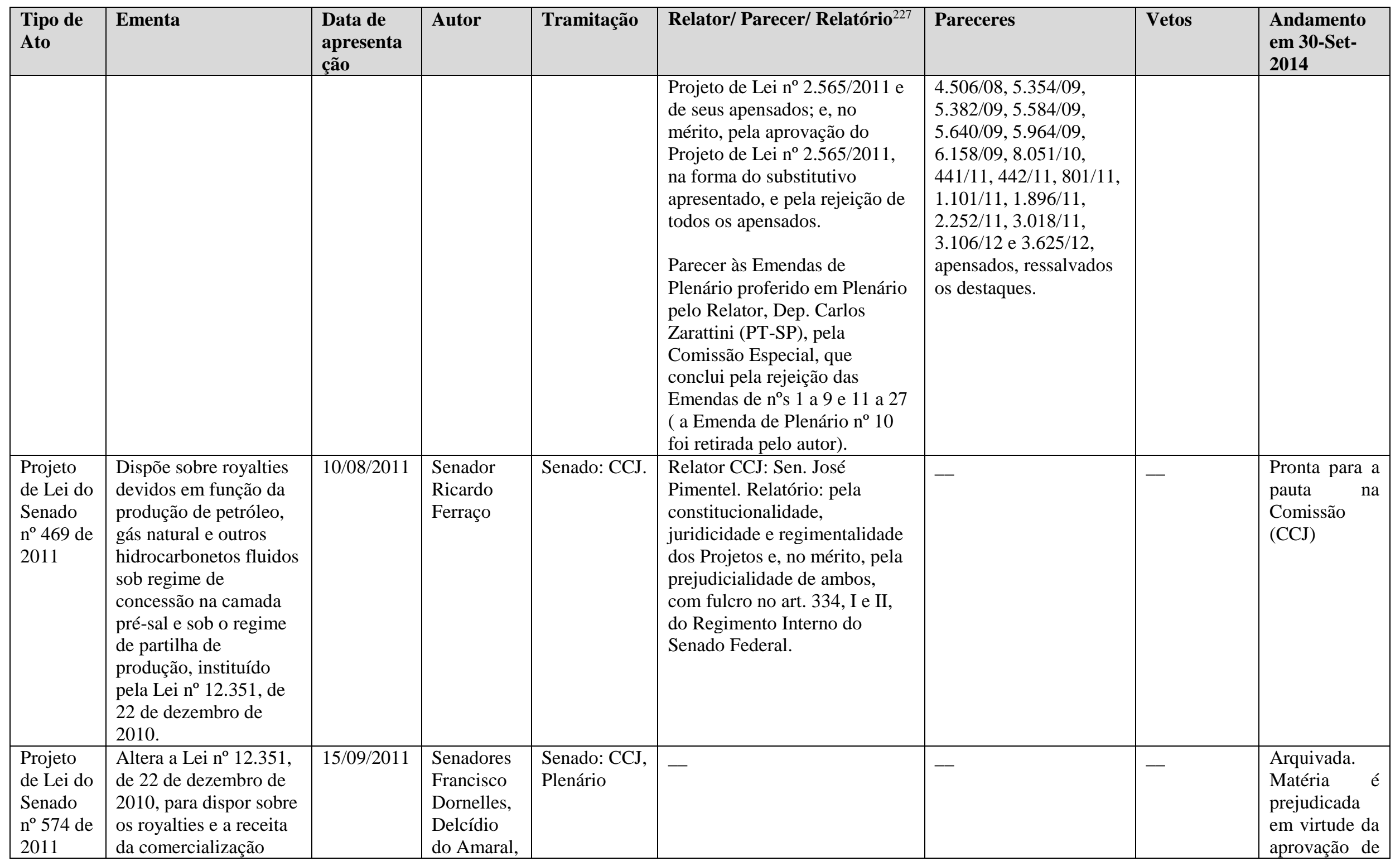




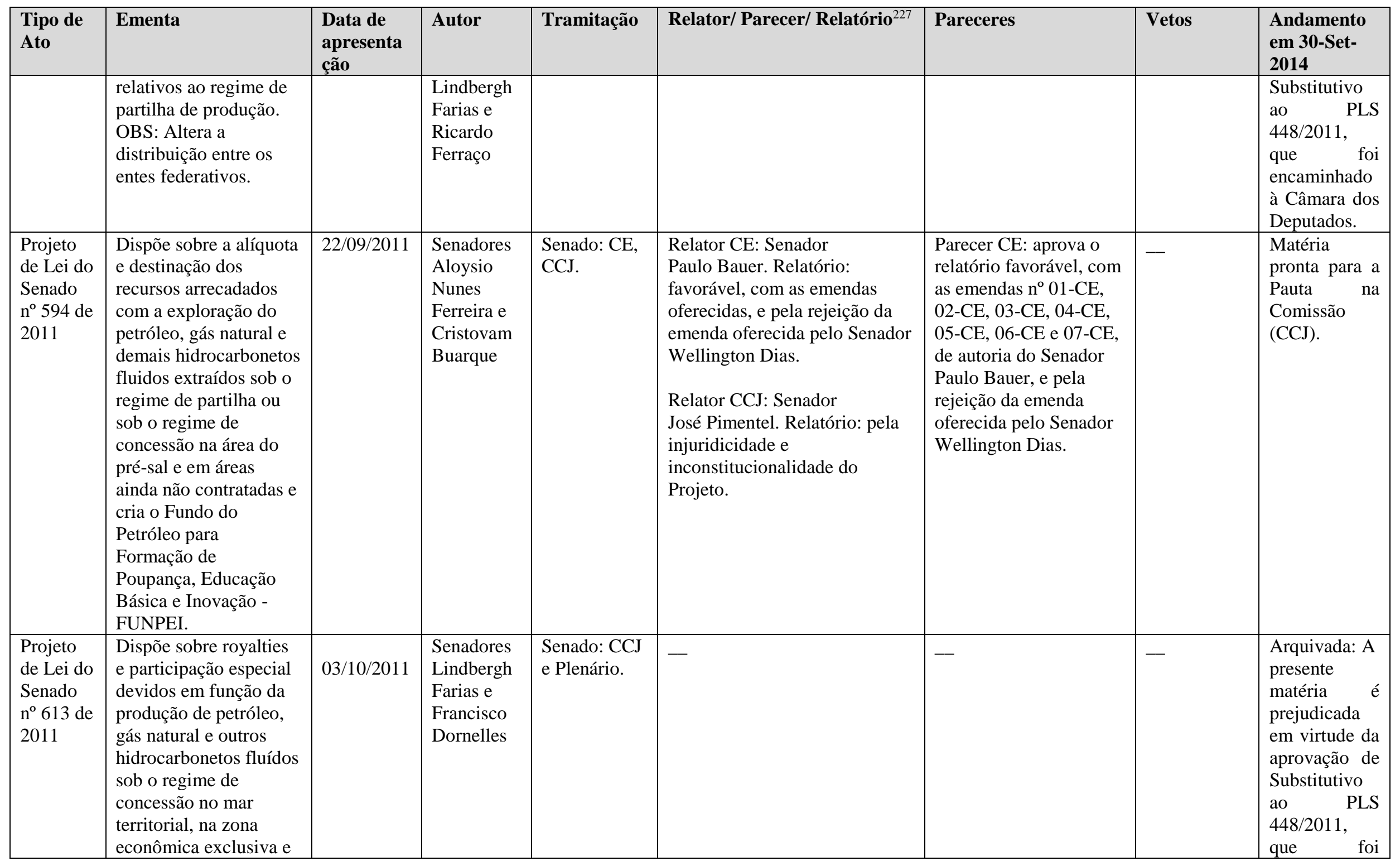




\begin{tabular}{|c|c|c|c|c|c|c|c|c|}
\hline $\begin{array}{l}\text { Tipo de } \\
\text { Ato }\end{array}$ & Ementa & $\begin{array}{l}\text { Data de } \\
\text { apresenta } \\
\text { cão }\end{array}$ & Autor & Tramitação & Relator/ Parecer/ Relatório ${ }^{227}$ & Pareceres & Vetos & $\begin{array}{l}\text { Andamento } \\
\text { em 30-Set- } \\
2014\end{array}$ \\
\hline & $\begin{array}{l}\text { na plataforma } \\
\text { continental, e sobre os } \\
\text { royalties devidos sob o } \\
\text { regime de partilha de } \\
\text { produção, em áreas do } \\
\text { pré-sal e em áreas } \\
\text { estratégicas, instituído } \\
\text { pela Lei no } 12.351 \text {, de } \\
22 \text { de dezembro de } \\
2010, \text { para os Estados, } \\
\text { Distrito Federal, } \\
\text { Municípios e órgãos da } \\
\text { administração direta da } \\
\text { União, e dá outras } \\
\text { providências. }\end{array}$ & & & & & & & $\begin{array}{l}\text { encaminhado } \\
\text { à Câmara dos } \\
\text { Deputados. }\end{array}$ \\
\hline $\begin{array}{l}\text { Projeto } \\
\text { de Lei do } \\
\text { Senado } \\
\text { n }^{\circ} 624 \text { de } \\
2011\end{array}$ & $\begin{array}{l}\text { Dispõe sobre os } \\
\text { royalties devidos em } \\
\text { função da produção de } \\
\text { petróleo, de gás natural } \\
\text { e de outros } \\
\text { hidrocarbonetos fluidos } \\
\text { sob o regime de } \\
\text { partilha de produção, } \\
\text { em áreas do présal e } \\
\text { em áreas estratégicas, } \\
\text { instituído pela Lei no } \\
12.351 \text {, de } 22 \text { de } \\
\text { dezembro de } 2010 .\end{array}$ & $04 / 10 / 2011$ & $\begin{array}{l}\text { Senador } \\
\text { Marcelo } \\
\text { Crivella }\end{array}$ & $\begin{array}{l}\text { Senado: CCJ } \\
\text { e Plenário. }\end{array}$ & - & - & - & $\begin{array}{l}\text { Arquivada: A } \\
\text { presente } \\
\text { matéria é } \\
\text { prejudicada } \\
\text { em virtude da } \\
\text { aprovação de } \\
\text { Substitutivo } \\
\text { ao PLS } \\
448 / 2011, \\
\text { que foi } \\
\text { encaminhado } \\
\text { à Câmara dos } \\
\text { Deputados. }\end{array}$ \\
\hline $\begin{array}{l}\text { Projeto } \\
\text { de Lei do } \\
\text { Senado } \\
\mathrm{n}^{\circ} 625 \text { de } \\
2011\end{array}$ & $\begin{array}{l}\text { Dispõe sobre royalties } \\
\text { devidos em função da } \\
\text { produção de petróleo, } \\
\text { gás natural e outros } \\
\text { hidrocarbonetos fluidos } \\
\text { sob o regime de } \\
\text { partilha de produção e }\end{array}$ & $5 / 10 / 2011$ & $\begin{array}{l}\text { Senadores } \\
\text { Francisco } \\
\text { Dornelles, } \\
\text { Delcídio } \\
\text { Amaral, } \\
\text { Lindbergh } \\
\text { Farias e }\end{array}$ & $\begin{array}{l}\text { Senado: CCJ } \\
\text { e Plenário }\end{array}$ & - & - & - & $\begin{array}{l}\text { Arquivada: A } \\
\text { presente } \\
\text { matéria é } \\
\text { prejudicada } \\
\text { em virtude da } \\
\text { aprovação de } \\
\text { Substitutivo }\end{array}$ \\
\hline
\end{tabular}




\begin{tabular}{|c|c|c|c|c|c|c|c|c|}
\hline $\begin{array}{l}\text { Tipo de } \\
\text { Ato }\end{array}$ & Ementa & $\begin{array}{l}\text { Data de } \\
\text { apresenta } \\
\text { ção }\end{array}$ & Autor & Tramitação & Relator/ Parecer/ Relatório $^{227}$ & Pareceres & Vetos & $\begin{array}{l}\text { Andamento } \\
\text { em 30-Set- } \\
2014\end{array}$ \\
\hline & $\begin{array}{l}\text { sobre receita da União } \\
\text { de comercialização dos } \\
\text { mesmos bens, } \\
\text { instituídos pela Lei no } \\
12.351 \text {, de } 22 \text { de } \\
\text { dezembro de } 2010 \text {, e } \\
\text { sobre participação } \\
\text { especial devida sob o } \\
\text { regime de concessão, } \\
\text { instituído pela Lei no } \\
\text { 9.478, de } 6 \text { de agosto } \\
\text { de } 1997 \text {. }\end{array}$ & & $\begin{array}{l}\text { Ricardo } \\
\text { Ferraço }\end{array}$ & & & & & $\begin{array}{l}\text { ao PLS } \\
448 / 2011 \text {, foi } \\
\text { que en } \\
\text { encaminhado } \\
\text { à Câmara dos } \\
\text { Deputados. }\end{array}$ \\
\hline $\begin{array}{l}\text { Projeto } \\
\text { de Lei do } \\
\text { Senado } \\
\text { n }^{\circ} 634 \text { de } \\
2011\end{array}$ & $\begin{array}{l}\text { Dispõe sobre royalties } \\
\text { e participação especial } \\
\text { devidos em função da } \\
\text { produção de petróleo, } \\
\text { gás natural e outros } \\
\text { hidrocarbonetos fluidos } \\
\text { sob o regime de } \\
\text { concessão no mar } \\
\text { territorial, na zona } \\
\text { econômica exclusiva e } \\
\text { na plataforma } \\
\text { continental, e sobre os } \\
\text { royalties devidos sob o } \\
\text { regime de partilha de } \\
\text { produção, em áreas do } \\
\text { pré-sale em áreas } \\
\text { estratégicas, instituído } \\
\text { pela Lei no 12.351, de } \\
22 \text { de dezembro de } \\
\text { 2010, para os Estados, } \\
\text { Distrito Federal, } \\
\text { Municípios e órgãos da } \\
\text { administração direta da }\end{array}$ & $6 / 10 / 2011$ & $\begin{array}{l}\text { Senador } \\
\text { Lindbergh } \\
\text { Farias }\end{array}$ & $\begin{array}{l}\text { Senado: CCJ } \\
\text { e Plenário }\end{array}$ & $\begin{array}{l}\text { Relator CCJ: Senador José } \\
\text { Pimentel. Relatório: pela } \\
\text { constitucionalidade, } \\
\text { juridicidade e regimentalidade } \\
\text { dos Projetos e, no mérito, pela } \\
\text { prejudicialidade de ambos, } \\
\text { com fulcro no art. 334, I e II, } \\
\text { do Regimento Interno do } \\
\text { Senado Federal. }\end{array}$ & - & - & $\begin{array}{l}\text { Matéria } \\
\text { pronta para a } \\
\text { Pauta na } \\
\text { Comissão } \\
(\text { CCJ). }\end{array}$ \\
\hline
\end{tabular}




\begin{tabular}{|c|c|c|c|c|c|c|c|c|}
\hline $\begin{array}{l}\text { Tipo de } \\
\text { Ato }\end{array}$ & Ementa & $\begin{array}{l}\text { Data de } \\
\text { apresenta } \\
\text { ção }\end{array}$ & Autor & Tramitação & Relator/ Parecer/ Relatório $^{227}$ & Pareceres & Vetos & $\begin{array}{l}\text { Andamento } \\
\text { em 30-Set- } \\
2014\end{array}$ \\
\hline & $\begin{array}{l}\text { União e dá outras } \\
\text { providências. }\end{array}$ & & & & & & & \\
\hline
\end{tabular}




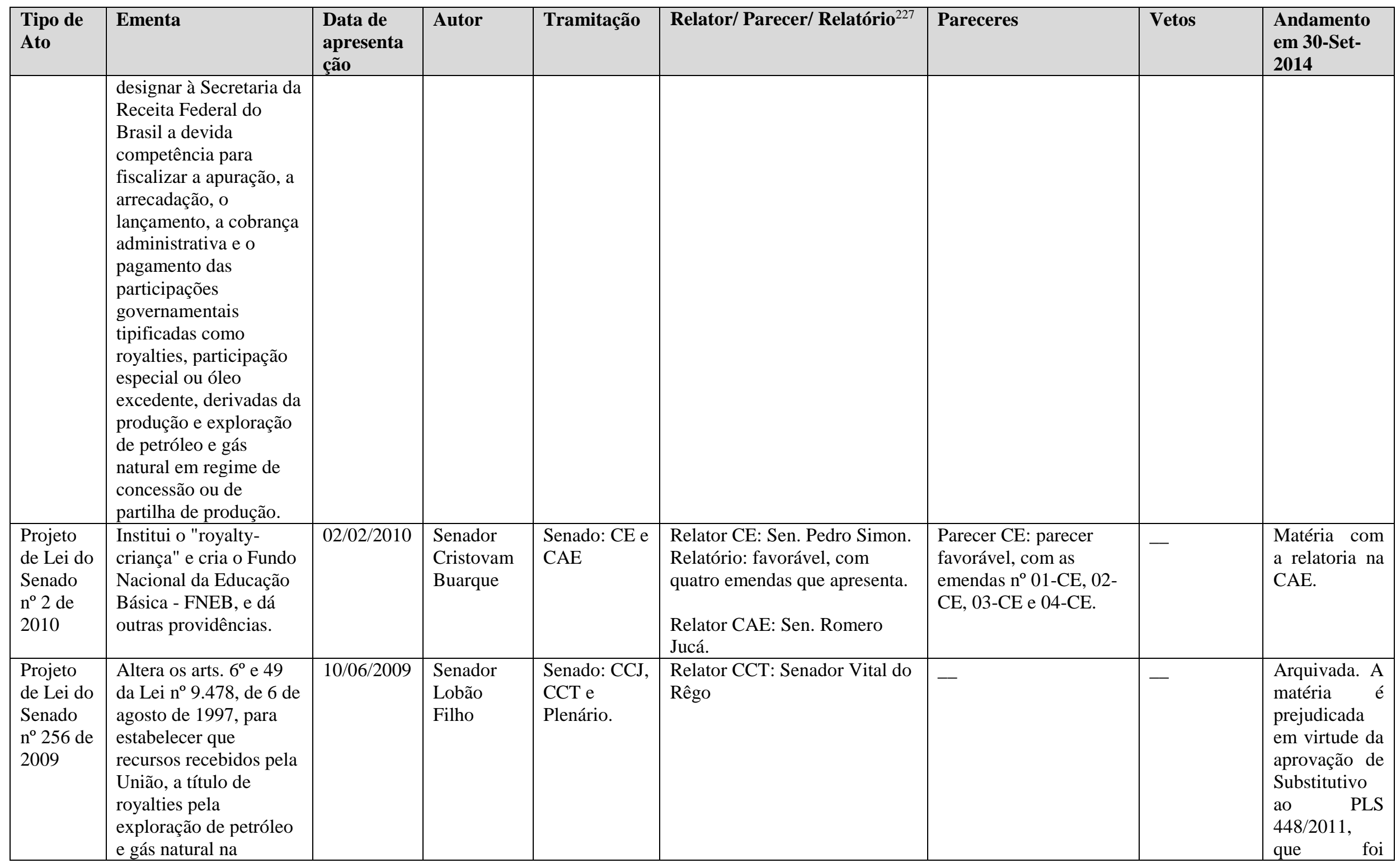




\begin{tabular}{|c|c|c|c|c|c|c|c|c|}
\hline $\begin{array}{l}\text { Tipo de } \\
\text { Ato }\end{array}$ & Ementa & $\begin{array}{l}\text { Data de } \\
\text { apresenta } \\
\text { ção }\end{array}$ & Autor & Tramitação & Relator/ Parecer/ Relatório ${ }^{227}$ & Pareceres & Vetos & $\begin{array}{l}\text { Andamento } \\
\text { em 30-Set- } \\
2014\end{array}$ \\
\hline & $\begin{array}{l}\text { camada pré-sal, sejam } \\
\text { destinados ao Fundo de } \\
\text { Participação dos } \\
\text { Estados e do Distrito } \\
\text { Federal (FPE). }\end{array}$ & & & & & & & $\begin{array}{l}\text { encaminhado } \\
\text { à Câmara dos } \\
\text { Deputados. }\end{array}$ \\
\hline $\begin{array}{l}\text { Projeto } \\
\text { de Lei do } \\
\text { Senado } \\
n^{\circ} 8 \text { de } \\
2008\end{array}$ & $\begin{array}{l}\text { Altera os arts. } 47 \text { e } 49 \\
\text { da Lei no } 9.478 \text {, de } 06 \\
\text { de agosto de } 1997 \text { - Lei } \\
\text { do Petróleo, e insere o } \\
\text { art. 49-A na mesma lei } \\
\text { para destinar parcela } \\
\text { dos royalties à } \\
\text { conservação da floresta } \\
\text { amazônica. }\end{array}$ & $11 / 02 / 2008$ & $\begin{array}{l}\text { Senador } \\
\text { Cristovam } \\
\text { Buarque }\end{array}$ & $\begin{array}{l}\text { Senado: } \\
\text { Comissão de } \\
\text { Meio } \\
\text { Ambiente, } \\
\text { Defesa do } \\
\text { Consumidor } \\
\text { e } \\
\text { Fiscalização } \\
\text { e Controle } \\
\text { (CMA), CCT } \\
\text { e Plenário }\end{array}$ & $\begin{array}{l}\text { Relator CMA: Senador } \\
\text { VALDIR RAUPP. Relatório: } \\
\text { pela rejeição da matéria } \\
\text { Relator CCT: Senador Vital do } \\
\text { Rêgo }\end{array}$ & - & - & $\begin{array}{l}\text { Arquivada. A } \\
\text { matéria é } \\
\text { prejudicada } \\
\text { em virtude da } \\
\text { aprovação de } \\
\text { Substitutivo } \\
\text { ao PLS } \\
448 / 2011, \\
\text { que foi } \\
\text { encaminhado } \\
\text { à Câmara dos } \\
\text { Deputados. }\end{array}$ \\
\hline $\begin{array}{l}\text { Projeto } \\
\text { de Lei do } \\
\text { Senado } \\
n^{\circ} 104 \text { de } \\
2008\end{array}$ & $\begin{array}{l}\text { Altera o inciso II do } \\
\text { art. } 49 \text { da Lei }{ }^{\circ} 9.478, \\
\text { de } 6 \text { de agosto de } 1997, \\
\text { e o parágrafo } 4^{\circ} \text { do art. } \\
27 \text { da Lei } \text { n}^{\circ} 2.004 \text {, de } 3 \\
\text { de outubro de } 1953 \text {, } \\
\text { para prever distribuição } \\
\text { de parcela dos royalties } \\
\text { referentes à lavra de } \\
\text { petróleo ou gás natural } \\
\text { ocorrida em plataforma } \\
\text { continental para o } \\
\text { custeio da Previdência } \\
\text { Social. }\end{array}$ & $27 / 03 / 2008$ & $\begin{array}{l}\text { Senador } \\
\text { Aloizio } \\
\text { Mercadant } \\
\text { e }\end{array}$ & $\begin{array}{l}\text { Senado: CCJ, } \\
\text { CCT e } \\
\text { Plenário }\end{array}$ & $\begin{array}{l}\text { Relator CCT: Senador Vital do } \\
\text { Rêgo }\end{array}$ & - & - & $\begin{array}{l}\text { Arquivada. A } \\
\text { matéria é } \\
\text { prejudicada } \\
\text { em virtude da } \\
\text { aprovação de } \\
\text { Substitutivo } \\
\text { ao PLS } \\
448 / 2011, \\
\text { que foi } \\
\text { encaminhado } \\
\text { à Câmara dos } \\
\text { Deputados. }\end{array}$ \\
\hline $\begin{array}{l}\text { Projeto } \\
\text { de Lei do } \\
\text { Senado } \\
\mathrm{n}^{\circ} 116 \text { de }\end{array}$ & $\begin{array}{l}\text { Acrescenta art. 52-A à } \\
\text { Lei no } 9.478, \text { de } 6 \text { de } \\
\text { agosto de 1997, para } \\
\text { estabelecer que os }\end{array}$ & $03 / 04 / 2008$ & $\begin{array}{l}\text { Senador } \\
\text { Cristovam } \\
\text { Buarque }\end{array}$ & $\begin{array}{l}\text { Senado: CE, } \\
\text { CCT e } \\
\text { Plenário. }\end{array}$ & $\begin{array}{l}\text { Relator CE: Senador } \\
\text { Marco Antônio Costa. } \\
\text { Relatório: pela aprovação do } \\
\text { Projeto. }\end{array}$ & - & - & $\begin{array}{l}\text { Arquivada. A } \\
\text { matéria é } \\
\text { prejudicada } \\
\text { em virtude da }\end{array}$ \\
\hline
\end{tabular}




\begin{tabular}{|c|c|c|c|c|c|c|c|c|}
\hline $\begin{array}{l}\text { Tipo de } \\
\text { Ato }\end{array}$ & Ementa & $\begin{array}{l}\text { Data de } \\
\text { apresenta } \\
\text { ção }\end{array}$ & Autor & Tramitação & Relator/ Parecer/ Relatório ${ }^{227}$ & Pareceres & Vetos & $\begin{array}{l}\text { Andamento } \\
\text { em 30-Set- } \\
2014\end{array}$ \\
\hline 2008 & $\begin{array}{l}\text { recursos recebidos por } \\
\text { Estados e Municípios a } \\
\text { título de royalties pela } \\
\text { exploração de petróleo } \\
\text { serão aplicados, } \\
\text { exclusivamente, em } \\
\text { ações e programas } \\
\text { públicos de educação } \\
\text { de base e de ciência e } \\
\text { tecnologia. }\end{array}$ & & & & $\begin{array}{l}\text { Relator CCT: Senador Vital do } \\
\text { Rêgo. }\end{array}$ & & & $\begin{array}{l}\text { aprovação de } \\
\text { Substitutivo } \\
\text { ao PLS } \\
448 / 2011 \text {, } \\
\text { que foi } \\
\text { encaminhado } \\
\text { à Câmara dos } \\
\text { Deputados. }\end{array}$ \\
\hline $\begin{array}{l}\text { Projeto } \\
\text { de Lei do } \\
\text { Senado } \\
\mathrm{n}^{\circ} 224 \text { de } \\
2008\end{array}$ & $\begin{array}{l}\text { Altera a Lei no } 9.478, \\
\text { de 06 de agosto de } \\
1997, \text { que "dispõe } \\
\text { sobre a política } \\
\text { energética nacional, as } \\
\text { atividades relativas ao } \\
\text { monopólio do petróleo, } \\
\text { institui o Conselho } \\
\text { Nacional de Política } \\
\text { Energética e a Agência } \\
\text { Nacional do Petróleo e } \\
\text { dá outras } \\
\text { providências", para } \\
\text { introduzir mudanças } \\
\text { nas regras de } \\
\text { distribuição dos } \\
\text { royalties provenientes } \\
\text { da exploração de } \\
\text { petróleo e de gás } \\
\text { natural na região } \\
\text { conhecida como Pré- } \\
\text { sal no mar territorial } \\
\text { brasileiro. }\end{array}$ & $04 / 06 / 2008$ & $\begin{array}{l}\text { Senador } \\
\text { João Pedro }\end{array}$ & $\begin{array}{l}\text { Senado: CI, } \\
\text { CCT e } \\
\text { Plenário. }\end{array}$ & $\begin{array}{l}\text { Relator CI: Senador } \\
\text { Heráclito Fortes. } \\
\text { Relator CCT: Senador Vital do } \\
\text { Rêgo. }\end{array}$ & - & - & $\begin{array}{l}\text { Arquivada. A } \\
\text { matéria é } \\
\text { prejudicada } \\
\text { em virtude da } \\
\text { aprovação de } \\
\text { Substitutivo } \\
\text { ao PLS } \\
448 / 2011, \\
\text { que foi } \\
\text { encaminhado } \\
\text { à Câmara dos } \\
\text { Deputados. }\end{array}$ \\
\hline $\begin{array}{l}\text { Projeto } \\
\text { de Lei do }\end{array}$ & $\begin{array}{l}\text { Cria o Fundo Nacional } \\
\text { do Petróleo para }\end{array}$ & $02 / 07 / 2008$ & $\begin{array}{l}\text { Senador } \\
\text { Tasso }\end{array}$ & $\begin{array}{l}\text { Senado: CI e } \\
\text { CCT. }\end{array}$ & $\begin{array}{l}\text { Relator CI: } \\
\text { Senador Francisco Dornelles. }\end{array}$ & - & - & $\begin{array}{ll}\text { Arquivada. } & \text { A } \\
\text { matéria } & \text { é }\end{array}$ \\
\hline
\end{tabular}




\begin{tabular}{|c|c|c|c|c|c|c|c|c|}
\hline $\begin{array}{l}\text { Tipo de } \\
\text { Ato }\end{array}$ & Ementa & $\begin{array}{l}\text { Data de } \\
\text { apresenta } \\
\text { ção }\end{array}$ & Autor & Tramitação & Relator/ Parecer/ Relatório ${ }^{227}$ & Pareceres & Vetos & $\begin{array}{l}\text { Andamento } \\
\text { em 30-Set- } \\
2014\end{array}$ \\
\hline $\begin{array}{l}\text { Senado } \\
n^{\circ} 268 \text { de } \\
2008\end{array}$ & $\begin{array}{l}\text { Formação de Poupança } \\
\text { e Desenvolvimento da } \\
\text { Educação Básica e } \\
\text { altera a Lei nº } 9.478 \text {, de } \\
6 \text { de agosto de } 1997, \\
\text { para determinar nova } \\
\text { distribuição dos } \\
\text { royalties e da } \\
\text { participação especial } \\
\text { decorrentes da } \\
\text { exploração de petróleo } \\
\text { e gás natural entre os } \\
\text { entes federativos. }\end{array}$ & & Jereissati & & Relator CCT: Vital do Rêgo & & & $\begin{array}{l}\text { prejudicada } \\
\text { em virtude da } \\
\text { aprovação de } \\
\text { Substitutivo } \\
\text { ao PLS } \\
448 / 2011, \\
\text { que foi } \\
\text { encaminhado } \\
\text { à Câmara dos } \\
\text { Deputados. }\end{array}$ \\
\hline $\begin{array}{l}\text { Projeto } \\
\text { de Lei do } \\
\text { Senado } \\
\text { n }^{\circ} 362 \text { de } \\
2008\end{array}$ & $\begin{array}{l}\text { Altera os arts. } 6^{\circ} \text { e } 49 \\
\text { da Lei no } 9.478 \text {, de } 6 \text { de } \\
\text { agosto de } 1997 \text {, para } \\
\text { estabelecer que } \\
\text { recursos recebidos pela } \\
\text { União, a título de } \\
\text { royalties pela } \\
\text { exploração de petróleo } \\
\text { na camada de pré-sal, } \\
\text { serão destinados } \\
\text { parcialmente à área de } \\
\text { saúde, à previdência } \\
\text { social e ao FUNDEB. }\end{array}$ & $07 / 10 / 2008$ & $\begin{array}{l}\text { Senador } \\
\text { Paulo Paim }\end{array}$ & $\begin{array}{l}\text { Senado: } \\
\text { CAS, CCT e } \\
\text { Plenário }\end{array}$ & $\begin{array}{l}\text { Relator CCT: Senador Vital do } \\
\text { Rêgo }\end{array}$ & - & - & $\begin{array}{l}\text { Arquivada. A } \\
\text { matéria é } \\
\text { prejudicada } \\
\text { em virtude da } \\
\text { aprovação de } \\
\text { Substitutivo } \\
\text { ao PLS } \\
448 / 2011, \\
\text { que foi } \\
\text { encaminhado } \\
\text { à Câmara dos } \\
\text { Deputados. }\end{array}$ \\
\hline $\begin{array}{l}\text { Projeto } \\
\text { de Lei do } \\
\text { Senado } \\
n^{\circ} 458 \text { de } \\
2008\end{array}$ & $\begin{array}{l}\text { Altera o inciso II do } \\
\text { artigo } 49 \text { da Lei no } \\
9.478, \text { de } 6 \text { de agosto } \\
\text { de } 1997 \text {, dando nova } \\
\text { distribuição de parcela } \\
\text { dos royalties referentes } \\
\text { à lavra de petróleo ou } \\
\text { gás natural ocorrida em } \\
\text { plataforma continental. }\end{array}$ & $01 / 12 / 2008$ & $\begin{array}{l}\text { Senadora } \\
\text { Serys } \\
\text { Slhessaren } \\
\text { ko }\end{array}$ & $\begin{array}{l}\text { Senado: } \\
\text { CAE, CCT e } \\
\text { Plenário }\end{array}$ & $\begin{array}{l}\text { Relator CCT: Senador Vital do } \\
\text { Rêgo }\end{array}$ & - & - & $\begin{array}{l}\text { Arquivada. A } \\
\text { matéria é } \\
\text { prejudicada } \\
\text { em virtude da } \\
\text { aprovação de } \\
\text { Substitutivo } \\
\text { ao PLS } \\
448 / 2011, \\
\text { que foi }\end{array}$ \\
\hline
\end{tabular}




\begin{tabular}{|c|c|c|c|c|c|c|c|c|}
\hline $\begin{array}{l}\text { Tipo de } \\
\text { Ato }\end{array}$ & Ementa & $\begin{array}{l}\text { Data de } \\
\text { apresenta } \\
\text { cão }\end{array}$ & Autor & Tramitação & Relator/ Parecer/ Relatório ${ }^{227}$ & Pareceres & Vetos & $\begin{array}{l}\text { Andamento } \\
\text { em 30-Set- } \\
2014\end{array}$ \\
\hline & & & & & & & & $\begin{array}{l}\text { encaminhado } \\
\text { à Câmara dos } \\
\text { Deputados. }\end{array}$ \\
\hline $\begin{array}{l}\text { Projeto } \\
\text { de Lei do } \\
\text { Senado } \\
n^{\circ} 166 \text { de } \\
2007\end{array}$ & $\begin{array}{l}\text { Altera a Lei no } 9.478, \\
\text { de } 6 \text { de agosto de } 1997 . \\
\text { (Critérios de } \\
\text { distribuição de } \\
\text { royalties). }\end{array}$ & $28 / 03 / 2007$ & $\begin{array}{l}\text { Senador } \\
\text { João } \\
\text { Vicente } \\
\text { Claudino }\end{array}$ & $\begin{array}{l}\text { Senado: } \\
\text { CAE, CCT, } \\
\text { Plenário }\end{array}$ & $\begin{array}{l}\text { Relator CAE: Senador } \\
\text { Jefferson Peres. Relatório: pela } \\
\text { rejeição do Projeto } \\
\text { Relator CCT: Senador Vital do } \\
\text { Rêgo }\end{array}$ & - & - & $\begin{array}{l}\text { Arquivada. A } \\
\text { matéria é } \\
\text { prejudicada } \\
\text { em virtude da } \\
\text { aprovação de } \\
\text { Substitutivo } \\
\text { ao PLS } \\
448 / 2011, \\
\text { que foi } \\
\text { encaminhado } \\
\text { à Câmara dos } \\
\text { Deputados. }\end{array}$ \\
\hline $\begin{array}{l}\text { Projeto } \\
\text { de Lei do } \\
\text { Senado } \\
n^{\circ} 270 \text { de } \\
2000\end{array}$ & $\begin{array}{l}\text { Altera dispositivos da } \\
\text { Lei no } 9478, \text { de } 06 \text { de } \\
\text { agosto de } 1997, \text { que } \\
\text { dispõe sobre a } \\
\text { compensação } \\
\text { financeira aos Estados, } \\
\text { Distrito Federal e } \\
\text { Municípios pelo } \\
\text { resultado da exploração } \\
\text { e da produção de } \\
\text { petróleo e gás natural. }\end{array}$ & $13 / 12 / 2000$ & $\begin{array}{l}\text { Senador } \\
\text { Ricardo } \\
\text { Santos }\end{array}$ & $\begin{array}{l}\text { Senado: } \\
\text { CAE }\end{array}$ & $\begin{array}{l}\text { Relator CAE: Senador José } \\
\text { Agripino. Relatório: favorável } \\
\text { ao projeto com a Emenda } \mathrm{N}^{\circ} 1 \\
\text { que apresenta. Relator ad hoc: } \\
\text { Senador Romero Jucá. } \\
\text { Relatório: A pedido do relator } \\
\text { foi retirada a Emenda } \mathrm{n}^{\circ} 01 \text {. A } \\
\text { Comissão aprova o Projeto } \\
\text { com a Emenda } \mathrm{n}^{\circ} 02 \text {-CAE. }\end{array}$ & $\begin{array}{l}\text { Parecer CAE: A } \\
\text { Comissão aprova o } \\
\text { Projeto com a Emenda } \\
\mathrm{n}^{\circ} \text { 02-CAE. }\end{array}$ & - & $\begin{array}{l}\text { Matéria } \\
\text { arquivada ao } \\
\text { final da } 52^{\mathrm{a}} \\
\text { Legislatura, } \\
\text { nos termos do } \\
\text { art. } 332 \text { do } \\
\text { Regimento } \\
\text { Interno e do } \\
\text { Ato } \mathrm{n}^{\circ} 97 \text { de } \\
2002 \text { do } \\
\text { Presidente do } \\
\text { Senado } \\
\text { Federal. }\end{array}$ \\
\hline $\begin{array}{l}\text { Veto } \mathrm{n}^{\circ} \\
38 \mathrm{de} \\
2012\end{array}$ & $\begin{array}{l}\text { Veto Parcial aposto ao } \\
\text { Projeto de Lei do } \\
\text { Senado } \mathrm{n}^{\circ} 448, \text { de } 2011 \\
\left(\mathrm{n}^{\circ} 2.5652011, \text { na }\right. \\
\text { Câmara dos } \\
\text { Deputados), que } \\
\text { "Modifica as Leis } \mathrm{n}^{\circ} \mathrm{s}\end{array}$ & $30 / 11 / 2012$ & $\begin{array}{l}\text { Presidente } \\
\text { da } \\
\text { República }\end{array}$ & $\begin{array}{l}\text { Plenário do } \\
\text { Congresso }\end{array}$ & - & $\begin{array}{l}\text { VETO DERRUBADO } \\
\text { em sessão conjunta do } \\
\text { Congresso de } 6 / 3 / 13 \text {. }\end{array}$ & - & Arquivado. \\
\hline
\end{tabular}




\begin{tabular}{|c|c|c|c|c|c|c|c|c|}
\hline $\begin{array}{l}\text { Tipo de } \\
\text { Ato }\end{array}$ & Ementa & $\begin{array}{l}\text { Data de } \\
\text { apresenta } \\
\text { ção }\end{array}$ & Autor & Tramitação & Relator/ Parecer/ Relatório $^{227}$ & Pareceres & Vetos & $\begin{array}{l}\text { Andamento } \\
\text { em 30-Set- } \\
2014\end{array}$ \\
\hline & $\begin{array}{l}\text { 9.478, de } 6 \text { de agosto } \\
\text { de } 1997 \text {, e no } 12.351, \\
\text { de } 22 \text { de dezembro de } \\
2010 \text {, para determinar } \\
\text { novas regras de } \\
\text { distribuição entre os } \\
\text { entes da Federação dos } \\
\text { royalties e da } \\
\text { participação especial } \\
\text { devidos em função da } \\
\text { exploração de petróleo, } \\
\text { gás natural e outros } \\
\text { hidrocarbonetos } \\
\text { fluidos, e para } \\
\text { aprimorar o marco } \\
\text { regulatório sobre a } \\
\text { exploração desses } \\
\text { recursos no regime de } \\
\text { partilha". }\end{array}$ & & & & & & & \\
\hline
\end{tabular}




\begin{tabular}{|c|c|c|c|c|c|c|c|c|}
\hline $\begin{array}{l}\text { Tipo de } \\
\text { Ato }\end{array}$ & Ementa & $\begin{array}{l}\text { Data de } \\
\text { apresenta } \\
\text { ção }\end{array}$ & Autor & Tramitação & Relator/ Parecer/ Relatório ${ }^{227}$ & Pareceres & Vetos & $\begin{array}{l}\text { Andamento } \\
\text { em 30-Set- } \\
2014\end{array}$ \\
\hline & & & & & & & & $\begin{array}{l}\text { Proposta de } \\
\text { Emenda à } \\
\text { Constituição } \\
\text { n. 220/2012 e } \\
\text { a Proposta de } \\
\text { Emenda à } \\
\text { Constituição } \\
\text { n. 545/2006 } \\
\text { tratam de } \\
\text { matérias } \\
\text { correlatas. } \\
\text { Publique-se. } \\
\text { Oficie-se }\end{array}$ \\
\hline $\begin{array}{l}\text { Projeto } \\
\text { de Lei da } \\
\text { Câmara } \\
\text { no }^{\circ} 4711 \\
\text { de } 2012\end{array}$ & $\begin{array}{l}\text { Determina que os } \\
\text { recursos oriundos da } \\
\text { distribuição dos } \\
\text { Royalties do Petróleo e } \\
\text { Participação Especial } \\
\text { sejam obrigatoriamente } \\
\text { aplicados em } \\
\text { Educação. }\end{array}$ & $13 / 11 / 2012$ & $\begin{array}{l}\text { Deputado } \\
\text { Otávio } \\
\text { Leite }\end{array}$ & $\begin{array}{l}\text { Câmara: } \\
\text { Proposição } \\
\text { sujeita à } \\
\text { apreciação } \\
\text { do Plenário }\end{array}$ & - & - & - & $\begin{array}{l}\text { 10/4/2013: } \\
\text { Apense-se } \\
\text { à(ao) PL- PL- } \\
4671 / 2012 . P r \\
\text { oposição } \\
\text { Sujeita à } \\
\text { Apreciação } \\
\text { do Plenário. } \\
\text { Regime de } \\
\text { Tramitação: } \\
\text { Ordinária }\end{array}$ \\
\hline $\begin{array}{l}\text { Projeto } \\
\text { de Lei da } \\
\text { Câmara } \\
n^{\circ} 3106 \\
\text { de } 2012\end{array}$ & $\begin{array}{l}\text { Dispõe sobre a divisão } \\
\text { dos royalties devidos } \\
\text { pela produção de } \\
\text { petróleo e gás natural } \\
\text { em áreas do pré-sal e } \\
\text { em áreas estratégicas } \\
\text { localizadas na } \\
\text { plataforma continental. }\end{array}$ & $02 / 02 / 2012$ & $\begin{array}{l}\text { Deputado } \\
\text { Roberto de } \\
\text { Lucena }\end{array}$ & $\begin{array}{l}\text { Câmara: } \\
\text { Plenário }\end{array}$ & - & - & - & $\begin{array}{l}\text { Declarado } \\
\text { prejudicado } \\
\text { em face da } \\
\text { aprovação do } \\
\text { PL no } \\
\text { 2.565/2011, } \\
\text { principal. }\end{array}$ \\
\hline $\begin{array}{l}\text { Projeto } \\
\text { de Lei da } \\
\text { Câmara }\end{array}$ & $\begin{array}{l}\text { Dispõe sobre os } \\
\text { royalties devidos em } \\
\text { função da produção de }\end{array}$ & $13 / 09 / 2011$ & $\begin{array}{l}\text { Deputado } \\
\text { Júlio César }\end{array}$ & $\begin{array}{l}\text { Câmara: } \\
\text { Comissão de } \\
\text { Minas e }\end{array}$ & - & - & - & $\begin{array}{l}\text { Declarado } \\
\text { prejudicado } \\
\text { em face da }\end{array}$ \\
\hline
\end{tabular}




\begin{tabular}{|c|c|c|c|c|c|c|c|c|}
\hline $\begin{array}{l}\text { Tipo de } \\
\text { Ato }\end{array}$ & Ementa & $\begin{array}{l}\text { Data de } \\
\text { apresenta } \\
\text { ção }\end{array}$ & Autor & Tramitação & Relator/ Parecer/ Relatório $^{227}$ & Pareceres & Vetos & $\begin{array}{l}\text { Andamento } \\
\text { em 30-Set- } \\
2014\end{array}$ \\
\hline $\begin{array}{l}\mathrm{n}^{\circ} 2252 \\
\text { de } 2011\end{array}$ & $\begin{array}{l}\text { petróleo, de gás natural } \\
\text { e de outros } \\
\text { hidrocarbonetos fluidos } \\
\text { sob o regime de } \\
\text { partilha de produção e } \\
\text { sobre a distribuição dos } \\
\text { royalties e da } \\
\text { participação especial } \\
\text { devidos pelo titular de } \\
\text { área situada no pré-sal } \\
\text { contratada sob o } \\
\text { regime de concessão e } \\
\text { sobre a distribuição dos } \\
\text { royalties devidos pela } \\
\text { Petróleo Brasileiro S.A } \\
\text { - Petrobras referente às } \\
\text { áreas objeto do } \\
\text { contrato de cessão } \\
\text { onerosa celebrado entre } \\
\text { a União e essa estatal, e } \\
\text { dá outras providências. }\end{array}$ & & & $\begin{array}{l}\text { Energia e } \\
\text { Plenário }\end{array}$ & & & & $\begin{array}{l}\text { aprovação do } \\
\text { PL n } \\
2.565 / 2011, \\
\text { principal. }\end{array}$ \\
\hline
\end{tabular}




\begin{tabular}{|c|c|c|c|c|c|c|c|c|}
\hline $\begin{array}{l}\text { Tipo de } \\
\text { Ato }\end{array}$ & Ementa & $\begin{array}{l}\text { Data de } \\
\text { apresenta } \\
\text { cão }\end{array}$ & Autor & Tramitação & Relator/ Parecer/ Relatório ${ }^{227}$ & Pareceres & Vetos & $\begin{array}{l}\text { Andamento } \\
\text { em 30-Set- } \\
2014\end{array}$ \\
\hline & $\begin{array}{l}\text { Distrito Federal, } \\
\text { Municípios e órgãos da } \\
\text { administração direta da } \\
\text { União, e dá outras } \\
\text { providências. }\end{array}$ & & & & & & & \\
\hline $\begin{array}{l}\text { Projeto } \\
\text { de Lei da } \\
\text { Câmara } \\
\mathrm{n}^{\circ} \quad 4476 \\
\text { de } 2008\end{array}$ & 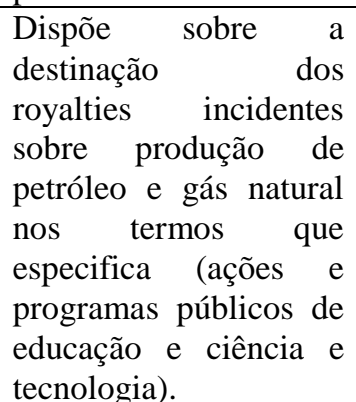 & $10 / 12 / 2008$ & $\begin{array}{l}\text { Deputado } \\
\text { Henrique } \\
\text { Fontana }\end{array}$ & $\begin{array}{l}\text { Câmara: } \\
\text { CME } \\
\text { Plenário. }\end{array}$ & - & - & - & $\begin{array}{l}\text { Declarado } \\
\text { prejudicado } \\
\text { em face da } \\
\text { aprovação do } \\
\text { PL no } \\
2.565 / 2011, \\
\text { principal. }\end{array}$ \\
\hline $\begin{array}{l}\text { Projeto } \\
\text { de Lei da } \\
\text { Câmara } \\
\mathrm{n}^{\circ} \quad 1678 \\
\text { de } 2003\end{array}$ & $\begin{array}{l}\text { Obriga os Estados, } \\
\text { Territórios r e } \\
\text { Municípios a aplicarem } \\
20 \% \text { (vinte por cento) } \\
\text { da arrecadação em } \\
\text { royalties do petróleo, } \\
\text { na proteção ao meio } \\
\text { ambiente. }\end{array}$ & $12 / 08 / 2003$ & $\begin{array}{l}\text { Dep. } \\
\text { Eduardo } \\
\text { Paes }\end{array}$ & - & - & - & - & $\begin{array}{l}\text { Devolvido ao } \\
\text { autor, nos } \\
\text { termos do } \\
\text { artigo } 137, \S \\
1^{\circ} \text { do RI. }\end{array}$ \\
\hline $\begin{array}{l}\text { Projeto } \\
\text { de Lei da } \\
\text { Câmara } \\
\mathrm{n}^{\circ} \quad 1550 \\
\text { de } 1989\end{array}$ & $\begin{array}{l}\text { Dispõe sobre a } \\
\text { participação dos } \\
\text { estados, do distrito } \\
\text { federal e dos órgãos da } \\
\text { administração direta da } \\
\text { união, no resultado da } \\
\text { exploração do petróleo } \\
\text { (artigo 20, parágrafo } \\
\text { primeiro } \\
\text { constituição federal). }\end{array}$ & $23 / 02 / 1989$ & $\begin{array}{l}\text { Dep. Jorge } \\
\text { Arbage }\end{array}$ & $\begin{array}{l}\text { Câmara: } \\
\text { CCJC, CME } \\
\text { e Plenário }\end{array}$ & $\begin{array}{l}\text { Relator CCJC: Dep. } \\
\text { Chaves. Ploysio } \\
\text { constitucionalidader } \\
\text { juridicidade pela } \\
\text { legislativa. } \\
\text { Relator CME: Dep. Antonio } \\
\text { Perosa. }\end{array}$ & $\begin{array}{l}\text { Parecer CCJC: pela } \\
\text { constitucionalidade, } \\
\text { juridicidade e técnica } \\
\text { legislativa. }\end{array}$ & - & $\begin{array}{l}\text { Prejudicado } \\
\text { pela } \\
\text { aprovação da } \\
\text { emenda } \\
\text { aglutinativa } \\
\text { ao PL n } \\
\text { 3931/89. }\end{array}$ \\
\hline
\end{tabular}


TABELA 2 - PROCESSOS JUDICIAIS RELEVANTES

\begin{tabular}{|c|c|c|c|c|c|c|c|c|}
\hline $\begin{array}{l}\mathbf{N}^{0} \text { da } \\
\text { Ação }\end{array}$ & $\begin{array}{l}\text { Demandant } \\
\text { e }\end{array}$ & Demandado & Tipo de Ação & $\begin{array}{l}\text { Data } \\
\text { ajuizamento }\end{array}$ & Outros atores processuais & Decisões judiciais & $\begin{array}{l}\text { Peças } \\
\text { processuais }\end{array}$ & $\begin{array}{l}\text { Andament } \\
\text { o em } 30 \\
\text { set. } 2014\end{array}$ \\
\hline $\begin{array}{l}\text { ADI } \\
4917- \\
\text { Medida } \\
\text { Cautelar }\end{array}$ & $\begin{array}{l}\text { Governador } \\
\text { do Estado } \\
\text { Rio de } \\
\text { Janeiro }\end{array}$ & $\begin{array}{l}\text { Presidente } \\
\text { da República } \\
\text { e Congresso } \\
\text { Nacional }\end{array}$ & $\begin{array}{l}\text { Medida Cautelar em } \\
\text { Ação Direta de } \\
\text { Inconstitucionalidade }\end{array}$ & $15 / 3 / 2013$ & $\begin{array}{l}\text { Ministério Público Federal. } \\
\text { Amici curiae: Rio Grande do } \\
\text { Sul; Paraíba; Alagoas; Mato } \\
\text { Grosso do Sul; Goiás; Bahia; } \\
\text { Paraná; Confederação } \\
\text { Nacional de Municípios - } \\
\text { CNM; Associação dos } \\
\text { Municípios Excluídos do } \\
\text { Rol dos Recebedores de } \\
\text { Royalties do Petróleo e Gás } \\
\text { - Amroy; Organização dos } \\
\text { Municípios Produtores de } \\
\text { Petróleo e Gás e Limítrofes } \\
\text { da Zona de Produção } \\
\text { Principal da Bacia de } \\
\text { Campos, Estado do Rio de } \\
\text { Janeiro - Ompetro; } \\
\text { Associação Brasileira dos } \\
\text { Municípios com Terminais } \\
\text { Marítimos, Fluviais e } \\
\text { Terrestres de Embarque e } \\
\text { Desembarque de Petróleo e } \\
\text { Gás Natural - Abramt; } \\
\text { Ordem dos Advogados do } \\
\text { Brasil - Seção do Estado do } \\
\text { Rio de Janeiro; Associação } \\
\text { dos Municípios Produtores } \\
\text { de Gás Natural, Petróleo, } \\
\text { Possuidores de Gasodutos, } \\
\text { Oleodutos, Áreas de } \\
\text { Tancagem, Estação de } \\
\text { Bombeamento e Zona de } \\
\text { Influência da Bacia de }\end{array}$ & $\begin{array}{l}\text { Medida cautelar deferida } \\
\text { para suspender os efeitos dos } \\
\text { arts. 42-B; 42-C; 48, II; 49, } \\
\text { II; 49-A; 49-B; 49-C; } § 2^{\circ} \text { do } \\
\text { art. 50; 50-A; 50-B; } \\
\text { 50-C; 50-D; e 50-E da Lei } \\
\text { Federal n. 9.478/97, com as } \\
\text { alterações } \\
\text { promovidas pela Lei n. } \\
\text { 12.734/2012. DJE de } \\
\text { 20/3/2013. }\end{array}$ & $\begin{array}{l}\text { Petição inicial. } \\
\text { Agravo } \\
\text { Regimental - } \\
\text { Petição: } 13693 \\
\text { Data: } \\
\text { 25/03/2013 }\end{array}$ & $\begin{array}{l}\text { Autos } \\
\text { conclusos } \\
\text { à } \\
\text { Relatora pa } \\
\text { ra apreciar } \\
\text { petição } \\
\text { protocolad } \\
\text { a por } \\
\text { amicus } \\
\text { curiae. }\end{array}$ \\
\hline
\end{tabular}




\begin{tabular}{|c|c|c|c|c|c|c|c|c|}
\hline $\begin{array}{l}N^{0} \text { da } \\
\text { Ação }\end{array}$ & $\begin{array}{l}\text { Demandant } \\
\text { e }\end{array}$ & Demandado & Tipo de Ação & $\begin{array}{l}\text { Data } \\
\text { ajuizamento }\end{array}$ & Outros atores processuais & Decisões judiciais & $\begin{array}{l}\text { Peças } \\
\text { processuais }\end{array}$ & $\begin{array}{l}\text { Andament } \\
\text { o em } 30 \\
\text { set. } 2014\end{array}$ \\
\hline & & & & & $\begin{array}{l}\text { Santos - Amprogás; } \\
\text { Assembleia Legislativa do } \\
\text { Estado de São Paulo; } \\
\text { Associação dos Municípios } \\
\text { Sede de Pontos de Entrega } \\
\text { e/ou Recebimento de Gás } \\
\text { Natural - AMPEGAS. }\end{array}$ & & & \\
\hline $\begin{array}{l}\text { ADI } \\
4917\end{array}$ & $\begin{array}{l}\text { Governador } \\
\text { do Estado } \\
\text { Rio de } \\
\text { Janeiro }\end{array}$ & $\begin{array}{l}\text { Presidente } \\
\text { da República } \\
\text { e Congresso } \\
\text { Nacional }\end{array}$ & $\begin{array}{l}\text { Ação Direta de } \\
\text { Inconstitucionalidade }\end{array}$ & $15 / 03 / 2013$ & $\begin{array}{l}\text { Ministério Público Federal. } \\
\text { Amici curiae: Rio Grande do } \\
\text { Sul; Paraíba; Alagoas; Mato } \\
\text { Grosso do Sul; Goiás; Bahia; } \\
\text { Paraná; Confederação } \\
\text { Nacional de Municípios - } \\
\text { CNM; Associação dos } \\
\text { Municípios Excluídos do } \\
\text { Rol dos Recebedores de } \\
\text { Royalties do Petróleo e Gás } \\
\text { - AMROY; Organização } \\
\text { dos Municípios Produtores } \\
\text { de Petróleo e Gás e } \\
\text { Limítrofes da Zona de } \\
\text { Produção Principal da Bacia } \\
\text { de Campos, Estado do Rio } \\
\text { de Janeiro - OMPETRO; } \\
\text { Associação Brasileira dos } \\
\text { Municíios com Terminais } \\
\text { Marítimos, Fluviais e } \\
\text { Terrestres de Embarque e } \\
\text { Desembarque de Petróleo e } \\
\text { Gás Natural - ABRAMT; } \\
\text { Ordem dos Advogados do } \\
\text { Brasil - Seção do Estado do } \\
\text { Rio de Janeiro; Associação } \\
\text { dos Municípios Produtores }\end{array}$ & $\begin{array}{l}\text { Decisão que admite o } \\
\text { ingresso da Assembleia } \\
\text { Legislativa de São Paulo na } \\
\text { ADI, como amicus curiae. } \\
\text { DJE de 8/8/2013. } \\
\\
\text { Decisão que admite o } \\
\text { ingresso do Estado do Rio } \\
\text { Grande do Sul; do Estado } \\
\text { da Paraíba; do Estado de } \\
\text { Alagoas; da CNM; da } \\
\text { AMROY; da } \\
\text { OMPETRO; do } \\
\text { Estado do Mato Grosso do } \\
\text { Sul e do Estado de Goiás; da } \\
\text { ABRAMT; da } \\
\text { Ordem dos Advogados do } \\
\text { Brasil - Seção do Estado do } \\
\text { Rio de Janeiro - } \\
\text { OAB-RJ; da } \\
\text { AMPROGÁS; do Estado do } \\
\text { Paraná e do Estado da Bahia } \\
\text { na presente } \\
\text { Ação Direta de } \\
\text { Inconstitucionalidade, como } \\
\text { amici curiae e indeferimento } \\
\text { do pedido formulado pelo }\end{array}$ & $\begin{array}{l}\text { Petição inicial. } \\
\text { Informações } \\
\text { da Mesa do } \\
\text { Congresso } \\
\text { Nacional - } \\
\text { Petição: } 65324 \\
\text { Data: } \\
\text { 19/12/2013 } \\
\text { Informações } \\
\text { da AGU - } \\
\text { Petição: } 65451 \\
\text { Data: } \\
\text { 20/12/2013 } \\
\text { 19/05/2014 - } \\
\text { Parecer no } \\
\text { 1.947- } \\
\text { AsJConst/SAJ } \\
\text {, PGR - Opina } \\
\text { pelo } \\
\text { conhecimento } \\
\text { parcial da ação } \\
\text { e, no mérito, } \\
\text { pela } \\
\text { procedência }\end{array}$ & $\begin{array}{l}\text { Autos } \\
\text { conclusos } \\
\text { à Relatora } \\
\text { para } \\
\text { apreciar } \\
\text { petição } \\
\text { protocolad } \\
\text { a por } \\
\text { amicus } \\
\text { curiae. }\end{array}$ \\
\hline
\end{tabular}




\begin{tabular}{|c|c|c|c|c|c|c|c|c|}
\hline $\begin{array}{l}\mathbf{N}^{0} \text { da } \\
\text { Ação }\end{array}$ & $\begin{array}{l}\text { Demandant } \\
\text { e }\end{array}$ & Demandado & Tipo de Ação & $\begin{array}{l}\text { Data } \\
\text { ajuizamento }\end{array}$ & Outros atores processuais & Decisões judiciais & $\begin{array}{l}\text { Peças } \\
\text { processuais }\end{array}$ & $\begin{array}{l}\text { Andament } \\
\text { o em } 30 \\
\text { set. } 2014\end{array}$ \\
\hline & & & & & $\begin{array}{l}\text { de Gás Natural, Petróleo, } \\
\text { Possuidores de Gasodutos, } \\
\text { Oleodutos, Áreas de } \\
\text { Tancagem, Estação de } \\
\text { Bombeamento e Zona de } \\
\text { Influência da Bacia de } \\
\text { Santos - AMPROGÁs; } \\
\text { Assembleia Legislativa do } \\
\text { Estado de São Paulo; } \\
\text { Associação dos Municípios } \\
\text { Sede de Pontos de Entrega } \\
\text { e/ou Recebimento de Gás } \\
\text { Natural - AMPEGAS. }\end{array}$ & $\begin{array}{l}\text { Instituto dos Auditores } \\
\text { Fiscais } \\
\text { do Estado da Bahia - IAF. } \\
\text { DJE de 8/8/2013. } \\
\text { Decisão que admite o } \\
\text { ingresso da AMPEGÁS na } \\
\text { Ação Direta de } \\
\text { Inconstitucionalidade, como } \\
\text { amicus curiae. DJE de } \\
\text { 7/8/2014. }\end{array}$ & $\begin{array}{l}\text { parcial do } \\
\text { pedido. Petiçã } \\
\text { o: } 22657\end{array}$ & \\
\hline $\begin{array}{l}\text { ADI } \\
4916\end{array}$ & $\begin{array}{l}\text { Governador } \\
\text { do Estado do } \\
\text { Espírito } \\
\text { Santo }\end{array}$ & $\begin{array}{l}\text { Presidente } \\
\text { da República } \\
\text { e Congresso } \\
\text { Nacional }\end{array}$ & $\begin{array}{l}\text { Ação Direta de } \\
\text { Inconstitucionalidade }\end{array}$ & $15 / 03 / 2013$ & $\begin{array}{l}\text { Ministério Público. Amici } \\
\text { curiae: Estado do Rio } \\
\text { Grande do Sul, Estado da } \\
\text { Paraíba, Estado da Bahia, } \\
\text { Confederação Nacional de } \\
\text { Municípios- CNM, } \\
\text { Associação } \\
\text { Brasileira dos Municípios } \\
\text { com Terminais Marítimos, } \\
\text { Fluviais e Terrestres } \\
\text { de Embarque e } \\
\text { Desembarque de Petróleo e } \\
\text { Gás Natural - ABRAMT e } \\
\text { Associação dos Municípios } \\
\text { Produtores de Gás Natural, } \\
\text { Petróleo, Possuidores de } \\
\text { Gasodutos, Oleodutos, Áreas } \\
\text { de Tancagem, } \\
\text { Estação de Bombeamento e } \\
\text { Zona de Influência da Bacia } \\
\text { de Santos - }\end{array}$ & $\begin{array}{l}\text { Nos termos do art. 10 da Lei } \\
\text { n. 9.868/1999, requisita, } \\
\text { com urgência e prioridade, } \\
\text { informações sobre o } \\
\text { alegado, relativamente à } \\
\text { medida cautelar requerida, } \\
\text { da Presidenta da República e } \\
\text { do Presidente do Congresso } \\
\text { Nacional, no prazo máximo } \\
\text { de cinco dias (caput do art. } \\
10 \text { da lei 9.868/1999) e, } \\
\text { simultaneamente, } \\
\text { manifestação do Advogado- } \\
\text { Geral da União e do } \\
\text { Procurador-Geral da } \\
\text { República, essas no prazo } \\
\text { máximo de três dias ( } 1^{\circ} \text { do } \\
\text { art. 10 da Lei n. } \\
9.868 / 1999) \text {. DJE de } \\
\text { 21/5/13. }\end{array}$ & $\begin{array}{l}\text { Informações } \\
\text { da AGU - } \\
\text { Petição: } 15671 \\
\text { Data: 8/4/2013 } \\
\text { Informações } \\
\text { da Mesa do } \\
\text { Congresso } \\
\text { Nacional - } \\
\text { Petição: } \\
\text { 15680. Data: } \\
\text { 8/4/2013. } \\
\text { Parecer } \\
\text { n 9804/RG, } \\
\text { PGR, } \\
\text { 08/04/2013 - } \\
\text { Opina pelo } \\
\text { referendo da } \\
\text { liminar } \\
\text { concedida. Dat }\end{array}$ & $\begin{array}{l}\text { Distribuída } \\
\text { s cópias do } \\
\text { Relatório } \\
\text { aos } \\
\text { Exmos. } \\
\text { Srs. } \\
\text { Ministros, } \\
\text { como } \\
\text { determina } \\
\text { o art. } 172 \\
\text { do } \\
\text { Regimento } \\
\text { Interno. }\end{array}$ \\
\hline
\end{tabular}




\begin{tabular}{|c|c|c|c|c|c|c|c|c|}
\hline $\begin{array}{l}\mathbf{N}^{0} \text { da } \\
\text { Ação }\end{array}$ & $\begin{array}{l}\text { Demandant } \\
\text { e }\end{array}$ & Demandado & Tipo de Ação & $\begin{array}{l}\text { Data } \\
\text { ajuizamento }\end{array}$ & Outros atores processuais & Decisões judiciais & $\begin{array}{l}\text { Peças } \\
\text { processuais }\end{array}$ & $\begin{array}{l}\text { Andament } \\
\text { o em } 30 \\
\text { set. } 2014\end{array}$ \\
\hline & & & & & AMPROGÁS. & $\begin{array}{l}\text { Decisão que admite o } \\
\text { ingresso do Estado do Rio } \\
\text { Grande do Sul; do Estado da } \\
\text { Paraíba; do Estado da Bahia; } \\
\text { da CNM; da ABRAMT; e da } \\
\text { AMPROGÁS na presente } \\
\text { Ação Direta de } \\
\text { Inconstitucionalidade, como } \\
\text { amici curiae (art. } 7^{\circ}, \S 2^{\circ} \text {, da } \\
\text { Lei n. 9.868/99), } \\
\text { observando-se, quanto à } \\
\text { sustentação oral, o art. 131, } \\
\text { § 3º do Regimento Interno } \\
\text { do Supremo Tribunal } \\
\text { Federal (alterado pela } \\
\text { Emenda Regimental n. } \\
\text { 15/2004). DJE de 31/7/13. }\end{array}$ & a $9 / 4 / 2013$. & \\
\hline $\begin{array}{l}\text { ADI } \\
4918\end{array}$ & $\begin{array}{l}\text { Assembleia } \\
\text { Legislativa } \\
\text { do Estado do } \\
\text { Rio de } \\
\text { Janeiro }\end{array}$ & $\begin{array}{l}\text { Presidente } \\
\text { da República } \\
\text { e Congresso } \\
\text { Nacional }\end{array}$ & $\begin{array}{l}\text { Ação Direta de } \\
\text { Inconstitucionalidade }\end{array}$ & $15 / 03 / 2013$ & $\begin{array}{l}\text { Ministério Público. Amici } \\
\text { curiae: Rio Grande do Sul, } \\
\text { Paraíba, Bahia, } \\
\text { Confederação Nacional de } \\
\text { Municípios- CNM, } \\
\text { Associação } \\
\text { Brasileira dos Municípios } \\
\text { com Terminais Marítimos, } \\
\text { Fluviais e Terrestres } \\
\text { de Embarque e } \\
\text { Desembarque de Petróleo e } \\
\text { Gás Natural - ABRAMT e } \\
\text { Associação dos Municípios } \\
\text { Produtores de Gás Natural, } \\
\text { Petróleo, Possuidores de } \\
\text { Gasodutos, Oleodutos, Áreas } \\
\text { de Tancagem, }\end{array}$ & $\begin{array}{l}\text { Nos termos do art. } 10 \text { da Lei } \\
\text { n. 9.868/1999, requisita, } \\
\text { com urgência e prioridade, } \\
\text { informações sobre o } \\
\text { alegado, relativamente à } \\
\text { medida cautelar requerida, } \\
\text { da Presidenta da República e } \\
\text { do Presidente do Congresso } \\
\text { Nacional, no prazo máximo } \\
\text { de cinco dias (caput do art. } \\
10 \text { da lei 9.868/1999) e, } \\
\text { simultaneamente, } \\
\text { manifestação do Advogado- } \\
\text { Geral da União e do } \\
\text { Procurador-Geral da } \\
\text { República, essas no prazo } \\
\text { máximo de três dias ( } 1^{\circ} \text { do }\end{array}$ & 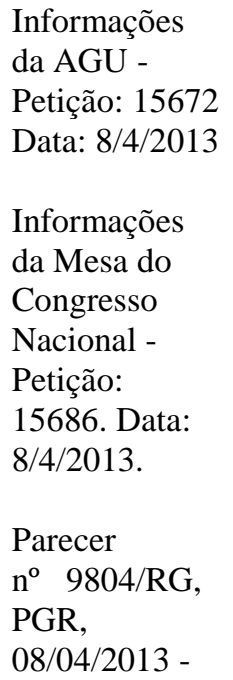 & $\begin{array}{l}\text { Distribuída } \\
\text { s cópias do } \\
\text { Relatório } \\
\text { aos } \\
\text { Exmos. } \\
\text { Srs. } \\
\text { Ministros, } \\
\text { como } \\
\text { determina } \\
\text { o art. } 172 \\
\text { do } \\
\text { Regimento } \\
\text { Interno. }\end{array}$ \\
\hline
\end{tabular}




\begin{tabular}{|c|c|c|c|c|c|c|c|c|}
\hline $\begin{array}{l}\mathbf{N}^{0} \text { da } \\
\text { Ação }\end{array}$ & $\begin{array}{l}\text { Demandant } \\
\text { e }\end{array}$ & Demandado & Tipo de Ação & $\begin{array}{l}\text { Data } \\
\text { ajuizamento }\end{array}$ & Outros atores processuais & Decisões judiciais & $\begin{array}{l}\text { Peças } \\
\text { processuais }\end{array}$ & $\begin{array}{l}\text { Andament } \\
\text { o em } 30 \\
\text { set. } 2014\end{array}$ \\
\hline & & & & & $\begin{array}{l}\text { Estação de Bombeamento e } \\
\text { Zona de Influência da Bacia } \\
\text { de Santos - } \\
\text { AMPROGÁs. }\end{array}$ & $\begin{array}{l}\text { art. } 10 \text { da Lei n. } \\
\text { 9.868/1999). DJE de } \\
\text { 21/5/13. } \\
\\
\text { Decisão que admite o } \\
\text { ingresso do Estado do Rio } \\
\text { Grande do Sul; do Estado da } \\
\text { Paraíba; do Estado da Bahia; } \\
\text { da CNM; da ABRAMT; e da } \\
\text { AMPROGÁS na presente } \\
\text { Ação Direta de } \\
\text { Inconstitucionalidade, como } \\
\text { amici curiae (art. } 7^{\circ}, \S 2^{\circ} \text {, da } \\
\text { Lei n. 9.868/99), } \\
\text { observando-se, quanto à } \\
\text { sustentação oral, o art. } 131 \text {, } \\
\text { § } 3^{\circ}, \text { do Regimento Interno } \\
\text { do Supremo Tribunal } \\
\text { Federal (alterado pela } \\
\text { Emenda Regimental n. } \\
\text { 15/2004). DJE de } 31 / 7 / 13 \text {. }\end{array}$ & $\begin{array}{l}\text { Opina pelo } \\
\text { referendo da } \\
\text { liminar } \\
\text { concedida. Pet } \\
\text { ição: } 15859 . \\
\text { Data 9/4/2013. }\end{array}$ & \\
\hline $\begin{array}{l}\text { ADI } \\
4920\end{array}$ & $\begin{array}{l}\text { Governador } \\
\text { do Estado de } \\
\text { São Paulo }\end{array}$ & $\begin{array}{l}\text { Presidente } \\
\text { da República } \\
\text { e Congresso } \\
\text { Nacional }\end{array}$ & $\begin{array}{l}\text { Ação Direta de } \\
\text { Inconstitucionalidade }\end{array}$ & $15 / 03 / 2013$ & $\begin{array}{l}\text { Ministério Público. Amici } \\
\text { curiae: Rio Grande do Sul, } \\
\text { Paraíba, Bahia, } \\
\text { Confederação Nacional de } \\
\text { Municípios-CNM, } \\
\text { Associação } \\
\text { Brasileira dos Municípios } \\
\text { com Terminais Marítimos, } \\
\text { Fluviais e Terrestres } \\
\text { de Embarque e } \\
\text { Desembarque de Petróleo e } \\
\text { Gás Natural - ABRAMT e } \\
\text { Associação dos Municípios }\end{array}$ & $\begin{array}{l}\text { Nos termos do art. } 10 \text { da Lei } \\
\text { n. 9.868/1999, requisita, } \\
\text { com urgência e prioridade, } \\
\text { informações sobre o } \\
\text { alegado, relativamente ao } \\
\text { requerimento de medida } \\
\text { cautelar, da Presidenta da } \\
\text { República e do Presidente do } \\
\text { Congresso Nacional, no } \\
\text { prazo máximo de cinco dias } \\
\text { (caput do art. 10 da lei } \\
\text { 9.868/1999) e, } \\
\text { simultaneamente, }\end{array}$ & $\begin{array}{l}\text { Petição inicial } \\
\text { - Petição: } \\
\text { 11768 Data: } \\
\text { 15/03/2013. } \\
\text { Informações } \\
\text { da AGU - } \\
\text { Petição: } 15673 \\
\text { Data: } \\
\text { 08/04/2013. } \\
\text { Informações } \\
\text { da Mesa do }\end{array}$ & $\begin{array}{l}\text { Distribuída } \\
\text { s cópias do } \\
\text { Relatório } \\
\text { aos } \\
\text { Exmos. } \\
\text { Srs. } \\
\text { Ministros, } \\
\text { como } \\
\text { determina } \\
\text { o art. } 172 \\
\text { do } \\
\text { Regimento } \\
\text { Interno. }\end{array}$ \\
\hline
\end{tabular}




\begin{tabular}{|c|c|c|c|c|c|c|c|c|}
\hline $\begin{array}{l}\mathbf{N}^{0} \text { da } \\
\text { Ação }\end{array}$ & $\begin{array}{l}\text { Demandant } \\
\text { e }\end{array}$ & Demandado & Tipo de Ação & $\begin{array}{l}\text { Data } \\
\text { ajuizamento }\end{array}$ & Outros atores processuais & Decisões judiciais & $\begin{array}{l}\text { Peças } \\
\text { processuais }\end{array}$ & $\begin{array}{l}\text { Andament } \\
\text { o em } 30 \\
\text { set. } 2014\end{array}$ \\
\hline & & & & & $\begin{array}{l}\text { Produtores de Gás Natural, } \\
\text { Petróleo, Possuidores de } \\
\text { Gasodutos, Oleodutos, Áreas } \\
\text { de Tancagem, } \\
\text { Estação de Bombeamento e } \\
\text { Zona de Influência da Bacia } \\
\text { de Santos - } \\
\text { AMPROGÁS. }\end{array}$ & $\begin{array}{l}\text { manifestação do Advogado- } \\
\text { Geral da União e do } \\
\text { Procurador-Geral da } \\
\text { República. DJE de 25/3/13. } \\
\text { Decisão que admite o } \\
\text { ingresso do Estado do Rio } \\
\text { Grande do Sul; do Estado da } \\
\text { Paraíba; do Estado da Bahia; } \\
\text { da Confederação Nacional } \\
\text { de Municípios - CNM; da } \\
\text { Associação Brasileira dos } \\
\text { Municípios com Terminais } \\
\text { Marítimos, Fluviais e } \\
\text { Terrestres de Embarque e } \\
\text { Desembarque de Petróleo e } \\
\text { Gás Natural - ABRAMT; da } \\
\text { Associação dos Municípios } \\
\text { Produtores de Gás Natural, } \\
\text { Petróleo, Possuidores de } \\
\text { Gasodutos, Oleodutos, Áreas } \\
\text { de Tancagem, Estação de } \\
\text { Bombeamento e Zona de } \\
\text { Influência da Bacia de } \\
\text { Santos - AMPROGÁS na } \\
\text { presente Ação Direta de } \\
\text { Inconstitucionalidade, como } \\
\text { amici curiae (art. } 7^{\circ}, \S 2^{\circ} \text {, da } \\
\text { Lei n. 9.868/99), } \\
\text { observando-se, quanto à } \\
\text { sustentação oral, o art. 131, } \\
\text { § 3º, do Regimento Interno } \\
\text { do Supremo Tribunal } \\
\text { Federal. DJE de } 31 / 7 / 13 \text {. }\end{array}$ & $\begin{array}{l}\text { Congresso } \\
\text { Nacional - } \\
\text { Petição: } 15689 \\
\text { Data: } \\
\text { 08/04/2013 } \\
\text { - Parecer } \\
\text { n.9804/RG, } \\
\text { PGR, } \\
\text { 08/04/2013 - } \\
\text { Opina pelo } \\
\text { referendo da } \\
\text { liminar } \\
\text { concedida. Pet } \\
\text { ição 15860. } \\
\text { Data: } \\
\text { 09/04/2013 }\end{array}$ & \\
\hline
\end{tabular}




\begin{tabular}{|c|c|c|c|c|c|c|c|c|}
\hline $\begin{array}{l}\mathrm{N}^{\circ} \mathrm{da} \\
\text { Ação }\end{array}$ & $\begin{array}{l}\text { Demandant } \\
\text { e }\end{array}$ & Demandado & Tipo de Ação & $\begin{array}{l}\text { Data } \\
\text { ajuizamento }\end{array}$ & Outros atores processuais & Decisões judiciais & $\begin{array}{l}\text { Peças } \\
\text { processuais }\end{array}$ & $\begin{array}{l}\text { Andament } \\
\text { o em } 30 \\
\text { set. } 2014\end{array}$ \\
\hline $\begin{array}{l}\text { MS } \\
31816 \\
\text { /DF - } \\
\text { Medida } \\
\text { Cautela } \\
\text { r }\end{array}$ & $\begin{array}{l}\text { Deputado } \\
\text { Alessandro } \\
\text { Lucciola } \\
\text { Molon }\end{array}$ & $\begin{array}{l}\text { Congresso } \\
\text { Nacional } \\
\text { e Presidente } \\
\text { do } \\
\text { Congresso } \\
\text { Nacional }\end{array}$ & $\begin{array}{l}\text { Medida Cautelar em } \\
\text { Mandado de } \\
\text { Segurança }\end{array}$ & $13 / 12 / 2012$ & Ministério Público Federal & $\begin{array}{l}\text { Decisão monocrática: } \\
\text { Liminar deferida, inaudita } \\
\text { altera parte, para determinar } \\
\text { à Mesa Diretora do } \\
\text { Congresso Nacional que se } \\
\text { abstenha de deliberar acerca } \\
\text { do veto parcial no } 38 / 2012 \\
\text { antes que se proceda à } \\
\text { análise de todos os vetos } \\
\text { pendentes com prazo de } \\
\text { análise expirado até a } \\
\text { presente data, em ordem } \\
\text { cronológica de recebimento } \\
\text { da respectiva comunicação, } \\
\text { observadas as regras } \\
\text { regimentais pertinentes. } \\
\text { Cumpra-se imediatamente } \\
\text { por Oficial de Justiça. DJE } \\
\text { de 18/12/2012. } \\
\\
\text { O Tribunal, por maioria, deu } \\
\text { provimento ao agravo } \\
\text { regimental, vencidos os } \\
\text { Ministros Luiz Fux } \\
\text { (Relator), Marco Aurélio, } \\
\text { Celso de Mello e Joaquim } \\
\text { Barbosa (Presidente). } \\
\text { Redigirá o acórdão o } \\
\text { Ministro Teori Zavascki. } \\
\text { DJE de } 10 / 05 / 2013 \text {. }\end{array}$ & $\begin{array}{l}\text { Interposto } \\
\text { Agravo } \\
\text { Regimental } \\
\text { em } \\
\text { 18/12/2012 } \\
\\
\text { 26/04/2013 - } \\
\text { Ministério } \\
\text { Público } \\
\text { Federal - } \\
\text { Apresenta } \\
\text { parecer, } \\
\text { opinando pelo } \\
\text { reconheciment } \\
\text { o da } \\
\text { prejudicialidad } \\
\text { e do mandado } \\
\text { de segurança } \\
\text { ou, superada a } \\
\text { preliminar, } \\
\text { pela } \\
\text { denegação da } \\
\text { segurança. } \\
\text { Petição 19464. }\end{array}$ & $\begin{array}{l}\text { Baixa ao } \\
\text { arquivo do } \\
\text { STF em } \\
27 / 9 / 2013\end{array}$ \\
\hline $\begin{array}{l}\text { MS } \\
31816 \\
\text { /DF }\end{array}$ & $\begin{array}{l}\text { Alessandro } \\
\text { Lucciola } \\
\text { Molon }\end{array}$ & $\begin{array}{l}\text { Congresso } \\
\text { Nacional } \\
\text { e Presidente } \\
\text { do }\end{array}$ & $\begin{array}{l}\text { Mandado de } \\
\text { Segurança }\end{array}$ & $13 / 12 / 2012$ & Ministério Público Federal & $\begin{array}{l}\text { Decisão que julga } \\
\text { prejudicado o mandado de } \\
\text { segurança, } \\
\text { diante da perda }\end{array}$ & - & $\begin{array}{l}\text { Baixa ao } \\
\text { arquivo do } \\
\text { STF em } \\
27 / 9 / 2013\end{array}$ \\
\hline
\end{tabular}




\begin{tabular}{|c|c|c|c|c|c|c|c|c|}
\hline $\begin{array}{l}\mathrm{N}^{\circ} \mathrm{da} \\
\text { Ação }\end{array}$ & $\begin{array}{l}\text { Demandant } \\
\text { e }\end{array}$ & Demandado & Tipo de Ação & $\begin{array}{l}\text { Data } \\
\text { ajuizamento }\end{array}$ & Outros atores processuais & Decisões judiciais & $\begin{array}{l}\text { Peças } \\
\text { processuais }\end{array}$ & $\begin{array}{l}\text { Andament } \\
\text { o em } 30 \\
\text { set. } 2014\end{array}$ \\
\hline & & $\begin{array}{l}\text { Congresso } \\
\text { Nacional }\end{array}$ & & & & $\begin{array}{l}\text { superveniente de seu objeto. } \\
\text { DJE de } 26 / 8 / 2013 \text {. }\end{array}$ & & \\
\hline $\begin{array}{l}\text { MS } \\
31.814 / \\
\text { DF }\end{array}$ & $\begin{array}{l}\text { Luiz } \\
\text { Lindbergh } \\
\text { Farias } \\
\text { Filho e } \\
\text { Leonardo } \\
\text { Carneiro } \\
\text { Monteiro } \\
\text { Picciani }\end{array}$ & $\begin{array}{l}\text { Presidente } \\
\text { do } \\
\text { Congresso } \\
\text { Nacional e } \\
\text { Presidente } \\
\text { do Senado } \\
\text { Federal. }\end{array}$ & $\begin{array}{l}\text { Mandado de } \\
\text { Segurança }\end{array}$ & $12 / 12 / 2012$ & - & $\begin{array}{l}\text { Decisão que julga } \\
\text { prejudicado o mandado de } \\
\text { segurança, } \\
\text { diante da perda } \\
\text { superveniente de seu objeto. } \\
\text { DJE de } 23 / 8 / 2013 \text {. }\end{array}$ & - & $\begin{array}{l}\text { Baixa ao } \\
\text { arquivo do } \\
\text { STF em } \\
27 / 9 / 2013 \text {. }\end{array}$ \\
\hline $\begin{array}{l}\text { MS } \\
\text { 31828 / } \\
\text { DF }\end{array}$ & $\begin{array}{l}\text { Ana Rita } \\
\text { Esgario, } \\
\text { Carlos } \\
\text { Humberto } \\
\text { Mannato, } \\
\text { Cesar } \\
\text { Roberto } \\
\text { Colnaghi, } \\
\text { Iriny Nicolal } \\
\text { Corres } \\
\text { Lopes, } \\
\text { Ricardo De } \\
\text { Rezende } \\
\text { Ferraço, } \\
\text { Jorge Silva, } \\
\text { Lauriete } \\
\text { Rodrigues } \\
\text { Pinto, Paulo } \\
\text { Roberto } \\
\text { Foleto, } \\
\text { Audifax } \\
\text { Charles }\end{array}$ & $\begin{array}{l}\text { Presidente } \\
\text { do } \\
\text { Congresso } \\
\text { Nacional }\end{array}$ & $\begin{array}{l}\text { Mandado de } \\
\text { Segurança }\end{array}$ & $17 / 12 / 2012$ & - & $\begin{array}{l}\text { Decisão que julga } \\
\text { prejudicado o mandado de } \\
\text { segurança, } \\
\text { diante da perda } \\
\text { superveniente de seu objeto. } \\
\text { DJE de } 23 / 8 / 2013 \text {. }\end{array}$ & - & $\begin{array}{l}\text { Baixa ao } \\
\text { arquivo do } \\
\text { STF em } \\
16 / 9 / 2013 \text {. }\end{array}$ \\
\hline
\end{tabular}




\begin{tabular}{|c|c|c|c|c|c|c|c|c|}
\hline $\begin{array}{l}\mathrm{N}^{\circ} \mathrm{da} \\
\text { Ação }\end{array}$ & $\begin{array}{l}\text { Demandant } \\
\text { e }\end{array}$ & Demandado & Tipo de Ação & $\begin{array}{l}\text { Data } \\
\text { ajuizamento }\end{array}$ & Outros atores processuais & Decisões judiciais & $\begin{array}{l}\text { Peças } \\
\text { processuais }\end{array}$ & $\begin{array}{l}\text { Andament } \\
\text { o em } 30 \\
\text { set. } 2014\end{array}$ \\
\hline & $\begin{array}{l}\text { Pimentel } \\
\text { Barcelos, } \\
\text { Magno } \\
\text { Pereira } \\
\text { Malta, } \\
\text { Welington } \\
\text { Coimbra e } \\
\text { Sueli Rangel } \\
\text { Silva } \\
\text { Vidigal. }\end{array}$ & & & & & & & \\
\hline $\begin{array}{l}\text { MS } \\
\text { 31938 / } \\
\text { DF }\end{array}$ & $\begin{array}{l}\text { Ricardo de } \\
\text { Rezende } \\
\text { Ferraço e } \\
\text { Luiz } \\
\text { Lindbergh } \\
\text { Farias Filho }\end{array}$ & $\begin{array}{l}\text { Presidente } \\
\text { do Senado } \\
\text { Federal } \\
\text { e Vice- } \\
\text { Presidente } \\
\text { da Câmara } \\
\text { dos } \\
\text { Deputados }\end{array}$ & $\begin{array}{l}\text { Mandado de } \\
\text { Segurança }\end{array}$ & $6 / 3 / 2013$ & - & $\begin{array}{l}\text { Decisão que julga } \\
\text { prejudicado o mandado de } \\
\text { segurança, } \\
\text { diante da perda } \\
\text { superveniente de seu objeto. } \\
\text { DJE de } 23 / 8 / 2013 \text {. }\end{array}$ & $\begin{array}{l}\text { Informações - } \\
\text { Petição: } 13314 \\
\text { Data: } \\
\text { 22/03/2013 }\end{array}$ & $\begin{array}{l}\text { Baixa ao } \\
\text { arquivo do } \\
\text { STF em } \\
\text { 19/9/2013. }\end{array}$ \\
\hline $\begin{array}{l}\text { MS } \\
\text { 31031 / } \\
\text { DF }\end{array}$ & $\begin{array}{l}\text { Anthony } \\
\text { William } \\
\text { Garotinho, } \\
\text { Matheus de } \\
\text { Oliveira, } \\
\text { Arolde de } \\
\text { Oliveira, } \\
\text { Andréia } \\
\text { Almeida } \\
\text { Zito dos } \\
\text { Santos, } \\
\text { Romário de } \\
\text { Souza Faria, } \\
\text { Neilton } \\
\text { Mulim da }\end{array}$ & $\begin{array}{l}\text { Presidente } \\
\text { da Câmara } \\
\text { dos } \\
\text { Deputados, } \\
\text { Câmara dos } \\
\text { Deputados, } \\
\text { Mesa da } \\
\text { Câmara dos } \\
\text { Deputados }\end{array}$ & $\begin{array}{l}\text { Mandado de } \\
\text { Segurança }\end{array}$ & $29 / 11 / 2011$ & - & $\begin{array}{l}\text { Decisão que julga } \\
\text { prejudicado o mandado de } \\
\text { segurança, } \\
\text { diante da perda } \\
\text { superveniente de seu objeto. } \\
\text { DJE de } 26 / 8 / 2013 \text {. }\end{array}$ & $\begin{array}{l}\text { 10/02/2012 - } \\
\text { OF. N. } \\
\text { 51/SGM/P/20 } \\
\text { 12, Câmara } \\
\text { dos Deputados } \\
\text { - presta } \\
\text { informações } \\
\text { em atenção ao } \\
\text { ofício no } 187 / \text { p. } \\
\text { 10/02/2012 - } \\
\text { (Petição } \\
\text { eletrônica com } \\
\text { certificação } \\
\text { digital) união - }\end{array}$ & $\begin{array}{l}\text { Baixa ao } \\
\text { arquivo do } \\
\text { STF em } \\
\text { 25/9/2013. }\end{array}$ \\
\hline
\end{tabular}




\begin{tabular}{|c|c|c|c|c|c|c|c|c|}
\hline $\begin{array}{l}N^{0} \text { da } \\
\text { Ação }\end{array}$ & $\begin{array}{l}\text { Demandant } \\
\text { e }\end{array}$ & Demandado & Tipo de Ação & $\begin{array}{l}\text { Data } \\
\text { ajuizamento }\end{array}$ & Outros atores processuais & Decisões judiciais & $\begin{array}{l}\text { Peças } \\
\text { processuais }\end{array}$ & $\begin{array}{l}\text { Andament } \\
\text { o em } 30 \\
\text { set. } 2014\end{array}$ \\
\hline & $\begin{array}{l}\text { Costa, } \\
\text { Adilson } \\
\text { Soares, } \\
\text { Wanderley } \\
\text { Alves de } \\
\text { Oliveira, } \\
\text { Benedita } \\
\text { Souza da } \\
\text { Silva } \\
\text { Sampaio, } \\
\text { Otávio } \\
\text { Santos Silva } \\
\text { Leite, } \\
\text { Sueli Rangel } \\
\text { Silva } \\
\text { Vidigal, } \\
\text { Paulo Cesar } \\
\text { da Guia } \\
\text { Almeida, } \\
\text { Edson } \\
\text { Santos de } \\
\text { Souza, Hugo } \\
\text { Leal Melo } \\
\text { da } \\
\text { Silva,Fernan } \\
\text { do Antônio } \\
\text { Ceciliano } \\
\text { Jordão, } \\
\text { Washington } \\
\text { Reis de } \\
\text { Oliveira, } \\
\text { Audifax } \\
\text { Charles } \\
\text { Pimentel }\end{array}$ & & & & & & $\begin{array}{l}\text { requer } \\
\text { ingresso no } \\
\text { feito e } \\
\text { intimação } \\
\text { pessoal. }\end{array}$ & \\
\hline
\end{tabular}




\begin{tabular}{|c|c|c|c|c|c|c|c|c|}
\hline $\begin{array}{l}\mathbf{N}^{0} \text { da } \\
\text { Ação }\end{array}$ & $\begin{array}{l}\text { Demandant } \\
\text { e }\end{array}$ & Demandado & Tipo de Ação & $\begin{array}{l}\text { Data } \\
\text { ajuizamento }\end{array}$ & Outros atores processuais & Decisões judiciais & $\begin{array}{l}\text { Peças } \\
\text { processuais }\end{array}$ & $\begin{array}{l}\text { Andament } \\
\text { o em } 30 \\
\text { set. } 2014\end{array}$ \\
\hline & $\begin{array}{l}\text { Barcelos, } \\
\text { Simão } \\
\text { Sessim, } \\
\text { Lauriete } \\
\text { Rodrigues } \\
\text { de Almeida, } \\
\text { Cesar } \\
\text { Colnago, } \\
\text { Miro } \\
\text { Teixeira, } \\
\text { Adrian } \\
\text { Mussi } \\
\text { Ramos, } \\
\text { Jorge de } \\
\text { Oliveira, } \\
\text { Paulo } \\
\text { Roberto } \\
\text { Foletto, } \\
\text { Liliam Sá de } \\
\text { Paula, Aureo } \\
\text { Lidio } \\
\text { Moreira } \\
\text { Ribeiro,Feli } \\
\text { pe Leone } \\
\text { Bornier de } \\
\text { Oliveira, } \\
\text { Aluizio dos } \\
\text { Santos } \\
\text { Junior, } \\
\text { Jorge Silva, } \\
\text { Cesar } \\
\text { Humberto } \\
\text { Mannato, } \\
\text { Cesar }\end{array}$ & & & & & & & \\
\hline
\end{tabular}




\begin{tabular}{|c|c|c|c|c|c|c|c|c|}
\hline $\begin{array}{l}\mathrm{N}^{0} \mathrm{da} \\
\text { Ação }\end{array}$ & $\begin{array}{l}\text { Demandant } \\
\text { e }\end{array}$ & Demandado & Tipo de Ação & $\begin{array}{l}\text { Data } \\
\text { ajuizamento }\end{array}$ & Outros atores processuais & Decisões judiciais & $\begin{array}{l}\text { Peças } \\
\text { processuais }\end{array}$ & $\begin{array}{l}\text { Andament } \\
\text { o em } 30 \\
\text { set. } 2014\end{array}$ \\
\hline & $\begin{array}{l}\text { Roberto } \\
\text { Colnaghi, } \\
\text { Alexandre } \\
\text { José Santos, } \\
\text { Francisco } \\
\text { José } \\
\text { D'Angelo } \\
\text { Pinto, Filipe } \\
\text { de Almeida } \\
\text { Pereira, } \\
\text { Francisco } \\
\text { Floriano de } \\
\text { Souza Silva, } \\
\text { Glauber de } \\
\text { Medeiros } \\
\text { Braga, Jair } \\
\text { Messias } \\
\text { Balsonaro, } \\
\text { Marcelo } \\
\text { Viviani } \\
\text { Gonçalves, } \\
\text { Ricardo de } \\
\text { Rezende } \\
\text { Ferraço, } \\
\text { Paulo Feijó, } \\
\text { Walney da } \\
\text { Rocha } \\
\text { Carvalho,Ed } \\
\text { uardo } \\
\text { Cosentino } \\
\text { Cunha, } \\
\text { Stepan } \\
\text { Nercessian, } \\
\text { Rodrigo }\end{array}$ & & & & & & & \\
\hline
\end{tabular}




\begin{tabular}{|c|c|c|c|c|c|c|c|c|}
\hline $\begin{array}{l}\mathbf{N}^{0} \text { da } \\
\text { Ação }\end{array}$ & $\begin{array}{l}\text { Demandant } \\
\text { e }\end{array}$ & Demandado & Tipo de Ação & $\begin{array}{l}\text { Data } \\
\text { ajuizamento }\end{array}$ & Outros atores processuais & Decisões judiciais & $\begin{array}{l}\text { Peças } \\
\text { processuais }\end{array}$ & $\begin{array}{l}\text { Andament } \\
\text { o em } 30 \\
\text { set. } 2014\end{array}$ \\
\hline & $\begin{array}{l}\text { Felinto } \\
\text { Ibarra } \\
\text { Epitácio } \\
\text { Maia, } \\
\text { Edson } \\
\text { Ezequiel de } \\
\text { Matos, } \\
\text { Nelson } \\
\text { Roberto } \\
\text { Bornier de } \\
\text { Oliveira, } \\
\text { Rosilda de } \\
\text { Freitas, } \\
\text { Jandira } \\
\text { Feghali, } \\
\text { Camilo Cola } \\
\text { e Welington } \\
\text { Coimbra. }\end{array}$ & & & & & & & \\
\hline
\end{tabular}


TABELA 3 - FUNDAMENTOS UTILIZADOS PELO LEGISLATIVO: FAVORÁVEIS À REDISTRIBUIÇÃO DOS ROYALTIES E PE

\begin{tabular}{|c|c|c|c|}
\hline & Fundamento utilizado & Onde utilizou (referência) & $\begin{array}{l}\text { Classificação do } \\
\text { fundamento }^{228}\end{array}$ \\
\hline L1 & \multicolumn{2}{|c|}{ Modificações no quadro fático: descoberta do pré-sal, aumento da produção, valorização do produto } & $\begin{array}{l}\text { O } \\
\text { Econômico } 229 .\end{array}$ \\
\hline \multicolumn{2}{|r|}{$\begin{array}{l}\text { "O volume de recursos envolvidos é grande e crescente. Em } 2010 \text {, royalties e participação especial } \\
\text { geraram, em conjunto, quase } \mathrm{R} \$ 22 \text { bilhões para os cofres públicos. Os cenários mais moderados preveem } \\
\mathrm{R} \$ 60 \text { bilhões para } 2020 \text {. Cenários mais otimistas chegam a prever até } \mathrm{R} \$ 100 \text { bilhões anuais na virada da } \\
\text { próxima década." }\end{array}$} & $\begin{array}{l}\text { Parecer } \mathrm{n}^{\mathrm{o}} 1.109 / 2011, \mathrm{de} \\
\text { Plenário (ao PLS n } \mathrm{n}^{\mathrm{o}} 448 / 2011 \\
\text { e outros) }\end{array}$ & $\begin{array}{l}\text { O } \\
\text { Econômico. }\end{array}$ \\
\hline \multicolumn{2}{|r|}{$\begin{array}{l}\text { A receita gerada pelos exploração do petróleo, em } 1998 \text {, após a Lei } n^{\circ} 9.478 / 97 \text {, era de } \mathrm{R} \$ 283 \text { milhões, } \\
\text { enquanto que em } 2010 \text { foi de } \mathrm{R} \$ 21,6 \text { bilhões. Só foram descobertas } 28 \% \text { das reservas de pré-sal, restando } \\
78 \% \text { para serem exploradas. }\end{array}$} & $\begin{array}{l}\text { Parecer } \mathrm{n}^{\circ} 1.109 / 2011, \mathrm{de} \\
\text { Plenário - p. } 45\end{array}$ & $\begin{array}{l}\mathrm{O} \\
\text { Econômico. }\end{array}$ \\
\hline \multicolumn{2}{|r|}{$\begin{array}{l}\text { "Há um conjunto de novos campos, ano a ano. Este ano, por exemplo, de 2011, são mais } 150 \text { mil ou } 160 \\
\text { mil de campos novos a se somarem àqueles } 2 \text { milhões do ano passado. E vamos chegar a, mais ou menos, } \\
2,4 \text { milhões no próximo ano; a } 4 \text { milhões, pela previsão, em } 2017 \text {; e a } 6 \text { milhões de barris em } 2020 \text { - que } \\
\text { estimei para 2022, pois sou até um pouco mais pessimista do que a própria EPE." }\end{array}$} & $\begin{array}{l}\text { Sessão do Senado Federal de } \\
19 / 10 / 11 \text { - p. } 42818 .\end{array}$ & $\begin{array}{l}\text { O } \\
\text { Econômico. }\end{array}$ \\
\hline \multicolumn{2}{|r|}{$\begin{array}{l}\text { O forte aumento do preço do petróleo em âmbito internacional (valorização do produto) fez com que as } \\
\text { receitas aumentassem consideravelmente, o que justifica a redistribuição. }\end{array}$} & $\begin{array}{l}\text { Parecer no } 1.109 / 2 \\
\text { Plenário - p. } 11\end{array}$ & $\begin{array}{l}\text { O } \\
\text { Econômico. }\end{array}$ \\
\hline $\mathbf{L 2}$ & \multicolumn{2}{|c|}{ 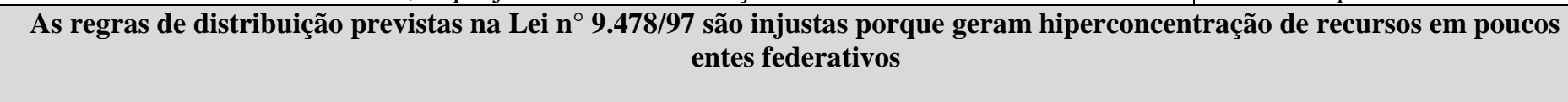 } & $\begin{array}{l}\text { O } \\
\text { Jurídico (não dogmático), } \\
\text { econômico e federativo. }\end{array}$ \\
\hline \multicolumn{2}{|r|}{$\begin{array}{l}\text { "As regras atuais, estabelecidas na Lei n }{ }^{\circ} .478 \text {, de } 1997 \text {, dão aos Estados e Municípios produtores cerca } \\
\text { de } 60 \% \text { dos royalties e } 50 \% \text { da participação especial. À União cabe } 30 \% \text { dos royalties e os outros } 50 \% \text { da } \\
\text { participação especial. Para todos os demais Estados e Municípios são destinados menos de } 10 \% \text { dos } \\
\text { royalties, e nada da participação especial. Trata-se de uma distribuição claramente injusta." }\end{array}$} & $\begin{array}{l}\text { Parecer no } 1.109 / 2011, \text { de } \\
\text { Plenário - p. 11-12. }\end{array}$ & $\begin{array}{l}\text { O } \\
\text { Jurídico (não dogmático), } \\
\text { econômico e federativo. }\end{array}$ \\
\hline \multicolumn{2}{|r|}{$\begin{array}{l}\text { "Em } 2010 \text {, somente o Rio de Janeiro, considerando o Estado e seus Municípios, arrecadou } \mathrm{R} \$ 4,3 \text { bilhões } \\
\text { de royalties, } 67 \% \text { dos royalties distribuídos aos Estados e Municípios, e } \$ 5,5 \text { bilhões de participação } \\
\text { especial, mais de } 90 \% \text { da participação especial distribuída aos entes subnacionais." }\end{array}$} & $\begin{array}{l}\text { Sessão do Senado Federal de } \\
19 / 10 / 11 \text { - p. } 42851\end{array}$ & $\begin{array}{l}\text { O } \\
\text { Econômico e federativo. }\end{array}$ \\
\hline \multicolumn{2}{|r|}{$\begin{array}{l}\text { "Vimos que a proposta que apresentamos atende aos interesses da União e não prejudica Estados e } \\
\text { Municípios produtores. Devemos ressaltar, por fim, que a distribuição proposta na tabela acima é também }\end{array}$} & $\begin{array}{l}\text { Parecer n }^{\circ} 1.109 / 2011, \text { de } \\
\text { Plenário - p. } 17\end{array}$ & \\
\hline
\end{tabular}

${ }^{228}$ Legenda: Fundamentos respaldados nas visões dominantes do direito constitucional brasileiro $=$ VD, os quais incluem: fundamentos de origem neoconstitucionalista $=$ Neo, fundamentos jurídicos dogmáticos e fundamentos jurídico historicistas.

Fundamentos de outra natureza $=\mathrm{O}$, os quais incluem: fundamentos econômicos, ambientais, jurídicos (não dogmáticos) e federativos.

${ }^{229}$ Os fundamentos foram sintetizados, a fim de facilitar a sua compreensão. No entanto, por serem apresentados de diversas formas, entendeu-se relevante trazer exemplos de sua utilização. A classificação em negrito considera todas as categorias envolvidas nos exemplos.

${ }^{230}$ Parecer n $n^{\circ}$ 1.109/2011 ao PLS no 448/2011 e outros. Disponível em: <http://www.senado.gov.br/atividade/materia/getPDF.asp?t=98278\&tp=1>. Acesso em 25 fev. 2015. 


\begin{tabular}{|c|c|c|c|}
\hline & Fundamento utilizado & Onde utilizou (referência) & $\begin{array}{l}\text { Classificação do } \\
\text { fundamento }^{228}\end{array}$ \\
\hline \multicolumn{2}{|r|}{$\begin{array}{l}\text { uma solução para os mais de } 5.000 \text { Municípios que têm direito a uma parte da riqueza da nação, } \\
\text { independentemente de sua localização geográfica e que, atualmente, recebem somente algo em torno de } \\
6 \% \text { dos royalties e, absolutamente nada das receitas da participação especial. De acordo com nossas } \\
\text { previsões, o fundo especial destinará para a totalidade dos Muncípios, já em 2012, o equivalente a } R \$ 4 \\
\text { bilhões, que serão distribuídos de acordo com o mesmo critério de rateio do FPM. Isso representa um } \\
\text { aumento de quase sete vezes em relação aos valores de 2010.”. }\end{array}$} & & \\
\hline \multicolumn{2}{|r|}{$\begin{array}{l}\text { "O fundo especial também destinará } \mathrm{R} \$ 4 \text { bilhões a todos os Estados e ao Distrito Federal, já em } 2012 . \\
\text { Isso beneficiará diretamente os } 17 \text { Estados (além do Distrito Federal) que, atualmente, encontram-se } \\
\text { praticamente alijados do processo de distribuição das receitas de petróleo. Em } 2010 \text { o fundo especial } \\
\text { destinou a todos os Estados somente } \mathrm{R} \$ 160 \text { milhões. }\end{array}$} & $\begin{array}{l}\text { Parecer } \mathrm{n}^{\circ} 1.109 / 2011, \mathrm{de} \\
\text { Plenário - p. } 18 .\end{array}$ & $\begin{array}{l}\mathrm{O} \\
\text { Econômico e federativo.. }\end{array}$ \\
\hline \multicolumn{2}{|r|}{$\begin{array}{l}\text { "Sobre os recursos destinados aos Municípios produtores, confrontantes ou afetados por operações de } \\
\text { embarque e desembarque do petróleo, julgamos importante limitar suas receitas com royalties e } \\
\text { participação especial, para evitar a concentração de recursos em poucos entes. Atualmente, há verdadeiras } \\
\text { aberraçes, com Municípios arrecadando mais de } \mathrm{R} \$ 1 \text { bilhão por ano com royalties e participação } \\
\text { especial." }\end{array}$} & $\begin{array}{l}\text { Parecer } \mathrm{n}^{\circ} 1.109 / 2011, \mathrm{de} \\
\text { Plenário - p. } 19 .\end{array}$ & O \\
\hline \multicolumn{2}{|r|}{$\begin{array}{l}\text { “Isto é o que aconteceu em } 2010 \text {. Tivemos, em 2010, R } \$ 8,6 \text { bilhões para a União, de um total de } \mathrm{R} \$ 21,6 \\
\text { bilhões; } \mathrm{R} \$ 9,8 \text { bilhões ficaram com o Estado do Rio de Janeiro e seus Municípios; } \mathrm{R} \$ 900 \text { milhões, com o } \\
\text { Espírito Santo; } \mathrm{R} \$ 700 \text { milhões, com todos os demais Estados do Brasil; e R } \$ 1,6 \text { bilhão, com todos os } \\
\text { Municípios do Brasil. Por que coloco isso? } \\
\text { Para mostrarmos claramente: é razoável que, tratando-se de uma riqueza de petróleo em mar, que pertence } \\
\text { a todos os brasileiros, possamos manter uma regra em que } 80 \% \text { fiquem com um Estado brasileiro? Creio } \\
\text { que não. Creio que o bom senso não leva a isso." }\end{array}$} & $\begin{array}{l}\text { Sessão do Senado Federal de } \\
\text { 19/10/11 - p. } 42818 .\end{array}$ & $\begin{array}{l}\mathrm{O} \\
\text { Econômico e federativo. }\end{array}$ \\
\hline $\mathbf{L 3}$ & \multicolumn{2}{|l|}{ Produção em mar cada vez mais longe da costa, o que atenua os impactos } & $\begin{array}{l}\text { O } \\
\text { Econômico e ambiental. }\end{array}$ \\
\hline \multicolumn{2}{|r|}{$\begin{array}{l}\text { "A perpetuação do quadro atual torna-se ainda mais grave diante de dois fatos. O primeiro é que a maior } \\
\text { parte da produção tende a ocorrer a dezenas, ou mesmo centenas de quilômetros da costa. Torna-se, assim, } \\
\text { cada vez mais tênue a relação entre a produção e o impacto [econômico e ambiental] sobre o Município } \\
\text { ou o Estado confrontante." }\end{array}$} & $\begin{array}{l}\text { Parecer } \mathrm{n}^{\circ} 1.109 / 2011, \text { de } \\
\text { Plenário - p. } 12 .\end{array}$ & O \\
\hline L4 & \multicolumn{2}{|c|}{$\begin{array}{c}\text { A nova sistemática de distribuição não implicará queda substancial nas receitas dos entes produtores, confrontantes e } \\
\text { afetados }\end{array}$} & $\begin{array}{l}\text { O } \\
\text { Econômico. }\end{array}$ \\
\hline $\begin{array}{l}\text { "Con } \\
2011 \\
\text { redis } \\
\text { ganh } \\
\text { confi } \\
\text { subir }\end{array}$ & $\begin{array}{l}\text { iderando o aumento de arrecadação previsto, de } \mathrm{R} \$ 20,7 \text { bilhões em } 2010 \text { para } \mathrm{R} \$ 28 \text { bilhões em } \\
\text { considerando somente os royalties e participação especial decorrentes da produção em mar, a } \\
\text { ribuição que estamos propondo permite que os Estados confrontantes venham, efetivamente, a ter } \\
\text { s já em } 2012 \text {, comparativamente àquilo que receberam em } 2010 \text {. Mais precisamente, os Estados } \\
\text { nttantes arrecadaram } R \$ 7 \text { bilhões em } 2010 \text {. De acordo com as nossas projeções, sua arrecadação } \\
\text { para } R \$ 7,7 \text { bilhões em } 2012 \text {. No agregado, estados e municípios confrontantes e afetados por }\end{array}$ & $\begin{array}{l}\text { Parecer } \mathrm{n}^{\circ} 1.109 / 2011, \mathrm{de} \\
\text { Plenário - p. 16-17. }\end{array}$ & Oconômico. \\
\hline
\end{tabular}


operações de embarque e desembarque de petróleo deverão arrecadar $\mathrm{R} \$ 11,1$ bilhões em 2012, praticamente os mesmos $\mathrm{R} \$ 11,4$ bilhões que arrecadaram em 2010. Em 2013 a arrecadação deverá atingir $\mathrm{R} \$ 11,9$ bilhões e continuar crescendo, e chegar a quase $\mathrm{R} \$ 20$ bilhões em 2020. (...)Dessa forma, nossa proposta é que os entes produtores não percam. Pelo contrário, verão suas receitas crescer até o final desta década. À medida que a produção aumentar - e, até 2020, deve praticamente triplicar em relação a 2010, os produtores continuarão ganhando, embora suas receitas irão crescer mais lentamente do que cresceriam se não houvesse alterações no marco regulatório."

Os Estados confrontantes receberam R \$ 7,15 bilhões em 2010 e R \$ 8,5 bilhões em 2011; em 2012, de acordo com a nova sistemática de distribuicão receberão $\mathrm{R} \$ 7,7$ bilhões; em 2013, os produtores já recuperam e recebem $\mathrm{R} \$ 8,3$ bilhões; em 2014, $\mathrm{R} \$ 9$ bilhões; em 2015, $\mathrm{R} \$ 9,6$ bilhões; e, 2016, $\mathrm{R} \$$ 11,3bilhões; em 2017, R \$ 12 bilhões; em 2018, R \$ 12,8 bilhões; em 2019, quase R \$ 14 bilhões; em 2020, quase $\mathrm{R} \$ 16$ bilhões; em 2021, quase $\mathrm{R} \$ 18$ bilhões, ou seja, os produtores continuam ganhando em termos reais, só diminui a velocidade de apropriação desses recursos.

\section{A Lei ${ }^{0} 12.734$ não implica quebra contratual}

"O contrato é entre a União e a empresa de petróleo. Esse contrato estabelece a alíquota dos royalties, as regras de cálculo da participação especial, mas é silente no que diz respeito à distribuição dessas receitas. E nem poderia ser diferente! O que interessa para a empresa de petróleo é o valor que paga à União; a forma como esses recursos são distribuídos é irrelevante."

Também deve-se afastar a alegação de que a edição de lei determinando novos critérios de distribuição da renda do petróleo configure quebra de contrato. Isso porque o contrato de exploração e desenvolvimento de uma jazida petrolífera é firmado pela União, por intermédio da ANP, com as empresas de petróleo.

Nem os estados nem os municípios são parte no mencionado contrato.

"O contrato dos royalties do Espírito Santo não existe. O que existe, em termos legais (...) é um contrato entre a empresa de petróleo contratante e a União. E esse é o contrato da União, através da ANP, hoje e amanhã, da empresa específica do consórcio, e o contratante."

"Há uma questão que é muito séria: muitos dizem que não se pode mexer nos royalties quando se trata do "petróleo velho", porque isso é romper contrato. Os contratos são entre a empresa de petróleo e a União.

O que nós vamos discutir não é rompimento de contrato; nós vamos discutir uma lei que já foi alterada, no mínimo, quatro vezes por esta Casa. Então, não é rompimento de contrato."

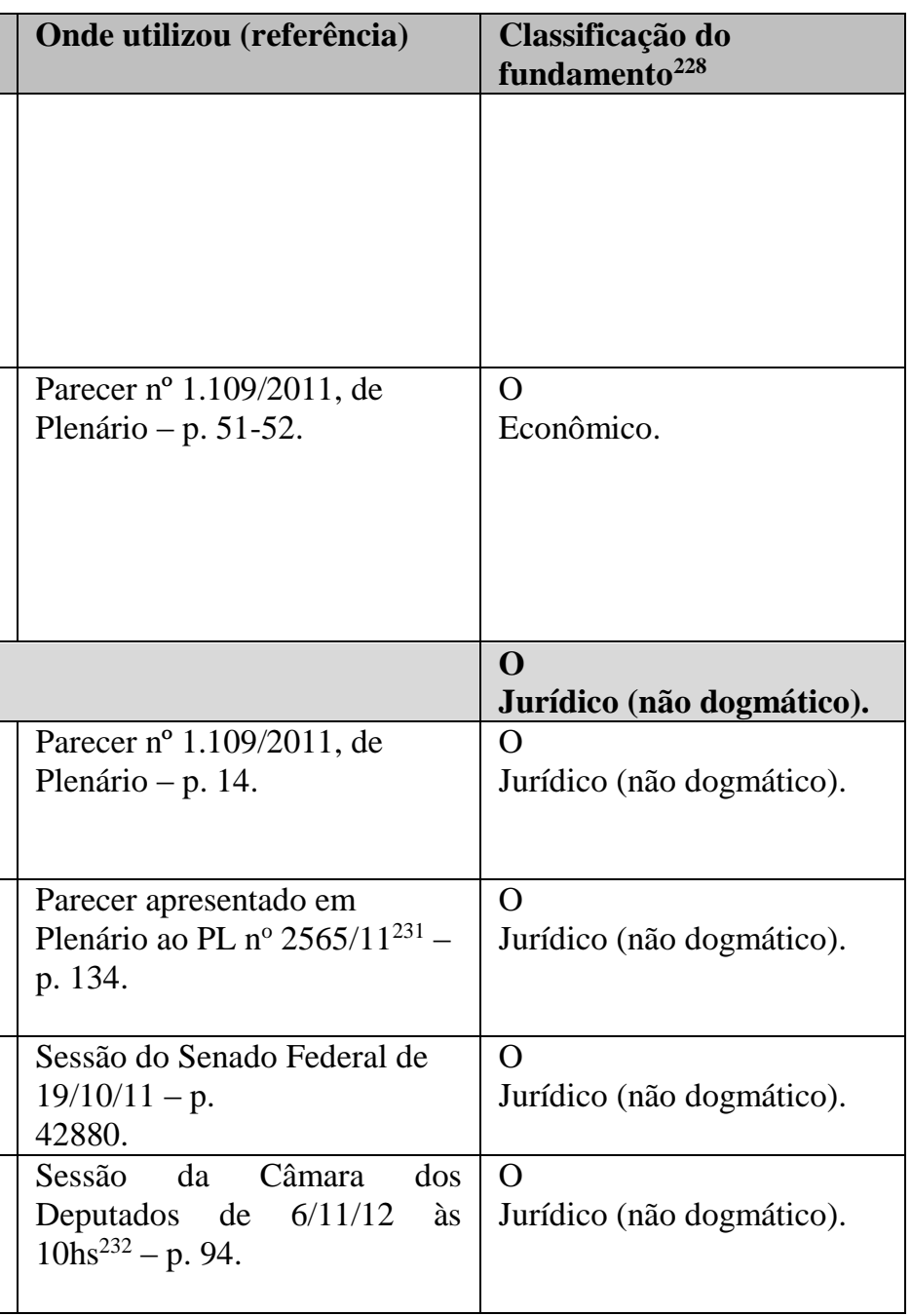

${ }^{231}$ Parecer apresentado em Plenário ao PL no 2565/11. Disponível em: <http://www.senado.gov.br/ atividade/materia/getPDF.asp?t=98278\&tp=1>. Acesso em 25 fev. 2015. ${ }^{232}$ Sessão da Câmara dos Deputados de 6/11/12 às 10hs. Disponível em: 〈http://www.camara.leg.br/internet/plenario/notas/extraord/em0611121000.pdf〉. Acesso em: 27 fev. 2015. 


\begin{tabular}{|c|c|c|c|}
\hline & Fundamento utilizado & Onde utilizou (referência) & $\begin{array}{l}\text { Classificação do } \\
\text { fundamento }^{228}\end{array}$ \\
\hline L6 & \multicolumn{2}{|c|}{$\begin{array}{l}\text { As novas regras de distribuição estabelecem compensação aos entes produtores, confrontantes e afetados ao destinar } \\
\text { alíquotas distintas dos não produtores para eles }\end{array}$} & $\begin{array}{l}\text { O } \\
\text { Jurídico (não dogmático) e } \\
\text { econômico. }\end{array}$ \\
\hline \multicolumn{2}{|r|}{$\begin{array}{l}\text { "Felizmente, esse desacordo com a Constituição pode ser facilmente sanado; basta garantir aos entes } \\
\text { produtores alguma forma de compensação. Nesse sentido, o substitutivo apresentado estipula percentuais } \\
\text { dos royalties e da participação especial que serão direcionados aos entes produtores. Os percentuais foram } \\
\text { escolhidos de forma a lhes garantir uma receita de } \mathrm{R} \$ 11,1 \text { bilhões em } 2012 \text {, supondo, de forma bastante } \\
\text { realista, uma arrecadação de royalties de } R \$ 13 \text { bilhões, e de participação especial de } \mathrm{R} \$ 15 \text { bilhões." }\end{array}$} & $\begin{array}{l}\text { Parecer no } \mathrm{n}^{\circ} .109 / 2011, \mathrm{de} \\
\text { Plenário - p. } 15 .\end{array}$ & $\begin{array}{l}\text { O } \\
\text { Jurídico (não dogmático) e } \\
\text { econômico. }\end{array}$ \\
\hline L7 & \multicolumn{2}{|c|}{$\begin{array}{l}\text { A nova sistemática de partilha possibilitará a redução das desigualdades regionais e sociais, bem como o desenvolvimento } \\
\text { nacional }\end{array}$} & $\begin{array}{l}\text { O } \\
\text { Federativo e econômico. }\end{array}$ \\
\hline \multicolumn{2}{|r|}{$\begin{array}{l}\text { "Não é possível os Municípios brasileiros ficarem de mãos estendidas, os prefeitos e as prefeitas deste } \\
\text { País afora, sobretudo os do interior. No meu Estado [Tocantins], por exemplo, a maior renda dos } \\
\text { pequenos Municípios é FPM, nem ICMS têm - muito pouco, muito pequeno; mal conseguem pagar a } \\
\text { folha de pagamento. E eu sei o quanto é gratificante quando nós chegamos a um Município e podemos } \\
\text { apontar para um posto de saúde e, muitas vezes, dizer que aquele posto de saúde foi fruto do trabalho } \\
\text { nosso, porque é assim que o eleitor pensa, sobretudo aquele que está na miséria, precisando de apoio do } \\
\text { governo ou dos seus representantes. (...)Sou um daqueles que defendem o novo pacto federativo, com } \\
\text { melhor distribuição de recursos para os Municípios, porque a Constituição de } 88 \text { deu muita tarefa, muita } \\
\text { missão para os Municípios, mas não deu dinheiro suficiente para bancar as demandas que os Municípios } \\
\text { brasileiros têm, sobretudo os pequenos Municípios." }\end{array}$} & $\begin{array}{l}\text { Sessão do Senado Federal de } \\
\text { 19/10/11 - p. } \\
42825 .\end{array}$ & $\begin{array}{l}\text { O } \\
\text { Federativo e econômico. }\end{array}$ \\
\hline \multicolumn{2}{|r|}{$\begin{array}{l}\text { "É graças a esse vigoroso crescimento da renda do petróleo que estou convencido que os critérios de } \\
\text { repartição propostos no substitutivo anexo vão dar expressiva contribuição para promoção do } \\
\text { desenvolvimento nacional, da erradicação da pobreza e da redução das desigualdades sociais e regionais." }\end{array}$} & $\begin{array}{l}\text { Parecer apresentado em } \\
\text { Plenário ao PL } \mathrm{n}^{\circ} 2565 / 11-\mathrm{p} \text {. } \\
136 .\end{array}$ & $\begin{array}{l}\text { O } \\
\text { Federativo e econômico }\end{array}$ \\
\hline \multicolumn{2}{|r|}{$\begin{array}{l}\text { "Esses recursos, bem utilizados e gerenciados adequadamente, poderão conduzir o Brasil rumo a um } \\
\text { estágio avançado de desenvolvimento econômico e social, com a erradicação plena da fome e da miséria } \\
\text { num curto de espaço de tempo. Com tais objetivos, a Lei no } 12.351 \text {, de } 2010 \text {, que dispõe sobre a } \\
\text { exploração e a produção do petróleo, instituiu o Fundo Social, de natureza contábil e financeira, vinculado } \\
\text { à Presidência da República, com a finalidade de constituir fundo de recursos para o desenvolvimento } \\
\text { social e regional, na forma de programas e projetos nas áreas de combate à pobreza e de } \\
\text { desenvolvimento." }\end{array}$} & $\begin{array}{l}\text { Sessão do Senado Federal de } \\
\text { 19/10/11 - p. } \\
42827 .\end{array}$ & $\begin{array}{l}\text { O } \\
\text { Federativo e econômico. }\end{array}$ \\
\hline \multicolumn{2}{|r|}{$\begin{array}{l}\text { "Não é possível reduzir essas desigualdades sociais, regionais, econômicas, sem que os bens naturais } \\
\text { deste Pais, sem que as riquezas naturais deste País possam ser usufruídas por toda a sua população. } \\
\text { Não temos apenas uma língua em comum. Nós somos um território, o Estado é parte desta Nação. } \\
\text { Portanto, não é justo que nós continuemos a ter o que temos hoje, a elevada concentração de apropriação } \\
\text { de recursos decorrentes da produção e comercialização do petróleo para pouquíssimos Estados e } \\
\text { pouquíssimos Municípios". }\end{array}$} & $\begin{array}{l}\text { Sessão do Senado Federal de } \\
\text { 19/10/11 - p. } 42835 .\end{array}$ & $\begin{array}{l}\text { O } \\
\text { Federativo. }\end{array}$ \\
\hline
\end{tabular}




\begin{tabular}{|c|c|c|c|}
\hline & Fundamento utilizado & Onde utilizou (referência) & $\begin{array}{l}\text { Classificação do } \\
\text { fundamento }\end{array}$ \\
\hline \multicolumn{2}{|r|}{$\begin{array}{l}\text { "Recebo com prazer o aparte de V. Exa } \text {, mas devo dizer que estava me referindo exatamente a esse } \\
\text { período da transição, porque os Estados que hoje estão desequilibrados e ainda vivendo numa situação de } \\
\text { subdesenvolvimento grave, enquanto outros têm crescido e se desenvolvido, precisam desses recursos } \\
\text { agora; o Brasil não pode se dar ao luxo de continuar a crescer de forma desigual, todos temos que } \\
\text { aproveitar, e todos os brasileiros têm que ter direito a fazer parte desse processo de desenvolvimento que } \\
\text { aconteceu nestes últimos oito anos." }\end{array}$} & $\begin{array}{l}\text { Sessão do Senado Federal de } \\
\text { 19/10/11 - p. } 42836\end{array}$ & $\begin{array}{l}\mathrm{O} \\
\text { Federativo. }\end{array}$ \\
\hline \multicolumn{2}{|r|}{$\begin{array}{l}\text { "Como eliminar desigualdades regionais, se a exploração de riquezas que a Constituição diz que são da } \\
\text { União, portanto, são de todo o País, podem ficar só na mão de dois, três, quatro ou cinco Estados? Isso se } \\
\text { aplica também, de modo semelhante, à questão dos minérios, e não só o petróleo." }\end{array}$} & $\begin{array}{l}\text { Sessão do Senado Federal de } \\
\text { 19/10/11 - p. } 42838 .\end{array}$ & $\begin{array}{l}\text { O } \\
\text { Federativo. }\end{array}$ \\
\hline \multicolumn{2}{|r|}{$\begin{array}{l}\text { "Isto aqui vai significar muito mais para eles. No debate de ontem e de hoje aqui, conseguimos fazer com } \\
\text { que esses cinco mil e poucos municípios se sentem à mesa e tenham o direito de comungar, quer dizer, a } \\
\text { essa comunhão nacional, do petróleo é nosso. Que coisa linda isso!" }\end{array}$} & $\begin{array}{l}\text { Sessão do Senado Federal de } \\
19 / 10 / 11-\text { p. } 42954 .\end{array}$ & $\begin{array}{l}\text { O } \\
\text { Federativo. }\end{array}$ \\
\hline \multicolumn{2}{|r|}{$\begin{array}{l}\text { "O meu Estado, Presidente, encravado no Nordeste brasileiro, o meu Estado, que é o penúltimo da } \\
\text { Federação, aguardava por isso há muitos anos. E hoje tomamos a decisão que vai ao encontro das } \\
\text { necessidades dos Estados pobres do Brasil, de que essa riqueza imensa, agora sim, será subdividida por } \\
\text { todos. E ouvi quando os representantes do Rio de Janeiro, com especialidade desse cacique da política } \\
\text { nacional, que é o Ministro Dornelles, traziam aqui uma conta nova, uma conta nova que não se paga tanto } \\
\text { quanto deveriam pagar, e essa conta nova não pode ser colocada agora à margem do processo. Vamos } \\
\text { continuar perseguindo para que tenhamos mais recursos para atender os Estados que estão reclamando e } \\
\text { os Estados que não tinham absolutamente nada." }\end{array}$} & $\begin{array}{l}\text { Sessão do Senado Federal de } \\
\text { 19/10/11 - p. } 42954 .\end{array}$ & $\begin{array}{l}\text { O } \\
\text { Federativo. }\end{array}$ \\
\hline \multicolumn{2}{|r|}{$\begin{array}{l}\text { "O Nordeste e o Norte foram desigualmente tratados ao longo da história deste País. A hora de recuperar, } \\
\text { de conceder melhorias a essas Regiões é agora, quando o Brasil passa por um momento extremamente } \\
\text { pródigo, com o pré-sal. } \\
\text { Por que não distribuir melhor? (...) Entendemos o jus sperniandi (sic) de alguns Estados, mas não } \\
\text { podemos aceitar isso, sob pena de mantermos o status da desigualdade. Basta olharmos a história do } \\
\text { Brasil, desde a implantação da indústria automobilística, da siderurgia. Tudo isso contemplou o Sul e o } \\
\text { Sudeste, principalmente o Sudeste, deixando as regiões mais pobres absolutamente descobertas. }\end{array}$} & $\begin{array}{l}\text { Sessão da Câmara } \\
\text { Deputados dos } \\
16 \text { hs }^{233}-\text { p. } 13 .\end{array}$ & $\begin{array}{l}\text { O } \\
\text { Federativo e econômico. }\end{array}$ \\
\hline $\mathbf{L 8}$ & \multicolumn{2}{|c|}{$\begin{array}{c}\text { A nova sistemática de partilha observa o pacto federativo, pois contribui para o equilíbrio da federação e para a harmonia } \\
\text { entre os entes políticos }\end{array}$} & $\begin{array}{l}\text { O } \\
\text { Federativo. }\end{array}$ \\
\hline \multicolumn{2}{|r|}{$\begin{array}{l}\text { "Quero dizer a Vossa Excelência, Senador José Sarney, e o faço por um dever de justiça, que estamos, } \\
\text { nesta data, a partir de agora, iniciando o novo de muitos, ou de muitas decisões neste Poder, que buscarão, } \\
\text { Paulo Davim, justiça social, equilíbrio federativo, harmonia entre os Estados, que são princípios basilares }\end{array}$} & $\begin{array}{l}\text { Parecer n }{ }^{\circ} 1.109 / 2011, \mathrm{de} \\
\text { Plenário - p. } 43 .\end{array}$ & $\begin{array}{l}\text { O } \\
\text { Federativo. }\end{array}$ \\
\hline
\end{tabular}

${ }^{233}$ Sessão da Câmara dos Deputados de 6/11/12 às 16hs ${ }^{233}$. Disponível em: 〈http://www. camara.leg.br/internet/plenario/notas/extraord/EV0611121620.pdf>. Acesso em 27 $\mathrm{f}^{233} \mathrm{ev} .2015$. 


\begin{tabular}{|c|c|c|c|}
\hline & Fundamento utilizado & Onde utilizou (referência) & $\begin{array}{l}\text { Classificação do } \\
\text { fundamento }^{228}\end{array}$ \\
\hline \multicolumn{4}{|c|}{ e constitucionais.". } \\
\hline \multicolumn{2}{|r|}{$\begin{array}{l}\text { "V. Exa } \text {, Senador José Sarney, teve a capacidade de equilibrar situações, e hoje nós caminhamos para } \\
\text { inaugurar uma decisão, sem dúvida alguma, senhoras e senhores brasileiros, Senadores amigos, de } \\
\text { fundamental importância para o pacto federativo, para o equilíbrio social a partir do econômico. E a mim } \\
\text { foi dada essa missão. Está cumprida, Sr. Presidente. Aqui está o nosso relatório. Aqui se encontram } 41 \\
\text { páginas de discussão, de análise e debates que quero fazer com os Srs. Senadores. Aqui se encontra, } \\
\text { certamente, não o projeto ideal que eu queria, mas o projeto possível de ser alcançado. E graças a aliados, } \\
\text { graças a parceiros, a partir do meu Partido, o PMDB, e principalmente a duas figuras às quais quero } \\
\text { prestar a minha homenagem pelo trabalho que desenvolveram ao longo de todo esse processo." }\end{array}$} & $\begin{array}{l}\text { Sessão do Senado Federal de } \\
18 / 10 / 11^{234}-\text { p. } 42546-42547\end{array}$ & $\begin{array}{l}\text { O } \\
\text { Federativo. }\end{array}$ \\
\hline L9 & \multicolumn{2}{|c|}{ O petróleo é finito e por isso sua receita deve ser usada em prol de toda a nação e das futuras gerações } & $\begin{array}{l}\text { O } \\
\text { Federativo e econômico }\end{array}$ \\
\hline $\begin{array}{l}\text { "Que } \\
\text { um cr } \\
\text { o Bra }\end{array}$ & $\begin{array}{l}\text { o pedir, concluindo, que tragam o debate nacional e não apenas estadual aqui para dentro; tragam } \\
\text { mpromisso com as próximas gerações e não apenas com a atual; façamos um pacto federativo com } \\
\text { ill, com as crianças de hoje e as do futuro e não apenas com cada um de nossos Estados." }\end{array}$ & $\begin{array}{l}\text { Sessão do Senado Federal de } \\
\text { 19/10/11 - p. } 42821\end{array}$ & $\begin{array}{l}\mathrm{O} \\
\text { Federativo. }\end{array}$ \\
\hline $\begin{array}{l}\text { "Entr } \\
\text { então } \\
\text { Cons } \\
\text { natur } \\
\text { Aque } \\
\text { Unid } \\
\text { como } \\
\text { habit } \\
\text { em re }\end{array}$ & $\begin{array}{l}\text { as experiências que mais se destacam, está justamente a do Estado do Alasca, pois, em 1976, o } \\
\text { Governador Jay Hammond propôs à Assembleia Legislativa daquele Estado uma emenda à } \\
\text { ituição que destinava pelo menos } 25 \% \text { de toda a receita dos royalties sobre a exploração de recursos } \\
\text { is para um fundo que a todos pertenceria e que foi aprovado por todo o povo, em referendo popular. } \\
\text { es recursos passaram a ser investidos em títulos de renda fixa, em ações de empresas dos Estados } \\
\text { s, em empreendimentos imobiliários e em outros títulos, inclusive ações de empresas internacionais, } \\
\text { as do Brasil. Os lucros passaram a reverter em benefício de todos os seus habitantes. (...) os } \\
\text { ntes daquele Estado encontraram uma maneira de converter um recurso não renovável, o petróleo, } \\
\text { curso completamente renovável para ser utilizado ao longo de várias gerações" }\end{array}$ & $\begin{array}{l}\text { Sessão do Senado Federal de } \\
\text { 19/10/11 - p. } 42827 .\end{array}$ & $\begin{array}{l}\mathrm{O} \\
\text { Federativo e econômico. }\end{array}$ \\
\hline $\begin{array}{l}\text { "Con } \\
\text { partil } \\
\text { Brasi } \\
\text { erro c } \\
\text { que a }\end{array}$ & $\begin{array}{l}\text { luo, lembrando que o Senador Ferraço falou em partilha. Caramba, estamos falando tanto em } \\
\text { a entre nós! Vamos partilhar com as gerações futuras! Vamos tratar-nos como uma coisa só: o } \\
\text { ! E tratar como Brasil não só os brasileiros de hoje, mas também os do futuro. Não vamos repetir o } \\
\text { ue fizemos, sem culpa nossa porque éramos colônia, e que Portugal fez conosco: queimar o ouro } \\
\text { terra brasileira teve durante algumas décadas.” }\end{array}$ & $\begin{array}{l}\text { Sessão do Senado Federal de } \\
\text { 19/10/11 - p. } 42832 .\end{array}$ & $\begin{array}{l}\mathrm{O} \\
\text { Federativo }\end{array}$ \\
\hline $\begin{array}{l}\text { "Entã } \\
\text { forme } \\
\text { forme } \\
\text { que e } \\
\text { conhe }\end{array}$ & $\begin{array}{l}\text { o, ter um projeto nacional, olhar o horizonte do Brasil, cuidar da educação, da tecnologia, da } \\
\text { ção de homens e mulheres, principalmente os mais pobres, que precisam ter acesso à educação, à } \\
\text { ção, ao conhecimento, é preparar o Brasil para o futuro. O Brasil tem como horizonte a de um País } \\
\text { tá em pleno desenvolvimento econômico e social, por isso precisa preparar seu povo para o } \\
\text { cimento, para a tecnologia, porque essa é a demanda mundial" }\end{array}$ & $\begin{array}{l}\text { Sessão da Câmara dos } \\
\text { Deputados de } 6 / 11 / 12 \text { às } 10 \mathrm{hs} \\
\text { - p. } 64 .\end{array}$ & $\begin{array}{l}\text { O } \\
\text { Econômico e federativo }\end{array}$ \\
\hline
\end{tabular}

${ }^{234}$ Diário do Senado Federal de 19/10/11, p. 42546-42547. Disponível em: <http://legis.senado.leg.br/diarios/BuscaDiario?tipDiario=1\&datDiario=19/10/2011\&pagina Direta=42544>. Acesso em: 27 fev. 2015. 


\begin{tabular}{|c|c|c|c|}
\hline & Fundamento utilizado & Onde utilizou (referência) & $\begin{array}{l}\text { Classificação do } \\
\text { fundamento } 228\end{array}$ \\
\hline \multicolumn{2}{|r|}{$\begin{array}{l}\text { "O petróleo é finito, ele vai acabar. E nós precisamos utilizar essa riqueza, esse patrimônio que pertence } \\
\text { ao povo brasileiro para prepararmos a população jovem para o futuro, para enfrentar os desafios da } \\
\text { ciência e da tecnologia e contribuir com o desenvolvimento do País." }\end{array}$} & $\begin{array}{l}\text { Sessão da Câmara dos } \\
\text { Deputados de } 6 / 11 / 12 \text { às } 10 \mathrm{hs} \\
\text { - p. } 93 .\end{array}$ & $\begin{array}{l}\text { O } \\
\text { Econômico }\end{array}$ \\
\hline \multicolumn{2}{|r|}{$\begin{array}{l}\text { "Como o petróleo é um recurso natural não renovável, com data para esgotar as suas reservas, os recursos } \\
\text { financeiros resultantes de sua exploração devem ser usados sabiamente, de modo a se incorporarem ao } \\
\text { patrimônio humano do País." }\end{array}$} & $\begin{array}{l}\text { Sessão da Câmara dos } \\
\text { Deputados de } 6 / 11 / 12 \text { às } 10 \mathrm{hs} \\
\text { - p. } 110 .\end{array}$ & $\begin{array}{l}\text { O } \\
\text { Econômico. }\end{array}$ \\
\hline \multicolumn{2}{|r|}{$\begin{array}{l}\text { "Os recursos do petróleo são finitos. É necessário, pois, garantir que seu aproveitamento não fique restrito } \\
\text { à atual geração. As gerações futuras também têm direito de usufruir dessa riqueza." }\end{array}$} & $\begin{array}{l}\text { Parecer do Senado ao PLC } n^{0} \\
41 / 13 \text { (Parecer de Plenário) } \\
- \text { p. } 5\end{array}$ & $\begin{array}{l}\text { O } \\
\text { Econômico. }\end{array}$ \\
\hline \multicolumn{2}{|r|}{$\begin{array}{l}\text { "Investir em educação e inovação é a melhor opção para aplicar os recursos do petróleo. Todos sabemos } \\
\text { que o petróleo é um recurso não renovável. Devemos ter a responsabilidade, portanto, de utilizar a renda } \\
\text { que o petróleo nos proporciona para criar uma fonte permanente de riqueza. Como se sabe, a educação e } \\
\text { inovação são a mola do desenvolvimento." }\end{array}$} & $\begin{array}{l}\text { Projeto de Lei do Senado } \mathrm{n}^{\circ} \\
594 / 11^{236}-\text { p. } 10 .\end{array}$ & $\begin{array}{l}\text { O } \\
\text { Econômico. }\end{array}$ \\
\hline L10 & \multicolumn{2}{|l|}{ O petróleo gera muito mais riqueza do que outros minérios } & $\begin{array}{l}\text { O } \\
\text { Econômico. }\end{array}$ \\
\hline \multicolumn{2}{|r|}{$\begin{array}{l}\text { "Este ano Minas Gerais vai receber menos de } 200 \text { milhões de reais de royalties do minério, enquanto o } \\
\text { Estado do Rio de Janeiro vai receber quase } 20 \text { bilhões de reais". }\end{array}$} & $\begin{array}{l}\text { Sessão da Câmara dos } \\
\text { Deputados de } 6 / 11 / 12 \text { às } \\
20 \text { hs }^{237}-\text { p. } 121 .\end{array}$ & $\begin{array}{l}\text { O } \\
\text { Econômico. }\end{array}$ \\
\hline L11 & \multicolumn{2}{|c|}{$\begin{array}{c}\text { O mar territorial e os minerais que se encontram na plataforma continental e zona econômica exclusiva são bens da União, } \\
\text { por isso a riqueza deve ser distribuída para todo o país }\end{array}$} & $\begin{array}{l}\text { O } \\
\text { Jurídico (não dogmático) e } \\
\text { federativo. }\end{array}$ \\
\hline \multicolumn{2}{|r|}{$\begin{array}{l}\text { "Mas eu começo fazendo uma citação ao dispositivo federal, que determina que os recursos naturais da } \\
\text { plataforma continental, bem como os da zona econômica exclusiva, são bens da União. Não se discute de } \\
\text { maneira alguma a exploração em solo territorial. O petróleo extraído no solo dos Estados brasileiros não } \\
\text { está sendo discutido neste projeto de lei." }\end{array}$} & $\begin{array}{l}\text { Sessão do Senado Federal de } \\
19 / 10 / 11 \text { - p. 42814-42815. }\end{array}$ & O Jurídico (não dogmático). \\
\hline \multicolumn{2}{|r|}{$\begin{array}{l}\text { "Eu advogo a tese de que não há que se falar que estamos tirando de A ou de B. Na verdade, estamos } \\
\text { tirando do que é da União, do que é do povo brasileiro. Isso está previsto no art. } 20 \text { da Constituição. O } \\
\text { projeto altera as regras de petróleo em mar - em rigor, mantêm-se regras de petróleo em terra -" }\end{array}$} & $\begin{array}{l}\text { Sessão do Senado Federal de } \\
19 / 10 / 11-\text { p. } 42818 .\end{array}$ & $\begin{array}{l}\text { O Jurídico (não dogmático) e } \\
\text { federativo. }\end{array}$ \\
\hline \multicolumn{2}{|r|}{$\begin{array}{l}\text { "Quero adiantar ainda que nós estamos construindo um sistema que garante os recursos em que } \\
\text { os Estados confrontantes, que é diferente de produtores, porque a produção do nosso petróleo, de que } \\
\text { estamos tratando aqui, é feita quase toda em alto mar, são terrenos da União... É por isso que quando o }\end{array}$} & $\begin{array}{l}\text { Sessão do Senado Federal de } \\
19 / 10 / 11-\text { p. } 42824 .\end{array}$ & $\begin{array}{l}\text { O } \\
\text { Jurídico (não dogmático). }\end{array}$ \\
\hline
\end{tabular}

${ }^{235}$ Parecer ao PLC no 41/13. Disponível em: < http://legis.senado.leg.br/mateweb/arquivos/mate-pdf/131443.pdf>. Acesso em: 8 mar. 2015.

${ }^{236}$ PLS no 594/11. Disponível em: < http://legis.senado.leg.br/mateweb/arquivos/mate-pdf/96777.pdf>. Acesso em: 8 mar. 2015.

${ }^{237}$ Sessão da Câmara dos Deputados de 6/11/12 às 20hs, p. 121. Disponível em: <http://www.camara. leg.br/internet/plenario/notas/extraord/EN0611122020.pdf>. Acesso em 27 fev. 2015 


\begin{tabular}{|c|c|c|c|}
\hline & Fundamento utilizado & Onde utilizou (referência) & $\begin{array}{l}\text { Classificação do } \\
\text { fundamento }\end{array}$ \\
\hline \multicolumn{4}{|c|}{$\begin{array}{l}\text { Estado democrático de Direito definiu que, a partir dos terrenos de marinha, aquelas terras pertencem à } \\
\text { União, e não a este ou àquele Estado membro, ou a este ou àquele Município. } \\
\text { Aqui, além de estar em alto mar, o próprio art. } 20 \text { da Constituição brasileira - e a Constituição é muito } \\
\text { clara - define que essas riquezas, essas reservas pertencem à União nacional." }\end{array}$} \\
\hline \multicolumn{2}{|r|}{$\begin{array}{l}\text { "Os recursos naturais, em especial do petróleo, pertencem à União e a todo o povo brasileiro, que se } \\
\text { garanta o benefício dos recursos do pré-sal, do petróleo, assim como de todos os recursos naturais, para } \\
\text { efetivamente garantir a todos o direito de participar da riqueza da Nação" }\end{array}$} & $\begin{array}{l}\text { Sessão do Senado Federal de } \\
\text { 19/10/11 - p. } 42828 .\end{array}$ & $\begin{array}{l}\text { O } \\
\text { Jurídico (não dogmático) e } \\
\text { federativo. }\end{array}$ \\
\hline \multicolumn{2}{|r|}{$\begin{array}{l}\text { "Portanto, o petróleo é nosso. O petróleo é do Brasil. O petróleo é do povo brasileiro. Se é, conforme a } \\
\text { Constituição diz, uma riqueza pertencente à União, } \\
\text { e sendo a União representativa da vontade da Nação, porque configura a união de todos os Estados e de } \\
\text { todos os Municípios, ela pertence ao povo brasileiro." }\end{array}$} & $\begin{array}{l}\text { Sessão do Senado Federal de } \\
\text { 19/10/11 - p. } 42840 .\end{array}$ & $\begin{array}{l}\text { O } \\
\text { Jurídico (não dogmático) e } \\
\text { federativo. }\end{array}$ \\
\hline \multicolumn{2}{|r|}{$\begin{array}{l}\text { "Sr. Presidente, Sras. e Srs. Parlamentares, povo brasileiro, nossos argumentos são simples, são claros, } \\
\text { são insofismáveis. Nós apresentamos nesta Casa uma emenda, de minha autoria, juntamente com o } \\
\text { Deputado Ibsen Pinheiro e com o Deputado Humberto Souto, fundamentada na Constituição Federal, que } \\
\text { no seu art. } 20 \text { diz, de maneira clara, que os recursos naturais da plataforma continental e da zona } \\
\text { econômica exclusiva, o mar territorial, são bens da União. Então, gente, é muito simples - e aqui, } \\
\text { Deputado Nazareno, lembro-me dos meus tempos de professor, do velho professor que sou -, quando a } \\
\text { PETROBRAS vai a Mossoró, no Rio Grande do Norte, perfura um poço e extrai petróleo, é lícito } \\
\text { dizermos: "Mossoró é um Município produtor de petróleo." Rio Grande do Norte é um Estado produtor } \\
\text { petróleo. Coisa completamente distinta é a PETROBRAS ir lá, no meio do Oceano Atlântico, a 300 } \\
\text { quilômetros de distância da costa, a } 7 \text { mil metros de profundidade, perfurar um poço e extrair petróleo. Aí, } \\
\text { eu pergunto: quem é o produtor de petróleo aqui? O território do Rio de Janeiro termina ali, na Praia de } \\
\text { Copacabana. O produtor de petróleo aqui é a União, como diz a Constituição brasileira. (Muito bem! } \\
\text { Palmas.) E a União, povo brasileiro, somos todos nós, os } 195 \text { milhões de brasileiros. Não há brasileiro de } \\
\text { primeira e de segunda categoria, todos os brasileiros são iguais e merecem o mesmo tratamento.” }\end{array}$} & $\begin{array}{l}\text { Sessão conjunta do Congresso } \\
\text { de } 6 / 3 / 13-\text { p. } 750 .\end{array}$ & $\begin{array}{l}\text { O } \\
\text { Jurídico (não dogmático) e } \\
\text { federativo. }\end{array}$ \\
\hline L12 & \multicolumn{2}{|c|}{ As novas regras de partilha implicarão um incremento de receita significativo para os demais entes da federação } & $\begin{array}{l}\text { O } \\
\text { Econômico. }\end{array}$ \\
\hline \multicolumn{2}{|r|}{$\begin{array}{l}\text { Rio Branco recebe hoje } R \$ 12 \text { milhões, vai receber } \mathrm{R} \$ 49 \text { milhões. O Acre recebe } 8,8 \text { milhões, já em } 2012 \\
\text { com as novas regras, vai receber } 157 \text { milhões. Alagoas recebe hoje } R \$ 81 \text { milhões, vai passar a receber } R \$ \\
283 \text { milhões, O Amapá de } R \$ 7,9 \text { milhões vai passar a receber } R \$ 150 \text { milhões. O Amazonas, que recebe } \\
\mathrm{R} \$ 250 \text { milhões vai receber } \mathrm{R} \$ 464 \text { milhões. A Bahia, de } R \$ 378 \text { milhões passará a ganhar } \mathrm{R} \$ 1,2 \text { bilhão. } \\
\text { O Estado do Paraná, hoje tem uma receita total de royalties de petróleo em torno de } \mathrm{R} \$ 48 \text { milhões. } \\
\text { Chegará, em 2012, a } \mathrm{R} \$ 400 \text { milhões, e poderá chegar, em } 2022 \text {, a } \mathrm{R} \$ 2 \text { bilhões. }\end{array}$} & $\begin{array}{l}\text { Parecer } \mathrm{n}^{\circ} \text { 1.109/2011, de } \\
\text { Plenário - p. } 53 \text { e Sessão do } \\
\text { Senado Federal de 19/10/11 - } \\
\text { p. } 42815 .\end{array}$ & $\begin{array}{l}\mathrm{O} \\
\text { Econômico. }\end{array}$ \\
\hline L13 & \multicolumn{2}{|c|}{$\begin{array}{l}\text { A redistribuição possibilitará melhora nos indicadores socioeconômicos de estados e municípios, sobretudo em educação e } \\
\text { saúde, já que parte da receita tem sua destinação vinculada a esses serviços }\end{array}$} & $\begin{array}{l}\text { O } \\
\text { Econômic } \\
\end{array}$ \\
\hline & 11stados nas ultimas decadas, tem in & Sessão da Câmara dos & \\
\hline
\end{tabular}




\begin{tabular}{|c|c|c|}
\hline Fundamento utilizado & Onde utilizou (referência) & $\begin{array}{l}\text { Classificação do } \\
\text { fundamento }^{228}\end{array}$ \\
\hline $\begin{array}{l}\text { educacional (...). } \\
\text { A solução pode estar nos royalties de petróleo. Essa é uma solução viável, considerando-se a carência de } \\
\text { tantas outras áreas a reclamar por mais recursos, como saneamento básico, educação e segurança, } \\
\text { infraestrutura urbana. Destinar os recursos dos royalties de petróleo para a educação pode suprir a lacuna } \\
\text { fiscal para atingirmos o valor reclamado por essa área. (...) } \\
\text { Os dados são preocupantes, pois demonstram que quase } 3,8 \text { milhões de alunos entre } 4 \text { e } 17 \text { anos estão fora } \\
\text { da escola. Detalhando os números, vê-se que } 19,9 \% \text { das crianças estão fora da escola. Dezessete por cento } \\
\text { dos jovens encontram-se também alijados da formação escolar. } \\
\text { A meta para que } 98 \% \text { dos alunos nessas faixas etárias frequentassem a escola não foi atingida por nenhum } \\
\text { Estado até } 2010 . \text { Cabe ressaltar que o ensino médio registra o maior número de evasão escolar. } \\
\text { Justamente quando se espera que o jovem "decole", tome um rumo na vida. Fato extremamente triste e } \\
\text { decepcionante. (...) Faltam creches e vagas nas escolas públicas, que, no interior do Norte e do Nordeste, } \\
\text { carecem de professores qualificados, instalações adequadas, material pedagógico e de livros." }\end{array}$ & $\begin{array}{l}\text { Deputados de } 6 / 11 / 12 \text { às } 10 \mathrm{hs} \\
- \text { p. } 89-90 .\end{array}$ & Econômico e federativo. \\
\hline $\begin{array}{l}\text { "Nós assistimos todos os dias à situação dramática que os Municípios vêm vivendo no setor de saúde. Os } \\
\text { hospitais não têm condições de atender os pacientes. E façamos justiça aos médicos e aos funcionários dos } \\
\text { hospitais, que fazem um trabalho extraordinário. A falta de recursos não permite que a saúde do Brasil dê } \\
\text { o devido atendimento às pessoas." }\end{array}$ & $\begin{array}{l}\text { Sessão da Câmara dos } \\
\text { Deputados de } 6 / 11 / 12 \text { às } 10 \mathrm{hs} \\
\text { - p. } 98\end{array}$ & $\begin{array}{l}\mathrm{O} \\
\text { Econômico. }\end{array}$ \\
\hline $\begin{array}{l}\text { "Nós queremos que o Brasil deixe o } 58^{\circ} \text { lugar no que se refere à educação. Somos a sexta economia do } \\
\text { mundo. Nós precisamos avançar em ciência tecnologia. A base está na formação de bons profissionais. } \\
\text { (...) Nós queremos fazer uma grande mudança, uma revolução educacional no País, mas, para isso, } \\
\text { precisamos de recursos" }\end{array}$ & $\begin{array}{l}\text { Sessão da Câmara dos } \\
\text { Deputados de } 6 / 11 / 12 \text { às } 10 \mathrm{hs} \\
\text { - p. } 194-195 .\end{array}$ & $\begin{array}{l}\mathrm{O} \\
\text { Econômico. }\end{array}$ \\
\hline $\begin{array}{l}\text { "Essa é uma oportunidade ímpar que temos no País para efetivamente aplicar recursos na educação. Já } \\
\text { aprovamos nesta Casa, no caso da Lei de Diretrizes e Bases da Educação, a destinação de } 10 \% \text { do PIB } \\
\text { para esse setor. Essa é a fonte de recursos [petróleo] que teremos para melhorar a educação, melhorando, } \\
\text { assim, o País, a inovação tecnológica, o desenvolvimento tecnológico e a vida das pessoas." }\end{array}$ & $\begin{array}{l}\text { Sessão da Câmara dos } \\
\text { Deputados de } 6 / 11 / 12 \text { às } 10 \mathrm{hs} \\
- \text { p. } 210 .\end{array}$ & $\begin{array}{l}\mathrm{O} \\
\text { Econômico. }\end{array}$ \\
\hline $\begin{array}{l}\text { "Em termos práticos, já a partir de } 2013 \text {, as receitas dos royalties poderão ajudar a Estados, DF e } \\
\text { Municípios a pagar o piso salarial do magistério nas carreiras profissionais e a investir na educação } \\
\text { integral de crianças e jovens de todo o País - dois grandes desafios do PNE. (...)" }\end{array}$ & $\begin{array}{l}\text { Sessão da Câmara dos } \\
\text { Deputados de } 6 / 11 / 12 \text { às } 16 \text { hs } \\
- \text { p. } 8 .\end{array}$ & $\begin{array}{l}\mathrm{O} \\
\text { Econômico. }\end{array}$ \\
\hline $\begin{array}{l}\text { "Pelas experiências internacionais, nós sabemos que, se um país investe em educação, esse país se } \\
\text { desenvolve e mostra que tem ciência, que tem tecnologia, e disputa o mercado, e não só o de } \\
\text { commodities. Foi o que aconteceu com o Japão, foi o que aconteceu com a Coreia do Sul, porque esses } \\
\text { países se preocuparam em investir na educação. (...) } \\
\text { E nada mais justo que esse dinheiro novo seja o dinheiro dos royalties. Sobre esse dinheiro o povo } \\
\text { brasileiro tem que ter uma decisão histórica, de uma vez por todas: a de investir na educação; a de investir } \\
\text { na criança e no adolescente; a de investir no ensino fundamental e no ensino médio; a de investir na } \\
\text { universidade pública; a de investir em ciência e tecnologia. }\end{array}$ & $\begin{array}{l}\text { Sessão da Câmara dos } \\
\text { Deputados de } 6 / 11 / 12 \text { às } 16 \mathrm{hs} \\
\text { - p. } 182 .\end{array}$ & $\begin{array}{l}\mathrm{O} \\
\text { Econômico. }\end{array}$ \\
\hline
\end{tabular}




\section{Fundamento utilizado}

"Hoje saiu uma matéria na revista Valor Econômico que, entre outras informações de um estudo feito pela FIESP, diz que o investimento de royalty em educação provoca um crescimento adicional do PIB em 1,14 ponto percentual ao ano. Ao mesmo tempo, o PIB per capita por ano aumentaria 0,57 ponto adicional ao ano. E diz ainda a matéria que em 2030, se todos os recursos de royalties forem aplicados em educação, nós teremos, - repito, não em 2020, em 2030 —, somando-se recursos públicos e privados, 6,6\% do PIB aplicados em educação."

"Num país como o nosso, apesar da melhoria acentuada na distribuição de renda nos últimos 10 anos, aproximadamente, segundo estudo do IPEA, uma das raríssimas formas de se fazer distribuição de renda é oferecer educação pública de qualidade e saúde pública de qualidade."

"Ao se apostar na educação, faz-se exatamente com que pobres, negros, aqueles que moram em regiões, eu diria, não totalmente desenvolvidas do nosso País comecem a quebrar as diferenças regionais, raciais e de classe através da educação."

"A outra oportunidade é relacionada ao financiamento da Educação. Penso que, diferentemente do que fazem os xeiques árabes, o Brasil deve investir os recursos obtidos com a exploração do petróleo na formação daquilo que ele tem de melhor: o seu povo. Devemos investir em educação e em ciência e tecnologia, pois essa é a única forma de assegurarmos um futuro realmente promissor para todos e todas." "Na educação infantil, faz-se necessário o aumento dos recursos para uma expansão da pré-escola, já que, aproximadamente $22 \%$ das crianças entre quatro e cinco anos ainda não são atendidas plenamente. Também é um grande desafio aumentar o número de creches".

"Admitindo-se uma produção diária de 1 milhão de barris de petróleo por dia, em 2022, um preço de U\$ 100 por barril, um custo de extração e de serviço de U\$ 25 por barril e uma taxa de câmbio de 2 reais por dólar, Libra pode gerar recursos para a educação, nesse ano, de $\mathrm{R} \$ 49,28$ bilhões. Toda a produção petrolífera nacional gerou, em 2012, R \$ 31,5 bilhões de royalties e participação especial."

"A Tabela 11 mostra uma estimativa de recursos destinados à educação, consideradas as alterações no Projeto de Lei ${ }^{\circ}$ 5.500/13 aqui julgadas importantes. Observa-se um aumento de recursos destinado à educação, nos próximos dez anos, de R $\$ 25,80$ para R \$ 335,84 bilhões."

L14 As novas regras de distribuição devem ser aplicada aos contratos em curso, pois as receitas do pré-sal só começarão a ser significativas a partir de 2020

"E o Governo Federal deu uma demonstração cabal de que quer contribuir para esse entendimento, está lá na discussão dos royalties dos recursos que já são hoje arrecadados. Sim, porque se for só para repartirmos a futura riqueza do pré-sal, será daqui a seis, a 10 anos, e o Brasil continua a aprofundar as suas desigualdades. Mas o Governo entendeu que tem que mexer agora e começou mexendo pela sua

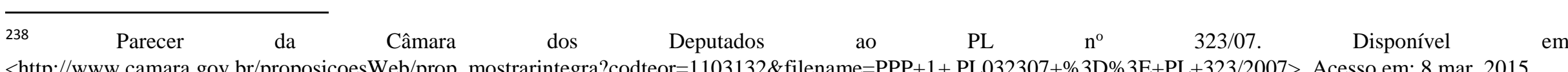

\section{damento 228}

Sessão da Câmara dos

Deputados de 6/11/12 às 16hs Econômico.

- p. 222.

Sessão da Câmara dos

Deputados de 6/11/12 às $16 \mathrm{hs}$

- p. 223.

Sessão da Câmara dos

Deputados de 6/11/12 às $16 \mathrm{hs}$

- p. 224.

Sessão da Câmara dos

Deputados de 6/11/12 às $16 \mathrm{hs}$

- p. 260.

Parecer da Câmara dos $\mathrm{O}$

Deputados ao PL no $323 / 07^{238}$ Econômico.

- p. 5-6

recer da Câmara dos

Deputados ao PL n ${ }^{\circ} 323 / 07$ p. 30.

Parecer da Câmara dos

p. 31-32.

Sessão do Senado Federal de

19/10/11 - p. 42836.

$\mathrm{O}$

Econômico

$\mathrm{O}$

Econômico

\section{O}

nômico e federativo.

Econômico e federativo
Deputados ao PL no 323/07 - 


\begin{tabular}{|c|c|c|c|}
\hline & Fundamento utilizado & Onde utilizou (referência) & $\begin{array}{l}\text { Classificação do } \\
\text { fundamento }^{228}\end{array}$ \\
\hline \multicolumn{4}{|c|}{$\begin{array}{l}\text { participação, reduziu em um terço o recebimento de royalties a que tem direito pela extração do petróleo } \\
\text { nesse modelo da concessão, uma contribuição fundamental. Por outro lado, abriu mão de oito pontos } \\
\text { percentuais no modelo da participação especial, que representam } 16 \% \text { da sua receita na participação } \\
\text { especial; } 8 \% \text {, de } 50 \% \text {, na verdade, são } 16 \% \text { do total da receita que a União...” }\end{array}$} \\
\hline L15 & \multicolumn{2}{|c|}{$\begin{array}{l}\text { Diversos municípios brasileiros dependem do FPM, cujos recursos foram reduzidos drasticamente, daí a importância de } \\
\text { serem contemplados com royalties }\end{array}$} & $\begin{array}{l}\text { O } \\
\text { Econômico e federativo. }\end{array}$ \\
\hline \multicolumn{2}{|r|}{$\begin{array}{l}\text { "Eu vi muitos Prefeitos demitirem servidores. Muitos Prefeitos nos fizeram dramático apelo para lhes } \\
\text { conseguirmos recursos, porque eles não têm como pagar o décimo terceiro dos seus servidores. } \\
\text { Municípios pequenos não vão pagar o décimo terceiro porque não têm recursos para tanto. O Fundo de } \\
\text { Participação dos Municípios caiu muito. E há Municípios que vivem exclusivamente desse fundo." }\end{array}$} & $\begin{array}{l}\text { Sessão da Câmara dos } \\
\text { Deputados de } 6 / 11 / 12 \text { às } 10 \mathrm{hs}, \\
\text { p. } 85 .\end{array}$ & $\begin{array}{l}\mathrm{O} \\
\text { Econômico e federativo. }\end{array}$ \\
\hline \multicolumn{2}{|r|}{$\begin{array}{l}\text { "Eu estava verificando, recentemente, a situação dramática de muitos Municípios, principalmente do } \\
\text { Norte e Nordeste. E não apenas dessas regiôes, mas de todo o País. Eu recebi hoje vários Prefeitos. Tenho } \\
\text { certeza de que os colegas também receberam vários Prefeitos. Eles vêm fazer um apelo para conseguirmos } \\
\text { recursos para que possam pagar o décimo terceiro de seus servidores. Por quê? Porque o valor do Fundo } \\
\text { de Participação dos Municípios caiu e, consequentemente, a receita dos Municípios caiu. Há Municípios, } \\
\text { principalmente os pequenos, que perderam quase toda a receita com a redução dos recursos do Fundo de } \\
\text { Participação dos Municípios." }\end{array}$} & $\begin{array}{l}\text { Sessão da Câmara dos } \\
\text { Deputados de 6/11/12 às } 10 \mathrm{hs,} \\
\text { p. } 99 .\end{array}$ & $\begin{array}{l}\mathrm{O} \\
\text { Econômico e federativo. }\end{array}$ \\
\hline L16 & \multicolumn{2}{|c|}{ A atividade petrolífera também gera benefícios aos entes produtores, e não apenas prejuízos } & $\begin{array}{l}\text { O } \\
\text { Econômico. }\end{array}$ \\
\hline \multicolumn{2}{|r|}{$\begin{array}{l}\text { "Os Estados e Municípios confrontantes já recebem, já são beneficiados pelo incremento da produção, } \\
\text { que acontece pelo embarque, pelo desembarque, pela movimentação e pelo acréscimo dos impostos como } \\
\text { o ISS, por exemplo." }\end{array}$} & $\begin{array}{l}\text { Sessão da Câmara dos } \\
\text { Deputados de } 6 / 11 / 12 \text { às } \\
16 \mathrm{~h}^{239}-\text { p. } 115\end{array}$ & $\begin{array}{l}\mathrm{O} \\
\text { Econômico. }\end{array}$ \\
\hline L17 & \multicolumn{2}{|l|}{ A má aplicação dos recursos leva à necessidade de redistribuição } & \begin{tabular}{|l|l|} 
O \\
Econômico.
\end{tabular} \\
\hline \multicolumn{2}{|r|}{$\begin{array}{l}\text { "Não cabe aqui discutir, embora seja importante registrar, o mal uso que diversos Municípios têm feito } \\
\text { com os recursos dos royalties. Além de denúncias de corrupção, observa-se que vários Municípios } \\
\text { beneficiados estão gastando os recursos com custeio de pessoal, com embelezamento de vias públicas ou } \\
\text { outras despesas que, certamente, não garantirão um desenvolvimento auto-sustentável no futuro, quando } \\
\text { cessar a extração desses recursos." }\end{array}$} & $\begin{array}{l}\text { Justificação do PLS nº 594/11 } \\
- \text { p. } 10 .\end{array}$ & $\begin{array}{l}\mathrm{O} \\
\text { Econômico. }\end{array}$ \\
\hline L18 & \multicolumn{2}{|c|}{ Possibilidade de utilização dos royalties para a prevenção de desastres naturais } & $\begin{array}{l}\text { O } \\
\text { Ambiental e econômico. }\end{array}$ \\
\hline
\end{tabular}

${ }^{239}$ Sessão da Câmara dos Deputados de 6/11/12 às 16hs. Disponível em: <http://www. camara.leg.br/internet/plenario/notas/extraord/EV0611121620.pdf>. Acesso em 27 fev. 2015. 


\begin{tabular}{|c|c|c|c|}
\hline & Fundamento utilizado & Onde utilizou (referência) & $\begin{array}{l}\text { Classificação do } \\
\text { fundamento }^{228}\end{array}$ \\
\hline \multicolumn{2}{|r|}{$\begin{array}{l}\text { "Anualmente, recebemos a triste notícia de desastres provocados por chuvas, ventanias, enchentes ou } \\
\text { outras causas naturais. Esses desastres atingem a todos os brasileiros, não escolhendo região, nem classe } \\
\text { social. E todos os anos os especialistas chamam a atenção para a necessidade de obras de prevenção, de } \\
\text { evacuação de áreas de risco, de reflorestamento de margens de rios, de contenção de encostas e de tantas } \\
\text { outras que poderiam evitar as tragédias que têm nos custado milhões de reais, e, pior ainda, milhares de } \\
\text { vidas. } \\
\text { O objetivo deste PLS é justamente garantir recursos para obras de prevenção dessas tragédias. Também } \\
\text { previmos o uso de recursos para atender as populações e áreas afetadas. Os recursos viriam de duas } \\
\text { fontes. A primeira corresponde a, no mínimo, } 20 \% \text { da parcela dos royalties que é direcionada par a um } \\
\text { fundo especial, que redistribui os recursos para todos os estados e municípios, utilizando os critérios de } \\
\text { rateio do fundo de Participação dos Estados e do Distrito Federal (FPE) e do Fundo de Participação dos } \\
\text { Municípios (FPM)". }\end{array}$} & $\begin{array}{l}\text { Parecer do Senado Federal ao } \\
\text { PLS n }{ }^{\circ} 227 / 11^{240}-\text { p.2-3. }\end{array}$ & $\begin{array}{l}\text { O } \\
\text { Ambiental e econômico. }\end{array}$ \\
\hline L19 & \multicolumn{2}{|c|}{$\begin{array}{c}\text { As várias tentativas do Congresso Nacional de alterar as regras de distribuição atuais indicam que há grande vontade em } \\
\text { fazê-lo }\end{array}$} & Não classificável. \\
\hline \multicolumn{2}{|r|}{$\begin{array}{l}\text { "E mais, depois que eu descobri que o que foi vetado da Emenda Ibsen Pinheiro, Humberto Souto e } \\
\text { Marcelo Castro, e muitos que apoiaram, veio outro projeto, que esta Casa aprovou quase que por } \\
\text { unanimidade, distribuindo esse royalty do petróleo, e o Presidente Lula vetou. Veio outro projeto, do } \\
\text { Senador Wellington Dias, relatado por Vital do Rêgo, que, por maioria, por mais de } 80 \% \text { desta Casa, foi } \\
\text { aprovado. E o que se discute? Sr. Presidente, em 2009." }\end{array}$} & $\begin{array}{l}\text { Sessão conjunta do Congresso } \\
\text { de } 6 / 3 / 13^{241} \text { - p. } 749 \text {. }\end{array}$ & Não classificável. \\
\hline L20 & \multicolumn{2}{|c|}{ A pesquisa necessária para descoberta e extração do pré-sal foi custeada por todo o país, e não só pelos entes produtores } & $\begin{array}{l}\text { O } \\
\text { Econômico e federativo. }\end{array}$ \\
\hline $\begin{array}{l}\text { "Quar } \\
\text { bilhõe } \\
\text { de gás } \\
\text { profuı } \\
\text { dinhei } \\
\text { Brasil }\end{array}$ & $\begin{array}{l}\text { do se abriu a expectativa da exploração do pré-sal, a PETROBRAS precisou de um aporte de } 50 \\
\text { de reais. Cinquenta bilhões! De onde? Não, eu estou falando é de tudo, é de petróleo, é de óleo, é } \\
\text { é da riqueza do País inteiro. É disso que estou falando. E para poder tirar essa riqueza das águas } \\
\text { das, de qualquer lugar, o investimento foi nacional, só o pré-sal. O Tesouro Nacional. Isso significa } \\
\text { o do Semiárido, dinheiro do Centro-Oeste, dinheiro do Norte, do Sul e do Sudeste, de todo o } \\
\text { para essa riqueza chegar às nossas mãos." }\end{array}$ & $\begin{array}{l}\text { Sessão conjunta do Congresso } \\
\text { de } 6 / 3 / 13 \text { - p. } 754 \text {. }\end{array}$ & $\begin{array}{l}\mathrm{O} \\
\text { Econômico e federativo. }\end{array}$ \\
\hline
\end{tabular}

${ }^{240}$ Parecer da comissão de Serviços de Infra-estrutura do Senado Federal ao PLS n ${ }^{\circ}$ 227/11. Disponível em: < http://legis.senado.leg.br/mateweb/arquivos/matepdf/92555.pdf>. Acesso em 2 mar. 15.

${ }^{241}$ Sessão conjunta do Congresso de 6/3/13. Diário do Congresso Nacional de 7/3/13. Disponível em: <http://legis.senado.leg.br/diarios/BuscaDiario?tipDiario= 2\&datDiario=07/03/2013\&paginaDireta=00747>. Acesso em 2 mar. 2015. 
Fundamento utilizado

"Eu pergunto a todos esses três Estados [Rio de Janeiro, Espírito Santo e São Paulo]: o mar pertence mais a eles ou a nós? Moro em Goiás, pago pela pesquisa feita pela PETROBRAS, pago pela exploração feita

em alto-mar, pago por todo o sistema de defesa do Ministério da Defesa em águas brasileiras. Por que

apenas as despesas são nossas e os benefícios são apenas de três Estados da Federação?"
Onde utilizou (referência)

Sessão conjunta do Congresso

de $6 / 3 / 13-$ p. 760

fundamento ${ }^{228}$

Econômico e federativo. 
TABELA 4 - FUNDAMENTOS DO LEGISLATIVO CONTRÁRIOS À REDISTRIBUIÇÃO DOS ROYALTIES E PE

\begin{tabular}{|c|c|c|c|}
\hline & Fundamento utilizado & \begin{tabular}{|l|}
$\begin{array}{l}\text { Onde utilizou } \\
\text { (referência) }\end{array}$ \\
\end{tabular} & $\begin{array}{l}\text { Classificação do } \\
\text { fundamento }\end{array}$ \\
\hline M1 & \multicolumn{2}{|c|}{ A exploração do petróleo gera impactos ambientais e econômicos que devem ser compensados com os royalties do petróleo } & $\begin{array}{l}\text { O } \\
\text { Jurídico (não } \\
\text { dogmático), ambiental e } \\
\text { econômico }^{242} \text {. }\end{array}$ \\
\hline \multicolumn{2}{|r|}{$\begin{array}{l}\text { "Ontem eu dizia do glamour que foi dado à Emenda Ibsen Pinheiro pelo Senador Vital do Rêgo, para mim, uma } \\
\text { emenda eleitoreira, irresponsável, que desqualifico plenamente. Meu grande drama com tudo isso - o Brasil que } \\
\text { me vê pela televisão e os senhores que estão aqui - é que fazem questão de misturar royalties com petróleo, } \\
\text { porque não têm coragem de falar a verdade, porque royalty não é petróleo, Senador Renan. A lei diz que o } \\
\text { petróleo é de todos. O que está no subsolo, é verdade, é de todos nós. Então vamos fazer conta em cima do que } \\
\text { está debaixo do subsolo, porque royalty não é nada disso. O que é royalty? Pergunto ao Brasil que está me vendo } \\
\text { e me ouvindo pela Rádio Senado, e aos senhores que estão aqui. Royalty é pagamento de passivo ambiental." }\end{array}$} & $\begin{array}{l}\text { Sessão do Senado } \\
\text { Federal de } 19 / 10 / 11^{243} \text { - } \\
\text { p. } 42876-42877 .\end{array}$ & $\begin{array}{l}\mathrm{O} \\
\text { Ambiental. }\end{array}$ \\
\hline \multicolumn{2}{|r|}{$\begin{array}{l}\text { "Quando há um vazamento, quando há um crime ambiental, é aquele Município que está lá que paga por isso. } \\
\text { Aquelas pessoas que vão para lá para a exploração do petróleo, depois, ficam lá. Isso causa um passivo muito } \\
\text { grande naqueles Municípios." }\end{array}$} & $\begin{array}{l}\text { Sessão da Câmara dos } \\
\text { Deputados de 6/11/12 às } \\
10 \mathrm{hs}^{244}-\text { p. } 24 .\end{array}$ & $\begin{array}{l}\mathrm{O} \\
\text { Ambiental. }\end{array}$ \\
\hline \multicolumn{2}{|r|}{$\begin{array}{l}\text { "Royalty é pagamento de passivo, porque, na hora que um trator, uma máquina, uma patrol entra e abre uma } \\
\text { estrada de chão, rasga uma mata para poder furar poço, esse passivo ambiental que foi feito, com essa máquina, o } \\
\text { royalty é para pagar isso. (...) Royalty é indenização!" }\end{array}$} & \begin{tabular}{|l|} 
Parecer no $^{\circ} 1.109 / 2011$, \\
de Plenário - p. 59 \\
(discussão e votação do \\
parecer em Plenário).
\end{tabular} & $\begin{array}{l}\mathrm{O} \\
\text { Ambiental. }\end{array}$ \\
\hline \multicolumn{2}{|r|}{$\begin{array}{l}\text { "Nós sabemos que os royalties podem ser considerados uma compensação exatamente pelo dano ambiental que os } \\
\text { nossos Estados sofreram. Sabemos que é incalculável a necessidade e a demanda social (...). Há um conjunto, } \\
\text { inclusive, de pessoas que, de todo o Brasil, tem oportunidade no mercado de trabalho, mas que precisa de } \\
\text { infraestrutura adequada, precisa de estrada para que os derivados de petróleo possam alcançar seu objetivo. } \\
\text { É preciso que haja, nessa exploração, infraestrutura, para que as comunidades locais tenham investimento social } \\
\text { adequado. Há necessidade de prevenção, principalmente no que diz respeito aos desastres ambientais que podem } \\
\text { ocorrer (...) existe uma necessidade de preparação futura, principalmente dos Estados que são considerados } \\
\text { produtores, porque - não podemos esquecer - o petróleo é uma riqueza finita. Como é riqueza finita, a }\end{array}$} & $\begin{array}{l}\text { Sessão da Câmara dos } \\
\text { Deputados de 6/11/12 às } \\
10 \mathrm{hs}-\text { p. } 37 .\end{array}$ & $\begin{array}{l}\text { O } \\
\text { Ambiental e econômico. }\end{array}$ \\
\hline
\end{tabular}

${ }^{242}$ Os fundamentos foram sintetizados, a fim de facilitar a sua compreensão. No entanto, por serem apresentados de diversas formas, entendeu-se relevante trazer exemplos de sua utilização. A classificação em negrito considera todas as categorias envolvidas nos exemplos.

${ }^{243}$ Diário do Senado Federal de 20/10/11, p. 42877. Disponível em: <http://legis.senado.leg.br/diarios/BuscaDiario?tipDiario=1\&datDiario=20/10/2011\&paginaDireta= 42763\#>. Acesso em: 27 fev. 2015.

${ }^{244}$ Sessão da Câmara dos Deputados de 6/11/12 às 10hs. Disponível em: 〈http://www.camara.leg.br/internet/plenario/notas/extraord/em0611121000.pdf〉. Acesso em: 27 fev. 2015. 


\begin{tabular}{|c|c|}
\hline $\begin{array}{l}\text { Onde utilizou } \\
\text { (referência) }\end{array}$ & $\begin{array}{l}\text { Classificação do } \\
\text { fundamento }\end{array}$ \\
\hline $\begin{array}{l}\text { Sessão da Câmara dos } \\
\text { Deputados de 6/11/12 às } \\
\text { 10hs - p. } 42 \text {. }\end{array}$ & $\begin{array}{l}\text { O } \\
\text { Jurídico (não dogmático), } \\
\text { ambiental e econômico. }\end{array}$ \\
\hline $\begin{array}{l}\text { Sessão do Senado } \\
\text { Federal de 19/10/11 - p. } \\
42821 .\end{array}$ & $\begin{array}{l}\mathrm{O} \\
\text { Ambiental. }\end{array}$ \\
\hline $\begin{array}{l}\text { Sessão do Senado } \\
\text { Federal de 19/10/11 - p. } \\
42837 .\end{array}$ & $\begin{array}{l}\text { O } \\
\text { Jurídico (não dogmático) e } \\
\text { econômico. }\end{array}$ \\
\hline $\begin{array}{l}\text { Sessão do Senado } \\
\text { Federal de 19/10/11 - p. } \\
42840 .\end{array}$ & $\begin{array}{l}\mathrm{O} \\
\text { Econômico e ambiental. }\end{array}$ \\
\hline ão produtores & $\begin{array}{l}\text { VD } \\
\text { Jurídico dogmático. }\end{array}$ \\
\hline $\begin{array}{l}\text { Sessão conjunta do } \\
\text { Congresso de } 6 / 3 / 13^{245} \text { - } \\
\text { p. } 749 \text {. }\end{array}$ & $\begin{array}{l}\text { VD } \\
\text { Jurídico dogmático. }\end{array}$ \\
\hline Iências graves a eles & $\begin{array}{l}\text { O } \\
\text { Econômico. }\end{array}$ \\
\hline $\begin{array}{l}\text { Sessão da Câmara dos } \\
\text { Deputados de } 6 / 11 / 12 \text { às }\end{array}$ & $\begin{array}{l}\text { O } \\
\text { Econômico. }\end{array}$ \\
\hline
\end{tabular}

preparação para um período futuro em que ele não mais existirá é da mais alta importância.".

"Royalties não é privilégio, não é benefício. É um direito constitucional, são compensações financeiras em função do que fica de negativo nas cidades e nos Municípios produtores: os danos ambientais, os danos sociais, os danos estruturais."

"Ora, se o risco ao meio ambiente é pequeno como é que nós vamos explicar aquele um milhão de litros de óleo cru que foram derramados na Baía de Guanabara, em 2000, e que até hoje trazem impacto terrível ao nosso meio ambiente, à fauna, à flora, a todo o bioma. Por acaso esse óleo foi parar nas praias do Piauí ou da Paraíba? Pois bem, eles agora estão recebendo compensações muito maiores do que o Rio de Janeiro."

"Discute-se a partilha de royalties, de participações especiais resultantes da exploração de um bem finito, de um recurso natural não renovável e que, por força da Constituição, deve ser destinado prioritariamente à compensação dos Estados chamados produtores, talvez até impropriamente, mas que recebem o impacto negativo, como sobrecarga à infraestrutura, por exemplo, da exploração do petróleo. Constitui receita originária desses Estados porque tem base constitucional esse caráter de ressarcimento dos eventuais inconvenientes resultantes da exploração do petróleo.

Daí por que eu não tenho dúvida em afirmar o direito de Estados como o Rio de Janeiro e Espírito Santo, em manterem a sua participação nos frutos dessa exploração".

"De sorte que temos que garantir a participação equânime dos Estados e Municípios não produtores, mas levando em consideração que os produtores merecem uma quota maior, até porque, Sr. Presidente, lá existem os fatores que contribuem para a modificação e a alteração do meio ambiente e, consequentemente, para a piora da qualidade de vida, caso o governo local não possa investir para proteger a sua população. É o caso, por exemplo, do Rio de Janeiro, do Espírito Santo, que têm que ter a sua quota de participação não de forma privilegiada, mas de forma justa. Temos que reconhecer isso.".

M2

$O$ art. $20, \$ 1^{\circ}$ da $\mathrm{CF}$ constitui

"Esse artigo [art. 20, $\S 1^{\circ}$, da Constituição] diz que os royalties do petróleo pertencem aos Estados em cujo território ou mar territorial ele é explorado ou que sofre as consequências da sua exploração. Os royalties do petróleo pertencem aos Estados produtores e confrontantes e, por isso, não podem ser destinados aos Fundos de Participação de Estados e Municípios que não são produtores, que não são confrontantes, que não são órgãos da Administração direta do País."

\begin{tabular}{|l|l|l|}
\hline M3 & Os entes produtores e confrontantes sofrerão perda significativa de recursos, o que trará consequências graves a eles & \multicolumn{2}{l|}{$\begin{array}{l}\text { O } \\
\text { Econômico. }\end{array}$} \\
\hline $\begin{array}{l}\text { "Vários pequenos Municípios do Estado do Rio de Janeiro, os chamados Municípios confrontantes, perdem } \\
\text { muito, se não tivermos uma distribuição sensível para com um Estado que, historicamente, foi também aquele que }\end{array}$ & $\begin{array}{l}\text { Sessão da Câmara dos } \\
\text { Deputados de 6/11/12 às }\end{array}$ & $\begin{array}{l}\text { O } \\
\text { Econômico. }\end{array}$ \\
\hline
\end{tabular}

${ }^{245}$ Sessão conjunta do Congresso de 6/3/13. Diário do Congresso Nacional de 7/3/13. Disponível em: <http://legis.senado.leg.br/diarios/BuscaDiario?tipDiario=2\&datDiario $=07 / 03 / 2013$ \&paginaDireta=00747> . Acesso em 2 mar. 2015. 


\begin{tabular}{|c|c|c|}
\hline Fundamento utilizado & \begin{tabular}{|l|l|}
$\begin{array}{l}\text { Onde utilizou } \\
\text { (referência) }\end{array}$ \\
\end{tabular} & $\begin{array}{l}\text { Classificação do } \\
\text { fundamento }\end{array}$ \\
\hline sofreu mais efeitos com a exploração do petróleo." & $10 \mathrm{hs}-\mathrm{p} .38$ & \\
\hline $\begin{array}{l}\text { "As concessões de royalties, em 2010, números realizados, somaram para Estados e } \\
\text { Municípios seis bilhões e duzentos e noventa e nove milhões de reais. Pelo relatório, esses mesmos Estados - } \\
\text { todos que recebem hoje, mas, sobretudo, Rio e Espírito Santo -, já em 2012, vão passar a receber três bilhões e } \\
\text { novecentos e setenta e dois milhões de reais; em } 2019 \text {, vão passar para dois bilhões e meio de reais. Isso aqui são } \\
\text { os números reais. Vão quebrar os Estados. Senador Cristovam Buarque, que defende a educação, V. Exa , se votar } \\
\text { com esse projeto, vai fechar escola no Rio e no Espírito Santo, vai acabar com merenda escolar. Esses são os } \\
\text { números reais. Esses são os números reais que nós estamos trazendo aqui. É por isso que a bancada do Rio e a do } \\
\text { Espírito Santo, reunidas ontem, durante a madrugada, e vendo os números reais, não os números falaciosos, } \\
\text { fictícios, chegam a uma angústia, ao desespero.” }\end{array}$ & $\begin{array}{l}\text { Sessão do Senado } \\
\text { Federal de 19/10/11 - p. } \\
\text { 42820. }\end{array}$ & $\begin{array}{l}\text { O } \\
\text { Econômico. }\end{array}$ \\
\hline $\begin{array}{l}\text { "Como é que vamos votar um Projeto que retira do Município, por exemplo, de Campos, que hoje sobrevive com } \\
\text { os royalties do petróleo, um bilhão de reais?" }\end{array}$ & $\begin{array}{l}\text { Sessão do Senado } \\
\text { Federal de } 19 / 10 / 11 \text { - p. } \\
42821\end{array}$ & $\begin{array}{l}\text { O } \\
\text { Econômico. }\end{array}$ \\
\hline $\begin{array}{l}\text { "A perda do Estado do Rio de Janeiro, no exercício de 2012, será de aproximadamente - Estado e Municípios - } \\
\text { R\$3 bilhões." }\end{array}$ & $\begin{array}{l}\text { Sessão do Senado } \\
\text { Federal de } 19 / 10 / 11 \text { - p. } \\
42868 .\end{array}$ & $\begin{array}{l}\text { O } \\
\text { Econômico. }\end{array}$ \\
\hline $\begin{array}{l}\text { "O que tem aqui, Presidente Sarney? Uma redução de } 2011 \text { dos Estados em relação a } 2012 \text { de } \\
\text { um bilhão. Vão tirar um bilhão dos Estados! Vão tirar sabe quanto dos Municípios? Cai de 2011, } 4.393 \text { para dois } \\
\text { bilhões e oitocentos! Um bilhão e quinhentos dos Municípios, do orçamento! No Rio são 92, são } 86 \text { Municípios } \\
\text { que vão fechar as portas de escolas, de postos de saúde!" }\end{array}$ & $\begin{array}{l}\text { Sessão do Senado } \\
\text { Federal de 19/10/11 - p. } \\
\text { 42872. }\end{array}$ & $\begin{array}{l}\text { O } \\
\text { Econômico. }\end{array}$ \\
\hline $\begin{array}{l}\text { "Encerro meu pronunciamento com muita tristeza em meu coração, até porque um Estado pequenininho como o } \\
\text { meu, o Estado do Espírito Santo, que tem } R \$ 1 \text { bilhão para investimentos, a partir do ano que vem vai perder } \\
\mathrm{R} \$ 1,2 \text { bilhão, } \mathrm{R} \$ 200 \text { milhões a mais do que tem para investir. Isso é brincadeira de mau gosto!" }\end{array}$ & $\begin{array}{l}\text { Sessão do Senado } \\
\text { Federal de } 9 / 10 / 11 \text { - p. } \\
\text { 42891-42892. } \\
\end{array}$ & $\begin{array}{l}\text { O } \\
\text { Econômico. }\end{array}$ \\
\hline $\begin{array}{l}\text { "Agora, Sr. Presidente, Sras. e Srs. Deputados, estamos discutindo os royalties do petróleo. O Espírito Santo e o } \\
\text { Rio de Janeiro são dois grandes produtores - nós somos o segundo produtor. O relatório do Deputado Zarattini } \\
\text { apresenta muitas melhorias em relação ao do Senador Vital do Rêgo, à proposta do Senado. Contudo, tomando-se } \\
\text { como base } 2011 \text {, o Espírito Santo vai perder } 8 \text { bilhões de } 2013 \text { a 2020. Esses são os cálculos da nossa Secretaria } \\
\text { de Desenvolvimento, que cuida disso.” }\end{array}$ & $\begin{array}{l}\text { Sessão da Câmara dos } \\
\text { Deputados de 6/11/12 às } \\
16 \mathrm{~h}^{246}-\text { p. } 48 .\end{array}$ & Oconômico. \\
\hline $\begin{array}{l}\text { "Dos } 92 \text { Municípios do Rio de Janeiro, se a Presidente vetar, } 85 \text {, na manhã do dia seguinte, terão } 50 \% \text { a menos } \\
\text { em sua participação especial. Falou-se aqui em falência de vários Municípios que precisavam de socorro. Mas o } \\
\text { remédio que foi aplicado ao mesmo tempo acabou de decretar a falência de inúmeros Municípios do Rio de }\end{array}$ & $\begin{array}{l}\text { Sessão da Câmara dos } \\
\text { Deputados de 6/11/12 às } \\
\text { 20hs }{ }^{247}-\text { p. } 126 .\end{array}$ & $\begin{array}{l}\text { O } \\
\text { Econômico. }\end{array}$ \\
\hline
\end{tabular}

${ }^{246}$ Sessão da Câmara dos Deputados de 6/11/12 às 16hs ${ }^{246}$. Disponível em: 〈http://www. camara.leg.br/internet/plenario/notas/extraord/EV0611121620.pdf〉. Acesso em 27 $\mathrm{f}^{246} \mathrm{ev} .2015$.

${ }^{247}$ Sessão da Câmara dos Deputados de 6/11/12 às 20hs, p. 121. Disponível em: 〈http://www.camara. leg.br/internet/plenario/notas/extraord/EN0611122020.pdf〉. Acesso em 27 fev. 2015. 


\begin{tabular}{|c|c|c|c|}
\hline & Fundamento utilizado & $\begin{array}{l}\begin{array}{l}\text { Onde utilizou } \\
\text { (referência) }\end{array} \\
\end{array}$ & $\begin{array}{l}\text { Classificação do } \\
\text { fundamento }\end{array}$ \\
\hline \multicolumn{4}{|c|}{ Janeiro. Não há sensatez nisso.” } \\
\hline \multicolumn{2}{|r|}{$\begin{array}{l}\text { "A aprovação do Projeto Vital do Rêgo significa a insolvência do Rio de Janeiro e do Espírito Santo, que não } \\
\text { poderão cumprir obrigações já assumidas com base nos royalties decorrentes de contratos assinados. A derrubada } \\
\text { do veto implicará perda de aproximadamente um quarto de suas receitas aos Municípios produtores afetados pelos } \\
\text { rovalties. No total, a perda estimada será de } 5 \text { bilhões de reais de forma automática e imediata." }\end{array}$} & $\begin{array}{l}\text { Sessão conjunta do } \\
\text { Congresso de } 6 / 3 / 13^{248}- \\
\text { p. } 750 .\end{array}$ & $\begin{array}{l}\mathrm{O} \\
\text { Econômico. }\end{array}$ \\
\hline M4 & \multicolumn{2}{|c|}{$\begin{array}{l}\text { O Estado do Rio de Janeiro, comparado a outros, já destina boa parte dos impostos por ele arrecadados para a União, por isso } \\
\text { não é justo que perca royalties e PE }\end{array}$} & $\begin{array}{l}\text { O } \\
\text { Econômico e federativo. }\end{array}$ \\
\hline \multicolumn{2}{|r|}{$\begin{array}{l}\text { "O Estado do Rio de Janeiro manda para a União, todos os anos, } \mathrm{R} \$ 110 \text { bilhões do seu imposto de renda e do seu } \\
\text { IPI e recebe de volta } R \$ 10 \text { bilhões. O Piaú, do Senador Wellington, manda } \mathrm{R} \$ 600 \text { milhões e recebe de volta } \mathrm{R} \$ 5 \\
\text { bilhões. Esse é o Fundo de Participação dos Estados e Municípios. Distribui riquezas. O Rio manda } \mathrm{R} \$ 100 \\
\text { bilhões e recebe } \mathrm{R} \$ 10 \text { bilhões. O Piauí manda } R \$ 600 \text { milhões e recebe } \mathrm{R} \$ 5 \text { bilhões. Então, o Rio faz uma } \\
\text { contribuição, e quer fazer mais, quer distribuir o petróleo do pré-sal, só não pode distribuir aquele petróleo, aquele } \\
\text { rendimento que hoje está pagando aposentados, está cuidando do meio ambiente. É a dívida do Rio. É sobre isso } \\
\text { que estão metendo a mão." }\end{array}$} & $\begin{array}{l}\text { Sessão do Senado } \\
\text { Federal de 19/10/11 - p. } \\
42834 \text {. }\end{array}$ & $\begin{array}{l}\text { O } \\
\text { Econômico e federativo. }\end{array}$ \\
\hline M5 & \multicolumn{2}{|c|}{ No caso da mineração, os royalties vão para os produtores, o que justifica raciocínio igual para o petróleo } & $\begin{array}{l}\text { O } \\
\text { Econômico e federativo. }\end{array}$ \\
\hline \multicolumn{2}{|r|}{$\begin{array}{l}\text { "Daqui a pouco, vamos estar discutindo sim a CFEM, contribuição financeira sobre mineração. E aí, de novo, nós } \\
\text { teremos o Estado do Pará e de Minas Gerais concentrando aproximadamente } 80 \% \text { daquilo que se cobra de CFEM } \\
\text { no País. Aí será que vamos partir de novo de garfo e faca em cima do Pará e de Minas Gerais? Não, nós não } \\
\text { precisamos avançar no quintal do vizinho" }\end{array}$} & $\begin{array}{l}\text { Sessão do Senado } \\
\text { Federal de } 18 / 10 / 11^{249} \text { - } \\
\text { p. } 42607\end{array}$ & $\begin{array}{l}\mathrm{O} \\
\text { Econômico e federativo. }\end{array}$ \\
\hline \multicolumn{2}{|r|}{$\begin{array}{l}\text { "Mas, repito, eu não queria criar uma briga com o Estado do Rio de Janeiro, até porque meu Estado é produtor de } \\
\text { minério. Na próxima partilha que houver, quem vai perder é o Estado de Goiás, porque a lógica que vale para um } \\
\text { vale para todos. À medida que vamos repartir o que hoje tem o Rio, o que hoje tem o Espírito Santo e outros } \\
\text { Estados, amanhã nós teremos que repartir o que têm os outros Estados." }\end{array}$} & $\begin{array}{l}\text { Sessão do Senado } \\
\text { Federal de 19/10/11 - p. } \\
42878 \text {. }\end{array}$ & $\begin{array}{l}\text { O } \\
\text { Econômico e federativo. }\end{array}$ \\
\hline \multicolumn{2}{|r|}{$\begin{array}{l}\text { "O que se faz hoje contra o Rio de Janeiro e o Espírito Santo pode ser feito amanhã contra o } \\
\text { Estado do Pará, que detém minério de ferro e recebe royalties; pode ser feito contra o Estado de Minas Gerais, } \\
\text { que recebe royalties do minério de ferro; pode ser feito contra o Paraná, que recebe royalties sobre a sua água da } \\
\text { Hidrelétrica de Itaipu." }\end{array}$} & $\begin{array}{l}\text { Sessão da Câmara dos } \\
\text { Deputados de 6/11/12 às } \\
16 \mathrm{hs}-\text { p. } 55 .\end{array}$ & $\begin{array}{l}\mathrm{O} \\
\text { Econômico e federativo. }\end{array}$ \\
\hline
\end{tabular}

${ }^{248}$ Diário do Congresso Nacional de 7/3/13. Disponível em: 〈http://legis.senado.leg.br/diarios/BuscaDiario?tipDiario=2\&datDiario=07/03/2013 \&paginaDireta=00747>. Acesso em 2 mar. 2015.

${ }^{249}$ Diário do Senado Federal de 19/10/11. Disponível em: 〈http://legis.senado.leg.br/ diarios/BuscaDiario?tipDiario=1\&datDiario=19/10/2011\&paginaDireta=42544> .

Acesso em: 27 fev. 2015 


\begin{tabular}{|c|c|c|c|}
\hline & Fundamento utilizado & $\begin{array}{l}\begin{array}{l}\text { Onde utilizou } \\
\text { (referência) }\end{array} \\
\end{array}$ & $\begin{array}{l}\text { Classificação do } \\
\text { fundamento }\end{array}$ \\
\hline M6 & \multicolumn{2}{|c|}{$\begin{array}{l}\text { A redistribuição deveria ter sido feita reduzindo-se a parcela de recursos da União e das petroleiras, e não dos entes } \\
\text { produtores }\end{array}$} & $\begin{array}{l}\text { O } \\
\text { Econômico e federativo. }\end{array}$ \\
\hline \multicolumn{2}{|r|}{$\begin{array}{l}\text { "A União, em relação a sua arrecadação total, que é } \mathrm{R} \$ 862 \text { bilhões, em } 2010 \text {, vai contribuir sabe com quanto? } \\
\text { Com } 0,15 \% \text { de sua receita. Estão querendo tirar dos Estados } 8 \% \text {, dos Municípios } 16 \% \text {. É isso que estão trazendo } \\
\text { aqui, senhores!” }\end{array}$} & \begin{tabular}{|l|} 
Sessão do Senado \\
Federal de $18 / 10 / 11$ - p. \\
42604.
\end{tabular} & $\begin{array}{l}\mathrm{O} \\
\text { Econômico e federativo. }\end{array}$ \\
\hline \multicolumn{2}{|r|}{$\begin{array}{l}\text { "A nossa proposta dá mais dinheiro aos Estados não produtores do que a do Senador Vital, apenas acontece o } \\
\text { seguinte: a origem vem da União e das petroleiras que pagam no Brasil o imposto mais baixo do mundo. Nós } \\
\text { precisamos dar dinheiro aos não produtores, mas precisamos ver a origem. A razão é que, Sr. Presidente, quando } \\
\text { foi criado o pré-sal, mudou-se o esquema de concessão para partilha, criou-se uma ficção de que se tinha } \\
\text { descoberto o eldorado e todo mundo iria ganhar dinheiro. Quando se voltou à realidade, verificou-se que o pré-sal } \\
\text { só vai sair em } 2018 \text { ou } 2020 \text {, mas ficou criada a expectativa de dinheiro. } \\
\text { Então, quem é que tinha de destinar recursos aos não produtores? A União e as petroleiras que não pagam. O } \\
\text { Senador Vital, por quem quero reiterar o meu maior respeito e admiração, fez um parecer junto com a União } \\
\text { Federal. Sendo que a União está abrindo mão de } 0,15 \% \text { e os Estados e Municípios de } 10 \% \text {. São } 0,15 \% \text { numa } \\
\text { arrecadação de } \mathrm{R} \$ 800 \text { bilhões, sendo que se tiram dos Estados } 9,26 \% \text { e dos Municípios 5,83\%.” }\end{array}$} & $\begin{array}{l}\text { Sessão do Senado } \\
\text { Federal de } 18 / 10 / 11 \text { - p. } \\
42605 .\end{array}$ & $\begin{array}{l}\mathrm{O} \\
\text { Econômico e federativo. }\end{array}$ \\
\hline \multicolumn{2}{|r|}{$\begin{array}{l}\text { "No Brasil, há mais de } 320 \text { reservas hoje produzindo. Todavia, Senador Mário Couto e demais Senadores, são } \\
\text { apenas } 15 \text { ou } 16 \text { que pagam os impostos. Nós temos, lamentavelmente, um mecanismo que não cobra dos demais } \\
\text { os impostos. Diante do quê? Da sua produção. Quando lá atrás se cobrava US } \$ 15,00 \text {, foi feito um decreto da } \\
\text { Presidência da República regulamentando. Todavia, com o passar do tempo, hoje se cobra US } \$ 80,00 \text { e o Governo } \\
\text { Federal não tributou. É o País que menos cobra com relação ao petróleo. Então, precisamos mudar o mecanismo. } \\
\text { Não podemos enriquecer as grandes multinacionais." }\end{array}$} & $\begin{array}{l}\text { Sessão do Senado } \\
\text { Federal de 19/10/11 - p. } \\
42843\end{array}$ & $\begin{array}{l}\mathrm{O} \\
\text { Econômico. }\end{array}$ \\
\hline \multicolumn{2}{|r|}{$\begin{array}{l}\text { "Por que tirar dos Estados produtores, de maneira violenta, como estamos fazendo agora, recursos que hoje } \\
\text { poderiam ser tirados, aumentando-se o imposto das petroleiras? Foi dito aqui, há } 300 \text { poços de petróleo } \\
\text { produzindo em nossos campos, sobretudo no mar, pouco mais de } 300 \text {, se somarmos os da terra, e só } 17 \text { poços } \\
\text { pagam impostos. Há mais de } 290 \text { poços que não pagam impostos; as petroleiras não recolhem os impostos. Se } \\
\text { cobrarmos esses impostos, se fizermos uma divisão melhor com a União, poderemos contemplar os Estados com } \\
\text { mais recursos e não vamos sacrificar o Estado do Rio de Janeiro e o Estado do Espírito Santo." }\end{array}$} & $\begin{array}{l}\text { Sessão do Senado } \\
\text { Federal de 19/10/11 - p. } \\
42869\end{array}$ & $\begin{array}{l}\mathrm{O} \\
\text { Econômico e federativo. }\end{array}$ \\
\hline \multicolumn{2}{|r|}{$\begin{array}{l}\text { "Sr. Presidente, outro ponto que eu queria destacar - e eu falei nisso aqui - é que foram muito corajosos para cima } \\
\text { do Rio e Espírito Santo, mas, com a União, não tiveram essa coragem toda. Olha aqui, em relação à participação } \\
\text { especial, e eu vi vários Senadores falando que estavam tirando da União. Eles saem de } 50 \text {, em } 2012 \text { vão para 42, } \\
\text { em } 2019 \text {, 46. Ou seja, tiram de } 50 \text { para } 46 \text {. Em relação aos Estados produtores caem de } 40 \text { para } 20 \text {. Com a União, } \\
\text { Senador Vital do Rêgo, paraibano, eu queria a mesma posição ousada em relação à União! } \\
\text { E eu quero falar aqui sobre a proporcionalidade dessa contribuição, como bem falou o Senador Dornelles, em } \\
\text { relação à arrecadação da União. Sabe o que isso significa? Zero vírgula quinze por cento de toda arrecadação da } \\
\text { União; em relação aos Estados, } 8 \% \text {; em relação aos Municípios, } 16 \% \text {. E o que a gente sabe - e não vou citar } \\
\text { números - é que cresce cada vez mais a arrecadação da União.. (...)o apelo para apoiarmos o projeto do Senador }\end{array}$} & $\begin{array}{l}\text { Sessão do Senado } \\
\text { Federal de 19/10/11 - p. } \\
42872\end{array}$ & $\begin{array}{l}\text { O } \\
\text { Econômico e federativo. }\end{array}$ \\
\hline
\end{tabular}




\begin{tabular}{|c|c|c|}
\hline Fundamento utilizado & $\begin{array}{l}\text { Onde utilizou } \\
\text { (referência) }\end{array}$ & $\begin{array}{l}\text { Classificação do } \\
\text { fundamento }\end{array}$ \\
\hline \multicolumn{3}{|l|}{ Dornelles é que as petroleiras podem pagar mais e a União pode pagar mais" } \\
\hline $\begin{array}{l}\text { "Volto a dizer o que tenho argumentado sempre nesse debate: há uma distorção na nossa Federação. A União } \\
\text { cada vez arrecada mais. Em } 2008 . . . \text { Já citei dados aqui, mas quero citar mais dados, porque, agora, é preciso que } \\
\text { se diga que, com a partilha, aumenta a concentração da arrecadação nas mãos da União. Hoje, na concessão, nós } \\
\text { temos royalties e participação especial. Na partilha, só tem royalties. A participação especial vira óleo excedente } \\
\text { nas mãos da União. Mas não, Senador Renan, nós estamos aqui um a atacar o outro. E vamos ter - quero chamar } \\
\text { a atenção para isto - sérios problemas federativos neste País." }\end{array}$ & $\begin{array}{l}\text { Sessão do Senado } \\
\text { Federal de 19/10/11 - p. } \\
42890\end{array}$ & $\begin{array}{l}\text { O } \\
\text { Federativo. }\end{array}$ \\
\hline $\begin{array}{l}\text { "Sr. Presidente, o PSDB encaminha favoravelmente à emenda do Senador Lindbergh e, por mais uma vez, reitero } \\
\text { aqui que considero adequado que a União possa superar, permitir que o Brasil supere essa disputa federativa, } \\
\text { dando ela a contribuição que pode dar aos Estados não produtores, sem onerar os Estados produtores, Sr. } \\
\text { Presidente." }\end{array}$ & $\begin{array}{l}\text { Sessão do Senado } \\
\text { Federal de 19/10/11 - p. } \\
42901\end{array}$ & $\begin{array}{l}\mathrm{O} \\
\text { Federativo. }\end{array}$ \\
\hline $\begin{array}{l}\text { "Sr. Presidente, eu queria aproveitar esta oportunidade e compartilhar algumas reflexões com os nobres } \\
\text { Deputados e Deputadas. Eu creio que nós estamos tendo uma discussão eminentemente federativa e estamos, } \\
\text { nesse bojo, perdendo a oportunidade ímpar de corrigirmos uma distorção que cada vez mais se agrava no Brasil. } \\
\text { Qual é essa distorção? A concentração de poder político na União. Esse poder político é proveniente } \\
\text { essencialmente da maior parte do bolo das receitas que são geradas pelos tributos neste País. Cada vez mais, a } \\
\text { União concentra poder. Isso é perverso para a democracia, porque o passo seguinte é o aliciamento fácil das } \\
\text { forças políticas e a composição de uma maioria que vai atropelando. Isso é muito negativo no meu entendimento. } \\
\text { (...)os Estados produtores e os Municípios produtores vão perder. É óbvio que eles perdendo os Municípios que } \\
\text { não são produtores vão ganhar. Mas vão ganhar tirando de quem? Dos Estados produtores, dos Municípios } \\
\text { produtores." }\end{array}$ & $\begin{array}{l}\text { Sessão da Câmara dos } \\
\text { Deputados de 6/11/12 às } \\
\text { 10hs - p. } 232 .\end{array}$ & $\begin{array}{l}\mathrm{O} \\
\text { Federativo. }\end{array}$ \\
\hline $\begin{array}{l}\text { "A solução é fácil. A solução é tirar da União. Onze bilhões de reais a União vai receber este ano, enquanto todos } \\
\text { os outros Estados vão receber apenas } 11 \text { bilhões de reais também. Um, sozinho, recebe } 11 \text { bilhões de reais. E nós, } \\
\text { junto com todos os outros, inclusive Municípios confrontantes - são mais de } 800 \text { no Brasil -, recebemos outros } \\
11 \text { bilhões de reais. Isso está errado. A solução é tirar do primo rico, nesse processo, que é a União. Viva a } \\
\text { Federação, com a União equilibrada, e não concentrada!" }\end{array}$ & $\begin{array}{l}\text { Sessão da Câmara dos } \\
\text { Deputados de } 6 / 11 / 12 \text { às } \\
10 \text { hs }- \text { p. } 233-234 \text {. }\end{array}$ & $\begin{array}{l}\mathrm{O} \\
\text { Federativo. }\end{array}$ \\
\hline $\begin{array}{l}\text { "Aqui, não se teve a coragem de tirar do primo rico, que é a União, que prossegue recebendo } 40 \% \text { da } \\
\text { participação especial, por exemplo. Dos } 92 \text { Municípios do Rio de Janeiro, se a Presidente vetar, } 85 \text {, na manhã do } \\
\text { dia seguinte, terão } 50 \% \text { a menos em sua participação especial." }\end{array}$ & $\begin{array}{l}\text { Sessão da Câmara dos } \\
\text { Deputados de } 6 / 11 / 12 \text { às } \\
\text { 20hs - p. } 126 .\end{array}$ & $\begin{array}{l}\mathrm{O} \\
\text { Federativo. }\end{array}$ \\
\hline $\begin{array}{l}\text { "As participações do governo brasileiro por barril foram de, respectivamente, } 35,73 \%, 40,95 \% \text { e } 39,99 \% \text {. Como } \\
\text { já mencionado, nos anos de } 2009,2010 \text { e } 2011 \text {, as participações do governo norueguês por barril foram de, } \\
\text { respectivamente, } 85,5 \%, 76,3 \% \text { e } 79,3 \% \text {. Observa-se, então que sob o regime de concessão, a participação }\end{array}$ & $\begin{array}{l}\text { Parecer da Câmara dos } \\
\text { Deputados ao } \\
\text { Substitutivo do Senado }\end{array}$ & $\begin{array}{l}\mathrm{O} \\
\text { Econômico. }\end{array}$ \\
\hline
\end{tabular}




\begin{tabular}{|c|c|c|c|}
\hline & Fundamento utilizado & $\begin{array}{l}\text { Onde utilizou } \\
\text { (referência) }\end{array}$ & $\begin{array}{l}\text { Clas: } \\
\text { fund }\end{array}$ \\
\hline \multicolumn{2}{|r|}{$\begin{array}{l}\text { governamental brasileira na renda petrolífera é baixíssima para os padrões internacionais e que, mesmo sob o } \\
\text { regime de partilha de produção, essa participação tende a continuar baixa, a menos que se estabeleça um } \\
\text { excedente em óleo da União de, no mínimo, } 60 \% \text {." }\end{array}$} & $\begin{array}{l}\text { ao Projeto de L } \\
\text { Câmara } \mathrm{n}^{\circ} 41, \mathrm{c} \\
- \text { p. } 9-10 .\end{array}$ & \\
\hline M7 & \multicolumn{2}{|c|}{$\begin{array}{c}\text { As novas regras de rateio violam a sistemática de compensação existente entre os royalties e o ICMS sobre operações com } \\
\text { petróleo }\end{array}$} & $\begin{array}{l}\text { O Jurídico (não dogmático) } \\
\text { Jut }\end{array}$ \\
\hline \multicolumn{2}{|r|}{$\begin{array}{l}\text { "Quando o constituinte decidiu que o ICMS, em relação a petróleo, não seria cobrado no Estado de origem, ele } \\
\text { decidiu compensar essa não tributação outorgando àqueles Estados produtores, bem como aos que sofressem o } \\
\text { desgaste dessa operação, o direito de cobrar royalties e participação especial em relação ao petróleo." }\end{array}$} & $\begin{array}{l}\text { Sessão do Senado } \\
\text { Federal de 19/10/11 - p. } \\
\text { 42868. }\end{array}$ & O Jurídico (não dogmático). \\
\hline \multicolumn{2}{|r|}{$\begin{array}{l}\text { "Estabeleceu-se que o ICMS não incidiria sobre operações que se destinassem a outros } \\
\text { Estados, petróleo e energia elétrica. Decidiu-se da seguinte forma: tira-se o ICMS da origem e se dá aos Estados } \\
\text { em compensação financeira por essa perda. Aí criou-se o } \S 1^{\circ} \text { do art. } 20 . "\end{array}$} & $\begin{array}{l}\text { Sessão do Senado } \\
\text { Federal de } 19 / 10 / 11-\text { p. } \\
42872 .\end{array}$ & O Jurídico (não dogmático). \\
\hline \multicolumn{2}{|r|}{$\begin{array}{l}\text { "Então, na verdade, os royalties são uma compensação. O art. 155, § } 2^{\circ} \text {, inciso X, alínea b, diz que sobre as } \\
\text { operações não incidirão impostos - ICMS, no nosso caso —, sobre operações que destinem a outros Estados } \\
\text { petróleo, inclusive lubrificantes, combustíveis líquidos e gasosos deles derivados e energia elétrica. O que } \\
\text { significa isso? Que o Rio de Janeiro e o Espírito Santo tenham uma compensação financeira, porque sobre elas } \\
\text { não incide ICMS." }\end{array}$} & $\begin{array}{l}\text { Sessão da Câmara dos } \\
\text { Deputados de } 6 / 11 / 12 \text { às } \\
16 \mathrm{hs}-\text { p. } 105 .\end{array}$ & $\begin{array}{l}\text { O } \\
\text { Jurídico (não dogmático). }\end{array}$ \\
\hline M8 & \multicolumn{2}{|c|}{$\begin{array}{l}\text { O valor arrecadado com ICMS pelos entes produtores, caso fosse devido na origem, seria maior do que o valor de royalties e } \\
\text { PE destinado a esses entes }\end{array}$} & \\
\hline \multicolumn{2}{|r|}{$\begin{array}{l}\text { "Pois bem. Em um estudo do José Roberto Afonso, da UFRJ e Consultor do Senado, juntamente com Kléber } \\
\text { Pacheco de Castro, da UFRJ, se o Espírito Santo ou o Rio de Janeiro, ex-Governador Garotinho, cobrassem ICMS } \\
\text { sobre o petróleo - está no livro publicado por eles - isso seria o dobro do ICMS do que se recolhe de } \\
\text { participações especiais e de royalties." }\end{array}$} & $\begin{array}{l}\text { Sessão da Câmara dos } \\
\text { Deputados de } 6 / 11 / 12 \text { às } \\
\text { 16hs - p. } 106 .\end{array}$ & O Econômico. \\
\hline M9 & \multicolumn{2}{|c|}{$\begin{array}{c}\text { A aplicação das novas regras viola a segurança jurídica e o direito adquirido, na medida em que atingem os contratos em } \\
\text { curso }\end{array}$} & $\begin{array}{l}\text { VD } \\
\text { Jurídico d }\end{array}$ \\
\hline \multicolumn{2}{|r|}{$\begin{array}{l}\text { "Eu votarei contra a urgência porque é um dever preservar a nossa Constituição. Nós estamos } \\
\text { infringindo, de forma absoluta, o direito adquirido no art. } 5^{\circ} \text {, inciso XXXVI, da Constituição. Nós estamos } \\
\text { também atacando o art. } 20, \S 1^{\circ} \text {, da compensação financeira." }\end{array}$} & $\begin{array}{l}\text { Sessão da Câmara dos } \\
\text { Deputados de } 6 / 11 / 12 \text { às } \\
\text { 10hs - p. } 242 .\end{array}$ & $\begin{array}{l}\text { VD } \\
\text { Jurídico dogmático. }\end{array}$ \\
\hline \multicolumn{2}{|r|}{$\begin{array}{l}\text { "Presidente, eu quero cumprimentar V.Exa., os demais Parlamentares, e dizer que a minha posição é contrária ao } \\
\text { projeto porque ele viola um princípio básico que deve ser respeitado no nosso Pais e que a Presidente da } \\
\text { República vem defendendo que seja mantido e respeitado pelo Governo dela e pelos poderes constituídos: o } \\
\text { princípio do respeito aos contratos, aos pactos assumidos, à segurança jurídica, ao pacto federativo. E tudo isso } \\
\text { cai por terra quando a regra nova, que se quer aprovar nesta Casa, atinge os royalties dos campos já licitados, já }\end{array}$} & $\begin{array}{l}\text { Sessão da Câmara dos } \\
\text { Deputados de } 6 / 11 / 12 \text { às } \\
\text { 16hs - p. } 99 .\end{array}$ & $\begin{array}{l}\text { VD } \\
\text { Jurídico dogmático. }\end{array}$ \\
\hline
\end{tabular}

${ }^{250}$ Parecer disponível em: <http://www.camara.gov.br/proposicoesWeb/prop_mostrarintegra?codteor=1108666\&filename=PPP+4+PL032307+\%3D\%3E+PL+323/2007>. Acesso em: 7 mar. 2015. 


\begin{tabular}{|c|c|c|c|}
\hline & Fundamento utilizado & $\begin{array}{l}\begin{array}{l}\text { Onde utilizou } \\
\text { (referência) }\end{array} \\
\text { (rê }\end{array}$ & $\begin{array}{l}\text { Classificação do } \\
\text { fundamento }\end{array}$ \\
\hline \multicolumn{4}{|c|}{$\begin{array}{l}\text { em produção. Isso fere os direitos do Estado do Rio de Janeiro, e, mais do que isso, fere um dos fundamentos da } \\
\text { República, que é o respeito à segurança jurídica, aos contratos, e assim por diante." }\end{array}$} \\
\hline \multicolumn{2}{|r|}{$\begin{array}{l}\text { "Primeiro, eu quero discordar do relatório do Deputado Zarattini, que trabalha uma planilha. Mas é que ele } \\
\text { afronta diretamente o art. } 5^{\circ} \text { da Constituição, que diz, no inciso XXXVI: 'A lei não prejudicará o direito } \\
\text { adquirido, o ato jurídico perfeito e a coisa julgada'." }\end{array}$} & $\begin{array}{l}\text { Sessão da Câmara dos } \\
\text { Deputados de } 6 / 11 / 12 \text { às } \\
16 \text { hs }- \text { p. } 105 .\end{array}$ & $\begin{array}{l}\text { VD } \\
\text { Jurídico dogmático. }\end{array}$ \\
\hline \multicolumn{2}{|r|}{$\begin{array}{l}\text { "Mudanças posteriores não podem atingir os royalties de campos já licitados ou já contratados. Essas regras não } \\
\text { podem ser modificadas posteriormente. Também volto agora ao argumento da Presidenta da República: 'As novas } \\
\text { regras de distribuição de royalties previstas no art. } 13 \text { a a não ressaltar sua aplicação aos contratos já em vigor, } \\
\text { violam frontalmente o disposto no inciso XXXVI do art. } 5^{o} \text {, o que traz enorme insegurança jurídica para todos } \\
\text { aqueles que atuam no petróleo." ". }\end{array}$} & $\begin{array}{l}\text { Sessão conjunta do } \\
\text { Congresso de } 6 / 3 / 13 \text { - p. } \\
749 \text {. }\end{array}$ & $\begin{array}{l}\text { VD } \\
\text { Jurídico dogmático. }\end{array}$ \\
\hline M10 & \multicolumn{2}{|l|}{ Vinculação dos royalties e PE ao pagamento de dívidas dos estados produtores } & $\begin{array}{l}\text { O } \\
\text { Econômico. }\end{array}$ \\
\hline \multicolumn{2}{|r|}{$\begin{array}{l}\text { "Em nenhum momento nós contestamos essa distribuição pelo inverso da renda per capita. Agora, não podemos } \\
\text { abrir mão da arrecadação de uma receita que é originária do Rio de Janeiro, que pertence ao povo do Rio de } \\
\text { Janeiro, que está compromissada com o pagamento da dívida do Rio e com o Instituto da Previdência. Se for } \\
\text { retirada essa receita do Rio, simplesmente, o nosso Estado vai à falência." }\end{array}$} & $\begin{array}{l}\text { Sessão do Senado } \\
\text { Federal de } 19 / 10 / 11-\text { p. } \\
\text { 42868. }\end{array}$ & O Econômico. \\
\hline \multicolumn{2}{|r|}{$\begin{array}{l}\text { "Se for aprovado o substitutivo de V. Exa a o Rio de Janeiro não terá dinheiro para honrar compromisso de sua } \\
\text { dívida pública assumida com a União nem poderá manter o compromisso de capitalização do Rio Previdência." }\end{array}$} & $\begin{array}{l}\text { Sessão do Senado } \\
\text { Federal de } 19 / 10 / 11-\text { p. } \\
42869 \text {. }\end{array}$ & $\begin{array}{l}\mathrm{O} \\
\text { Econômico. }\end{array}$ \\
\hline \multicolumn{2}{|r|}{$\begin{array}{l}\text { "No relatório, não há nenhuma menção aos contratos dos Estados do Rio de Janeiro e do Espírito Santo com a } \\
\text { União. Foram dados em garantia para a União os royalties futuros, sendo inclusive transferido o direito sobre as } \\
\text { receitas de royalties em determinadas concessões." }\end{array}$} & $\begin{array}{l}\text { Sessão do Senado } \\
\text { Federal de } 19 / 10 / 11-\text { p. } \\
42879 .\end{array}$ & $\begin{array}{l}\text { O } \\
\text { Econômico. }\end{array}$ \\
\hline \multicolumn{2}{|r|}{$\begin{array}{l}\text { "É isso que as bancadas de Estados produtores vêm aqui defender, porque esses recursos já estão comprometidos } \\
\text { com políticas públicas, com investimentos. Há dívidas lastreadas sobre esses recursos. Há Municípios que } \\
\text { necessitam desses recursos e que precisam fazer políticas universais inclusivas, com Prefeitos recentemente } \\
\text { eleitos que precisam avançar." }\end{array}$} & $\begin{array}{l}\text { Sessão da Câmara dos } \\
\text { Deputados de } 6 / 11 / 12 \text { às } \\
16 \text { hs }- \text { p. } 112 \text {. }\end{array}$ & $\begin{array}{l}\text { O } \\
\text { Econômico. }\end{array}$ \\
\hline M11 & \multicolumn{2}{|l|}{ Os critérios de rateio do FPE e do FPM são inconstitucionais } & $\begin{array}{l}\text { O } \\
\text { Jurídico (não dogmático) } \\
\text { e federativo. }\end{array}$ \\
\hline $\begin{array}{l}\text { "O Su } \\
\text { Estad, } \\
\text { S. Ex } \\
2020 . \\
\text { tornad }\end{array}$ & $\begin{array}{l}\text { premo Tribunal Federal, recentemente, declarou a inconstitucionalidade do Fundo de Participação dos } \\
\text { s e também concluiu que esse é um critério absolutamente defasado. E esse é o critério, segundo o relato de } \\
\text {, que deverá presidir a distribuição dos royalties, pelo menos em todo o sistema de concessão de } 2012 \text { a } \\
\text { Como sustentar um fundamento como esse em torno de uma lei, em torno de um critério, de uma regra } \\
\text { la inconstitucional pelo Supremo Tribunal Federa??" }\end{array}$ & $\begin{array}{l}\text { Sessão do Senado } \\
\text { Federal de } 19 / 10 / 11-\text { p. } \\
42882\end{array}$ & $\begin{array}{l}\text { O } \\
\text { Jurídico (não dogmático) e } \\
\text { federativo. }\end{array}$ \\
\hline & upremo Tribunal Federal declarou o Fundo de Particip & Sessão do Senado & $\mathrm{O}$ \\
\hline
\end{tabular}




\section{Fundamento utilizado}

Congresso Nacional, até 2012, a tarefa de construir critérios para o Fundo de Participação dos Estados. Esse tipo de discussão aqui, eu fico pensando: seremos capazes de construir critérios em relação ao Fundo de Participação dos Estados?"

"Eu apresento, Deputado Arnaldo Faria de Sá, emenda que altera a distribuição da parcela dos royalties que vão para os Estados. E por quê, Deputado Onyx Lorenzoni? Porque o critério usado e proposto no relatório é de distribuição pelo Fundo de Participação dos Estados, que tem um conjunto de regras que não garantem o equilíbrio necessário, relacionado à população que vive em cada Estado. Então, se nós consolidarmos a distribuição de uma riqueza, que alguns estimam de 10 a 15 bilhões por ano em royalties de petróleo, seguindo a regra do FPE, São Paulo, por exemplo, receberia 1\%, ou seja, 100 milhões de reais. Outro Estado, que evidentemente tem todo o meu respeito como brasileiro, mas que não tem uma população que possa justificar uma diferença tão grande, é a Bahia, que receberia 9,40\%, ou seja, 940 milhões de reais por ano. Se isso for levado para 10 anos, receberia ela 9,4 bilhões, e, São Paulo, 1 bilhão de reais. O Rio Grande do Sul — e assumo que esta emenda reequilibra a situação e beneficia o Rio Grande do Sul — hoje recebe 2,35\%, ou seja, 235 milhões de reais por ano. Com essa correção baseada na população, no critério populacional e no inverso da renda per capita, ele passaria para $4,29 \%$."

"Veja bem, o parecer do Deputado Zarattini estabelece como parâmetros o FPE e o FPM para distribuição dos royalties. Acontece que nós não temos a definição dos parâmetros do FPE e do FPM. Como é que podemos votar um projeto que se reporta a outro projeto, se naquele projeto nós não temos a definição?!"

As novas regras de distribuição se reportam ao "Fundo de Participação dos Estados, cujos critérios são absolutamente insustentáveis e já condenados pelo Supremo Tribunal Federal."

"Hoje nós estamos discutindo um dos quatro pilares necessários para manter o pacto federativo. O primeiro é a questão relacionada aos critérios de partição dos Fundos dos Estados e dos Municípios. Esses critérios estão defasados, e precisamos enfrentar a necessidade de atualizá-los.”.

\section{M12 \\ A aplicação da nova sistemática de distribuição viola o pacto federativo}

“Achamos legítima a ideia de que todos os Estados e Municípios da Federação também sejam beneficiados com o aumento dos royalties por conta do pré-sal, mas não é justo que isso se faça à custa dos direitos adquiridos dos

Estados produtores. O Pacto Federativo se apoia no equilíbrio de direitos e deveres de todos os Estados, e isso não pode ser rompido. Sr. Presidente, concluo afirmando que tenho confiança que esta Casa saberá resguardar o equilíbrio federativo ao votar essa importante questão."

A regra nova fere o pacto federativo, sobretudo quando atinge os royalties dos campos já licitados, tendo em vista que os entes produtores já contavam com essas receitas.

\section{Onde utilizou}

(referência)

Federal de 19/10/11 - p.

42890

Sessão da Câmara dos

Deputados de 6/11/12 às

10hs - p. 214.

Deputados de 6/11/12 às

$10 \mathrm{hs}-$ p. 235

Sessão da Câmara dos

Deputados de 6/11/12 às 16 hs - p. 112.

Sessão da Câmara dos

Deputados de 6/11/12 às 16hs - p. 189

Sessão da Câmara dos

Deputados de 6/11/12 às

10hs - p. 111.

Sessão da Câmara dos

Deputados de 6/11/12 às

16hs - p. 99-100
Classificação do

\section{damento}

Jurídico (não dogmático) e federativo.

\section{O}

Jurídico (não dogmático) e federativo.

O

Jurídico (não dogmático) e federativo.

O

Jurídico (não dogmático) e federativo.

Federativo.

\section{O}

\section{Federativo}

Federativo.

$\mathrm{O}$

Federativo. 
TABELA 5 - FUNDAMENTOS UTILIZADOS PELO EXECUTIVO

\begin{tabular}{|c|c|c|c|}
\hline & Fundamento utilizado & Onde utilizou (referência) & Classificação do fundamento \\
\hline E1 & $\begin{array}{l}\text { "Da forma como redigido, o artigo não estabelece a fórmula ou a alíquota para obtenção do } \\
\text { montante total dos recursos provenientes dos royalties. Igualmente, não é fixado o percentual } \\
\text { desses valores que corresponderá à participação da União nem, consequentemente, o } \\
\text { percentual que será destinado aos Estados, Distrito Federal e Municípios. Tais dados são } \\
\text { imprescindíveis ao cálculo da parte a ser dividida entre a União e os demais entes, na forma do } \\
\text { caput e dos incisos, e de eventual compensação, prevista no } \S 2^{\circ} \text {." }\end{array}$ & $\begin{array}{l}\text { Veto Parcial } \mathrm{n}^{\circ} 39 / 10, \text { ao art. } \\
64^{251} \text { do Projeto de Lei no } \\
5.940 \text {, de } 2009\left(\mathrm{n}^{\mathrm{o}} 7 / 10 \text { no }\right. \\
\text { Senado Federal })^{252}-\text { p. } 2\end{array}$ & $\begin{array}{l}\text { O } \\
\text { Jurídico (não dogmático) e } \\
\text { econômico }\end{array}$ \\
\hline E2 & $\begin{array}{l}\text { "A proposta também não deixa claro se as regras para divisão dos recursos se restringem aos } \\
\text { contratos futuros ou se são aplicáveis aos já em vigor". }\end{array}$ & Veto Parcial no $39 / 10-$ p. 2. & $\begin{array}{l}\text { O } \\
\text { Jurídico (não dogmático) }\end{array}$ \\
\hline E3 & $\begin{array}{l}\text { "Também se observa que não foi adotado critério para a compensação de receitas aos Estados e } \\
\text { Municípios pela União. Em ambos os casos, a consequência poderia ser uma alta litigiosidade } \\
\text { entre os diversos atores." }\end{array}$ & Veto Parcial no $39 / 10-$ p. 2. & $\begin{array}{l}\text { O } \\
\text { Jurídico (não dogmático) e } \\
\text { econômico }\end{array}$ \\
\hline E4 & $\begin{array}{l}\text { "O texto proposto é inconstitucional, pois conflita diretamente com as disposições previstas no } \\
\text { art. } 5^{\circ} \text { e no } \S 1^{o} \text { do art. } 20 \text { da Constituição, ao obrigar os Estados e Municípios a renunciarem a } \\
\text { direito constitucional originário para participar da distribuição do Fundo Especial destinado a } \\
\text { todos os entes federados." }\end{array}$ & $\begin{array}{l}\text { Veto Parcial } n^{\circ} 38 / 12 \text {, ao } \\
\text { Projeto de Lei do Senado } n^{\circ} \\
448 / 11 \text { (Projeto de Lei no } \\
\text { 2565/11 na Câmara dos } \\
\text { Deputados) }{ }^{253}-\text { p. } 3 .\end{array}$ & $\begin{array}{l}\text { O } \\
\text { Jurídico (não dogmático) }\end{array}$ \\
\hline E5 & $\begin{array}{l}\text { "A imposição de limites máximos para o recebimento de valores referentes aos royalties viola } \\
\text { o disposto no } \S 1 \text { o do art. } 20 \text { da Constituição. A compensação financeira aos municípios } \\
\text { produtores, confrontantes ou afetados deve guardar equivalência com o impacto decorrente da } \\
\text { produção e da exploração de petróleo e gás natural. Ao determinar um teto de receita, os } \\
\text { dispositivos desvirtuam tal sistemática constitucional de proporcionalidade entre a exploração } \\
\text { e a compensação." }\end{array}$ & Veto Parcial no $38 / 12-$ p. 4 & $\begin{array}{l}\text { O } \\
\text { Jurídico (não dogmático) e } \\
\text { econômico }\end{array}$ \\
\hline E6 & $\begin{array}{l}\text { "Os royalties fixados na legislação em vigor constituem uma compensação financeira dada aos } \\
\text { Estados e Municípios produtores e confrontantes em razão da exploração do petróleo em seu } \\
\text { território. Devido a sua natureza indenizatória, os royalties incorporam-se às receitas }\end{array}$ & Veto Parcial no 38/12 - p. 13 & $\begin{array}{l}\text { VD } \\
\text { Jurídico dogmático } 254\end{array}$ \\
\hline
\end{tabular}

${ }^{251} \mathrm{O}$ art. 64 estabelecia novas regras de distribuição para os contratos de partilha de produção ou de concessão, quando a lavra ocorresse na plataforma continental, mar territorial ou zona econômica exclusiva.

${ }^{252}$ Veto Parcial no 39/10, p. 2. Disponível em: <http://www.senado.gov.br/atividade/materia/detalhes. asp?p_cod_mate=98783>. Acesso em: 27 fev. 2015.

${ }^{253}$ Veto Parcial no 38/12. Disponível em: <http://www. senado.gov.br/atividade/materia/ detalhes.asp?p_cod_mate=109332>. Acesso em 27 fev. 2015.

${ }^{254}$ Os argumentos de caráter jurídico dogmático foram assim classificados porque a) partem da premissa de que o art. 20 , $\$ 1^{\circ}$ estabelece que os royalties são compensações financeiras pelos danos causados aos entes produtores, confrontantes ou afetados, sem sequer haver uma análise sobre que danos seriam esses, qual seria a sua abrangência e se essa é a única forma de indenizá-los; b) afirmam que a aplicação das novas regras aos contratos em curso ofende a segurança jurídica, sem discutir a possibilidade de alteração da sistemática legal de distribuição, ou se a distribuição dos royalties entre os entes federativos é especificada em tais contratos. Enfim, são fixadas algumas "verdades" como indiscutíveis, quando o que se verifica, na realidade, é que o tema envolve aspectos bem mais complexos do que o enquadramento de fatos em normas. 


\begin{tabular}{|c|c|c|c|}
\hline & Fundamento utilizado & Onde utilizou (referência) & Classificação do fundamento \\
\hline & originárias dos entes confrontantes, inclusive para efeitos de disponibilidade futura." & & \\
\hline E7 & $\begin{array}{l}\text { "As novas regras de distribuição dos royalties previstas no art. 3o do projeto, ao não ressalvar } \\
\text { sua aplicação aos contratos já em vigor, violam frontalmente o disposto no inciso XXXVI do } \\
\text { art. } 5^{\circ} \text { ". }\end{array}$ & Veto Parcial no 38/12 - p. 13. & $\begin{array}{l}\text { VD } \\
\text { Jurídico dogmático }\end{array}$ \\
\hline E8 & $\begin{array}{l}\text { Os royalties constituem uma receita certa, com a qual já contavam os entes produtores e } \\
\text { confrontantes. A alteração da sistemática de partilha afronta o princípio do equilíbrio } \\
\text { orçamentário previsto no art. } 167 \text { da Constituição Federal. }\end{array}$ & Veto Parcial $n^{\circ} 38 / 12-$ p. 13 & $\begin{array}{l}\text { O } \\
\text { Jurídico (não dogmático) e } \\
\text { econômico }\end{array}$ \\
\hline E9 & $\begin{array}{l}\text { Os royalties, em vários casos, foram objeto de securitização ou operações de antecipação de } \\
\text { recebíveis, sendo que a perda desses recursos impediria o estado ou município de arcar com os } \\
\text { compromissos assumidos. }\end{array}$ & Veto Parcial n $\mathrm{n}^{0}$ 38/12 - p. 13. & $\begin{array}{l}\text { O } \\
\text { Jurídico (não dogmático) e } \\
\text { econômico }\end{array}$ \\
\hline E10 & $\begin{array}{l}\text { A proposta restabelece relevantes proposições do Congresso Nacional, formuladas no interesse } \\
\text { público, que distribuem de forma mais equitativa os recursos do petróleo entre os entes } \\
\text { federativos, sem alcançar, contudo, as situações que provocaram o veto de dispositivos no } \\
\text { Projeto de Lei do Senado } \mathrm{n}^{\mathrm{o}} 448 / 11 \text { ( } \mathrm{PL} \mathrm{n}^{\mathrm{o}} 2565 / 11 \text { na Câmara). }\end{array}$ & $\begin{array}{l}\text { Razões que justificam a edição } \\
\text { da Medida Provisória } \mathrm{n}^{\mathrm{o}} \\
592 / 12^{255}\left(\text { EMI }^{\circ} 00244 / 2012\right. \\
\text { MF MME). }\end{array}$ & $\begin{array}{l}\mathrm{O} \\
\text { Federativo. }\end{array}$ \\
\hline E11 & $\begin{array}{l}\text { "Tais efeitos [decorrentes da aplicação das novas regras de distribuição aos contratos em } \\
\text { curso], de difícil mensuração, impactam gravemente as finanças públicas dos Estados e } \\
\text { Municípios, os quais têm obrigações a honrar com as receitas oriundas de sua participação, } \\
\text { inclusive aquelas decorrentes de compromissos futuros, firmados com base na receita a } \\
\text { receber.". Por sua vez, a medida provisória não impacta gravemente as finanças dos estados e } \\
\text { municípios produtores, tendo em vista que não alcança os contratos já firmados. }\end{array}$ & $\begin{array}{l}\text { Razões que justificam a edição } \\
\text { da Medida Provisória no }{ }^{\circ} \text { 592/12 }\end{array}$ & $\begin{array}{l}\mathrm{O} \\
\text { Econômico. }\end{array}$ \\
\hline
\end{tabular}

255 Texto integral da MP no 592/12. Disponível em: <http://www.senado.gov.br/atividade/materia/detalhes.asp?p_cod_mate=109360>. Acesso em: 2 mar. 2015. 
TABELA 6: FUNDAMENTOS UTILIZADOS PELO JUDICIÁRIO

\begin{tabular}{|c|c|c|c|}
\hline & Fundamento utilizado & Onde utilizou (referência) & $\begin{array}{l}\text { Classificação do } \\
\text { fundamento }\end{array}$ \\
\hline $\mathrm{J} 1$ & $\begin{array}{l}\text { "A alegada urgência pode ser fácil e claramente demonstrada pela possibilidade ou probabilidade } \\
\text { de imediata aplicação das novas regras no cálculo e na entrega dos valores devidos a Estados } \\
\text { Federados e Municípios e com os quais contam essas pessoas políticas para o desempenho de } \\
\text { suas atividades e para a prestação dos serviços que lhes são constitucionalmente cometidos." }\end{array}$ & $\begin{array}{l}\text { Decisão proferida nos autos } \\
\text { da Medida Cautelar na Ação } \\
\text { Direta de } \\
\text { Inconstitucionalidade } \mathrm{n}^{\circ} \\
\text { 4917-DF } 256 \text { - p. } 6 .\end{array}$ & $\begin{array}{l}\mathrm{O} \\
\text { Econômico }\end{array}$ \\
\hline $\mathrm{J} 2$ & $\begin{array}{l}\text { "Embora não expresso na peça inicial, tem-se desde a previsão do art. } 8^{\circ} \text { da Lei n. } 7990 / 1989, \\
\text { alterada pela Lei n. } 8001 / 1990 \text {, que 'o pagamento das compensações financeiras previstas nesta } \\
\text { Lei, inclusive o da indenização pela exploração do petróleo, do xisto betuminoso e do gás natural } \\
\text { será efetuado mensalmente, diretamente aos Estados, ao Distrito Federal, aos Municípios e aos } \\
\text { órgãos da Administração Direta da União, até o último dia útil do segundo mês subsequente ao do } \\
\text { fato gerador, devidamente corrigido pela variação do Bônus do Tesouro Nacional (BTN), ou } \\
\text { outro parâmetro de correção monetária que venha a substituí-lo, vedada a aplicação dos recursos } \\
\text { em pagamento de dívida e no quadro permanente de pessoal'. (...) } \\
\text { A previsão legal quanto à periodicidade do pagamento e a necessidade de se conferir certeza às } \\
\text { diferentes pessoas da Administração Pública da União, dos Estados e dos Municípios quanto aos } \\
\text { efeitos das normas e aos comportamentos a serem adotados, os valores a serem entregues e a } \\
\text { quem, segundo quais regras jurídicas, qualifica a urgência do exame e da decisão sobre a medida } \\
\text { cautelar suspensiva dos efeitos dos dispositivos legais promulgados em 15.3.2013." }\end{array}$ & Decisão - p. 6-7. & $\begin{array}{l}\text { O } \\
\text { Jurídico (não dogmático) e } \\
\text { econômico. }\end{array}$ \\
\hline $\mathrm{J} 3$ & $\begin{array}{l}\text { "O orçamento aprovado pelas entidades federadas para o ano de } 2013 \text { considerou a realidade } \\
\text { jurídica de } 2012 \text {, quando inexistentes ou inaplicáveis as novas regras, pelo que não haveria como } \\
\text { assegurar o cumprimento do arcabouço normativo vigente (tais como a Lei de Responsabilidade } \\
\text { Fiscal e a Lei Orçamentária) se a aplicação da nova legislação fosse imediata.". }\end{array}$ & Decisão - p. 30. & $\begin{array}{l}\text { O } \\
\text { Jurídico (não dogmático), } \\
\text { econômico. }\end{array}$ \\
\hline $\mathrm{J} 4$ & $\begin{array}{l}\text { "A gravidade dos efeitos imediatos das regras questionadas fica patenteada pela afirmativa do } \\
\text { Governador do Estado de que 'as vinculações orçamentárias fariam com que, em 2013, restassem } \\
\text { apenas } \mathrm{R} \$ 300 \text { milhões disponíveis para custeio de diversos programas sociais." ". }\end{array}$ & Decisão - p. 10 & $\begin{array}{l}\mathrm{O} \\
\text { Econômico. }\end{array}$ \\
\hline J5 & $\begin{array}{l}\text { "A dicção do } \S 1^{\circ} \text { do art. } 20 \text { da Constituição brasileira define os titulares do direito à participação } \\
\text { no resultado da exploração de petróleo ou gás natural no respectivo território, plataforma } \\
\text { continental, mar territorial ou zona econômica exclusiva, ou compensação financeira por essa } \\
\text { exploração. } \\
\text { O direito das entidades federadas, Estados e Municípios, constitucionalmente assegurado, decorre } \\
\text { de sua condição territorial e dos ônus que têm de suportar ou empreender pela sua geografia e, } \\
\text { firmado nesta situação, assumir em sua geoeconomia, decorrentes daquela exploração. Daí a }\end{array}$ & Decisão-p. 21. & $\begin{array}{l}\text { VD } \\
\text { Jurídico dogmático. }\end{array}$ \\
\hline
\end{tabular}

${ }^{256}$ Medida cautelar na ADI no 4917-DF. Decisão. Disponível em: <http://redir.stf.jus.br/paginador pub/paginador.jsp?docTP=TP\&docID=3518637\&ad=s\#28\%20-

\%20Decis\%E3o\%20monocr\%E1tica>. Acesso em $1^{\circ}$ mar. 2015. 


\begin{tabular}{|c|c|c|c|}
\hline & Fundamento utilizado & Onde utilizou (referência) & $\begin{array}{l}\text { Classificação do } \\
\text { fundamento }\end{array}$ \\
\hline & $\begin{array}{l}\text { garantia constitucional de que participam no resultado ou compensam-se pela exploração de } \\
\text { petróleo ou gás natural. Como observado por Célio Borja, no parecer antes mencionado, ‘a } \\
\text { Constituição não partilha participação na produção nem compensação financeira a Estados e } \\
\text { Municípios de cujos territórios o petróleo e o gás não são extraídos ou que não se delimitam } \\
\text { geograficamente com as áreas exploradas, nem concorrem operacionalmente para a produção, } \\
\text { porque esses direitos federativos são territoriais e decorrem de confrontação com as jazidas } \\
\text { exploradas. A inexistência dessas vinculações topográficas, produtivas e operacionais exclui } \\
\text { Estados e Municípios da participação no resultado da exploração e na compensação financeira' ”. }\end{array}$ & & \\
\hline J6 & $\begin{array}{l}\text { "Daí a norma da al. b do inc. X do } \S 2^{\circ} \text { do art. } 155 \text { da Constituição, segundo a qual não incidirá } \\
\text { ICMS sobre operações que destinem a outros Estados petróleo, inclusive lubrificantes, } \\
\text { combustíveis líquidos e gasosos dele derivados e energia elétrica. Vale dizer, orienta-se a hipótese } \\
\text { de incidência tributária segundo o destino e não a origem do produto tributado, exatamente para } \\
\text { se acomodar o regime de finanças na Federação. } \\
\text { A alteração das regras relativas ao regime de participação no resultado da exploração de petróleo } \\
\text { ou gás natural ou da compensação pela exploração, sem mudança constitucional do sistema } \\
\text { tributário, importa em desequilibrar o tão frágil equilíbrio federativo nacional e em desajustar, } \\
\text { mais ainda, o regime financeiro das pessoas federadas sem atenção aos princípios e às regras que } \\
\text { delineiam a forma de Estado adotada constitucionalmente.". }\end{array}$ & Decisão-p. 22-23. & $\begin{array}{l}\text { O } \\
\text { Federativo. }\end{array}$ \\
\hline J7 & $\begin{array}{l}\text { "Nas palavras do Autor, as normas legais que, em contrariedade ao que se extrai da interpretação } \\
\text { sistemática dos dispositivos constitucionais acima transcritos, restringem a autonomia financeira } \\
\text { de algumas entidades federadas, subtraindo delas valores compensatórios decorrentes de danos } \\
\text { suportados pela exploração do petróleo, para beneficiar outras pessoas federadas, sem respeito ao } \\
\text { que estatuído pela Constituição, desborda da competência legislativa válida e incide em, } \\
\text { desobediência a princípios fundamentais, no caso, o da Federação e seus consectários." }\end{array}$ & Decisão - p. 23. & $\begin{array}{l}\text { O } \\
\text { Federativo. }\end{array}$ \\
\hline J8 & $\begin{array}{l}\text { "Quanto à alegação de afronta ao inc. XXXVI do art. } 5^{\circ} \text { da Constituição do Brasil, relativa ao } \\
\text { direito adquirido mencionado pelo Autor, é de se observar serem protegidos constitucionalmente, } \\
\text { como direitos fundamentais, o direito adquirido, o ato jurídico perfeito e a coisa julgada. } \\
\text { Esses institutos são desdobramentos ou especificações do princípio da segurança jurí́dica, um dos } \\
\text { esteios da ideia de Justiça, cuja concretização é buscada pelo direito. O direito ordena (é ordem } \\
\text { normativa) em busca da Justiça (sua finalidade) para tanto propiciando segurança (que é a força } \\
\text { do direito para conforto de todas as pessoas).". }\end{array}$ & Decisão - p. 24. & $\begin{array}{l}\text { VD } \\
\text { Neo } \\
\text { (fundamentação em } \\
\text { princípio abstrato). }\end{array}$ \\
\hline J9 & $\begin{array}{l}\text { "Das concessões acabadas decorreram direitos que ingressaram no patrimônio público das } \\
\text { pessoas federadas e que, mesmo se desdobrando em recebimentos de valores no presente e } \\
\text { parcelas no futuro, fundamentam-se em processos findos, válidos, que se formaram e se } \\
\text { aperfeiçoaram segundo a legislação vigente no período em que se deram os seus atos. } \\
\text { Aplicar a nova legislação àqueles atos e processos aperfeiçoados segundo as normas vigentes }\end{array}$ & Decisão - p. 25. & $\begin{array}{l}\text { VD } \\
\text { Jurídico dogmático }\end{array}$ \\
\hline
\end{tabular}




\begin{tabular}{|c|c|c|c|}
\hline & Fundamento utilizado & Onde utilizou (referência) & $\begin{array}{l}\text { Classificação do } \\
\text { fundamento }\end{array}$ \\
\hline & $\begin{array}{l}\text { quando de sua realização seria retroação, dotar de efeitos pretéritos atos e processos acabados } \\
\text { segundo o direito, em clara afronta à norma constitucional do inc. XXXVI do art. } 5^{\circ} \text {, antes } \\
\text { mencionado.”. }\end{array}$ & & \\
\hline $\mathrm{J} 10$ & $\begin{array}{l}\text { "O direito de Estados e Municípios, a ser exercido nos termos da lei, não pode ser porta de } \\
\text { entrada para o seu amesquinhamento pelo legislador, não se podendo permitir seja esse direito } \\
\text { constitucionalmente estabelecido mais formal que real, ainda que o objetivo tenha sido o de } \\
\text { angariar novos recursos às demais entidades federadas, igualmente necessitadas de novos aportes } \\
\text { para fazer face às demandas sociais. } \\
\text { Por mais nobres e defensáveis sejam os motivos que conduzem os legisladores, não se atém o } \\
\text { controle de constitucionalidade a suas razões, mas à compatibilidade do ato legislado com as } \\
\text { normas constitucionais." }\end{array}$ & Decisão - p. 23. & $\begin{array}{l}\text { VD } \\
\text { Jurídico dogmático. }\end{array}$ \\
\hline
\end{tabular}


TABELA 7 - FUNDAMENTOS UTILIZADOS PELOS DEMAIS ATORES PROCESSUAIS FAVORÁVEIS À REDISTRIBUIÇÃO DOS ROYALTIES E PE

\begin{tabular}{|c|c|c|c|c|}
\hline & Fundamento utilizado & Quem utilizou & Onde utilizou & $\begin{array}{l}\text { Classificação do } \\
\text { fundamento }\end{array}$ \\
\hline A1 & \multicolumn{3}{|c|}{ A natureza jurídica dos royalties é de participação nos resultados, e não compensação - interpretação do art. $20, \mathbf{~}^{\circ}$ da $C F$} & $\begin{array}{l}\text { VD } \\
\text { Jurídico dogmático }{ }^{257}\end{array}$ \\
\hline \multicolumn{2}{|r|}{$\begin{array}{l}\text { "Os recursos decorrentes do petróleo da camada do pré-sal constituem-se, de forma inequívoca, } \\
\text { participação decorrente da exploração, não compensação financeira". }\end{array}$} & $\begin{array}{l}\text { Confederação } \\
\text { Nacional dos } \\
\text { Municípios } \\
\text { (amicus curiae) } \\
\end{array}$ & $\begin{array}{l}\text { Apresentação de } \\
\text { razões de mérito }{ }^{258}- \\
\text { p. } 31\end{array}$ & $\begin{array}{l}\text { VD } \\
\text { Jurídico dogmático. }\end{array}$ \\
\hline \multicolumn{2}{|r|}{$\begin{array}{l}\text { "Dessa forma, a natureza jurídica do conhecido royalties do petróleo é participação da } \\
\text { exploração. Em verdade, os royalties são umas das formas de participação, conforme } \\
\text { estipulado pelo art. } 45 \text { da Lei n. } 9.478 / 97 . ” \text { Logo, a natureza dos royalties não é de } \\
\text { indenização ou compensação, mas sim de participação. }\end{array}$} & $\begin{array}{l}\text { Ordem dos } \\
\text { Advogados do } \\
\text { Brasil - Seccional } \\
\text { de Minas Gerais } \\
\text { (OAB/MG). } \\
\text { Amicus curiae } \\
\end{array}$ & $\begin{array}{l}\text { Petição apresentada }{ }^{259} \\
- \text { p. } 11 .\end{array}$ & $\begin{array}{l}\text { VD } \\
\text { Jurídico dogmático. }\end{array}$ \\
\hline A2 & \multicolumn{3}{|c|}{$\begin{array}{l}\text { A nova sistemática continua distribuindo fatia maior dos recursos para os entes produtores e confrontantes e não } \\
\text { implicará queda substancial em suas receitas }\end{array}$} & $\begin{array}{l}\text { O } \\
\text { Econômico e jurídico } \\
\text { (não dogmático) }\end{array}$ \\
\hline $\begin{array}{l}\text { "Nãc } \\
\text { Estac } \\
\text { da pr } \\
\text { de at } \\
\text { Lei } 1 \\
\text { Com } \\
\text { surp } \\
\text { nos }\end{array}$ & $\begin{array}{l}\text { obstante a redução do percentual dos royalties e das participações especiais devidos aos } \\
\text { los e Municípios confrontantes e afetados, deve-se ter presente que a certeza de incremento } \\
\text { odução de petróleo acarretará compensação. Nesses termos, merece destaque a estimativa } \\
\text { recadação dos Estados confrontantes, em bilhões de reais, adotando-se os percentuais da } \\
\text { o } 12.734 / 2012 \text {, conforme informações da ANP (...). } \\
\text { se nota, a incidência imediata das inovações trazidas pela Lei } \mathrm{n}^{\circ} 12.734 / 2012 \text { não } \\
\text { eenderá bruscamente os entes produtores/confrontantes, eis que, a par da redução gradativa } \\
\text { percentuais dos royalties devidos aos Estados e Municípios confrontantes ou afetados, }\end{array}$ & $\begin{array}{l}\text { Advocacia Geral da } \\
\text { União (AGU). }\end{array}$ & $\begin{array}{l}\text { Informações } \\
\text { prestadas }^{260}-\text { p. } 41- \\
42 .\end{array}$ & $\begin{array}{l}\text { O } \\
\text { Econômico e jurídico (não } \\
\text { dogmático). }\end{array}$ \\
\hline
\end{tabular}

${ }^{257}$ Os fundamentos foram sintetizados, a fim de facilitar a sua compreensão. No entanto, por serem apresentados de diversas formas, entendeu-se relevante trazer exemplos de sua utilização. A classificação em negrito considera todas as categorias envolvidas nos exemplos.

${ }^{258}$ Razões de mérito apresentadas pela Confederação Nacional dos Municípios, p. 4. Disponível em: <http://redir.stf.jus.br/paginadorpub/paginador.jsp?docTP=TP\&docID= $3582768 \& \mathrm{ad}=\mathrm{s} \# 48 \% 20-\% 20 \mathrm{Pedido} \% 20 \mathrm{de} \% 20$ ingresso $\% 20$ como $\% 20$ amicus $\% 20$ curiae $\% 20-\% 20 \mathrm{Pedido} \% 20 \mathrm{de} \% 20 \mathrm{ingresso} \% 20$ como $\% 20$ amicus $\% 20$ curiae $\% 201>$. Acesso em: 3 mar. 2015.

259 Petição apresentada pela OAB-MG. Disponível em: <http://redir.stf.jus.br/paginadorpub/paginador.jsp?docTP=TP\&docID=6597076\&ad=s\#197\%20$\% 20$ Pedido $\% 20$ de $\% 20$ ingresso $\% 20$ como \%20amicus \%20curiae\%20-\%20Pedido\%20de\%20ingresso\%20como\%20amicus\%20curiae $\% 201>$. Acesso em: 3 mar. 2015.

${ }^{260}$ Informações prestadas pela AGU. Disponível em: <http://redir.stf.jus.br/paginadorpub/paginador.jsp?docTP=TP\&docID=5101334\&ad=s\#157\%20-\%20Presta\%E7\%E3o\% 20de\%20informa\% E7\% F5es \%20-\%20Presta\%E7\%E3o\%20de\%20informa\% E7\%F5es\%201>. Acesso em: 3 mar. 2015. 


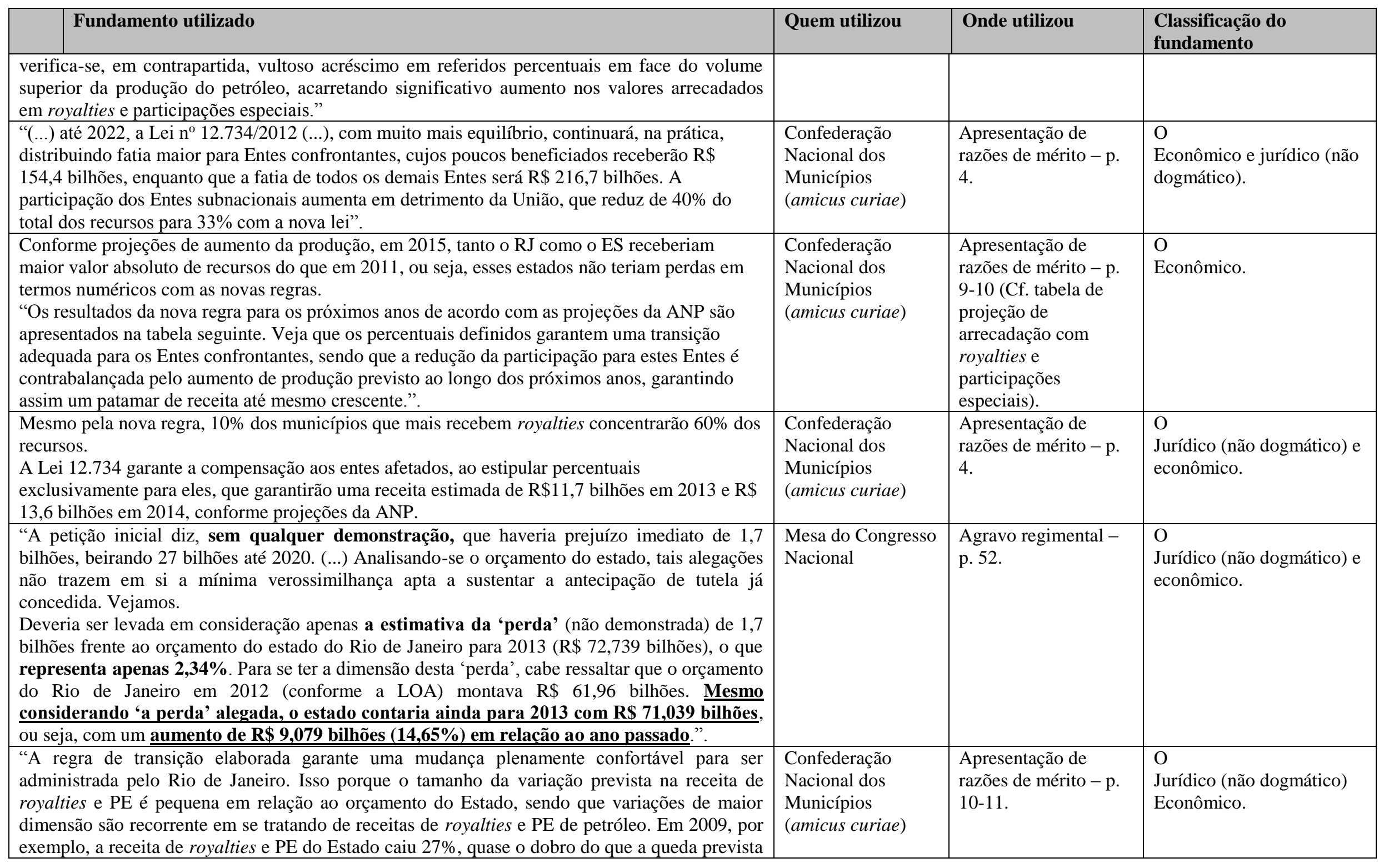




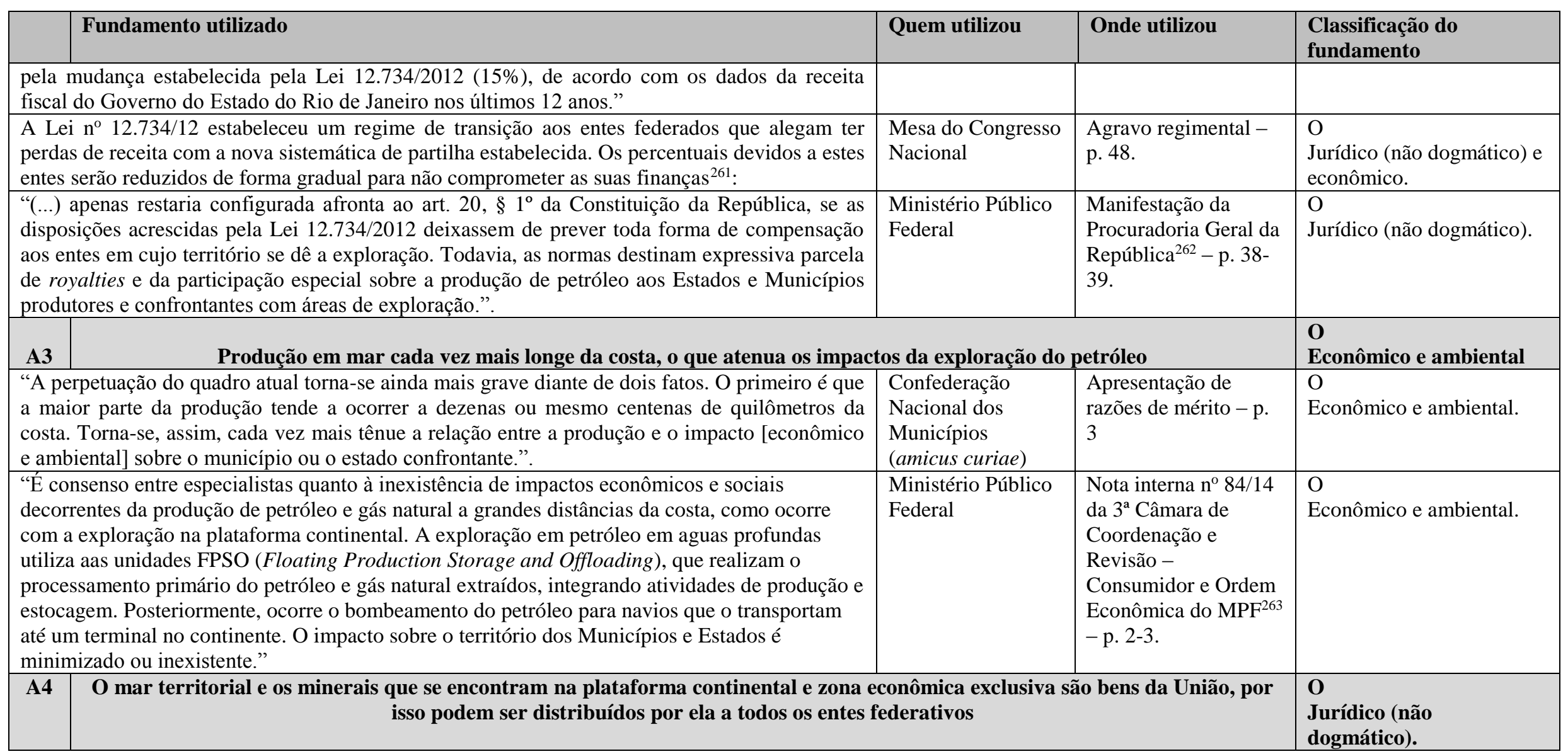

${ }^{261}$ Agravo Regimental interposto pela Mesa do Congresso Nacional, p. 48. Disponível em: <http://redir.stf.jus.br/paginadorpub/paginador.jsp?docTP=TP\&docID= 3562121\&ad=s\#2\%20-\%20Peti\%E7\%E3o\%20de\%20Interposi\%E7\%E3o\%20de\%20Agravo\%20Regimental\%20-\%20Peti\%E7\%E3o\%20de\%20Interposi\%E7\%E3o\%20 de\%20Agravo\%20Regimental\%201>. Acesso em 3 mar. 2015.

${ }^{262}$ Manifestação da Procuradoria Geral da República. Disponível em: <http://redir.stf.jus.br/paginadorpub/paginador.jsp?docTP=TP\&docID=295725189\&ad=s\#184\%20\%20Peti\%E7\%E3o\%20-\%2022657/2014>. Acesso em 3 mar. 2015.

${ }^{263}$ Nota interna $\mathrm{n}^{\mathrm{o}}$ 84/14 da $3^{\mathrm{a}}$ Câmara de Coordenação e Revisão - Consumidor e Ordem Econômica do Ministério Público Federal (MPF). Disponível em: <http://redir.stf.jus.br/paginadorpub/paginador.jsp?docTP=TP\&docID=299403256\&ad=s\#191\%20-\%20Peti\%E7\%E3o\%20-\%2024486/2014>. Acesso em: 3 mar. 2015. 


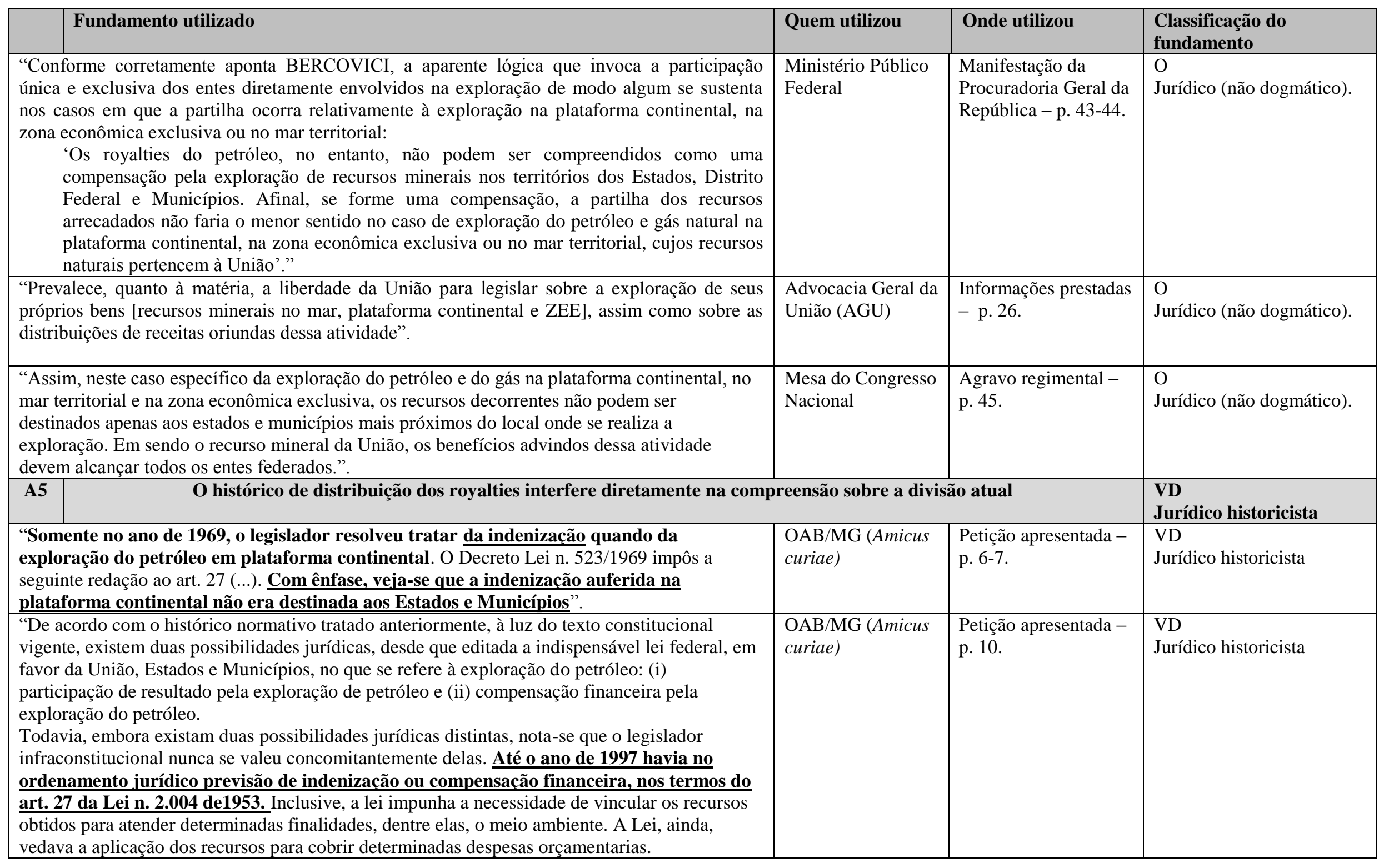




\begin{tabular}{|c|c|c|c|c|}
\hline & Fundamento utilizado & Quem utilizou & Onde utilizou & $\begin{array}{l}\text { Classificação do } \\
\text { fundamento }\end{array}$ \\
\hline \multicolumn{5}{|c|}{$\begin{array}{l}\text { Após 1997, a Lei n. 9.478/97 passou a tratar de participações pela exploração. Os royalties } \\
\text { passaram a ser uma das formas de participações.” }\end{array}$} \\
\hline \multicolumn{2}{|r|}{$\begin{array}{l}\text { "A distribuição de recursos estatais angariados com a exploração de petróleo e gás natural aos } \\
\text { demais entes da Federação não constitui inovação das normas impugnadas. De feito, segundo se } \\
\text { depreende do artigo } 27 \text {, } 4^{\circ} \text {, da Lei n }{ }^{\circ} 2.004 / 53 \text {, na redação conferida pela Lei n }{ }^{\circ} 7.453 / 85 \text {, } \\
\text { mesmo antes da promulgação da Constituição Federal de } 1988 \text {, parcela das participações } \\
\text { governamentais era destinada à constituição de um fundo especial a ser distribuído entre todos } \\
\text { os Estados, Territórios e Municípios". }\end{array}$} & $\begin{array}{l}\text { Advocacia Geral da } \\
\text { União (AGU) }\end{array}$ & $\begin{array}{l}\text { Informações prestadas } \\
- \text { p. } 27 \text {. }\end{array}$ & $\begin{array}{l}\text { VD } \\
\text { Jurídico historicista }\end{array}$ \\
\hline \multicolumn{2}{|r|}{$\begin{array}{l}\text { A compensação dos danos só é cabível aos estados e municípios que o comprovarem, pois a) os } \\
\text { royalties têm natureza de participação nos resultados da exploração e b) o petróleo é extraído do } \\
\text { mar, que é bem da União. Assim, cabe à União indenizar os prejuízos concretamente apurados. }\end{array}$} & $\begin{array}{l}\text { Confederação } \\
\text { Nacional dos } \\
\text { Municípios } \\
\text { (amicus curiae) }\end{array}$ & $\begin{array}{l}\text { Apresentação de } \\
\text { razões de mérito }- \text { p. } \\
27,30,31\end{array}$ & $\begin{array}{l}\text { O } \\
\text { Jurídico (não dogmático). }\end{array}$ \\
\hline \multicolumn{2}{|r|}{$\begin{array}{l}\text { "Para tanto, o pagamento de indenização ou compensação deveria ser precedido de prévio } \\
\text { estudo demonstrando de forma justificada os prejuízos experimentados e, aí sim, sustentar } \\
\text { contrapartida financeira diferenciada entre os Estados federados, a depender do impacto que a } \\
\text { atividade exploratória representa para cada um." }\end{array}$} & $\begin{array}{l}\text { OAB/MG (Amicus } \\
\text { curiae) }\end{array}$ & $\begin{array}{l}\text { Petição apresentada - } \\
\text { p. } 11 .\end{array}$ & $\begin{array}{l}\text { O } \\
\text { Jurídico (não dogmático). }\end{array}$ \\
\hline \multicolumn{2}{|r|}{$\begin{array}{l}\text { "As alterações da Lei } 12.734 / 2012 \text { repousam na expectativas de grandes incrementos de } \\
\text { produção, consoante dados oficiais que indicam salto dos números atuais, estabilizados em } \\
2010 \text {,em dois milhões de barris/dia, para algo em torno de } 5,8 \text { milhões de barris/dia, até } 2020 \text {. } \\
\text { (...) } \\
\text { As bases objetivas sob as quais royalties e participações especiais eram repassados aos Estados } \\
\text { confrontantes sofreram importante alteração, circunstância em que o direito admite revisão de } \\
\text { obrigações firmadas no passado sem apelo a violação de legítimas expectativas. Ao contrário, }\end{array}$} & $\begin{array}{l}\text { Ministério Público } \\
\text { Federal }\end{array}$ & $\begin{array}{l}\text { Manifestação da } \\
\text { Procuradoria Geral da } \\
\text { República - p. 52-53. }\end{array}$ & $\begin{array}{l}\text { O } \\
\text { Econômico e Jurídico (não } \\
\text { dogmático). }\end{array}$ \\
\hline
\end{tabular}




\begin{tabular}{|c|c|c|c|c|}
\hline & Fundamento utilizado & Quem utilizou & Onde utilizou & $\begin{array}{l}\text { Classificação do } \\
\text { fundamento }\end{array}$ \\
\hline \multicolumn{5}{|c|}{$\begin{array}{l}\text { não parece razoável admitir que Estados confrontantes mantenham os padrões de ganhos } \\
\text { intensos com essas parcelas". }\end{array}$} \\
\hline \multicolumn{2}{|r|}{$\begin{array}{l}\text { "Especificamente em relação à região do pré-sal, estima a Petrobrás que a marca de um milhão } \\
\text { de barris de petróleo por dia será superada em } 2017 \text { e atingirá 2,1 milhões de barris em 2020.”. }\end{array}$} & $\begin{array}{l}\text { Advocacia Geral da } \\
\text { União (AGU) }\end{array}$ & $\begin{array}{l}\text { Informações prestadas } \\
\text { - p. } 21 \text {. }\end{array}$ & $\begin{array}{l}\text { O } \\
\text { Econômico. }\end{array}$ \\
\hline \multicolumn{2}{|r|}{$\begin{array}{l}\text { "Não se poderia vislumbrar em } 1988 \text { que as reservas brasileiras provadas de petróleo e a } \\
\text { produção fossem crescer da forma verificada nos últimos vinte anos, e muito menos que o } \\
\text { preço do barril do petróleo aumentaria significativamente na última década. } \\
\text { (...) a finalidade do art. } 20, \S 1^{\circ} \text {, da Constituição foi a de permitir ao Congresso Nacional } \\
\text { assegurar o equilíbrio federativo mediante a concepção de um instrumento adaptável no tempo, } \\
\text { ou seja, mediante a possibilidade de alteração dos critérios e percentuais de distribuição dos } \\
\text { royalties e das participações especiais oriundos da exploração do petróleo e do gás natural, na } \\
\text { medida em que modificadas as circunstâncias fáticas e econômicas." }\end{array}$} & $\begin{array}{l}\text { Mesa do Congresso } \\
\text { Nacional }\end{array}$ & $\begin{array}{l}\text { Agravo regimental - } \\
\text { p. } 32 .\end{array}$ & $\begin{array}{l}\text { O } \\
\text { Econômico e Jurídico (não } \\
\text { dogmático). }\end{array}$ \\
\hline \multicolumn{2}{|r|}{$\begin{array}{l}\text { "Com a descoberta de reservas de petróleo e gás natural nos campos de pré-sal a partir de } 2006 \text {, } \\
\text { acentuou-se ainda mais a necessidade de se estabelecer um novo marco regulatório da matéria. } \\
\text { A realidade da exploracão de petróleo no Brasil modificou-se substancialmente nas } \\
\text { últimas seis décadas, mas o critério de distribuicãa de royalties não acompanhou tal } \\
\text { evolucão.o." }\end{array}$} & $\begin{array}{l}\text { Mesa do Congresso } \\
\text { Nacional }\end{array}$ & $\begin{array}{l}\text { Agravo regimental - } \\
\text { p. } 19 .\end{array}$ & $\begin{array}{l}\text { O } \\
\text { Econômico e jurídico (não } \\
\text { dogmático). }\end{array}$ \\
\hline \multicolumn{2}{|r|}{$\begin{array}{l}\text { As bases objetivas sob as quais os royalties e participações especiais eram repassados aos } \\
\text { estados confrontantes sofreram importante alteração, circunstância em que o direito admite } \\
\text { revisão de obrigações firmadas no passado", sem que haja quebra de legítimas expectativas. }\end{array}$} & $\begin{array}{l}\text { Ministério Público } \\
\text { Federal }\end{array}$ & $\begin{array}{l}\text { Manifestação da } \\
\text { Procuradoria Geral da } \\
\text { República - p. } 52 .\end{array}$ & $\begin{array}{l}\text { O } \\
\text { Jurídico (não dogmático). }\end{array}$ \\
\hline \multicolumn{2}{|r|}{$\begin{array}{l}\text { "Constata-se ser essencial, para a interpretação constitucional subjacente à controvérsia } \\
\text { instaurada, a verificação de dados e fatos concretos de todos os envolvidos. (...) é essencial, para } \\
\text { o debate constitucional objeto da presente ADI, o acesso aos dados da realidade social." }\end{array}$} & $\begin{array}{l}\text { OMPETRO } \\
\text { (amicus curiae) }\end{array}$ & $\begin{array}{l}\text { Petição de habilitação } \\
\text { como amicus curiae - } \\
\text { p. } 9\end{array}$ & $\begin{array}{l}\text { O } \\
\text { Jurídico (não dogmático) e } \\
\text { econômico }\end{array}$ \\
\hline $\mathbf{A 8}$ & \multicolumn{3}{|c|}{ As novas regras de partilha devem ser aplicada aos contratos em curso, caso contrário não haveria redistribuição efetiva } & $\begin{array}{l}\text { O } \\
\text { Jurídico (não dogmático) } \\
\text { e econômico. }\end{array}$ \\
\hline \multicolumn{2}{|r|}{$\begin{array}{l}\text { "As regras têm de ser alteradas para campos já licitados e em produção. Se as novas regras } \\
\text { somente forem aplicadas para campos ainda a serem licitados, quase a totalidade dos recursos }\end{array}$} & $\begin{array}{l}\text { Confederação } \\
\text { Nacional dos }\end{array}$ & $\begin{array}{l}\text { Apresentação de } \\
\text { razões de mérito }- \text { p. }\end{array}$ & $\begin{array}{l}\text { O } \\
\text { Jurídico (não dogmático) e }\end{array}$ \\
\hline
\end{tabular}




\section{Fundamento utilizado}

que serão distribuídos na próxima década continuaria com a concentração absurda estabelecida pela legislação atual, já que a receita de novos campos demorará esse tempo para gerar royalties. De acordo com Plano Decenal de Energia (PDE) 2020, elaborado pela Empresa de Pesquisa Energética (EPE), do Ministério de Minas e Energia, até 2020, da produção prevista de 6 milhões de barris/dia, 5,7 milhões de barris/dia serão provenientes de campos concedidos.".

A9 A hiperconcentração de recursos decorrente da aplicação das regras de distribuição da Lei n ${ }^{\circ}$ 9.478/97 não contribui para 0 desenvolvimento nacional

"No entanto, de acordo com a sistemática normativa pretérita, cerca de $60 \%$ das receitas de royalties e participações especiais de petróleo eram preponderantemente distribuídos aos Estados e Municípios com base no critério de confrontação, o que denota a forte concentração dessas rendas em poucos entes federados. (...)

Assim, de acordo com a Agência Nacional do Petróleo, apenas o Estado do Rio de Janeiro teria recebido, a título de royalties e participações especiais, no ano de $\mathbf{2 0 1 1}$, cerca de R\$ 7 bilhões. Tal informação é confirmada pelo próprio requerente, no item 32 da fl. 35 da petição inicial. Mencionados valores representam, aproximadamente, $17 \%$ dos royalties e participações especiais distribuídos apenas naquele ano, desconsiderados, ainda, os valores recebidos individualmente pelos Municípios do referido ente, pela condição de confrontantes.

Ademais, de acordo com os dados fornecidos pela ANP relativamente ao ano de 2011, a distribuição de royalties e participações especiais, nos termos do regime anterior, contemplava não mais do que 10 Estados da Federação, dentre os quais São Paulo e Rio de Janeiro, economicamente mais estruturados que os demais 24 Estados e o Distrito Federal."

"Segundo a Agência Nacional do Petróleo, o Estado do Rio de Janeiro, em 1994 recebeu

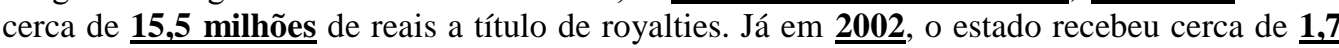
bilhões de reais a título de royalties e participação especial e em 2011 este montante alcançou a astronômica cifra de mais de 7 bilhões de reais!"

"O modelo vigente desde a Lei $\mathrm{n}^{\circ}$ 9.478/97 trouxe, ao longo dos anos, um forte desequilíbrio federativo, evidenciado na comparação entre os pagamentos de participação especial sobre a produção de petróleo e gás natural aos municípios brasileiros".

O sobrefinanciamento de poucos estados e municípios não tem contribuído para o seu desenvolvimento, devido à incapacidade das administrações para gerenciar a aplicação de vultosos recursos. Esse é o caso da cidade de Campos que possui um dos mais baixos indicadores de nível educacional avaliado pelo Ideb. Pesquisa constatou que "o aumento das receitas provenientes dos royalties não provocou melhorias nos serviços prestados à população dos municípios beneficiados" e na qualidade de vida das populações, ou seja, não houve

\begin{tabular}{|c|c|c|}
\hline Quem utilizou & Onde utilizou & $\begin{array}{l}\text { Classificação do } \\
\text { fundamento }\end{array}$ \\
\hline $\begin{array}{l}\text { Municípios } \\
\text { (amicus curiae) }\end{array}$ & 8. & Econômico. \\
\hline \multicolumn{2}{|c|}{ o da Lei ${ }^{\circ}$ 9.478/97 não contribui para 0} & $\begin{array}{l}\text { O } \\
\text { Jurídico (não } \\
\text { dogmático), econômico e } \\
\text { federativo. }\end{array}$ \\
\hline $\begin{array}{l}\text { Advocacia Geral da } \\
\text { União (AGU) }\end{array}$ & $\begin{array}{l}\text { Informações prestadas } \\
- \text { p. } 21-22 \text {. }\end{array}$ & $\begin{array}{l}\text { O } \\
\text { Jurídico (não dogmático) e } \\
\text { econômico. }\end{array}$ \\
\hline $\begin{array}{l}\text { Mesa do Congresso } \\
\text { Nacional }\end{array}$ & $\begin{array}{l}\text { Agravo regimental - } \\
\text { p. } 20\end{array}$ & $\begin{array}{l}\mathrm{O} \\
\text { Econômico. }\end{array}$ \\
\hline $\begin{array}{l}\text { Mesa do Congresso } \\
\text { Nacional }\end{array}$ & $\begin{array}{l}\text { Agravo regimental - } \\
\text { p. } 42\end{array}$ & $\begin{array}{l}\text { O } \\
\text { Jurídico (não dogmático) e } \\
\text { federativo. }\end{array}$ \\
\hline $\begin{array}{l}\text { Ministério Público } \\
\text { Federal }\end{array}$ & $\begin{array}{l}\text { Nota interna } \mathrm{n}^{\circ} 84 / 14 \\
\text { da } 3^{\mathrm{a}} \text { Câmara de } \\
\text { Coordenação e } \\
\text { Revisão - } \\
\text { Consumidor e Ordem } \\
\text { Econômica do MPF - }\end{array}$ & $\begin{array}{l}\text { O } \\
\text { Econômico. }\end{array}$ \\
\hline
\end{tabular}




\begin{tabular}{|c|c|c|c|c|}
\hline & Fundamento utilizado & Quem utilizou & Onde utilizou & $\begin{array}{l}\text { Classificação do } \\
\text { fundamento }\end{array}$ \\
\hline \multicolumn{2}{|c|}{ promoção da justiça intergeracional. } & & p. 3 e 5 . & \\
\hline \multicolumn{2}{|r|}{$\begin{array}{l}\text { Estados e municípios produtores, juntamente com a União, concentram } 97 \% \text { dos recursos } \\
\text { distribuídos. Dois estados (ES e RJ) e } 30 \text { municípios concentram } 83 \% \text { dos recursos. } \\
\text { Considerando a sistemática de distribuição vigente os entes confrontantes receberão R } \$ 306 \\
\text { bilhões, enquanto o restante do país receberá R } \$ 24,5 \text { bilhões. } \\
\text { "Na regra atual apenas os } 0,36 \% \text { dos municípios brasileiros que mais recebem recursos } \\
\text { concentram } 60 \% \text { das receitas distribuídas". } \\
\text { Em } 2012,11 \text { municípios receberam } 50 \% \text { dos royalties e participações especiais destinadas a } \\
\text { todos os municípios. O Município de Campos/RJ, por exemplo, recebeu 17,6\%, que significou } \\
\mathrm{R} \$ 705 \text { milhões. }\end{array}$} & $\begin{array}{l}\text { Confederação } \\
\text { Nacional dos } \\
\text { Municípios } \\
\text { (amicus curiae) }\end{array}$ & $\begin{array}{l}\text { Apresentação de } \\
\text { razões de mérito - p. } \\
3,4,5,18\end{array}$ & $\begin{array}{l}\mathrm{O} \\
\text { Econômico e federativo. }\end{array}$ \\
\hline \multicolumn{2}{|r|}{$\begin{array}{l}\text { Impede-se a fruição ampla de direitos fundamentais no país, já que a distribuição anterior } \\
\text { restringe o capital de desenvolvimento a apenas parte dos entes federados (como Rio de Janeiro } \\
\text { e Espírito Santo). }\end{array}$} & $\begin{array}{l}\text { Confederação } \\
\text { Nacional dos } \\
\text { Municípios } \\
\text { (amicus curiae) }\end{array}$ & $\begin{array}{l}\text { Apresentação de } \\
\text { razões de mérito - p. } \\
3,4,5,18\end{array}$ & $\begin{array}{l}\text { O } \\
\text { Econômico e federativo. }\end{array}$ \\
\hline A10 & \multicolumn{3}{|c|}{ O estabelecimento de critérios de distribuição dos royalties é competência do Poder Legislativo } & $\begin{array}{l}\text { O } \\
\text { Jurídico (não } \\
\text { dogmático). }\end{array}$ \\
\hline \multicolumn{2}{|r|}{$\begin{array}{l}\text { O Congresso Nacional já aprovou por cinco vezes novas regras de distribuição: Emenda Ibsen } \\
\text { ao PLC no }{ }^{\circ} 16 / 10 \text {, Emenda Pedro Simon ao PLC } 7 / 10 \text {, aprovação no Senado e na Câmara da Lei } \\
\text { n }^{\circ} 12.734 / 12 \text { e derrubada do veto da Presidente a essa lei, o que demonstra a vontade de } \\
\text { mudança das regras pelo povo brasileiro. }\end{array}$} & $\begin{array}{l}\text { Confederação } \\
\text { Nacional dos } \\
\text { Municípios } \\
\text { (amicus curiae) }\end{array}$ & $\begin{array}{l}\text { Apresentação de } \\
\text { razões de mérito - p. } \\
6-7\end{array}$ & $\begin{array}{l}\text { O } \\
\text { Não classificável. }\end{array}$ \\
\hline \multicolumn{2}{|r|}{$\begin{array}{l}\text { A natureza da decisão acerca da partilha dos royalties é política, competindo ao Parlamento que } \\
\text { se revela "o espaço mais amplo e pluralizado para essa prática discursiva". O Congresso } \\
\text { Nacional "representa a vontade popular em ação - articulando, desarticulando, construindo, } \\
\text { demolindo e reconstruindo - a vivência sociopolítica e espelhando, da melhor maneira até hoje } \\
\text { alcançável, o querer dos cidadãos. } \\
\text { Assim é que se sustenta que os Tribunais Constitucionais têm, como função, não introduzir } \\
\text { novas dificuldades no sistema político-constitucional, econômico e social, mas sim o de afastar } \\
\text { os porventura existentes. A justiça constitucional, para estes autores, deve sempre facilitar, não } \\
\text { obstaculizar } \\
\text { Portanto, espera-se do exegeta jurídico que opte pelas alternativas de julgamento que } \\
\text { preservem e afiancem o sistema político fixado no pacto político nacional e que, ademais, ao } \\
\text { agir, sopese, sempre, as consequências políticas de suas sentenças, tendo em vista a precisa }\end{array}$} & $\begin{array}{l}\text { Mesa do Congresso } \\
\text { Nacional }\end{array}$ & $\begin{array}{l}\text { Agravo regimental - } \\
\text { p. } 13,17-18 .\end{array}$ & $\begin{array}{l}\text { O } \\
\text { Jurídico (não dogmático). }\end{array}$ \\
\hline
\end{tabular}




\begin{tabular}{|c|c|c|c|c|}
\hline & Fundamento utilizado & Quem utilizou & Onde utilizou & $\begin{array}{l}\text { Classificação do } \\
\text { fundamento }\end{array}$ \\
\hline \multicolumn{5}{|c|}{$\begin{array}{l}\text { distribuição das forças políticas parlamentares, suas necessidades e interesses, aos quais o Poder } \\
\text { Judiciário não pode pretender substituir.”. }\end{array}$} \\
\hline \multicolumn{2}{|r|}{$\begin{array}{l}\text { "Em verdade, a edição dos dispositivos impugnados decorre de válida opção político-legislativa } \\
\text { exercida pelo Congresso Nacional, que decidiu adotar critérios mais equânimes de repartição de } \\
\text { recursos, buscando, como já anotado, conferir efetividade aos objetivos fundamentais } \\
\text { contemplados nos incisos II, III e IV do artigo } 3^{\circ} \text { da Constituição, quais sejam: garantir o } \\
\text { desenvolvimento nacional; reduzir as desigualdades regionais; e promover o bem de todos.". }\end{array}$} & $\begin{array}{l}\text { Advocacia Geral da } \\
\text { União (AGU) }\end{array}$ & Manifestação - p. 29. & $\begin{array}{l}\text { O } \\
\text { Jurídico (não dogmático). }\end{array}$ \\
\hline A11 & \multicolumn{3}{|c|}{ A redistribuição de royalties e PE beneficia maior quantidade de entes federativos } & $\begin{array}{l}\text { O } \\
\text { Econômico. }\end{array}$ \\
\hline A12 & \multicolumn{3}{|c|}{ As novas regras de distribuição observam o princípio da proporcionalidade } & $\begin{array}{l}\text { Neo } \\
\text { (fundamentação em } \\
\text { princípio abstrato). }\end{array}$ \\
\hline \multicolumn{2}{|r|}{$\begin{array}{l}\text { "E, sob este fundamento, não resistem razões capazes de justificar uma parcela maior para os } \\
\text { Estados e Municípios produtores exclusivamente porque o são, já que em relação a esta parte } \\
\text { dos recursos, todos os Estados devem ser tratados com igualdade, segundo uma aplicação } \\
\text { adequada do princípio da proporcionalidade. } \\
\text { Sabe-se que através do princípio da proporcionalidade, visa-se avaliar a correlação entre os fins } \\
\text { visados e meios empregados nos atos do Poder Público. Não serve para aferir a legitimidade de } \\
\text { todo e qualquer ato ou decisão do Estado, mas somente aqueles em que haja uma relação de } \\
\text { causalidade entre meio e fim. Estruturalmente, é dividido em três subprincípios: adequação, } \\
\text { necessidade e proporcionalidade em sentido estrito.". }\end{array}$} & $\begin{array}{l}\text { Mesa do Congresso } \\
\text { Nacional }\end{array}$ & $\begin{array}{l}\text { Agravo regimental - } \\
\text { p. } 28 .\end{array}$ & $\begin{array}{l}\text { Neo } \\
\text { (fundamentação em } \\
\text { princípio abstrato). }\end{array}$ \\
\hline \multicolumn{2}{|r|}{$\begin{array}{l}\text { "A visão adotada como base da interpretação do caso concreto pode ser centralizada em uma } \\
\text { ideia de proporcionalidade, objetivando alcançar um resultado equilibrado, a fim de impedir a } \\
\text { ofensa aos parâmetros básicos do princípio em análise, ou seja, o que se deseja é evitar a lesão } \\
\text { às linhas de proibição do excesso e de proteção deficiente". }\end{array}$} & $\begin{array}{l}\text { Confederação } \\
\text { Nacional dos } \\
\text { Municípios } \\
\text { (amicus curiae) }\end{array}$ & $\begin{array}{l}\text { Apresentação de } \\
\text { razões de mérito }-\mathrm{p} \text {. } \\
18 .\end{array}$ & $\begin{array}{l}\text { Neo } \\
\text { (fundamentação em } \\
\text { princípio abstrato). }\end{array}$ \\
\hline A13 & \multicolumn{3}{|c|}{ A redistribuição de recursos respeita o pacto federativo - federalismo cooperativo } & $\begin{array}{l}\text { O } \\
\text { Federativo. }\end{array}$ \\
\hline \multicolumn{2}{|r|}{$\begin{array}{l}\text { A distribuição prevista anteriormente implica "descumprimento do pacto federativo, a partir de } \\
\text { uma lógica de solidariedade, visto que 'em consequência das desigualdades existentes, } \\
\text { reconhece-se e garante a solidariedade de todos os componentes que integram o Estado" ". }\end{array}$} & $\begin{array}{l}\text { Confederação } \\
\text { Nacional dos } \\
\text { Municípios } \\
\text { (amicus curiae) }\end{array}$ & $\begin{array}{l}\text { Apresentação de } \\
\text { razões de mérito }- \text { p. } \\
20 .\end{array}$ & $\begin{array}{l}\text { O } \\
\text { Federativo. }\end{array}$ \\
\hline
\end{tabular}




\section{Fundamento utilizado}

Não há ofensa ao equilíbrio federativo, que se ampara tanto na autonomia dos entes como na interdependência entre eles. “A cooperação entre União, Estados, Distrito Federal e Municípios deve dar-se em prol da redução das desigualdades, tanto no aspecto formal quanto no econômico. Maior distribuição de recursos financeiros é vital para a própria configuração federalista, sendo a equiparação de condições materiais passo fundamental para a real autonomia de cada célula da Federação.".

De acordo com o federalismo cooperativo, as leis e processos legislativos dos diversos entes federados devem se complementar, em prol da comunidade federativa global. Deve haver solidariedade e união de esforços em prol da coletividade.

"Por idêntica razão, não há que se falar em ofensa ao princípio federativo, até mesmo porque as normas hostilizadas asseguram o direito dos Estados e Municípios produtores às participações governamentais em quinhão maior do que aquele reservado, individualmente, aos entes federados não produtores, reconhecendo a peculiar situação que os distinguem [sic]."

"É certo que a participação total dos estados e municípios confrontantes será menor no novo marco regulatório. Esse fato, contudo, não é suficiente por si só para determinar qualquer vício de constitucionalidade da nova regra, ainda mais tendo em conta que a nova sistemática adotada propicia uma redistribuição de renda pautada em critérios que retratem a realidade socioeconômica dos destinatários das transferências dotando 'o federalismo cooperativo brasileiro de mais um instrumento apto a promover o desenvolvimento equilibrado e harmônico do país'."

"Tratava-se, portanto, de distribuição altamente assimétrica que olvidava e violava a forma de Estado adotado pela Constituição da República, qual seja o Federalismo cooperativo. Este princípio fundador de nossa carta permeia toda a estruturação do Estado brasileiro e, por isso, a Constituição estabelece como objetivos fundamentais da República garantir o desenvolvimento nacional e reduzir as desigualdades sociais e regionais (artigo $3^{\circ}$ ). Reforça esse objetivo a previsão de que a redução das desigualdades regionais e sociais é um dos princípios da ordem econômica (art. 170), bem como a disciplina de repasse de recursos da União para os estados (art. 157) e destes para os municípios (158, III e IV) e a criação de diversos fundos de distribuição de receitas entre os entes federados (art. 159, I).".

\section{A14}

(a)

A sistemática de distribuição anterior beneficiava desmedidamente estados e municípios

confrontantes. A Lei $\mathrm{n}^{\circ}$ 12.734/12, ao mudar essa realidade, vai ao encontro "dos objetivos mais

centrais do pacto político, tendentes à construção de sociedade livre, justa e solidária, à garantia

\begin{tabular}{|c|c|c|}
\hline Quem utilizou & Onde utilizou & $\begin{array}{l}\text { Classificação do } \\
\text { fundamento }\end{array}$ \\
\hline $\begin{array}{l}\text { Ministério Público } \\
\text { Federal }\end{array}$ & $\begin{array}{l}\text { Manifestação da } \\
\text { Procuradoria Geral da } \\
\text { República - p. } 47 .\end{array}$ & $\begin{array}{l}\mathrm{O} \\
\text { Federativo.. }\end{array}$ \\
\hline $\begin{array}{l}\text { Confederação } \\
\text { Nacional dos } \\
\text { Municípios } \\
\text { (amicus curiae) }\end{array}$ & $\begin{array}{l}\text { Apresentação de } \\
\text { razões de mérito }-\mathrm{p} \text {. } \\
38 .\end{array}$ & $\begin{array}{l}\mathrm{O} \\
\text { Federativo.. }\end{array}$ \\
\hline $\begin{array}{l}\text { Advocacia Geral da } \\
\text { União (AGU) }\end{array}$ & Manifestação - p. 36. & $\begin{array}{l}\mathrm{O} \\
\text { Federativo. }\end{array}$ \\
\hline $\begin{array}{l}\text { Mesa do Congresso } \\
\text { Nacional }\end{array}$ & $\begin{array}{l}\text { Agravo regimental - } \\
\text { p. } 45 .\end{array}$ & $\begin{array}{l}\text { O } \\
\text { Federativo. }\end{array}$ \\
\hline $\begin{array}{l}\text { Mesa do Congresso } \\
\text { Nacional }\end{array}$ & $\begin{array}{l}\text { Agravo regimental - } \\
\text { p. } 46 .\end{array}$ & $\begin{array}{l}\text { O } \\
\text { Federativo. }\end{array}$ \\
\hline \multicolumn{2}{|c|}{ possibilita o desenvolvimento nacional } & $\begin{array}{l}\text { O } \\
\text { Jurídico (não dogmático) } \\
\text { e federativo. }\end{array}$ \\
\hline $\begin{array}{l}\text { Ministério Público } \\
\text { Federal }\end{array}$ & $\begin{array}{l}\text { Manifestação da } \\
\text { Procuradoria Geral da } \\
\text { República - p. } 43\end{array}$ & $\begin{array}{l}\text { O } \\
\text { Jurídico (não dogmático) e } \\
\text { federativo. }\end{array}$ \\
\hline
\end{tabular}




\begin{tabular}{|c|c|c|c|c|}
\hline & Fundamento utilizado & Quem utilizou & Onde utilizou & $\begin{array}{l}\text { Classificação do } \\
\text { fundamento }\end{array}$ \\
\hline \multicolumn{5}{|c|}{$\begin{array}{l}\text { do desenvolvimento nacional, à erradicação da pobreza e da marginalização, à redução das } \\
\text { desigualdades sociais e regionais }\left(\mathrm{CR} \text {, art. } 3^{\circ}\right) . ”\end{array}$} \\
\hline \multicolumn{2}{|r|}{$\begin{array}{l}\text { “A destinação desses bens à União -e não ao Estado ou Município em que estão situados - } \\
\text { harmoniza-se com os objetivos traçados no artigo } 3^{\circ} \text { da Lei Maior, propiciando que tais } \\
\text { recursos contribuam para o desenvolvimento de toda a nação, para a erradicação das diferenças } \\
\text { regionais e para a promoção do bem de todos, sem qualquer tipo de discriminação (artigo } 3^{\circ} \text {, } \\
\text { incisos II, III e IV, da Carta).”. }\end{array}$} & $\begin{array}{l}\text { Advocacia Geral da } \\
\text { União (AGU) }\end{array}$ & $\begin{array}{l}\text { Informações prestadas } \\
- \text { p. } 23 \text {. }\end{array}$ & $\begin{array}{l}\text { O } \\
\text { Jurídico (não dogmático) e } \\
\text { federativo. }\end{array}$ \\
\hline \multicolumn{2}{|r|}{$\begin{array}{l}\text { "14. E para superar desequilíbrio e desigualdade foi que, cumprindo o programa do art. } 3^{\circ} \text { da } \\
\text { Constituição Federal, o Parlamento - que é espaço privilegiado para as decisões públicas de } \\
\text { partilha do que é público - deliberou destinar recursos, do patrimônio da União, não somente } \\
\text { aos Estados que tiveram a sorte de situar-se em locais de produção de petróleo mas, também, } \\
\text { para os demais, muitos dos quais bem menos abastados. (..) } \\
\text { 16. Cumpre-se, com ele, uma promessa cuja realização, como impõe o art. } 3^{\circ} \text { da Constituição } \\
\text { Federal, cabe a cada agente constitucional: a erradicação da pobreza e a redução das } \\
\text { desigualdades sociais e regionais.” }\end{array}$} & $\begin{array}{l}\text { Estado da Bahia } \\
\text { (amicus curiae) }\end{array}$ & $\begin{array}{l}\text { Petição apresentada } \\
\text { pelo Estado }{ }^{264} \text {-p. } 4 .\end{array}$ & $\begin{array}{l}\text { O } \\
\text { Jurídico (não dogmático e } \\
\text { federativo. }\end{array}$ \\
\hline \multicolumn{2}{|r|}{$\begin{array}{l}\text { "Ocorre que a participação de todos os Entes da Federação no resultado da exploração de } \\
\text { petróleo e gás é constitucional e propicia a aplicação efetiva da regra contida no texto do art. } 3^{\circ} \text {, } \\
\text { II e III da CF. Logo, consagra os objetivos fundamentais da República Federativa do Brasil, } \\
\text { pois garante o desenvolvimento nacional e a redução das desigualdades regionais.". }\end{array}$} & $\begin{array}{l}\text { Ordem dos } \\
\text { Advogados do } \\
\text { Brasil - Seccional } \\
\text { do Mato Grosso do } \\
\text { Sul (OAB/MS); }\end{array}$ & $\begin{array}{l}\text { Petição apresentada } \\
\text { pela OAB/MS- p. } 4 .\end{array}$ & $\begin{array}{l}\text { O } \\
\text { Jurídico (não dogmático) e } \\
\text { federativo. }\end{array}$ \\
\hline A15 & \multicolumn{3}{|c|}{$\begin{array}{l}\text { A redistribuição das rendas petrolíferas não viola o pacto federativo originário, na medida em que não há relação entre a } \\
\text { sistemática de incidência do ICMS sobre as operações com petróleo, no destino, e a destinação de royalties aos entes produtores }\end{array}$} & $\begin{array}{l}\text { O } \\
\text { Federativo. }\end{array}$ \\
\hline $\begin{array}{l}\text { A tril } \\
\text { Cons }\end{array}$ & $\begin{array}{l}\text { utação do petróleo sempre foi de competência federal e estava nas mãos da União até a } \\
\text { ituição de } 1988 \text { (art. 22, VIII da Constituição de } 1967 \text { e art. 15, III da Constituição de }\end{array}$ & $\begin{array}{l}\text { Confederação } \\
\text { Nacional dos }\end{array}$ & $\begin{array}{l}\text { Apresentação de } \\
\text { razões de mérito - p. }\end{array}$ & $\begin{array}{l}\text { O } \\
\text { Federativo. }\end{array}$ \\
\hline
\end{tabular}

${ }^{264}$ Petição apresentada pelo Estado da Bahia (amicus curiae). Disponível em:

<http://redir.stf.jus.br/paginadorpub/paginador.jsp?docTP=TP\&docID=3793469\&ad=s\#123\%20-

\%20Peti\%E7\%E3o\%20de\%20apresenta\%E7\%E30\%20de\%20manifesta\%E7\%E3o\%20-\%20Peti\%E7\%E3o\%20de\%20apresenta\%E7\%E3o\%20de\%20manifesta\%E7\%E3o $\% 201>$. Acesso em: 3 mar. 2015

265 Memoriais apresentados pelo Estado de Tocantins. Disponível em: http://redir.stf.jus.br/paginadorpub/paginador.jsp?docTP=TP\&docID=3763933\&ad=s\#119\%20\%20Pedido\%20de\%20ingresso\%20como\%20interessado\%20-\%20Pedido\%20de\%20ingresso\%20como\%20interessado\%201>. Acesso em: 3 mar. 2015. 


\begin{tabular}{|c|c|c|c|}
\hline Fundamento utilizado & Quem utilizou & Onde utilizou & $\begin{array}{l}\text { Classificação do } \\
\text { fundamento }\end{array}$ \\
\hline $\begin{array}{l}\text { 1946). Assim, não se discutia perda de arrecadação, porque a matéria não era sujeita ao ICMS. } \\
\text { Anais da Constituinte de } 1988 \text { comprovam a tese. Na fase decisiva (1987-1988), debateu-se a } \\
\text { repartição das receitas de operações com petróleo, por meio do ICMS. Os debates tentavam } \\
\text { evitar uma guerra fiscal por refinarias no regime misto do ICMS, pois a incidência do imposto } \\
\text { na origem poderia gerar conflito entre os estados, pelo simples fato de determinada fonte de } \\
\text { geração ou transformação de energia ter sido localizada aqui ou ali. "O desejo do constituinte } \\
\text { foi o de favorecer a federação por meio da descentralização de recursos, e não privilegiar uma } \\
\text { suposta compensação aos Estados produtores". Dados demonstram que o atual regime tributário } \\
\text { do petróleo, da energia elétrica e das comunicações é descentralizador das receitas e favorece o } \\
\text { combate às desigualdades regionais, pois quanto menos desenvolvido é o estado, mais a receita } \\
\text { estadual depende desses insumos. }\end{array}$ & $\begin{array}{l}\text { Municípios } \\
\text { (amicus curiae) }\end{array}$ & $21-24$ & \\
\hline $\begin{array}{l}\text { "Conforme se expôs, os Estados produtores beneficiam-se do pagamento dos royalties desde a } \\
\text { edição da Lei 2.004/1953. Não foram estes criados pelo constituinte de 1987-1988. O } \\
\text { argumento de que vieram como compensação por perda de receita de ICMS não parece exato. A } \\
\text { exceção criada na sistemática do ICMS é que veio como forma de equilibrar os ganhos, em suas } \\
\text { variadas acepções, decorrentes da exploração do petróleo. Optou-se, na Assembleia Nacional } \\
\text { Constituinte, por retirar parcela do que seriam, a partir dali, os ganhos dos Estados mais } \\
\text { diretamente beneficiados com a exploração. Considerando que, até a Constituição de 1988, o } \\
\text { antigo ICMS era tributo federal, a preocupação era criar exceção à regra geral do ICMS, o qual, } \\
\text { ao invés de beneficiar os Estados já agraciados com os royalties de petróleo, favorecesse os } \\
\text { demais Estados, dando melhor equilíbrio à repartição de rendas decorrentes dessa atividade } \\
\text { econômica.". }\end{array}$ & $\begin{array}{l}\text { Ministério Público } \\
\text { Federal }\end{array}$ & $\begin{array}{l}\text { Manifestação da } \\
\text { Procuradoria Geral da } \\
\text { República - p. 40-41. }\end{array}$ & $\begin{array}{l}\mathrm{O} \\
\text { Federativo. }\end{array}$ \\
\hline
\end{tabular}




\begin{tabular}{|c|c|c|c|c|}
\hline & Fundamento utilizado & Quem utilizou & Onde utilizou & $\begin{array}{l}\text { Classificação do } \\
\text { fundamento }\end{array}$ \\
\hline \multicolumn{2}{|r|}{$\begin{array}{l}\text { "Ainda que se admitisse que a regra constante do artigo } 20, \S 1^{\circ} \text {, da Constituição Federal deva } \\
\text { ser interpretada em conjunto com o artigo } 155, \S 2^{\circ} \text {, inciso X, alínea "b", da Carta, numa } \\
\text { espécie de pacto informal ajustado durante os debates da Assembleia Nacional Constituinte, não } \\
\text { se pode desconsiderar a evolução da produção de petróleo e gás natural no País, após a } \\
\text { promulgação da Carta Política de 1988. A respeito do tema, a Consultoria Legislativa da } \\
\text { Câmara dos Deputados salienta que, comparativamente à época em que foi promulgada a } \\
\text { Constituição da República, a participação dos Estados confrontantes na receita advinda da } \\
\text { exploraça de petróleo aumentou sensivelmente, mesmo com a edição das normas impugnadas, } \\
\text { de modo que não se verifica a ocorrência de quebra do pacto federativo firmado em 1988.". }\end{array}$} & $\begin{array}{l}\text { Advocacia Geral da } \\
\text { União (AGU) }\end{array}$ & $\begin{array}{l}\text { Informações prestadas } \\
- \text { p. } 34 \text {. }\end{array}$ & $\begin{array}{l}\text { O } \\
\text { Federativo. }\end{array}$ \\
\hline A16 & \multicolumn{3}{|c|}{ O princípio da igualdade exige a distribuição equânime de recursos } & $\begin{array}{l}\text { VD } \\
\text { Neo } \\
\text { (fundamentação em } \\
\text { princípio abstrato). }\end{array}$ \\
\hline \multicolumn{2}{|r|}{$\begin{array}{l}\text { "Assim, se o legislador entender que os recursos da União devem ser partilhados - in abstrato } \\
\text { pela simples exploração econômica com Estados e Municípios - e deve ser festejada esta } \\
\text { possibilidade, pois compatível com a subsidiariedade administrativa - tal distribuição deve ser } \\
\text { igualitária, pois entendimento diverso ofenderia o princípio da igualdade.". }\end{array}$} & $\begin{array}{l}\text { Confederação } \\
\text { Nacional dos } \\
\text { Municípios } \\
\text { (amicus curiae) }\end{array}$ & $\begin{array}{l}\text { Apresentação de } \\
\text { razões de mérito - p. } \\
\text { 30-31. }\end{array}$ & $\begin{array}{l}\text { Neo } \\
\text { (fundamentação em } \\
\text { princípio abstrato). }\end{array}$ \\
\hline A18 & \multicolumn{3}{|c|}{ A Lei $\mathbf{n}^{0} \mathbf{1 2 . 7 3 4 / 1 2}$ não viola direito adquirido, ato jurídico perfeito ou a segurança jurídica } & $\begin{array}{l}\text { O } \\
\text { Jurídico (não } \\
\text { dogmático). }\end{array}$ \\
\hline $\begin{array}{l}\text { "Os } \\
\text { repres } \\
\text { empre } \\
\text { das p } \\
\text { espec } \\
\text { Sendo } \\
\text { extrac }\end{array}$ & $\begin{array}{l}\text { contratos de concessão para exploração de petróleo são firmados entre a União, } \\
\text { entada pela Agência Nacional do Petróleo, Gás Natural e Biocombustíveis -ANP, e a } \\
\text { sa vencedora da concorrência. Referidos contratos, que têm por objeto direitos e deveres } \\
\text { artes, não contemplam cláusulas concernentes à distribuição de royalties e participações } \\
\text { lais entre os entes federados, a qual é estabelecida nos termos da legislação federal. (...) } \\
\text { assim, tem-se que os royalties e as participações especiais só serão devidos após a } \\
\text { ão dos recursos minerais pela concessionária, o que já afasta, de plano, a alegação dos }\end{array}$ & $\begin{array}{l}\text { Advocacia Geral da } \\
\text { União (AGU) }\end{array}$ & $\begin{array}{l}\text { Informações prestadas } \\
- \text { p. } 37-38 \text {. }\end{array}$ & $\begin{array}{l}\text { O Jurídico (não dogmático). } \\
\text {. }\end{array}$ \\
\hline
\end{tabular}




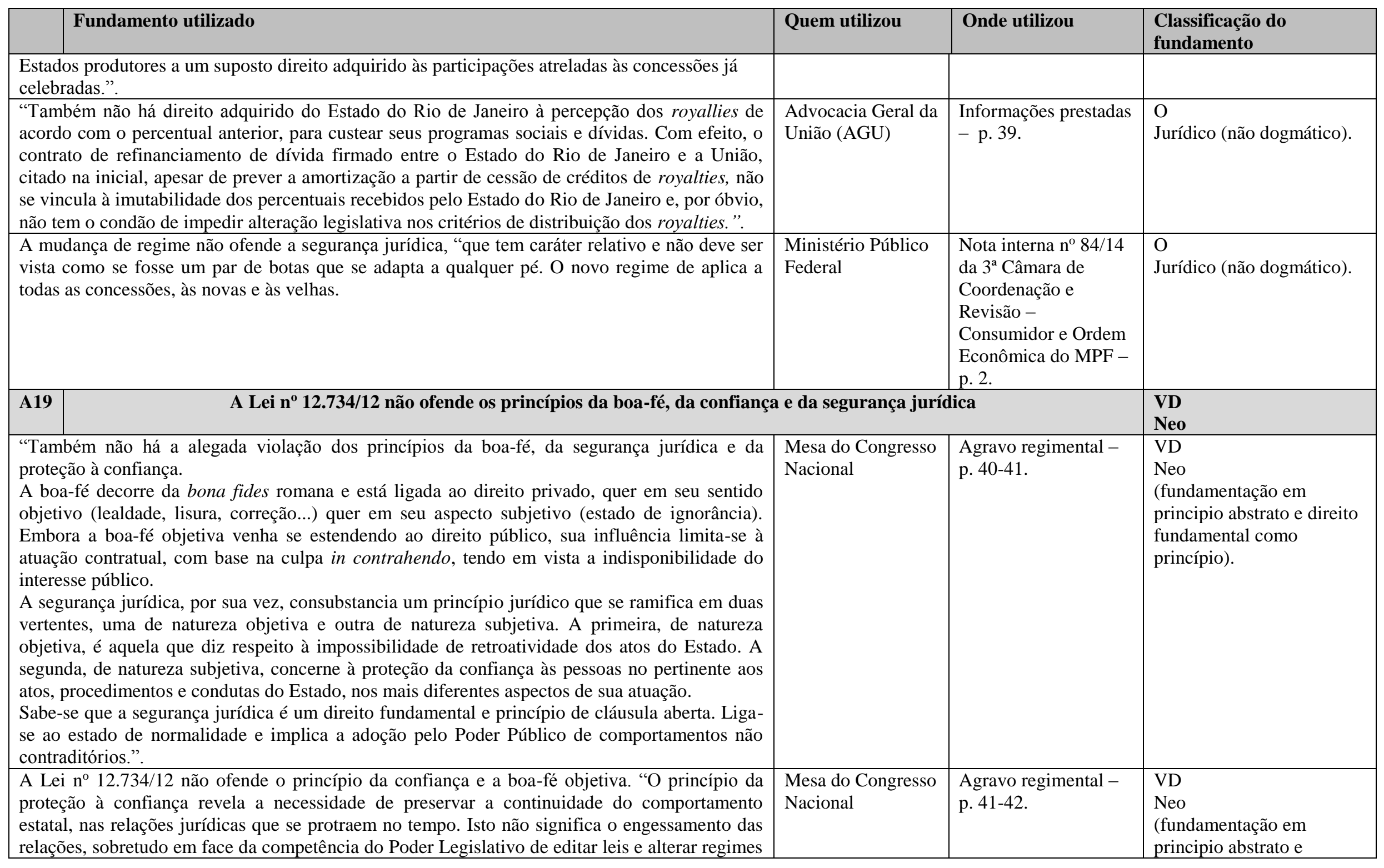




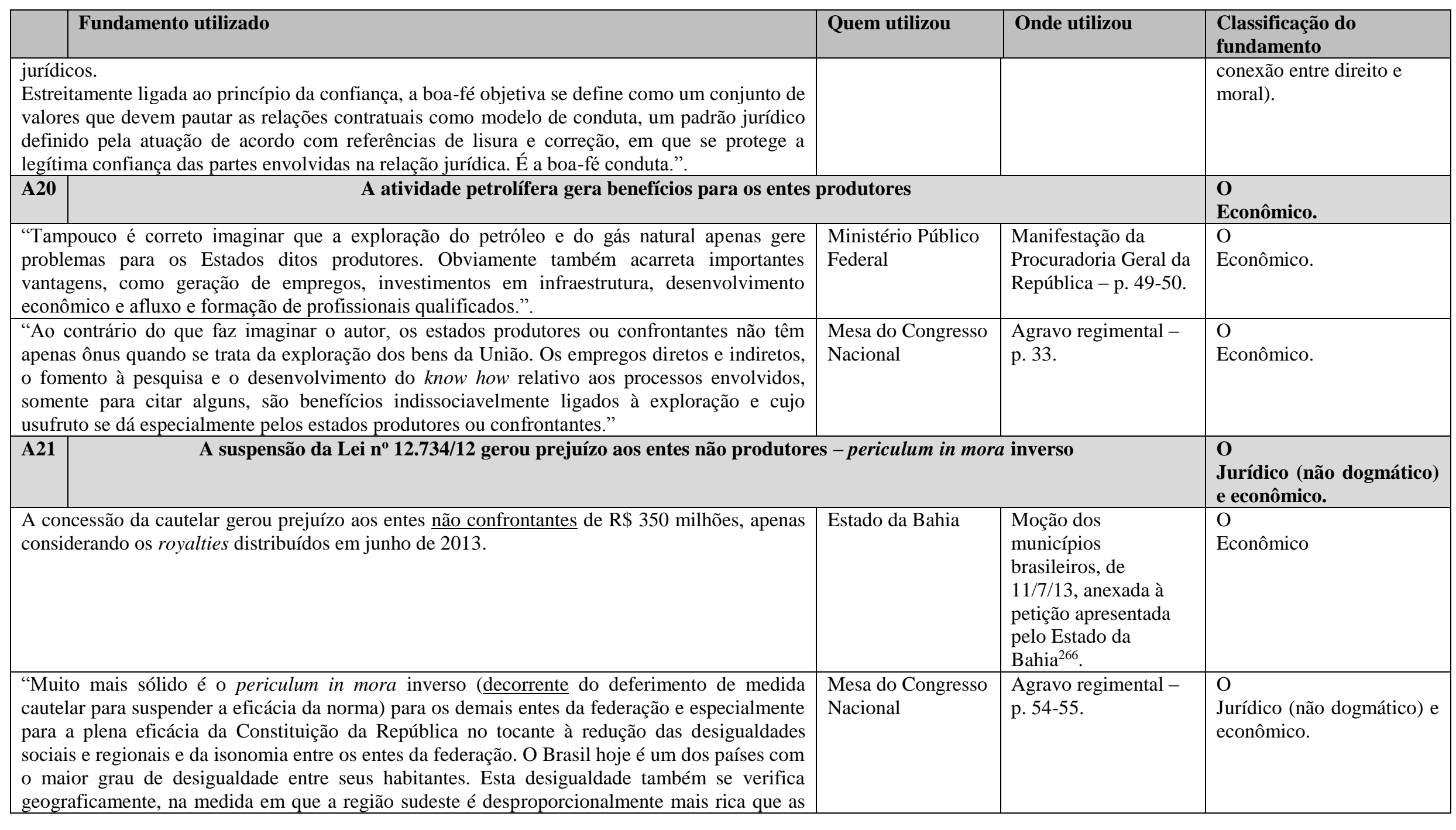

266 Moção dos municípios brasileiros, de 11/7/13, anexada à petição apresentada pelo Estado da Bahia. Disponível em: <http://redir.stf.jus.br/paginadorpub/paginador.jsp?docTP=TP\&docID=3793469\&ad=s\#123\%20-\%20Peti\%E7\%E3o\%20de\%20apresenta\%E7\%E3o\%20de\%20manifesta\%E 7\%E3o\%20-\% 20Peti\%E7\%E3o\%20de\%20apresenta\% E7\%E3o\%20de\%20manifesta\%E7\%E3o\%201>. Acesso em: 3 mar. 2015. 


\begin{tabular}{|c|c|c|c|c|}
\hline & Fundamento utilizado & Quem utilizou & Onde utilizou & $\begin{array}{l}\text { Classificação do } \\
\text { fundamento }\end{array}$ \\
\hline \multicolumn{5}{|c|}{$\begin{array}{l}\text { outras regiões, especialmente Norte e Nordeste. (...) } \\
\text { Assim, a população dos estados e municípios não-confrontantes já contam com os recursos } \\
\text { adicionais que passariam a receber este ano, cuja ausência poderá representar dano mais grave, } \\
\text { porque atinge cada pessoa e seu direito à saúde, à moradia, etc”. }\end{array}$} \\
\hline A22 & \multicolumn{3}{|c|}{$\begin{array}{l}\text { A pesquisa necessária para descoberta do pré-sal foi custeada por todo o país, daí porque os frutos da exploração também } \\
\text { devem ser repartidos }\end{array}$} & $\begin{array}{l}\text { O } \\
\text { Econômico. }\end{array}$ \\
\hline $\begin{array}{l}\text { "Tod } \\
\text { litorâ } \\
\text { por } 1 \\
\text { todos } \\
\text { suces }\end{array}$ & $\begin{array}{l}\text { os os brasileiros, e não somente os brasileiros residentes nos Estados e Municípios } \\
\text { neos e confrontantes, confiaram, investiram e aplicaram na Petrobrás, empresa responsável } \\
\text { ccalizar o Pré-Sal. Agora, mais do que justo que se proceda ao repasse isonômico para } \\
\text { os entes federados, possibilitando que todos os brasileiros compartilhem igualmente o } \\
\text { so.". }\end{array}$ & $\begin{array}{l}\text { OAB/MG (Amicus } \\
\text { curiae) }\end{array}$ & $\begin{array}{l}\text { Petição apresentada - } \\
\text { p. } 12 .\end{array}$ & $\begin{array}{l}\text { O } \\
\text { Econômico. }\end{array}$ \\
\hline
\end{tabular}


TABELA 8 - FUNDAMENTOS UTILIZADOS PELOS DEMAIS ATORES PROCESSUAIS CONTRÁRIOS À REDISTRIBUIÇÃO DOS ROYALTIES E PE

\begin{tabular}{|c|c|c|c|c|}
\hline & Fundamento utilizado & Quem utilizou & Onde utilizou & $\begin{array}{l}\text { Classificação do } \\
\text { fundamento }\end{array}$ \\
\hline B1 & \multicolumn{3}{|c|}{ Natureza jurídica dos royalties - interpretação do art. $20, \$^{\circ}$ da CF } & $\begin{array}{l}\text { VD } \\
\text { Jurídico dogmático }\end{array}$ \\
\hline \multicolumn{2}{|r|}{$\begin{array}{l}\text { A Lei } n^{\circ} 12.734 / 12 \text { viola o art. } 20, \S 1^{\circ} \text { da Constituição, de acordo com o qual os royalties possuem } \\
\text { natureza compensatória, e não redistributiva. }\end{array}$} & $\begin{array}{l}\text { Governador do } \\
\text { Estado do Rio de } \\
\text { Janeiro (autor) }\end{array}$ & $\begin{array}{l}\text { Petição inicial. ADI } \\
\mathrm{n}^{\circ} 4917 / \mathrm{DF}^{268}-\mathrm{p} \\
1 .\end{array}$ & $\begin{array}{l}\text { VD } \\
\text { Jurídico dogmático }\end{array}$ \\
\hline \multicolumn{2}{|r|}{$\begin{array}{l}\text { "A Corte Suprema procurou determinar a natureza jurídica da "Compensação Financeira pela } \\
\text { Exploração de Recursos Minerais", comumente designada como CFEM. Na oportunidade, o } \\
\text { Tribunal identificou a CFEM com as retribuições financeiras disciplinadas pelo parágrafo } 1^{\circ} \text { do } \\
\text { artigo } 20 \text { da Constituição, dispondo, a propósito, que essa retribuição, dada a sua destinação } \\
\text { constitucional, não tem natureza tributária, mas de simples receita patrimonial (ou originária), e } \\
\text { que a sua cobrança é constitucional (...). } \\
\text { Em referência a esse julgamento, Romeu Thomé observa que o Tribunal Constitucional, na } \\
\text { oportunidade, 'abraçou a tese segundo a qual a natureza jurídica da CFEM, também designada } \\
\text { royalty ad valorem, é indenizatória.'”. }\end{array}$} & $\begin{array}{l}\text { Governador do } \\
\text { Estado do Espírito } \\
\text { Santo (autor) }\end{array}$ & $\begin{array}{l}\text { Petição inicial. ADI } \\
\text { n }^{\circ} 4916 / \mathrm{DF}-\text { p. } 51- \\
52\end{array}$ & $\begin{array}{l}\text { VD } \\
\text { Jurídico dogmático }\end{array}$ \\
\hline \multicolumn{2}{|r|}{$\begin{array}{l}\text { "Os royalties previstos no artigo } 20, \S 1^{\circ} \text {, da Constituição da República, ontologicamente estão } \\
\text { vinculados à necessidade de se viabilizar uma compensação aos impactos sociais, ambientais e } \\
\text { administrativos que a exploração do petróleo acaba por acarretar nos entes federativos produtores." }\end{array}$} & $\begin{array}{l}\text { OMPETRO } 269 \\
\text { (amicus curiae) }\end{array}$ & $\begin{array}{l}\text { Petição de } \\
\text { habilitação como } \\
\text { amicus curiae }{ }^{270}- \\
\text { p. } 10,11\end{array}$ & $\begin{array}{l}\text { VD } \\
\text { Jurídico dogmático. }\end{array}$ \\
\hline B2 & \multicolumn{3}{|c|}{ Os royalties sempre foram tratados como indenização e destinados aos entes produtores e afetados } & $\begin{array}{l}\text { VD } \\
\text { Jurídico historicista e } \\
\text { jurídico dogmático. }\end{array}$ \\
\hline & $\begin{array}{l}\text { nálise da disciplina jurídica da atividade petrolífera desde o Período Colonial até a } \\
\text { ituição de } 1988 \text { infere-se que desde sempre a legislação tratou as participações } \\
\text { namentais advindas da exploração de recursos naturais como "indenização", inclusive no que }\end{array}$ & $\begin{array}{l}\text { Governador do } \\
\text { Estado do Espírito } \\
\text { Santo (autor) }\end{array}$ & $\begin{array}{l}\text { Petição inicial. ADI } \\
\text { no } 4916 / \mathrm{DF}-\text { p. } 25- \\
26 \text { e } 58 .\end{array}$ & $\begin{array}{l}\text { VD } \\
\text { Jurídico historicista e } \\
\text { jurídico dogmático. }\end{array}$ \\
\hline
\end{tabular}

${ }^{267}$ Os fundamentos foram sintetizados, a fim de facilitar a sua compreensão. No entanto, por serem apresentados de diversas formas, entendeu-se relevante trazer exemplos de sua utilização. A classificação em negrito considera todas as categorias envolvidas nos exemplos.

${ }^{268}$ ADI 4917 (RJ). Petição inicial, p. 1. Disponível em: <http://redir.stf.jus.br/paginadorpub/paginador.jsp?docTP=TP\&docID=3511887\&ad=s\#5\%20-\%20Peti\%E7\%E3o\%20 inicial\%20-\%20 Peticao\%20inicial\%201>. Acesso em: 3 mar. 2015

${ }^{269}$ Organização dos Municípios Produtores de Petróleo e Gás e Limítrofes da Zona de Produção Principal da Bacia de Campos, Estado do Rio de Janeiro

${ }^{270}$ Petição de habilitação como amicus curiae da OMPETRO. Disponível em: <http://redir.stf.jus.br/paginadorpub/paginador.jsp?docTP=TP

$\&$ docID $=3654817 \&$ ad $=$ s $\# 62 \% 20-\% 20$ Pedido $\% 20$ de $\% 20$ ingresso $\% 20$ como $\% 20$ amicus $\% 20$ curiae $\% 20$ -

$\% 20$ Pedido $\% 20$ de $\% 20$ ingresso $\% 20$ como\%20amicus\%20curiae $\% 201>$. Acesso em: 3 mar. 2015. 


\begin{tabular}{|c|c|c|c|c|}
\hline & Fundamento utilizado & Quem utilizou & Onde utilizou & $\begin{array}{l}\text { Classificação do } \\
\text { fundamento }\end{array}$ \\
\hline \multicolumn{5}{|c|}{ concerne à extração offshore. } \\
\hline \multicolumn{2}{|r|}{$\begin{array}{l}\text { Análise dos debates ocorridos durante a Assembleia Nacional Constituinte em torno do art. } 20, \S 1^{\circ} \\
\text { da Constituição demonstra que em momento algum se fugiu da ideia de beneficiar os entes } \\
\text { afetados com os recursos advindos do petróleo, inclusive no que concerne à extração offshore. } \\
\text { "Essas manifestações, e também a evolução do texto construído pelos constituintes ao longo das } \\
\text { suas deliberações sobre o tema, revelam que a intenção do legislador (mens legislatoris) era } \\
\text { compensar (ou indenizar), de alguma forma, os Estados e Municípios impactados pela exploração } \\
\text { de determinados recursos naturais pelos reflexos dessa atividade econômica sobre as suas contas } \\
\text { públicas e sobre o modo de vida de suas respectivas populações.". }\end{array}$} & $\begin{array}{l}\text { Governador do } \\
\text { Estado do Espírito } \\
\text { Santo (autor) }\end{array}$ & $\begin{array}{l}\text { Petição inicial. ADI } \\
\text { no } 4916 / \mathrm{DF}-\text { p. } 31- \\
49 \text { e } 62 .\end{array}$ & $\begin{array}{l}\text { VD } \\
\text { Jurídico historicista e } \\
\text { jurídico dogmático. }\end{array}$ \\
\hline \multicolumn{2}{|r|}{$\begin{array}{l}\text { "São, pois, evidentes os riscos ambientais da atividade de exploração de petróleo no litoral } \\
\text { brasileiro. Também são manifestos os seus reflexos sobre as contas públicas dos Estados e } \\
\text { Municípios situados nas proximidades dos campos de produção desse recurso natural, que vêem } \\
\text { afetado o modo de vida das suas respectivas populações, e que por isso necessitam dos recursos } \\
\text { financeiros corporificados nos royalties e participações especiais advindos da exploração } \\
\text { petrolífera. Se o pior acontecer, as populações locais só contam com os seus respectivos Estados e } \\
\text { Municípios para minimizar os impactos da repercussão de acidentes desse tipo. Até porque, como } \\
\text { cediço, nada há no ordenamento jurídico-positivo que obrigue os demais Estados e Municípios a } \\
\text { socorrem-nas num evento dessa natureza." }\end{array}$} & $\begin{array}{l}\text { Governador do } \\
\text { Estado do Espírito } \\
\text { Santo (autor) }\end{array}$ & $\begin{array}{l}\text { Petição inicial. ADI } \\
\text { n }^{\circ} 4916 / \mathrm{DF}^{271}-\mathrm{p} \\
91 .\end{array}$ & $\begin{array}{l}\text { O } \\
\text { Jurídico (não } \\
\text { dogmático), econômico e } \\
\text { ambiental. }\end{array}$ \\
\hline \multicolumn{2}{|r|}{$\begin{array}{l}\text { Notícias sobre o vazamento de óleo no litoral norte do Estado de São Paulo, com as seguintes } \\
\text { manchetes: "Fiscais de São Sebastião encontram barreira de óleo em mangue", "Vazamento em } \\
\text { São Sebastião (SP) ocorreu por falha em inspeção, diz Petrobras", "Vereadores aprovam repasse }\end{array}$} & $\begin{array}{l}\text { AMPROGÁS }^{273} \\
\text { (amicus curiae) }\end{array}$ & $\begin{array}{l}\text { Doc. } 3 \text { - Notícias } \\
\text { sobre o recente } \\
\text { vazamento de óleo }\end{array}$ & $\begin{array}{l}\mathrm{O} \\
\text { Ambiental e econômico }\end{array}$ \\
\hline
\end{tabular}

${ }^{271}$ ADI 4916 (ES). Petição inicial. Disponível em: <http://redir.stf.jus.br/paginadorpub/paginador.jsp?docTP=TP\&docID=3511895\&ad=s\#1\%20-\%20Peti\%E7\%E3o\% 20inicial\%20-\%20 Peticao\%20 inicial\%201>. Acesso em 3 mar. 2015.

${ }^{272}$ ADI 4920 (SP). Petição inicial, p. 18. Disponível em: <http://redir.stf.jus.br/paginadorpub/paginador.jsp?docTP=TP\&docID=3513371\&ad=s\#1\%20-\%20Peti\%E7\%E3o\% 20inicial\%20-\%20Peticao\%20inicial\%201>. Acesso em 3 mar. 2015;

${ }^{273}$ Associação dos Municípios Produtores de Gás Natural, Petróleo e Possuidores de Gasodutos, Oleodutos, Área de Tancagem e Estação de Bombeamento na Zona de Influência da Bacia de Santos 


\begin{tabular}{|c|c|c|c|}
\hline Fundamento utilizado & Quem utilizou & Onde utilizou & $\begin{array}{l}\text { Classificação do } \\
\text { fundamento }\end{array}$ \\
\hline $\begin{array}{l}\text { de até } \mathrm{R} \$ 659 \text { mil para maricultores e pescadores afetados por vazamento de óleo", "São Sebastião } \\
\text { e Caraguá ainda sentem os efeitos do vazamento de combustível marítimo", comprovam os } \\
\text { impactos ambientais decorrentes da atividade petrolífera. }\end{array}$ & & $\begin{array}{l}\text { no litoral norte de } \\
\text { São Paulo }\end{array}$ & \\
\hline $\begin{array}{l}\text { "A exploração do petróleo e de seus derivados traz consigo um fluxo migratório de pessoas às } \\
\text { cidades produtoras, destinadas a desenvolver todas as atividades inerentes à exploração, criando, } \\
\text { assim, uma demanda de serviços e de políticas públicas destinadas a atender as necessidades dessa } \\
\text { crescente população. } \\
\text { Apenas para exemplificar, a população do Município de Campos dos Goytacazes cresceu, de } 1996 \\
\text { a 2010, de } 388.005 \text { habitantes para } 463.731 \text { habitantes, conforme censo do IBGE. O mesmo estudo } \\
\text { demostrou que no citado período a população de Macaé subiu de } 120.009 \text { para } 206.728 \text { e de Rio } \\
\text { das Ostras aumentou de } 27.842 \text { para } 105.676 \text {. } \\
\text { Diante desse inegável crescimento da população migratória, é evidente que também aumentam os } \\
\text { custos do Poder Público com o atendimento das necessidades dos cidadãos.”. }\end{array}$ & $\begin{array}{l}\text { OMPETRO (amicus } \\
\text { curiae) }\end{array}$ & $\begin{array}{l}\text { Petição de } \\
\text { habilitação como } \\
\text { amicus curiae - p. } \\
13\end{array}$ & $\begin{array}{l}\mathrm{O} \\
\text { Econômico. }\end{array}$ \\
\hline
\end{tabular}

${ }^{274}$ Cf. fotos dos acidentes descritos anexadas ao processo pela ABRAMT -Associação Brasileira dos Municípios com Terminais Marítimos, Fluviais e Terrestres de Embarque e Desembarque de Petróleo e Gás Natural (<http://redir.stf.jus.br/paginadorpub/paginador.jsp?docTP=TP\&docID=3665288\&ad=s\#89\%20-\%20 Pedido\%20de\%20ingresso\%20como\%20amicus\%20curiae\%20-\%20Pedido\%20de\%20ingresso\%20 como\%20amicus\%20curiae\%201>. Acesso em: 3 mar. 2015.

${ }^{275}$ Associação Brasileira dos Municípios com Terminais Marítimos, Fluviais e Terrestres de Embarque e Desembarque de Petróleo e Gás Natural.

276 Petição de ingresso da ABRAMT, p. 4. Disponível em: <http://redir.stf.jus.br/paginadorpub/paginador.jsp?docTP=TP\&docID=3665288\&ad=s\#89\%20-\%20 Pedido\%20de\%20ingresso\%20como\%20amicus\%20curiae\%20-\%20Pedido\%20de\%20ingresso\%20 como\%20amicus\%20curiae\%201>. Acesso em: 3 mar. 2015. 


\begin{tabular}{|c|c|c|c|c|}
\hline & Fundamento utilizado & Quem utilizou & Onde utilizou & $\begin{array}{l}\text { Classificação do } \\
\text { fundamento }\end{array}$ \\
\hline \multicolumn{5}{|c|}{ financeiros.". } \\
\hline B4 & \multicolumn{3}{|c|}{$\begin{array}{c}\text { A Lei no 12.734/12 ofende o pacto federativo, pois não respeita a compensação entre a sistemática de cobrança do ICMS e a } \\
\text { destinação dos royalties, bem como afeta o equilíbrio orçamentário e financeiro dos entes produtores }\end{array}$} & $\begin{array}{l}\text { O } \\
\text { Federativo. }\end{array}$ \\
\hline $\begin{array}{l}\text { "Ao } \\
\text { as pa } \\
\text { risco } \\
\text { feder } \\
\text { inusi } \\
\text { some }\end{array}$ & $\begin{array}{l}\text { uprimir seletivamente um dos elementos do referido sistema - a mínima equivalência entre } \\
\text { ticipações pagas aos produtores, de um lado, e a compensação pela perda de ICMS e os } \\
\text { e ônus da produção do petróleo, de outro -, efetivou-se uma ruptura do próprio equilíbrio } \\
\text { ativo: os Estados não-produtores passaram a se beneficiar da arrecadação de ICMS e de uma } \\
\text { ada compensação por prejuízos que nunca tiveram. Os Estados produtores ficaram tão } \\
\text { the com os encargos. }\end{array}$ & $\begin{array}{l}\text { Governador do } \\
\text { Estado do Rio de } \\
\text { Janeiro (autor) }\end{array}$ & $\begin{array}{l}\text { Petição inicial. ADI } \\
\text { no 4917/DF - p. } 39 .\end{array}$ & $\begin{array}{l}\mathrm{O} \\
\text { Federativo. }\end{array}$ \\
\hline $\begin{array}{l}\text { "A n } \\
\text { a se } 1 \\
\text { tiver: }\end{array}$ & $\begin{array}{l}\text { va lei quebra o equilíbrio federativo na medida em que os Estados não produtores passaram } \\
\text { eneficiar da arrecadação de ICMS e de uma inusitada compensação por prejuízos que nunca } \\
\text { m." }\end{array}$ & $\begin{array}{l}\text { ABRAMT } \\
\text { (amicus curiae) }\end{array}$ & $\begin{array}{l}\text { Pedido de ingresso } \\
\text { no feito }- \text { p. } 4\end{array}$ & $\begin{array}{l}\mathrm{O} \\
\text { Federativo. }\end{array}$ \\
\hline $\begin{array}{l}\text { O pa } \\
\text { Estac } \\
\text { tribu } \\
\text { "A L } \\
\text { da re } \\
\text { discr } \\
\text { pétre }\end{array}$ & $\begin{array}{l}\text { to federativo instaurado com a Carta de } 1988 \text { fixou o pagamento dos royalties e da PE aos } \\
\text { os e Municípios produtores, como contrapartida à fixação de um regime excepcional de } \\
\text { ação do ICMS dos produtos derivados do petróleo. } \\
\text { i } 12.734 / 12 \text {, ao retirar os royalties dos Estados e Municípios produtores, mantendo a perda } \\
\text { eita decorrente do ICMS e os ônus decorrentes da extração do petróleo, constituiu uma } \\
\text { minação odiosa entre entes federativos, ferindo de morte o pacto federativo, ora cláusula } \\
\text { prevista no artigo } 60, \S 4^{\circ} \text {, I CF." }\end{array}$ & $\begin{array}{l}\text { OMPETRO (amicus } \\
\text { curiae) }\end{array}$ & $\begin{array}{l}\text { Petição de } \\
\text { habilitação como } \\
\text { amicus curiae - p. } \\
10 \text { e } 18 \text {. }\end{array}$ & $\begin{array}{l}\mathrm{O} \\
\text { Federativo. }\end{array}$ \\
\hline $\begin{array}{l}\text { "Ass } \\
\text { dessa } \\
\text { indús } \\
\text { próp } \\
\text { popu } \\
\text { extra } \\
\text { deco } \\
\text { parti }\end{array}$ & $\begin{array}{l}\text { m, a pretensão do Parlamento de suprimir, por lei federal, parte substancial do pagamento } \\
\text { s receitas aos Estados e Municípios impactados (Estados e Municípios produtores) pela } \\
\text { tria petrolífera restringe a autonomia dessas unidades federadas para a execução dos seus } \\
\text { ios recursos orçamentários, que, em vez de serem aplicados em benefício das suas respectivas } \\
\text { açães, precisarão ser alocados, forçadamente, para cobrir os riscos e custos de atividade } \\
\text { ivista exercida por particulares, mas sob autorização e em benefício do ente federal. Disso } \\
\text { re a inconstitucionalidade, por ofensa ao princípio federativo, da distribuição dos royalties e } \\
\text { ipações especiais em maior proporção aos Estados e Municípios que não são impactados por }\end{array}$ & $\begin{array}{l}\text { Governador do } \\
\text { Estado do Espírito } \\
\text { Santo (autor) }\end{array}$ & $\begin{array}{l}\text { Petição inicial. ADI } \\
\text { n }^{\circ} 4916 / \mathrm{DF}-\mathrm{p} \text {. } \\
109 .\end{array}$ & \begin{tabular}{|l|l} 
O \\
Federativo.
\end{tabular} \\
\hline
\end{tabular}




\begin{tabular}{|c|c|c|c|c|}
\hline & Fundamento utilizado & Quem utilizou & Onde utilizou & $\begin{array}{l}\text { Classificação do } \\
\text { fundamento }\end{array}$ \\
\hline \multicolumn{5}{|c|}{ essa atividade econômica (Estados e Municípios não-produtores)." } \\
\hline B5 & \multicolumn{3}{|c|}{$\begin{array}{l}\text { A receita auferida pelos entes produtores com o ICMS, caso ele incidisse na origem, seria quase o dobro daquelas resultante de } \\
\text { royalties e PE }\end{array}$} & $\begin{array}{l}\text { O } \\
\text { Econômico }\end{array}$ \\
\hline \multicolumn{2}{|r|}{$\begin{array}{l}\text { A receita tributária auferida com o ICMS corresponde a pouco menos que o dobro das receitas } \\
\text { patrimoniais levantadas com royalties, PE e outras participações governamentais advindas do } \\
\text { petróleo e gás }{ }^{277} \text {. O Estado do Rio de Janeiro, por exemplo, deixa de arrecadar anualmente cerca } \\
\text { de } \mathrm{R} \$ 8 \text { bilhões por conta da imunidade de ICMS prevista no art. } 155, \S 2^{\circ}, \mathrm{X}, b \text {, valor que supera a } \\
\text { receita advinda dos royalties. }\end{array}$} & $\begin{array}{l}\text { Governador do } \\
\text { Estado do Rio de } \\
\text { Janeiro (autor) }\end{array}$ & $\begin{array}{l}\text { Petição inicial. ADI } \\
\text { n }^{\circ} 4917 / \mathrm{DF} \text { - p. } 35 .\end{array}$ & $\begin{array}{l}\mathrm{O} \\
\text { Econômico. }\end{array}$ \\
\hline B6 & \multicolumn{3}{|c|}{ A redistribuição dos royalties viola o equilíbrio financeiro e orçamentário } & $\begin{array}{l}\text { O } \\
\text { Jurídico (não } \\
\text { dogmático) e econômico }\end{array}$ \\
\hline \multicolumn{2}{|r|}{$\begin{array}{l}\text { "Afronta-se, assim, o art. } 167 \text { da Constituição: que dispõe sobre equilíbrio orçamentário, e que } \\
\text { exige, que receitas que componham o estoque de expectativas de um determinado Ente sejam } \\
\text { realizadas, pena que se comprometa o balanço entre entradas e saídas, no velho sistema de } \\
\text { partilhas dobradas, também de uso nas leis de meios." }\end{array}$} & União & $\begin{array}{l}\text { Manifestação da } \\
\text { Advocacia Geral da } \\
\text { União }^{278}-\text { p. } 6\end{array}$ & $\begin{array}{l}\text { O Jurídico (não dogmático) } \\
\text { e econômico }\end{array}$ \\
\hline \multicolumn{2}{|r|}{$\begin{array}{l}\text { "A incidência das inovações sobre concessões já existentes surpreenderia bruscamente os Estados } \\
\text { produtores, frustrando sua expectativa legítima em relação a receitas que vêm auferindo há muitos } \\
\text { anos. O impacto da medida sobre as contas estaduais seria brutal e imediato, violando o princípio } \\
\text { do equilíbrio orçamentário (CF/88, art. 167) e impossibilitando o cumprimento de normas } \\
\text { constitucionais e legais, bem como de obrigações contratuais já assumidas." }\end{array}$} & $\begin{array}{l}\text { Governador do } \\
\text { Estado do Rio de } \\
\text { Janeiro (autor) }\end{array}$ & $\begin{array}{l}\text { Petição inicial. ADI } \\
\text { n }^{\circ} 4917 / \mathrm{DF} \text { - p. } 44 .\end{array}$ & $\begin{array}{l}\text { O } \\
\text { Jurídico (não dogmático) } \\
\text { e econômico. }\end{array}$ \\
\hline B7 & \multicolumn{3}{|c|}{ A Lei $\mathrm{n}^{\circ} 12.734 / 12$ viola direito adquirido, segurança jurídica e boa-fé } & $\begin{array}{l}\text { VD } \\
\text { Jurídico dogmático. }\end{array}$ \\
\hline \multicolumn{2}{|r|}{$\begin{array}{l}\text { "Como é de conhecimento corrente, o art. } 5^{\circ} \text {, XXXVI, da Constituição de } 1988 \text {, impede que a } \\
\text { incidência de novas regras legais venha a afetar os direitos que hajam sido constituídos nos termos } \\
\text { da legislação anterior. Essa é uma forma elementar e tradicional de concretização da segurança } \\
\text { jurídica, destinada a atribuir um mínimo de confiabilidade às posições jurídicas criadas pelo } \\
\text { Direito. Sem isso, os titulares do direito subjetivo ficariam em um estado de incerteza permanente, } \\
\text { impedidos de planejar suas atividades de forma racional e sujeitos a todo tipo de voluntarismo } \\
\text { político. O ponto é amplamente reconhecido pela doutrina e pela jurisprudência, no Brasil e no } \\
\text { mundo, de modo que dispensa maiores considerações teóricas." }\end{array}$} & $\begin{array}{l}\text { Governador do } \\
\text { Estado do Rio de } \\
\text { Janeiro (autor) }\end{array}$ & $\begin{array}{l}\text { Petição inicial. ADI } \\
\text { n }^{\circ} 4917 / \mathrm{DF} \text { - p. } 40- \\
41 .\end{array}$ & $\begin{array}{l}\text { VD } \\
\text { Jurídico dogmático. }\end{array}$ \\
\hline
\end{tabular}

${ }^{277}$ ADI 4916 (ES). Petição inicial, p. 75. Disponível em: <http://redir.stf.jus.br/paginadorpub/paginador. jsp?docTP=TP\&docID=3511895\&ad=s\#1\%20\%20Peti\%E7\%E3o\%20inicial\%20-\%20Peticao\%20 inicial\%201>. Acesso em: 3 mar. 2015.

${ }^{278}$ Manifestação da Advocacia Geral da União. Disponível em: <http://redir.stf.jus.br/paginadorpub/paginador.jsp?doc TP=TP\&docID=5244147\&ad=s\#160\%20\%20Peti\%E7\%E3o\%20de\%20apresenta\%E7\%E3o\%20de \%20manifesta\%E7\%E3o\%20-\%20Peti\%E7\%E3o\%20de\%20apresenta\%E7\%E3o\%20de\%20manifesta $\%$ E7\%E3o\%201>. Acesso em: 3 mar. 2015. 


\begin{tabular}{|c|c|c|c|c|}
\hline & Fundamento utilizado & Quem utilizou & Onde utilizou & $\begin{array}{l}\text { Classificação do } \\
\text { fundamento }\end{array}$ \\
\hline \multicolumn{2}{|r|}{$\begin{array}{l}\text { "A questão sequer seria controvertida se o tema não envolvesse tantos interesses políticos de peso. } \\
\text { Em essência, aliás, a hipótese se aproxima da jurisprudência já tradicional dessa Eg. Corte no } \\
\text { sentido de que as posições de vantagem que se concretizam a partir de um determinado regime } \\
\text { jurídico incorporam-se à esfera de direitos do interessado." }\end{array}$} & $\begin{array}{l}\text { Governador do } \\
\text { Estado do Rio de } \\
\text { Janeiro (autor) }\end{array}$ & $\begin{array}{l}\text { Petição inicial. ADI } \\
n^{\circ} \text { 4917/DF - p. } 42 .\end{array}$ & $\begin{array}{l}\text { VD } \\
\text { Jurídico dogmático. }\end{array}$ \\
\hline \multicolumn{2}{|r|}{$\begin{array}{l}\text { "Sendo assim, uma modificação ulterior nas regras de distribuição de royalties e participações } \\
\text { especiais, porque capitaneada pela União Federal, mostra-se ofensiva à boa-fé objetiva, que evoca } \\
\text { a proibição de venire contra factum proprium (ou de voltar contra seus próprios passos)." }\end{array}$} & $\begin{array}{l}\text { Governador do } \\
\text { Estado do Espírito } \\
\text { Santo (autor) }\end{array}$ & $\begin{array}{l}\text { Petição inicial. ADI } \\
\text { n }^{\circ} 4916 / \mathrm{DF}-\mathrm{p} \text {. } \\
112 .\end{array}$ & $\begin{array}{l}\text { VD } \\
\text { Jurídico dogmático. }\end{array}$ \\
\hline B8 & \multicolumn{3}{|c|}{ A Lei $n^{0}$ 12.734/12 viola o princípio da segurança jurídica } & $\begin{array}{l}\text { VD } \\
\text { Neo }\end{array}$ \\
\hline \multicolumn{2}{|r|}{$\begin{array}{l}\text { A Lei } \mathrm{n}^{\circ} 12.734 / 12 \text { viola o princípio da segurança jurídica, que é identificada pelo STF como um } \\
\text { "protovalor no conjunto de valores do modelo constitucional vigente. A segurança jurídica é um } \\
\text { subprincípio do Estado de Direito": }\end{array}$} & União & $\begin{array}{l}\text { Manifestação da } \\
\text { Advocacia Geral da } \\
\text { União - p. } 6 .\end{array}$ & $\begin{array}{l}\text { VD } \\
\text { Neo } \\
\text { (Conexão entre direito e } \\
\text { moral e fundamentação } \\
\text { em princípio abstrato). }\end{array}$ \\
\hline \multicolumn{2}{|r|}{$\begin{array}{l}\text { A Lei } \mathrm{n}^{\mathrm{o}} 12.734 / 12 \text { ofende o princípio da segurança jurídica, consagrado no art. } 5^{\circ}, \text { XXXVI da } \\
\text { Constituição, que veda a interferência legislativa no direito adquirido, no ato jurídico perfeito e na } \\
\text { coisa julgada. "José Afonso da Silva leciona que 'a segurança é um dos valores que informa o } \\
\text { direito positivo', e que, 'em verdade, a positividade do direito é uma exigência dos valores da } \\
\text { ordem, da segurança e da certeza jurídicas'”. }\end{array}$} & $\begin{array}{l}\text { Governador do } \\
\text { Estado do Espírito } \\
\text { Santo (autor) }\end{array}$ & $\begin{array}{l}\text { Petição inicial. ADI } \\
n^{\circ} 4916 / \mathrm{DF}-\mathrm{p} . \\
\text { 109-110. }\end{array}$ & $\begin{array}{l}\text { VD } \\
\text { Neo } \\
\text { (Fundamentação em } \\
\text { princípio abstrato e } \\
\text { conexão entre direito e } \\
\text { moral). }\end{array}$ \\
\hline \multicolumn{2}{|r|}{$\begin{array}{l}\text { "Assim, em respeito ao princípio da solidariedade e da segurança jurídica, as condutas dos entes } \\
\text { federados devem ser sempre previsíveis, de forma a evitar prejuízos abruptos a uma parte da } \\
\text { Federação (...). } \\
\text { Sobre o assunto, ressalta-se que o princípio da segurança jurídica, como aponta Celso Antonio } \\
\text { Bandeira de Mello, muito embora não possa ser radicado em dispositivo constitucional específico, } \\
\text { decorre da própria essência do direito, notadamente de um Estado Democrático de Direito, de tal } \\
\text { sorte que faz parte do sistema constitucional como um todo e está preordenado a ensejar certa } \\
\text { estabilidade, um mínimo de certeza na regência da vida social. } \\
\text { Altamiro do Couto e Silva distingue duas acepções do princípio da segurança jurídica, apontando } \\
\text { uma de natureza objetiva, a qual envolve a questão dos limites à retroatividade dos atos do Estado, } \\
\text { inclusive legislativos, dizendo respeito, pois, à proteção do direito adquirido, ao ato jurídico } \\
\text { perfeito e à coisa julgada; e outra de natureza subjetiva, ligada à proteção da confiança, no que se } \\
\text { refere aos atos, procedimentos, e condutas do Estado, nos mais diferentes aspectos de sua atuação, } \\
\text { motivo pelo qual a doutrina moderna tem denominado tal concepção do princípio da segurança } \\
\text { jurídica como princípio da proteção à confiança." }\end{array}$} & $\begin{array}{l}\text { Governador do } \\
\text { Estado de São Paulo } \\
\text { (autor) }\end{array}$ & 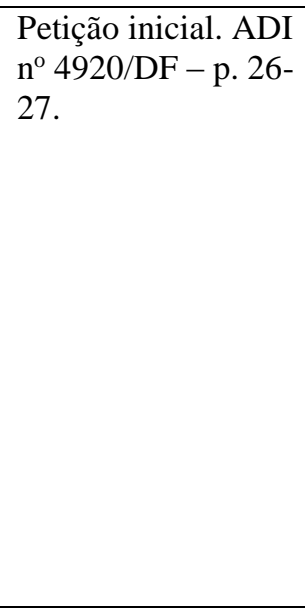 & $\begin{array}{l}\text { VD } \\
\text { Neo } \\
\text { (Fundamentação em } \\
\text { princípio abstrato). }\end{array}$ \\
\hline
\end{tabular}




\begin{tabular}{|c|c|c|c|c|}
\hline & Fundamento utilizado & Quem utilizou & Onde utilizou & $\begin{array}{l}\text { Classificação do } \\
\text { fundamento }\end{array}$ \\
\hline B9 & \multicolumn{3}{|c|}{$\begin{array}{l}\text { Haverá abalo profundo na lealdade federativa caso seja mantida a pretensão de redimensionar os royalties relativos a concessões já } \\
\text { estabelecidas }\end{array}$} & $\begin{array}{l}\text { O } \\
\text { Federativo. }\end{array}$ \\
\hline B10 & \multicolumn{3}{|c|}{ Os entes produtores e confrontantes sofrerão perda significativa de recursos, o que lhes trará consequências graves } & $\begin{array}{l}\text { O } \\
\text { Jurídico (não } \\
\text { dogmático) e econômico }\end{array}$ \\
\hline $\begin{array}{l}\text { A ap } \\
\text { para } \\
\text { Aden } \\
\text { milhi } \\
\text { restai } \\
\text { const } \\
\text { estad } \\
\text { de } 20\end{array}$ & $\begin{array}{l}\text { licação das novas regras resultaria "um prejuízo imediato de mais de R\$ } 1,6 \text { bilhões somente } \\
\text { o Estado do Rio de Janeiro, beirando a inacreditável marca de R\$27 bilhões (!!) até } 2020 \text {. } \\
\text { nais, as vinculações orçamentárias fariam com que, em } 2013 \text {, restassem apenas R\$ } 300 \\
\text { ôs disponíveis para custeio de diversos programas sociais. O equilíbrio das contas estaduais } \\
\text { ria severamente ameaçado, assim como a capacidade do Estado de honrar seus compromissos } \\
\text { itucionais, legais e contratuais - inclusive aqueles decorrentes do refinanciamento da dívida } \\
\text { ual junto à União e do esforço para a Copa do Mundo FIFA } 2014 \text { e para os Jogos Olímpicos } \\
\text { 16.”. }\end{array}$ & $\begin{array}{l}\text { Governador do } \\
\text { Estado do Rio de } \\
\text { Janeiro (autor) }\end{array}$ & $\begin{array}{l}\text { Petição inicial. ADI } \\
\mathrm{n}^{\circ} 4917 / \mathrm{DF} \text { - p. } 49 .\end{array}$ & $\begin{array}{l}\text { O } \\
\text { Econômico. }\end{array}$ \\
\hline $\begin{array}{l}\text { O Es } \\
\text { ultrat } \\
\text { partic }\end{array}$ & $\begin{array}{l}\text { tado do Rio de Janeiro não teria dinheiro para amortizar sua dívida junto à União “- que } \\
\text { passa } R \$ 2 \text { bilhões de reais - e é feita justamente com a cessão de créditos de royalties e } \\
\text { cipações.”. }\end{array}$ & $\begin{array}{l}\text { Governador do } \\
\text { Estado do Rio de } \\
\text { Janeiro (autor) }\end{array}$ & $\begin{array}{l}\text { Petição inicial. ADI } \\
\mathrm{n}^{\circ} \text { 4917/DF - p. } 45 .\end{array}$ & $\begin{array}{l}\mathrm{O} \\
\text { Econômico. }\end{array}$ \\
\hline $\begin{array}{l}\text { "Tam } \\
\text { tendo } \\
\text { de is } \\
\text { oport } \\
\text { a ess } \\
\text { que } \\
\text { gás } \mathrm{e}\end{array}$ & $\begin{array}{l}\text { hbém o Estado do Espírito Santo fez projeções de gastos e assumiu compromissos financeiros } \\
\text { em vista as receitas advindas dos campos de exploração confrontantes com seu território; e } \\
\text { gual modo assinou contrato de antecipação de recursos com a União Federal. Nessas } \\
\text { tunidades, o ente federal reconheceu a valiade e a segurança dos referidos créditos, o que deu } \\
\text { as unidades federadas, por ocasião da celebração desses ajustes, a clareza e a segurança de } \\
\text { poderiam contar, no futuro, com os recursos financeiros advindos da produção de petróleo e } \\
\text { m áreas já licitadas.". }\end{array}$ & $\begin{array}{l}\text { Governador do } \\
\text { Estado do Espírito } \\
\text { Santo (autor) }\end{array}$ & $\begin{array}{l}\text { Petição inicial. ADI } \\
\mathrm{n}^{\mathrm{o}} 4916 / \mathrm{DF}-\mathrm{p} \text {. } \\
112 .\end{array}$ & $\begin{array}{l}\text { O } \\
\text { Jurídico (não dogmático) } \\
\text { e econômico. }\end{array}$ \\
\hline "O d & escumprimento do acordo teria consequências gravíssimas: o Estado c & Governador do & Petição inicial. ADI & $\mathrm{O}$ \\
\hline
\end{tabular}




\begin{tabular}{|c|c|c|c|}
\hline Fundamento utilizado & Quem utilizou & Onde utilizou & $\begin{array}{l}\text { Classificação do } \\
\text { fundamento }\end{array}$ \\
\hline $\begin{array}{l}\text { recursos que receberia a título de impostos e de transferências obrigatórias constitucionais } \\
\text { [Cláusula } 13^{\mathrm{a}} \text { do contrato], sem prejuízo de outras penas contratuais [Cláusulas } 16^{\mathrm{a}}, 17^{\mathrm{a}} \text { e } 19^{\mathrm{a}} \text { ]. } \\
\text { Assim, se a União impedir o Rio de Janeiro de receber as participações governamentais } \\
\text { necessárias, o Estado se tornará inadimplente junto à própria União que, por sua vez, poderá } \\
\text { interromper as transferências constitucionais para o Estado e se apropriar de receitas tributárias } \\
\text { estaduais.” }\end{array}$ & $\begin{array}{l}\text { Estado do Rio de } \\
\text { Janeiro (autor) }\end{array}$ & $\begin{array}{l}\text { no } 4917 / \mathrm{DF}-\text { p. } 45- \\
46 .\end{array}$ & Econômico. \\
\hline $\begin{array}{l}\text { A aplicação das novas regras aos contratos em vigor representa intervenção da União em receitas } \\
\text { do Estado, "cujos recebíveis futuros estão estimados para fazer frente à execução das políticas } \\
\text { públicas planejadas. } \\
\text { Nesse sentido, cumpre lembrar que o Estado de São Paulo desenvolve, neste momento, diversos } \\
\text { projetos de grande vulto ligados à infraestrutura, em especial de transporte, tendo em vista a } \\
\text { preparação para relevantes eventos que ocorrerão em breve no Brasil, dentre eles, a Copa do } \\
\text { Mundo FIFA (2014) e as Olimpíadas (2016). O planejamento para os próximos anos tem como } \\
\text { foco uma ampla gama de programas, que inclui também a própria indústria de exploração do } \\
\text { petróleo e seus efeitos no Estado de São Paulo.”. }\end{array}$ & $\begin{array}{l}\text { Governador do } \\
\text { Estado de São Paulo } \\
\text { (autor) }\end{array}$ & $\begin{array}{l}\text { Petição inicial. ADI } \\
\mathrm{n}^{\circ} 4920 / \mathrm{DF}-\text { p. } 22 .\end{array}$ & $\begin{array}{l}\text { O } \\
\text { Econômico. }\end{array}$ \\
\hline $\begin{array}{l}\text { A nova sistemática de partilha reduz as participações dos entes confrontantes em um terço ou } \\
\text { mesmo à metade. }\end{array}$ & $\begin{array}{l}\text { Governador do } \\
\text { Estado do Rio de } \\
\text { Janeiro (autor) }\end{array}$ & $\begin{array}{l}\text { Petição inicial. ADI } \\
\mathrm{n}^{\circ} 4917 / \mathrm{DF}-\text { p. } 23 \text {. }\end{array}$ & $\begin{array}{l}\text { O } \\
\text { Econômico. }\end{array}$ \\
\hline $\begin{array}{l}\text { "Das } 92 \text { cidades do Estado, } 87 \text { recebem recursos dos royalties e da participação especial. A perda } \\
\text { em } 2013 \text { seria de R } \$ 2,470 \text { bilhões (49\% da receita prevista) e de R } \$ 32,599 \text { bilhões para o período } \\
\text { de 2014/2020." }\end{array}$ & $\begin{array}{l}\text { Governador do } \\
\text { Estado do Rio de } \\
\text { Janeiro (autor) }\end{array}$ & $\begin{array}{l}\text { Petição inicial. ADI } \\
\mathrm{n}^{\circ} 4917 / \mathrm{DF}-\text { p. } 24 .\end{array}$ & $\begin{array}{l}\text { O } \\
\text { Econômico. }\end{array}$ \\
\hline $\begin{array}{l}\text { "Para se ter uma idéia do impacto financeiro dessa nova sistemática de distribuição de royalties e } \\
\text { participações, estima-se: } \\
\text { (a) que o Estado do Espírito Santo e os Municípios Capixabas produtores de petróleo deixariam de } \\
\text { arrecadar até o ano de } 2020 \text { aproximadamente R } \$ 23.700 .000 .000,00 \text { (vinte e três bilhões e } \\
\text { setecentos milhões de reais) em royalties e participações especiais;" (Números apurados pela } \\
\text { Secretaria de Estado de Desenvolvimento do Estado do Espírito Santo). }\end{array}$ & $\begin{array}{l}\text { Governador do } \\
\text { Estado do Espírito } \\
\text { Santo (autor) }\end{array}$ & $\begin{array}{l}\text { Petição inicial. ADI } \\
\mathrm{n}^{\circ} 4916 / \mathrm{DF}-\mathrm{p} . \\
140 .\end{array}$ & $\begin{array}{l}\mathrm{O} \\
\text { Econômico. }\end{array}$ \\
\hline $\begin{array}{l}\text { O Estado de São Paulo perderia R } \$ 4,9 \text { bilhões no período de } 2013 \text { a } 2020 \text {, se a nova lei fosse } \\
\text { aplicada aos contratos já firmados, conforme projeções elaboradas pelos técnicos da Secretaria da } \\
\text { Fazenda e da Secretaria de Energia. }\end{array}$ & $\begin{array}{l}\text { Governador do } \\
\text { Estado de São Paulo } \\
\text { (autor) }\end{array}$ & $\begin{array}{l}\text { Petição inicial. ADI } \\
\mathrm{n}^{\circ} 4920 / \mathrm{DF}-\text { p. } 15 .\end{array}$ & $\begin{array}{l}\text { O } \\
\text { Econômico. }\end{array}$ \\
\hline "O percentual destinado a municípios afetados cairá de $8,75 \%$ para 3\% e a partir de 2017 cairá & ABRAMT & Pedido de ingresso & $\mathrm{O}$ \\
\hline
\end{tabular}




\begin{tabular}{|c|c|c|c|c|}
\hline & Fundamento utilizado & Quem utilizou & Onde utilizou & $\begin{array}{l}\text { Classificação do } \\
\text { fundamento }\end{array}$ \\
\hline \multicolumn{2}{|c|}{ para $2 \% . "$} & (amicus curiae) & no feito - p. 4 & Econômico. \\
\hline \multicolumn{2}{|r|}{$\begin{array}{l}\text { "Os Municípios Afetados terão uma redução de praticamente } 2 / 3 \text { [de } 8,75 \% \text { em } 2011 \text {, o percentual } \\
\text { desses municípios passaria para } 3 \% \text { em 2012] no montante a ser repassado, com o agravante da } \\
\text { inclusão de centenas de outros municípios que possuem city-gates e que passarão a ser } \\
\text { considerados Municípios Afetados." }\end{array}$} & $\begin{array}{l}\text { ABRAMT } \\
\text { (amicus curiae) }\end{array}$ & $\begin{array}{l}\text { Pedido de ingresso } \\
\text { no feito }- \text { p. } 6 .\end{array}$ & $\begin{array}{l}\mathrm{O} \\
\text { Econômico. }\end{array}$ \\
\hline \multicolumn{2}{|r|}{$\begin{array}{l}\text { A Prefeitura Municipal de Tramandaí foi surpreendida com ofício da ANP, informando que o seu } \\
\text { repasse de royalties de junho de } 2013 \text { cairia de } \mathrm{R} \$ 1.615 .449,42 \text { para } \mathrm{R} \$ 580.000,00 \text {. Para } \\
\text { justificar a queda no respectivo repasse, foi dito que a decisão liminar da Ministra Cármem Lúcia } \\
\text { não atingiu a parte da legislação que determina que os pontos de entrega às concessionárias de gás } \\
\text { natural produzido no País serão considerados instalações de embarque e desembarque, para fins de } \\
\text { pagamento de royalties aos Municípios afetados por essas operações. }\end{array}$} & $\begin{array}{l}\text { ABRAMT (amicus } \\
\text { curiae) }\end{array}$ & $\begin{array}{l}\text { Petição - Pedido de } \\
\text { urgência por } \\
\text { desobediência à } \\
\text { medida cautelar }-\mathrm{p} \text {. } \\
1-2\end{array}$ & $\begin{array}{l}\text { O } \\
\text { Econômico e jurídico } \\
\text { (não dogmático). }\end{array}$ \\
\hline \multicolumn{2}{|r|}{$\begin{array}{l}\text { O planejamento estratégico lançado por cada Chefe do Poder Executivo, os programas sociais em } \\
\text { andamento, as obras já iniciadas, as crianças matriculadas em escolas estarão fadadas a um futuro } \\
\text { incerto, com cortes que os membros da Organização terão que fazer em seus orçamentos. } \\
\text { Encontrarão dificuldade, com a vigência imediata da Lei no. 12.734/2012, de arcar com suas folhas } \\
\text { de pagamento, quiçá alcançar os limites de gastos exigidos pela Lei de Responsabilidade Fiscal. } \\
\text { O cenário é tenebroso: os serviços de saúde e educação serão drasticamente reduzidos, e, } \\
\text { inevitavelmente, cidadãos brasileiros terão suas qualidades de vida diminuídas, com a diminuição } \\
\text { dos serviços prestados pelos Poderes Públicos. }\end{array}$} & $\begin{array}{l}\text { OMPETRO (amicus } \\
\text { curiae) }\end{array}$ & $\begin{array}{l}\text { Petição de } \\
\text { habilitação como } \\
\text { amicus curiae - } \mathrm{p} \text {. } \\
\text { 22-23. }\end{array}$ & $\begin{array}{l}\mathrm{O} \\
\text { Econômico }\end{array}$ \\
\hline B11 & \multicolumn{3}{|c|}{ A Lei ${ }^{0}$ 12.734/12 destina percentual superior de royalties e PE aos entes não produtores em relação aos produtores } & $\begin{array}{l}\text { O } \\
\text { Jurídico (não } \\
\text { dogmático) e } \\
\text { econômico. }\end{array}$ \\
\hline $\begin{array}{l}\text { "Dele } \\
\text { petró } \\
\text { feder } \\
\text { "fund } \\
\text { Obse } \\
\text { espec }\end{array}$ & $\begin{array}{l}\text { S se extrai, com relativa facilidade, que as unidades federadas impactadas pela exploração de } \\
\text { eo e gás passarão a receber menos royalties e participações especiais que as unidades } \\
\text { adas que não são impactadas, a quem serão distribuídos os recursos destinados aos chamados } \\
\text { os especiais". } \\
\text { ve-se, a propósito, que já neste ano de } 2013 \text { o percentual de royalties destinados aos "fundos } \\
\text { iais" (42\%) supera o somatório dos percentuais atribuídos aos Estados e Municípios }\end{array}$ & $\begin{array}{l}\text { Governador do } \\
\text { Estado do Espírito } \\
\text { Santo (autor) }\end{array}$ & $\begin{array}{l}\text { Petição inicial. ADI } \\
\text { n }^{0} 4916 / \mathrm{DF}-\text { p. } 12- \\
13 .\end{array}$ & $\begin{array}{l}\text { O } \\
\text { Jurídico (não dogmático) } \\
\text { e econômico. }\end{array}$ \\
\hline
\end{tabular}




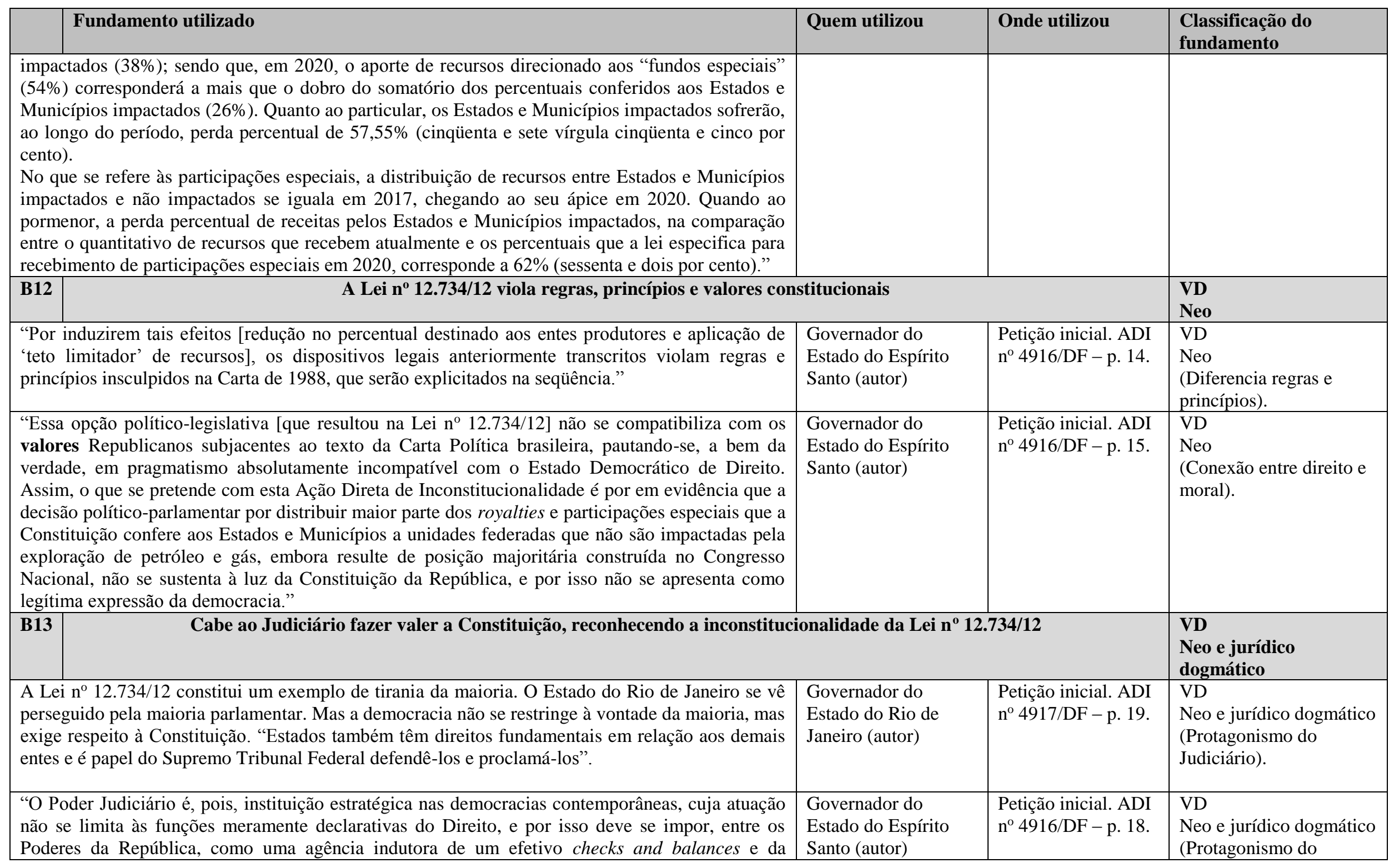




\begin{tabular}{|c|c|c|c|c|}
\hline & Fundamento utilizado & Quem utilizou & Onde utilizou & $\begin{array}{l}\text { Classificação do } \\
\text { fundamento }\end{array}$ \\
\hline \multicolumn{2}{|c|}{ garantia individual e cidadã.". } & & & Judiciário). \\
\hline \multicolumn{2}{|r|}{$\begin{array}{l}\text { A atuação do Judiciário de declarar a inconstitucionalidade das leis não ofende o princípio } \\
\text { democrático, ao contrário, o confirma. Mesmo Alexy, afamado pelo desenvolvimento da teoria do } \\
\text { discurso, designa essa dimensão do princípio democrático como "democracia deliberativa", } \\
\text { dispondo taxativamente que "o princípio do discurso exige a democracia deliberativa". E se } \\
\text { espera que o STF faça valer o texto constitucional. }\end{array}$} & $\begin{array}{l}\text { Governador do } \\
\text { Estado do Espírito } \\
\text { Santo (autor) }\end{array}$ & $\begin{array}{l}\text { Petição inicial. ADI } \\
\text { no 4916/DF - p. 19- } \\
21 .\end{array}$ & $\begin{array}{l}\text { VD } \\
\text { Neo e jurídico dogmático } \\
\text { (protagonismo do } \\
\text { Judiciário e } \\
\text { fundamentação em } \\
\text { princípios abstratos). }\end{array}$ \\
\hline B14 & \multicolumn{3}{|c|}{ A Lei ${ }^{0} 12.734 / 12$ ofende o princípio da supremacia da Constituição } & $\begin{array}{l}\text { VD } \\
\text { Neo }\end{array}$ \\
\hline \multicolumn{2}{|r|}{$\begin{array}{l}\text { A defesa de que o legislador tem liberdade para dispor como bem entende acerca da distribuição } \\
\text { dos royalties, porque o art. } 20, \S 1^{\circ} \text { emprega a expressão "na forma da lei" é incompatível com a } \\
\text { ideia de supremacia da Constituição. "As Cartas Políticas ostentam inequívoca força normativa, } \\
\text { que lhes permite interferir no modo como são produzidos os textos legislativos que conferem } \\
\text { completude aos direitos e deveres estabelecidos em seu corpo. Elas ostentam eficácia normativa, } \\
\text { pois impõem ao exegeta, na análise de quaisquer atos ou relações jurídicas o dever jurídico } \\
\text { irrecusável de interpretá-los na mesma linha e direção aponta o dispositivo constitucional". }\end{array}$} & $\begin{array}{l}\text { Governador do } \\
\text { Estado do Espírito } \\
\text { Santo (autor) }\end{array}$ & $\begin{array}{l}\text { Petição inicial. ADI } \\
\text { n }^{\circ} 4916 / \mathrm{DF} \text { - p. } 77- \\
78 .\end{array}$ & $\begin{array}{l}\text { VD } \\
\text { Neo } \\
\text { (constitucionalização do } \\
\text { direito). }\end{array}$ \\
\hline $\begin{array}{l}\text { "Por } \\
\text { prodi } \\
\text { explc } \\
\text { econ } \\
\text { conce } \\
\text { das } \\
\text { tratar } \\
\text { desti }\end{array}$ & $\begin{array}{l}\text { um e outro argumento, isto é, seja porque os Estados e Municípios produtores e não- } \\
\text { tores não se encontram em situação semelhante frente aos riscos e custos inerentes à } \\
\text { ração petrolífera, pois somente os primeiros são impactados pelo exercício dessa atividade } \\
\text { mica, seja porque a própria Constituição os distinguiu, quanto a esse aspecto, quando } \\
\text { beu, na aliena "b" do inciso X do parágrafo } 2^{\circ} \text { do seu artigo } 155 \text {, imunidade para a tributação } \\
\text { aídas de petróleo e derivados pelos Estados produtores, o legislador não pode atribuir } \\
\text { ento normativo mais vantajoso aos Estados e Municípios não-produtores acerca da } \\
\text { ação da compensação financeira prevista pelo parágrafo } 1^{\circ} \text { do artigo } 20 \text { da mesma Carta }\end{array}$ & $\begin{array}{l}\text { Governador do } \\
\text { Estado do Espírito } \\
\text { Santo (autor) }\end{array}$ & $\begin{array}{l}\text { Petição inicial. ADI } \\
\text { n }^{\circ} 4916 / \mathrm{DF}-\mathrm{p} . \\
100 .\end{array}$ & $\begin{array}{l}\text { O } \\
\text { Jurídico (não dogmático) } \\
\text { e econômico. }\end{array}$ \\
\hline
\end{tabular}




\begin{tabular}{|c|c|c|c|c|}
\hline & Fundamento utilizado & Quem utilizou & Onde utilizou & $\begin{array}{l}\text { Classificação do } \\
\text { fundamento }\end{array}$ \\
\hline \multicolumn{5}{|c|}{$\begin{array}{l}\text { Política, de modo a distribuir-lhes, em maior proporção, receitas financeiras decorrentes do } \\
\text { pagamento de royalties e participações especiais. O que se dá é que, como a verdadeira igualdade } \\
\text { pressupõe o tratamento paritário aos iguais e tratamento diferenciado aos desiguais, a distribuição } \\
\text { de royalties e participações especiais em maior proporção a unidades federadas que não são } \\
\text { impactadas pelo exercício dessa atividade econômica (Estados e Municípios produtores) é também } \\
\text { ofensiva ao princípio da isonomia, de que trata o artigo } 5^{\circ} \text { da Lei Maior" }\end{array}$} \\
\hline B16 & \multicolumn{3}{|c|}{ A Lei n $^{\circ}$ 12.734/12 viola o princípio da solidariedade, que é garantia do equilíbrio federativo } & $\begin{array}{l}\text { O } \\
\text { Federativo. }\end{array}$ \\
\hline B17 & \multicolumn{3}{|c|}{ Os critérios de rateio do FPE e do FPM são inconstitucionais, pois não refletem a realidade socioeconômica dos estados } & $\begin{array}{l}\text { O } \\
\text { Jurídico (não } \\
\text { dogmático) e econômico }\end{array}$ \\
\hline
\end{tabular}




\begin{tabular}{|c|c|c|c|c|}
\hline & Fundamento utilizado & Quem utilizou & Onde utilizou & $\begin{array}{l}\text { Classificação do } \\
\text { fundamento }\end{array}$ \\
\hline \multicolumn{2}{|r|}{$\begin{array}{l}\text { (d) que, em resumo, os critérios que deveriam ser estipulados por lei complementar, visando } \\
\text { a promover o equilibrio socioeconômico entre Estados e entre Municípios, nunca foram } \\
\text { devidamente fixados, no que reside violação ao disposto no inciso II do artigo } 161 \text { da } \\
\text { Constituição. }\end{array}$} & & & \\
\hline \begin{tabular}{l|l|} 
B18 \\
\end{tabular} & \multicolumn{3}{|c|}{$\begin{array}{l}O \text { art. 42-B da Lei } \mathbf{n}^{0} 12.734 / 12 \text { é inconstitucional, pois obrigaria os produtores a renunciarem a direito constitucional previsto no } \\
\text { art. } 20, \$^{\circ} \mathrm{e} \text { fomentaria um conflito federativo. }\end{array}$} & $\begin{array}{l}\text { O Jurídico (não } \\
\text { dogmático) e federativo }\end{array}$ \\
\hline $\begin{array}{l}\text { "28. } \\
\text { Estad } \\
\text { Execu } \\
\text { na me } \\
\text { condi } \\
\text { Além } \\
\text { demai } \\
29 \text {. Cc } \\
\text { Munic } \\
\text { destin } \\
\text { do art }\end{array}$ & $\begin{array}{l}\text { corre que a lei promulgada constituiu fundos especiais para distribuição de recursos entre } \\
\text { os, Distrito Federal e Municípios, art.42-B. Segundo se discutiu no âmbito do Poder } \\
\text { tivo, fixou-se, entre outros, a impossibilidade de que Estados, Distrito Federal e Municípios, } \\
\text { dida em que produtores e confrontantes, ao mesmo tempo, recebessem, royalties nessa } \\
\text { cão dupla, bem como na qualidade de destinatários de recursos de fundo especial específico. } \\
\text { do que, os recursos não distribuídos, por força do acima indicado, seriam direcionados aos } \\
\text { is entes. É desse arranjo que se discordou. } \\
\text { onsequentemente, haveria mecanismo de indução, que obrigaria Estados, Distrito Federal e } \\
\text { cípios, quando como produtores ou confrontantes, simultaneamente ao fato de serem } \\
\text { atários de recursos do respectivo fundo, a renunciar o direito constitucional previsto no } \S 1^{\circ} \\
\text {. } 20 \text { da Constituição.”. }\end{array}$ & União & $\begin{array}{l}\text { Manifestação da } \\
\text { Advocacia Geral da } \\
\text { União - p. } 5 .\end{array}$ & $\begin{array}{l}\text { O Jurídico (não } \\
\text { dogmático). }\end{array}$ \\
\hline
\end{tabular}


TABELA 9 - POSICIONAMENTOS DE JURISTAS E ECONOMISTAS: CONTRA E A FAVOR DA REDISTRIBUIÇÃO DOS ROYALTIES E PE

\begin{tabular}{|c|c|c|c|}
\hline & Título da obra & A favor da redistribuição & Contra a redistribuição \\
\hline \multirow{16}{*}{$\begin{array}{l}\mathbf{E} \\
\mathbf{C} \\
\mathbf{O} \\
\mathbf{N} \\
\mathbf{O} \\
\mathbf{M} \\
\mathbf{I} \\
\mathbf{A}\end{array}$} & $\begin{array}{l}\text { AFONSO, José Roberto Rodrigues; GOBETTI, Sérgio Wulff. Renda do petróleo no Brasil: alguns aspectos } \\
\text { fiscais e federativos. Revista do BNDES, Rio de Janeiro, v. } 15 \text {, n. 30, p. 231-269, dez. } 2008 .\end{array}$ & $\mathrm{X}$ & \\
\hline & DECAT, Erich. A maldição do petróleo. Desafios do desenvolvimento, v. 6, n. 48, p. 56-61, mar. 2009. & $\mathrm{X}$ & \\
\hline & $\begin{array}{l}\text { CARNICELLI, Laur; POSTALI, Fernando Antonio Slaibe. Royalties do petróleo e emprego público nos } \\
\text { municípios brasileiros. Estudos econômicos, São Paulo, v. 44, n. 3, p. 469-495, jul./set. } 2014 \text {. }\end{array}$ & $\mathrm{X}$ & \\
\hline & $\begin{array}{l}\text { SERRA, Rodrigo Valente. O seqüestro das rendas petrolíferas pelo poder local: a gênese das quase sortudas } \\
\text { regiões produtoras. Revista brasileira de estudos urbanos e regionais, v. } 9 \text {, n. 1, p. 101-114, maio } 2007 \text {. }\end{array}$ & $\mathrm{X}$ & \\
\hline & $\begin{array}{l}\text { MESQUITA, Ribamar. Pré-sal: um novo projeto para o Nordeste. Rumos: economia \& desenvolvimento para os } \\
\text { novos tempos, v. } 34 \text {, n. } 248 \text {, p. 40-41, nov./dez. } 2009 .\end{array}$ & $\mathrm{X}$ & \\
\hline & $\begin{array}{l}\text { FREITAS, Paulo Springer de. Rendas do petróleo, questão federativa e instituição de fundo soberano. } \\
\text { Releitura: compilação de textos para discussão, v. 1, n. 1, p. 79-126, jan./jun. } 2010 .\end{array}$ & $\mathrm{X}$ & \\
\hline & $\begin{array}{l}\text { POSTALI, Fernando Antonio Slaibe; NISHIJIMA, Marislei. Distribuição das rendas do petróleo e indicadores } \\
\text { de desenvolvimento municipal no Brasil nos anos 2000. Estudos econômicos, São Paulo, v. 41, n. 2, p. 463-485, } \\
\text { abr./jun. 2011. }\end{array}$ & $\mathrm{X}$ & \\
\hline & $\begin{array}{l}\text { MERCADANTE, Aloizio. Os campos do possível: a oportunidade histórica do pré-sal. Interesse nacional, v. } 1 \text {, } \\
\text { n. 4, p. 30-38, jan./mar. } 2009 .\end{array}$ & $\mathrm{X}$ & \\
\hline & $\begin{array}{l}\text { LIMA, Paulo César Ribeiro. Os “royalties do petróleo”, a Lei no 12.734/2012 e Ação a ser julgada pelo STF. } \\
\text { Disponível em: <http://www.aslegis.org/2013/04/os-royalties-do-petroleo-lei-n.html>. Acesso em } 15 \text { fev. } 2015 .\end{array}$ & $\mathrm{X}$ & \\
\hline & BARROS, Daniel; IKEDA, Patrícia. A festa dos royalties. Exame, v. 46, n. 16, p. 186-193, ago. 2012. & $\mathrm{X}$ & \\
\hline & $\begin{array}{l}\text { MACROPLAN. Royalties do Petróleo e Desenvolvimento Municipal: avaliação e propostas de melhoria. } \\
\text { Relatório Final. Jun. 2012. Disponível em: <http://macroplan.com.br/ Documentos/EstudoMacroplan } \\
\text { 201282717367.pdf>. Acesso em } 22 \text { fev. 2015. }\end{array}$ & $\mathrm{X}$ & \\
\hline & $\begin{array}{l}\text { RIBEIRO, Edivan Guidote; TEIXEIRA, Arilton; GUTIERREZ, Carlos Enrique Carrasco. Impacto dos royalties } \\
\text { do petróleo no PIB per capita dos municípios do Estado do Espírito Santo, Brasil. Revista Brasileira de Gestão } \\
\text { de Negócios. Disponível em: <www.spell.org.br/documentos/download/6586>. Acesso em: } 20 \text { fev. } 15 .^{279} \\
\end{array}$ & $\mathrm{X}$ & \\
\hline & TOTAL: 12 & TOTAL: 12 & TOTAL: 0 \\
\hline & Título da obra & A favor da redistribuição & Contra a redistribuição \\
\hline & $\begin{array}{l}\text { OLIVEIRA, Samuel Cunha de. A distribuição dos royalties do petróleo entre os entes federados: Uma análise } \\
\text { da Lei } \mathrm{n}^{\circ} 12.734 / 2012 \text {. Disponível em: <http://jus.com.br/artigos/27646/a-distribuicao-dos-royalties-do- } \\
\text { petroleo-entre-os-entes-federados/2>. Acesso em: } 15 \text { fev. } 2015 \text {. }\end{array}$ & $\mathrm{X}$ & \\
\hline & FERNANDES, Andressa Guimarães Torquato. Do tratamento constitucional à partilha de royalties: o que nos & $\mathrm{X}$ & \\
\hline
\end{tabular}

${ }^{279} \mathrm{O}$ artigo não investiga se é necessário ou não redistribuir royalties entre os entes da federação, tendo por foco a análise do desenvolvimento dos municípios do Estado do Espírito Santo que recebem royalties. No entanto, verifica que os recursos não propiciaram desenvolvimento, sugerindo a revisão da política pública de royalties no Brasil. 
diz o par. 1 do art. 20 da CF?. Revista tributária e de finanças públicas, v. 21, n. 109, p. 281-297, mar./abr. 2013. ${ }^{280}$

D CAVALCANTI, Caio César Torres. Responsabilidade civil por dano ambiental causado pela atividade

I petrolífera : uma análise a partir do Caso Chevron e da sua repercussão no projeto de distribuição dos royalties

$\mathbf{R}$ do petróleo. Revista Fórum de direito civil, v. 1, n. 1, p. 55-72, set./dez. 2012.

E COÊLHO, Sacha Calmon Navarro. Royalties do petróleo: a lei nova $\mathrm{n}^{\circ}$ 12.734/2012: constitucionalidade.

I Revista brasileira de direito tributário e finanças públicas, v. 7, n. 38, p. 65-82, maio/jun. 2013.

T PAIXÃO Jr., Sebastião Ventura Pereira da. Os royalties, a constituição e o supremo. Consulex: revista jurídica,

O v. 17, n. 394, p. 20-21, jun. 2013.

FARO, Julio Pinheiro. O petróleo é nosso, mas o dinheiro é meu. Consulex: revista jurídica, v. 17, n. 390, p. 55, abr. 2013.

BARROSO, Luís Roberto. Federalismo, isonomia e segurança jurídica: inconstitucionalidade das alterações na distribuição de royalties do petróleo. Disponível em: <http://www.luisrobertobarroso.com.br/wp-

content/themes/LRB/pdf/royalties_do_petroleo.pdf>. Acesso em 15 fev. 2015

ALMEIDA FILHO, Jorge Celso Fleming de. Os royalties do petróleo e a impossibilidade de sua partilha

igualitária entre os entes federativos. Disponível em: <http://www.e-publicacoes.uerj.br/index.php/rfptd/article/ view/5127>. Acesso em 15 fev. 2015.

MADUREIRA, Claudio Penedo. Licitações sustentáveis e royalties de petróleo. Interesse público, v. 16, n. 83,

p. 153-193, jan./fev. 2014.

MADUREIRA, Cláudio. Royalties de petróleo e federação. Belo Horizonte: Fórum, 2012. 157 p.

PATRUS, Rafael Dilly. Nem tanto ao mar nem tanto a terra: a saia-justa das novas regras de distribuição dos royalties e participações especiais devidos pela exploração do petróleo. Fórum administrativo, v. 13, n. 148, p. 62-74, jun. 2013. ${ }^{281}$

TOTAL: 11

Título da obra

I. BROSIO, Giorgio; LOUREIRO, Gustavo Kaercher. Custos e rendas na distribuição federativa dos recursos do pré-sal. Revista de direito público da economia, v. 12, n. 46, p. 79-103, abr./jun. 2014.

E TOTAL: 1

C.

TOTAL DE ARTIGOS PESOUISADOS: 24

\begin{tabular}{|c|c|}
\hline $\mathrm{X}$ & \\
\hline $\mathrm{X}$ & \\
\hline $\mathrm{X}$ & \\
\hline & $X$ \\
\hline & $\mathrm{X}$ \\
\hline & $\mathrm{X}$ \\
\hline & $\mathrm{X}$ \\
\hline & $\mathrm{X}$ \\
\hline & $\mathrm{X}$ \\
\hline TOTAL: 5 & TOTAL: 6 \\
\hline A favor da redistribuição & Contra a redistribuiçãa \\
\hline$X$ & \\
\hline TOTAL: 1 & TOTAL: 0 \\
\hline
\end{tabular}

${ }^{280}$ Não há um posicionamento claro da autora, mas a maioria dos fundamentos utilizados aponta para a necessidade de redistribuição.

${ }^{281}$ Também não apresenta posição clara a respeito da necessidade de redistribuir os royalties, pois o foco do artigo é avaliar o papel do Judiciário na decisão sobre a constitucionalidade da Lei no 12.734/12. No entanto, a autora, ao analisar os fundamentos da decisão, conclui que são adequados e que, portanto, a decisão do Judiciário teria sido a melhor, embora ela apresente risco para a legitimidade democrática e para a estabilidade político-institucional. 


\section{TABELA 10 - FUNDAMENTOS UTILIZADOS POR JURISTAS E ECONOMISTAS FAVORÁVEIS À REDISTRIBUIÇÃO DOS} ROYALTIES E PE

\begin{tabular}{|c|c|c|c|}
\hline & Fundamento utilizado & Referência & \begin{tabular}{|l|}
$\begin{array}{l}\text { Classificação do } \\
\text { fundamento }\end{array}$ \\
\end{tabular} \\
\hline D1 & \multicolumn{2}{|c|}{$\begin{array}{l}\text { A distribuição dos royalties varia de acordo com o local de produção do petróleo, se onshore ou offshore, pois no primeiro caso } \\
\text { ela ocorre no território dos entes subnacionais, enquanto no segundo, se dá em território da União }\end{array}$} & $\begin{array}{l}\text { O } \\
\text { Jurídico (não } \\
\text { dogmático) e } \\
\text { econômico } \\
\end{array}$ \\
\hline \multicolumn{2}{|r|}{$\begin{array}{l}\text { A participação dos entes subnacionais nas rendas do petróleo ocorre de duas } \\
\left.\text { formas: “1 } 1^{\mathrm{a}}\right) \text { privativamente, quando a exploração ocorrer nos respectivos } \\
\text { territórios, e } 2^{\mathrm{a}} \text { ) em igualdade entre eles, quando a exploração ocorrer na } \\
\text { plataforma continental (...) do contrário o uso da expressão 'respectivos } \\
\text { territórios' seria desnecessária”, já que são bens da União o mar territorial e os } \\
\text { recursos naturais da plataforma continental e zona econômica exclusiva. Por } \\
\text { isso a Lei no }{ }^{\circ} 12.734 / 12 \text { é constitucional. }\end{array}$} & $\begin{array}{l}\text { COÊLHO, Sacha Calmon Navarro. Royalties do petróleo: a lei } \\
\text { nova } \mathrm{n}^{\circ} \text { 12.734/2012: constitucionalidade. Revista brasileira } \\
\text { de direito tributário e finanças públicas, v. } 7, \text { n. } 38, \text { p. } 71-72, \\
\text { maio/jun. } 2013 \text {. }\end{array}$ & $\begin{array}{l}\text { O } \\
\text { Jurídico } \\
\text { dogmático). }\end{array}$ \\
\hline \multicolumn{2}{|r|}{$\begin{array}{l}\text { "No caso da produção na plataforma continental, a perda é de todo o País, pois } \\
\text { ocorre em uma área nacional, e não em área estadual ou municipal. Assim, } \\
\text { deve haver uma recomposição da perda a todos os entes federados.". }\end{array}$} & $\begin{array}{l}\text { LIMA, Paulo César Ribeiro. Os “royalties do petróleo”, a Lei } \\
\text { no 12.734/2012 e Ação a ser julgada pelo STF, p. } 7 . \\
\text { Disponível em: <http://www.aslegis.org/2013/04/os-royalties- } \\
\text { do-petroleo-lei-n.html>. Acesso em } 15 \text { fev. 2015. }\end{array}$ & $\begin{array}{l}\text { O } \\
\text { Jurídico (não dogmático) } \\
\text { e econômico. }\end{array}$ \\
\hline \multicolumn{2}{|r|}{$\begin{array}{l}\text { "No caso de exploração offshore, o legislador federal pode - segundo as } \\
\text { diferentes circunstâncias em que ocorre a exploração do recurso natural - } \\
\text { dar às participações governamentais um caráter remuneratório ou } \\
\text { compensatório em favor dos entes subnacionais. No primeiro caso, } \\
\text { distribuirá renda; no segundo, neutralizará certos impactos da indústria (não } \\
\text { cobertos por outros mecanismos à disposição dos entes subnacionais afetados, } \\
\text { tornando-os custos de produção. } \\
\text { (...) a alocação de renda - diferentemente daquela relativa à compensação } \\
\text { financeira - não obedece a um critério específico e fixo de distribuição entre } \\
\text { os diferentes entes subnacionais. Deve, entretanto, e qualquer que seja o } \\
\text { percentual aplicado, ser distribuída de modo igual para todos os entes } \\
\text { subnacionais, tendo em vista a propriedade pública do recurso natural } \\
\text { (petróleo) e as exigências do Federalismo construído pela Constituição de }\end{array}$} & $\begin{array}{l}\text { BROSIO, Giorgio; LOUREIRO, Gustavo Kaercher. Custos e } \\
\text { rendas na distribuição federativa dos recursos do pré-sal. } \\
\text { Revista de direito público da economia, v. 12, n. 46, p. } 99- \\
\text { 100, abr./jun. } 2014 \text {. }\end{array}$ & Oconômico \\
\hline
\end{tabular}

${ }^{282}$ Os fundamentos foram sintetizados, a fim de facilitar a sua compreensão. No entanto, por serem apresentados de diversas formas, entendeu-se relevante trazer exemplos de sua utilização. A classificação em negrito considera todas as categorias envolvidas nos exemplos. 


\begin{tabular}{|c|c|c|c|}
\hline & Fundamento utilizado & Referência & $\begin{array}{l}\text { Classificação do } \\
\text { fundamento }\end{array}$ \\
\hline \multicolumn{2}{|r|}{$\begin{array}{l}1988 . \\
\text { Se acatada a presente proposta, a única alocação de recursos que deve seguir } \\
\text { necessariamente o critério geográfico puro é a distribuição de renda nos casos } \\
\text { de exploração onshore.". }\end{array}$} & & \\
\hline \multicolumn{2}{|r|}{$\begin{array}{l}\text { A origem dos royalties demonstra que, inicialmente, estavam relacionados à } \\
\text { ideia de propriedade do bem explorado, ou seja, à própria gênese do termo }{ }^{283} \text {, } \\
\text { pois os recursos advindos da exploração em terra eram legalmente destinados } \\
\text { aos estados, enquanto que aqueles decorrentes da extração em mar ficavam } \\
\text { apenas com a União. Esse fundamento corrobora a defesa de que, na extração } \\
\text { offshore, ou seja, quando se trata de bem da União, cabe a ela repartir as } \\
\text { receitas, não restando direito subjetivo aos entes confrontantes na manutenção } \\
\text { do atual regime. }\end{array}$} & $\begin{array}{l}\text { AFONSO, José Roberto Rodrigues; GOBETTI, Sérgio Wulff. } \\
\text { Renda do petróleo no Brasil: alguns aspectos fiscais e } \\
\text { federativos. Revista do BNDES, Rio de Janeiro, v. 15, n. 30, p. } \\
\text { 237, dez. 2008. }\end{array}$ & $\begin{array}{l}\text { O } \\
\text { Jurídico (não } \\
\text { dogmático). }\end{array}$ \\
\hline D2 & \multicolumn{2}{|c|}{ O Brasil adotou, em relação aos royalties, o modelo de participação no resultado. } & $\begin{array}{l}\text { O } \\
\text { Jurídico (não } \\
\text { dogmático) }\end{array}$ \\
\hline \multicolumn{2}{|r|}{$\begin{array}{l}\text { A compensação financeira, por seu caráter indenizatório, deve ser limitada ao } \\
\text { valor do dano. Assim, embora a legislação brasileira fale em "compensação", } \\
\text { o que se tem na verdade é apenas o modelo de participação no resultado, já } \\
\text { que além de não haver limite para os royalties, a sua base de cálculo é o } \\
\text { faturamento da União com a atividade petrolífera, e não o valor do dano. Daí } \\
\text { porque a divisão deve ser igualitária. }\end{array}$} & $\begin{array}{l}\text { FERNANDES, Andressa Guimarães Torquato. Do tratamento } \\
\text { constitucional à partilha de royalties: o que nos diz o par. } 1 \text { do } \\
\text { art. } 20 \text { da CF?. Revista tributária e de finanças públicas, v. } \\
21, \text { n. } 109 \text {, p. } 292 \text {, mar./abr. } 2013 \text {. }\end{array}$ & $\begin{array}{l}\text { O } \\
\text { Jurídico (não dogmático) } \\
\text { e econômico. }\end{array}$ \\
\hline D3 & \multicolumn{2}{|c|}{ Não há correspondência entre a destinação dos royalties e a não incidência de ICMS sobre operações com petróleo na origem } & $\begin{array}{l}\text { O } \\
\text { Jurídico (não } \\
\text { dogmático). }\end{array}$ \\
\hline & $\begin{array}{l}\text { verdade, contudo, tal compensação nem mesmo existe. Não faria sentido } \\
\text { amento de royalties a Municípios (mesmo produtores), e nem à União, } \\
\text { dida em que o ICMS é um imposto estadual.”. }\end{array}$ & $\begin{array}{l}\text { OLIVEIRA, Samuel Cunha de. A distribuição dos royalties do } \\
\text { petróleo entre os entes federados: Uma análise da Lei }{ }^{\circ} \\
\text { 12.734/2012. Disponível em: <http://jus.com.br/artigos/ } \\
\text { 27646/a-distribuicao-dos-royalties-do-petroleo-entre-os-entes- } \\
\text { federados/2>. Acesso em: } 15 \text { fev. } 2015 \text {. }\end{array}$ & $\begin{array}{l}\text { O } \\
\text { Jurídico (não } \\
\text { dogmático). }\end{array}$ \\
\hline $\begin{array}{l}\text { "A e } \\
\text { sem }\end{array}$ & $\begin{array}{l}\text { tração do petróleo em alto mar e sua chegada aos terminais portuários - } \\
\text { que haja alteração de domínio da coisa -, quase que totalmente da }\end{array}$ & $\begin{array}{l}\text { COÊLHO, Sacha Calmon Navarro. Royalties do petróleo: a lei } \\
\text { nova n }{ }^{\circ} \text { 12.734/2012: constitucionalidade. Revista brasileira }\end{array}$ & $\begin{array}{l}\text { O } \\
\text { Jurídico (não }\end{array}$ \\
\hline
\end{tabular}

283 “'Os royalties são uma das formas mais antigas de pagamento de direitos e propriedade. A palavra royalty vem do inglês royal, que significa 'da realeza' ou 'relativo ao rei'. Originalmente, era o direito que o rei tinha de receber pagamentos pelo uso de minerais em suas terras. Na literatura econômica, os royalties são comumente tratados como uma forma de renda." (AFONSO, José Roberto Rodrigues; GOBETTI, Sérgio Wulff. Renda do petróleo no Brasil: alguns aspectos fiscais e federativos. Revista do $B N D E S$, Rio de Janeiro, v. 15, n. 30, p. 236, dez. 2008). 


\begin{tabular}{|c|c|c|c|}
\hline & Fundamento utilizado & Referência & $\begin{array}{l}\text { Classificação do } \\
\text { fundamento }\end{array}$ \\
\hline \multicolumn{2}{|r|}{$\begin{array}{l}\text { Petrobras, naturalmente não está sujeita ao ICMS. Aqui não temos imunidade, } \\
\text { mas absoluta ausência de fato gerador, pois, extraído, continua sendo } \\
\text { propriedade da contribuinte que o extraiu. É por essa razão que o petróleo e os } \\
\text { minérios, pelo simples fato de serem extraídos, transportados e estocados não } \\
\text { geram ICMS.". }\end{array}$} & $\begin{array}{l}\text { de direito tributário e finanças públicas, v. } 7, \text { n. 38, p. 80, } \\
\text { maio/jun. } 2013 \text {. }\end{array}$ & dogmático). \\
\hline D4 & \multicolumn{2}{|c|}{ A exploração do petróleo aumenta a arrecadação de tributos, pois estimula o comércio e a prestação de serviços } & \begin{tabular}{|l|}
$\mathbf{O}$ \\
Econômico. \\
\end{tabular} \\
\hline \multicolumn{2}{|r|}{$\begin{array}{l}\text { Embora não incida ICMS nas operaç̃̃es com petróleo, a atividade permite o } \\
\text { aumento da arrecadação, pois os salários e as encomendas da indústria do } \\
\text { petróleo estimulam o comércio, "contribuindo para maior pagamento de } \\
\text { ICMS em atividades não-petrolíferas, e aumentam a procura por serviços, } \\
\text { imóveis e veículos, gerando maior arrecadação de ISS, IPTU e IPVA". Prova } \\
\text { disso é que a cidade de Macaé, onde se instalou a maior base de produção de } \\
\text { petróleo, teve aumento das receitas tributárias per capita (o que não inclui } \\
\text { royalties e PE) em } 463 \% \text {. }\end{array}$} & $\begin{array}{l}\text { FREITAS, Paulo Springer de. Rendas do petróleo, questão } \\
\text { federativa e instituição de fundo soberano. Releitura: } \\
\text { compilação de textos para discussão, v. 1, n. 1, p. 102-103, } \\
\text { jan./jun. } 2010 .\end{array}$ & \begin{tabular}{|l|}
$\mathrm{O}$ \\
Econômico.
\end{tabular} \\
\hline D5 & \multicolumn{2}{|c|}{ Manteve-se o pacto federativo originário no que tange à destinação de royalties para o Estado do Rio de Janeiro } & \begin{tabular}{|l|} 
O \\
Federativo \\
\end{tabular} \\
\hline \multicolumn{2}{|r|}{$\begin{array}{l}\text { "Se, em 1988, o Rio de Janeiro foi tratado como Estado de origem, de fato } \\
\text { deve haver uma compensação para ele, a fim de se manter o pacto federativo } \\
\text { originário. Mantido esse pacto, ao Estado do Rio de Janeiro seria destinado, } \\
\text { no ano de } 2012,1,5 \% \text { do valor da produção ( } 30 \% \text { de royalties de } 5 \% \text { ), o que } \\
\text { corresponde a R\$ } \$ 1,48 \text { bilhão. Esse Estado, contudo, recebeu R } \$ 8,23 \text { bilhões } \\
\text { em } 2012 . \\
\text { O valor de R } \$ 8,23 \text { bilhões corresponde, como já citado, a } 30 \% \text { da parcela do } \\
\text { valor do royalty que representa } 5 \% \text { da produção, acrescido de } 22,5 \% \text { da } \\
\text { parcela que exceder a } 5 \% \text { da produção e acrescido de } 40 \% \text { da participação } \\
\text { especial, em razão da Lei no } 9.478 / 1997 \text {. Dessa forma, o Estado do Rio de } \\
\text { Janeiro recebeu R } \$ 6,75 \text { bilhões a mais do que seria necessário para } \\
\text { compensar a perda de ICMS e garantir o pacto federativo.". }\end{array}$} & $\begin{array}{l}\text { LIMA, Paulo César Ribeiro. Os “royalties do petróleo", a Lei } \\
\text { no 12.734/2012 e Ação a ser julgada pelo STF, p. } 18 . \\
\text { Disponível em: <http://www.aslegis.org/2013/04/os-royalties- } \\
\text { do-petroleo-lei-n.html>. Acesso em } 15 \text { fev. 2015. }\end{array}$ & \begin{tabular}{|l}
$\mathrm{O}$ \\
Federativo
\end{tabular} \\
\hline D6 & \multicolumn{2}{|c|}{ Mudança no quadro fático da exploração de petróleo: descoberta do pré-sal e significativo aumento da produção } & \begin{tabular}{|l|} 
O \\
Econômico
\end{tabular} \\
\hline \multicolumn{2}{|r|}{$\begin{array}{l}\text { A descoberta do pré-sal fez com que o volume de reservas de petróleo } \\
\text { comprovadas saísse de "um patamar de } 14 \text { bilhões de barris para números que, } \\
\text { em um cenário otimista, ultrapassam } 100 \text { bilhões de barris, colocando o Brasil } \\
\text { entre as potências petrolíferas do planeta.". }\end{array}$} & $\begin{array}{l}\text { FREITAS, Paulo Springer de. Rendas do petróleo, questão } \\
\text { federativa e instituição de fundo soberano. Releitura: } \\
\text { compilação de textos para discussão, v. 1, n. 1, p. 79, jan./jun. } \\
2010 . \\
\end{array}$ & $\begin{array}{l}\mathrm{O} \\
\text { Econômico }\end{array}$ \\
\hline \multicolumn{2}{|r|}{ Os testes feitos em uma área de $14.000 \mathrm{~km}^{2}$ permitem inferir que as jazidas } & \begin{tabular}{|l} 
MERCADANTE, Aloizio. Os campos do possível: a \\
\end{tabular} & $\mathrm{O}$ \\
\hline
\end{tabular}




\begin{tabular}{|c|c|c|c|}
\hline & Fundamento utilizado & Referência & \begin{tabular}{|l|} 
Classificação do \\
fundamento
\end{tabular} \\
\hline \multicolumn{2}{|r|}{$\begin{array}{l}\text { podem ter entre } 50 \text { e } 80 \text { bilhões de barris, sendo que a formação do pré-sal } \\
\text { possui uma extensão de mais de } 160.000 \mathrm{~km} \text {. "Levando em conta as } \\
\text { estimativas mais otimistas o Brasil passaria a ter cerca de } 6,5 \% \text { das reservas } \\
\text { mundiais.". }\end{array}$} & $\begin{array}{l}\text { oportunidade histórica do pré-sal. Interesse nacional, v. } 1, \mathrm{n} \text {. } \\
4 \text {, p. 32, jan./mar. } 2009 .\end{array}$ & Econômico \\
\hline \multicolumn{2}{|r|}{$\begin{array}{l}\text { O crescimento de produção do petróleo não tem acompanhado a demanda, o } \\
\text { que leva a crer que haverá valorização do preço do petróleo em nível mundial. }\end{array}$} & $\begin{array}{l}\text { MERCADANTE, Aloizio. Os campos do possível: a } \\
\text { oportunidade histórica do pré-sal. Interesse nacional, v. 1, n. } \\
\text { 4, p. 33-34, jan./mar. 2009. }\end{array}$ & $\begin{array}{l}\text { O } \\
\text { Econômico }\end{array}$ \\
\hline \multicolumn{2}{|r|}{$\begin{array}{l}\text { "Não há estimativa concreta do potencial do pré-sal. Os mais pessimistas } \\
\text { falam em algo entre } 30 \text { bilhões e } 50 \text { bilhões de barris, o que elevaria em cerca } \\
\text { de quatro vezes as reservas do País. Mas há quem diga que esse valor pode ser } \\
\text { seis vezes maior. Segundo o ex-diretor da Agência Nacional do Petróleo } \\
\text { (ANP) Newton Monteiro, o pré-sal pode guardar } 338 \text { bilhões de barris. Caso } \\
\text { esse número se confirme, o Brasil poderá ser o maior detentor de reservas } \\
\text { provadas do mundo. (...) o pré-sal poderá render mais de R } \$ 47 \text { bilhões em } \\
\text { arrecadação de royalties, participação especial e impostos, nos próximos } 50 \\
\text { anos. (...) A necessidade de mudança se torna cada vez mais urgente, visto que } \\
\text { as regras atuais incentivam a concentração das compensações financeiras.". }\end{array}$} & $\begin{array}{l}\text { DECAT, Erich. A maldição do petróleo. Desafios do } \\
\text { desenvolvimento, v. } 6 \text {, n. } 48 \text {, p. } 58 \text {, mar. } 2009 .\end{array}$ & $\begin{array}{l}\mathrm{O} \\
\text { Econômico }\end{array}$ \\
\hline D7 & \multicolumn{2}{|c|}{$\begin{array}{l}\text { Os critérios de distribuição de royalties são inadequados, pois não há correspondência entre os valores distribuídos a título de } \\
\text { royalties e PE e a extensão do risco ou dano causado pela exploração do petróleo }\end{array}$} & $\begin{array}{l}\text { O } \\
\text { Jurídico (não } \\
\text { dogmático), } \\
\text { ambiental e econômico }\end{array}$ \\
\hline $\begin{array}{l}\text { "A L } \\
\text { "con } \\
\text { Estac } \\
\text { espec } \\
\text { oper } \\
\text { ativi } \\
\text { Ness } \\
\text { é a á } \\
\text { com } \\
\text { Estac } \\
\text { Já o } \\
\text { prod } \\
\text { local } \\
\text { Cara }\end{array}$ & $\begin{array}{l}\text { i no } 12.734 / 2012 \text { apresenta alguns problemas. Ela privilegia critérios de } \\
\text { rontação" em vez de critérios de real impacto ou de "afetação". Os } \\
\text { os e Municípios não deveriam receber receitas de royalties e participação } \\
\text { ial por serem confrontantes, mas por serem afetados ou impactados pelas } \\
\text { ções de produção, processamento, transporte e logística, decorrentes da } \\
\text { ade petrolífera na plataforma continental. } \\
\text { contexto, é importante registrar o que ocorre com o campo de Lula, que } \\
\text { ea mais importante da província do Pré-Sal. Apesar de ser confrontante } \\
\text { Estado do Rio de Janeiro, o campo de Lula pouco impacto causa nesse } \\
\text { o. } \\
\text { Estado de São Paulo é bastante afetado, em razão de o gás natural } \\
\text { zido em Lula ser processado em uma unidade de processamento } \\
\text { zada na cidade de Caraguatatuba. Em razão dessa unidade, } \\
\text { uatatuba está recebendo royalties. No entanto, o Estado de São Paulo, }\end{array}$ & $\begin{array}{l}\text { LIMA, Paulo César Ribeiro. Os "royalties do petróleo", a Lei } \\
\text { n }^{\circ} 12.734 / 2012 \text { e Ação a ser julgada pelo STF, p. } 21 . \\
\text { Disponível em: <http://www.aslegis.org/2013/04/os-royalties- } \\
\text { do-petroleo-lei-n.html>. Acesso em } 15 \text { fev. 2015. }\end{array}$ & $\begin{array}{l}\text { O } \\
\text { Jurídico (não } \\
\text { dogmático), econômico } \\
\text { e ambiental. }\end{array}$ \\
\hline
\end{tabular}




\begin{tabular}{|c|c|c|}
\hline Fundamento utilizado & Referência & $\begin{array}{l}\text { Classificação do } \\
\text { fundamento }\end{array}$ \\
\hline \multicolumn{3}{|l|}{$\begin{array}{l}\text { por não ser confrontante, não recebe royalties nem participação especial } \\
\text { decorrentes da produção no campo de Lula.”. }\end{array}$} \\
\hline $\begin{array}{l}\text { Os critérios de distribuição dos royalties decorrentes da exploração offshore } \\
\text { entre os municípios "encerram um notável determinismo físico", pois } \\
\text { contempla aqueles que estão mais próximos dos campos de produção, sem } \\
\text { considerar a efetiva presença das empresas petrolíferas no continente, que é o } \\
\text { fator que efetivamente gera impactos ambientais e econômicos. Por isso, os } \\
\text { municípios mais agraciados pelos royalties são, na verdade, "sortudos". }\end{array}$ & $\begin{array}{l}\text { SERRA, Rodrigo Valente. O seqüestro das rendas petrolíferas } \\
\text { pelo poder local: a gênese das quase sortudas regiões } \\
\text { produtoras. Revista brasileira de estudos urbanos e regionais, } \\
\text { v. } 9, \text { n. } 1 \text {, p. 102-103, maio } 2007 \text {. }\end{array}$ & $\begin{array}{l}\text { O } \\
\text { Jurídico (não } \\
\text { dogmático), econômico } \\
\text { e ambiental. }\end{array}$ \\
\hline $\begin{array}{l}\text { O critério de distribuição utilizado pelo IBGE cria situações esdrúxulas. O } \\
\text { Município de Quissamã, por exemplo, recebe ao ano quase R\$ } 7 \text { mil per } \\
\text { capita de royalties, enquanto que Belford Roxo, um município com graves } \\
\text { problemas sociais decorrentes da exploração do petróleo recebe apenas R\$ } \\
13,00 \text {. Tais distorções fazem com que seja "imprescindível rever os critérios } \\
\text { para a distribuição dos royalties e participações especiais.". }\end{array}$ & $\begin{array}{l}\text { MERCADANTE, Aloizio. Os campos do possível: a } \\
\text { oportunidade histórica do pré-sal. Interesse nacional, v. 1, n. } \\
\text { 4, p. 36, jan./mar. } 2009 \text {. }\end{array}$ & $\begin{array}{l}\mathrm{O} \\
\text { Econômico. }\end{array}$ \\
\hline $\begin{array}{l}\text { "O critério selecionado não necessariamente garante que haverá alguma } \\
\text { atividade direta ou indiretamente relacionada à extração do petróleo." São } \\
\text { citadas como exemplo as cidades de Campos e Macaé. Macaé é a maior } \\
\text { impactada pela atividade petrolífera, pois possui a maior estrutura de apoio à } \\
\text { produção, no entanto Campos é a cidade mais beneficiada pelos royalties. }\end{array}$ & $\begin{array}{l}\text { FREITAS, Paulo Springer de. Rendas do petróleo, questão } \\
\text { federativa e instituição de fundo soberano. Releitura: } \\
\text { compilação de textos para discussão, v. 1, n. 1, p. 87, jan./jun. } \\
2010 \text {. } \\
\text { No mesmo sentido cf. LIMA, Paulo César Ribeiro. Os } \\
\text { "royalties do petróleo", a Lei no } 12.734 / 2012 \text { e Ação a ser } \\
\text { julgada pelo STF, p. } 11-12 \text {. Disponível em: } \\
\text { <http://www.aslegis.org/2013/04/os-royalties-do-petroleo-lei- } \\
\text { n.html>. Acesso em } 15 \text { fev. 2015. }\end{array}$ & $\begin{array}{l}\text { O } \\
\text { Jurídico (não dogmático) } \\
\text { e econômico }\end{array}$ \\
\hline $\begin{array}{l}\text { A distribuição das rendas petrolíferas no Brasil é marcada por um } \\
\text { determinismo físico, o que deve ser mudado. "Deve haver uma maior } \\
\text { democratização no repasse dessas rendas aos municípios, pois o fator local } \\
\text { não deve ser o determinante para isso". }\end{array}$ & $\begin{array}{l}\text { PINTO, Nelson Guilherme Machado; CORONEL, Daniel } \\
\text { Arruda. Se o petróleo é nosso, porque os royalties petrolíferos } \\
\text { beneficiam apenas alguns municípios? Observatorio de la } \\
\text { Economía Latinoamericana, Número } 179,2013 \text {. Disponível } \\
\text { em: <http://www.eumed.net/cursecon/ecolat/br/13/ royalties- } \\
\text { petroleo-brasil.html>. Acesso em } 19 \mathrm{fev} .15 \text {. }\end{array}$ & 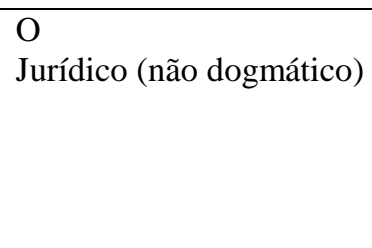 \\
\hline $\begin{array}{l}\text { Não há correspondência entre os valores distribuídos a título de royalties e PE } \\
\text { e a extensão do risco ou dano causado pela exploração do petróleo. O aumento } \\
\text { da produção gerou grande aumento de arrecadação do Estado do Rio de } \\
\text { Janeiro e de alguns de seus municípios, por exemplo, "sem haver qualquer } \\
\text { relação da compensação financeira com as perdas e danos a ela associadas" }\end{array}$ & $\begin{array}{l}\text { LIMA, Paulo César Ribeiro. Os "royalties do petróleo", a Lei } \\
\mathrm{n}^{\mathrm{0}} 12.734 / 2012 \text { e Ação a ser julgada pelo STF, p. } 14 . \\
\text { Disponível em: <http://www.aslegis.org/2013/04/os-royalties- } \\
\text { do-petroleo-lei-n.html>. Acesso em } 15 \text { fev. 2015. }\end{array}$ & $\begin{array}{l}\mathrm{O} \\
\text { Econômico }\end{array}$ \\
\hline Os impactos ambientais causados peli & CAVALCANTI, Caio César Torres. Resp & $\mathrm{O}$ \\
\hline
\end{tabular}




\begin{tabular}{|c|c|c|c|}
\hline & Fundamento utilizado & Referência & $\begin{array}{l}\text { Classificação do } \\
\text { fundamento }\end{array}$ \\
\hline \multicolumn{2}{|r|}{$\begin{array}{l}\text { redistribuição dos recursos. A partir do "caso Chevron" (derramamento de } \\
\text { óleo na Bacia de Campos), sob a ótica da responsabilidade civil, é possível } \\
\text { concluir que os encargos decorrentes da prevenção do dano, bem como a sua } \\
\text { indenização, em caso de ocorrência, compete exclusivamente à empresa que } \\
\text { explora o mineral (a não ser que haja omissão do Poder Público na } \\
\text { fiscalização da atividade, o que é uma exceção e não ocorreu no "caso } \\
\text { Chevron", por exemplo). Por isso, "o critério do risco ambiental, avaliado a } \\
\text { partir do fenômeno jurídico da responsabilidade civil objetiva, não é um } \\
\text { obstáculo para que toda a nação possa ser beneficiada com uma redistribuição } \\
\text { mais igualitária dos royalties." }\end{array}$} & $\begin{array}{l}\text { por dano ambiental causado pela atividade petrolífera : uma } \\
\text { análise a partir do Caso Chevron e da sua repercussão no } \\
\text { projeto de distribuição dos royalties do petróleo. Revista } \\
\text { Fórum de direito civil, v. } 1 \text {, n. 1, p. } 70-71 \text {, set./dez. } 2012 .\end{array}$ & $\begin{array}{l}\text { Jurídico (não dogmático) } \\
\text { e ambiental }\end{array}$ \\
\hline D8 & \multicolumn{2}{|c|}{$\begin{array}{l}\text { A exploração dos royalties offshore não justifica a concentração de royalties, tendo em vista que os danos ambientais e } \\
\text { econômicos causados aos entes confrontantes são mínimos. }\end{array}$} & $\begin{array}{l}\text { O } \\
\text { Ambiental e econômico }\end{array}$ \\
\hline \multicolumn{2}{|r|}{$\begin{array}{l}\text { Os danos ambientais e econômicos "aproximam-se de zero quando a atividade } \\
\text { de extração se dá na plataforma continental, a dezenas (e, com a exploração } \\
\text { do pré-sal, a centenas) de quilômetros da costa". }\end{array}$} & $\begin{array}{l}\text { FREITAS, Paulo Springer de. Rendas do petróleo, questão } \\
\text { federativa e instituição de fundo soberano. Releitura: } \\
\text { compilação de textos para discussão, v. 1, n. 1, p. 121, } \\
\text { jan./jun. } 2010 .\end{array}$ & $\begin{array}{l}\text { O } \\
\text { Ambiental e econômico }\end{array}$ \\
\hline D9 & \multicolumn{2}{|c|}{$\begin{array}{l}\text { O pacto federativo também se fundamenta na solidariedade entre os membros e a distribuição mais equânime dos royalties e PE } \\
\text { diminui as desigualdades regionais e sociais }\end{array}$} & $\begin{array}{l}\text { O } \\
\text { Jurídico (não } \\
\text { dogmático) e federativo }\end{array}$ \\
\hline \multicolumn{2}{|r|}{$\begin{array}{l}\text { Pesquisadores do Ipea constataram que o maior volume das compensações } \\
\text { financeiras é destinado às cidades já consideradas ricas, o que acirra as } \\
\text { desigualdades econômicas. Tal quadro justificaria a redistribuição dos } \\
\text { royalties, a fim de reduzir as desigualdades regionais. }\end{array}$} & $\begin{array}{l}\text { DECAT, Erich. A maldição do petróleo. Desafios do } \\
\text { desenvolvimento, v. } 6 \text {, n. } 48 \text {, p. } 59 \text {, mar. } 2009 .\end{array}$ & O Federativo. \\
\hline \multicolumn{2}{|r|}{$\begin{array}{l}\text { "Se existe uma preocupação em utilizar os recursos do petróleo para reduzir as } \\
\text { disparidades regionais, deveria ser criado um mecanismo de redistribuição } \\
\text { dessas receitas com base na renda per capita de cada ente federativo". }\end{array}$} & $\begin{array}{l}\text { FREITAS, Paulo Springer de. Rendas do petróleo, questão } \\
\text { federativa e instituição de fundo soberano. Releitura: } \\
\text { compilação de textos para discussão, v. } 1 \text {, n. } 1 \text {, p. } 108 \text {, } \\
\text { jan./jun. } 2010 \text {. }\end{array}$ & $\begin{array}{l}\text { O } \\
\text { Federativo. }\end{array}$ \\
\hline \multicolumn{2}{|r|}{$\begin{array}{l}\text { A hiperconcentração dos recursos do petróleo gera disparidades que } \\
\text { desequilibram o pacto federativo, ao contemplar poucos entes. A distorção é } \\
\text { comprovada pelo fato de que, em } 2012 \text {, os Estados confrontantes receberam } \\
\mathrm{R} \$ 10,94 \text { bilhões, enquanto todos os Estados brasileiros, por meio do Fundo } \\
\text { Especial, receberam R } \$ 249 \text { milhões, montante } 44 \text { vezes menor que o dos } \\
\text { Estados confrontantes. }\end{array}$} & $\begin{array}{l}\text { LIMA, Paulo César Ribeiro. Os "royalties do petróleo", a Lei } \\
\mathrm{n}^{\circ} 12.734 / 2012 \text { e Ação a ser julgada pelo STF, p. } 17 . \\
\text { Disponível em: <http://www.aslegis.org/2013/04/os-royalties- } \\
\text { do-petroleo-lei-n.html>. Acesso em } 15 \text { fev. 2015. }\end{array}$ & $\begin{array}{l}\text { O } \\
\text { Federativo }\end{array}$ \\
\hline \multicolumn{2}{|r|}{$\begin{array}{l}\text { "De } 1988 \text { para 2012, a relação entre o que os Estados confrontantes receberam } \\
\text { e o que todos os Estados receberam, por meio do Fundo Especial, aumentou } \\
\text { de } 15 \text { para } 44 \text {. Em suma, apesar de todas as alterações ocorridas no cenário de }\end{array}$} & $\begin{array}{l}\text { LIMA, Paulo César Ribeiro. Os "royalties do petróleo", a Lei } \\
\mathrm{n}^{\circ} 12.734 / 2012 \text { e Ação a ser julgada pelo STF, p. } 17 . \\
\text { Disponível em: <http://www.aslegis.org/2013/04/os-royalties- }\end{array}$ & $\begin{array}{l}\text { O } \\
\text { Federativo }\end{array}$ \\
\hline
\end{tabular}




\begin{tabular}{|c|c|c|}
\hline Fundamento utilizado & Referência & $\begin{array}{l}\text { Classificação do } \\
\text { fundamento }\end{array}$ \\
\hline $\begin{array}{l}\text { produção, em que, gradativamente, reduziu-se o impacto nos entes } \\
\text { confrontantes, essa relação, em vez de diminuir drasticamente, aumentou de } \\
15 \text { para } 44 \text {. } \\
\text { Na verdade, a Lei no } 9.478 / 1997 \text { desequilibrou o pacto federativo ao destinar } \\
40 \% \text { da participação especial para os Estados confrontantes, } 22,5 \% \text { da parcela } \\
\text { que excede } 5 \% \text { dos royalties também para os Estados confrontantes e apenas } \\
7,5 \% \text { dessa parcela ao Fundo Especial e nenhuma parcela da participação } \\
\text { especial a esse Fundo. } \\
\text { (...) } \\
\text { Se, em 1988, o Rio de Janeiro foi tratado como Estado de origem, de fato deve } \\
\text { haver uma compensação para ele, a fim de se manter o pacto federativo } \\
\text { originário. Mantido esse pacto, ao Estado do Rio de Janeiro seria destinado, } \\
\text { no ano de } 2012,1,5 \% \text { do valor da produção (30\% de royalties de } 5 \% \text { ), o que } \\
\text { corresponde a } \mathrm{R} \$ 1,48 \text { bilhão. Esse Estado, contudo, recebeu } \mathrm{R} \$ 8,23 \text { bilhões } \\
\text { em } 2012 \text {. }\end{array}$ & do-petroleo-lei-n.html>. Acesso em 15 fev. 2015. & \\
\hline $\begin{array}{l}\text { Quando os royalties e PE tiverem caráter remuneratório - caso em que devem } \\
\text { ser partilhados de maneira equânime entre os entes federativos -, a sua } \\
\text { eventual distribuição de modo desigual não pode ser respaldada no art. } 20, \S 1^{\circ} \\
\text { da Constituição, mas "terá que ser justificada em outras bases, como o } \\
\text { mandamento constitucional da redução das desigualdades sociais e regionais } \\
\text { (art. } 3^{\circ} \text {, inc. III, da Constituição), por exemplo". }\end{array}$ & $\begin{array}{l}\text { BROSIO, Giorgio; LOUREIRO, Gustavo Kaercher. Custos e } \\
\text { rendas na distribuição federativa dos recursos do pré-sal. } \\
\text { Revista de direito público da economia, v. 12, n. } 46 \text {, p. 101, } \\
\text { abr./jun. 2014. }\end{array}$ & $\begin{array}{l}\text { O } \\
\text { Jurídico (não dogmático) } \\
\text { e federativo. }\end{array}$ \\
\hline \begin{tabular}{l|l} 
D10 & A hiperconcentração de recursos não favorece o desenvolvimento eco
\end{tabular} & nômico dos entes mais beneficiados & $\begin{array}{l}\text { O } \\
\text { Econômico e federativo }\end{array}$ \\
\hline $\begin{array}{l}\text { O grau de dependência de alguns municípios das receitas do petróleo é } \\
\text { tamanha, que já se pode considerar que eles sofrem da "maldição dos recursos } \\
\text { naturais". Dados do FMI apontam que os países ricos em hidrocarbonetos e } \\
\text { minerais têm mais da metade de suas receitas advindas desses recursos, o que } \\
\text { se constata em } 40 \text { entre } 79 \text { municípios examinados no Rio de Janeiro, } \\
\text { conforme a STN e o TCE/RJ. }\end{array}$ & $\begin{array}{l}\text { AFONSO, José Roberto Rodrigues; GOBETTI, Sérgio Wulff. } \\
\text { Renda do petróleo no Brasil: alguns aspectos fiscais e } \\
\text { federativos. Revista do BNDES, Rio de Janeiro, v. 15, n. 30, p. } \\
\text { 243, dez. 2008. Para maiores detalhes, cf. tabela (p. 244) que } \\
\text { expõe a receita tributária per capita dos Municípios, segundo } \\
\text { dependência ou não dos royalties do petróleo. }\end{array}$ & $\begin{array}{l}\text { O } \\
\text { Econômico. }\end{array}$ \\
\hline $\begin{array}{l}\text { A partir de um certo ponto, o aumento da renda per capita provocada pela } \\
\text { distribuição dos royalties e PE do petróleo implicam redução da eficiência } \\
\text { tributária, ou seja, os governos locais tendem a relaxar na arrecadação de } \\
\text { tributos próprios, pois eles não são necessários para o custeio das despesas } \\
\text { municipais. }\end{array}$ & $\begin{array}{l}\text { AFONSO, José Roberto Rodrigues; GOBETTI, Sérgio Wulff. } \\
\text { Renda do petróleo no Brasil: alguns aspectos fiscais e } \\
\text { federativos. Revista do BNDES, Rio de Janeiro, v. } 15 \text {, n. 30, p. } \\
\text { 245-246, dez. 2008. }\end{array}$ & $\begin{array}{l}\mathrm{O} \\
\text { Econômico. }\end{array}$ \\
\hline
\end{tabular}




\begin{tabular}{|c|c|c|}
\hline Fundamento utilizado & Referência & \begin{tabular}{|l|}
$\begin{array}{l}\text { Classificação do } \\
\text { fundamento }\end{array}$ \\
\end{tabular} \\
\hline $\begin{array}{l}\text { Quanto maior a renda per capita com royalties, maior o gasto per capita com } \\
\text { o legislativo municipal (vereadores e funcionários) e com funcionalismo } \\
\text { público de modo geral. Os gastos com pessoal "são mais elevados no grupo } \\
\text { dos cem principais beneficiários dos royalties, ultrapassando em } 33 \% \text { a média } \\
\text { per capital dos demais municípios recebedores desse tipo de compensação } \\
\text { financeira." Entre } 2002 \text { e } 2006 \text {, as despesas desse caráter nos vinte municípios } \\
\text { que mais receberam royalties aumentou } 70,7 \% \text { em valores nominais, o dobro } \\
\text { da inflação verificada no período. Em Campos, por exemplo, o aumento } \\
\text { chegou a } 306,9 \% \text {. }\end{array}$ & $\begin{array}{l}\text { AFONSO, José Roberto Rodrigues; GOBETTI, Sérgio Wulff. } \\
\text { Renda do petróleo no Brasil: alguns aspectos fiscais e } \\
\text { federativos. Revista do BNDES, Rio de Janeiro, v. 15, n. 30, p. } \\
\text { 246-247, dez. 2008. }\end{array}$ & $\begin{array}{l}\text { O } \\
\text { Econômico. }\end{array}$ \\
\hline $\begin{array}{l}\text { "Os gastos com o ensino fundamental são praticamente uniformes em todos os } \\
\text { grupos [municípios produtores e não produtores]. As despesas com atenção } \\
\text { básica em saúde são inferiores entre os recebedores de rendas do petróleo e os } \\
\text { investimentos em gestão ambiental - um dos pilares da argumentação em } \\
\text { favor da concentração dos royalties em um grupo restrito de localidades sob } \\
\text { impacto das atividades petrolíferas - são irrisórios em todas as classes de } \\
\text { municípios. } \\
\text { As evidências reunidas indicam, portanto, que há sobrefinanciamento de } \\
\text { alguns nichos da esfera municipal e que isso não está gerando nem retorno } \\
\text { social à população das localidades impactadas pelas atividades petrolíferas } \\
\text { nem ações preventivas para preparar economicamente essas regiôes para um } \\
\text { futuro sem petróleo. Mais do que isso, pode-se dizer que, em alguns casos } \\
\text { específicos, há fortes indícios de desperdício de recursos públicos". }\end{array}$ & $\begin{array}{l}\text { AFONSO, José Roberto Rodrigues; GOBETTI, Sérgio Wulff. } \\
\text { Renda do petróleo no Brasil: alguns aspectos fiscais e } \\
\text { federativos. Revista do BNDES, Rio de Janeiro, v. 15, n. 30, p. } \\
248 \text {, dez. } 2008 .\end{array}$ & $\begin{array}{l}\mathrm{O} \\
\text { Econômico }\end{array}$ \\
\hline $\begin{array}{l}\text { Carnicelli e Postali, em pesquisa que avalia o gasto dos royalties e PE com } \\
\text { pessoal, concluem que ela "apresenta uma evidência sólida, a partir de uma } \\
\text { metodologia robusta a vários vieses, de que as localidades beneficiadas estão } \\
\text { direcionando os royalties a fins que não condizem com os preceitos } \\
\text { econômicos e legais de bom uso destas riquezas.". }\end{array}$ & $\begin{array}{l}\text { CARNICELLI, Laur; POSTALI, Fernando Antonio Slaibe. } \\
\text { Royalties do petróleo e emprego público nos municípios } \\
\text { brasileiros. Estudos econômicos, São Paulo, v. 44, n. 3, p. } \\
491-492 \text {, jul./set. } 2014 .\end{array}$ & $\begin{array}{l}\mathrm{O} \\
\text { Econômico }\end{array}$ \\
\hline $\begin{array}{l}\text { Freitas avalia os indicadores socioeconômicos dos municípios por grau de } \\
\text { dependência dos royalties e participações especiais advindos do petróleo e } \\
\text { conclui que "não houve diferenças estatisticamente significantes entre os } \\
\text { municípios que dependem fortemente das receitas do petróleo e os demais. } \\
\text { Em relação ao PIB per capita, (...) o desempenho dos municípios dependentes } \\
\text { de petróleo foi inferior à média nacional.". }\end{array}$ & $\begin{array}{l}\text { FREITAS, Paulo Springer de. Rendas do petróleo, questão } \\
\text { federativa e instituição de fundo soberano. Releitura: } \\
\text { compilação de textos para discussão, v. 1, n. 1, p. 97, jan./jun. } \\
2010 .\end{array}$ & $\begin{array}{l}\mathrm{O} \\
\text { Econômico. }\end{array}$ \\
\hline $\begin{array}{l}\text { Postali e Nishijima, ao investigar empiricamente se os royalties contribuem } \\
\text { para a melhoria dos indicadores educação, saúde e emprego e renda dos }\end{array}$ & $\begin{array}{l}\text { POSTALI, Fernando Antonio Slaibe; NISHIJIMA, Marislei. } \\
\text { Distribuição das rendas do petróleo e indicadores de }\end{array}$ & $\begin{array}{l}\text { O } \\
\text { Econômico e federativo }\end{array}$ \\
\hline
\end{tabular}




\begin{tabular}{|c|c|c|}
\hline Fundamento utilizado & Referência & \begin{tabular}{|l}
$\begin{array}{l}\text { Classificação do } \\
\text { fundamento }\end{array}$ \\
\end{tabular} \\
\hline $\begin{array}{l}\text { municípios beneficiados (medidos pelo IFDM - Índice Firjan de } \\
\text { Desenvolvimento Municipal), em relação à média nacional, concluem que } \\
\text { apenas nos anos de } 2005 \text { e } 2006 \text { o indicador relativo à emprego e renda foi } \\
\text { superior nos municípios beneficiários. Para os demais indicadores, as médias } \\
\text { dos municípios petro-rentistas ficaram abaixo das médias dos municípios não } \\
\text { beneficiados com royalties. Quando analisado o indicador como um todo, } \\
\text { verificou-se que embora a abundância de recursos (medida por royalties per } \\
\text { capita) não tenha interferência, "quanto mais dependente de rendas do } \\
\text { petróleo, menor o IFDM do Munićpio em relação à média nacional." O } \\
\text { mesmo ocorre com os indicadores relacionados ao mercado de trabalho } \\
\text { formal: quanto mais dependente de royalties, maior a informalidade das } \\
\text { relações de trabalho. Por isso, sustentam que as regras atuais não parecem } \\
\text { adequadas para promover o desenvolvimento nacional, "de modo que a } \\
\text { revisão das regras de distribuição destas rendas - na esteira da revisão do } \\
\text { marco regulatório do pré-sal - deve fazer parte da agenda política no futuro } \\
\text { próximo." }\end{array}$ & $\begin{array}{l}\text { desenvolvimento municipal no Brasil nos anos 2000. Estudos } \\
\text { econômicos, São Paulo, v. } 41 \text {, n. } 2 \text {, p. } 474,478-483 \text {, abr./jun. } \\
2011 .\end{array}$ & \\
\hline $\begin{array}{l}\text { A cidade de Campos, apesar de líder em volume de repasses, está na posição } \\
445^{\circ} \text { no ranking nacional de desenvolvimento municipal realizado pela } \\
\text { Federação de Indústrias do Estado do Rio de Janeiro, enquanto Quissamã, } \\
\text { também grande beneficiária, está em } 1.290^{\circ} \text { da lista. }\end{array}$ & $\begin{array}{l}\text { DECAT, Erich. A maldição do petróleo. Desafios do } \\
\text { desenvolvimento, v. } 6 \text {, n. } 48 \text {, p. } 59 \text {, mar. } 2009 .\end{array}$ & $\begin{array}{l}\text { O } \\
\text { Econômico. }\end{array}$ \\
\hline $\begin{array}{l}\text { Os municípios de Campos (RJ) e Guamaré (RN), embora destinatários de } \\
\text { parcela significa de royalties e PE, aplicam mal esses recursos. Em Campos, } \\
\text { faltam escolas para as crianças e jovens e as existentes estão em péssima } \\
\text { condiçãa. Tanto que o Î́ndice de Desenvolvimento da Educação Básica em } \\
2010 \text { foi o mais baixo do estado para os primeiros anos do ensino } \\
\text { fundamental. Guamaré é hoje o } 20^{\circ} \text { município brasileiro em renda per capita. } \\
\text { No entanto, há bairros sem água, energia e esgoto. Um quarto da cidade } \\
\text { trabalha para a prefeitura e os analfabetos representam mais de } 1 / 5 \text { (um } \\
\text { quinto) da população. }\end{array}$ & $\begin{array}{l}\text { BARROS, Daniel; IKEDA, Patrícia. A festa dos royalties. } \\
\text { Exame, v. 46, n. 16, p. 186-188, ago. } 2012 .\end{array}$ & $\begin{array}{l}\mathrm{O} \\
\text { Econômico }\end{array}$ \\
\hline Estudo realizado pela consultoria Macroplan que analisou os indicadores & MACROPLAN. Royalties do Petróleo e Desenvol & $\mathrm{O}$ \\
\hline
\end{tabular}




\begin{tabular}{|c|c|c|c|}
\hline & Fundamento utilizado & Referência & $\begin{array}{l}\text { Classificação do } \\
\text { fundamento }\end{array}$ \\
\hline \multicolumn{2}{|r|}{$\begin{array}{l}\text { econômicos, sociais e de finanças públicas das } 25 \text { (vinte e cinco) cidades que } \\
\text { mais receberam royalties entre } 2000 \text { e } 2010^{284} \text {, nos Estados do Rio de Janeiro, } \\
\text { São Paulo e Espírito Santo, concluiu que os recursos não beneficiaram a } \\
\text { maioria da população. } \\
\text { "Isto torna ainda mais urgente a adoção de medidas para redirecionar a } \\
\text { alocação e aprimorar a gestão da aplicação dos recursos com o objetivo de } \\
\text { garantir o dinamismo econômico e o desenvolvimento sustentado das } \\
\text { economias dos entes federativos, em todos os níveis, reduzindo no futuro a } \\
\text { dependência dos royalties. A discussão instaurada sobre a distribuição, a } \\
\text { despeito do seu forte componente político, expõe as fragilidades do modelo } \\
\text { atual, entre outras, a alta concentração geográfica das receitas em poucos } \\
\text { municípios e alocação de recursos com mecanismos de controle deficientes e } \\
\text { de baixa transparência. } \\
\text { Alia-se a isso, o fato de que o recebimento destes recursos, especialmente nos } \\
\text { entes municipais, como demonstrado neste documento, não tem sido } \\
\text { acompanhado de avanços substanciais no desenvolvimento socioeconômico, } \\
\text { nem produzido uma melhoria de qualidade de vida para a população } \\
\text { compatível com o PIB per capita do município.". }\end{array}$} & $\begin{array}{l}\text { Municipal: avaliação e propostas de melhoria. Relatório Final. } \\
\text { Jun. 2012. Disponível em: } \\
\text { <http://macroplan.com.br/Documentos/EstudoMacroplan } \\
\text { 201282717367.pdf>. Acesso em } 22 \text { fev. } 2015 \text {. }\end{array}$ & Econômico e federativo. \\
\hline \multicolumn{2}{|r|}{$\begin{array}{l}\text { "Historicamente observou-se que a receita de royalties vem crescendo, } \\
\text { fortalecendo o papel arrecadador do Estado. Apesar disso, os resultados não } \\
\text { apresentaram evidências de que essa transferência de recursos do setor } \\
\text { privado para o setor público e forma de royalties do petróleo e gás natural } \\
\text { tenha proporcionado um efeito positivo no crescimento econômico dos } \\
\text { municípios do Estado do Espírito Santo, aqui medido pelo PIB per capita } \\
\text { municipal. (...) } \\
\text { Os resultados empíricos sugerem a necessidade de uma reavaliação de política } \\
\text { pública de royalties no Brasil, buscando fundamentação econômica na sua } \\
\text { condução, com o propósito de gerar sustentação financeira entre os entes } \\
\text { federativos quando os recursos naturais se exaurirem.”. }\end{array}$} & $\begin{array}{l}\text { RIBEIRO, Edivan Guidote; TEIXEIRA, Arilton; } \\
\text { GUTIERREZ, Carlos Enrique Carrasco. Impacto dos royalties } \\
\text { do petróleo no PIB per capita dos municípios do Estado do } \\
\text { Espírito Santo, Brasil. Revista Brasileira de Gestão de } \\
\text { Negócios. Disponível em: } \\
\text { <www.spell.org.br/documentos/download/6586>. Acesso em: } \\
20 \text { fev. } 15 \text {. }\end{array}$ & $\begin{array}{l}\mathrm{O} \\
\text { Econômico e federativo. }\end{array}$ \\
\hline D11 & Os royalties e PE devem ser usados em prol de toda a nação e das fut & uras geraçoes, e nao concentrados em poucos & $\begin{array}{l}\text { O } \\
\text { Econômico } \\
\end{array}$ \\
\hline
\end{tabular}

${ }^{284} \mathrm{O}$ PIB per capita é maior nessas cidades se comparados ao Brasil e aos seus Estados. Em alguns casos, seu valor chega a ser de cinco a mais de dez vezes o nacional (MACROPLAN. Royalties do Petróleo e Desenvolvimento Municipal: avaliação e propostas de melhoria. Relatório Final. Jun. 2012. Disponível em: <http://macroplan.com.br/Documentos/EstudoMacroplan 201282717367.pdf〉. Acesso em 22 fev. 2015). 


\begin{tabular}{|c|c|c|c|}
\hline & Fundamento utilizado & Referência & $\begin{array}{l}\text { Classificação do } \\
\text { fundamento }\end{array}$ \\
\hline \multicolumn{2}{|r|}{$\begin{array}{l}\text { Os critérios de distribuição de royalties vigentes "não atendem a qualquer } \\
\text { objetivo de justiça intergeracional e geram um excesso de recursos em alguns } \\
\text { governos locais, que induz desperdício e ineficieincia". Os recursos são mal } \\
\text { aplicados e não revertem em benefícios para a sociedade ou para as futuras } \\
\text { gerações. "Em vez disso, o futuro está sendo hipotecado em nome de um } \\
\text { equilíbrio financeiro presente, tanto no caso federal quanto no dos estados que } \\
\text { anteciparam as receitas dos anos vindouros para abater suas dívidas com a } \\
\text { União.". (...) } \\
\text { "O ideal seria construir uma solução nacional. Que os recursos fossem } \\
\text { pplicados de forma a atender ao conjunto da sociedade. Que não fossem vistos } \\
\text { como pertencentes a uma só esfera de governo (...). A riqueza precisa } \\
\text { pertencer à Federação, e não a parte ou a cada um de seus membros.". }\end{array}$} & $\begin{array}{l}\text { AFONSO, José Roberto Rodrigues; GOBETTI, Sérgio Wulff. } \\
\text { Renda do petróleo no Brasil: alguns aspectos fiscais e } \\
\text { federativos. Revista do BNDES, Rio de Janeiro, v. } 15 \text {, n. 30, p. } \\
231,250 \text { e 263-264, dez. } 2008 \text {. }\end{array}$ & $\begin{array}{l}\text { O } \\
\text { Econômico e Federativo }\end{array}$ \\
\hline \multicolumn{2}{|r|}{$\begin{array}{l}\text { Ainda temos três grandes entraves que nos impedem de alçar voos maiores no } \\
\text { desenvolvimento sustentado: O entrave da educação de baixa qualidade, que } \\
\text { repercute na ausência de inovação e pesquisa mais robustas, o entrave da } \\
\text { infra-estrutura e logística precárias, que inibe investimentos e eleva custos, e o } \\
\text { entrave da desigualdade social que, apesar dos avanços recentes, limita o } \\
\text { dinamismo do mercado interno e gera tensões sociais e políticas. } \\
\text { É aí que o petróleo recém-descoberto pode fazer diferença. Grande diferença. } \\
\text { Se os recursos do pré-sal forem bem investidos e distribuídos com objetivo } \\
\text { estratégico de superar esses obstáculos, o Brasil poderá acelerar o tempo } \\
\text { histórico do seu crescimento dar grande salto de qualidade no } \\
\text { desenvolvimento econômico e social. }\end{array}$} & $\begin{array}{l}\text { MERCADANTE, Aloizio. Os campos do possível: a } \\
\text { oportunidade histórica do pré-sal. Interesse nacional, v. 1, n. } \\
4, \text { p. 38, jan./mar. } 2009 \text {. }\end{array}$ & $\begin{array}{l}\text { O } \\
\text { Econômico }\end{array}$ \\
\hline D12 & \multicolumn{2}{|c|}{ 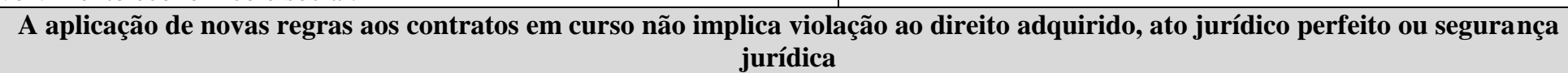 } & $\begin{array}{l}\text { VD } \\
\text { Jurídico (dogmático) }\end{array}$ \\
\hline \multicolumn{2}{|r|}{$\begin{array}{l}\text { "No que diz respeito à distribuição dos royalties e participação especial, esses } \\
\text { contratos não são atos jurídicos perfeitos, pois seu objeto não é regular essa } \\
\text { distribuição. Dessa forma, não há que falar em quebra de contrato se o } \\
\text { Congresso Nacional decidir alterar a legislação relativa aos critérios para } \\
\text { distribuição dos royalties e participação especial entre Estados, Distrito } \\
\text { Federal, Municípios e União. } \\
\text { Assim sendo, não há que falar em direito adquirido por Estados e Municípios } \\
\text { a receitas em razão dos contratos já celebrados entre a ANP e as empresas } \\
\text { contratadas. Eles têm apenas expectativa de direito com base na lei em vigor." }\end{array}$} & $\begin{array}{l}\text { LIMA, Paulo César Ribeiro. Os "royalties do petróleo", a Lei } \\
\mathrm{n}^{\circ} 12.734 / 2012 \text { e Ação a ser julgada pelo STF, p. } 5 . \\
\text { Disponível em: <http://www.aslegis.org/2013/04/os-royalties- } \\
\text { do-petroleo-lei-n.html>. Acesso em } 15 \text { fev. 2015. }\end{array}$ & VD \\
\hline D13 & \multicolumn{2}{|c|}{$\begin{array}{l}\text { A aplicação imediata das novas regras de distribuição não geraria impactos significativos nas receitas dos entes produtores e } \\
\text { confrontantes }\end{array}$} & \\
\hline
\end{tabular}




\begin{tabular}{|c|c|c|c|}
\hline & Fundamento utilizado & Referência & $\begin{array}{l}\text { Classificação do } \\
\text { fundamento }\end{array}$ \\
\hline \multicolumn{2}{|r|}{$\begin{array}{l}\text { A aplicação imediata da lei não geraria grandes impactos no orçamento dos } \\
\text { estados confrontantes. Apesar de o Rio de Janeiro ser o maior beneficiário dos } \\
\text { royalties (cerca de } 85 \% \text { dos valores destinados aos estados) e o mais } \\
\text { dependente desses recursos entre os estados, "por possuir uma economia mais } \\
\text { diversificada, as receitas do petróleo contribuíram com somente } 12 \% \text { da } \\
\text { receita corrente líquida no ano de } 2007 \text { ". Para os demais estados esse } \\
\text { percentual é inferior a 5\%. }\end{array}$} & $\begin{array}{l}\text { FREITAS, Paulo Springer de. Rendas do petróleo, questão } \\
\text { federativa e instituição de fundo soberano. Releitura: } \\
\text { compilação de textos para discussão, v. 1, n. 1, p. } 93 \text {, jan./jun. } \\
2010 .\end{array}$ & $\begin{array}{l}\text { O } \\
\text { Econômico. }\end{array}$ \\
\hline D14 & \multicolumn{2}{|c|}{$\begin{array}{c}\text { A diminuição do percentual de royalties destinados aos entes produtores, previsto na Lei } \text { n }^{0} 12.734 / 12 \text {, será compensada com o } \\
\text { aumento da produção }\end{array}$} & $\begin{array}{l}\text { O } \\
\text { Jurídico (não } \\
\text { dogmático) e } \\
\text { econômico }\end{array}$ \\
\hline $\begin{array}{l}\text { Mesn } \\
\text { confr } \\
\text { produ } \\
\text { propc } \\
\text { da in }\end{array}$ & $\begin{array}{l}\text { o com a aplicação dos novos critérios, os entes produtores e } \\
\text { ntantes "ainda terão uma parcela própria, que, com o aumento da } \\
\text { ção, representará valor substancial, apto a provê-los de condições para } \\
\text { rcionar a infraestrutura que seja eventualmente necessária às atividades } \\
\text { ústria petrolífera.". }\end{array}$ & $\begin{array}{l}\text { OLIVEIRA, Samuel Cunha de. A distribuição dos royalties do } \\
\text { petróleo entre os entes federados: Uma análise da Lei } \mathrm{n}^{\circ} \\
\text { 12.734/2012. Disponível em: } \\
\text { <http://jus.com.br/artigos/27646/a-distribuicao-dos-royalties- } \\
\text { do-petroleo-entre-os-entes-federados/2>. Acesso em: } 15 \text { fev. } \\
2015 \text {. }\end{array}$ & $\begin{array}{l}\text { O } \\
\text { Jurídico (não dogmático) } \\
\text { e econômico. }\end{array}$ \\
\hline
\end{tabular}




\section{TABELA 11 - FUNDAMENTOS UTILIZADOS POR JURISTAS E ECONOMISTAS CONTRÁRIOS À REDISTRIBUIÇÃO DOS} ROYALTIES E PE

\begin{tabular}{|c|c|c|c|}
\hline & Fundamento utilizado & Onde utilizou (referência) & \begin{tabular}{|l|}
$\begin{array}{l}\text { Classificação do } \\
\text { fundamento }\end{array}$ \\
\end{tabular} \\
\hline C1 & \multicolumn{2}{|c|}{$\begin{array}{l}\mathrm{O} \text { art. } 20, \$ 1^{0} \text { da Constituição estabelece o direito subjetivo de os estados e municípios produtores e confrontantes } \\
\text { receberem royalties e PE, conforme interpretação gramatical e teleológica do dispositivo }\end{array}$} & \begin{tabular}{|l|} 
VD \\
Jurídico dogmático $^{285}$.
\end{tabular} \\
\hline \multicolumn{2}{|c|}{$\begin{array}{l}\text { "Em suma: a interpretação gramatical ou semântica restringe os direitos previstos } \\
\text { no art. } 20, \S 1^{\circ} \text { aos Estados e Municípios cujos territórios são afetados pela } \\
\text { exploração de petróleo ou gás natural. Trata-se de verdadeiro direito subjetivo } \\
\text { constitucional ao recebimento de tais receitas. A lei destinada a regulamentar o } \\
\text { dispositivo constitucional não pode ignorar esse sentido mínimo do texto, sob } \\
\text { pena de nulidade. Assim, a lei federal é necessária para detalhar a repartição dos } \\
\text { recursos, mas deve obedecer à premissa estabelecida pela própria Constituição.". }\end{array}$} & $\begin{array}{l}\text { BARROSO, Luís Roberto. Federalismo, isonomia e } \\
\text { segurança jurídica: inconstitucionalidade das alterações } \\
\text { na distribuição de royalties do petróleo, p. 6. Disponível } \\
\text { em: <http://www.luisrobertobarroso. com.br/wp- } \\
\text { content/themes/LRB/pdf/royalties_do_petroleo.pdf>. } \\
\text { Acesso em } 15 \text { fev. 2015. }\end{array}$ & $\begin{array}{l}\text { VD } \\
\text { Jurídico dogmático. }\end{array}$ \\
\hline \multicolumn{2}{|c|}{$\begin{array}{l}\text { "Cumpre abordar a interpretação teleológica, que leva em conta, sobretudo, os } \\
\text { fins visados pela norma, o valor ou bem jurídico tutelado pelo ordenamento. } \\
\text { Veja-se bem: o propósito subjacente ao art. } 20, \S 1^{\circ} \text {, como todo modelo de } \\
\text { pagamento de royalties, está associado a compensar Estados e Municípios pelos } \\
\text { impactos ambientais e socioeconômicos causados ou potencializados pela } \\
\text { atividade petrolífera. Tal fim constitucional resulta frustrado pelo rateio linear do } \\
\text { produto dos royalties, sem considerar os riscos e encargos dos Estados } \\
\text { confrontantes da exploração marítima do petróleo.". }\end{array}$} & $\begin{array}{l}\text { BARROSO, Luís Roberto. Federalismo, isonomia e } \\
\text { segurança jurídica: inconstitucionalidade das alterações } \\
\text { na distribuição de royalties do petróleo, p. 16-17. } \\
\text { Disponível em: <http://www.luisrobertobarroso.com.br/ } \\
\text { wp-content/themes/LRB/pdf/royalties_do_petroleo.pdf>. } \\
\text { Acesso em } 15 \text { fev. } 2015 \text {. }\end{array}$ & $\begin{array}{l}\text { VD } \\
\text { Jurídico dogmático. }\end{array}$ \\
\hline $\mathrm{C2}$ & \multicolumn{2}{|c|}{ Os royalties sempre tiveram finalidade compensatória, desde a sua origem } & $\begin{array}{l}\text { VD } \\
\text { Jurídico historicista. }\end{array}$ \\
\hline \multicolumn{2}{|c|}{$\begin{array}{l}\text { "Já a interpretação histórica leva em conta a conjuntura em que produzida a } \\
\text { norma, os trabalhos legislativos e a intenção do constituinte ou legislador. } \\
\text { Quando o constituinte de } 1988 \text { decidiu trazer para a Constituição a matriz da } \\
\text { disciplina dos royalties, eles já eram tratados pela legislação ordinária desde } \\
\text { 1953, quando promulgada a lei de criação da Petrobras. E, como se assinalou em } \\
\text { tópico anterior, desde sempre os royalties se destinaram a compensar os Estados } \\
\text { produtores e confrontantes, no caso de exploração marítima. Ao } \\
\text { constitucionalizar a matéria, da forma como fez, o constituinte claramente } \\
\text { manifestou a intenção de manter o regime jurídico até então existente. Do } \\
\text { contrário, teria feito menção expressa de que as participações e compensações } \\
\text { passariam a ser devidas a todos os Estados e Municípios, diferentemente do que }\end{array}$} & 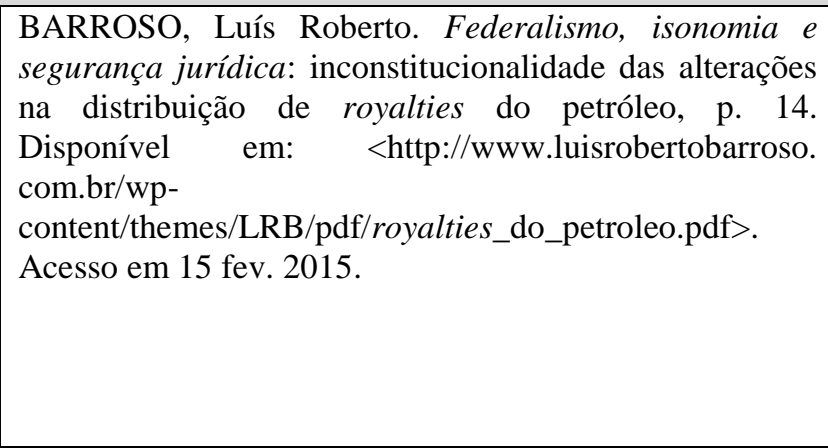 & $\begin{array}{l}\text { VD } \\
\text { Jurídico historicista. }\end{array}$ \\
\hline
\end{tabular}

${ }^{285}$ Os fundamentos foram sintetizados, a fim de facilitar a sua compreensão. No entanto, por serem apresentados de diversas formas, entendeu-se relevante trazer exemplos de sua utilização. A classificação em negrito considera todas as categorias envolvidas nos exemplos. 


\begin{tabular}{|c|c|c|c|}
\hline & Fundamento utilizado & Onde utilizou (referência) & $\begin{array}{l}\text { Classificação do } \\
\text { fundamento }\end{array}$ \\
\hline \multicolumn{4}{|c|}{$\begin{array}{l}\text { vigorara até então. Como não procedeu assim, resulta clara a sua intenção de } \\
\text { chancelar o modelo que sempre fora praticado e que, aliás, continuou a ser } \\
\text { praticado nos mais de } 20 \text { anos de vigência da Constituição de } 1988 . " \text {. }\end{array}$} \\
\hline $\mathbf{C 3}$ & \multicolumn{2}{|c|}{ A exploração do petróleo gera impactos econômicos e ambientais que necessitam ser compensados } & $\begin{array}{l}\text { O } \\
\text { Econômico e ambiental. }\end{array}$ \\
\hline $\begin{array}{l}\text { A at } \\
\text { ativic } \\
\text { natur } \\
\text { prote } \\
\text { eleva } \\
\text { áreas } \\
\text { por } r \\
\text { que } \\
\text { afeta } \\
\text { mate }\end{array}$ & $\begin{array}{l}\text { ade petrolífera gera "aumento da demanda por serviços públicos e } \\
\text { s governamentais, como distribuição de água, energia elétrica e gás } \\
\text { segurança pública, transportes, habitação, urbanismo, defesa civil, } \\
\text { ao meio ambiente, dentre outros. Da mesma forma, são evidentes os } \\
\text { impactos e riscos ambientais impostos aos Estados confrontantes às } \\
\text { produção - sua existência e gravidade foram tristemente demonstradas } \\
\text { te acidente de grandes proporções, ocorrido no Golfo do México. Para } \\
\text { nha uma dimensão do problema: estima-se que um vazamento similar } \\
\text { a costa do Rio de Janeiro em apenas dois dias, gerando prejuízos } \\
\text { e imateriais incalculáveis.". }\end{array}$ & $\begin{array}{l}\text { BARROSO, Luís Roberto. Federalismo, isonomia e } \\
\text { segurança jurídica: inconstitucionalidade das alterações } \\
\text { na distribuição de royalties do petróleo, p. } 17 . \\
\text { Disponível em: <http://www.luisroberto } \\
\text { barroso.com.br/wp- } \\
\text { content/themes/LRB/pdf/royalties_do_petroleo.pdf>. } \\
\text { Acesso em } 15 \text { fev. } 2015 \text {. }\end{array}$ & $\begin{array}{l}\text { O } \\
\text { Econômico e ambiental. }\end{array}$ \\
\hline $\begin{array}{l}\text { São r } \\
\text { Citan } \\
\text { empr } \\
\text { aume } \\
\text { popu }\end{array}$ & $\begin{array}{l}\text { ifestos os impactos da exploração do petróleo sobre o ambiente local. } \\
\text { como exemplos os acidentes ambientais, como aquele provocado pela } \\
\text { Chevron na Bacia de Campos e o ocorrido no Golfo do México, o } \\
\text { do gasto público com infraestrutura local e serviços e o inchaço } \\
\text { onal. }\end{array}$ & $\begin{array}{l}\text { MADUREIRA, Claudio. Licitações sustentáveis e } \\
\text { royalties de petróleo. Interesse público, v. 16, n. 83, p. } \\
162-170 \text {, jan./fev. } 2014 .\end{array}$ & $\begin{array}{l}\text { O } \\
\text { Econômico e ambiental. }\end{array}$ \\
\hline $\begin{array}{l}\text { Estuc } \\
\text { litorâ } \\
\text { impli } \\
\text { favel } \\
\text { tamb } \\
\text { infra } \\
\text { empr } \\
\text { para } \\
\text { espec } \\
\text { muni } \\
\text { traba }\end{array}$ & $\begin{array}{l}\text { realizados sobre os impactos dessa atividade nas regiões das baixadas } \\
\text { s e do norte fluminense demonstram que a exploração do petróleo } \\
\text { crescimento populacional, com consequente aumento do custo de vida, } \\
\text { ão, invasões e loteamentos clandestinos. O fluxo migratório diário } \\
\text { é intenso, pressionando os transportes, o setor de habitação e de } \\
\text { atura. O fato é que embora o setor seja responsável pela criação de } \\
\text { s, que beneficiam também a população local, "os melhores empregos vão } \\
\text { amigos dos executivos das empresas" e "mesmo para funções de baixa } \\
\text { zação a população macaense sofre concorrência do pessoal de vários } \\
\text { os vizinhos". A isso se deve um fluxo diário aproximado de } 20.000 \\
\text { lores e visitantes. }\end{array}$ & $\begin{array}{l}\text { CASTRO, Antonio O. Impactos Sociais do } \\
\text { Desenvolvimento da Atividade de Exploraçãa e e } \\
\text { Produção de Petróleo nas Regiôes das Baixadas } \\
\text { Litorâneas e do Norte Fluminense. Projeto CTPETRO: } \\
\text { Tendências Tecnológicas. p. 7, 11-12. Disponível em: } \\
\text { <www.cgee.org.br/atividades/redirKori/461>. Acesso } \\
\text { em } 1^{\circ} \text { mar. 2015. }\end{array}$ & $\begin{array}{l}\mathrm{O} \\
\text { Econômico }\end{array}$ \\
\hline $\begin{array}{l}\text { A mi } \\
\text { recur } \\
\text { grave }\end{array}$ & $\begin{array}{l}\text { tude dos empreendimentos relacionados à exploração do petróleo exige } \\
\text { financeiros, obras para a sua implantação que, muitas vezes, geram } \\
\text { esequilíbrios ecológicos nas regiões em que se localizam. }\end{array}$ & $\begin{array}{l}\text { CASTRO, Antonio O. Impactos Sociais do } \\
\text { Desenvolvimento da Atividade de Exploraçãa e e } \\
\text { Produçâa de Petróleo nas Regiôes das Baixadas } \\
\text { Litorâneas e do Norte Fluminense. Projeto CTPETRO: } \\
\text { Tendências Tecnológicas. p. 18. Disponível em: }\end{array}$ & $\begin{array}{l}\mathrm{O} \\
\text { Ambiental }\end{array}$ \\
\hline
\end{tabular}




\begin{tabular}{|c|c|c|c|}
\hline & Fundamento utilizado & Onde utilizou (referência) & $\begin{array}{l}\text { Classificação do } \\
\text { fundamento }\end{array}$ \\
\hline & & $\begin{array}{l}\text { <www.cgee.org.br/atividades/redirKori/461>. } \\
\mathrm{em} 1^{\circ} \text { mar. } 2015 .\end{array}$ & \\
\hline $\mathbf{C 4}$ & \multicolumn{2}{|c|}{$\begin{array}{l}\text { Os royalties foram destinados aos estados e municípios produtores/confrontantes por conta da não incidência de ICMS } \\
\text { sobre operacões com petróleo na origem }\end{array}$} & $\begin{array}{l}\text { O } \\
\text { Federativo }\end{array}$ \\
\hline \multicolumn{2}{|c|}{$\begin{array}{l}\text { "A mudança pretendida viola a igualdade e o equilíbrio federativo estabelecido } \\
\text { pela Constituição ainda por outra razão. Na sistemática constitucional, o } \\
\text { pagamento de royalties e participações especiais aos Estados produtores funciona } \\
\text { como uma compensação pela não-aplicação, ao petróleo, da regra geral de que o } \\
\text { recolhimento do ICMS se dá no Estado de origem, e não no de destino da } \\
\text { mercadoria. Se os Estados produtores, que têm de suportar os ônus do impacto da } \\
\text { exploração petrolífera, ficarem sem o ICMS e sem os royalties, estarão sofrendo } \\
\text { discriminação incompatível com a Constituição. O legislador ordinário não pode } \\
\text { desfigurar o desenho institucional traçado pelo constituinte." }\end{array}$} & $\begin{array}{l}\text { BARROSO, Luís Roberto. Federalismo, isonomia e } \\
\text { segurança jurídica: inconstitucionalidade das alterações } \\
\text { na distribuição de royalties do petróleo, p. } 32-33 \text {. } \\
\text { Disponível em: <http://www.luisroberto } \\
\text { barroso.com.br/wp- } \\
\text { content/themes/LRB/pdf/royalties_do_petroleo.pdf>. } \\
\text { Acesso em } 15 \text { fev. } 2015 \text {. }\end{array}$ & $\begin{array}{l}\text { O } \\
\text { Federativo }\end{array}$ \\
\hline \multicolumn{2}{|c|}{$\begin{array}{l}\text { A compensação financeira de que trata o art. } 20, \S 1^{\circ} \text { faz parte "de um pacto } \\
\text { federativo mais complexo, o qual compreende variáveis múltiplas, dentre as quais } \\
\text { o previsto no art. } 155, \S 2^{\circ} \text {, inciso } \mathrm{X} \text {, alínea b - concernente à imunidade do ICMS } \\
\text { sobre operações que destinem petróleo a outros Estados". }\end{array}$} & $\begin{array}{l}\text { PATRUS, Rafael Dilly. Nem tanto ao mar nem tanto a } \\
\text { terra: a saia-justa das novas regras de distribuição dos } \\
\text { royalties e participações especiais devidos pela } \\
\text { exploração do petróleo. Fórum administrativo, v. } 13 \text {, n. } \\
148, \text { p. } 63-64 \text {, jun. } 2013 \text {. }\end{array}$ & $\begin{array}{l}\mathrm{O} \\
\text { Federativo }\end{array}$ \\
\hline $\mathbf{C 5}$ & \multicolumn{2}{|c|}{ A distribuição igualitária dos royalties viola regra e princípios constitucionais } & $\begin{array}{l}\text { VD } \\
\text { Neo }\end{array}$ \\
\hline \multicolumn{2}{|c|}{$\begin{array}{l}\text { "O critério de distribuição igualitária dos royalties é inconstitucional, pois viola a } \\
\text { um só tempo uma regra e três princípios constitucionais: (i) o desenho } \\
\text { constitucional de compensação entre o ICMS nas operações interestaduais e os } \\
\text { royalties; (ii) o princípio da conduta amistosa federativa; (iii) a face material do } \\
\text { princípio da isonomia; (iv) o princípio da segurança jurídica em sua dupla } \\
\text { dimensão.". }\end{array}$} & $\begin{array}{l}\text { ALMEIDA FILHO, Jorge Celso Fleming de. Os royalties } \\
\text { do petróleo e a impossibilidade de sua partilha } \\
\text { igualitária entre os entes federativos, p. 1. Disponível } \\
\text { em: <http://www.e-publicacoes. uerj.br/index.php/ } \\
\operatorname{rfptd} / \text { article/view/5127>. Acesso em } 15 \text { fev. } 2015 \text {. }\end{array}$ & $\begin{array}{l}\text { VD } \\
\text { Neo } \\
\text { (Fundamentação em } \\
\text { princípios e diferenciação } \\
\text { entre regras e princípios). }\end{array}$ \\
\hline C6 & \multicolumn{2}{|c|}{ A alteração dos critérios de partilha afeta o equilíbrio orçamentário dos estados e municípios atualmente privilegiados } & $\begin{array}{l}\text { O } \\
\text { Jurídico (não dogmático) } \\
\text { e econômico. }\end{array}$ \\
\hline \multicolumn{2}{|c|}{$\begin{array}{l}\text { "Além dos riscos de inadimplência e de insolvência, o Estado não terá condições } \\
\text { de cumprir normas orçamentárias, financeiras e de responsabilidade fiscal, em } \\
\text { razão da frustração arbitrária dos ingressos patrimoniais resultantes dos royalties, } \\
\text { sujeitando-se a consequências jurídicas graves do ponto de vista constitucional e } \\
\text { legal.". }\end{array}$} & $\begin{array}{l}\text { BARROSO, Luís Roberto. Federalismo, isonomia e } \\
\text { segurança jurídica: inconstitucionalidade das alterações } \\
\text { na distribuição de royalties do petróleo, p. } 33 \text {. } \\
\text { Disponível em: <http://www.luisroberto } \\
\text { barroso.com.br/wp-content/themes/LRB/pdf/royalties_ } \\
\text { do_petroleo.pdf }>\text {. Acesso em } 15 \text { fev. } 2015 \text {. }\end{array}$ & $\begin{array}{l}\text { O Jurídico (não dogmático) e } \\
\text { econômico. }\end{array}$ \\
\hline
\end{tabular}




\begin{tabular}{|c|c|c|c|}
\hline & Fundamento utilizado & Onde utilizou (referência) & $\begin{array}{l}\text { Classificação do } \\
\text { fundamento }\end{array}$ \\
\hline C7 & \multicolumn{2}{|c|}{ A redistribuição dos royalties viola o princípio federativo } & $\begin{array}{l}\text { O } \\
\text { Federativo }\end{array}$ \\
\hline \multicolumn{2}{|c|}{$\begin{array}{l}\text { A redistribuição dos royalties "repercute também, e de forma intensa, sobre o } \\
\text { princípio federativo. Tal princípio pressupõe a atuação coordenada dos entes } \\
\text { políticos, que, afinal, constituem partes integrantes da República Federativa do } \\
\text { Brasil e não estranhos entre si, muito menos inimigos. Por conta dessa } \\
\text { circunstância, eventuais atos de deslealdade de um ente para com outro não } \\
\text { caracterizam apenas uma violação à segurança jurídica, mas sim um verdadeiro } \\
\text { conflito federativo. No caso em tela, a conduta desleal da União seria } \\
\text { caracterizada por pelo menos dois fundamentos inequívocos.". }\end{array}$} & $\begin{array}{l}\text { BARROSO, Luís Roberto. Federalismo, isonomia e } \\
\text { segurança jurídica: inconstitucionalidade das alterações } \\
\text { na distribuição de royalties do petróleo, p. 27. } \\
\text { Disponível em: <http://www.luisrobertobarroso. } \\
\text { com.br/wp- } \\
\text { content/themes/LRB/pdf/royalties_do_petroleo.pdf>. } \\
\text { Acesso em } 15 \text { fev. } 2015 \text {. }\end{array}$ & $\begin{array}{l}\text { O } \\
\text { Federativo }\end{array}$ \\
\hline \multicolumn{2}{|c|}{$\begin{array}{l}\text { “Assim, uma iniciativa da União Federal por suprimir, por lei federal, parte do } \\
\text { pagamento dessas receitas aos estados e municípios afetados pela indústria do } \\
\text { petróleo restringe a sua autonomia para a execução dos seus próprios recursos } \\
\text { orçamentários, que, em vez de serem aplicados em benefício das suas respectivas } \\
\text { populações, precisarão ser alocados, forçadamente, para cobrir os riscos e custos } \\
\text { de atividade extrativista exercida por particulares, mas sob autorização e em } \\
\text { benefício do ente federal. Disso decorre a inconstitucionalidade, por ofensa ao } \\
\text { princípio federativo, de uma opção político-legislativa por distribuir as } \\
\text { participações governamentais de que trata o parágrafo primeiro do art. } 20 \text { da } \\
\text { Constituição (royalties, participações especiais, etc.) a todas as unidades } \\
\text { federadas, sem ter em consideração a situação especial vivenciada pelos estados e } \\
\text { municípios afetados por essa atividade econômica.”. }\end{array}$} & $\begin{array}{l}\text { MADUREIRA, Cláudio. Royalties de petróleo e } \\
\text { federação. Belo Horizonte: Fórum, 2012, p. } 113 .\end{array}$ & $\begin{array}{l}\text { O } \\
\text { Federativo. }\end{array}$ \\
\hline $\mathbf{C 8}$ & \multicolumn{2}{|c|}{$\begin{array}{c}\text { A redução das desigualdades sociais e regionais não é adequada como fundamento para a alteração dos critérios de partilha } \\
\text { de royalties e PE }\end{array}$} & $\begin{array}{l}\text { VD } \\
\text { Jurídico dogmático }\end{array}$ \\
\hline \multicolumn{2}{|c|}{$\begin{array}{l}\text { "Alguém poderia afirmar que o critério socioeconômico de repartição dos } \\
\text { royalties do petróleo, proposto pelas Emendas Ibsen e Simon, realiza o fim } \\
\text { constitucional de "reduzir as desigualdades sociais e regionais" (art. } 3^{\circ}, \text { III). Há } \\
\text { diversos problemas com esse argumento. Em primeiro lugar, por importar na } \\
\text { utilização de um critério de participação antagônico ao que foi determinado pela } \\
\text { norma constitucional que trata especificamente do caso, contida no art. } 20, \S 1^{\circ} \text {. } \\
\text { Em segundo lugar, a utilização de critérios socioeconômicos não é adequada em } \\
\text { todo e qualquer contexto. (...)Repita-se um ponto já destacado: nada impede que a }\end{array}$} & $\begin{array}{l}\text { BARROSO, Luís Roberto. Federalismo, isonomia e } \\
\text { segurança jurídica: inconstitucionalidade das alterações } \\
\text { na distribuição de royalties do petróleo, p. } 21-22 \text {. } \\
\text { Disponível em: } \\
\text { <http://www.luisrobertobarroso.com.br/wp- } \\
\text { content/themes/LRB/pdf/royalties_do_petroleo.pdf>. } \\
\text { Acesso em } 15 \text { fev. } 2015 \text {. }\end{array}$ & $\begin{array}{l}\text { VD } \\
\text { Jurídico dogmático. }{ }^{286}\end{array}$ \\
\hline
\end{tabular}

${ }^{286}$ Trata-se de fundamento jurídico dogmático, pois evoca o art. 20, $\S 1^{\circ}$ como dogma, como óbice intransponível para a alteração da partilha dos royalties e PE, aduzindo, inclusive, que não se pode utilizar critérios socioeconômicos para modificar as regras atuais, ou seja, parte de uma premissa (imutabilidade das regras atuais por força do art. $20, \S 1^{\circ}$ ) como se ela fosse absoluta e incontestável. 


\begin{tabular}{|c|c|c|c|}
\hline & Fundamento utilizado & Onde utilizou (referência) & $\begin{array}{l}\text { Classificação do } \\
\text { fundamento }\end{array}$ \\
\hline \multicolumn{2}{|c|}{$\begin{array}{l}\text { lei federal distribua entre todos os entes federativos parte dos recursos que cabem } \\
\text { à União por conta da produção de petróleo, com base em critérios } \\
\text { socioeconômicos. Só não pode fazê-lo mediante subtração do quinhão dos } \\
\text { Estados e Municípios produtores, cuja situação específica é tratada pelo art. } 20, \S \\
1^{\circ} \text { da Constituicãa.”. }\end{array}$} & & \\
\hline \multicolumn{2}{|c|}{$\begin{array}{l}\text { O repasse dos royalties aos estados produtores é obrigatório por força do art. } 20, \\
\S 1^{\circ} \text { da Constituição. "Não se pode admitir, portanto, que a União se valha de } \\
\text { receitas dos estados e municípios produtores para promover o desenvolvimento } \\
\text { socioeconômico de outras regiões do país". Ademais, o argumento de redução das } \\
\text { desigualdades "não é suficiente para afastar a inconstitucionalidade das alterações } \\
\text { trazidas pelo projeto de lei em comento, porquanto, querendo promover a } \\
\text { igualdade, acabou por violá-la na medida em que equiparou desiguais.". }\end{array}$} & $\begin{array}{l}\text { ALMEIDA FILHO, Jorge Celso Fleming de. Os royalties } \\
\text { do petróleo e a impossibilidade de sua partilha } \\
\text { igualitária entre os entes federativos, p. } 8 \text { e } 15 . \\
\text { Disponível } \quad \text { em: } \quad \text { http://www.e- } \\
\text { publicacoes.uerj.br/index.php/ rfptd/article/view/5127>. } \\
\text { Acesso em } 15 \text { fev. } 2015 .\end{array}$ & $\begin{array}{l}\text { VD } \\
\text { Jurídico dogmático. }\end{array}$ \\
\hline C9 & \multicolumn{2}{|c|}{$\begin{array}{c}\text { O critério utilizado para a divisão dos recursos no fundo especial foi declarado inconstitucional pelo STF, por não mais } \\
\text { refletir a realidade socioeconômica }\end{array}$} & $\begin{array}{l}\text { O } \\
\text { Jurídico (não dogmático) } \\
\text { e econômico }\end{array}$ \\
\hline \multicolumn{2}{|c|}{ 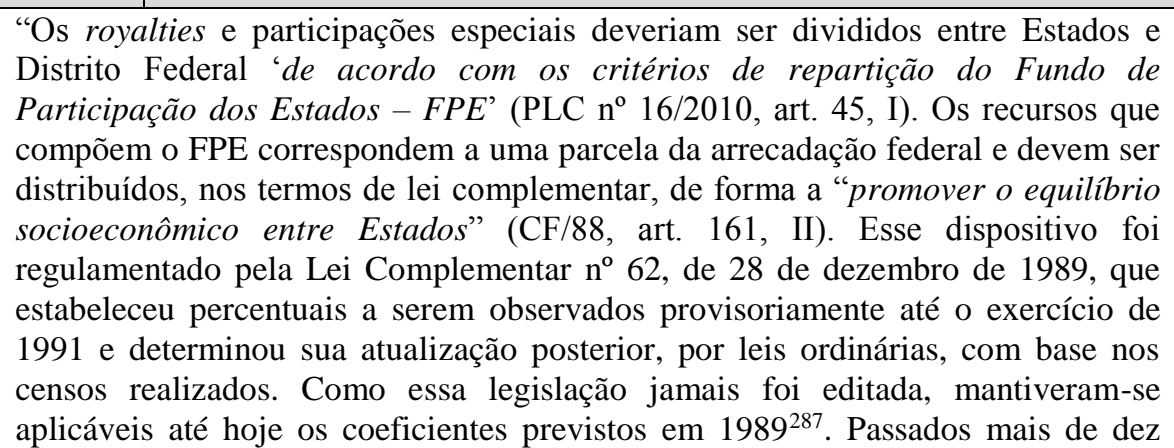 } & $\begin{array}{l}\text { BARROSO, Luís Roberto. Federalismo, isonomia e } \\
\text { segurança jurídica: inconstitucionalidade das alterações } \\
\text { na distribuição de royalties do petróleo, p. } 22 . \\
\text { Disponível em: }<\text { http://www.luisrobertobarroso. } \\
\text { com.br/wp-content/themes/LRB/pdf/royalties_- } \\
\text { do_petroleo.pdf }>\text {. Acesso em } 15 \text { fev. } 2015 .\end{array}$ & $\begin{array}{l}\text { O } \\
\text { Jurídico (não dogmático) e } \\
\text { econômico. }\end{array}$ \\
\hline
\end{tabular}

${ }^{287}$ LC 62/89, art. 2 $2^{\circ}$ : "Os recursos do Fundo de Participação dos Estados e do Distrito Federal - FPE serão distribuídos da seguinte forma: I - 85\% (oitenta e cinco por cento) às Unidades da Federação integrantes das regiões Norte, Nordeste e Centro-Oeste; II - 15\% (quinze por cento) às Unidades da Federação integrantes das regiões Sul e Sudeste. $\S 1^{\circ}$ Os coeficientes individuais de participação dos Estados e do Distrito Federal no Fundo de Participação dos Estados e do Distrito Federal - FPE a serem aplicados até o exercício de 1991, inclusive, são os constantes do Anexo Único, que é parte integrante desta Lei Complementar. § $2^{\circ}$ Os critérios de rateio do Fundo de Participação dos Estados e do Distrito Federal, a vigorarem a partir de 1992, serão fixados em lei específica, com base na apuração do censo de 1990. $\S 3^{\circ}$ Até que sejam definidos os critérios a que se refere o parágrafo anterior, continuarão em vigor os coeficientes estabelecidos nesta Lei Complementar". 


\begin{tabular}{|c|c|c|c|}
\hline & Fundamento utilizado & Onde utilizou (referência) & $\begin{array}{l}\text { Classificação do } \\
\text { fundamento }\end{array}$ \\
\hline \multicolumn{3}{|c|}{$\begin{array}{l}\text { anos, esses percentuais já se tornaram defasados e não se sustentam mais diante } \\
\text { da realidade de fato. Com esse divórcio entre os percentuais legais e a situação } \\
\text { real dos Estados, a LC } \mathrm{n}^{\circ} 62 / 89 \text { tornou-se incapaz de promover 'o equilibrio } \\
\text { socioeconômico entre Estados', podendo até contribuir para o aumento de } \\
\text { desigualdades. Exatamente por isso, o STF declarou inconstitucional, no ponto, a } \\
\text { mencionada lei complementar }{ }^{36} \text {. Dessa forma, adotar o mesmo modelo } \\
\text { inadequado para distribuir os royalties do petróleo - como pretendem as emendas } \\
\text {-, longe de reduzir, pode ampliar as desigualdades sociais entre as regiões do } \\
\text { País.". }\end{array}$} & \\
\hline C10 & \multicolumn{2}{|c|}{ A Lei ${ }^{0} 12.734 / 12$ ofende o princípio da isonomia } & $\begin{array}{l}\text { VD } \\
\text { Neo }\end{array}$ \\
\hline \multicolumn{2}{|c|}{$\begin{array}{l}\text { "Em diferentes dispositivos, a Constituição veda discriminações, distinções e } \\
\text { preferências indevidas, seja entre pessoas ou entre entidades estatais (e.g., arts. } 3^{\circ} \text {, } \\
\text { IV, } 5^{\circ} \text {, caput e } 19 \text {, III). Na formulação clássica do princípio, os iguais deverão ser } \\
\text { tratados igualmente e os desiguais, desigualmente, na medida da sua } \\
\text { desigualdade. O que a isonomia veda, portanto, são as desequiparações que não } \\
\text { tenham um fundamento racional e razoável e que não se destinem a promover um } \\
\text { fim constitucionalmente legítimo. Veda-se o arbítrio, o capricho, o aleatório, o } \\
\text { desvio. O princípio da isonomia forma uma imperativa parceria com o princípio } \\
\text { da razoabilidade. A razoabilidade é o parâmetro pelo qual se vai aferir se o } \\
\text { fundamento da diferenciação levada a cabo por qualquer agente público é } \\
\text { aceitável e se o fim por ela visado é legítimo32. Em suma: o princípio pode ser } \\
\text { violado pela desequiparação de iguais ou pela equiparação de desiguais." }\end{array}$} & $\begin{array}{l}\text { BARROSO, Luís Roberto. Federalismo, isonomia e } \\
\text { segurança jurídica: inconstitucionalidade das alterações } \\
\text { na distribuição de royalties do petróleo, p. } 19 . \\
\text { Disponível em: <http://www.luisrobertobarroso. } \\
\text { com.br/wp- } \\
\text { content/themes/LRB/pdf/royalties_do_petroleo.pdf>. } \\
\text { Acesso em } 15 \text { fev. } 2015 \text {. }\end{array}$ & $\begin{array}{l}\text { VD } \\
\text { Neo } \\
\text { Fundamentação em } \\
\text { princípio abstrato. }\end{array}$ \\
\hline \multicolumn{2}{|c|}{$\begin{array}{l}\text { "O tratamento mais favorecido entre entes da federação é recomendável em } \\
\text { países de grande diversidade cultural e social, como é o caso do Brasil. É a } \\
\text { aplicação do princípio da igualdade em sua acepção material, cujo enunciado } \\
\text { determina que se trate igualmente os iguais e desigualmente os desiguais, na justa } \\
\text { medida de suas desigualdades.". }\end{array}$} & $\begin{array}{l}\text { ALMEIDA FILHO, Jorge Celso Fleming de. Os royalties } \\
\text { do petróleo e a impossibilidade de sua partilha } \\
\text { igualitária entre os entes federativos. Disponível em: } \\
\text { <http://www.e-publicacoes. uerj.br/index.php/ } \\
\operatorname{rfptd} / / \text { article/view/5127>. Acesso em } 15 \text { fev. } 2015 \text {. }\end{array}$ & $\begin{array}{l}\text { VD } \\
\text { Neo } \\
\text { Fundamentação em } \\
\text { princípio abstrato. }\end{array}$ \\
\hline C11 & \multicolumn{2}{|c|}{$\begin{array}{l}\text { O Estado Constitucional Democrático impõe a necessidade de proteção das minorias contra a vontade das maiorias, o que é } \\
\text { feito pela jurisdição constitucional }\end{array}$} & $\begin{array}{l}\text { VD } \\
\text { Neo e jurídico } \\
\text { dogmático. }\end{array}$ \\
\hline "Tam & né importante que se diga que não é possível justificar o critério & ALMEIDA FILHO, Jorge Celso Fleming de. Os royalties & VD \\
\hline
\end{tabular}

${ }^{288}$ Esse fundamento, embora de caráter jurídico (não dogmático), por defender a inconstitucionalidade de uma lei com base na declaração de inconstitucionalidade de outra, acaba revelando também um caráter econômico, pois essa foi a natureza do argumento utilizado pelo STF para declarar a inconstitucionalidade da norma que estabelece os critérios de rateio do FPE e FPM (Lei Complementar n ${ }^{\circ} 62 / 89$ ). 


\begin{tabular}{|l|l|}
\hline & Fundamento utilizado \\
\hline \multicolumn{2}{|c|}{ socioeconômico de repartição dos royalties no fato de que são poucos os Estados }
\end{tabular}
produtores e muitos os consumidores. A proteção das minorias é, como se sabe, uma das faces da democracia no Estado Constitucional Democrático. (...) Neste contexto, surgem importantes debates ligados à jurisdição constitucional em razão da dificuldade contra-majoritária inerente ao controle de constitucionalidade feito pelo Poder Judiciário. Nesta linha de idéias, percebemos que a constituição se impõe como instrumento de preservação de determinados valores e de proteção de minorias contra a vontade das maiorias e de seu poder de manipulação do processo político.".

"É, pois, absolutamente relevante o enfrentamento, nesta sede, da discussão relativa à validade constitucional da proposição parlamentar por distribuir os royalties e participações especiais advindos da exploração do petróleo a todas as unidades federadas. Com efeito, se os cidadãos e seus representantes devem justificar as leis que querem impor uns aos outros (Gutman e Thompson), e se, como cediço, os debates realizados no Parlamento baseiam-se, como regra, em argumentos políticos, não abarcando, muitas vezes, os aspectos jurídicos (...), cumpre, então, que a doutrina jurídica se apresente como foro qualificado para a deliberação pública sobre o tema"."

(...)

O Poder Judiciário é "instituição estratégica nas democracias contemporâneas, cuja atuação não se limita às funções meramente declarativas do Direito, e por isso deve se impor, entre os Poderes da República.".

C12

A Lei $\mathrm{n}^{\circ}$ 12.734/12 viola o direito adquirido, o ato jurídico perfeito e a segurança jurídica

"Não pode a lei nova pretender cancelar os atos/contratos celebrados, sob os auspícios da legislação pretérita, com vistas à exploração de petróleo e gás sob o regime de concessão; mesmo que essa exploração ocorra dentro do perímetro designado pelo ordenamento jurídico-positivo como 'área do pré-sal', e que a lei disponha que a exploração de petróleo na 'área do pré-sal' deva se dar sob o regime de partilha de produção. E isso porque, em razão do princípio da segurança jurídica, e em especial da proteção conferida pela Constituição ao ato

\section{Onde utilizou (referência)}

do petróleo e a impossibilidade de sua partilha

igualitária entre os entes federativos, p. 18. Disponível

em: <http://www.e-publicacoes. uerj.br/index.php/

rfptd/article/view/5127>. Acesso em 15 fev. 2015.

MADUREIRA, Cláudio. Royalties de petróleo e federação. Belo Horizonte: Fórum, 2012, p. 30 e 33.

\section{Classificação do}

fundamento

Neo

Primazia do Poder

Judiciário. ${ }^{289}$

\section{VD}

Primazia do Poder

Judiciário.

${ }^{289}$ Trata-se de fundamento essencialmente neoconstitucionalista, pois confere posição de destaque ao Poder Judiciário, como defensor dos direitos fundamentais da minoria, contra a vontade da maioria.

${ }^{290}$ Nesse trecho, a segurança jurídica e o ato jurídico perfeito não são tratados como princípios abstratos, mas sim como dogmas que impedem a modificação das regras de partilha de royalties e PE.

MADUREIRA, Cláudio. Royalties de petróleo federação. Belo Horizonte: Fórum, 2012. 157, p. 126127.
VD

Jurídico dogmático

Jurídico dogmático. ${ }^{290}$ 


\begin{tabular}{|l|l|l|}
\hline Fundamento utilizado & Onde utilizou (referência) & $\begin{array}{l}\text { Classificação do } \\
\text { fundamento }\end{array}$ \\
\hline jurídico perfeito, a lei nova não atinge da validade dos atos praticados sob o \\
império da lei anterior. De igual modo, o legislador não pode pretender alcançar \\
os efeitos de ato/contrato consolidado sob a legislação pretérita, contexto em que \\
se destaca o pagamento aos Estados e Municípios dos royalties e participações \\
especiais advindos da exploração de petróleo e gás nos campos de produção \\
relativos às áreas já licitadas, que persistem regidos pela lei do tempo do fato. Do \\
contrário, ter-se-ia, na espécie, a afetação de ato perfeito e acabado por nova \\
vontade legislativa, em contrariedade ao comando do inciso XXXVI do artigo 5º \\
da Constituição, que dispõe, taxativamente, que 'a lei não prejudicará o direito \\
adquirido, o ato jurídico perfeito e a coisa julgada'.”. & & \\
& & \\
\end{tabular}

